$\star^{*^{\star *}}$ *UACES

CONTEMPORARY EUROPEAN STUDIES

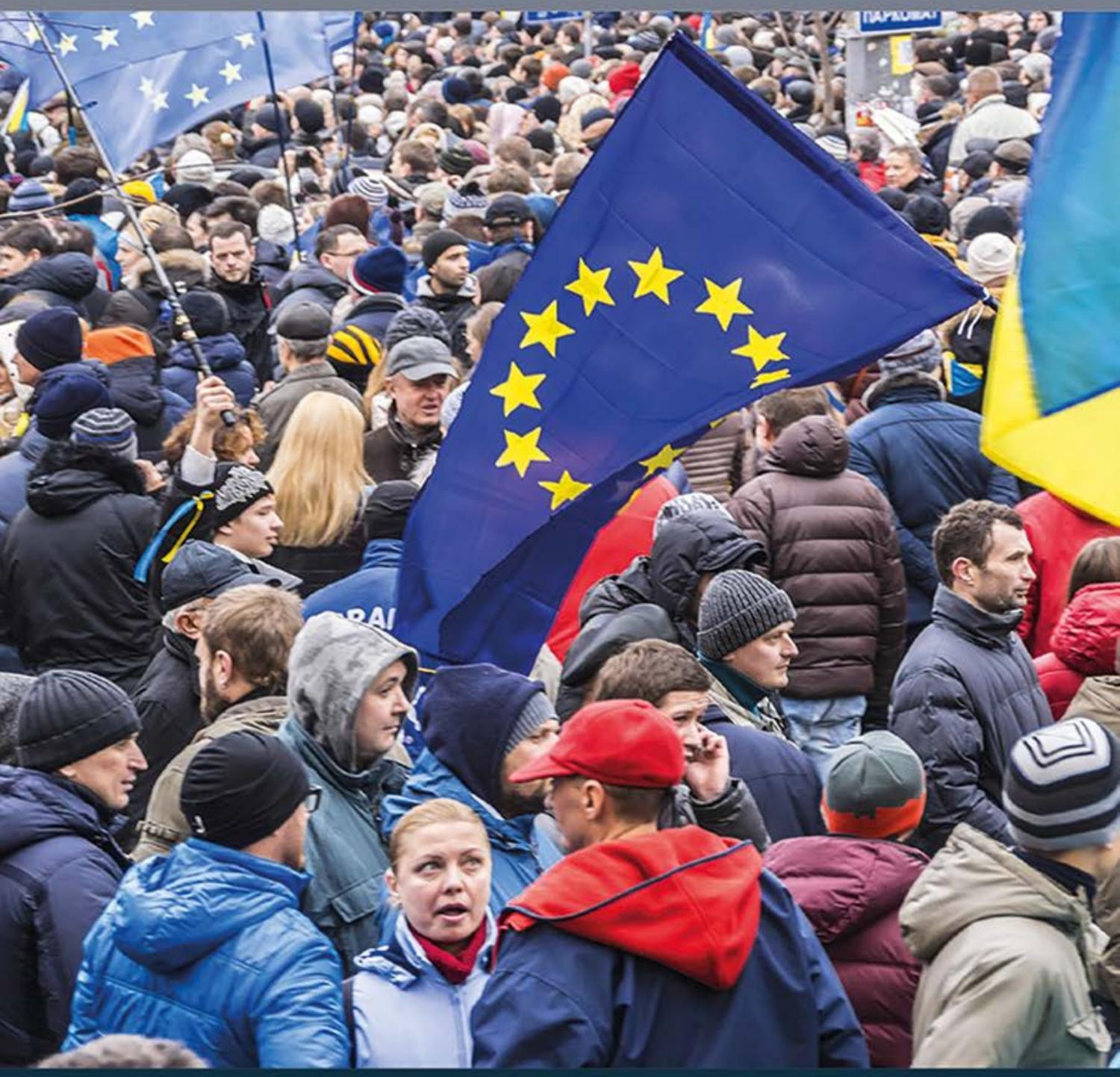

\title{
Domestic Politics and Norm Diffusion in International Relations
}

Ideas do not float freely 


\section{Domestic Politics and Norm Diffusion in International Relations}

This book collects Thomas Risse's most important articles together in a single volume. Covering a wide range of issues - the end of the Cold War, transatlantic relations, the "democratic peace," human rights, governance in areas of limited statehood, Europeanization, European identity and public spheres, most recently comparative regionalism - it is testament to the breadth and excellence of this highly respected International Relations scholar's work. The collection is organized thematically - domestic politics and international relations, international sources of domestic change, and the diffusion of ideas and institutions - and a brand new introductory essay provides additional coherence.

This text will be of key interest to scholars and students of International Relations, European Politics, and Comparative Politics.

Thomas Risse is Director of the Center for Transnational Relations, Foreign and Security Policy at the Otto Suhr Institute of Political Science at the Freie Universität Berlin, Germany. He has previously held teaching positions at the University of Konstanz, Germany, and at the European University Institute (EUI), Florence, Italy. He has also taught at Cornell, Yale, Stanford, and Harvard universities and at the University of Wyoming. He is co-ordinator of the Collaborative Research Center 700 Governance in Areas of Limited Statehood, funded by the German Research Foundation (DFG), and co-director of the DFG funded Research College The Transformative Power of Europe. 


\section{Routledge / UACES Contemporary European Studies}

Edited by Federica Bicchi

London School of Economics and Political Science

Tanja Börzel

Free University of Berlin

Mark Pollack

Temple University, on behalf of the University Association

for Contemporary European Studies

Editorial Board: Grainne De Búrca, European University Institute and Columbia University; Andreas Føllesdal, Norwegian Centre for Human Rights, University of Oslo; Peter Holmes, University of Sussex; Liesbet Hooghe, University of North Carolina at Chapel Hill, and Vrije Universiteit Amsterdam; David Phinnemore, Queen's University Belfast; Ben Rosamond, University of Warwick; Vivien Ann Schmidt, University of Boston; Jo Shaw, University of Edinburgh; Mike Smith, University of Loughborough and Loukas Tsoukalis, ELIAMEP, University of Athens and European University Institute.

The primary objective of the new Contemporary European Studies series is to provide a research outlet for scholars of European Studies from all disciplines. The series publishes important scholarly works and aims to forge for itself an international reputation.

30 The European Union's Foreign Policy in Comparative Perspective Beyond the "actorness and power" debate Edited by Ingo Peters

\section{The Formulation of EU Foreign Policy}

Socialization, negotiations and disaggregation of the state

Nicola Chelotti

32 Core-periphery Relations in the European Union

Power and conflict in a dualist political economy

Edited by José M. Magone, Brigid Laffan and

Christian Schweiger

33 Russia's Impact on EU Policy Transfer to the Post-Soviet Space

The contested neighborhood

Esther Ademmer

34 Domestic Politics and Norm Diffusion in International Relations Ideas do not float freely

Thomas Risse 


\title{
Domestic Politics and Norm Diffusion in International Relations \\ Ideas do not float freely
}

\author{
Thomas Risse
}


First published 2017

by Routledge

2 Park Square, Milton Park, Abingdon, Oxon OX14 4RN

and by Routledge

711 Third Avenue, New York, NY 10017

Routledge is an imprint of the Taylor \& Francis Group, an informa business

(C) 2017 Thomas Risse

The right of Thomas Risse to be identified as author of this work has been asserted by him in accordance with sections 77 and 78 of the Copyright, Designs and Patents Act 1988.

All rights reserved. No part of this book may be reprinted or reproduced or utilised in any form or by any electronic, mechanical, or other means, now known or hereafter invented, including photocopying and recording, or in any information storage or retrieval system, without permission in writing from the publishers.

Trademark notice: Product or corporate names may be trademarks or registered trademarks, and are used only for identification and explanation without intent to infringe.

\section{British Library Cataloguing in Publication Data}

A catalogue record for this book is available from the British Library

Library of Congress Cataloging-in-Publication Data

Names: Risse-Kappen, Thomas, author.

Title: Domestic politics and norm diffusion in international relations : ideas do not float freely / Thomas Risse.

Description: New York, NY : Routledge, 2016. | Series: Routledge/UACES contemporary European studies series ; $34 \mid$ Includes bibliographical references and index.

Identifiers: LCCN 2016021689 | ISBN 9781138653665 (hardback) | ISBN 9781315623665 (ebook)

Subjects: LCSH: International relations-Political aspects. | Comparative politics. | Diplomacy.

Classification: LCC JZ1242 .R57 2016 | DDC 327-dc23

LC record available at https://lccn.loc.gov/2016021689

ISBN: 978-1-138-65366-5 (hbk)

ISBN: 978-1-315-62366-5 (ebk)

Typeset in Times New Roman

by Apex CoVantage, LLC 


\section{Contents}

Sources vii

List of tables and figures $\quad$ ix

Preface $\quad x$

1 Domestic politics and norm diffusion in international relations: An intellectual journey

\section{PART I}

From the inside out: The domestic politics of international relations

2 Public opinion, domestic structure, and foreign policy in liberal democracies (1991)

3 Democratic peace - warlike democracies? A social constructivist interpretation of the liberal argument (1995)

4 Collective identity in a democratic community: The case of NATO (1996)

\section{PART II}

From the outside in: The international sources of domestic change

5 The socialization of international human rights norms into domestic practices: Introduction (with Kathryn Sikkink; 1999)

6 Conceptualizing the domestic impact of Europe (with Tanja A. Börzel; 2003) 
vi Contents

7 European institutions and identity change: What have we learned? (2004)

8 External actors, state-building, and service provision in areas of limited statehood:

Introduction (with Stephen D. Krasner; 2014)

PART III

In between spaces: Transnational relations and the diffusion of ideas and institutions

9 Ideas do not float freely: Transnational coalitions, domestic structures, and the end of the Cold War (1994)

10 "Let's argue!": Communicative action in world politics (2000)

11 From Europeanization to diffusion: Introduction (with Tanja A. Börzel; 2012) 


\section{Sources}

Chapter 2 "Public opinion, domestic structure, and foreign policy in liberal democracies," World Politics, Vol. 43, No. 4, July 1991, 479-512. Cambridge University Press. Reprinted with permission of the publisher.

Chapter 3 "Democratic peace - warlike democracies? A social constructivist interpretation of the liberal argument," European Journal of International Relations, Vol. 1, No. 4, 1995, 489-515. Reproduced by permission of SAGE Publications Ltd., London, Los Angeles, New Delhi, Singapore and Washington DC. Copyright (C SAGE, 1995). Reprinted with permission of the publisher.

Chapter 4 "Collective identity in a democratic community: The case of NATO," in Peter Katzenstein (ed.), The Culture of National Security. Norms and Identity in World Politics (New York: Columbia University Press, 1996), 357-399. Copyright (C) 1996 Columbia University Press. Reprinted with permission of the publisher.

Chapter 5 (with Kathryn Sikkink) "The socialization of international human rights norms into domestic practices: Introduction," in Thomas Risse, Stephen S. Ropp, Kathryn Sikkink (eds.), The Power of Human Rights. International Norms and Domestic Change (Cambridge: Cambridge University Press, 1999), 1-38. Reprinted with permission of the publisher.

Chapter 6 (with Tanja A. Börzel) "Conceptualizing the domestic impact of Europe," in Kevin Featherstone, Claudio M. Radaelli (eds.), The Politics of Europeanisation (Oxford: Oxford University Press, 2003), 57-80. Free permission co-author's own material. By permission of Oxford University Press.

Chapter 7 "European institutions and identity change: What have we learned?" in Richard Herrmann, Thomas Risse, Marilynn Brewer (eds.), Transnational Identities. Becoming European in the European Union (Lanham MD: Rowman \& Littlefield, 2004), 247-271. Reprinted with permission of the publisher. 
Chapter 8 (with Stephen D. Krasner) "External actors, state-building, and service provision in areas of limited statehood: Introduction," in Thomas Risse, Stephen D. Krasner (eds.), External Actors, StateBuilding, and Service Provision in Areas of Limited Statehood. Special Issue of Governance, Vol. 27, No. 4, 2014, 545-567. Reproduced with permission of the publisher. (C) 2014 Wiley Periodicals, Inc.

Chapter 9 "Ideas do not float freely: Transnational coalitions, domestic structures, and the end of the Cold War," International Organization, Vol. 48, No. 2, Spring 1994, 185-214. Copyright (C) 1995 Columbia University Press. Reprinted with permission of the publisher and $\odot 1994$ by the World Peace Foundation and the Massachusetts Institute of Technology.

Chapter 10 "'Let's argue!': Communicative action in world politics," International Organization, Vol. 54, No. 1, 2000, 1-39. (C) 2000 by the IO Foundation and the Massachusetts Institute of Technology.

Chapter 11 (with Tanja A. Börzel) "From Europeanization to diffusion: Introduction," West European Politics, Special Issue From Europeanization to Diffusion, Vol. 35, No. 1, 2012, 1-19. Reproduced with permission of the publisher, www.tandfonline.com. 


\section{Tables and figures}

\section{Tables}

2.1 Domestic structures 33

5.1 The spiral model, dominant actors, and dominant interaction modes 142

6.1 The different degrees of domestic change 163

11.1 Diffusion mechanisms following direct influence model 294

11.2 Emulation: Indirect mechanisms of diffusion 297

$\begin{array}{lll}11.3 & \text { Theoretical framework } & 302\end{array}$

\section{Figures}

2.1 Net threat perception of the USSR 35

2.2 Net support for defense spending 36

2.3 Policy toward the Soviet Union 38

5.1 The process of norms socialization $\quad 125$

5.2 The "boomerang effect" 131

5.3 The "spiral model" of human rights change $\quad 132$

6.1 The domestic effect of Europeanization 153

6.2 Two logics of domestic change 161

8.1 World map: Degrees of statehood 201

8.2 Service provision and degrees of statehood $2010 \quad 204$

8.3 Legitimacy, task complexity, and institutional design 211

10.1 Three logics of social action 252 


\section{Preface}

Three people were crucial in persuading me to publish this collection of my articles: Federica Bicchi (London School of Economics and Political Science), Mark Pollack (Temple University, Philadelphia), and Tanja A. Börzel (Freie Universität Berlin). Interestingly enough, I came to know all of them in Florence at the European University Institute (EUI) during the mid-to-late 1990s. Fede was one of my first PhD students in Florence; I hired Mark as scientific director of a transatlantic program; and Tanja has been my partner, wife, and collaborator ever since.

Fede, Mark, and Tanja not only talked me into publishing this book, they were also critical in helping me to select the various pieces and in commenting on the introductory chapter. So, a huge thank you to all three of them!

Moreover, Anja Jetschke (University of Göttingen) and Andrea Liese (University of Potsdam), one of my first $\mathrm{PhD}$ researchers and postdocs, respectively, organized a workshop, "Re-Reading Risse," at the occasion of my 60th birthday in Berlin, December 18-19, 2015. This workshop came as a complete surprise to me. I had the honor and pleasure of colleagues discussing and critically commenting on my work, including some of the articles included in this volume. I learned so much from these two days, and I am extremely grateful for the experience.

Last but not least, I want to thank Susan Bergner, Alexandra Kuhles, and Stefan Wiechmann for helping to prepare the manuscript, Sophie Iddamalgoda as the editor at Routledge, Jennifer Bonnar for her project management, Katie McIlvanie for her very careful copyediting, Francesca Hearn for production editing, and Michael McKeen for preparing the index.

Thomas Risse Berlin, May 2016 


\title{
1 Domestic politics and norm diffusion in international relations
}

\author{
An intellectual journey
}

According to Wikipedia, I am a social constructivist who borrows heavily from the work of Jürgen Habermas. ${ }^{1}$ Yet, I did not start out that way. If one wants to label me at all, I have been a liberal scholar of international relations from the beginning with a heavy emphasis on domestic politics, domestic (institutional) structures, and transnational relations among non-state actors (see chapters 2, 3, 5, and 9, this volume). As a young doctoral student at the University of Frankfurt, Germany, during the 1980s, I worked on the domestic politics of German foreign policy. Thirty years later, I am still interested in domestic politics, state institutions, and the study of governance in "areas of limited statehood" (see chapter 8, this volume; see also Risse 2011).

In that sense, my work has always been at the intersection of international relations and comparative politics focusing on three interrelated themes:

1 "From the inside out": The domestic politics of international relations.

2 "From the outside in": The international sources of domestic change.

3 "In between spaces": Transnational relations and the diffusion of ideas and institutions.

This volume contains a collection of my articles and book chapters from the early 1990s to the mid 2010s. The chapters are ordered according to the three themes above - irrespective of whether they take an explicit social constructivist stance (chapters $3,4,5,7,10$, this volume) or whether they deal with Western democracies, East-West relations, and NATO (chapters 2, 4, 9, this volume), with human rights and the global South (chapters 5 and 8 , this volume), or with Europe and comparative regionalism (chapters 6, 7, 11, this volume).

However, this introductory chapter is structured differently since it attempts to describe my intellectual journey from the $1980 \mathrm{~s}$ to the 2010s. ${ }^{2}$ I start with reviewing the intellectual origins of my research on foreign policy, transatlantic relations, and the "democratic peace." I then discuss my contributions to social constructivist theory-building - the "Habermas" part mentioned previously - and to the diffusion of ideas and international norms, particularly in the human rights domain and with regard to areas of limited statehood. The third part of this chapter focuses on research on Europeanization, European identities, and comparative regionalism. The chapter concludes with some ideas about future research 
on norm diffusion and the translation of norms into domestic practices of adoption, appropriation and resistance.

\section{Beginnings: Foreign policy analysis, transatlantic relations, and the "democratic peace"}

After graduating from the University of Bonn, I started out in the early 1980s as a "missiles and bombs" peace researcher at the Peace Research Institute Frankfurt (PRIF), Germany. At the time, I was privileged to learn from three most inspiring scholars in German International Relations (IR), Ernst-Otto Czempiel, my doctoral supervisor; Gert Krell, my "boss" and friend in the research group on arms dynamics and arms control; and, last not least, Harald Müller, my close friend who guided my research in those days in more than one way. From the beginning, I was interested in the domestic side of foreign policy. I had already written my Master's thesis at the University of Bonn on the West German foreign policy decision-making process with regard to Ostpolitik and the 1970 German-Polish treaty, which marked Germany's new détente policy during the Cold War under then-Chancellor Willy Brandt.

Czempiel taught us that we needed to study domestic politics if we wanted to understand U.S. foreign policy (e.g. Czempiel 1979). He also introduced us to the system analytical framework of David Easton and applied it to comparative foreign policy analysis (Easton 1965). My $\mathrm{PhD}$ dissertation then served as an attempt to apply Easton's approach to the study of German security policy (Risse-Kappen 1988a).

I had come to peace research as an activist engaged in a Catholic peace movement, Pax Christi. I also had a background in Catholic theology and ethics from my undergraduate years. My first job at PRIF was part of a larger project on "ethics and security policy" with an emphasis on nuclear weapons and nuclear deterrence, which was funded by the German Catholic church (e.g. Böckle and Krell 1984). The early 1980s were exciting times in Germany. Hundred thousands of peace activists gathered at mass rallies against the deployment of U.S. nuclear missiles in Germany and against Ronald Reagan's foreign policy.

I quickly learned that peace activism and peace research are two different things as a result of which I increasingly distanced myself from the slogans of the peace movement. My PhD was all about analyzing how the demands of the peace movements affected the political positions of the West German political parties and then again the security policy of the Federal Republic with regard to various issue-areas, including nuclear weapons. The demands of the peace movement led to a new West German foreign policy consensus on "common security" and the recognition that unilateral security was not an option in the nuclear age. This shift prepared the ground for the enthusiastic West German reaction to Michal Gorbachev's new foreign policy of "perestroika" and, thus, in a way for German unification and the peaceful end of the Cold War (Sarotte 2009; see also Risse-Kappen 1991). Chapters 2 and 9 in this volume contain some of the empirical material collected during my dissertation research. 
At the same time, and initially as part of my $\mathrm{PhD}$ dissertation, ${ }^{3}$ I process-traced NATO's nuclear decision-making processes with regard to the 1979 "doubletrack" decision on intermediate-range nuclear forces (INF) and the subsequent nuclear arms negotiations, which then led to the 1987 INF disarmament treaty between the U.S. and the Soviet Union (Risse-Kappen 1988b). The West German peace movement had blamed the U.S. and particularly Ronald Reagan for NATO's nuclear policies. In contrast, I demonstrated that then-German Chancellor Helmut Schmidt and the Federal Republic in general were crucial for NATO's decisions at every step of the way and that the West Germans exercised a strong influence on U.S. foreign policy-making, even under President Reagan and throughout the arms control negotiations with the Soviets. These findings had quite an influence on my later work on transatlantic relations.

In 1988, I moved to the U.S., where I spent two years at Cornell University's Peace Studies Program, followed by another two years at Yale University's Department of Political Science. My first tenure-track job was at the University of Wyoming in 1992-93. The intellectual impact of each of these places was profound.

Let me start with Cornell where Peter Katzenstein and Richard Ned Lebow became my intellectual mentors - together with a whole group of terrific graduate students who taught me U.S. political science and methods. ${ }^{4}$ Katzenstein's work was crucial in, first, adding a comparative perspective to my work on German foreign policy and, second, directing me toward studying the embeddedness of domestic politics in political institutions and the structure of statesociety relations (see e.g. Katzenstein 1978, 1985). The latter was known at the time as the "domestic structure" approach, which inspired both historical institutionalism and the "varieties of capitalism" perspective (see e.g. Steinmo, Thelen, and Longstreth 1992; Hall and Taylor 1996; Hall and Soskice 2001).

My first attempt at applying the domestic structure framework and, at the same time, engaging in comparative foreign policy analysis was the 1991 World Politics article (chapter 2, this volume). In short, I argued that domestic structures various combinations of state-society relations - explain the degree to which societal demands influence foreign policy decisions in liberal democracies. My 1994 article in International Organization (chapter 9, this volume) also uses the domestic structure framework. So does the edited volume on transnational relations which uses domestic structures as the main variable to explain the access and influence of non-state actors on state policies (Risse-Kappen 1995a).

Starting at Cornell, I also continued researching the transatlantic relationship. The INF book led me to conclude that the European influence on U.S. foreign policy might have been greater throughout the Cold War and beyond than conventional wisdom would have it. I decided, therefore, to dig deeper into EuropeanAmerican interactions during the Cold War.

At this point, the Cornell graduate students educated me in what is known today as social constructivism. During the late 1980s and early 1990 s, a weekly Peace Studies Program seminar followed by (mostly pizza) dinner took place at the home of some Cornell faculty. We read and discussed the works of Friedrich 
Kratochwil, Nicolas Onuf, John Ruggie, Alexander Wendt, and others - sometimes deep into the night (Kratochwil and Ruggie 1986; Wendt 1987; Kratochwil 1989; Onuf 1989).

The other part of my social constructivist education took place at Yale University. From 1988-1990, I was commuting between Ithaca, New York, and New Haven, Connecticut. At Yale, Bruce Russett, whom I knew from my time in Frankfurt since he was a friend of Czempiel, became my mentor. ${ }^{5}$ Russett has been "Mister Democratic Peace, of course" (see Russett 1993; Russett and Oneal 2001), and a hard-core quantitative scholar. When Russett heard about my interest in transatlantic relations, he suggested that I read Karl W. Deutsch's work on security communities (Deutsch et al. 1957). The other acquaintance at Yale was Alex Wendt, an assistant professor at the time who was working on the "Anarchy Is What States Make of It" manuscript, one of the defining pieces of social constructivism (Wendt 1992).

Karl Deutsch, the early social constructivist scholarship, and the literature on the "democratic peace" were eye openers for me. I started interpreting NATO not so much as a traditional alliance, but as a security community of liberal democracies. It incorporated a distinctive set of norms of consultation regulating the relationship, which then explained the extraordinarily significant influence of the British and the Germans in particular on U.S. foreign policy during the Cold War (Risse-Kappen 1995b). I used comparative case studies throughout the history of the Cold War to proof my argument empirically (the Korean War, the Suez crisis, the Limited Test Ban Treaty, the Cuban Missile Crisis, and - of course - my earlier work on INF). I learned the hard way what it means to go to the archives and to interpret historical sources. While I was trying to make a social constructivist argument, Bob Keohane convinced me in ten-page singlespaced comments that I need to take alternative explanations more seriously, particularly a sophisticated realist account rather than simply Waltzian structural realism (Waltz 1979). A summary of my argument can be found in a chapter in The Culture of National Security volume edited by Katzenstein (Katzenstein 1996; chapter 4, this volume). The book established to a skeptical U.S. IR audience that the study of norms from a constructivist perspective yields significant insights in crucial issues of world politics.

Cooperation Among Democracies (Risse-Kappen 1995b) established me as a scholar of the transatlantic affairs, for better or worse. Almost ten years later, when I had moved on to different topics, the transatlantic crisis following the U.S. invasion of Iraq in 2003 renewed my interest in NATO. I got together with G. John Ikenberry and Jeffrey Anderson to put together an edited volume investigating the fundamentals of the transatlantic security community (Anderson, Ikenberry, and Risse 2008). My conclusion at the time was that the security community was still intact but that the European-American relationship was faced with a lingering crisis. At the end of Obama's second term as President, I have become more pessimistic (Risse 2016). As Adler and Barnett suggested quite some time ago (Adler and Barnett 1998), the norms holding security communities together can actually erode. 
During my time as a visiting assistant professor at Yale in the early 1990s, I became exposed to the emerging literature on the "democratic peace" through Russett's work. Czempiel, my PhD supervisor, had written about democracy and peace already for a long time, but his work had been practically ignored outside Germany (Czempiel 1986; see, however, Czempiel and Rosenau 1992). The empirical evidence became ever more robust that consolidated liberal democracies almost never fight each other. What was lagging behind was the theoretical explanation. Neither Bueno de Mesquita's argument about the constraining forces of democratic institutions (Bueno de Mesquita and Lalman 1992; Bueno de Mesquita et al. 1999) nor Russett's emphasis on the norms of restraint embedded in the political cultures of liberal democracies (Russett 1990, 1993) convinced me. If one wanted to explain the democratic peace, one also had to account for democratic wars. Yet, the prevailing theories at the time emphasized variables that would make democracies peaceful on the monadic rather than the dyadic level. The empirical evidence only supported the latter, while disconfirming that democracies were peaceful in general.

Dissatisfied with the prevailing accounts, I developed a social constructivist interpretation of the "democratic peace," arguing that elites in liberal democracies take their cues about the peaceful (or aggressive) intentions of their counterparts from their domestic political orders and the degree of transparency and publicity embedded in these orders. Chapter 3 of this volume re-prints my contribution to the literature on the "democratic peace" (for a similar, less constructivist argument see Owen 1994, 1997). Ten years later, Harald Müller at PRIF developed a research program around investigating the dark sides of the "democratic peace," namely aggressive interventionism of liberal democracies in the post-Cold War era (Müller 2002; Geis, Müller, and Schörnig 2013).

\section{The end of the Cold War: Transnational actors, international norms, and domestic change}

In the meantime, a momentous event in the history of the 20th century happened before our eyes, namely the end of the Cold War. The sudden and peaceful end of the division of Europe and of Germany challenged core assumptions of our prevailing IR theories, which simply led us to misperceive what was happening before our eyes. I am no exception. In late 1989 when the Berlin wall was coming down, I published a short piece why German unification was not in the cards any time soon - and I had many good reasons for my judgement (Risse-Kappen 1989). ${ }^{6}$ So, the end of the Cold War was quite a puzzling event in search of explanation.

As a result, Ned Lebow and I began planning a conference at Cornell to probe our IR theories with regard to accounts for the sudden and peaceful end of the East-West conflict (Lebow and Risse-Kappen 1995). My contribution was based on my own experience at PRIF during the 1980s (chapter 9, this volume). I had witnessed first-hand transnational exchanges between West German arms control experts and peace researchers, on the one hand, and Soviet security specialists 
at various institutes, including the Moscow Institute for World Economy and International Relations (IMEMO) and the Institute for US and Canadian Studies (ISKRAN), on the other. Little did we know at the time that the Soviet experts were becoming leading foreign policy advisors to Mikhail Gorbachev. In a way, this piece was my first attempt to write about the diffusion of ideas, and thus, it is located in the third part of this volume.

This piece was about transnational actors and their contribution to the end of the Cold War (for a similar argument about transnational human rights networks see Thomas 2001). Therefore, I thought that it was about time to revive the theme of transnational relations in world politics (Keohane and Nye 1971), which had been all but forgotten by state-centered international relations approaches in the U.S. I organized two workshops at Yale, which resulted in the 1995 Bringing Transnational Relations Back In volume (Risse-Kappen 1995a). We - once again used a domestic structure approach claiming that differences in political institutions explained both the policy access of transnational actors and their ability to build domestic winning coalitions.

When I returned to Germany in late 1993 to take up a position at the University of Konstanz, the articles and books on domestic structures, transatlantic as well as transnational relations, and the end of the Cold War were either finished or in their final stages. Thus, it was time to move on. So far, most of my research had focused on the "second image," i.e., liberal approaches to international relations emphasizing domestic politics and structures as well as interconnections among societal actors. The "dependent variables" - so to speak - had been national foreign policies or outcomes on the international (inter-state) level, such as the emergence of new international norms. By the mid-1990s, we sort of knew how to explain national foreign policies or to account for the emergence of international institutions. The "neo-neo" debate was over, and (moderate) social constructivism had become a widely accepted paradigm in IR theories.

But what about the impact of all those international norms? Mostly inspired by the emerging social constructivist work on norms and on socialization (e.g. Finnemore 1996a, b; Checkel 1997), I changed the perspective toward the "second image reversed" (Gourevitch 1978). How and under what conditions do international institutions and the norms embedded in them affect domestic policies as well as domestic structures (political institutions) of states?

This marks the beginning of my scholarship on international human rights (chapter 5, this volume) and on Europeanization (chapter 6, this volume). With regard to human rights and similarly to my earlier work on peace and security, there is a personal history to it. In the early 1970 s, I had been one of the founders of our local Amnesty International group in my hometown - together with other high school students. Our activism was heavily influenced by Pinochet's military coup in Chile in 1973 and by the widespread reports about torture. More than twenty years later, I returned to research on human rights and successfully applied for my first research grant by the German Research Foundation (Deutsche Forschungsgemeinschaft, DFG), which has funded most of my subsequent research. This and other projects also employed my first graduate students. 
In particular, Anja Jetschke (Jetschke 2010) and Hans Peter Schmitz (Schmitz 2006) have to be mentioned here. We started our work with pairwise comparisons of human rights change in North African, Subsaharan African, and Southeast Asian countries (Gränzer 1999; Jetschke 1999; Schmitz 1999).

In this context, I met Kathryn Sikkink for the first time. She was interested in my work on transnational relations, while I was attracted to her research on transnational advocacy networks with Margret Keck (Keck and Sikkink 1998). This encounter led to a long-lasting cooperation. Keck and Sikkink had theorized the "boomerang effect" in their book, arguing that domestic norm change was likely to occur when domestic opposition groups mobilized and linked up with transnational networks so that repressive regimes were somehow "sandwiched" between domestic and transnational pressure. Stephen Ropp, my former colleague from the University of Wyoming and a Latin Americanist, Sikkink, and myself got together and concocted a joint project that resulted in the Power of Human Rights volume (Risse, Ropp, and Sikkink 1999; see chapter 5, this volume). Our final meeting took place in the winter at the National Museum of Wildlife Art in Jackson Hole, Wyoming, overlooking a herd of 5,000 elk who had migrated down from the Yellowstone National Park. Inside the museum, we reported the findings of our various empirical case studies. We scribbled our findings on a large piece of brown wallpaper on the floor distinguishing various phases of human rights change. Suddenly, Kathryn exclaimed: "This looks like a spiral!" This was the birth of the "spiral model" of human rights change, an attempt to transform the "boomerang effect" into a more dynamic model.

When we started our work on human rights and domestic change, the method of choice for most researchers in this area was qualitative comparative case studies and process-tracing. This changed dramatically over time, when large-n quantitative research entered the human rights scholarship (e.g. Hafner-Burton 2008, 2013; Simmons 2009). For some time, it looked as if qualitative researchers were the "optimists" with regard to the possibility of sustained compliance with human rights norms, while quantitative scholars were the "pessimists" who doubted that ratification of international treaties had any effect on compliance (Hafner-Burton and Ron 2009). Moreover, scholars started to argue that the scholarship of the 1990s was too positive with regard to the effects of transnational mobilization. Human rights backlash became the conventional wisdom in the post-9/11 period (see e.g. Hopgood 2013; Posner 2014). Last not least, Power of Human Rights (PoHR) was still rather state-centric in the sense that we concentrated on national governments as the main perpetrators of human rights violations. But what about human rights violations by non-state actors such as firms or rebel groups?

Thus, in 2009, ten years after PoHR had been published, we met again in Wyoming to take stock of human rights research. This workshop ultimately resulted in an update of PoHR, the Persistent Power of Human Rights (PPoHR) volume (Risse, Ropp, and Sikkink 2013). We tried to demonstrate that sophisticated qualitative and quantitative work on human rights yields rather similar results, confirming basic insights of the original "spiral model" (particularly 
Simmons 2013). We also suggested that the "spiral model" could deal with rights violations by firms (Deitelhoff and Wolf 2013), rebel groups (Jo and Bryant 2013), and private individuals (Brysk 2013). And we investigated backlash dynamics of great powers such as China (Kinzelbach 2013) or the U.S. under George W. Bush (Sikkink 2013).

As mentioned previously, the beginning of my work on "the second image reversed," the international sources of domestic change, at the University of Konstanz also concerned my venturing into a new field of empirical inquiry: European integration. It was only natural that I became interested in the European Union (EU) when returning from the U.S. to Europe. Besides, I had to teach a core class on European integration in Konstanz. Since I had not worked on the EU before, I was on a steep learning curve at the time - mostly from bright graduate students whose diploma theses on the EU I supervised (including my later wife, Tanja Börzel, who studied in Konstanz at the time before pursuing her $\mathrm{PhD}$ at the European University Institute [EUI]). A 1996 article in the Journal of Common Market Studies (Risse-Kappen 1996) was my first attempt at making sense of the EU. So little did I know about EU scholarship that it did not even occur to me that the title - "Exploring the Nature of the Beast" - was a take on Donald Puchala's famous article "Of Blind Men, Elephants, and International Integration" (Puchala 1972).

I was not interested in explaining the EU or in engaging in the various debates between neo-functionalism, (liberal) intergovernmentalism, or multi-level governance. Instead, and in parallel to the human rights project, I wanted to know how the European integration process affected domestic politics and institutions in the member states. At a meeting in Chicago in early 1996, I met Jim Caporaso and Maria Green Cowles who were also interested in this question. This led to the book Transforming Europe (Cowles, Caporaso, and Risse 2001). Chapter 6 of this volume summarizes the state of the art of Europeanization research at the beginning of the 2000s. It is co-authored with Tanja Börzel since my work on Europeanization coincided with her own research interests (for similar attempts see Olsen 2002; Featherstone and Radaelli 2003; Radaelli and Pasquier 2006).

My collaboration with Tanja (as well as my dating and later marrying her) started at the EUI, overlooking the city of Florence where I had moved from Konstanz in early 1997. Tanja not only became my partner, but also my closest academic collaborator. We worked together on Europeanization and - more recently - on diffusion and comparative regionalism as well as governance in areas of limited statehood (see the next section). Over the past twenty years, there is nobody else in my life who has had a greater intellectual (and, of course, other) influence on me than Tanja.

Besides, it was virtually impossible to work at the EUI and its Robert Schuman Centre for Advanced Studies and NOT to study Europe and the EU. For somebody like me who had just begun research on the EU, the EUI turned out to be a most inspiring place. There is probably no other place in the world where your colleagues and your doctoral students, as well as the many postdocs and visitors, are focusing on Europe and European integration from a variety of disciplinary perspectives. 
Apart from working on Europeanization and the EU, I quickly became involved in another collaborative project when I moved to the EUI. I had barely arrived in Florence when Walter Carlsnaes of the University of Uppsala contacted me. He had been approached by Sage to edit a Handbook of International Relations, the first of its kind. We agreed to co-edit the book, together with Beth Simmons of Harvard University (Carlsnaes, Risse, and Simmons 2002; for the revised edition ten years later see Carlsnaes, Risse, and Simmons 2013).

Chapter 7 of this volume also pertains to research that started in Konstanz in the mid-1990s and then took off when I came to the EUI. This project - also funded by DFG - was inspired by social constructivist research about norms and ideas. My research associates - Daniela Engelmann-Martin, Hans-Joachim Knopf, and Klaus Roscher, who were joined at the EUI by Martin Marcussen and I began by mapping parliamentary debates about Europe and European integration in the UK, France, and Germany from the 1990s on. It quickly became obvious to us that ideas about European order could not be disentangled from questions of European identity: What we want in Europe depends a lot on who we are and how we see ourselves as Europeans.

Our research group then focused on identity discourses in the EU (Marcussen et al. 1999; Risse et al. 1999; Risse 2001). However, when one studies social identities as a political scientist, one needs help from other disciplines. I got together with political psychologist Richard Herrmann and social psychologist Marilynn Brewer from Ohio State University to look at the Europeanization of collective identities in more detail (Herrmann, Brewer, and Risse 2004; cf. chapter 7 , this volume). ${ }^{7}$

Questions of European identity continued to preoccupy me throughout the 2000s when I moved to the Freie Universität Berlin. My 2010 book A Community of Europeans? summarizes my own research and that of others on the Europeanization of national identities (Risse 2010; for a related attempt see Checkel and Katzenstein 2009). I looked at European identity both as a "dependent" and an "independent variable," so to speak. Frank Schimmelfennig recently summarized my work in three sentences: ${ }^{8}$

1 Risse is right in arguing that the Europeanization of identities (or lack thereof) explains EU member states' attitudes toward European integration to a large degree.

2 Risse is wrong in claiming that the EU and its institutions have a strong impact on the Europeanization of identities (see also Checkel 2005 on this point).

3 So, Risse has been right about $50 \%$ of the time!

A Community of Europeans? also summarizes research on the Europeanization of public spheres. In a way, this work combined my interest in Habermasian communicative action (see the next section), including his writings on public spheres (Habermas 1980 [1962]) with the scholarship on European identity. If there is such a community of Europeans, it should express itself politically in transnational 
public spheres. Fellow Europeans should be treated as legitimate speakers in the various national public spheres, and issue frames should be similar across public spaces so as to allow for cross-national debates (Kantner 2004; Kantner 2016; see also Wessler et al. 2008; Koopmans and Statham 2010; Statham and Trenz 2013). I started my first project on the Europeanization of public spheres at the EUI in Florence (with Bernd Giesen, a sociologist at the University of Konstanz, and Marianne van de Steeg, an EUI PhD researcher at the time). We conducted computer-aided content analyses of newspaper reporting in various EU member states with regard to the so-called Haider debate. In 2000, a right-wing populist party led by Jörg Haider had entered the Austrian government, leading to Europewide protests and a condemnation by the EU Council of Ministers (Risse 2002; Van de Steeg 2006).

In Berlin, I teamed up with Cathleen Kantner, a sociologist. We carried out media content analyses of newspapers in several EU member states (including Poland as a new member state) on questions of war and peace (Renfordt 2011; Kantner 2015, 2016). In 2011, I gathered U.S. and European scholars for a book project to analyze the state of the art with regard to the Europeanization of public spheres. At the time, the Euro crisis was in full swing and the authors were asked to evaluate how their findings were holding up in light of the crisis. The volume (Risse 2015b) showed that the various public spheres had become increasingly Europeanized over time. Moreover, the Euro crisis (and the recent migration challenges, I should add) led to an unprecedented politicization of EU policies at the various domestic levels with high degrees of polarization in the public spheres. We disagreed, however, on the likely consequences of politicization (see Grande and Kriesi 2015 and Risse 2015a for diverging views).

\section{From communicative action to limited statehood and the diffusion of ideas}

One contribution of the 1999 Power of Human Rights volume (Risse, Ropp, and Sikkink 1999) had been to specify causal mechanisms of norms change. This work profited significantly from a theoretical debate that preoccupied German IR scholars during the 1990s. It became known as the ZIB debate, named after the Germanlanguage IR journal Zeitschrift für Internationale Beziehungen, which was founded in 1994 (see Risse forthcoming). The ZIB debate represented a German version of the controversy between rational choice and constructivist approaches. Harald Müller's seminal contribution introduced Habermas's theory of communicative action (Habermas 1981, 1992) to the study of international politics and demonstrated its potential for the explanation of empirical phenomena in global affairs (Müller 1994; English version: Müller 2001). Müller suggested that actors do not only have strategic action repertoires at their disposal, but they can revert to what Habermas calls "communicative action," that is, communication geared toward deliberation and achieving a common understanding.

A rather heated discussion ensued to what extent rational choice can accommodate communicative action or not. Some argued that "cheap talk" models are 
able to take care of the ability of actors to truthfully signal their preferences (Schneider 1994; Keck 1995, 1997; Grobe 2010). "Habermasians" replied that talk is never cheap and that rationalist institutionalism has a hard time to accommodate practical discourses over norms and rules (e.g. Müller 1995; Risse-Kappen 1995c). Others formulated a middle ground between the two positions by accommodating some of the Habermasians' concerns within a broader understanding of rational choice (Zangl and Zürn 1996; Schimmelfennig 1997). Schimmelfennig in particular developed a theory of "rhetorical action" focusing on the strategic use of arguments and reasoning in order to further actors' interests (Schimmelfennig 2001, 2003).

This debate was largely confined to the German-speaking IR community (but see Crawford 2002). In 2000, I "translated" the ZIB debate into English by publishing my "Let's Argue!" piece in International Organization (Chapter 10, this volume). I used Gorbachev's agreement to NATO membership of unified Germany as well as transnational discourses over human rights as empirical illustrations. At the time, however, these were mere plausibility probes.

By the turn of the century, the debate between rational choice and social constructivism focusing on communicative action in the Habermasian sense had run its course. As a result, those interested in the logic of communicative action turned toward empirical research and investigated whether reasoning and deliberation actually mattered to account for outcomes of international negotiations. The empirical turn of research into the conditions and effects of communicative action and deliberation in world politics concentrated, first, on various sets of international negotiations and their outcomes (e.g. Prittwitz 1996; Lynch 1999; Risse, Ropp, and Sikkink 1999; Crawford 2002; Deitelhoff 2006, 2009; Holzscheiter 2010; see also Quantin and Smith 2013). The "deliberative turn" also reached EU studies, albeit a bit belatedly (see e.g. Joerges and Neyer 1997; Checkel 2001; Niemann 2004; Panke 2006; Risse and Kleine 2010; Neyer 2012).

Empirical research on arguing and deliberation moved from determining the extent to which arguments, reasons, and justification were given in various communication settings to establishing the effects of these deliberative communications. The research question that originally triggered the debate was reformulated: Which institutional scope conditions are conducive for arguing to matter in communicative settings and, thus, to affect both processes and outcomes? In this context, Vivien Schmidt has suggested an entire research program labeled "discursive institutionalism" (Schmidt 2002, 2008). (International) institutions are treated as discourse arenas that enable deliberative processes.

My research on communicative action in international relations had started in Konstanz, continued in Florence and still pre-occupied me when I returned to Germany in the fall of 2001 to the Freie Universität Berlin. But the move to Berlin also marked the beginning of a new interdisciplinary research program. My earlier work on human rights focused on the domestic impact of international norms, mainly in the global South. But it was still state-centric in the sense that the "target" of domestic change was the state and national government. While I worked on transnational relations, I did not consider non-state actors as "governors" (for this term see 
Avant, Finnemore, and Sell 2010) either in the transnational or in the domestic realms.

In the meantime, however, the "governance" paradigm had reached both comparative politics and the field of IR (see e.g. Czempiel and Rosenau 1992; Rhodes 1997; Pierre and Peters 2000; Mayntz 2002; Benz 2004). The governance concept allows us to shed light on the governance role of non-state actors as "governors" and to incorporate non-hierarchical modes of social coordination such as bargaining and communicative action. Our Collaborative Research Center 700 (Sonderforschungsbereich in German) "Governance in Areas of Limited Statehood" has been a twelve-year project (2006 to 2017) and generously funded - once again - by the DFG. ${ }^{9}$ More than twenty research projects investigate how and under what conditions governance can be effective and legitimate if central state institutions are too weak to be able to implement and enforce decisions and the law of the land. By whom and how can public services be provided and binding rules be implemented when statehood is weak and when - in some cases - even the state monopoly on the means of violence is lacking (see Risse and Lehmkuhl 2007; Risse 2011)? We submit that areas of limited statehood are not only the rule in the contemporary global South, but that they are actually the default condition in the current international system and in most of known history. That is, most people in the world - contemporary and in the past - have to cope with these conditions. Yet, areas of limited statehood are neither ungovernable nor ungoverned, as the literature on so-called failed states falsely implies (e.g. Rotberg 2003; Messner et al. 2015). Somebody - often non-state actors - always governs, and governance can even be effective and legitimate in many cases. For example, large parts of the quintessential failed state of Somalia are actually rather well-governed - even absent a functioning state (Menkhaus 2006/2007; Renders and Terlinden 2010; Richards 2014; Schäferhoff 2014). In other words, our research center challenges mainstream and Western-centric assumptions of modernization approaches and other theories (e.g. Fukuyama 2014). In addition, my article with Stephen Krasner argues that legitimacy as the "license to govern," i.e., the social acceptance of the "governors" by the local elites and peoples constitutes a necessary condition for effective governance in areas of limited statehood (chapter 8, this volume).

The "governance in areas of limited statehood" program also marked my continued research collaboration with Tanja (e.g. Börzel and Risse 2010, 2016a). In addition, the last chapter in this volume (chapter 11) reflects research cooperation, which Tanja and I have been carrying out in the framework of the Research College (Kolleg-Forschergruppe or KFG) "Transformative Power of Europe," funded by the DFG from 2008-2018. The KFG allowed us to invite senior scholars, postdoctoral fellows, and $\mathrm{PhD}$ researchers to work on questions of common interest. Theoretically, we centered our common endeavor on the spread of norms, institutions, and policies inside Europe and beyond, thereby linking up with the wider scholarly interest in transnational diffusion processes (see e.g. Solingen 2012; Gilardi 2013). In a way, and without labeling it as such, the 1994 article in International Organization (IO) (chapter 9, this volume) had already been about the diffusion of ideas. Moreover, 
my work on communicative action (chapter 10, this volume) focused on a particular diffusion mechanism, again implicitly at the time.

Europeanization also represents a particular case of diffusing policies and institutions. Tanja and I increasingly became interested in not just Europeanization but in the spread of European institutions and policy ideas to other regions of the world. The special issue of West European Politics (Börzel and Risse 2012; chapter 11, this volume) represents our transition from Europeanization research toward the study of diffusion of regional institutions and governance practices and to comparative regionalism more generally. This also allowed us to "de-center" Europe and to analyze European integration as just one instance of regional cooperation and integration among many others. This turn from Europeanization to comparative regionalism has now led to the publication of the Oxford Handbook of Comparative Regionalism (Börzel and Risse 2016b), the first of its kind.

\section{Conclusions: Where to go from here and lessons learned}

This book reflects an intellectual journey that started with research on the domestic fabric of (West) German foreign and security policy in the 1980s and continued with studies on the transatlantic security community and the "democratic peace"; on transnational relations, international norms, and communicative action; and on the domestic impact of international human rights during the 1990s. Over the past fifteen years, I became more and more interested in the global South, focusing on the governance problematique in areas of limited statehood. At the same time, and from the mid-1990s on, I also studied Europeanization and domestic change, European identities and public spheres, and - most recently - the diffusion of regional cooperation and integration.

While this looks like a pretty disparate and even eclectic research agenda, there are three streams of inquiry that hold these various empirical strands together, namely

- a strong focus on domestic politics and domestic institutions, in terms of both "from the inside out" and "from the outside in" perspectives on international relations; ${ }^{10}$

- $\quad$ an emphasis on non-state actors and transnational relations both as affecting state interactions and as "governors" in their own right; and

- an interest in the diffusion of international norms and ideas with particular attention to the mechanisms and the domestic-international linkages in these diffusion processes.

So, where to go from here? I submit that we still know little about processes of international norm diffusion and their transformation in domestic practices. The "spiral model" of human rights change represented a first attempt at theorizing these processes, but it assumed that the content of human rights norms and their understandings remained stable when being transferred from international treaties 
into domestic practices (for a critique see Wiener 2008). Acharya has called this process "localization" (Acharya 2004), but his work tends to privilege the domestic over the international. Translation approaches in cultural studies (e.g. Bachmann-Medick 2014) remind us that the diffusion of norms and ideas from one socio-cultural context into another changes the meaning of these norms and ideas. In other words, selective adoption and appropriation are likely diffusion outcomes. Yet, translation studies tend to be rather underspecified with regard to the scope conditions of norm adoption and transformation. Which diffusion mechanisms lead to which outcomes? Is it all a question of domestic and international power and/or of setting the right incentives for instrumentally rational actors? What role do socialization, persuasion, and communicative action play? Do regime type and degrees of (limited) statehood matter, and in what way? To what extent do diffusion processes vary with regard to issue-areas (e.g. human rights, environment, security, economy, etc.)? The journey continues.

Finally, are there any lessons learned? I want to point out three. The first concerns motivations. While my work has been empirical-analytical and I have stuck to conventional methodologies of "normal (political) science," vation as a scholar has been informed by normative concerns from the very beginning: ${ }^{12}$ I started out as a peace researcher in Frankfurt. I then focused on human rights in order to accumulate knowledge useful for the improvement of rights of individuals and human dignity. As a European, I still consider the EU a huge achievement after centuries of European warfare, which is worth preserving. Last not least, the research on areas of limited statehood is motivated by concerns about how to make governance more effective and more legitimate in countries in which state institutions lack the capacity to deliver public goods and services. I strongly believe that one cannot and should not become a social scientist without having at least some normative motivations.

Second, real world events matter hugely. Of course, a lot of social science research in an ever more specialized scholarly environment is driven by internal theoretical and methodological developments. For example, the social constructivist mantra of the early 1990s - "norms matter" - sounds rather out of place in the 2010s when we are dealing with norm contestation, norm robustness, and the like. Yet, if we do not pay attention to what is going on in the real world, we should not become social scientists. As to my own career, the Cold War and its peaceful ending had a decisive impact on both my empirical concerns and my theoretical development. The terrorist attacks on the World Trade Center on $9 / 11 / 2001$ also had an impact, albeit more indirectly. As a result, a lot of political and scholarly attention focused on so-called "failed states" from the early 2000 s on. My own research on "areas of limited statehood" reflects these concerns but takes a rather critical attitude toward the Western-centric mainstream. Last not least, the financial and economic crisis leading to the Euro crisis (and now the migration challenges) during the late 2000s and early 2010s hit while I was completing my books on European identity and European public spheres. The crises have become a real-life test of whether my (rather optimistic) claims hold under stress. 
Third, this chapter and the articles in this volume are all about my research, but there is a hidden story about my scholarship that must be mentioned. It concerns my teaching, which I have always enjoyed. Starting at the University of Wyoming in 1992, I have taught the "Introduction to International Relations" to undergraduate students ever since. The syllabus has changed tremendously over the years. Yet, engaging a large class of bright undergraduates has always been fun, particularly when students take a critical attitude and hammer me with questions for which I do not have good answers.

Moreover, teaching is not a one-way street. To begin with, I cannot teach something that I have not understood myself. Smart students will always call my bluff. Moreover, teaching is about bouncing off ideas and getting instant critical feedback. I cannot pinpoint it, but I am sure that my writings have been strongly influenced by my students. This is particularly true with regard to $\mathrm{PhD}$ training. I have learned at least as much from my doctoral students as they (hopefully) learned from me. This concerns empirical themes about which I did not know anything, but also theoretical and methodological questions. Examples include Foucault's discourse theory, informal governance in the EU, feminist approaches to IR, science and technology studies, translation studies, nonWestern approaches to IR, but also working with data sets and large-n statistical analyses as well as employing computer-aided content analyses. So, a huge thank you is in order to my PhD researchers with whom I had the honor and pleasure to work over the years!

\section{Notes}

$1 \mathrm{https} / /$ en.wikipedia.org/wiki/Thomas_Risse (last visited Jan. 5, 2016).

2 I am extremely grateful to Federica Bicchi, Tanja A. Börzel, and Mark Pollack for their excellent comments on this essay.

3 It was Czempiel who suggested publishing my dissertation work in two books, primarily because he refused to read a thesis of more than 300 pages. . .

4 Among them were Bob Herman, Christine Ingebritsen, Beth Kier, Audie Klotz, Sarah Mendelson, Richard Price, Chris Reus-Smit, Nina Tannenwald, and Dan Thomas, most of whom are now teaching at U.S. universities and around the globe.

5 I got to know Russett in the 1980s because he was an advisor to the U.S. Catholic bishops in matters of nuclear deterrence. We got together at various German-American conferences on questions of nuclear ethics.

$6 \mathrm{I}$ kept to my conviction even in January 1990. I was just back at Cornell from Germany. In a packed room with Cornell students and faculty, Peter Katzenstein and I argued against the entire crowd that German unification would take a long time and was laden with problems and difficulties.

7 This project also told me how not to do interdisciplinary research. During our first meeting at Ohio State University, we asked participants how they defined social identity. A huge controversy over ontological and epistemological issues ensued which led nowhere. We then hit the "reset button" and asked them what they thought they knew empirically about European identities. This led to most fruitful crossdisciplinary exchanges.

8 At the "Re-Reading Risse" workshop in Berlin, December 18-19, 2015.

9 See http://www.sfb-governance.de/en/index.html (last visited Jan. 30, 2016).

10 For an early argument see Müller and Risse-Kappen 1993. 
11 I have to admit that I have never been particularly interested in the various epistemological debates that have swept through the field of IR every once in a while.

12 I thank Ingo Peters for pointing this out to me at the "Re-Reading Risse" workshop. In fact, my Catholic upbringing might have to do with it, too.

\section{References}

Acharya, Amitav. 2004. How Ideas Spread: Whose Norms Matter? Norm Localization and Institutional Change in Asian Regionalism. International Organization 58 (2): 239-275.

Adler, Emanuel, and Michael Barnett, eds. 1998. Security Communities. Cambridge: Cambridge University Press.

Anderson, Jeffrey J., G. John Ikenberry, and Thomas Risse, eds. 2008. The End of the West? Crisis and Change in the Atlantic Order. Ithaca, NY: Cornell University Press.

Avant, Deborah, Martha Finnemore, and Susan K. Sell. 2010. Who Governs the Globe? In Who Governs the Globe?, edited by Deborah Avant, Martha Finnemore and Susan K. Sell. Cambridge, UK: Cambridge University Press, 1-31.

Bachmann-Medick, Doris, ed. 2014. The Trans/National Study of Culture: A Translational Perspective. Berlin: De Gruyter.

Benz, Arthur. 2004. Governance - Regieren in komplexen Regelsystemen. Wiesbaden: VS Verlag für Sozialwissenschaften.

Böckle, Franz, and Gert Krell, eds. 1984. Politik und Ethik der Abschreckung. MainzMünchen: Grünewald-Kaiser.

Börzel, Tanja A., and Thomas Risse. 2010. Governance Without a State - Can It Work? Regulation and Governance 4 (2): 1-22.

- eds. 2012. From Europeanization to Diffusion. Special Issue of West European Politics 35 (1): 1-19.

. 2016a. Dysfunctional State Institutions, Trust, and Governance in Areas of Limited Statehood. Regulation and Governance 10: 149-160.

- eds. 2016b. The Oxford Handbook of Comparative Regionalism. Oxford: Oxford University Press.

Brysk, Alison. 2013. Changing Hearts and Minds: Sexual Politics and Human Rights. In The Persistent Power of Human Rights: From Commitment to Compliance, edited by Thomas Risse, Stephen C. Ropp and Kathryn Sikkink. Cambridge, UK: Cambridge University Press, 259-274.

Bueno de Mesquita, Bruce, and David Lalman. 1992. War and Reason. New Haven, CT: Yale University Press.

Bueno de Mesquita, Bruce, James D. Morrow, Randolph M. Siverson, and Alistair Smith. 1999. An Institutional Explanation of the Democratic Peace. American Political Science Review 93 (4): 791-807.

Carlsnaes, Walter, Thomas Risse, and Beth Simmons, eds. 2002. Handbook of International Relations. London: Sage.

Carlsnaes, Walter, Thomas Risse, and Beth A. Simmons, eds. 2013. Handbook of International Relations, Second Edition. London: Sage.

Checkel, Jeffrey T. 1997. International Norms and Domestic Politics: Bridging the RationalistConstructivist Divide. European Journal of International Relations 3 (4): 473-495.

. 2001. Why Comply? Social Learning and European Identity Change. International Organization 55 (3): 553-588.

$\longrightarrow$, ed. 2005. International Institutions and Socialization in Europe: Special Issue of International Organization. Cambridge: Cambridge University Press.

Checkel, Jeffrey T., and Peter J. Katzenstein, eds. 2009. European Identity. Cambridge, UK: Cambridge University Press. 
Cowles, Maria Green, James A. Caporaso, and Thomas Risse, eds. 2001. Transforming Europe: Europeanization and Domestic Change. Ithaca, NY: Cornell University Press.

Crawford, Neta C. 2002. Argument and Change in World Politics: Ethics, Decolonization, and Humanitarian Intervention. Cambridge, UK: Cambridge University Press.

Czempiel, Ernst-Otto. 1979. Amerikanische Außenpolitik. Stuttgart: Kohlhammer.

. 1986. Friedensstrategien: Systemwandel durch internationale Organisationen, Demokratisierung und Wirtschaft. Paderborn: Schöningh.

Czempiel, Ernst-Otto, and James Rosenau, eds. 1992. Governance Without Government: Order and Change in World Politics. Cambridge, UK: Cambridge University Press.

Deitelhoff, Nicole. 2006. Überzeugung in der Politik. Grundzüge einer Diskurstheorie internationalen Regierens. Frankfurt/Main: Suhrkamp Taschenbuch Wissenschaft.

2009. The Discursive Process of Legalization: Charting Islands of Persuasion in the ICC Case. International Organization 63 (1): 33-65.

Deitelhoff, Nicole, and Klaus Dieter Wolf. 2013. Business and Human Rights: How Corporate Norm Violators Become Norm Entrepreneurs. In The Persistent Power of Human Rights: From Commitment to Compliance, edited by Thomas Risse, Stephen C. Ropp and Kathryn Sikkink. Cambridge, UK: Cambridge University Press, 222-238.

Deutsch, Karl W., Sidney A. Burell, Robert A. Kann, Jr., Maurice Lee, Martin Lichterman, Raymond E. Lindgren, Francis L. Loewenheim, and Richard W. van Wagenen. 1957. Political Community and the North Atlantic Area: International Organization in the Light of Historical Experience. Princeton, NJ: Princeton University Press.

Easton, David. 1965. A Systems Analysis of Political Life. New York: Wiley \& Sons.

Featherstone, Keith, and Claudio Radaelli, eds. 2003. The Politics of Europeanization. Oxford: Oxford University Press.

Finnemore, Martha. 1996a. Constructing Norms of Humanitarian Intervention. In The Culture of National Security: Norms and Identity in World Politics, edited by Peter J. Katzenstein. New York: Columbia University Press, 153-185.

. 1996b. National Interests in International Society. Ithaca: Cornell University Press.

Fukuyama, Francis. 2014. Political Order and Political Decay: From the Industrial Revolution to the Globalization of Democracy. New York: Farrar, Straus and Giroux.

Geis, Anna, Harald Müller, and Niklas Schörnig, eds. 2013. The Militant Face of Democracy: Liberal Forces for Good. Cambridge, UK: Cambridge University Press.

Gilardi, Fabrizio. 2013. Transnational Diffusion: Norms, Ideas, and Policies. In Handbook of International Relations, Second Edition, edited by Walter Carlsnaes, Thomas Risse and Beth Simmons. London: Sage, 453-477.

Gourevitch, Peter. 1978. The Second Image Reversed: The International Sources of Domestic Politics. International Organization 32 (4): 881-912.

Grande, Edgar, and Hanspeter Kriesi. 2015. The Re-Structuring of Political Conflict in Europe and the Politicization of European Integration. In European Public Spheres: Politics Is Back, edited by Thomas Risse. Cambridge, UK: Cambridge University Press, 190-225.

Gränzer, Sieglinde. 1999. Changing Discourse: Transnational Advocacy Networks in Tunisia and Morocco. In The Power of Human Rights: International Norms and Domestic Change, edited by Thomas Risse, Stephen C. Ropp and Kathryn Sikkink. Cambridge: Cambridge University Press, 109-133.

Grobe, Christian. 2010. The Power of Words: Argumentative Persuasion in International Negotiations. European Journal of International Relations 16 (1): 5-29.

Habermas, Jürgen. 1980 (1962). Strukturwandel der Öffentlichkeit. Untersuchungen zu einer Kategorie der bürgerlichen Gesellschaft. Darmstadt - Neuwied: Luchterhand. 1981. Theorie des kommunikativen Handelns. 2 vols. Frankfurt/Main: Suhrkamp. 1992. Faktizität und Geltung. Beiträge zur Diskurstheorie des Rechts und des demokratischen Rechtsstaats. Frankfurt/Main: Suhrkamp. 
Hafner-Burton, Emilie M. 2008. Sticks and Stones: Naming and Shaming the Human Rights Enforcement Problem. International Organization 62 (4): 689-716.

. 2013. Making Human Rights a Reality. Princeton, NJ: Princeton University Press.

Hafner-Burton, Emilie M., and James Ron. 2009. Seeing Double: Human Rights Impact Through Qualitative and Quantitative Eyes. World Politics 61 (2): 360-401.

Hall, Peter, and David Soskice, eds. 2001. Varieties of Capitalism: The Institutional Foundations of Comparative Advantage. Oxford, UK: Oxford University Press.

Hall, Peter A., and Rosemary C. R. Taylor. 1996. Political Science and the Three New Institutionalisms. Political Studies 44 (5): 952-973.

Herrmann, Richard K., Marilynn Brewer, and Thomas Risse, eds. 2004. Transnational Identities: Becoming European in the EU. Lanham, MD: Rowman \& Littlefield.

Holzscheiter, Anna. 2010. Children's Rights in International Politics: The Transformative Power of Discourse. Houndmills, Basingstoke: Palgrave Macmillan.

Hopgood, Stephen. 2013. The Endtimes of Human Rights. Ithaca, NY: Cornell University Press.

Jetschke, Anja. 1999. Linking the Unlinkable? International Norms and Nationalism in Indonesia and the Philippines. In The Power of Human Rights: International Norms and Domestic Change, edited by Thomas Risse, Stephen C. Ropp and Kathryn Sikkink. Cambridge: Cambridge University Press, 134-171.

. 2010. Human Rights and State Security: Indonesia and the Philippines. University Park, PA: Penn State Press.

Jo, Hyeran, and Katherine Bryant. 2013. Taming of the Warlords: Commitment and Compliance by Armed Opposition Groups in Civil Wars. In The Persistent Power of Human Rights: From Commitment to Compliance, edited by Thomas Risse, Stephen C. Ropp and Kathryn Sikkink. Cambridge, UK: Cambridge University Press, 239-274.

Joerges, Christian, and Jürgen Neyer. 1997. Transforming Strategic Interaction into Deliberative Problem-Solving: European Comitology in the Foodstuffs Sector. Journal of European Public Policy 4: 609-625.

Kantner, Cathleen. 2004. Kein modernes Babel. Kommunikative Voraussetzungen europäischer Öffentlichkeit. Wiesbaden: VS Verlag für Sozialwissenschaften.

- 2015. National Media as Transnational Discourse Arenas: The Case of Humanitarian Military Interventions. In European Public Spheres: Politics Is Back, edited by Thomas Risse. Cambridge, UK: Cambridge University Press, 84-107.

.2016. War and Intervention in the Transnational Public Sphere: Problem-Solving and European Identity-Formation, Routledge/UACES Contemporary European Studies. Abingdon: Routledge.

Katzenstein, Peter J., ed. 1978. Between Power and Plenty: Foreign Economic Policies of Advanced Industrial States. Madison: Wisconsin University Press.

- 1985. Small States in World Markets: Industrial Policy in Europe. Ithaca - London: Cornell University Press.

- ed. 1996. The Culture of National Security: Norms and Identity in World Politics. New York: Columbia University Press.

Keck, Margaret E., and Kathryn Sikkink. 1998. Activists Beyond Borders: Advocacy Networks in International Politics. Ithaca, NY: Cornell University Press.

Keck, Otto. 1995. Rationales kommunikatives Handeln in den internationalen Beziehungen. Ist eine Verbindung von Rational-Choice-Theorie und Habermas' Theorie des kommunikativen Handelns möglich? Zeitschrift für Internationale Beziehungen 2 (1): 5-48.

- 1997. Zur sozialen Konstruktion des Rational-Choice-Ansatzes. Einige Klarstellungen zur Rationalismus-Konstruktivismus-Debatte. Zeitschrift für Internationale Beziehungen 4 (1): 139-151.

Keohane, Robert O., and Joseph S. Nye, Jr., eds. 1971. Transnational Relations and World Politics. Cambridge, MA: Harvard University Press.

Kinzelbach, Katrin. 2013. Resisting the Power of Human Rights: The People's Republic of China. In The Persistent Power of Human Rights: From Commitment to Compliance, 
edited by Thomas Risse, Stephen C. Ropp and Kathryn Sikkink. Cambridge, UK: Cambridge University Press, 164-181.

Koopmans, Ruud, and Paul Statham, eds. 2010. The Making of a European Public Sphere: The Europeanisation of Media Discourse and Political Contention. Cambridge, UK: Cambridge University Press.

Kratochwil, Friedrich, and John G. Ruggie. 1986. International Organization: A State of the Art on an Art of the State. International Organization 40 (4): 753-775.

Kratochwil, Friedrich V. 1989. Rules, Norms, and Decisions: On the Conditions of Practical and Legal Reasoning in International Relations and Domestic Affairs. Cambridge: Cambridge University Press.

Lebow, Richard N., and Thomas Risse-Kappen, eds. 1995. International Relations Theory and the End of the Cold War. New York: Columbia University Press.

Lynch, Marc. 1999. State Interests and Public Spheres: The International Politics of Jordanian Identity. New York: Columbia University Press.

Marcussen, Martin, Thomas Risse, Daniela Engelmann-Martin, Hans-Joachim Knopf, and Klaus Roscher. 1999. Constructing Europe: The Evolution of French, British, and German Nation-State Identities. Journal of European Public Policy 6 (4): 614-633.

Mayntz, Renate. 2002. Common Goods and Governance. In Common Goods. Reinventing European and International Governance, edited by Adrienne Heritier. Lanham, MD: Rowman \& Littlefield, 15-27.

Menkhaus, Ken. 2006/2007. Governance without Government in Somalia: Spoilers, State Building, and the Politics of Coping. International Security 31 (3): 74-106.

Messner, J. J., Nate Haken, Patricia Taft, Hannah Blyth, Kendall Lawrence, Sebastian Pavlou, and Felipe Umaña. 2015. Fragile States Index: The Book. Washington, DC: The Fund for Peace.

Müller, Harald. 1994. Internationale Beziehungen als kommunikatives Handeln. Zur Kritik der utilitaristischen Handlungstheorien. Zeitschrift für Internationale Beziehungen 1 (1): 15-44.

- 1995. Spielen hilft nicht immer. Die Grenzen des Rational-Choice-Ansatzes und der Platz der Theorie kommunikativen Handelns in der Analyse internationaler Beziehungen. Zeitschrift für Internationale Beziehungen 2 (2): 371-391.

- 2001. International Relations as Communicative Action. In Constructing International Relations: The Next Generation, edited by Karin M. Fierke and Knud Erik Jorgensen. Armonk, NY: M.E. Sharpe, 160-178.

. 2002. Antinomien des demokratischen Friedens. Politische Vierteljahresschrift 43 (1): 46-81.

Müller, Harald, and Thomas Risse-Kappen. 1993. From the Outside In and the Inside Out: International Relations, Domestic Politics, and Foreign Policy. In The Limits of State Autonomy: Societal Groups and Foreign Policy Formulation, edited by Valerie Hudson and David Skidmore. Boulder, CO: Westview, 25-48.

Neyer, Jürgen. 2012. The Justification of Europe: A Political Theory of Supranational Integration. Oxford: Oxford University Press.

Niemann, Arne. 2004. Between Communicative Action and Strategic Action: The Article 113 Committee and the Negotiations on the WTO Basic Telecommunications Services Agreement. Journal of European Public Policy 11 (3): 379-407.

Olsen, Johan P. 2002. The Many Faces of Europeanization. Journal of Common Market Studies 40 (5): 921-952.

Onuf, Nicholas. 1989. World of Our Making: Rules and Rule in Social Theory and International Relations. Columbia, SC: University of South Carolina Press.

Owen, John M. 1994. How Liberalism Produces Democratic Peace. International Security 19 (2): 87-125.

1997. Liberal Peace, Liberal War: American Politics and International Security. Ithaca, NY: Cornell University Press. 
Panke, Diana. 2006. More Arguing Than Bargaining? The Institutional Design of the European Convention and Intergovernmental Conferences Compared. Journal of European Integration 28 (4): 357-379.

Pierre, J., and B. Guy Peters. 2000. Governance, Politics, and the State. London: Macmillan.

Posner, Eric A. 2014. The Twilight of Human Rights Law. Oxford: Oxford University Press.

Prittwitz, Volker von, ed. 1996. Verhandeln und Argumentieren. Dialog, Interesse und Macht in der Umweltpolitik. Opladen: Westdeutscher Verlag.

Puchala, Donald J. 1972. Of Blind Men, Elephants, and International Integration. Journal of Common Market Studies 10 (3): 267-284.

Quantin, Patrick, and Andy Smith. 2013. Risse's Deliberative Logic and Governance: A Critical Engagement. Critical Policy Studies 7 (3): 263-272.

Radaelli, Claudio M., and Romain Pasquier. 2006. Conceptual Issues. In Handbook of Europeanization: New Research Agendas, edited by Paolo Graziano and Maarten P. Vink. Houndmills: Palgrave, 35-45.

Renders, Marleen, and Ulf Terlinden. 2010. Negotiating Statehood in a Hybrid Political Order: The Case of Somaliland. Development and Change 41 (4): 723-746.

Renfordt, Swantje. 2011. Framing the Use of Force: An International Rule of Law in Media Reporting - A Comparative Analysis of Western Media Debates about Military Intervention, 1990-2005. Baden-Baden: Nomos.

Rhodes, R. A. W. 1997. Understanding Governance: Policy Networks, Governance, Reflexivity and Accountability. Buckingham and Philadelphia: Open University Press.

Richards, Rebecca. 2014. Understanding Statebuilding: Traditional Governance and the Modern State in Somaliland. Farnham: Ashgate.

Risse, Thomas. 2001. A European Identity? Europeanization and the Evolution of NationState Identities. In Transforming Europe: Europeanization and Domestic Change, edited by Maria Green Cowles, James A. Caporaso and Thomas Risse. Ithaca, NY: Cornell University Press, 198-216.

. 2002. Zur Debatte um die (Nicht-) Existenz einer europäischen Öffentlichkeit. Was wir wissen und wie es zu interpretieren ist. Berliner Debatte Initial 13 (5-6): 15-23.

2010. A Community of Europeans? Transnational Identities and Public Spheres. Ithaca, NY: Cornell University Press.

- ed. 2011. Governance without a State? Policies and Politics in Areas of Limited Statehood. New York, NY: Columbia University Press.

- 2015a. European Public Spheres, the Politicization of EU Affairs, and Its Consequences. In European Public Spheres: Politics Is Back, edited by Thomas Risse. Cambridge, UK: Cambridge University Press, 141-164.

, ed. 2015b. European Public Spheres: Politics Is Back. Cambridge, UK: Cambridge University Press.

- 2016. The Transatlantic Security Community? Erosion from Within? In Transatlantic Relations in an Era of Transition: Europe and America in a Multipolar World, edited by John Peterson, Riccardo Alcaro and Natalie Tocchi. Houndmills, Basingstoke: Palgrave Macmillan, 21-42.

. forthcoming. Arguing and Deliberation in International Relations. In Oxford Handbook of Deliberative Democracy, edited by André Bächtiger, John Dryzek, Jane Mansbridge and Marc E. Warren. Oxford: Oxford University Press.

Risse, Thomas, Daniela Engelmann-Martin, Hans Joachim Knopf, and Klaus Roscher. 1999. To Euro or Not to Euro: The EMU and Identity Politics in the European Union. European Journal of International Relations 5 (2): 147-187.

Risse, Thomas, and Mareike Kleine. 2010. Deliberation in Negotiations. Journal of European Public Policy 17 (5): 708-726.

Risse, Thomas, and Ursula Lehmkuhl, eds. 2007. Regieren ohne Staat? Governance in Räumen begrenzter Staatlichkeit. Baden-Baden: Nomos. 
Risse, Thomas, Stephen C. Ropp, and Kathryn Sikkink, eds. 1999. The Power of Human Rights: International Norms and Domestic Change. Cambridge: Cambridge University Press.

, eds. 2013. The Persistent Power of Human Rights: From Commitment to Compliance. Cambridge, UK: Cambridge University Press.

Risse-Kappen, Thomas. 1988a. Die Krise der Sicherheitspolitik. Neuorientierungen und Entscheidungsprozesse im politischen System der Bundesrepublik Deutschland, 1977_ 1984. Mainz - München: Kaiser - Grünewald.

. 1988b. The Zero Option: INF, West Germany, and Arms Control. Boulder, CO: Westview.

1989. Reflections on the German Puzzle. Peace and Security: Canadian Institute for International Peace and Security 4 (4): 8-9.

. 1991. Did 'Peace Through Strength' End the Cold War? Lessons from INF. International Security 16 (1): 162-188.

- ed. 1995a. Bringing Transnational Relations Back In: Non-State Actors, Domestic Structures, and International Institutions. Cambridge: Cambridge University Press.

- 1995b. Cooperation Among Democracies: The European Influence on U.S. Foreign Policy. Princeton, NJ: Princeton University Press.

- 1995c. Reden ist nicht billig. Zur Debatte um Kommunikation und Rationalität. Zeitschrift für Internationale Beziehungen 2 (1): 171-184.

. 1996. Exploring the Nature of the Beast: International Relations Theory and Comparative Policy Analysis Meet the European Union. Journal of Common Market Studies 34 (1): 53-80.

Rotberg, Robert I., ed. 2003. State Failure and State Weakness in a Time of Terror. Washington, DC: Brookings Institution Press.

Russett, Bruce. 1990. Controlling the Sword: The Democratic Governance of National Security. Cambridge, MA: Harvard University Press.

- 1993. Grasping the Democratic Peace: Principles for a Post-Cold War World. Princeton, NJ: Princeton University Press.

Russett, Bruce, and John R. Oneal. 2001. Triangulating Peace: Democracy, Interdependence, and International Organizations, the Norton Series in World Politics. New York London: W. W. Norton.

Sarotte, Mary E. 2009 (1989). The Struggle to Create Post-Cold War Europe. Princeton, NJ: Princeton University Press.

Schäferhoff, Marco. 2014. External Actors and the Provision of Public Health Services in Somalia - Task Complexity Matters. Governance 27 (4): 675-695.

Schimmelfennig, Frank. 1997. Rhetorisches Handeln in der internationalen Politik. Zeitschrift für internationale Beziehungen 4 (2): 219-254.

- 2001. Liberal Norms, Rhetorical Action, and the Enlargement of the EU. International Organization 55 (1): 47-80.

. 2003. The EU, NATO, and the Integration of Europe: Rules and Rhetoric. Cambridge: Cambridge University Press.

Schmidt, Vivien A. 2002. Does Discourse Matter in the Politics of Welfare Adjustment? Comparative Political Studies 35 (2): 168-193.

2008. Discursive Institutionalism: The Explanatory Power of Ideas and Discourse. Annual Review of Political Science 11: 303-326.

Schmitz, Hans Peter. 1999. Transnational Activism and Political Change in Kenya and Uganda. In The Power of Human Rights: International Norms and Domestic Change, edited by Thomas Risse, Stephen C. Ropp and Kathryn Sikkink. Cambridge: Cambridge University Press, 39-77.

- 2006. Transnational Mobilization and Domestic Regime Change: Africa in Comparative Perspective. Houndmills: Palgrave Macmillan.

Schneider, Gerald. 1994. Rational Choice und kommunikatives Handeln. Eine Replik auf Harald Müller. Zeitschrift für Internationale Beziehungen 1 (2): 357-366. 
Sikkink, Kathryn. 2013. The United States and Torture: Does the Spiral Model Work? In The Persistent Power of Human Rights: From Commitment to Compliance, edited by Thomas Risse, Stephen C. Ropp and Kathryn Sikkink. Cambridge, UK: Cambridge University Press, 145-163.

Simmons, Beth A. 2009. Mobilizing for Human Rights: International Law in Domestic Politics. Cambridge: Cambridge University Press.

2013. From Ratification to Compliance: Quantitative Evidence on the Spiral Model. In The Persistent Power of Human Rights: From Commitment to Compliance, edited by Thomas Risse, Stephen C. Ropp and Kathryn Sikkink. Cambridge, UK: Cambridge University Press, 43-59.

Solingen, Etel. 2012. Of Dominoes and Firewalls: The Domestic, Regional, and Global Politics of International Diffusion. International Studies Quarterly 56: 631-644.

Statham, Paul, and Hans-Jörg Trenz. 2013. The Politicization of Europe: Contesting the Constitution in the Mass Media. London: Routledge.

Steinmo, Sven, Kathleen Thelen, and Frank Longstreth, eds. 1992. Structuring Politics: Historical Institutionalism in Comparative Analysis. Cambridge - New York: Cambridge University Press.

Thomas, Daniel C. 2001. The Helsinki Effect: International Norms, Human Rights, and the Demise of Communism. Princeton, NJ: Princeton University Press.

Van de Steeg, Marianne. 2006. Does a Public Sphere Exist in the European Union? An Analysis of the Content of the Debate on the Haider Case. European Journal of Political Research 45 (4): 609-634.

Waltz, Kenneth N. 1979. Theory of International Politics. Reading, MA: Addison-Wesley.

Wendt, Alexander. 1987. The Agent-Structure Problem in International Relations Theory. International Organization 41 (3): 335-370.

1992. Anarchy Is What States Make of It: The Social Construction of Power Politics. International Organization 88 (2): 384-396.

Wessler, Hartmut, Bernhard Peters, Michael Brüggemann, Katharina Kleinen von Königslow, and Stefanie Sifft. 2008. Transnationalization of Public Spheres, Transformations of the State. Houndmills, Basingstoke - New York: Palgrave Macmillan.

Wiener, Antje. 2008. The Invisible Constitution of Politics: Contested Norms and International Encounters. Cambridge, UK: Cambridge University Press.

Zangl, Bernhard, and Michael Zürn. 1996. Argumentatives Handeln bei internationalen Verhandlungen. Moderate Anmerkungen zur post-realistischen Debatte. Zeitschrift für Internationale Beziehungen 3 (2): 341-366. 


\section{Part I}

\section{From the inside out}

The domestic politics of international relations 
$\because$ Taylor \& Francis

Taylor \& Francis Group

http://taylorandfrancis.com 


\title{
2 Public opinion, domestic structure, and foreign policy in liberal democracies (1991)
}

\author{
Thomas Risse-Kappen*
}

\section{Introduction}

How is it to be explained that similarly powerful states more often than not respond differently to the same international conditions and constraints? Efforts to answer this question lead inevitably to the study of the domestic sources of foreign policy and international politics. One issue, though, is rarely addressed by the available literature: Who is in charge of the foreign policy-making process in liberal democratic states? Elites or masses? Who influences whom? What is the policy impact of societal actors and public opinion? Are public attitudes on foreign affairs manipulated by the elites? Finally, if public attitudes follow similar patterns, what accounts for differences between various countries in the policy impact of public opinion?

This paper tries to shed light on the relationship between public opinion and the foreign policy of liberal democracies. ${ }^{1}$ I will argue that the policy impact of public opinion does not depend so much on the specific issues involved or on the particular pattern of public attitudes as on the domestic structure and the coalition-building processes in the respective country. The paper analyzes the impact of public opinion on the foreign policy-making process in four liberal democracies with distinct domestic structures: the United States, France, the Federal Republic of Germany, and Japan. I will show that differences in political institutions, policy networks, and societal structures account for different foreign policy outcomes when the impact of the international environment is controlled for and public attitudes follow similar patterns across countries. Thus, the four countries responded differently to Soviet policies during the 1980s despite more or less comparable trends in mass public opinion. The analysis of the interaction between public opinion and elite coalition-building processes in the four countries reveals that the policy outcomes differ according to variances in domestic structures and not in the international status of the states.

\section{Public opinion and foreign policy: Theoretical concepts and methodological problems}

\section{Who follows whom? Elites and masses}

Most of the available literature on the interaction between mass public opinion and elites in the foreign policy-making process of liberal democracies can be categorized according to two broad concepts. ${ }^{2}$ In accordance with the pluralist 
theory of democracy, a "bottom-up" approach assumes that the general public has a measurable and distinct impact on the foreign policy-making process. ${ }^{3}$ In sum, leaders follow masses. However, the bottom-up concept is difficult to reconcile with the following empirical counterevidence:

-In Western Europe, the U.S., and Japan, elites and masses show similar support for basic foreign policy goals and institutions. Prevailing political, religious, and ideological cleavages structure elite as well as mass public opinion. ${ }^{4}$

- There are many cases in which crucial foreign policy decisions have been taken in the absence of mass public consensus. Examples are the U.S. decisions in favor of an active international role in the postwar world and of becoming permanently involved in European security affairs; the West German decisions to rearm and join nato in the early 1950s and to pursue an active Ostpolitik in the late 1960s; the French decisions to build an independent nuclear force in the 1950s and to leave nato's military institutions in the mid-1960s.

Therefore, a second approach representing the conventional wisdom in the literature suggests a "top-down" process, according to which popular consensus is a function of the elite consensus and elite cleavages trickle down to mass public opinion. This viewpoint concurs with either a "power elite" (C. Wright Mills) or a state-centered and realist approach to foreign policy. It is assumed that the public is easily manipulated by political leaders, because of (1) the low salience, or significance, of foreign and security policy issues as compared with economic policies, (2) the low degree of knowledge about the issues involved, and (3) the volatility of public opinion. ${ }^{5}$

Again, empirical evidence suggests that these assumptions are questionable:

- While only a minority can be regarded as politically active, large portions of the public seem regularly to follow news about foreign policy in the media. ${ }^{6}$ While domestic problems usually outweigh foreign and security issues in public salience, data reveal that substantial minorities consider foreign affairs among the most important problems facing their respective countries. On the average, 20-30 percent of the public indicate serious concern about foreign affairs. ${ }^{7}$

-Public attitudes, at least on basic foreign policy issues, seem to be more stable than is usually assumed. A large percentage of the public does not change attitudes frequently. In sum, the public seems to be more rational and less open to elite manipulation than the top-down thesis asserts. ${ }^{8}$

- That leaders try to manipulate masses and that governments launch sophisticated propaganda campaigns only suggest that the elites take the power of the uneducated masses seriously and feel vulnerable to it. The very existence of state propaganda and efforts at "spin control" belies the "power elite" hypothesis. 
In addition to these empirical problems, the bottom-up and the top-down models both suffer from conceptual shortcomings. First, they treat masses and elites as unitary actors. While certain segments of the public may be manipulated by government propaganda, others may resist efforts to influence them. ${ }^{9}$ One should at least distinguish between (1) mass public opinion, (2) the attentive public, which has a general interest in politics, and (3) issue publics, which are particularly attentive to specific questions. Moreover, elites are themselves frequently divided, and different segments of the elite try to convince the general public of their respective viewpoints. ${ }^{10}$

Second, a simplistic view of either bottom-up or top-down processes tends to ignore that public opinion and societal groups may influence the policy-making process in several ways and at different stages. They can directly affect the choices of top decision makers by changing policy goals or how those goals are prioritized, by narrowing the range of options and/or means to implement goals, or by winning symbolic concessions in the sense of changed rhetoric rather than policy reforms. Moreover, the public may also indirectly affect policies by influencing the coalition-building processes among the elites. It can strengthen or weaken the positions of bureaucracies or single actors within the government. Public opinion and the activities of public interest groups may lead to changes and/or realignments within or between political organizations such as parties. These indirect effects on policy are difficult to trace and are therefore easily overlooked. However, their impact may be as important as the above-mentioned direct influences.

Finally, it cannot be assumed that public and elite opinion interact with each other and are transformed into policy decisions in the same way across different countries. In other words, similarities in public attitudes across various countries do not necessarily lead to similar policies. Public attitudes and policies toward nuclear weapons provide a good example. The patterns of mass public opinion in the U.S., Western Europe, and Japan are more or less similar. Nuclear weapons are mostly tolerated for their deterrent value, provided that arms control efforts are underway. Attitudes become increasingly hostile if nuclear use in wartime situations is contemplated. Throughout the cold war, "first use" of nuclear weapons had only minority support in the U.S., France, West Germany, and Japan. ${ }^{11}$

However, for all these similarities in public attitudes, the nuclear policies of the four countries have differed from one another. Japan has had the strongest antinuclear policy in place since the late 1960s. The Federal Republic of Germany changed from an outspoken supporter of U.S. extended deterrence and "coupling" to a strong advocate of nuclear arms control. The United States emphasized arms control in the 1970s, turned to a massive arms buildup during Ronald Reagan's first term, and returned to arms control from the mid-1980s on. Finally, France has pursued the most pronuclear policy of the four countries and has refused so far to take part in nuclear arms control.

The variations in policies are in part a result of different positions and capabilities in the international environment (for example, the nuclear status of France and the U.S. as compared with that of Japan and Germany). However, while the 
frequent changes in United States arms-control policies might be considered to be reactions to changes in the "threat environment" (Soviet arms buildup in the 1970s; Soviet intervention in Afghanistan; the "Gorbachev revolution"), French policy seems to remain largely unaffected by either external or internal factors. The change in West German policies even runs counter to what one would expect from looking solely at the "threat environment" such as the Soviet arms buildup of the late 1970s. The stability of Japanese nuclear policies, while in line with public attitudes, is also not explicable in terms of changes in the country's international environment.

\section{The missing link: Domestic structures and coalition-building processes}

If, first, public attitudes as such cannot account for differences in policies and, second, variations in the international environment do not explain them either, what is the missing link between mass public opinion and elite decisions in foreign and security policy? It is suggested here that one has to look at domestic structures and coalition-building processes to understand the impact of public opinion on the foreign policy of liberal democracies. ${ }^{12}$

Domestic structure approaches deal with the nature of the political institutions (the "state"), basic features of the society, and the institutional and organizational arrangements linking state and society and channeling societal demands into the political system. In other words, domestic structures determine how political systems respond to societal demands. Social movement research talks about "political opportunity structures."

Several approaches can be distinguished. The first focuses on state institutions and has found its most prominent expression in the concept of "strong" and "weak" states. It emphasizes the degree of centralization of state institutions and the ability of political systems to control society and to overcome domestic resistance. ${ }^{14}$ Weak states have fragmented political institutions and are open to pressures by societal interest groups and political parties. Their ability to impose policies on society and to extract resources from it is fairly limited. Strong states, by contrast, consist of centralized political institutions with strong bureaucracies; they are able to resist public demands and to preserve a high degree of autonomy vis-à-vis society.

However, the "strong versus weak states" distinction, while parsimonious, is too simplistic to account for the variations between domestic structures. Weak states like the U.S. are sometimes able to conduct highly efficient policies, whereas strong systems might not always pursue forceful and energetic foreign policies. ${ }^{15}$ Moreover, institutionalist approaches have been challenged as apolitical and therefore unable to explain specific policy outcomes. Rather than emphasizing state structures, one should analyze the coalition-building processes within societies and political systems. ${ }^{16}$ These approaches focus on the "policy networks," that is, the mechanisms and processes of interest representation by political parties and interest groups that link the societal environment to the 
political systems. This concept emphasizes the ability of political actors to build consensus among the relevant elite groups in support of their policies. ${ }^{17}$

Simply to set off the coalition argument against the institutionalist approach seems to be inappropriate, though. On the one hand, state structures do not determine the specific content or direction of policies. On the other hand, coalition building takes place in the framework of political and societal institutions. The structures of the society and the political system determine the size and strength of policy coalitions needed to create the support basis for specific policies. Domestic structures also seem to account for general features of foreign policies, the degree of stability as well as the level of activity and commitment. ${ }^{18}$

In sum, a "mixed" approach encompassing both institutional structures and coalition-building processes seems to be more appropriate. In their later works Peter Gourevitch and Peter Katzenstein, who had previously argued about the respective merits of institutionalist versus coalition-building concepts, both moved toward combined approaches that basically emphasized three factors: ${ }^{19}$

1 The nature of the political institutions and the degree of their centralization: Is executive power concentrated in the hands of one decision maker (president, prime minister, chancellor) who controls the bureaucratic infighting among governmental agencies? To what extent can the government control the legislative process?

2 The structure of society regarding its polarization, the strength of social organization, and the degree to which societal pressure can be mobilized: How heterogeneous is the society in terms of ideological and/or class cleavages? How well developed are social coalitions and organizations in their ability to express grievances and raise demands?

3 Finally, the nature of the coalition-building processes in the policy networks linking state and society:

a In countries with centralized political institutions but polarized societies and rather weak social organizations, the policy network is likely to be state-dominated. The policy-relevant coalition building would then be restricted to the political elites and would more or less exclude societal actors and/or public opinion.

b By contrast, societal control of the policy network is to be expected in countries with comparatively homogeneous societies and a high degree of societal mobilization but weak state structures. The policy-relevant coalition building would take place among societal actors; accordingly, public opinion would play a major role.

c Countries with political institutions and social organizations of comparable strength are likely to have a policy network characterized by democratic corporatism. Political and societal actors would be engaged in continuous bargaining processes in search of policy compromises in an environment of give-and-take. ${ }^{20}$ As a result, some sorts of middle-of-the-road-policies are to be expected, reflecting the common denominator of public opinion. 


\section{The impact of public opinion in four liberal democracies}

The United States, France, Germany, and Japan are characterized by distinct domestic structures. I argue that these differences largely account for the variations in the impact of public opinion on foreign and security policy. And I test this proposition by discussing the various responses to changes in Soviet foreign policy from the late 1970s to the late 1980s (from Brezhnev to Gorbachev).

\section{The domestic structures of the United States, France, Japan, and the Federal Republic of Germany}

\section{Political institutions}

The U.S. undoubtedly has the most decentralized foreign and security policymaking structure of the four countries. The built-in tensions within the executive between the Pentagon, the State Department, and the National Security Council, which lead to continuous infighting over defense and arms-control policies, are well documented. Moreover, Congress has more authority over the conduct of foreign policy than do most other Western parliaments due to (1) the weakness of the American party system, which severely limits the power of the executive over congressional decisions and (2) institutional provisions such as the twothirds majority requirement for the ratification of international treaties.

The very different French political structure consists of the strongest state institutions of the four countries. The Fifth Republic institutionalized a centralized political system that all presidents since de Gaulle have reinforced. The power of the French bureaucracy enhances the strength of the executive. ${ }^{21}$ This general feature of the French political system is particularly relevant for foreign and defense policy-making, the domaine réservée of the president. ${ }^{22}$ Furthermore, the French Parliament - in striking contrast to the U.S. Congress - plays an almost negligible role in foreign policy. In sum, the centralization of the French decision-making apparatus seems to be even greater in foreign policy than in other issue-areas.

Japan resembles the French case insofar as its political system is usually described as a strong state. Indeed, the power of the state bureaucracy extends into foreign affairs. However, the Foreign Ministry, which dominates Japanese foreign and security policy and outweighs the Defense Agency, usually cannot compete internally with the Ministry of International Trade and Industry (miti) or the Ministry of Finance. ${ }^{23}$ The distribution of power within the government thus reflects the predominance of economic over defense issues in Japanese foreign policy. While the Japanese parliament, the Diet, plays only a minor role in foreign affairs, the Liberal Democratic Party (LDP), which has controlled the government since 1955, is among the most important actors in Japanese foreign policy. $^{24}$

In the Federal Republic of Germany executive control over foreign and defense policy is generally stronger than in the U.S. ${ }^{25}$ With the exception of the 1972 
ratification process concerning the treaties with Eastern Europe and the Soviet Union (Ostpolitik), the role of Parliament has been fairly limited. This weakness, however, does not simply result in strengthening executive power as in France. Rather, the political parties constrain both the legislative and the executive branches. Partly as a result of peculiar election procedures ${ }^{26}$ the party system is smaller and less polarized than in France. The ruling parties in coalition governments must engage in constant consensus building on major foreign policy decisions. "Party democracy" permeates the government bureaucracy insofar as internal divisions since the mid-1960s are usually related to the party affiliation of the respective minister rather than to traditional bureaucratic roles. ${ }^{27}$

\section{Structure of the society}

In sharp contrast to its centralized political system, French society is usually described as fragmented along ideological, religious, and class lines. ${ }^{28}$ While this polarization has declined considerably over the past ten years (partly as a result of the French Left taking over the presidency), ${ }^{29}$ the weakness and fragmentation of the French social organizations is still striking. (Compare, for example, the ideological divisions between the numerous French trade unions with the unified strength of the German Federation of Trade Unions [Deutscher Gewerkschaftsbund].) This general description extends into the foreign policy area.

French mass public opinion is more divided on security policy than is that of most other Western European nations. The divisions are strongest along party lines, which in turn reflect ideological cleavages between the Left and the Right. Concerning attitudes on defense spending, for example, supporters of the French Socialist Party (PSF) have been more than 20 percentage points apart from adherents of the Gaullist Party (RPR), whereas the respective gap between supporters of the German Social Democrats (SPD) and of the Christian Democrats (CDU/CSU) was only 10-15 points..$^{30}$ Moreover, the opposition to the French defense policy was never able to mobilize much societal support. Although a majority of the French public rejected the independent nuclear force well into the 1970s, this opposition never manifested itself in strong peace movements, as has frequently been the case in the U.S., West Germany, and Japan. ${ }^{31}$

Compared with France, Japan seems to be an almost homogeneous society in which the achievement of social consensus ranks among the highest cultural values. Accordingly, mass public opinion on foreign policy is among the most stable and most consistent of all industrialized democracies. ${ }^{32}$ Moreover, Japanese society, in particular the business community, is highly organized. In the security policy area, for example, the defense industry can marshal strong institutions to further its interests. On the other side of the spectrum, the Japanese peace movements have also been well organized, particularly during the 1950s and 1960s, and have maintained strong links to trade unions and left-wing opposition parties. ${ }^{33}$ In 1960, for example, the renewal of the Mutual Security Treaty with the U.S. led to the most serious political crisis in postwar Japan, as peace movements, 
opposition parties, and trade unions launched a massive campaign against the treaty, including the largest strikes in Japanese history.

In general, American society resembles French society more than Japanese society in terms of class divisions and ideological cleavages. Again, this has repercussions in foreign and security policy. As Eugene Wittkopf and others have shown, the bifurcation of the American people into "militant internationalists" and "cooperative internationalists" is strongly correlated with ideological divisions between conservatives and liberals and, to a lesser extent, with partisanship; the cleavages have increased since the $1970 \mathrm{~s} .{ }^{34}$ Nevertheless, the ability of societal actors to mobilize support for their demands and to organize themselves seems to be greater in the U.S. than in France. One only has to mention the significant power of the American defense industry, as well as the importance of countervailing public interest groups lobbying for arms control and disarmament. ${ }^{35}$

German society seems to be less fragmented than either U.S. or French society in terms of ideological and class cleavages. Moreover, the country enjoys comparatively strong social organizations and a high level of participation in those associations. The three most important and centralized social organizations business, trade unions, and churches - never hesitate to speak out on foreign and security issues, usually on the dovish side of the debate. The peace movements of both the 1950s and the 1980s were able to overcome their internal divisions and create strong coordinating mechanisms. ${ }^{36}$

\section{Policy networks}

Concerning the policy networks, the American system seems to come closest to the society-dominated type. Constant building and rebuilding of coalitions among societal actors and political elites is fairly common even in foreign and security policy. The openness of the political system provides the society with comparatively easy access to the decision-making process. Accordingly, corporatist structures such as the military-industrial complex linking business, military, and political interests have only a limited impact on foreign policy decisions beyond the weapons-procurement process and demands for a certain level of defense spending. ${ }^{37}$

The policy network in France, by contrast, seems to be almost completely dominated by the state and, above all, the presidency, particularly concerning foreign and defense policy. Even when Socialist President Mitterrand was forced into "cohabitation" with a Conservative government from 1986 to 1988, he continued to control the foreign policy-making process. ${ }^{38}$ State dominance in the policy network is facilitated by the famous French "defense consensus" among the elites and all political parties in support of French independence in world politics and of the force de dissuasion. As a result, the French foreign policy-making process has been described as that of a "nuclear monarchy." 39

Differing from the French and U.S. cases, the situation of the Germans and Japanese resembles the corporatist model. In the Federal Republic the party system not only permeates the state institutions, but it also forms the most 
important link between society and the political system. The two major parties the Christian Democratic Union (CDU) and the Social Democratic Party (SPD) are essentially catchall organizations that integrate rather divergent societal demands. Sometimes intraparty divisions are greater than the cleavages between parties, as was the case with the CDU and Ostpolitik during the 1970s and with the SPD and deterrence during the 1980s. Additionally, institutional arrangements as well as the political culture emphasize consensus building and the mutually beneficial reconciliation of diverging societal interests (Interessenausgleich). There is a clear analogy between the domestic emphasis on social partnership and a foreign policy trying to achieve its goals by security partnership with Germany's neighbors. ${ }^{40}$

Consensus building is of similar and probably even greater importance in Japan. The need to bring almost every relevant player into the decision-making process and to strike a balance between different views is frequently cited as a major reason that Japanese foreign policy seems so slow moving and low-key. ${ }^{41}$ However, to portray the Japanese policy network as "corporatism without labor" that is, having strong and intimate linkages between the state bureaucracy, the LDP, and big business ${ }^{42}$ - does not seem to make as much sense in security policy. A military-industrial complex that includes the Defense Agency and the weapons industry, while having increased its role during the defense buildup of the $1980 \mathrm{~s},{ }^{43}$ by no means dominates Japanese security policy. Even more than in the West German case, the legacy of World War II prevented the rise of a new Japanese militarism. A firm national consensus including all relevant elite factions, the opposition, and society insures that Japanese security policy has been first and foremost a matter of foreign economic policy. As a result, military policy seems to be one issue-area in Japanese politics that does not systematically exclude labor and the Left from the policy-making process, at least not since the 1960 Security Treaty crisis.

Table 2.1 summarizes the similarities and differences in the domestic structures of the four liberal democracies under consideration here.

The comparison leads to several assumptions about the impact of public opinion on foreign policy in the four countries. The comparatively open and decentralized American political system and its society-dominated policy network should provide

Table 2.1 Domestic structures

\begin{tabular}{|c|c|c|c|c|}
\hline & U.S.A. & W. Germany & Japan & France \\
\hline $\begin{array}{l}\text { Political } \\
\text { system }\end{array}$ & decentralized & $\begin{array}{l}\text { intermediate } \\
\text { level of } \\
\text { centralization }\end{array}$ & $\begin{array}{l}\text { intermediate } \\
\text { level of } \\
\text { centralization }\end{array}$ & centralized \\
\hline Society & $\begin{array}{l}\text { heterogeneous, weak } \\
\text { organizations }\end{array}$ & $\begin{array}{l}\text { heterogeneous, } \\
\text { strong } \\
\text { organizations }\end{array}$ & $\begin{array}{l}\text { homogeneous, } \\
\text { strong } \\
\text { organizations }\end{array}$ & $\begin{array}{l}\text { heterogeneous, } \\
\text { weak } \\
\text { organizations }\end{array}$ \\
\hline $\begin{array}{l}\text { Policy } \\
\text { network }\end{array}$ & society-dominated & $\begin{array}{l}\text { democratic, } \\
\text { corporatist }\end{array}$ & quasi-corporatist & state-dominated \\
\hline
\end{tabular}




\section{From the inside out}

public opinion with ample opportunity to affect policy outcomes. In short, the interaction of public opinion and elites in the decision-making process is expected to come comparatively close to the bottom-up model. In contrast to the U.S. case, French public opinion is likely to play only a marginal role in the foreign policymaking process. The Fifth Republic's centralized political system and a fragmented societal structure make it difficult to build a public consensus on policy issues and would be expected to limit the public impact on foreign and security policy. The German domestic structure, in which comparatively strong state institutions deal with well-organized societal actors in a democratic corporatist network, suggests that public opinion influences foreign policy mainly through the party system and that interactive patterns prevail between elites and masses. Finally, the Japanese case is expected to resemble Germany insofar as both countries possess strong political institutions and corporatist policy networks. There is a difference, however; Japanese society is more homogeneous than German society, and the public has been less divided on foreign and security policy issues.

\section{Withering threat: Public opinion reactions to Soviet foreign policy, 1980-90}

To isolate the role of domestic structures as the intervening variable between public opinion and policy decisions requires a case in which the influence of the international environment appears constant for the four countries and in which under ideal conditions public attitudes are also more or less similar. From the late 1970 s to the late 1980 s the four countries were exposed to a drastically changing Soviet policy. Moscow's conventional and nuclear arms buildup of the 1970s was followed by the intervention in Afghanistan and the stalemate in superpower arms control during the early 1980s. From 1985-86 on the new Soviet leader, Mikhail Gorbachev, initiated the politics of perestroika, which resulted in a turnaround of Soviet security policy toward "common security." Moscow accepted the zero option for intermediate-range nuclear forces (inf), withdrew its troops from Afghanistan, announced unilateral troop cuts in Europe, and finally revoked the Brezhnev doctrine of limited sovereignty for Eastern Europe, thereby triggering the democratic revolutions of 1989 . How did mass public opinion in the four countries perceive these drastic changes in Soviet foreign policy? ${ }^{44}$

Figure 2.1 reveals that, with the exception of Japan, the public perception of a Soviet threat declined from unusually high levels in the early 1980s to its virtual disappearance in the late 1980s. The initial public reaction to Soviet actions in the late 1970s and early 1980s, particularly the intervention in Afghanistan, was unanimously hostile and negative. While the most dramatic change from a very high degree of threat perception occurred in the U.S., the West Germans were the first to react positively to the turnaround of Soviet foreign policy. In 1986, that is, during the very first year of Gorbachev's "peace offensive" and one year before the inf treaty (which particularly affected German security) was concluded, a majority became convinced that the Soviet threat had disappeared. The threat as perceived by the French declined in 1987-88, whereas 


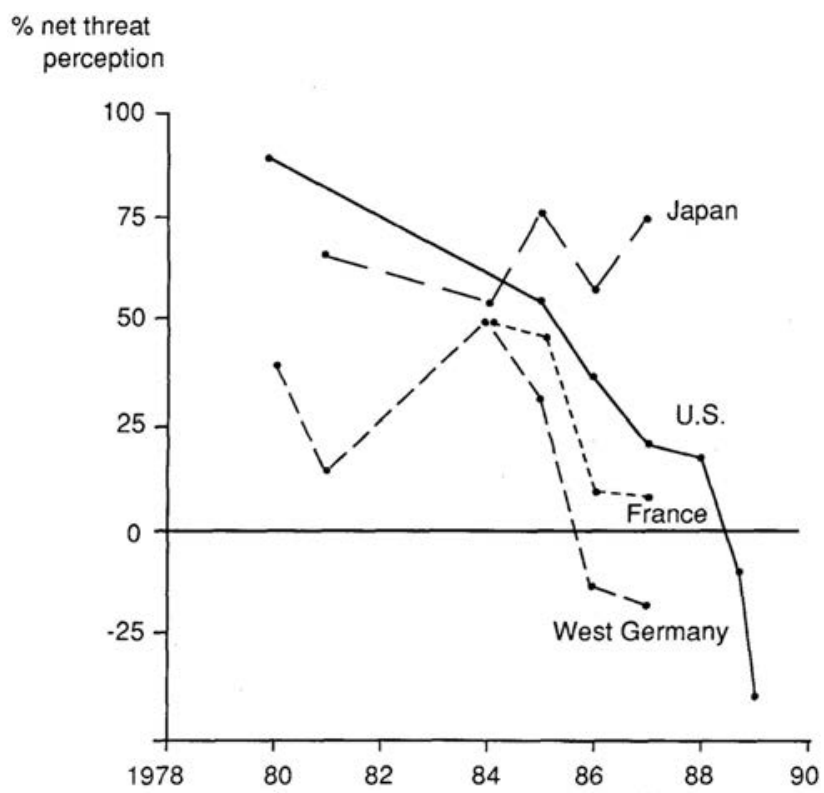

Figure 2.1 Net threat perception of the $\operatorname{USSR}^{\mathrm{a}}$

Sources: U.S.: Americans Talk Security, no. 12 (1989), 58; CBS/New York Times polls; France: USIA polls; Michel Girard, "L'opinion publique et la politique extérieure," Pouvoirs, no. 51 (1989); Szabo (fn. 11); West Germany: Hans Rattinger, "The INF Agreement and Public Opinion in West Germany" (Manuscript, March 1988); Gebhard Schweigler, Grundlagen der aussenpolitischen Orientierung der Bundesrepublik Deutschland (Baden-Baden: Nomos, 1985), 183; Szabo (fn. 11); Japan: Hastings and Hastings, Index to International Public Opinion, 1981-1982ff. (New York: Greenwood, 1983ff.).

Note: a "Net threat perception" is defined as the percentage of those perceiving a Soviet threat minus the percentage of those perceiving no threat.

it was only in late 1988 that more than 50 percent of Americans thought that the Soviet threat had withered away. Finally, the "Gorbachev revolution" apparently did not affect Japanese public opinion. Not only did comparatively more Japanese perceive a Soviet threat throughout the 1980s, but the percentage remained high even in 1987-88.

This evaluation is confirmed by an opinion poll taken immediately after the Washington summit in December 1987 at which the inf treaty was signed. Seventy-three percent of the Germans, 55 percent of the Americans, 54 percent of the French, but only 34 percent of the Japanese thought that the Soviet Union was becoming a more trustworthy nation as a result of the reforms initiated by Gorbachev. ${ }^{45}$ Thus, the Germans appeared to be the most enthusiastic supporters of Gorbachev, while the Japanese remained unaffected by the new Soviet foreign policy, and the Americans and the French were in between.

How did the changes in threat perceptions translate into attitudes on how to deal with the Soviet Union? The data reveal a major difference between public 
opinion trends in the United States as compared with those in France, Germany, and Japan. Only in the U.S. did the negative reaction to Moscow's policies during the late Brezhnev era result in increasing support for hawkish policies. From late 1979 to early 1981 a majority of Americans favored increases in defense spending (see Figure 2.2) and opposed the ratification of the salt ii treaty. However, the support for a tougher stance disappeared as quickly as it had emerged. By mid-1981, 65 percent of Americans favored the resumption of nuclear arms talks. By 1982 support for increased defense spending was back at the 1978 level; at the same time, a near consensus emerged in the U.S. mass public regarding a bilateral freeze of the superpowers' nuclear arsenals. ${ }^{46}$ It should be noted that these attitude changes occurred before Gorbachev assumed power. They might be explicable by the "politics of opposites" as described by Miroslav Nincic, who suggested that U.S. policies that are either too dovish or too hawkish toward the Soviet Union would be opposed by the public mainstream. ${ }^{47}$

Compared with the shifts in U.S. public opinion, French, German, and Japanese public opinion has been far more stable in support of or in opposition to specific policies. This is most obvious in the attitudes toward defense spending, which remained largely unaffected by the changes in Soviet policy (see Figure 2.2).

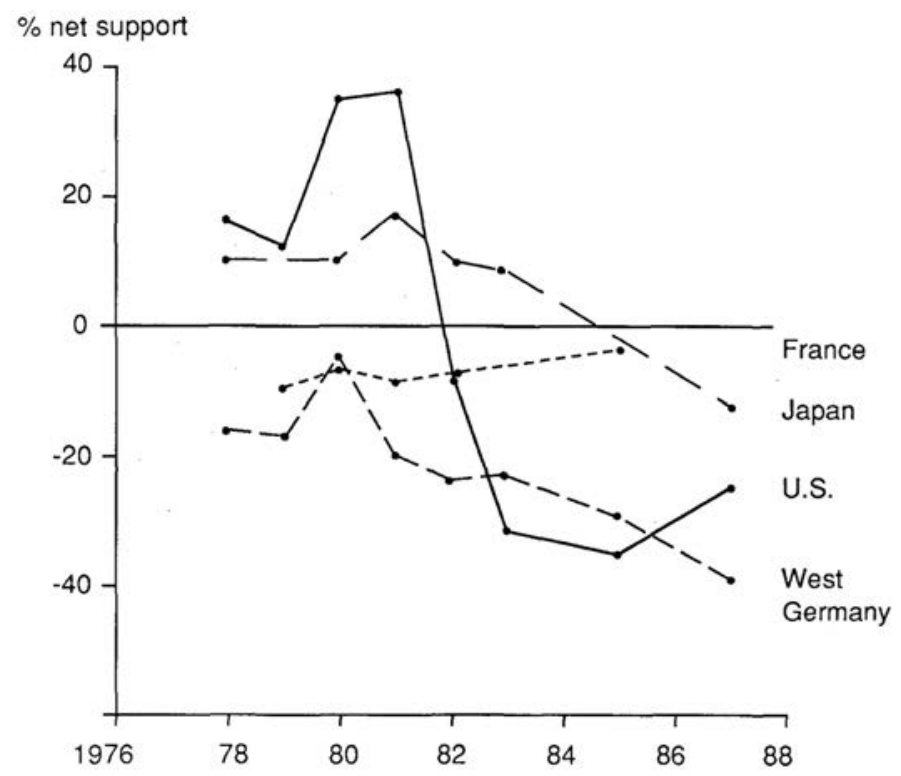

Figure 2.2 Net support for defense spending ${ }^{\mathrm{a}}$

Sources: U.S.: CBS/New York Times polls; Sean M. Lynn-Jones, "Lulling and Stimulating Effects of Arms Control," in A. Carnesale and R. Hass, eds., Superpower Arms Control (Cambridge, Mass.: Ballinger, 1987), 237; France and West Germany: Eichenberg (fn. 1), 161-62; Japan: Hastings and Hastings, Index to International Public Opinion, 1979-1980ff. (New York: Greenwood, 1981ff.).

Note: a "Net support for defense spending" is defined as the percentage of those favoring increases in defense spending minus the percentage of those supporting defense reductions. The graph plots change rather than continuity, since it does not include those who favored "leaving the defense budget as it is." 
From the late 1970s to the mid-1980s a majority of Germans preferred a stable defense budget; the number favoring reductions increased in the late 1980s. The same applies roughly for the French and the Japanese, although comparatively more Japanese than Germans advocated an increased defense budget. In sum, however, the perceived Soviet threat prior to Gorbachev did not result in demands for a military buildup in the three countries.

If anything, the Japanese were more hawkish than the French and the Germans during the early 1980s. In 1981, 31 percent maintained that a military balance was the most important source of security, while only 12 percent and 8 percent believed in détente and arms control, respectively. Two years later, however, Japanese public opinion was back in line with the French and West Germans, who had always thought that détente and/or arms control were more important than maintaining a military balance with the Soviet Union. ${ }^{48}$ A particularly interesting finding is revealed by a 1984 Japanese poll. Fifty-nine percent of those who perceived the USSR as a threat nevertheless favored the improvement of peaceful diplomatic relations between the two countries, as compared with only 21 percent who wanted to strengthen military security. ${ }^{49}$ In sum, the public consensus in Japan on basic foreign policy problems emphasizing economic strength as well as peaceful diplomacy remained largely intact throughout the 1980s.

West German public opinion came out as the most dovish throughout the decade. In sharp contrast to the Americans, 74 percent of the Germans continued to support détente and Ostpolitik in the midst of the Afghanistan crisis in early 1980. Nuclear-arms-control efforts such as the zero option for inf enjoyed near consensus in the 70-90 percent range. ${ }^{50}$ Moreover, an increasing number of Germans favored unilateral Western arms reductions to encourage Soviet disarmament; by 1987 more than 50 percent supported such a strategy of reassurance. $^{51}$

A March 1985 international opinion poll asking for people's preferred Western strategy toward the new Soviet leadership confirms the overall pattern (see Figure 2.3). Once again, there is a striking contrast between German, French, and Japanese public opinion on the one hand and that of the U.S. on the other. Whereas only a minority in each of the four countries supports hawkish policies emphasizing military strength, a plurality of Americans seems to be more cautious than the dovish Europeans, favoring instead an "owlish" approach (that is, combining military strength with the preparedness to compromise). Again, West German public opinion is most supportive of arms control and détente.

While it is not the purpose of this paper to explain the patterns of public opinion, a note is offered on the developments in public opinion in the U.S. as compared with developments in France, Germany, and Japan. The data are consistent with an explanation according to which in Western Europe (and probably in Japan, too) negative feelings toward the Soviet Union did not determine the preferences for specific security policies; rather, the fear of war and of the arms race in general as well as the perception of U.S. policies were of at least equal significance..$^{52}$ Indeed, during the early 1980 s a plurality of West Germans and French perceived U.S. policies as risking war rather than promoting peace, and the 
Question: In view of the change in Soviet leadership, in which one of the ways listed below should the West proceed in its negotiation with the Soviet Union in order to reach an agreement on arms control?

— "tough/no compromise + military buildup" (Hawks)

— "more moderate + maintain current military strength" (Owls)

- "offer compromise to encourage the Soviets" (Doves)

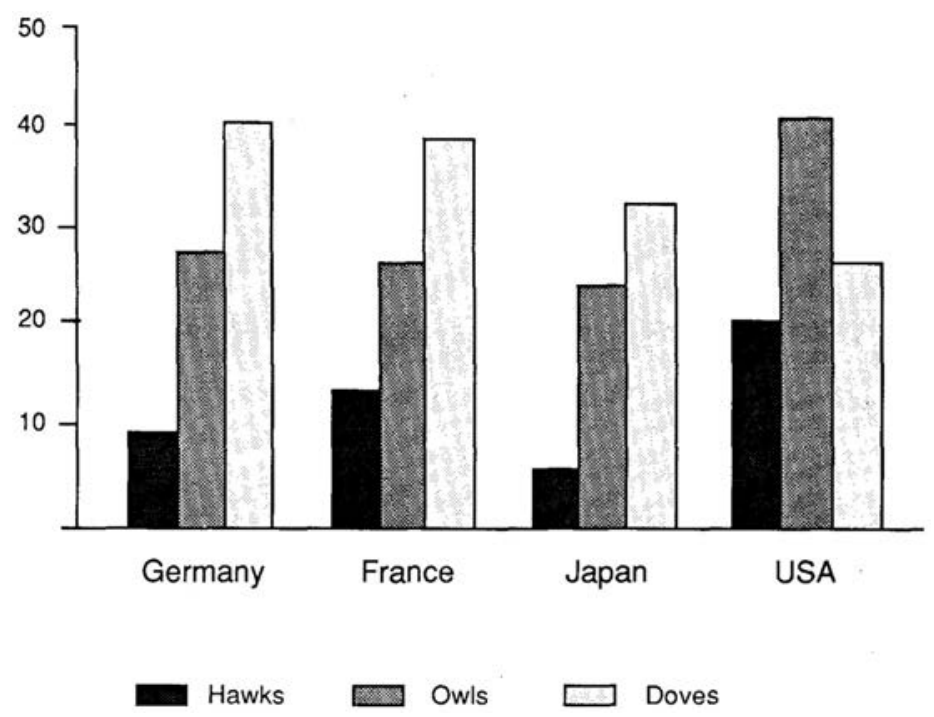

Figure 2.3 Policy toward the Soviet Union

Source: Hastings and Hastings, Index to International Public Opinion, 1985-1986 (New York: Greenwood, 1987), 591.

general fear of war reached unusual highs. ${ }^{53}$ In sum, even before the cold war was actually over, large segments of Western European - and, maybe, Japanese public opinion subscribed to a "post-cold war" international environment in which the Soviet threat no longer dominated the agenda. ${ }^{54}$

To conclude, the data reveal similarities as well as differences in the public attitudes of the four countries toward the Soviet Union. While the change in the perception of threat occurred at a different time for each, by 1988 the Soviet threat had withered away everywhere except Japan. Moreover, West Germans, French, and Japanese continuously preferred détente and arms control policies to a military buildup, albeit to different degrees. The deviant case was public opinion in the U.S., which favored rather hawkish policies during the early 1980s. But even there arms control was supported again as early as 1982-83. Thus, there have been discernible differences in public attitudes across the four countries. But the similarities seem to be substantial enough to merit a comparative study of their policy impact. 


\section{The public impact on foreign policy toward the Soviet Union during the 1980s}

A comparison of the above data on policy preferences toward the Soviet Union (see Figure 2.3) with the actual policies of the four countries indicates some preliminary results. On the one hand, Reagan's initial, owlish policy toward Gorbachev as well as the West German embrace of the new Soviet foreign policy right from the beginning - "Genscherism" - seem to be roughly in line with the public opinion trends in the two countries. On the other hand, both the French and the Japanese conducted rather cautious and sometimes even hostile policies toward Gorbachev, policies that seem to have been out of touch with public opinion, particularly in the case of France. This pattern - of a match of public opinion and policy in the cases of the U.S. and the Federal Republic of Germany, less of a match in Japan, and no match in France - is exactly what one would expect using the domestic structure approach. However, detailed process tracing is required to confirm the proposition.

\section{Two sides of openness: The United States}

Given the domestic structure of the United States, the interaction of public opinion, societal forces, and political elites in the foreign policy process would be expected to resemble the bottom-up model. Indeed, a longitudinal analysis of public opinion and policy changes from 1935 to 1979 revealed a congruence between public opinion changes and policy shifts, especially in cases of high issue salience and drastic changes in public attitudes. Benjamin Page and Robert Shapiro found essentially no difference between domestic and foreign policy issues. More important, in at least half of the cases the policy changes followed the shifts in public opinion. ${ }^{55}$

U.S. policy toward the Soviet Union from the late 1970s to the late 1980s reveals the general validity of the hypothesis. Right after the conclusion of the salt $i$ treaties, the American security elite became increasingly split on the virtues of arms control and détente. During the late 1970s the U.S. public was presented with two different approaches for dealing with the Soviet Union: the views of the traditional arms-control establishment represented in the Carter administration and an outlook most prominently expressed by the Committee on the Present Danger. ${ }^{56}$ As the data presented above reveal, the change in public opinion toward "peace through strength" policies took place in late 1979/early 1980. The Soviet intervention in Afghanistan and not just the conservative part of the U.S. elites tipped the balance in favor of the antidétente mood among the public. This contributed to the election victory of Ronald Reagan, and, as a result, to the anti-salt coalition. ${ }^{57}$ In other words, while the events of the late 1970s and early 1980s do not confirm a simplistic version of the bottom-up model, they nevertheless show that U.S. public opinion played a role in bringing the anti-salt coalition to power.

A similar process can be observed in 1982-84. Reagan's military buildup and his cold war rhetoric quickly eroded the public support for his defense policy. 
The "politics of opposites" (Nincic) worked (see data above). This change as well as the stable public consensus against the first use of nuclear weapons provided issue publics such as the freeze campaign with a window of opportunity. The nuclear protest was a bottom-up movement that originated outside of Washington's arms-control elite. ${ }^{58}$ It quickly gained ground, penetrated the more skeptical arms-control community, and found support among numerous social organizations such as the Catholic church. Given the openness of the U.S. political system, the movement found easy access to the political elites. In 1983 the House of Representatives adopted a freeze resolution. Congress became increasingly active on issues of nuclear arms control.

As a result of these coalition-building processes in the policy network, the power balance in the Reagan administration between hardliners in the Pentagon and more pragmatic conservatives in the State Department slowly shifted in favor of the latter. ${ }^{59}$ By 1984 and continuing throughout 1985, that is, before Mikhail Gorbachev entered upon the scene, Ronald Reagan had softened his rhetoric and adopted a more compromising stance on arms control. The superpower relationship improved, nuclear-arms-control talks resumed in early 1985, and the U.S. defense budget began to decline by 1986. However, the freeze campaign failed to achieve its immediate goals, and the shift in Reagan's policy did not produce substantial arms-control results until the late 1980s (inf Treaty 1987). But public opinion clearly affected the ability of the issue public and interest groups to promote their cause and thereby influence the coalition-building process among the elites, which in turn produced tangible, albeit limited, results in U.S. policies.

The impact of public opinion on the conduct of U.S. policy toward the Soviet Union was also noticeable in the spring of 1989. When the Bush administration came into power, government officials conducted a comprehensive review of Reagan's policies and apparently concluded that a more cautious approach should be adopted toward Moscow. However, as discussed above, by that time the Soviet threat had already withered away for the American public, so much so that the public reacted negatively to Bush's early foreign policy statements. The administration quickly adjusted to the public mood, however, and in June 1989 the president assured the public and the allies that the U.S. was firmly supportive of Gorbachev and the politics of perestroika. ${ }^{60}$

While public opinion did not determine U.S. policy toward the Soviet Union during the 1980s, it nevertheless left a discernible mark on the decision-making process. The analysis confirms that the U.S. domestic structure is a comparatively open system that allows societal actors to mobilize support and to affect the balance of forces within the policy network. Nevertheless, the fragmentation and decentralization of the political system work against the stabilization and institutionalization of policies. Policymakers were able to decrease the salience of the issues in question by symbolically adjusting to the public mood, as was the case in 1984-85. The public impact was more limited regarding the substance of policies, mainly because the domestic structure does not provide institutional support for lasting consensus among the elites (as, for example, a strong party 
system would). In sum, the very openness of the U.S. system to societal pressures also limits their impact.

\section{Weaknesses of a "nuclear monarchy": France}

The French domestic structure, as compared with that of the U.S., provides public opinion with only limited influence on foreign policy decisions. With the possible exception of the ending of the Algerian war, ${ }^{61}$ there is indeed not much evidence that any of the major foreign policy decisions by the presidents of the Fifth Republic were taken in response to public opinion. This holds true for the building of an independent nuclear force, the withdrawal from nato's military command, the policy of détente toward the Soviet Union in the 1960s and 1970s, and the gradual shift toward more pro-European attitudes under de Gaulle's successors. In most cases public opinion was deeply split on the issues. Moreover, the French presidents were usually able to create a public consensus supporting their foreign policies after the event. ${ }^{62}$

A similar pattern prevailed during the 1980s. As shown above, French public opinion did not develop in a markedly more hawkish way than did public opinion in Germany or Japan. Nevertheless, the new Socialist president, Mitterrand, adopted a more hostile approach toward the Soviet Union than that held by his predecessors, who had basically continued the legacy of de Gaulle's independent policy of détente. While Mitterrand's policy change did not reflect trends in mass public opinion, it was in line with parts of the issue public and the political elites. French left-wing intellectuals who had been fairly pro-Soviet during the 1950s and 1960s "discovered" repression in the USSR in the early 1970s and turned overwhelmingly anticommunist as a result. When President Giscard D'Estaing tried to continue détente in the aftermath of the Soviet intervention in Afghanistan, he was chastised by the intellectuals and the media. His successor, Mitterrand, changed the policy, not least of all for domestic reasons, in an effort to isolate and marginalize the French Communist Party (PCF) on the Left. ${ }^{63}$

The limited role of French society and public opinion in influencing policy decisions was also apparent during the early 1980s when France was the only major Western European country that did not face a significant public security debate and protest movements against nuclear weapons. This may be explained in part by the fact that the new U.S. inf missiles were not about to be deployed in France. Still, the French favored nuclear arms control and were as opposed to Reagan's policy as was any other European public. However, the French peace movement never developed into a mass movement; on the contrary, it was not only marginalized by the mass media but also internally split along ideological lines from the very beginning. In that sense, it reflected the fragmentation of French society. ${ }^{64}$

While the French centralized political institutions and the state-dominated policy network seem to constrain the public impact on foreign policy, there are a few instances in which public opinion apparently did play a role. One recent 
example was Mitterrand's decision in 1987 to endorse the inf treaty, despite the objections of his conservative foreign and defense ministers and of the majority of the French security community, who thought that the zero option was detrimental to Western deterrence policy. One year before the presidential elections, Mitterrand was apparently aware that French public attitudes overwhelmingly endorsed the U.S.-Soviet agreement. The decision is an example of presidential dominance in foreign policy matters even in times of "cohabitation"; it also suggests that public opinion sometimes affects French foreign policy directly, through presidential decisions rather than through coalition-building processes among the elites. ${ }^{65}$

While French public opinion only marginally influenced foreign policy decisions during the 1980s, the process did not resemble the top-down model. The French public did not just follow the policies of the elites or of Mitterrand. A comparison between public opinion and elite opinion shows that the attitude gap between elites and masses in France is one of the largest in Europe. ${ }^{66}$ French public opinion seems simply to be disconnected from the policy-making process.

The limited role of French society in the country's foreign policy-making process does not, however, result in a highly active policy unhampered by domestic constraints and able to concentrate solely on external factors, as the concept of "state strength" would assume. The powerful, centralized state institutions of the Fifth Republic were designed to integrate a heavily divided and fragmented society. The foreign policy of de Gaulle and, albeit to a lesser extent, of his successors was intimately linked to the efforts to strengthen the societal support basis for the institutions of the Fifth Republic. ${ }^{67}$ To this day the official ideology emphasizes French unity, grandeur, and independence from external influences and alliances, notions that cut across ideological cleavages. ${ }^{68}$ As a result, the famous French consensus on foreign and defense affairs remains fragile. The French state pays a price for excluding society from the foreign policy-making process. Rather than being able to pursue an autonomous and active policy. French decision makers seem to be constantly concerned with stabilizing a vulnerable elite consensus.

\section{From top-down to bottom-up: The federal republic of Germany}

A review of West German foreign policy reveals that the impact of public opinion increased over time and that the decision-making process became more democratic. In the 1950s, when Chancellor Adenauer integrated the Federal Republic into the Western alliance and the European Community, general public opinion was as deeply divided on the issue as were the political elites and the parties. However, Adenauer went ahead, and by about 1960 the public as well as the opposition had accepted his security policies. ${ }^{69}$

This top-down pattern gradually changed over the next two decades. In 196870, when Chancellor Brandt began his Ostpolitik and concluded the treaties with the Soviet Union and Eastern Europe, public opinion as well as the political 
elites were again divided on the policy. The Christian Democratic opposition (CDU) launched a vehement campaign against Ostpolitik and was even successful in depriving the government of its majority in Parliament. This time, however, and unlike the 1950s, the populace decided the issue: Brandt won the 1972 national elections primarily on the basis of Ostpolitik. ${ }^{70}$ Throughout the 1970s the public consensus in favor of détente stabilized, and by 1980, despite the Soviet arms buildup and the intervention in Afghanistan, it was firmly in place, as shown in the data above.

The opposition Christian Democrats, although internally divided, continued to oppose détente and in 1980 conducted another anti-Ostpolitik election campaign, hoping it would succeed because of the deterioration in East-West relations. Unlike the anti-salt coalition in the U.S., however, they failed. In November 1980, that is, two years before he became chancellor, Helmut Kohl finally declared the battle over, and the CDU accepted Ostpolitik. ${ }^{71}$ In sum, general public opinion was crucial in affecting the coalition-building process within the party system and, thus, in bringing about the German détente consensus. Unlike the French case, the domestic structure of the Federal Republic not only proved to be more open to societal influences, but it also institutionalized the consensus in the policy network, thus allowing for a highly active Ostpolitik.

General public opinion and societal actors also made a difference during the nuclear debate of the 1980s..$^{72}$ The nuclear controversy originally began at the elite level - mainly within the SPD - in 1977-78, in the debate over the neutron bomb. NATO's inf decision of 1979, the new "cold war" between the U.S. and the USSR, and the election of Ronald Reagan then triggered mass opposition. New peace movements launched their protests against the deployment of inf missiles. As with the freeze campaign in the U.S., the protesters in Germany relied on general public opinion as a support basis regarding two issues: (1) opposition to a belligerent U.S. policy and (2) opposition to nuclear weapons as instruments of war fighting and to their deployment on German soil.

While the peace movements failed to prevent the inf deployment in 1983, they had a profound impact on the coalition-building process among the elites. First, support for vigorous arms-control efforts increased within all parties, in particular within the CDU. Second, the "disarmers" entered the party system. Since 1983 policy decisions within the SPD elite have resulted from policy compromises between disarmers and the traditional arms-control establishment, but excluding members of the right wing of the party, such as former Chancellor Helmut Schmidt. Moreover, a disarmament party, the Greens, entered the political scene. Third, the nuclear elite consensus broke down as a result. By 1984 the SPD had adopted an antinuclear stance. In sum, the coalitions within the policy network gradually moved to the Left - in line with trends in general public opinion and in response to the protests of the issue publics.

The consequences of both the détente debate and the antinuclear protests were seen in the mid- to late 1980s. Germans were the first to embrace Gorbachev's new policy, because it responded favorably to what had previously emerged as a consensus on Ostpolitik and common security. Moreover, the 
opposition to new nuclear weapons increasingly included the CDU, the consequences of which became apparent during nato's debate on the modernization of battlefield nuclear weapons in the spring of 1989. There was a coincidence of public opinion, left-wing antinuclearism, and conservative fears that shortrange systems would "singularize" Germany in the aftermath of the inf treaty. As a result, Chancellor Kohl had no choice but to resist a modernization decision by nato.

To conclude, the role of public opinion in West German security policy changed over time and moved closer to the bottom-up model during the 1980s. The general and the issue publics decisively affected the coalition-building processes within the party system, which in turn considerably narrowed the range of options available to policymakers. However, the change has nothing to do with public opinion as such. For example, the public had been as ambiguous about the deployment of nuclear weapons in West Germany in the 1950s as it was in the 1980s, although the policy impact was markedly different in the latter case. Rather, the difference in influence seems to reflect a change in the domestic structure that opened up German politics to societal pressures. Adenauer's "chancellor democracy" changed into a "party democracy" during the 1960s, thereby establishing a democratic corporatist policy network. On top of that, new social movements - from the student protests of the late 1960s to the environmentalists of the 1970s and the peace groups of the $1980 \mathrm{~s}$ - affected the political culture and were crucial in opening the party system to societal influences. ${ }^{73}$ In contrast to France the domestic structure of the Federal Republic was open enough to allow for such changes in the first place. And unlike the United States, the strength of the party system in the policy network allowed for the institutionalization of the societal consensus.

\section{Conservative leaders versus public opinion: Japan}

Given the Japanese domestic structure and the stability of Japanese public opinion, the case is expected to resemble Germany. If one considers the low-key approach of Japanese military security policy over the last forty years, the selfimposed arms-control measures such as the nonnuclear principles and the limits on defense spending, and the reluctance to play a more global role in world politics, Japanese public opinion and foreign policy seem to be more or less in line. Indeed, almost every analysis of Japanese defense policy points to the constraining forces of public opinion on the margins of maneuver of the policymakers. $^{74}$

At first glance, Japanese foreign policy during the 1980s seems to confirm the analysis. Prime Minister Nakasone met with firm domestic opposition when he talked about making Japan an "unsinkable aircraft carrier" 75 and tried to move Japanese security policy toward a more pro-defense stance and to initiate a major military buildup program. While all Japanese governments of the 1980s declared that they wanted to abandon the principle of not exceeding 1 percent of the gnp for defense expenditures, they were only able to do so from 1986 to 1989 . The 
principle was reinstated in December 1989. Finally, Japanese policy toward the Soviet Union remained in line with the comparatively high degree of public threat perception (see data above). Japan was reluctant to react to Gorbachev's peace initiatives and to the changes in Soviet foreign policy. In contrast to the Federal Republic of Germany, Tokyo only grudgingly accepted the inf treaty after having insisted that the Asian-based Soviet SS-20s be included in the zero option. ${ }^{76}$

However, this description gives only half of the picture. The very fact that Nakasone and his successors were able to change Japanese defense posture as well as to implement a more globally oriented foreign policy belies the notion that Japanese policy-making is dominated by trends in public opinion. Moreover, the 1 percent gnp limit on defense procurement seems to be largely symbolic and primarily meant for domestic consumption. If one uses nato criteria to measure military expenditures, Japan had the third highest military budget worldwide in 1988. Finally, Tokyo's tough-minded policy vis-à-vis Gorbachev's Soviet Union reflected public opinion on only a superficial level. As the above-quoted data suggest, most Japanese would have been perfectly willing to support a policy that tried to resolve the grievances with the USSR - particularly the dispute over the northern territories - by means of diplomacy.

The contradictory evidence is explainable: simply put, the LDP's conservative leaders did not share the general public's outlook on Japan's role in the world and moreover felt under constant U.S. pressure to build up the military. In essence, security policy seems to have remained the one issue-area in Japanese politics in which the beliefs of the leaders of the conservative coalition did not accord with public attitudes. As a result, Nakasone and his successors had to conduct their defense policy against the prevailing trends in public opinion; unable to change it and given Japan's domestic structure, however, they had to acquiesce to it. They thus muddled through while stretching public tolerance to its limits. If one accepts the notion that the Japanese governments indeed felt vulnerable to public opinion, the strange coincidence of low-key rhetoric (except for Nakasone's early years) and considerably more active security policies becomes explicable.

Thus, in the 1980s Japanese public opinion placed broad, but nevertheless effective, constraints on the actions of policymakers. The impact of the public was reinforced by the peculiarities of the Japanese domestic structure, in particular, the emphasis on consensus building in the policy network. Unlike France and more comparable to Germany's corporatist process, issue publics and societal actors were able to affect the coalition-building processes within the LDP by forcing it to take account of the viewpoints of the opposition parties. As a long-term consequence of the 1960 crisis, the conservative coalition tried to include the opposition parties in major decisions concerning foreign and security policy. The institutionalization within the LDP of "policy tribes" corresponding to the particular ministries and Diet committees also enhanced the consensus-building capacity within the LDP and reduced the impact of factionalism. ${ }^{77}$ 


\section{Conclusions}

The study leads to three major conclusions. First, mass public opinion mattered in each of the four countries, albeit to very different degrees. Policymakers in liberal democracies do not decide against an overwhelming public consensus. In most cases, mass public opinion set broad and unspecified limits to the foreign policy choices. In the U.S. and - more recently - Germany it also defined the range of options available for implementing policy goals. Additionally, general issue salience seems to be of minor importance, once there is a clear majority in favor of certain policies. In the Japanese case the issue salience of foreign policy was comparatively low; decision makers nevertheless felt the pressure of mass public opinion. In sum, public consensus may substitute for a lack of issue salience, whereas highly mobilized societal actors may be able to influence policies even in the absence of such consensus. Neither was the case in France.

However, there are discernible limits to the impact of the general public on foreign and security policies. Rarely does general public opinion directly affect policy decisions or the implementation of specific policies. In sum, the bottomup and the top-down models are too simplistic to fit the reality in the four countries.

Second, most of the previous research on the policy impact of public opinion treats the domestic decision-making process as a black box and directly compares opinion polls with policy outcomes. This study suggests, however, that the indirect effects of public opinion are far more important. To the extent that the empirical material was available, ${ }^{78}$ it could be shown that the main role of the public in liberal democracies is to influence the coalition-building processes among elite groups. In the U.S. and the Federal Republic of Germany public opinion had a crucial impact on elites as they reconfigured their coalitions; groups in line with public preferences were able to carry the day. In Japan the public forced the ruling conservative coalition to integrate the opposition into the decision-making process, at least to some extent.

Moreover, support by mass public opinion seems to be essential for issue publics, public interest groups, and other societal actors to influence policy decisions. This accounts for the partial success of the peace movements in Germany and the U.S. and of the otherwise marginalized opposition parties in Japan in affecting the debates in the policy network. For both the political elites and societal actors, mass public opinion proves to be a resource for strengthening one's position in the coalition-building process.

The third conclusion concerns the usefulness of the domestic structure approach. Domestic structures seem indeed to account for the differences between the four countries. The degree of mass public consensus on foreign policy correlates strongly with the degree of societal fragmentation, in particular, the ideological divisions between Left/liberals and Right/conservatives. Japan as the most homogeneous society of the four countries also enjoys the most stable public foreign policy consensus. By contrast, the divisions in French public opinion on security policy reflect the country's ideological and class cleavages. The U.S. and Germany are cases in between. 
Furthermore, there is strong empirical evidence that domestic structures are the intervening variable between public opinion and foreign policy. Under given international conditions and despite relatively similar public attitudes across countries, variances in the interaction between the general public and elites in the foreign policy-making process can be explained by differences in domestic structures. The degree to which political institutions are centralized and the degree to which the state dominates the policy networks seem to be the determining factors. In both categories, France and the U.S. are located at opposite ends of the spectrum. The two countries also form the two cases in which public opinion seems to have the greatest (U.S.) and the least (France) impact on policy decisions. The Federal Republic of Germany changed over time from top-down to a more interactive or even bottom-up process, which in turn seems to reflect changes in the overall domestic structure. In the Japanese case the stable public consensus in favor of a nonmilitary security policy severely constrained a political elite that tried to pursue a more active foreign policy. Moreover, societal protest such as was experienced during the 1960 crisis left a discernible mark on the consensus-building process in the conservative coalition and, as a result, on Japanese foreign policy.

At first glance, the empirical findings appear to confirm the distinction between strong and weak states. The stronger the state institutions and the greater their control of the policy networks, the less access the public has to the policy-making process. However, while the strong versus weak state distinction seems to make sense regarding the input side of the political system, it is flawed if one considers the relationship between societal demands and policy outcomes. The strong French state and corporatist Japan both pursued comparatively low-key and noncommittal policies with respect to the Western alliance system, arms control, and the Soviet Union during the 1980s, but for very different reasons. French foreign policy reflected not so much state strength as the fragility of an elite consensus and a general lack of policy legitimacy in the absence of societal input into the decisionmaking process. But Japanese foreign policy was constrained by the institutionalization of the domestic consensus - elite and public - in the policy network.

The comparison between the weak U.S. state and corporatist Germany is also revealing. Both countries pursued comparatively active and highly visible foreign policies (Germany at least in the East-West context). But there are important differences that reflect the respective domestic structures. The frequent volatility and unpredictability of American policies seems to result from constantly shifting coalitions in Washington's domestic process. In comparison, the Federal Republic has pursued a more stable foreign policy over the last twenty years. In contrast to the U.S., but similar to Japan, the German policy network and the political structure emphasize consensus building and the institutionalization of coalitions in support of specific policies. As a result, the Germans have less direct input into the policy-making process than the Americans have, but their impact on policy outcomes seems to last longer.

I am aware that this paper suffers from a number of limitations and that further comparative research is indicated. First, while this article more or less covers the spectrum of domestic structures in liberal democracies, it deals neither with 
authoritarian regimes nor with one-party systems. Does the empirical evidence confirm the conventional wisdom that public opinion does not count in those countries, or do systems that are not democratic in the Western sense provide the masses with different ways to influence policies? Second, the role of cultural factors to facilitate or to complicate the public's impact on foreign policy has to be examined systematically. The emphasis on consensus building as a social value in both Japan and Germany suggests, for example, that the domestic structure approach as presented here might have to be expanded. Finally, this paper does not deal with the role of the media, though it is fair to assume that the media play a critical role both in the process of opinion formation and in conveying public attitudes to the policymakers.

\section{Notes}

* Drafts of this paper were presented at the European Consortium of Political Research (ECPR) Workshop on "Public Opinion, Foreign Policy, and the Democratic Process," Bochum, West Germany, April 2-7, 1990, and at the Annual Convention of the International Studies Association, Washington D.C., April 10-14, 1990. For very valuable comments I thank Richard Eichenberg, Matthew Evangelista, Philip Everts, Kjell Goldmann, Paul Joseph, Claudia Kappen, Peter Katzenstein, Richard N. Lebow, David Meyer, Nobuo Okawara, Hans Rattinger, Bruce Russett, and the participants in the ECPR workshop. For their help and advice regarding public opinion data I thank Lisa Brandes and Richard Eichenberg.

1 The paper is part of a growing body of literature. See, for example, Michael Barnett, "High Politics Is Low Politics: The Domestic and Systemic Sources of Israeli Security Policy, 1967-1977," World Politics 42 (July 1990), 529-62; Richard Eichenberg, Public Opinion and National Security in Western Europe (Ithaca, N.Y.: Cornell University Press, 1989); Matthew Evangelista, Innovation and the Arms Race (Ithaca, N.Y.: Cornell University Press, 1988); Gert Krell, Rüstungsdynamik und Rüstungskontrolle: Die gesellschaftlichen Auseinandersetzungen um SALT in den USA 1969-1975 (Frankfurt am Main: Haag und Herchen, 1976); Richard N. Lebow, Between Peace and War (Baltimore, Md.: Johns Hopkins University Press, 1981); Jack S. Levy, "Domestic Politics and War," Journal of Interdisciplinary History 18 (Spring 1988), 653-73; Erwin Müller, Rüstungspolitik und Rüstungskontrolle: Fall USA (Baden-Baden: Nomos, 1985); Bruce Russett, Controlling the Sword: The Democratic Governance of National Security (Cambridge: Harvard University Press, 1990); and Eugene Wittkopf, Faces of Internationalism: Public Opinion and American Foreign Policy (Durham, N.C.: Duke University Press, 1990).

2 For excellent reviews of the debate, see Philip Everts and Arthur Faber, "Public Opinion, Foreign Policy, and Democracy" (Paper presented at the ECPR Workshop "Public Opinion, Foreign Policy, and the Democratic Process," Bochum, April 2-7, 1990); and Russett (fn. 1).

3 See, e.g., Benjamin I. Page and Robert Y. Shapiro, "Effects of Public Opinion on Policy," American Political Science Review 77, no. 1 (1983), 175-90.

4 For Western Europe, see Eichenberg (fn. 1), pt. 5. For the U.S., see Ole R. Holsti and James N. Rosenau, "The Domestic and Foreign Policy Beliefs of American Leaders," Journal of Conflict Resolution 32 (June 1988), 248-94; and Wittkopf (fn. 1). For Japan, see Davis Bobrow, "Japan in the World: Opinion from Defeat to Success," Journal of Conflict Resolution 33 (December 1989), 571-603.

5 See, e.g., Noam Chomsky and Edward Herman, Manufacturing Consent (New York: Pantheon, 1988); Benjamin Ginsberg, The Captive Public: How Mass Opinion 
Promotes State Power (New York: Basic Books, 1986); Barry Hughes, The Domestic Context of American Foreign Policy (San Francisco: Freeman, 1979); Michael Margolis and Gary Mauser, eds., Manipulating Public Opinion: Essays on Public Opinion as a Dependent Variable (Belmont, Calif.: Wadsworth, 1989); and James N. Rosenau, Public Opinion and Foreign Policy (New York: Random House, 1961).

6 During election campaigns in the U.S., for example, the majority of the public was aware of the different foreign policy choices under debate and could identify the positions of the presidential candidates. See John H. Aldrich et al., "Foreign Affairs and Issue Voting: Do Presidential Candidates 'Waltz before a Blind Audience'?" American Political Science Review 83, no. 1 (1989), 123-41; Hans Rattinger, "Foreign Policy and Security Issues as Determinants of Voting Behavior in the 1988 U.S. Presidential Election" (Paper presented at the ECPR Workshop "Public Opinion, Foreign Policy, and the Democratic Process," Bochum, April 2-7, 1990). See also Thomas Graham, "The Pattern and Importance of Public Knowledge in the Nuclear Age," Journal of Conflict Resolution 32, no. 2 (1988), 319-34.

7 For the U.S., see Tom W. Smith, "The Polls: America's Most Important Problem, Part I: National and International," Public Opinion Quarterly 49, no. 2 (1985), 264-74; for France, West Germany, and Japan, see Hastings and Hastings, eds., Index to International Public Opinion, 1982-1983 (New York: Greenwood, 1984), 563; and 1983-1984, 689.

8 Robert Shapiro and Benjamin I. Page, "Foreign Policy and the Rational Public," Journal of Conflict Resolution 32, no. 2 (1988), 211-47. For data, see Eichenberg (fn. 1); Gregory Flynn and Hans Rattinger, eds., The Public and Atlantic Defense (London: Croom Helm, 1985); Thomas Graham, American Public Opinion on NATO, Extended Deterrence, and Use of Nuclear Weapons (Cambridge: Center for Science and International Affairs, Harvard University, 1989); and Russett (fn. 1), chap. 4.

9 For example, the well-documented "rally around the flag" effect, according to which presidents can use military interventions to raise their popular support, applies only to a minority of the U.S. population and does not last very long. See Russett (fn. 1), 34-51. For the original study on the effect, see John Mueller, War, Presidents, and Public Opinion (New York: Wiley, 1973). For a general argument regarding elite-public interactions, see Paul Joseph, Realizing the Peace Dividend: The End of the Cold War and the Emergence of Progressive Politics (forthcoming), chap. 4.

10 For a discussion of the cleavages in U.S. public and elite opinion, see Michael Mandelbaum and William Schneider, "The New Internationalism: Public Opinion and American Foreign Policy," in Kenneth Oye et al., eds., Eagle Entangled: U.S. Foreign Policy in a Complex World (New York: Longman, 1979), 34-90; and Wittkopf (fn. 1).

11 For data regarding the U.S., see Graham (fn. 8); and Russett (fn. 1), 57-65; regarding Western Europe, see Eichenberg (fn. 1), chap. 4; and Stephen Szabo, "West European Public Perceptions of Security Issues" (Manuscript, prepared for the USIA, July 1988); for Japan, see Bobrow (fn. 4).

12 For a similar argument focusing on the effects of party systems and electoral rules, see Eichenberg (fn. 1), 235-41.

13 See, for example, Herbert P. Kitschelt, "Political Opportunity Structures and Political Protest: Anti-Nuclear Movements in Four Democracies," British Journal of Political Science 16 (January 1986), 57-85; and Sidney Tarrow, Struggle, Politics, and Reform: Collective Action, Social Movements, and Cycles of Protest (Ithaca, N.Y.: Center for International Studies, Cornell University, 1989). For an overview, see David Meyer, "Peace Movements and National Security Policy: An Agenda for Study" (Paper prepared for the Annual Meeting of the American Political Science Association, Atlanta, Ga., August 31-September 3, 1989).

14 The concept was originally developed by Peter Katzenstein, "International Relations and Domestic Structures: Foreign Economic Policies of Advanced Industrial States," International Organization 30 (Winter 1976), 1-45; Stephen Krasner, Defending the 
National Interest: Raw Materials, Investments, and U.S. Foreign Policy (Princeton: Princeton University Press, 1978). For more recent discussions, see Michael Mastanduno et al., "Toward a Realist Theory of State Action," International Studies Quarterly 33 (December 1989), 457-74; and G. John Ikenberry, "Conclusion: An Institutional Approach to American Foreign Economic Policy," International Organization 42 (Winter 1988), 219-43.

15 See, for example, G. John Ikenberry, "The Irony of State Strength: Comparative Responses to the Oil Shocks in the 1970s," International Organization 40 (Winter 1986), 105-37. See also the special edition of International Organization 42 (Winter 1988), "Approaches to Explaining American Foreign Economic Policy."

16 Peter Gourevitch, "The Second Image Reversed: The International Sources of Domestic Politics," International Organization 32 (Autumn 1978), 881-911, at 904.

17 For coalition-building approaches, see, e.g., Ernst-Otto Czempiel, Amerikanische Außenpolitik (Stuttgart: Kohlhammer, 1979); Joe D. Hagan, "Regimes, Political Oppositions, and the Comparative Analysis of Foreign Policy," in C. F. Hermann et al., eds., New Directions in the Study of Foreign Policy (Boston: Allen and Unwin, 1987), 339-65; Helen Milner, Resisting Protectionism: Global Industries and the Politics of International Trade (Princeton: Princeton University Press, 1988); Thomas RisseKappen, Die Krise der Sicherheitspolitik: Neuorientierungen und Entscheidungsprozesse im politischen System der Bundesrepublik Deutschland, 1977-1984 (Mainz-Munich: Grünewald-Kaiser, 1988); and Ronald Rogowski, Commerce and Coalitions: How Trade Affects Domestic Political Alignments (Princeton: Princeton University Press, 1989).

18 See Hagan (fn. 17).

19 See Peter Gourevitch, Politics in Hard Times (Ithaca, N.Y.: Cornell University Press, 1986); Peter Katzenstein, "Introduction" and "Conclusion," in Katzenstein, ed., Between Power and Plenty: Foreign Economic Policies of Advanced Industrial States (Madison: University of Wisconsin Press, 1978), 3-22, 295-336; and idem, Small States in World Markets (Ithaca, N.Y.: Cornell University Press, 1985).

20 For the concept of "democratic corporatism," see Peter Katzenstein, Corporatism and Change (Ithaca, N.Y.: Cornell University Press, 1984); and Katzenstein (fn. 19, 1985). See also Philippe Schmitter and Gerhard Lehmbruch, eds., Trends towards Corporatist Intermediation (Beverly Hills, Calif.: Sage, 1979).

21 See Vincent Wright, The Government and Politics of France (New York: Holmes and Meier, 1978). On the role of the bureaucracy in French foreign policy, see Mark B. Hayne, "The Quai d'Orsay and the Formation of French Foreign Policy in Historical Context," in Robert Aldrich and John Connell, eds., France in World Politics (London: Routledge, 1989), 194-218.

22 See Alfred Grosser, Affaires extérieures: La politique de la France, 1944-1984 (Paris: Flammarion, 1984), 151-54. For a critical analysis of the institutions of French foreign policy, see Samy Cohen, La monarchie nucléaire: Les coulisses de la politique étrangére sous la V République (Paris: Hachette, 1986).

23 See Reinhold Drifte, Japan's Foreign Policy (London: Chatham House Papers, Royal Institute of International Affairs, 1990), 21-24; Haruhiro Fukui, "Policy-making in the Japanese Foreign Ministry," in R.A. Scalapino, ed., The Foreign Policy of Modern Japan (Berkeley: University of California Press, 1977), 3-35; and Gaston J. Sigur, "Power, Politics, and Defense," in J.H. Buck, ed., The Modern Japanese Military System (Beverly Hills, Calif:: Sage, 1975), 181-95.

24 For details, see Hans Baerwald, "The Diet and Foreign Policy," in Scalapino (fn. 23), 37-54; and John Welfield, An Empire in Eclipse: Japan in the Postwar American Alliance System (London: Athlone Press, 1988).

25 See Helga Haftendorn, ed., Verwaltete Außenpolitik (Cologne: Wissenschaft und Politik, 1978); and Barry Blechman et al., The Silent Partner: West Germany and Arms Control (Cambridge, Mass.: Ballinger, 1988), 27-60. On the German domestic 
structure in general, see Peter Katzenstein, Policy and Politics in West Germany (Philadelphia: Temple University Press, 1989).

26 In particular, the proportionate vote combined with the provision that a party has to gain at least $5 \%$ of the votes nationwide in order to be represented in the Parliament.

27 Thus, unlike the U.S. case, where hawks and doves are usually represented along bureaucratic roles, the party affiliation of the minister determines the policy direction of the Foreign Office as compared with that of the Ministry of Defense.

28 After all, the strong state institutions of the Fifth Republic were intended to counterbalance the divisions of French society. See Douglas E. Ashford, Policy and Politics in France: Living with Uncertainty (Philadelphia: Temple University Press, 1982).

29 See Paul Godt, ed., Policy-making in France: From de Gaulle to Mitterrand (London: Pinter, 1989).

30 Data for 1979-83 are in Eichenberg (fn. 1), 186-87. For further evidence, see Eichenberg, 68, 141, 147, 189.

31 See Jolyon Howorth, France: The Politics of Peace (London: Merlin Press, 1984).

32 For data, see Bobrow (fn. 4); and James A.A. Stockwin, "Japanese Public Opinion and Policies on Security and Defence," in Ronald Dore and Radha Sinha, eds., Japan and World Depression (New York: St. Martin's Press, 1987), 111-34.

33 For details, see Reinhold Drifte, Arms Production in Japan (Boulder, Colo.: Westview Press, 1986), 21-29; Kai Fabig, Japan: Wirtschaftsriese - Rüstungszwerg (Bochum: Studienverlag Brockmeyer, 1984); and Welfield (fn. 24), 434-41.

34 Wittkopf (fn. 1), 34-36, 44-49. In fact, the ideological cleavages are deeper than those in the sociodemographic realm. See also Rattinger (fn. 6).

35 On the U.S. armaments industry, see, e.g., Gordon Adams, The Politics of Defense Contracting: The Iron Triangle (New York: Council on Economic Priorities, 1981); Fen O. Hampson, Un-guided Missiles: How America Buys Its Weapons (New York: W.W. Norton, 1989); on the U.S. peace movements, see David S. Meyer, A Winter of Discontent: The Nuclear Freeze and American Politics (New York: Praeger, 1990); and Frances B. McCrea and Gerald E. Markle, Minutes to Midnight: Nuclear Weapons Protest in America (Newbury Park, Calif.: Sage, 1989).

36 For the 1980s, see Risse-Kappen (fn. 17). For the 1950s, see Marc Cioc, Pax Atomica: The Nuclear Defense Debate in West Germany during the Adenauer Era (New York: Columbia University Press, 1988).

37 This, at least, is the finding of various studies. See, for example, Stephen Rosen, ed., Testing the Theory of the Military Industrial Complex (Lexington, Mass.: Lexington Books, 1973); Krell (fn. 1); and Müller (fn. 1). On the military procurement process, see Hampson (fn. 35).

38 See Phillippe G. LePrestre, "Lessons of Cohabitation," in LePrestre, ed., French Security Policy in a Disarming World (Boulder, Colo.: Lynne Rienner, 1989), 15-47.

39 See Philippe G. LePrestre, "Lessons of Cohabitation," in LePrestre, ed., French Security Howorth and Patricia Chilton, eds., Defence and Dissent in Contemporary France (London: Croom Helm, 1984).

40 A content analysis of party and government documents for 1977-84 showed that "international cooperation" was by far the most frequently mentioned foreign policy objective. See Risse-Kappen (fn. 17).

41 On the importance of consensus building in Japanese politics and particularly in foreign policy, see Takeshi Ishida, Japanese Political Culture (New Brunswick, N.J.: Transaction Books, 1983), 3-22; Douglas Mendel, "Public Views of the Japanese Defense System," in Buck (fn. 23), 150; and Scalapino (fn. 23), xv-xviii.

42 See, for example, T. J. Pempel, Politics and Policy in Japan: Creative Conservatism (Philadelphia: Temple University Press, 1982). For a critique of this analysis evaluating public policy in Japan as a more open process, see Kent Calder, Crisis and Compensation: Public Policy and Political Stability in Japan, 1949-1986 (Princeton: Princeton University Press, 1988). 
43 See Drifte (fn. 33).

44 The following data are taken from a variety of opinion polls. Although I have tried to use as many comparable data as possible, the wording of questions sometimes differed considerably from country to country. As a result, a note of caution is appropriate regarding the interpretation of these data. For example, I will refrain from analyzing minor changes in percentage. Also, I can only present here data on the aggregate level of overall mass public opinion. For comprehensive studies with breakdowns according to age, education, and political orientation, see Eichenberg (fn. 1); and Wittkopf (fn. 1).

45 Data in Hastings and Hastings, eds., Index to International Public Opinion, 1987-1988 (New York: Greenwood, 1989), 574.

46 Data on support for nuclear arms control are taken from various U.S. polls on file at the Yale Public Opinion Research Project, New Haven.

47 See Nincic, "The United States, the Soviet Union, and the Politics of Opposites," World Politics 40 (July 1988), 452-75; and idem, "U.S. Soviet Policy and the Electoral Connection," World Politics 42 (April 1990), 370-96. However, the "politics of opposites" seems to be a unique U.S. phenomenon. A similar cycle is not observable in the three other countries.

48 See data in Gregory Flynn, Public Images of Western Security (Paris: Atlantic Institute for International Affairs, 1985), 65.

49 Data in Hastings and Hastings, eds., Index to International Public Opinion, 1984-1985 (New York: Greenwood, 1986), 237.

50 For data on Ostpolitik, see Elisabeth Noelle-Neuman and Edgar Piel, eds., Allensbacher Jahrbuch der Demoskopie 1978-1983 (Munich: Saur, 1983), 637; on nuclear arms control, see various USIA polls, quoted in Szabo (fn. 11).

51 Data in Elisabeth Noelle-Neumann, "Wenn das Gefühl der Bedrohung schwindet," Frankfurter Allgemeine Zeitung, July 22, 1988. In comparison, about 80 percent of the American public rejected such unilateral steps during the 1980s; data according to Roper and other U.S. polls, on file at the Yale Public Opinion Research Project, New Haven.

52 For this explanation, see Don Munton, "NATO up against the Wall: Changing Security Attitudes in Germany, Britain, and Canada" (Paper presented at the Annual Meeting of the International Studies Association, Washington, D.C., April 1990).

53 For data regarding the perception of U.S. policies, see Szabo (fn. 11).

54 This consideration would also explain why Nincic's "politics of opposites" (fn. 47, 1988) was not observable in Western Europe and Japan. The model is based on a pattern of attitudes in which the perception of Soviet foreign policy still dominates the preferences for specific security policies.

55 See Page and Shapiro (fn. 3). Note, however, that the study does not prove the bottomup model. It correlates public opinion data with policy outcomes and does not control for the impact of elite opinion. It would be consistent with the data to assume, for example, that elite opinion changed first and then affected the general public, which in turn led to policy changes.

56 On the latter, see Max Kampelmann, ed., Alerting America: The Papers of the Committee on the Present Danger (Washington, D.C.: Pergamon-Brassey's, 1984); and Jerry W. Sanders, Peddlers of Crisis: The Committee on the Present Danger (Boston: South End Press, 1983).

57 For details, see Bernd W. Kubbig, Amerikanische Rüstungskontrollpolitik: Die innergesellschaftlichen Kräfteverhältnisse in der ersten Amtszeit Reagans (1981-1985) (Frankfurt am Main: Campus, 1988); and Barry Posen and Stephen Van Evera, "Defense Policy and the Reagan Administration: Departure from Containment," International Security 8 (Summer 1983), 3-45. The best account of U.S. nuclear arms control policy during Reagan's first term is Strobe Talbot, Deadly Gambits (New York: Knopf, 1984). 
58 The most comprehensive account of the freeze movement is Meyer (fn. 35).

59 For details, see Strobe Talbot, The Master of the Game: Paul Nitze and the Nuclear Arms Race (New York: Knopf, 1988). See also Ernst-Otto Czempiel, "U.S. Policy towards the Soviet Union under Carter, Reagan, and Bush" (Paper presented to the Annual Convention of the International Studies Association, Washington, D.C., April 10-14, 1990); and Joseph (fn. 9), chap. 5.

60 This account is based largely on newspaper articles. See, e.g., "Cheney Remarks on Soviet Future Ruffle the White House's Feathers," New York Times, May 1, 1989; "Bush Asks an End to Divided Europe," New York Times, June 1, 1989; and "Bush Policy Makers Reach Uneasy Balance on an Approach to the Soviets," New York Times, July 2, 1989.

61 See Grosser (fn. 22), 161-72.

62 For details, see Cohen (fn. 22); Grosser (fn. 22); Howorth (fn. 31); and Aldrich and Connell (fn. 21).

63 For details, see Cohen (fn. 22); Julius W. Friend, Seven Years in France (Boulder, Colo.: Westview Press, 1989), 75-81; and Michel Tatu, "Valéry Giscard d'Estaing et la détente," in Samy Cohen and Marie Claude Smouts, eds., La politique extérieure de Valéry Giscard d'Estaing (Paris: Presses de la fondation nationale des sciences politiques, 1985), 196-217.

64 In addition, there were historical reasons for the isolation of the French peace movement. The notion of pacifism was identified with the politics of appeasement in the 1930s, and the largest French peace movement, the Mouvement de la Paix, was never able to distance itself convincingly from the Communist Party. For details, see Howorth and Chilton (fn. 39).

65 In this particular case, Mitterrand was apparently influenced by public opinion not only in France but also in West Germany and by the fear that rejection of zero inf would lead to German neutralism. Cf. Jolyon Howorth, "Consensus and Mythology: Security Alternatives in Post-Gaullist France," in Aldrich and Connell (fn. 21), 16-34; and LePrestre (fn. 38).

66 See Eichenberg (fn. 1), 222-24.

67 See Philip G. Cerny, "Gaullism, Nuclear Weapons, and the State," in Howorth and Chilton (fn. 39), 46-74; and David Hanley, "The Parties and the Nuclear Consensus," ibid., 75-93. On the institutional uncertainty of the French system as a dominant feature of the country's policy network, see Ashford (fn. 28).

68 "Independence," for example, was understood in an anti-Soviet sense by the French conservatives, in an anti-American way by the Left, and in a neutralist sense by nationalists at both ends of the political spectrum.

69 For details, see Arnulf Baring, Am Anfang war Adenauer: Die Entstehung der Kanzlerdemokratie (Munich: Deutscher Taschenbuch-Verlag, 1971); Cioc (fn. 36); and Hans-Karl Rupp, Außerparlamentarische Opposition in der Ära Adenauer (Cologne: Pahl-Rugenstein, 1970).

70 For details, see Helga Haftendorn, Sicherheit und Entspannung: Zur Außenpolitik der Bundesrepublik Deutschland, 1955-1982 (Baden-Baden: Nomos, 1983); Wolfram F. Hanrieder, Germany, America, Europe (New Haven: Yale University Press, 1989), 170-219; Clay Clemens, Reluctant Realists: The Christian Democrats and West German Ostpolitik (Durham, N.C.: Duke University Press, 1989); and Christian Hacke, Die Ost- und Deutschlandpolitik der CDU/CSU (Cologne: Wissenschaft und Politik, 1975).

71 For details, see Risse-Kappen (fn. 17), pt. B.

72 For the following, see details ibid. On the peace movements in particular, see Josef Janning et al., eds., Friedensbewegungen (Cologne: Wissenschaft und Politik, 1987); and Thomas Rochon, The Politics of the Peace Movement in Western Europe (Princeton: Princeton University Press, 1988).

73 For analyses of these changes, see Kendall Baker et al., Germany Transformed: Political Culture and the New Politics (Cambridge: Harvard University Press, 1981); 


\section{From the inside out}

Samuel Barnes et al., Political Action: Mass Participation in Five Western Democracies (Beverly Hills, Calif.: Sage, 1979); Karl-Werner Brand et al., Aufbruch in eine andere Gesellschaft: Neue soziale Bewegungen in der Bundesrepublik Deutschland (Opladen: Westdeutscher Verlag, 1983); and Richard Stöss, ed., Parteien-Handbuch, 2 vols. (Opladen: Westdeutscher Verlag, 1983-84).

74 See, for example, J.W.M. Chapman, R. Drifte, and I.T.M. Gow, Japan's Quest for Comprehensive Security (New York: St. Martin's Press, 1982); Scalapino (fn. 23); and Welfield (fn. 24).

75 In March 1983, 72\% of Japanese were worried about Nakasone's defense policy; 48\% disagreed with his remarks about the "unsinkable aircraft carrier." While public opposition to Nakasone's policies declined somewhat over the years, he was nevertheless unable to change the prevailing trends. For data, see Hastings and Hastings, eds., Index to International Public Opinion, 1982-1983 (New York: Greenwood, 1984), 316. For analyses of Japanese foreign policies during the 1980s, see, e.g., Drifte (fn. 23); idem, Japan's Rise to International Responsibilities (London: Athlone Press, 1990); and Malcolm McIntosh, Japan Re-Armed (London: Frances Pinter, 1986).

76 See details in Drifte (fn. 75, 1990), 48-58.

77 I thank Nobuo Okawara for pointing this out to me. See also Calder (fn. 42), 463. The most recent domestic turmoil in Japan on how to deal with the crisis and the war in the Persian Gulf confirms the analysis that mass public opinion severely constrains the country's ruling conservative coalition.

78 This proved to be a major limitation of this study, particularly in the French case. The prevailing realist paradigm in international relations and the focus of most studies on elites do not encourage scholars to trace the impact of public opinion and societal actors on decisions in detail. 


\title{
3 Democratic peace - warlike democracies?
}

\author{
A social constructivist interpretation \\ of the liberal argument (1995)
}

\author{
Thomas Risse-Kappen
}

\section{Introduction}

The liberal argument that democratic political structures form a precondition for stable peace orders in International Relations has become conventional wisdom among Western policy-makers. Immanuel Kant's postulate developed in his 'Perpetual Peace' (1795/1991) has been empirically substantiated. Peace and conflict research has reached a consensus that democracies rarely fight each other (Bueno de Mesquita et al., 1991; Chan, 1993; Russett, 1993). But the 'democratic peace' only forms one part of the empirical finding. Democracies are Janus-faced. While they do not fight each other, they are frequently involved in militarized disputes and war with authoritarian regimes. Democratic peace despite warlike democracies?

This article does not pretend to add new data to the debate on democracy and peace. It is about theory-building. I argue that the two empirical findings on the dyadic level concerning the war involvement of democracies are under-theorized. Most liberal theories of international relations assume that democracies are inherently peaceful, while authoritarian regimes are considered intrinsically aggressive. However, these attempts at theorizing about democracy and warinvolvement do not capture the different behaviours by democratic states depending with whom they are dealing. There is little empirical support for the proposition that the war-involvement of democracies mostly results from the need to defend themselves against aggressive dictatorship. How is it then to be explained that, on the one hand, democracies rarely fight each other and build stable peace orders among themselves, but, on the other hand, can be rather belligerent in their interactions with authoritarian regimes? Following Ernst-Otto Czempiel (1986), Michael Doyle (1983, 1986), and Bruce Russett (1993), I start from the so-called 'normative explanation' of the democratic peace. I argue that this explanation can be considerably refined from a social-constructivist perspective. I claim that democracies to a large degree create their enemies and their friends - 'them' and 'us' - by inferring either aggressive or defensive motives from the domestic structures of their counterparts. As a result, they follow behavioural norms externalizing their internal compromise-oriented and nonviolent decision rules in their interactions with other democracies. 'Pacific 
federations' (Kant, 1795/1991) or pluralistic security communities (Deutsch et al., 1957), such as the European Union or the transatlantic relationship, can be easily created among democratic systems. The presumption of potential enmity, however, creates a realist world of anarchy when democratic states interact with authoritarian regimes. Limited 'cooperation under anarchy' is still possible, but problems of defection and relative gains might hamper cooperative arrangements between democracies and non-democracies.

The article consists of three parts. First, I briefly review the empirical state of the art. Second, I discuss the prevailing theoretical explanations for the dual finding of 'democratic peace' and 'warlike democracies'. I then present a socialconstructivist modification of the normative argument, concluding with suggestions for a research agenda with which to evaluate the argument presented in this article.

\section{The empirical findings: Democratic peace - warlike democracies?}

The empirical findings on the correlation between domestic political structures and foreign policy behaviour can be summarized in two statements: (1) democracies are involved in as many wars as other types of political systems; (2) democracies rarely fight each other.

\section{Warlike democracies?}

Between 1816 (i.e. after the end of the Napoleonic wars) and 1976, democratic political systems were involved in as many militarized disputes, international crises and wars as authoritarian regimes and proportionate to their percentage among states (Gleditsch and Hegre, 1995; see also Small and Singer, 1976; Maoz and Abdolali, 1989). The result does not change significantly when only 'politically relevant' dyads are examined; for example, great powers and/or contiguous states (Maoz and Russett, 1992: tables 2 and 3). It is virtually impossible without detailed historical case studies to determine aggressor and defender in the roughly 30 wars since 1816 in which democracies have been involved (Gleditsch and Hegre, 1995; Lake, 1992). It might not even make sense conceptually to distinguish between challenger and target of aggression except in very rare cases. Aggression and defence are usually in the eye of the beholder. Consider, for example, the four most violent interstate wars since 1816 in which democracies were involved. Only one of them - World War II - was a clear case of aggression by a totalitarian regime. The Korean War (1950-53) was a case in which the initial attack was undertaken by an authoritarian regime against another non-democracy. A US-led coalition that included many democracies then came to the defence of the target. However, this coalition then escalated the war considerably by crossing the 38 th parallel, which led to a - defensively motivated? - countermove in terms of the war involvement of China. ${ }^{1}$ It is even more difficult to identify aggressor and defender during World War I. As regards the Vietnam War, the USA not only intervened but also escalated it. 
In order to establish that democracies are inherently more peaceful than authoritarian regimes, one would need to show that democratic war involvement was provoked mostly by non-democracies. Rudolph Rummel appears to be a dissenting vote from the scholarly consensus that democracies are as war-prone as autocratic regimes (Rummel, 1995). He argues that democratic regimes are less violent in their foreign behaviour than autocratic regimes. His data suggest, however, that the main dividing line is not between democracies and nondemocracies, but between authoritarian and totalitarian regimes. ${ }^{2}$

In sum, there is little evidence that democracies are less frequently involved in military threats and the use of force in international relations or that they are disproportionately more often on the defensive than the offensive side in those militarized disputes or wars. The war involvement of democracies has somewhat decreased since the 1970s; there also seems to be a correlation between the stability of democratic systems and their war involvement (Chan, 1984; Russett and Maoz, 1993). But these negative correlations are not robust enough to infer a general peacefulness of participatory political systems.

\section{The democratic peace}

While democracies do not seem to be inherently more peaceful than autocratic regimes, there is nevertheless an island of peace in an ocean of conflicts and wars. Democracies rarely fight each other, at least not since $1816 .{ }^{3}$ There have been military threats, the mobilization of troops and small skirmishes between democracies, but (almost) no interstate war. Moreover, such militarized disputes among democracies occur significantly less frequently than can be expected in a random distribution. And those militarized disputes that do occur among democracies almost never escalate into war (Bremer, 1993; Maoz and Abdolali, 1989; Maoz and Russett, 1991). The finding of a 'democratic peace' is robust with regard to the time-period selected, the specific definition of democracy or the method used (quantitative or qualitative). At least three different data sets the Correlates of War project, the International Crisis Behaviour project and the Hamburg-based Ver-gleichende Kriegsursachenforschung project (Gantzel et al., 1986) - have been used to substantiate this claim (Bremer, 1993; Doyle, 1983; Gleditsch and Hegre, 1995; Maoz and Abdolali, 1989; Maoz and Russett, 1992; Nielebock, 1993). There is no other empirical finding in the realm of international relations that has reached a similar consensus among scholars.

Following Kenneth Waltz's earlier attack on the 'democratic peace' proposition, there have been two recent criticisms of this claim (Layne, 1994; Spiro, 1994; Waltz, 1993). Christopher Layne argues on the basis of four serious crises among democratic states that these did not escalate for 'realist' rather than 'liberal' reasons. David Spiro claims that the 'democratic peace' finding is not statistically significant, given that wars occur rarely and that democracies are also quite rare in the international system. Both attacks miss the mark. First, two of Layne's four cases have been thoroughly investigated by John Owen, who insists that the lack of escalation in Anglo-American relations in 1861 (US civil war) and in 
1895-96 (Venezuela crisis) had much to do with the mutual perception of them as liberal democracies (Owen, 1993, 1994). As for the 1923 Ruhr crisis, another case of Layne's 'near misses', it is equally questionable whether the French public and elites perceived Germany during the 1923 Ruhr crisis as a liberal democracy, given the instability of the Weimar Republic at the time. This leaves the 1898 Fashoda crisis to support Layne's argument. Not a very convincing database on which to challenge the 'democratic peace' proposition! ${ }^{4}$

Second, as for Spiro's claims about the statistical insignificance of the 'democratic peace' finding, Bruce Russett's rebuttal takes care of most points. If data are split into ever smaller parts, it is mathematically impossible to find statistical significance. Russett then used Spiro's method of year-by-year analysis with regard to the 'Militarized Interstate Dispute' data and confirmed the 'democratic peace' proposition in a statistically significant way (Russett, 1995). In sum, the challenge to the 'democratic peace' proposition rests on rather dubious assumptions and equally doubtful empirical analysis.

Bruce Russett and Zeev Maoz (1993) have examined alternative explanations for the 'democratic peace' hypothesis. They show that wealth and conflict behaviour are not correlated. While rich democracies are slightly more involved in militarized disputes among each other than poor ones are, wealthy authoritarian regimes fight each other far more frequently. While geographic proximity slightly increases the rate of disputes among democracies, this variable is far more significant with regard to autocratic regimes. Economic interdependence also adds to peace, but this finding does not eliminate the effect of democracy (Oneal et al., 1995). The only other variable that correlates significantly with peacefulness is the stability of the regime measured in years. Stable political systems, whether democracies or autocracies, are less likely to fight each other. This finding implies that stable democratic systems constitute the main inhabitants of the 'island of democratic peace'.

In sum, democracies almost never fight each other, even though they are sometimes involved in militarized disputes and the exchange of threats. They do not automatically form 'pacific federations' (Kant, 1795/1991) or 'pluralistic security communities' (Deutsch et al., 1957). But there appears to be a barrier that prevents militarized conflicts among democracies from escalating into war. As William Dixon has shown, third-party mediation is very likely to succeed when democratic systems threaten to use force against each other (Dixon, 1993, 1994). As a result, there is a contrast between the 'democratic peace', on the one hand, and the war involvement of democracies with authoritarian systems, on the other, that requires theoretical explanation.

\section{Prevailing explanations}

A theoretical explanation of the empirical findings of a 'democratic peace' despite frequent war involvement by democracies must answer four questions:

1 Why is it that militarized disputes are far less likely to occur among democratic dyads than among democratic-authoritarian or autocratic-autocratic dyads? 
2 Why is it that militarized disputes among democracies almost never escalate into war?

3 Why is it that democracies are more likely to cooperate in alliances and maybe - other international institutions than autocratic political systems?

4 Why is there less difference in the general war involvement of democracies as compared to other types of political systems?

These four questions can be summarized into one: why is it that the 'security dilemma' appears to be far less significant when democracies deal with each other, while it seems to govern their interactions with authoritarian systems? The 'security dilemma' represents a good starting-point for evaluating competing explanations of the empirical findings. It shows why and how even peacefully motivated states in an anarchic self-help system can end up in arms races, escalatory processes, crises and war with each other. To explain war, we do not need to assume aggressive intentions or expansionist motives on either side (Herz, 1950; Jervis, 1978). It is not so much intentions that drive the security dilemma, as lack of information and uncertainty about the motives of other states, which are then perceived as potential opponents. Of course, arguments about the security dilemma are firmly grounded in realist theory. Structural realism in the Waltzian tradition does not assume power-maximizing states to explain war in the international system. Rather, it is sufficient to conceptualize states as defensive positionalists concerned about their survival in a self-help environment in order to explain arms races, crises and war (Grieco, 1988; Waltz, 1979). A liberal response to the realist claims concentrating on establishing the inherent peacefulness of liberal democracies is, therefore, insufficient. Given the condition of uncertainty in an anarchic self-help system, states can be as peaceful as they want to be, they still have to be defensive positionalists if they want to survive in such a system. ${ }^{5}$ Rather, a liberal response to realism must, first, explain why and how democracies 'know' that other participatory systems have equally peaceful intentions, i.e. why the uncertainty that drives the security dilemma is far less relevant when democracies deal with each other. Second, it follows that such a response cannot exclusively focus on the unit-level of domestic polities and politics, but needs to include the level of international interactions among states. I argue below that the prevailing liberal interpretations of the 'democratic peace' fail on both accounts.

\section{Participatory constraints and rational cost-benefit calculations}

Immanuel Kant argued that democracies do not fight each other because of the participation of the citizens in the decision-making processes:

If . . the consent of the citizens is required to decide whether or not war is to be declared, it is very natural that they will have great hesitation in embarking on so dangerous an enterprise. For this would mean calling down on themselves all the miseries of war, such as doing the fighting themselves, 
supplying the costs of the war from their own resources, painfully making good the ensuing devastation. . . .

The peaceful foreign policy of democratic states is explained by the rational cost-benefit calculations of the citizens in a participatory polity. Aggressive foreign policy and the costs of war run counter to the welfare interests of the citizens - except for the immediate defence of one's territory and way of life. It is argued that the citizens in democratic states are primarily motivated to increase their economic well-being, as long as their external security is guaranteed. As a result, they are unlikely to support military adventures and wars of aggression, except, perhaps, under circumstances of low risk (Müller and RisseKappen, 1990: 390-1). While this account focuses on the cost-benefit calculations of the citizens, a 'political incentive explanation' of the democratic peace has been suggested that concentrates on such calculations by national leaders (Geva et al., 1993). ${ }^{6}$

Cost-benefit calculations and the price of war-fighting might explain a certain reluctance of participatory polities to engage in military adventures. But such calculations should apply irrespectively of whether democratic systems deal with each other or with dictatorships. Rational choice arguments might explain why democracies pursue aggressive foreign policies under specific circumstances, but not why societal support for such interventions can only be mobilized against authoritarian systems. Referring to utilitarian cost-benefit calculations of citizens in a democratic polity cannot explain why foreign aggression is absent even in extremely asymmetrical relations in which the costs of attack are low for the more powerful state - as long as democracies are involved on both sides. Moreover, the argument does not address the uncertainty issue that lies at the heart of the security dilemma. It merely accounts for some reluctance to engage in warfare. As I argue later in this article, costs and benefits of aggressive foreign policies are not quasi-objective entities, but depend on perceptions, norms and collective identities. The latter define the framework within which utility calculations take place.

\section{Institutional constraints and the complexity of democratic decision-making}

A second explanation emphasizes institutional constraints. Democratic political systems are characterized by an elaborate set of checks and balances - between the executive and the legislature, between the political system, interest groups and public opinion and so on. Decision-making processes, particularly those involving war and peace issues, need time, since leaders need to mobilize sufficient domestic support to go to war. The size of winning coalitions is expected to be far larger in democracies than in authoritarian systems, in which support by small elite groups might suffice. One could then argue that the complexity of the decision-making process makes it unlikely that leaders readily use military 
force unless they are confident of gathering enough domestic support and of the costs being low. They will perceive leaders of other democracies as equally constrained and, therefore, refrain from violence (Bueno de Mesquita and Lalman, 1992: Ch. 4; Morgan and Campbell, 1991; see also Russett, 1993: 38-40).

In a sense, the finding that democracies rarely fight each other would be a statistical artefact according to the 'institutional constraints' argument, since the democratic character of decision-making processes would not explain the absence of war among liberal systems, but the higher complexity of their policy-making institutions. The more centralized the political systems, the more likely it is that their leaders go to war. If such is the case the decisive distinction would not be between democracies and nondemocracies, but between highly centralized and fragmented political structures, between 'weak' and 'strong' states as far as the state-society relationships are concerned (Katzenstein, 1978; Krasner, 1978). The degree of autonomy which decision-makers enjoy vis-à-vis societal demands should then correlate with their preparedness to use force in international politics. One would expect, for example, that the French state with its highly centralized political institutions of the Fifth Republic would be more likely to go to war than the comparatively fragmented and 'society-dominated' US political system. There are not many empirical studies available investigating systematically the war involvement of 'strong' as compared to 'weak' states (see, however, Morgan and Campbell, 1991; Morgan and Schwebach, 1992; Russett and Maoz 1993).

More importantly, the 'institutional constraints' model is unconvincing theoretically, since it tries to separate norms and institutions. Institutions consist of norms of appropriate behaviour, rules defining role expectations and stabilized anticipations of the future. The complexity of democratic decision-making procedures is itself partly a function of democratic norms incorporated in the political institutions of liberal systems. The rule of law, for example, which is an intrinsic characteristic of liberal democracies and is emphasized in Kant's 'Perpetual Peace', is both normative and serves as an institutional constraint on decisionmakers. It is, therefore, almost impossible to distinguish between arguments focusing on the complexity of decision-making processes and those emphasizing norms.

Moreover, the model cannot explain why democratic leaders sometimes quickly decide to go to war against authoritarian systems, are able to mobilize large amounts of societal resources within a short period of time - and get away with it by counting on the 'rally round the flag' effect (Mueller, 1973; Russett, 1990: Ch. 2). The US initial escalation of the Vietnam War represents such a case, as do the interventions in Grenada and Panama. When liberal systems are faced with authoritarian adversaries, the complexity of democratic institutions appears to matter less. Finally, the 'institutional constraints' model might explain why complex decision-making systems exert checks on national leaders concerning war-fighting and, thus, emphasizes - again - some inherent peacefulness of such systems. However, the argument does not address the uncertainty question discussed above. It is not clear why institutionally constrained leaders who perceive their fellow democrats as equally constrained, should, therefore, refrain from 
violence. The model - in the absence of normative underpinnings - has no theoretically convincing argument why rational leaders of democratic systems should not be tempted to exploit equally constrained leaders for a quick and less costly military victory, thereby overcoming their own domestic restrictions. Rational leaders in institutionally constrained decision-making structures could even fear that their equally constrained counterparts make similar calculations, as a result of which uncertainty re-enters the calculus. And back we are in the security dilemma!

\section{The externalization of democratic norms}

Liberal democracies are characterized not only by the rule of law, the constraints of checks and balances and participatory rule of the citizens. Their domestic structures also consist of norms, rules and procedures embedded in the political culture and institutionalized in the political system. Democratic systems are supposed to guarantee freedom and human rights, to protect minorities and to establish the principal equality of citizens with regard to their participatory rights. Democratic decision-making rules emphasize the peaceful resolution of conflict through compromise and consensus, penalize the threat or the use of force in domestic disputes as illegitimate, and provide for the possibility that today's minority might become tomorrow's majority. Democratic governance emphasizes social diversity, shifting coalitions, the consent of the governed and the publicity of the political process. Authoritarian regimes are characterized mostly by the absence of these norms. If, however, the norms regulating the decision-making processes in democratic systems are oriented toward non-violence and the peaceful resolution of political conflicts, one could expect that democracies externalize these norms when dealing with each other.

This argument emphasizes the norms constituting the collective identity of actors in a democratic polity instead of utilitarian cost-benefit calculations or the complexity of decision-making processes. These norms are then expected to shape the motivations, perceptions and practices of actors in liberal systems. The argument offers a more convincing explanation for the 'democratic peace' than the other accounts, since it focuses on normative structures shaping interaction processes rather than on individual behaviour. Norms which have been internalized by actors to the extent that they affect their collective identities are expected to guide interactions, whether in the domestic or in the international realm. Democratic systems are expected to externalize their internal decisionmaking norms and rules in their foreign policy behaviour. Two functions of norms can be distinguished (Kratochwil, 1989). First, norms serve as communication devices that enable interactions in the first place by providing a framework of shared and collective understandings. Second, norms create, regulate and stabilize social order. It is the first function that might provide an explanation for the externalization of democratic norms when liberal polities deal with each other. We need additional arguments, however, in order to explain why democracies are also likely to externalize the regulatory functions of their domestic 
norms when dealing with each other. It is not obvious that democracies are likely to create cooperative international institutions on the basis of compromiseoriented decision-making norms - social order - among themselves. I come back to this point later.

The argument offers a convincing explanation why democratic state actors are in general defensively motivated when it comes to international relations. Norms as communication devices also provide a starting-point explaining why liberal democracies perceive each other as peacefully motivated. It is this perception that needs to be assumed in order to deal convincingly with the uncertainty factor inherent in the security dilemma. But the normative explanation for the democratic peace is still under-theorized. Bruce Russett, a leading advocate of the normative explanation, argues, for example, that:

. . . if people in a democracy perceive themselves as autonomous, selfgoverning people who share norms of live-and-let-live, they will respect the rights of others to self-determination if those others are also perceived as self-governing and hence not easily led into aggressive foreign policies by a self-serving elite.

(Russett, 1993: 31; see also Czempiel, 1981: 219; Doyle, 1986)

This argument rests on an assumption which is not self-evident. In a dog-eat-dog world of anarchy, the self-image as democratic and peaceful might or might not guide interactions with other democracies. Again, the perception of others as equally restrained might lead rational actors into adventurous foreign policies themselves or create the uncertainty that other rational leaders might come to the same conclusion. One frequently used line of reasoning to overcome this problem is to assume that aggressive behaviour is forced upon democracies by the mere existence of authoritarian regimes. Autocratic leaders are not bound by liberal norms of non-violent and compromise-oriented resolution of conflict, since they do not form part of their identity:

In non-democracies, decisionmakers use, and may expect their opponents to use, violence and the threat of violence to resolve conflict as part of their domestic political processes. ... Therefore nondemocracies may use violence and the threat of violence in conflicts with other states, and other states may expect them to use violence and the threat of violence in such conflicts.

(Russett, 1993: 35; see also Czempiel, 1992: 263)

In other words, authoritarian systems determine the rules of the game in their interactions with democratic states. The latter have to keep up their guard in order to contain potentially aggressive behaviour of the former. Aggressive behaviour of peacefully minded democratic states would ultimately result from the mere existence of autocratic regimes in the international system. As argued above, such an explanation cannot easily be reconciled with the empirical data. For example, one would expect to find clearer indications that militarized disputes between 
democracies and authoritarian systems are more often caused and initiated by the latter rather than by the former. In striking contrast to the robustness of the 'democratic peace' finding, there is not much in the empirical data to suggest this.

In sum, the normative explanation of the 'democratic peace' provides a good starting-point for theorizing about war and democracy. The arguments presented so far might explain the defensive motivations of democratic systems stemming from their collective identity as well as the potentially aggressive intentions of authoritarian systems. But if the argument is correct that the security dilemma results from uncertainty rather than from intentions, these explanations are insufficient. There must be something in the interactions between democracies and dictatorships, on the one hand, and among democracies, on the other, that explains the difference in behaviour. How do democracies 'know' that other democracies are equally peaceful and can, therefore, be trusted? And why do they feel potentially threatened by autocratic rulers, thus enacting the 'security dilemma' when dealing with them?

\section{A social constructivist interpretation of the normative argument}

Social constructivism as such does not provide a substantive theory of international relations. It is not a 'fair weather' theory of international politics, as some have misunderstood it to be. ${ }^{7}$ Rather, social constructivism provides a set of assumptions of what it is that we theorize about in International Relations:

- International Relations forms part of the social construction of reality. Social rather than material structures constitute actors as social individuals. Structures and agents are mutually constitutive

(Jepperson et al., 1996; Wendt, 1987, 1992).

It follows that anarchy and the resulting security dilemma are social constructs as well (see also Mercer, 1995). The structure of the international system has not somehow fallen from heaven, but has been created by states and their interactions. As a result, anarchy and self-help as fundamental characteristics of International Relations are not unavoidable.

- Actors' interests and preferences cannot be treated as exogenous or fixed in a theory of International Relations. Rather, they originate and change during the processes of social interaction. As a result, we must move beyond the logic of instrumental rationality implied by rational choice theory and incorporate the logic of persuasion and communicative action. Words matter as much as deeds (Müller, 1994).

- Ideas and norms have to be taken more seriously in International Relations than traditional theories based on material interests can account for.

In particular, the notion of ideas as 'switchmen' between material interests and behaviour has to be challenged (Hall, 1993). A more fundamental notion 
holds that ideas and norms have constitutive effects on the identity of actors and, as a result, on the way actors perceive their interests (Jepperson et al., 1996; Wendt, 1994). To put it differently, material interests do not exist in an idea-free vacuum.

What does a social constructivist interpretation of the democratic peace and the war involvement of democracies add to the liberal argument, particularly its normative version? Perceptions are the starting-point. The proposition that authoritarian regimes are potential aggressors given their domestic structure of oppression and violence can more readily be reconciled with the empirical data if it is not taken as a quasi-objective finding, but as a perception by democratic systems. As Michael Doyle put it:

[D]omestically just republics, which rest on consent, then presume foreign republics also to be consensual, just, and therefore deserving of accommodation. . . . At the same time, liberal states assume that non-liberal states, which do not rest on free consent, are not just. Because non-liberal governments are in a state of aggression with their own people, their foreign relations become for liberal governments deeply suspect. In short, fellow liberals benefit from a presumption of amity; nonliberals suffer from a presumption of enmity.

(Doyle, 1986: 1161)

In other words, enmity as well as friendship in the international system neither result from some inherent features of the international distribution of power, as realists would assume, nor from the domestic structures of states as such, as the above-quoted liberals argue. Rather, it is socially constructed. The democratic peace as well as the frequently aggressive behaviour by liberal states toward non-democracies then results from a rule learned through the processes of interaction, namely to infer aggressiveness or peacefulness from the degree of violence inherent in the domestic political structure of one's opponent. This explanation has to be distinguished from the liberal interpretations discussed above, in that it assumes neither some inherent aggressiveness of authoritarian systems nor some intrinsic peacefulness of liberal democracies. Rather, intersubjective perceptions count and the rule to infer external behaviour from one's internal political structures and its degree of violence and oppression. Peacefulness as well as enmity is learned through international interactions.

But why is it that the perception of others as either potentially hostile or probably friendly depends on an evaluation of their domestic political structures? We get closer to an answer if we conceptualize norms as communication devices. Decision-makers in democratic polities who have been socialized in the norms governing liberal states are likely to communicate their intentions in the international realm by referring to these very norms. When they encounter fellow democrats, a collective understanding of these norms can be readily established, providing a common basis for further communication of peaceful intentions. Leaders of democratic states communicating their peaceful intentions to each 
other can always validate their claims by pointing to the peaceful resolution of conflicts inherent in their domestic structures. In other words, the validity claims of peacefulness are substantiated by one's own domestic structure. As a result, the spiral model of the security dilemma is reversed and uncertainty reduced. The possibility to validate one's claim of peacefulness through reference to one's domestic norms also explains why the democratic peace is particularly characteristic of stable democracies. States in various stages of transition to democracy may still be met with suspicion given their domestic turmoil.

The argument that democratic norms serve as communication devices by which leaders of liberal states are likely to establish peaceful relations with fellow democracies can also account for the fact that there are indeed militarized disputes among democracies, but that these almost never escalate into war. First, nothing in the argument presented so far assumes that there are never real conflicts of interests among liberal states. The issue is about how these conflicts are dealt with, not their existence. Second, the argument about communication processes by which democratic leaders establish the mutual recognition of norms of peaceful conflict resolution implies that time is involved. The democratic peace results from a process of social interaction. Initially hostile confrontations particularly in cases of severe conflicts of interests are well within the realm of possible behaviour. The longer the crisis endures, the more likely it is that norms of peaceful resolution of conflict can finally be established or that third-party mediation succeeds. Third, norms do not guide behaviour in such a way that they are never violated. We do run red lights from time to time. Valid norms guide behaviour in a probabilistic sense. As a result, the argument presented here does not require zero wars among democracies. It does require, though, that leaders of democratic states use third-party mediation or engage in specific communicative behaviour such as apologies, justifications, or offers of compensatory action when violating norms.

Insights derived from psychological attribution theory shed further light on both the virtual absence of the security dilemma among democratic states and its presence in interactions between the latter and dictatorships. Attribution theory posits that individuals tend to judge the behaviour of others on the basis of dispositional rather than situational factors, while one's own behaviour is regarded as driven mostly by situational components (Crocker et al., 1983; Jones et al., 1971; Kahnemann et al., 1986; Lebow and Stein, 1993; Stein, 1994). Actors of democratic systems would then attribute potentially cooperative and non-aggressive behaviour to fellow democrats in the international system, since their domestic structures predispose them toward such conduct. If the other state is considered as democratic and just, one does not assume oneself to be potentially threatened. As a result, states start trusting each other. Trust, however, is a functional equivalent of complete information and, thus, reduces uncertainty, the driving force of the security dilemma (Luhmann, 1989). If actors of democratic states view each other as predisposed toward peacefulness, the significance of the security dilemma in their interactions is substantially reduced and, therefore, a major obstacle 
toward stable security cooperation removed. Actors who trust each other start behaving accordingly. They thereby create a peaceful and cooperative order through their interaction processes which reinforces the perception of one's peaceful intentions. In other words, the presumption that the other is predisposed toward peacefulness leads to a self-fulfilling prophecy if both sides act on this assumption. The 'democratic peace' is socially constructed.

The democratic character of one's domestic structures then leads to a collective identification process among actors of democratic states defining the "ingroup' (Wendt, 1994). Such a collective identity not only substantially reduces the significance of the security dilemma, it also decreases the importance of the two major obstacles to international cooperation identified by regime theory fear of cheating and the 'relative gains' problem (Baldwin, 1993; Grieco, 1988; Oye, 1986). Mutual trust reduces the fear of cheating. As for the 'relative gains' problem, actors of democratic states 'know' through the process of social identification that they are unlikely to fight each other in the future. The realist assumption is no longer valid that today's friend can always be tomorrow's enemy and that, therefore, each state has to worry that its partner might gain more from cooperation than oneself. Mutual gains through cooperative arrangements become possible. ${ }^{9}$

If we assume a collective identity because of shared liberal values among democratic state actors, cooperative norms regulating the interactions among democracies are likely to emerge when liberal systems are faced with cooperation problems. If these norms are institutionalized in regimes or international organizations such as NATO or the European Union, democracies are expected to form the Kantian 'pacific federations' (foedus pacificum), or what Karl W. Deutsch called a 'pluralistic security community'. Such communities are defined as:

... a group of people which has become 'integrated'. By integration we mean the attainment, within a territory, of a 'sense of community' and of institutions and practices strong enough and widespread enough to assure, for a 'long' time, dependable expectations of 'peaceful change' among its population.

(Deutsch et al., 1957: 5-6)

While Deutsch's notion of pluralistic security communities was not confined to democracies, it is unlikely that a similar collective identity and sense of mutual responsiveness could emerge among autocratic leaders. There is nothing in their values that would prescribe mutual sympathy, trust and consideration. Rather, cooperation among non-democracies is likely to emerge out of self-interests narrowly defined.

Why is it that domestic orders, norms and political cultures shape the identities of actors in the international realm? Why not economic orders such as capitalism? Why not geographic concepts such as 'the West', the 'North Atlantic area', and the like? Why not gender and race such as 'white males'? It is, of 
course, trivial that actors hold multiple identities. Which of these or which combination dominates their interests, perceptions and behaviour in a given area of social interaction needs to be examined through empirical analysis and cannot therefore be decided beforehand. I submit, however, that values and norms pertaining to questions of governance are likely to shape identities in the realm of the political - be it domestic or international. Moreover, notions such as 'the West' do not contradict the argument here, but seem to represent a specific enculturation of a broader liberal world-view. The same holds true for identities as 'capitalists', particularly if juxtaposed against 'Communist order'. The notion of the 'free world' which Western policy-makers used frequently during the Cold War to refer to their collective identity and to demarcate the boundaries against 'Communism' encompassed liberal values pertaining to both the political and the economic orders (Latham, 1995).

Most liberal systems share not only democratic values, but also a common appreciation of capitalist market economies. ${ }^{10}$ Why is it that their community of values is based upon the norms governing their domestic political rather than economic orders? If the latter were the case, relative gains would matter more, since the norms governing capitalist orders emphasize competition and - albeit regulated - conflict. Fierce economic competition among capitalist states does not contradict the notion of security community among democracies, though. International competition among capitalists is as much predicated upon a stable and peaceful international order as a domestic capitalist economy requires the state to guarantee property rights and the rule of law. Such a stable international order cannot be built upon capitalist values of competition, but requires the mutual recognition of democratic norms of peaceful conflict resolution.

If the predisposition of actors in democratic states leads them to trust other democracies, to externalize their internal decision-making norms in their interactions among each other, and, thus, to construct the 'democratic peace', how is the war involvement of liberal states with non-democracies to be explained? Starting from the above-quoted argument by Michael Doyle, I argue that the same rule - identity formation in international relations on the basis of one's domestic order - leads to the opposite predisposition and perception when actors of democracies deal with authoritarian regimes. It is irrelevant in this context whether dictatorships are inherently aggressive or not. It is enough to set a security dilemma in motion if one side perceives the other as potentially violent. If democracies infer potential aggressiveness out of the internal political structure of oppressive regimes, they will feel threatened and act accordingly by forming alliances, engaging in arms races and even aggressive foreign policy. While ambiguous behaviour by other democracies is likely to be perceived as confirming the assumption of friendliness, ambivalent behaviour of autocratic regimes will probably confirm the perception of their predisposition toward violence and, hence, the feeling of being threatened. As the security dilemma tells us, mutually aggressive behaviour might well occur despite mutually defensive intentions. Belligerence then results from uncertainty about each other's motives. Unlike realism, which posits that the security dilemma is caused by the eternal anarchic 
nature of the international system, a social constructivist interpretation of the liberal argument points out that, first, the security dilemma is confined to relations between democracies and autocracies or among the latter and, second, results from dispositional attributions in conjunction with behavioural consequences creating the anarchical structure in the first place. Enmity is socially constructed through mutual perceptions and interactions.

While democracies are likely to form a collective identity because of shared values whereby other liberal states become part of 'us', dictatorships are perceived as the 'other', the out-group. This does not exclude tactical alliances such as the US-UK alliance with the Soviet Union in 1941 or the American-Chinese relationship after 1972, but the cooperation problems identified by rationalist regime theory should apply. Since there is no mutual trust, fear of cheating might prevent cooperation. Since there is no sense of community, the 'relative gains' problem should play a more significant role. The Western aggressiveness during the Cold War and its sometimes grotesquely exaggerated threat perceptions can easily be accounted for in this context. The social construction of the Communist threat also explains why detente and arms control were so difficult to establish in the East-West relationship. If both sides perceive their conflict as irreconcilable, as caused by dispositional rather than situational factors, and as involving values and fundamental goals rather than means, conflict regulation becomes very difficult. $^{11}$

An approach combining domestic structural characteristics, perceptions and interaction patterns in the international realm appears to offer a better explanation than conventional liberal accounts for the dual finding of the 'democratic peace' despite frequent war involvement by democracies. However, if the presumption of friendship among democracies is as socially constructed as the presumption of hostility in relations between the latter and autocratic systems, one should assume that both did not automatically emerge with the existence of democratic states in international relations. Rather, one would assume an evolutionary process and learning (Levy, 1994; Russett, 1993: 5-11). Two factors might explain why leaders in democratic states learned to perceive other democracies as peaceful and, by the same token, to distance themselves from autocracies.

First, publicity is an important ingredient of democratic decision-making processes. When foreign policy becomes the subject of public controversies (Holsti, 1992; Russett, 1990: Ch. 4), and when aggressive foreign policies provoke counter-reactions in a democratic polity, actors can be more readily persuaded of the peaceful nature of democratic systems. The more decision-making processes become transparent, the more other political systems and societies can convince themselves that democracies are defensively motivated. The absence of publicity in autocratic systems, however, increases the feeling of uncertainty by liberal states and might lead to increased suspicions. Western speculations about Iraq during the Gulf crisis and war as well as about North Korean ambitions with regard to nuclear weapons illustrate the point. Iraqi and North Korean behaviour was frequently evaluated on the basis of dispositional factors, whereby 
the lack of transparency confirmed perceptions of the aggressive nature of these autocracies.

At the same time, the publicity of the democratic process is unlikely to be perceived as reassuring by non-democracies, since transparency threatens the rule of autocratic leaders. The CSCE process, for example, created international publicity on the violation of human rights in Eastern Europe and the Soviet Union, thereby empowering dissident groups and undermining the rule structure of the Communist systems (Deudney and Ikenberry, 1991/92; Thomas, forthcoming). In other words, the difference in publicity contributes to the democratic peace among liberal systems but also increases threat perceptions between democracies and authoritarian systems.

Second, liberal states generate transnational relations among societal actors, since democracies are characterized by the separation between state and society. The more autonomous societies are vis-à-vis the state, the less governments are capable of controlling or prohibiting the transnational activities of their citizens (Keohane and Nye, 1971, 1977; Risse-Kappen, 1995b). This is not to argue that transnational relations are restricted to democracies. I posit only that liberal societies facilitate the emergence of transnational actors, while transnational access to autocratic states tends to depend on the explicit consent of the rulers.

But transnational relations as such do not promote peace among states. They might have different effects depending on whether they link democratic systems with each other or democracies and dictatorships. Transnational relations within the democratic community of states might increase the sensitivity of the societies for each other, thereby providing one more mechanism by which liberal systems communicate peaceful intentions. Transnational contacts between democratic societies and autocratic states, however, are unlikely to communicate defensive motivations, but might undermine oppressive regimes by decreasing the closed character of their societies. There are several indications, for example, that transnational exchanges between Western human rights and peace movements, on the one hand, and dissident groups in Eastern Europe, the Philippines and South Africa, on the other, empowered the latter and, thus, undermined the autocratic rule structures (Klotz, 1995; Sikkink, 1993; Thomas, forthcoming). As a result, transnational linkages between democratic societies and authoritarian states might not contribute to peaceful relations, but actually increase the tensions between the former and the latter, since they challenge repressive rule from inside.

\section{Conclusions: Suggestions for a research agenda on democracy and peace}

I have argued in this article that a social constructivist interpretation of the normative explanation for the dual finding of 'democratic peace' and 'democratic war involvement' provides a better account than reference to cost-benefit calculations, institutional constraints, or an alleged inherent peacefulness of liberal 
systems. Democracies do not fight each other because they perceive each other as predisposed toward peacefulness and then act on this assumption. They perceive each other as peaceful, because of the democratic norms governing their domestic decision-making processes. These norms constitute their collective identity in international relations. They externalize them when dealing with each other, thus re-enforcing the presumption of peacefulness. For the same reason, they are likely to form pluralistic security communities based on a collective identity. Because they perceive each other as peaceful and express a sense of community, they are likely to overcome obstacles against international cooperation and to form international institutions. The norms regulating interactions in such institutions are expected to reflect the shared democratic values and to resemble the domestic decision-making norms.

At the same time, relations among democracies and authoritarian regimes suffer from the presumption of potentially aggressive intentions. Democratic state actors assume that autocratic leaders are predisposed toward belligerence, since their domestic rule is based on oppression and violence. This perception then creates a security dilemma leading to behavioural patterns that confirm the presumption of enmity. Both the absence of the security dilemma among democracies and its presence when democratic systems deal with dictatorships are then socially created through perceptual and interactive processes. Thus, the explanation is situated on both the domestic and the international levels.

The argument put forward in this article is speculative at the moment. While it is consistent with the empirical data, the processes it describes require detailed investigation. However, there are some empirical studies suggesting that collective identities and the perceptions of enmity and friendship matter indeed. John Owen $(1993,1994)$, for example, has shown in detail how perceptions of the other as democratic or non-democratic mattered in war-threatening crises involving the US, from the late 18th century to World War I. His work comes close to an empirical test of the argument developed above. Another study pertains to the question of whether the Peloponnesian war involved wars among democracies, particularly between Athens and Syracuse. Challenging the argument by Bruce Russett and William Antholis (1993), Tobias Bachteler (1995) argues that Athens and Syracuse did not perceive each other as stable democracies and, thus, could not develop a collective identity preventing them from fighting each other. Internal turmoil and frequent domestic violence prohibited a mutual perception as peaceful and liberal. My own work (Risse-Kappen, 1995a) on the European influence on US foreign policy elaborates on the proposition that democracies are more likely than other types of political systems to align with one another. I argue that interaction patterns in the transatlantic alliance can be explained by assuming a security community in Deutsch's sense creating a collective identity of shared democratic values which then leads to norms of consultation and consensus-based decision-making. I submit that this account provides a better explanation of the empirical evidence in the US-European Cold War relationship than traditional alliance theories based on realist bargaining theory. 


\section{From the inside out}

However, these studies represent only a first attempt at systematically evaluating normative-constructivist explanation of 'democratic peace' and 'democratic war involvement'. We need detailed case studies on:

- the domestic discourses leading to the war involvement of democracies as compared to 'near misses' when disputes among democracies did not escalate;

- the origins of such militarized disputes among democracies as well as the reasons for the lack of escalation to war (see Dixon, 1993, 1994);

- the role of publicity and of transnational relations in creating both the 'democratic peace' and perceptions of potential hostility between democracies and autocratic systems;

- the differential impact of mass public opinion and elite opinion in the processes described above. ${ }^{12}$

I particularly emphasize that such studies involve detailed analyses of communication processes. One fundamental problem of most quantitative studies on democracy and war is that they rely, first, on data on a highly aggregate level, and, second, on behavioural evidence. An explanation focusing on norms, identity and perceptions, however, must involve discourse analysis, since words matter as much as deeds in such an account. The main reason why current studies evaluating the normative explanation of the democratic peace against the 'institutional constraints' model have been found inconclusive is that measuring norms via behaviour alone is questionable. ${ }^{13}$ Norms and identities affect behaviour via processes of communicative action. If we ignore these processes in our research designs, we cannot convincingly prove or disprove the normative argument.

\section{Notes}

This is a thoroughly revised version of an article first published in German (RisseKappen 1994a; see also 1994b). The English version was first presented at the International Political Science Association Congress, Berlin, 25-28 August 1994. For comments on the draft I thank Nils Petter Gleditsch, Bruce Russett, several anonymous reviewers of this Journal and the panel participants in Berlin.

1 It is now clear that the crossing of the 38th parallel by the Western democracies constituted the major escalatory move during the Korean War leading to the Chinese intervention (Christensen, 1992).

2 Table 2, for example, which he considers superior to Table 1 relying solely on Correlate of War data, shows no difference between democracies and non-democracies for violence dead as percentage of population (Rummel, 1995).

3 Two points have to made here. First, if general and universal suffrage is considered the most significant criterion for the democratic character of a political system, it should be noted that there were no democracies until approximately 1900 . Until that time, women, for the most part, were not allowed to vote. How can one speak of democracies if half the population is excluded from participatory rights? It might well be that gender is relevant for the 'democratic peace' finding in the sense that the woman's vote strengthens it (see Brandes, 1994; Russett, 1995: 167, fn. 8). Second, most scholars argue that democracies 'rarely' fight each other, since there are some 
borderline cases depending on how strict the criteria one uses for what constitutes a democracy. According to James Lee Ray (1993), however, none of the alleged 'wars among democracies' qualifies, if peaceful change of government following free elections that involve at least $50 \%$ of the population is used as the definitional criterion for 'democracy.'

4 Layne's treatment of pre-World War I Imperial Germany as a democracy so that World War I was a war among democracies is too grotesque to require a comment by a European scholar. For example, the controversy surrounding Fritz Fischer's work that Layne calls 'ideologically tinged' was not about the alleged democratic character of Wilhelmine Germany, but about the domestic causes of World War I and their relative significance compared to other causes of war (Layne, 1994: 41-4).

5 On this point, I agree with Christopher Layne's criticism of the prevailing liberal explanations for the 'democratic peace' (Layne, 1994: 7-13; see also Owen, 1994: 90-103).

6 I thank an anonymous reviewer for alerting me to this article.

7 See, for example, John Mearsheimer's recent analysis of 'critical theory.' He lumps together very different approaches having allegedly in common the assertion that ideas move the world. See Mearsheimer (1994/95).

8 For a similar point, see Russett (1993: 33). As the above-quoted excerpt from Russett's book shows, however, he appears to argue more from a position which assumes an intrinsic malevolence of at least some authoritarian systems than a socially constructed enmity between democracies and dictatorships.

9 This is not to argue that only liberal democracies form stable international regimes. Rather, I submit that democratic states can overcome obstacles to international cooperation more easily than other types of systems.

10 I thank Mark Laffey for alerting me to this point.

11 On this point see the 'problem-structural' approach to regime analysis as developed by the Tübingen group (Efinger and Zürn, 1990).

12 In this article, I have deliberately avoided the issue whether the social construction of the democratic peace and the war involvement of democracies only concerns the elite level or must include the level of mass public opinion. I suspect the latter, but am unable to provide a convincing argument. I thank an anonymous reviewer for alerting me to this point.

13 Bruce Russett and Zeev Maoz, for example, operationalize the normative approach via the persistence of a political regime and the level of violent internal conflict. Neither indicator can be regarded as directly and causally linked to norms. In fact, the persistence of political regimes over time can just as well be explained within the 'institutional constraints' model (Russett and Maoz, 1993).

\section{References}

Bachteler, Tobias (1995) 'Demokratischer Friede im klassischen Griechenland? Überlegungen zum Phänomen des demokratischen Friedens anhand der sizilischen Expedition Athens und des Kriegsverhaltens der Demokratien des Ersten Attischen Seebundes', unpublished manuscript, Konstanz University.

Baldwin, David A. (ed.) (1993) Neorealism and Neoliberalism: The Contemporary Debate. New York: Columbia University Press.

Brandes, Lisa (1994) 'The Liberal Feminist State and War', paper prepared for presentation at the Annual Meeting of the American Political Science Association, New York, 1-4 September.

Bremer, Stuart (1993) 'Democracy and Militarized Interstate Conflict, 1816-1965', International Interactions 18 (3): 231-49. 


\section{From the inside out}

Bueno de Mesquita, Bruce J., Robert W. Jackman and Randolph M. Siverson (eds) (1991) Democracy and Foreign Policy: Community and Constraint, special issue of Journal of Conflict Resolution 35 (2).

Bueno de Mesquita, Bruce J. and David Lalman (1992) War and Reason. New Haven, CT: Yale University Press.

Chan, Steve (1984) 'Mirror, Mirror on the Wall . . Are the Freer Countries More Pacific?' Journal of Conflict Resolution 28 (4): 617-48.

Chan, Steve (ed.) (1993) Special issue of International Interactions 18 (3).

Christensen, Thomas (1992) 'Threats, Assurances, and the Last Chance for Peace', International Security 17 (1): 122-54.

Crocker, Jennifer, Darlene B. Hannah and Ren Weber (1983) 'Person Memory and Causal Attributions', Journal of Personality and Social Psychology 44: 55-66.

Czempiel, Ernst-Otto (1981) Internationale Politik. Paderborn: Schöningh.

Czempiel, Ernst-Otto (1986) Friedensstrategien. Paderborn: Schöningh.

Czempiel, Ernst-Otto (1992) 'Governance and Democratization', in Ernst-Otto Czempiel and James N. Rosenau (eds) Governance without Government: Order and Change in World Politics, pp. 250-71. Cambridge: Cambridge University Press.

Deudney, Daniel and G. John Ikenberry (1991/92) 'The International Sources of Soviet Change', International Security 16 (3): 74-118.

Deutsch, Karl W. (1957) Political Community and the North Atlantic Area. Princeton, NJ: Princeton University Press.

Dixon, William J. (1993) 'Democracy and the Management of International Conflict', Journal of Conflict Resolution 37 (1): 42-68.

Dixon, William J. (1994) 'Democracy and the Peaceful Settlement of International Conflict', American Political Science Review 88 (1): 14-32.

Doyle, Michael (1983) 'Kant, Liberal Legacies, and Foreign Affairs', Philosophy and Public Affairs 12 (3/4): 205-35.

Doyle, Michael (1986) 'Liberalism and World Politics', American Political Science Review 80 (4): 1151-9.

Efinger, Manfred and Michael Zürn (1990) 'Explaining Conflict Management in EastWest Relations: A Quantitative Test of Problem-Structural Typologies', in Volker Rittberger (ed.), International Regimes in East-West Politics, pp. 64-89. London: Pinter.

Gantzel, Klaus-Jürgen and Joerg Mayer-Stamer (1986) Die Kriege nach dem Zweiten Weltkrieg bis 1984: Daten und erste Analysen. Munich: Weltforum.

Geva, Nehemia, Karl DeRouen and Alex Mintz (1993) 'The Political Incentive Explanation of the "Democratic Peace" Phenomenon: Evidence from Experimental Research', International Interactions 18 (3): 215-29.

Gleditsch, Nils Petter and Havard Hegre (1995) 'Peace and Democracy: Three Levels of Analysis', unpublished manuscript, PRIO, Oslo.

Grieco, Joseph M. (1988) 'Anarchy and the Limits of Cooperation. A Realist Critique of the Newest Liberal Institutionalism', International Organization 42 (3): 485-507.

Hall, John A. (1993) 'Ideas and the Social Sciences', in Judith Goldstein and Robert Keohane (eds) Ideas and Foreign Policy, pp. 31-54. Ithaca, NY: Cornell University Press.

Herz, John (1950) 'Idealist Internationalism and the Security Dilemma', World Politics 2 (2): $157-80$.

Holsti, Ole (1992) 'Public Opinion and Foreign Policy: Challenges to the AlmondLippmann Consensus', International Studies Quarterly 36 (4): 439-66. 
Jepperson, Ron, Alexander Wendt and Peter Katzenstein (1996) 'Norms, Identity, Culture, and National Security', in Katzenstein (ed.) The Culture of National Security: Norms and Identity in World Politics. New York: Columbia University Press (forthcoming).

Jervis, Robert (1978) 'Cooperation Under the Security Dilemma', World Politics 30 (2): $167-214$.

Jones, Edward (ed.) (1971) Attribution: Perceiving the Causes of Behavior. Morristown, NJ: General Learning Press.

Kahnemann, Daniel, et al. (1986) Judgement under Uncertainty: Heuristics and Biases. New York: Cambridge University Press.

Kant, Immanuel (1795/1991) 'Perpetual Peace. A Philosophical Sketch', in Hans Reiss (ed.) Kant Political Writings, 2nd edn, pp. 93-130. Cambridge: Cambridge University Press.

Katzenstein, Peter (ed.) (1978) Between Power and Plenty. Madison: University of Wisconsin Press.

Keohane, Robert O. and Joseph S. Nye Jr (eds) (1971) Transnational Relations and World Politics. Cambridge, MA: Harvard University Press.

Keohane, Robert O. and Joseph S. Nye (1977) Power and Interdependence. Boston, MA: Little Brown.

Klotz, Audie (1995) Protesting Prejudice. Apartheid and the Politics of Norms in International Relations. Ithaca, NY: Cornell University Press.

Krasner, Stephen (1978) Defending the National Interest. Princeton, NJ: Princeton University Press.

Kratochwil, Friedrich (1989) Norms, Rules, and Decisions. Cambridge: Cambridge University Press.

Lake, David (1992) 'Powerful Pacifists: Democratic States and War', American Political Science Review 86 (1): 24-37.

Latham, Robert (1995) 'Liberalism's Order/Liberalism's Other: A Genealogy of Threat', Alternatives 20 (1): 111-46.

Layne, Christopher (1994) 'Kant or Cant: The Myth of the Democratic Peace', International Security 19 (2): 5-49.

Lebow, Richard N. and Janice G. Stein (1993) 'Afghanistan, Carter, and Foreign Policy Change: The Limits of Cognitive Models', in Timothy McKeown and Dan Caldwell (eds) Force, Diplomacy, and Statecraft: Essays in Honor of Alexander L. George. Boulder, CO: Westview Press.

Levy, Jack (1994) 'Learning and Foreign Policy: Sweeping a Conceptual Minefield', International Organization 48 (2): 279-312.

Luhmann, Niklas (1989) Vertrauen. Ein Mechanisms zur Reduktion sozialer Komplexität, 3rd edn. Stuttgart: Enke.

Maoz, Zeev and Nasrin Abdolali (1989) 'Regime Types and International Conflict, 18161976', Journal of Conflict Resolution 33 (1): 3-35.

Maoz, Zeev and Bruce Russett (1992) 'Alliances, Contiguity, Wealth, and Political Stability: Is the Lack of Conflict among Democracies a Statistical Artefact?', International Interactions 17 (3): 245-68.

Mearsheimer, John (1994/95) 'The False Promise of International Institutions', International Security 19 (3): 5-49.

Mercer, Jonathan (1995) 'Anarchy and Identity', International Organization 49 (2): 229-52.

Morgan, Clifton T. and Sally H. Campbell (1991) 'Domestic Structures, Decisional Constraints, and War: So Why Kant Democracies Fight?', Journal of Conflict Resolution 35 (2): 187-211. 
Morgan, Clifton T. and Valerie Schwebach (1992) 'Take Two Democracies and Call Me in the Morning: A Prescription for Peace?' International Interactions 17(4): 305-20.

Müller, Harald (1994) 'Internationale Beziehungen als kommunikatives Handeln', Zeitschrift für Internationale Beziehungen 1 (1): 15-44.

Müller, Harald and Thomas Risse-Kappen (1990) 'Internationale Umwelt, gesellschaftliches Umfeld und außenpolitischer Prozeß in liberaldemokratischen Industrienationen', in Volker Rittberger (ed.) Theorien der internationalen Beziehungen, special issue of Politische Vierteljahresschrift 21: 376-400.

Mueller, John E. (1973) War, Presidency, and Public Opinion. New York: Wiley.

Nielebock, Thomas (1993) 'Frieden zwischen Demokratien: Ein empirisches Gesetz der Internationalen Beziehungen auf der Suche nach seiner Erklärung', Österreichische Zeitschrift für Politikwissenschaft 22 (2): 179-93.

Oneal, John R., Frances H. Oneal, Zeev Maoz and Bruce M. Russett (1995) 'The Liberal Peace: Trade, Democracy, and International Conflict, 1950-1985', Journal of Peace Research, 33 (1), in press.

Owen, John M. (1993) 'Testing the Democratic Peace: American Diplomatic Crises, 1794-1917', PhD dissertation, Harvard University.

Owen, John M. (1994) 'How Liberalism Produces Democratic Peace', International Security 19 (2): 87-125.

Oye, Kenneth (ed.) (1986) Cooperation under Anarchy. Princeton, NJ: Princeton University Press.

Ray, James L. (1993) 'Wars between Democracies: Rare, or Nonexistent?', International Interactions 18 (3): 251-76.

Risse-Kappen, Thomas (1994a) 'Demokratischer Frieden? Unfriedliche Demokratien? Überlegungen zu einem theoretischen Puzzle', in Gert Krell and Harald Müller (eds) Frieden und Konflikt in den internationalen Beziehungen. Festschrift für Ernst-Otto Czempiel, pp. 159-89. Frankfurt am Main: Campus.

Risse-Kappen, Thomas (1994b) 'Wie weiter mit dem “demokratischen Frieden"?', Zeitschrift für internationale Beziehungen 1 (2): 367-79.

Risse-Kappen, Thomas (1995a) Cooperation among Democracies. The European Influence on US Foreign Policy. Princeton, NJ: Princeton University Press.

Risse-Kappen, Thomas (ed.) (1995b) Bringing Transnational Relations Back In: Non-State Actors, Domestic Structures, and International Institutions. Cambridge: Cambridge University Press.

Rummel, Rudolph J. (1995) 'Democracies ARE Less Warlike than Other Regimes', European Journal of Internation Relations 1 (4): 457-79.

Russett, Bruce (1990) Controlling the Sword. Cambridge, MA: Harvard University Press.

Russett, Bruce (1993) Grasping the Democratic Peace. Princeton, NJ: Princeton University Press.

Russett, Bruce (1995) 'The Democratic Peace: “And yet it Moves”, , International Security 19 (4): 164-75.

Russett, Bruce and William Antholis (1993) 'The Imperfect Democratic Peace of Ancient Greece', in Russett (1993): 43-71.

Russett, Bruce and Zeev Maoz (1993) 'The Democratic Peace since World War II', in Russett (1993): 72-93.

Sikkink, Kathryn (1993) 'Human Rights, Principled Issue Networks, and Sovereignty in Latin America', International Organization 47 (3): 411-41.

Small, Melvin and J. David Singer (1976) 'The War-Proneness of Democratic Regimes', Jerusalem Journal of International Relations 1 (4): 50-69. 
Spiro, David E. (1994) 'The Insignificance of the Democratic Peace', International Security 19 (2): 50-86.

Stein, Janice G. (1994) 'Political Learning by Doing: Gorbachev as Uncommitted Thinker and Motivated Learner', International Organization 48 (2): 155-83.

Thomas, Daniel (forthcoming) 'When Norms and Movements Matter: Helsinki, Human Rights, and Political Change in Eastern Europe, 1970-1990', PhD dissertation, Cornell University, NY.

Waltz, Kenneth (1979) Theory of International Politics. Reading, MA: Addison-Wesley.

Waltz, Kenneth (1993) 'The Emerging Structure of International Politics', International Security 18 (2): 44-79.

Weede, Erich (1984) 'Democracy and War Involvement', Journal of Conflict Resolution 28 (4): 649-64.

Weede, Erich (1992) 'Some Simple Calculations on Democracy and War Involvement', Journal of Peace Research 29: 377-83.

Weede, Erich (1994) 'Determinanten der Kriegsverhütung während des Kalten Krieges und danach: Abschreckung, Demokratie und Freihandel', Politische Vierteljahresschrift 35 (1): $62-84$.

Wendt, Alexander (1987) 'The Agent-Structure Problem in International Relations Theory', International Organization 41: 335-70.

Wendt, Alexander (1992) 'Anarchy Is What States Make of It: The Social Construction of Power Politics', International Organization 46 (2): 391-425.

Wendt, Alexander (1994) 'Collective Identity Formation and the International State', American Political Science Review 88 (2): 384-96. 


\section{Collective identity in a democratic community \\ The case of NATO (1996)}

Thomas Risse-Kappen*

\section{The puzzle}

Why was it that the United States, the undisputed superpower of the early post1945 period, found itself entangled in the North Atlantic Treaty Organization (NATO) with Western Europe only four years after the end of World War II? Why was it that a pattern of cooperation evolved in NATO that survived not only the ups and downs of the Cold War and various severe interallied conflicts from the 1956 Suez crisis to the conflict over Euromissiles in the 1980s - but also the end of the Cold War? Why is it that NATO has emerged as the strongest among the post-Cold War security institutions - as compared to the Organization for Security and Cooperation in Europe (OSCE), the West European Union (WEU), not even to mention the EU's Common Foreign and Security Policy (CFSP)?

Traditional (realist) alliance theory ${ }^{1}$ at least has a simple answer to the first two questions: the Soviet threat. But what constituted the Soviet threat? Was it Soviet power, ideology, behavior, or all three combined? I argue in this essay that the notion of the "Soviet threat" needs to be unpacked and problematized if we want to understand what it contributed to the emergence and the endurance of NATO. I also claim that realism might provide first-cut answers to the questions above but that it is indeterminate with regard to explaining particular Western European and U.S. choices at critical junctures of the Cold War, not even to mention its aftermath. Moreover, sophisticated power-based arguments that try to account for these choices do so at the expense of parsimony. Why should they be privileged as providing the baseline story, while more elegant alternative explanations are used to add some local coloration? ${ }^{2}$

I provide an account for the origins and the endurance of NATO different from the conventional wisdom. NATO and the transatlantic relationship can be better understood on the basis of republican liberalism linking domestic polities systematically to the foreign policy of states. ${ }^{3}$ Liberal democracies are likely to form "pacific federations" (Immanuel Kant) or "pluralistic security communities" (Karl W. Deutsch). Liberalism in the Kantian sense, however, needs to be distinguished from the conventional use of the term, as in neoliberal institutionalism, denoting the "cooperation under anarchy" perspective of rationalist regime analysis. ${ }^{4}$ I present a social constructivist interpretation of republican 
liberalism, emphasizing collective identities and norms of appropriate behavior. To illustrate my argument, I discuss the origins of NATO, the transatlantic interactions during two major Cold War "out-of-area" crises (the 1956 Suez crisis and the 1962 Cuban missile crisis), and the persistence of NATO after the end of the Cold War.

\section{Theorizing about alliances realism and NATO: The indeterminacy of the conventional wisdom}

Traditional alliance theory is firmly grounded in realist thinking. Realism, however, is indeterminate with regard to explaining the origins of, the interaction patterns in, and the endurance of NATO.

\section{Realism and the origins of NATO}

Structural realism contains a straightforward alliance theory. ${ }^{5}$ States balance rather than bandwagon; alliances form because weak states band together against great powers in order to survive in an anarchic international system. Alliance patterns change because the international distribution of power changes. This is particularly true under multipolarity; great powers do not need allies under bipolarity. The latter structure consists of only two great powers, which are selfsufficient in terms of their ability to survive. As a result, alliances become a matter of convenience rather than necessity.

It is hard to reconcile Waltzian realism with the history of NATO. The U.S. emerged from World War II as the undisputed superpower in the international system, enjoying a monopoly (and later superiority) with regard to the most advanced weapons systems, i.e., nuclear forces. Its gross domestic product (GDP) outweighed that of all Western European states combined, not even to mention the Soviet Union. If material capabilities are all that counts in world politics, one would have expected Western Europe to align with the Soviet Union rather than with the U.S. ${ }^{6}$

But the Waltzian argument rests on some peculiar assumptions about bipolarity. While great powers may not need allies to ensure their survival, client states might become an asset in the competition between the two hegemonic rivals. After all, bipolarity means that the two great powers in the system have to cope primarily with each other. As "defensive positionalists," they are expected to be concerned about relative gains and losses vis-á-vis each other and to compete fiercely. ${ }^{7}$ The more important relative gains are, however, the more significant the acquisition of client states should become. While the loss or defection of one small ally might not be important, superpowers might fear that even small losses might set in motion a chain reaction.

Thus, if we change our understanding of bipolarity only slightly, American Cold War policies of acquiring allies around the globe, including the Western Europeans, can be explained. In other words, structural realism can be made consistent with actual U.S. behavior during the Cold War, but the theory could also explain the opposite behavior. 
What about Stephen Walt's more sophisticated realism emphasizing the "balance of threat" rather than the "balance of power"? ${ }^{8}$ Does it reduce the indeterminacy of structural realism by adding more variables? Walt argues that states align against what they perceive as threats rather than against economic and military capabilities as such. States feel threatened when they face powers that combine superior capabilities with geostrategic proximity, offensive military power, and offensive ideology. One could then argue that the proximity of the Soviet landmass to Western Europe, Moscow's offensive military doctrine backed by superior conventional forces, and the aggressive communist ideology constituted the Soviet threat leading to the formation of NATO.

There is no question that Western decision makers perceived a significant Soviet threat during the late 1940s and that this threat perception was causally consequential for the formation of NATO. The issue is not the threat perception, but what constituted it: Soviet power, ideology, behavior, or a combination of the three? As to Soviet power, the geographic proximity of the Soviet landmass Walt's first indicator - could explain the Western European threat perception and the British and French attempts to lure reluctant decision makers in Washington into a permanent alliance with Europe. ${ }^{9}$ But it is still unclear why the U.S. valued Western Europe so much that it decided to join NATO. The argument that the U.S. wanted to prevent Soviet control over the Eurasian rimland ${ }^{10}$ makes sense only if we also assume that decision makers in Washington saw themselves as defensive positionalists in a fierce hegemonic rivalry rather than more relaxed Waltzian realists (see above). In this case, sophisticated realism is as inconclusive as structural realism.

Moreover, the Soviet Union was not considered an offensive military threat to Western Europe during the late 1940s. Military estimates did increasingly point to Soviet military superiority in Europe, but that did not lead to the perception of an imminent attack. As John Lewis Gaddis put it, "Estimates of Moscow's intentions, whether from the Pentagon, the State Department, or the intelligence community, consistently discounted the possibility that the Russians might risk a direct military confrontation within the foreseeable future."11

Rather, the U.S. threat perception at the time focused on potential Soviet ability to psychologically blackmail war-weakened Western Europe and to destabilize these countries politically and economically. This American view of a significant Soviet threat was concerned about actual Soviet behavior in Eastern Europe and the Soviet offensive political ideology - the third of Walt's indicators. If this is indeed what constituted the Soviet threat in Western eyes in the late 1940s, it can be better explained by liberal theories than by even sophisticated realism (see below). At least, the two accounts become indistinguishable at this point.

\section{Realism and cooperation patterns in NATO}

Realism's indeterminacy with regard to the origins of NATO also applies to interaction patterns within the Western Alliance. To begin with, structural realism of the Waltzian variety has a clear expectation regarding cooperation among allies. If great powers do not need allies under bipolarity, they also do not need 
to listen to them. As Waltz put it, the contributions of smaller states to alliances "are useful even in a bipolar world, but they are not indispensable. Because they are not, the policies and strategies of alliance leaders are ultimately made according to their own calculations and interests." 12

If this argument holds true, one would not expect much European influence on U.S. decisions during the Cold War - particularly not in cases, such as the Cuban missile crisis, when the U.S. perceived its supreme national interests at stake. I show later in this essay that this expectation proves to be wrong. Close cooperation among the allies was the rule rather than the exception throughout the history of NATO - with regard to European security, the U.S.-Soviet relationship, and "out-of-area" cases. The power asymmetry within NATO did not translate into American dominance. Rather, the European allies managed to influence U.S. foreign policy significantly even in cases when the latter considered its supreme national interests to be at stake. ${ }^{13}$

More sophisticated realists, however, should not be too surprised by these findings. If we assume that decision makers in Washington needed allies to fight the Cold War, we would expect some degree of cooperation within the Western Alliance, including European influence on U.S. policies. Allies who need each other to balance against a perceived threat are expected to cooperate with each other. Unfortunately, this assumption is demonstrably wrong. Cooperation among allies is by no means assured. Allies are as likely to fight each other as they are to fight non-allies - except for democratic alliances. ${ }^{14}$ Thus we need additional assumptions about the conditions under which nations in alliances are likely to cooperate. According to realist bargaining theory, for example, we would expect a higher degree of interallied cooperation,

- $\quad$ the higher the perceived level of external threat

- the more allies fear that their partners might abandon them or defect, particularly in crisis situations

- the more issue-specific power resources are used in interallied bargaining situations. ${ }^{15}$

At this point, sophisticated realism loses much of its parsimony. Evaluating these propositions against alternative claims requires detailed process-tracing of interallied bargaining. We cannot simply assume a realist bargaining process when we find outcomes consistent with one specific version of realist theory.

\section{Realism and the endurance of NATO after the Cold War}

The indeterminacy of realism also applies when we start using the theory to predict the survivability of NATO after the Cold War. Structural realists in the Waltzian tradition should expect NATO to wither away with the end of the Cold War. If great powers do not need allies under bipolarity for their survival, this should be all the more true when the hegemonic rivalry ceases to dominate world politics. In Waltz's own words, "NATO is a disappearing thing. It is a question of how long it is going to remain as a significant institution even though its name may linger on."16 
In the absence of indicators of what "lingering on" means, it is hard to evaluate the proposition. I argue later in this essay that NATO is alive and well so far, at least as compared to other security institutions in Europe.

Sophisticated realism and "balance-of-threat" arguments are indeterminate with regard to the future of NATO. On the one hand, one could argue that the Western Alliance should gradually disintegrate as a result of the Soviet withdrawal from Eastern Europe and the drastically decreased military threat. On the other hand, the Russian landmass might still constitute a residual risk to Western Europe, thus necessitating a hedge against a potential reemergence of the threat. ${ }^{17}$ In any case, the Western offer for a "partnership for peace" to Russia is difficult to account for even by sophisticated realism.

In sum, a closer look at realism as the dominant alliance theory reveals its indeterminacy with regard to the origins of, the interaction patterns in, and the endurance of NATO. In retrospect, almost every single choice of states can be accommodated somehow by realist thinking. As a Waltzian realist, the U.S. could have concluded that the direct confrontation with the USSR was all that mattered, while the fate of the Western Europeans would not alter the global balance of power. As a more sophisticated realist, the U.S. would have decided - as it actually did - that the fate of the Eurasian rim was geostrategically too significant to leave the Western Europeans alone. If decision makers in Washington listened to their allies during the Cuban missile crisis, we can invoke realist arguments about reputation and the need to preserve the alliance during crises. Had the U.S. not listened to the Western Europeans during the crisis, one could have argued that superpowers do not need to worry about their allies when they perceive that their immediate survival is at stake. If NATO survives the end of the Cold War, it is "lingering on" as a hedge; if it disappears, the threat has withered away. As others have noted before, realism is not especially helpful in explaining particular foreign policy choices. ${ }^{18}$ I now look at a liberal account emphasizing a community among democracies, collective identity, and alliance norms.

\section{Democratic allies in a pluralistic security community: A liberal constructivist approach}

The U.S. had quite some latitude as to how it defined its interests in Europe. Thus we need to "look more closely at this particular hegemon" in order to "determine why this particular . . agenda was pursued." 19 Domestic politics and structures have to be considered, and the realm of liberal theories of international relations is to be entered.

To avoid confusion, particularly with what is sometimes called neoliberal institutionalism, I reserve the term liberal theories of international relations for approaches agreeing that ${ }^{20}$

1 the fundamental agents in international politics are not states but individuals acting in a social context - whether governments, domestic society, or international institutions; 
2 the interests and preferences of national governments have to be analyzed as a result of domestic structures and coalition-building processes responding to social demands as well as to external factors such as the (material and social) structure of the international system;

3 ideas - values, norms, and knowledge - are causally consequential in international relations, particularly with regard to state interests, preferences, and choices;

4 international institutions form the social structure of international politics presenting constraints and opportunities to actors.

Immanuel Kant's argument ${ }^{21}$ that democratic institutions characterized by the rule of law, the respect for human rights, the nonviolent and compromise-oriented resolution of domestic conflicts, and participatory opportunities for the citizens are a necessary condition for peace has been empirically substantiated. Most scholars agree that liberal democracies rarely fight each other, even though they are not peaceful toward autocratic regimes. ${ }^{22}$ The reasons for these two findings are less clear, since explanations focusing solely on democratic domestic structures miss the point that liberal states are not inherently peaceful. Rather, we need theoretical accounts that link the domestic level to interactions on the international level. ${ }^{23}$

Two domestic-level explanations prevail in the literature. ${ }^{24}$ The first emphasizes institutional constraints. Democracies are characterized by an elaborate set of checks and balances - between the executive and the legislature, between the political system and interest groups, public opinion, and so on. It is then argued that the complexity of the decision-making process makes it unlikely that leaders will readily use military force unless they are confident of gathering enough domestic support for a low-cost war. This explanation is theoretically unconvincing. Why is it that the complexity of democratic institutions seems to matter less when liberal states are faced with authoritarian adversaries?

The second explanation focuses on the norms governing democratic decisionmaking processes and establishing the nonviolent and compromise-oriented resolution of political conflicts, the equality of the citizens, majority rule, tolerance for dissent, and the rights of minorities. These norms are firmly embedded in the political culture of liberal states and shape the identity of political actors through processes of socialization, communication, and enactment. This normand identity-based account appears to offer a better understanding of why it is that democratic governments refrain from violence when dealing with fellow democracies. But its exclusive focus on the domestic level still does not show why such restraints disappear when liberal governments deal with autocratic regimes.

The norm- and identity-based explanation nevertheless can be easily amended and linked to the level of international interactions. Collectively held identities not only define who "we" are, but they also delineate the boundaries against "them," the "other." ${ }^{25}$ Identities then prescribe norms of appropriate behavior toward those perceived as part of "us" as well as toward the "other." There is 
no reason that this argument should not equally apply to the domestic and the international realm. A sociological interpretation of a liberal theory of international relations then claims that actors' domestic identities are crucial for their perceptions of one another in the international realm. As Michael Doyle put it,

Domestically just republics, which rest on consent, then presume foreign republics also to be consensual, just, and therefore deserving of accommodation. . . . At the same time, liberal states assume that non-liberal states, which do not rest on free consent, are not just. Because non-liberal governments are in a state of aggression with their own people, their foreign relations become for liberal governments deeply suspect. In short, fellow liberals benefit from a presumption of amity; nonliberals suffer from a presumption of enmity. ${ }^{26}$

Threat perceptions do not emerge from a quasi-objective international power structure, but actors infer external behavior from the values and norms governing the domestic political processes that shape the identities of their partners in the international system. Thus, France and Britain did not perceive the superior American power at the end of World War II as threatening, because they considered the U.S. as part of "us"; Soviet power, however, became threatening precisely because Moscow's domestic order identified the Soviet Union as "the other." The collective identity of actors in democratic systems defines both the "in-group" of friends and the "out-group" of potential foes. Liberal theory posits that the realist world of anarchy reigns in relations between democratic and authoritarian systems, while "democratic peace" prevails among liberal systems.

But liberal theory does not suggest that democracies live in perpetual harmony with each other or do not face cooperation problems requiring institutional arrangements. Kant's "pacific federation" (foedus pacificum) does not fall from heaven, but has to be "formally instituted" (gestiftet). ${ }^{27}$

Since the security dilemma ${ }^{28}$ is almost absent among democracies, they face fewer obstacles to creating cooperative security institutions. Actors of democratic states "know" through the process of social identification described above that they are unlikely to fight each other in the future. They share liberal values pertaining to political life and are likely to form what Deutsch called a "pluralistic security community," leading to mutual responsiveness in terms of "mutual sympathy and loyalties; of 'we-feeling,' trust, and consideration; of at least partial identification in terms of self-images and interests; of the ability to predict each other's behavior and ability to act in accordance with that prediction." ${ }^{29}$

While Deutsch's notion of pluralistic security communities is not confined to democracies, it is unlikely that a similar sense of mutual responsiveness could emerge among autocratic leaders. There is nothing in their values that would prescribe mutual sympathy, trust, and consideration. Rather, cooperation among nondemocracies is likely to emerge out of narrowly defined self-interests. It should remain fragile, and the "cooperation under anarchy" perspective to international relations should apply. ${ }^{30}$ 
If democracies are likely to overcome obstacles against international cooperation and to enter institutional arrangements for specific purposes, what about the rules and decision-making procedures of these institutions? One would expect the regulative norms ${ }^{31}$ of these institutions to reflect the constitutive norms that shape the collective identity of the security community. Democracies are then likely to form democratic international institutions whose rules and procedures are aimed toward consensual and compromise-oriented decision-making respecting the equality of the participants. The norms governing the domestic decisionmaking processes of liberal systems are expected to regulate their interactions in international institutions. Democracies externalize their internal norms when cooperating with each other. Power asymmetries will be mediated by norms of democratic decision-making among equals emphasizing persuasion, compromise, and the non-use of force or coercive power. Norms of regular consultation, of joint consensus-building, and of nonhierarchy legitimize and enable a habit of mutual influence on each other's preferences and behaviors. These norms serve as key obligations translating the domestic decision-making rules of democracies to the international arena. This is not to suggest that consultation norms exist only in alliances among democracies. But consultation means "codetermination" when democracies are involved.

But how are these regulative norms expected to affect interaction processes among democratic allies? First, decision makers either anticipate allied demands or directly consult their partners before preferences are formed and conclusions are reached. Actors then make a discernible effort to define their preferences in a way that is compatible with the allied views and to accommodate allied demands.

Second, norms serve as collective understandings of appropriate behavior, which can be invoked by the participants in a discourse to justify their arguments. Consultation norms affect the reasoning process by which decision makers identify their preferences and choices. Actors are expected to invoke the norms to back up their respective views and to give weight to their arguments.

Third, the cooperation rules and procedures are also expected to influence the bargaining processes among the allies. This is fairly obvious with regard to consultation. In addition, democratic decision-making procedures deemphasize the use of material power resources in intra-allied bargaining processes, thereby delegitimating to play out one's superior military or economic power in intraalliance bargaining. Both the pluralistic security community and specific consultation norms work against the use of coercive power in bargaining processes among democracies.

But norms can be violated. Norms compliance in human interactions is to be expected only in a probabilistic sense. Instances in which actors violate specific rules and obligations are of particular interest to the analysis. If norms regulate the interaction but are breached, one would expect peculiar behavior by both the violator and the victim, such as excuses, justifications, or compensatory action. ${ }^{32}$

Finally, the allied community of values does not exclude democracies' driving hard bargains when dealing with each other in conflictual situations. While using material power resources to strengthen one's bargaining position is considered 
illegitimate among democracies, references to domestic pressures and constraints are likely to occur frequently. After all, liberal systems have in common that their leaders are constrained by the complexities of democratic political institutions. Since these procedures form the core of the value community, it should be appropriate to play "two-level games" using domestic pressures - small domestic "win-sets," in Robert Putnam's terms - to increase one's bargaining leverage. ${ }^{33}$ The argument presented above assumes that the values and norms embedded in the political culture of liberal democracies constitute the collective identity of a security community among democracies and that the regulative norms of the community institutions reflect these constitutive norms. This claim is subject to two objections: ${ }^{34}$

1 Why is it that domestic orders, norms, and political cultures shape the identities of actors in the international realm? Why not economic orders, such as capitalism? Why not geographic concepts, such as "the West," the "North Atlantic area," and the like? Why not gender and race, such as "white males"?

2 Democratic identities appear to be constant and acontextual rather than historically contingent. Is there never any change as to what constitutes an identity as "liberal democrat"?

As to the first point, it is, of course, trivial that actors hold multiple identities. Which of these or which combination dominates their interests, perceptions, and behavior in a given area of social interaction needs to be examined through empirical analysis and cannot be decided beforehand. I submit, however, that values and norms pertaining to questions of governance are likely to shape identities in the realm of the political - be it domestic or international. Moreover, such notions as "the West" do not contradict the argument here but seem to represent a specific enculturation of a broader liberal worldview. The same holds true for identities as "capitalists," particularly if juxtaposed against "communist order." The notion of the "free world," which Western policy makers used frequently during the Cold War to refer to their collective identity and to demarcate the boundaries against "Communism," encompassed liberal values pertaining to both the political and the economic orders.

As to the second point, and unlike several versions of neoliberalism, a sociological interpretation of the liberal argument posits historical contingency and contextuality. The zone of the "democratic peace" in the Northern Hemisphere did not fall from heaven but was created through processes of social interaction and learning. ${ }^{35}$ The emergence of NATO is part and parcel of that story. Moreover, the norms of the democratic peace can in principle be unlearned, since collective identities might change over time. But to argue that the social structure of international relations is somehow more malleable and subject to change than material structures represents a misunderstanding of social constructivism. ${ }^{36}$

The argument then can be summarized as follows: Democracies rarely fight each other: they perceive each other as peaceful. They perceive each other as peaceful because of the democratic norms governing their domestic 
decision-making processes. For the same reason, they form pluralistic security communities of shared values. Because they perceive each other as peaceful and express a sense of community, they are likely to overcome obstacles against international cooperation and to form international institutions such as alliances. The norms regulating interactions in such institutions are expected to reflect the shared democratic values and to resemble the domestic decision-making norms.

In the following sections, I illustrate the argument with regard to the formation of NATO, two cases of inter-allied conflict during Cold War crises, and the future of the transatlantic relationship in the post-Cold War environment.

\section{A liberal interpretation of the transatlantic security community}

\section{The origins of NATO}

The North Atlantic Treaty Organization represents an institutionalization of the security community to respond to a specific threat. While the perceived Soviet threat strengthened the sense of common purpose among the allies, it did not create the community in the first place. ${ }^{37}$ NATO was preceded by the wartime alliance of the U.S., Great Britain, and France, which also collaborated closely to create various postwar regimes in the economic area. Particularly the British worked hard to ensure that the U.S. did not withdraw from Europe, as it had after World War I, but remained permanently involved in European affairs. $^{38}$

While the European threat perceptions at the time might be explained on sophisticated realist grounds using Stephen Walt's "balance-of-threat" argument, U.S. behavior as the undisputed hegemon of the immediate post-World War II era is more difficult to understand. The U.S. faced several choices, each of which was represented in the administration as well as in the American public. President Roosevelt, for example, tried to preserve the wartime alliance with the Soviet Union until his death and to realize a collective security order guaranteed by the "four policemen" (the U.S., the USSR, Great Britain, and China), a concept that he had first proposed in 1941. His successor, President Truman, continued on this path during his first months in office. After Truman had changed his mind, Secretary of Commerce Henry Wallace still advocated a modus vivendi with the Soviet Union and the need to respect a Soviet sphere of influence in Europe until he was removed from office in September 1946. In the U.S. public, Walter Lippmann became the leading advocate of that argument when responding to George F. Kennan's containment strategy.

Early supporters of a tougher policy toward Moscow included the U.S. ambassador to Moscow, Averell Harriman, Kennan, and particularly Secretary of the Navy James Forrestal, while Secretary of State George Marshall steered a middle course until about 1948. How is it to be explained that this latter argument carried the day and that particularly President Truman became a firm advocate of a policy of containment? ${ }^{39}$

An obvious answer pertains, of course, to Soviet behavior. Western leaders, including Roosevelt, would have accepted a Soviet sphere of influence in Europe 
and were prepared to accommodate its security concerns - see Churchill's famous trip to Moscow in October 1944 and the Soviet-British "percentages agreement" on Southeast Europe..$^{40}$ But when the Red Army moved into Eastern Europe in 1944, Moscow immediately started to suppress potential political opposition in Romania, Bulgaria, Hungary, and, above all, Poland. Stalin broke what Roosevelt considered a Soviet commitment to free elections negotiated at Yalta, provoking the president to complain, "We can't do business with Stalin. He has broken every one of the promises he made at Yalta." ${ }^{41}$

The Truman administration, which had supported friendly relations with the Soviet Union until December 1945, began to change its position in early 1946, in conjunction with the Soviet reluctance to carry out the Moscow agreements to include non-Communists in the governments of Romania and Bulgaria. ${ }^{42}$ These early disputes focused on domestic order issues in Soviet-controlled Eastern Europe.

Had Stalin "Finlandized" rather than "Sovietized" Eastern Europe, the Cold War could have been avoided. In the perception of U.S. decision makers, the Soviet threat emerged as a threat to the domestic order of Western Europe, whose economies were devastated by the war. As the CIA concluded in mid-1947, "the greatest danger to the security of the United States is the possible economic collapse in Western Europe and the consequent accession to power of Communist elements. ${ }^{43}$ U.S. administrations from Roosevelt to Truman considered Western Europe vital to American security interests, both for historical reasons (after all, two world wars had been fought over Western Europe) and because it was viewed as a cornerstone of the liberal - political and economic - world order that both Roosevelt and Truman envisaged ${ }^{44}$ But it was not Soviet power as such that constituted a threat to these interests; rather it was the Soviet domestic order, combined with Soviet behavior in Eastern Europe, indicating a willingness to expand Communism beyond the USSR. In other words, Soviet power became threatening as a tool to expand the Soviet domestic order. Moreover, the Soviet Union also refused to join the Bretton Woods institutions of the World Bank and the International Monetary Fund, thus ending hopes that it might participate in the postwar international economic order.

This is not to suggest that the Soviet Union was solely responsible for the origins of the Cold War. Rather, differing views of domestic and international order clashed after World War II. Moscow refused to join the American liberal project based upon an open international order and free trade, free-market economies, and liberal systems of governance. ${ }^{45}$ Roosevelt and Truman tried to accommodate the Soviet view at first but then gradually abandoned that idea in favor of tougher policies. Stalin's behavior in Eastern Europe and elsewhere - irrespective of whether it was motivated by genuine security concerns or aggressive intentions - reinforced the emerging perceptions of threat, both in the public and in the administration. Over against those promoting a modus vivendi between the U.S. and the Soviet Union, Stalin helped another worldview to carry the day in Washington, one that interpreted the post-World War II situation in terms of a long-lasting strategic rivalry between the U.S. and the USSR - the Cold War. 
The emerging conflict was increasingly framed in Manichaean terms. As Anders Stephanson put it,

[The Cold War] was launched in fiercely ideological terms as an invasion or delegitimation of the Other's social order, a demonology combined of course with a mythology of the everlasting virtues of one's own domain. This is not surprising, considering the universalism of the respective ideologies. $^{46}$

The liberal interpretation of Stalin's behavior transformed the Soviet Union from a wartime ally to an opponent, the "other":

There isn't any difference in totalitarian states. . . . Nazi, Communist or Fascist, or Franco, or anything else - they are all alike.

The stronger the voice of a people in the formulation of national policies, the less the danger of aggression. When all governments derive their just powers from the consent of the governed, there will be enduring peace. ${ }^{47}$

The various declarations of the Cold War - Kennan's "long telegram," Churchill's 1946 "iron curtain" speech in Fulton, Missouri, and the 1947 Truman doctrine - all made the same connection between a liberal interpretation of the Soviet threat stemming from its "totalitarian" domestic character, on the one hand, and a realist balance of power ("containment") strategy to counter it. Kennan's "long telegram" and his later "X" article connected two liberal interpretations of the Soviet threat to promote his preferred course of action. ${ }^{48}$ He portrayed the Soviet Union as combining an ancient autocratic tradition that was deeply suspicious of its neighbors with a Communist ideology. Of course, cooperation was not an option with an opponent whose aggressiveness resulted from a historically derived sense of insecurity together with ideological aspirations that were ultimately caused by the fear of authoritarian rulers that they would be overthrown by their own people.

To what extent were these interpretations of the Soviet threat merely justifying rhetoric to gather public support for U.S. foreign policy rather than genuine concerns of decision makers? First, as argued above, there was nothing inevitable about the emergence of the Cold War, as far as U.S. decision makers were concerned. Soviet behavior, U.S. responses, the clash of worldviews, and mutual threat perceptions reinforced each other to create the East-West conflict. Second, the historical record appears to indicate that Harry Truman genuinely changed his mind about the extent to which one could cooperate with the Soviet Union during his first year in office. ${ }^{49}$ Third, an exaggerated rhetoric constructing the Soviet Union as the "empire of the evil" (Reagan) created the Cold War consensus in the U.S., since public opinion and Congress at the time were reluctant to accept new commitments overseas shortly after World War II had been won. The Truman doctrine, for example, deliberately oversold the issue of granting financial aid to Greece and Turkey as a fight between "freedom" and "totalitarianism" to get the 
package through Congress. But this point only confirms the power of the liberal argument in creating winning domestic coalitions in the U.S.

Even after the perception of a Soviet threat had won out in Washington, the U.S. still faced choices. Joining NATO was only one of them. It could have fought the Soviet Union on its own in a bipolar confrontation. Another option was to negotiate bilateral security arrangements with selected Western European states, as the Soviet Union did with Eastern Europe between 1945 and 1948, and as British Foreign Secretary Ernest Bevin suggested in $1948 .^{50}$ Instead, the U.S. chose to entangle itself in a multilateral alliance based on the indivisibility of security, diffuse reciprocity, and democratic decision-making procedures. ${ }^{51}$

Since it is impossible to present a detailed history of the North Atlantic Treaty in a few pages, some general remarks must suffice. ${ }^{52}$ First, NATO came about against the background of the emerging sense of threat in both Western Europe and the U.S. Soviet behavior in Eastern Europe and in its German occupation zone might have been motivated by Moscow's own threat perceptions and by an attempt to prevent a Western anti-Soviet bloc. But Stalin's behavior once again proved counterproductive and served to fuel Western threat perception. The Prague Communist "coup," for example, occurred precisely when negotiations for the Brussels Treaty creating the West European Union were under way and led to their speedy conclusion. The events in Czechoslovakia, as well as Soviet pressure against Norway, convinced U.S. Secretary of State Marshall that a formal alliance between the U.S. and Western Europe was necessary. The Soviet blockade of Berlin's Western sectors in 1948 not only "created" Berlin as the symbol of freedom and democracy - i.e., the values for which the Cold War was fought - but also proved crucial to move the U.S. closer to a firm commitment to European security.

Second, major initiatives toward the formation of a North Atlantic Alliance originated in Europe, mainly in the British Foreign Office. ${ }^{53}$ A close transgovernmental coalition of like-minded U.S., British, Canadian, and - later on French senior officials worked hard to transform the growing sense of threat into a firm U.S. commitment toward European security. The negotiations leading to the North Atlantic Treaty resembled a "three-level" game involving U.S. domestic politics, transgovernmental consensus-building, and intergovernmental bargains across the Atlantic. As to the last, probably the most important deal concerned Germany: the French would support U.S. policies toward the creation of a West German state in exchange for an American security commitment to Europe in terms of "dual containment" (protection against the Soviet Union and Germany). ${ }^{54}$

Third, a multilateral institution had advantages over alternative options, since it enhanced the legitimacy of American leadership by giving the Western Europeans a say in the decision-making process. In this context, it was self-evident and not controversial on either side of the Atlantic that an alliance of democratic states had to be based on democratic principles, norms, and decision-making rules. The two major bargains about the North Atlantic Treaty concerned, first, the nature of the assistance clause (article 5 of the treaty) and, second, the extent 
to which the consultation commitment (article 4) would include threats outside the NATO area. Neither the commitment to democratic values (preamble) nor the democratic decision-making procedures as outlined in articles 2, 3, and 8 were controversial in the treaty negotiations. Rather, the controversy between the U.S. Congress, on the one hand, and the administration together with the Western European governments, on the other, focused on the indivisibility of the mutual security assistance..$^{55}$

In sum, a liberal interpretation of NATO's origins holds that the Cold War came about when fundamental ideas - worldviews - about the domestic and the international order for the post-World War II era clashed. The Western democracies perceived a threat to their fundamental values resulting from the "Sovietization" of Eastern Europe. While the perceived Soviet threat certainly strengthened the sense of community among the Western democracies, it did not create the collective identity in the first place. In light of the liberal collective identity and its views of what constituted a "just" domestic and international order, Stalin's behavior and his refusal to join the liberal order confirmed that the Soviet Union could not be trusted. NATO then institutionalized the transatlantic security community to cope with the threat. The multilateral nature of the organization based on democratic principles and decision rules reflected the common values and the collective identity.

Regulatory norms of multilateralism and joint decision making were not just rhetoric covering up American hegemony, but shaped the interallied relationship. These norms were causally consequential for transatlantic security cooperation during the Cold War, since they allowed for disproportionate European influence on U.S. foreign policies. During the Korean war, for example, norms of consultation had an overall restraining effect on American decisions with regard to the localization of the war in Korea instead of its extension into China, the non-use of nuclear weapons, and the conclusion of the armistice negotiations. ${ }^{56}$

Western Europeans also had quite an impact on the early stages of nuclear arms control, especially during the test ban negotiations when the British in particular pushed and pulled the U.S. toward an agreement. As to NATO decisions pertaining to European security, joint decision making quickly became the norm. This has been shown to be true in most crucial cases, such as decisions on nuclear strategy and deployments. ${ }^{57}$ The evidence also suggests that the transatlantic relationship cannot be conceptualized as merely interstate relations; rather, the interaction patterns are significantly influenced by transnational and transgovernmental coalition-building processes..$^{58}$

I will briefly discuss here two cases of interallied dispute over policies during the Cold War. The first, the 1956 Suez crisis, probably constituted the most severe transatlantic crisis of the 1950 s, leading to a temporary breakdown of the community. I argue, however, that reference to a conflict of interests alone does not explain the interallied confrontation, in particular not the United States' coercion of its allies. The transatlantic dispute can be better understood in the framework of norm-guided behavior, as a dispute over obligations and appropriate behavior in a security community. The second case, the 1962 Cuban missile 
crisis, was the most serious U.S.-Soviet confrontation during the Cold War. I argue that U.S. decisions during the crisis cannot be explained without reference to the normative framework of the transatlantic security community.

\section{The 1956 Suez Crisis: The violation of community norms}

A temporary breakdown of the allied community resulted from the $1956 \mathrm{Suez}$ crisis when the U.S. coerced Britain, France, and Israel through economic pressure to give up their attempts to regain control of the Suez Canal. I suggest that the "realist" outcome of the crisis - the strong defeating the weak - needs to be explained by a "liberal" process. The American coercion of its allies resulted from a mutual sense of betrayal of the community leading to the violation of consultation norms and the temporary breakdown of the community itself.

The conflict of interests between the U.S. and its two allies was obvious to both sides from the beginning of the crisis. ${ }^{59}$ The British and French governments knew that the U.S. profoundly disagreed with them on whether or not force should be used to restore control over the Suez Canal. The attitudes of the U.S. as compared with those of its allies were rooted in diverging assessments of the situation in the Middle East, of the larger political context, and of the particular actions by Egypt's Nasser. The U.S. made a major effort to restrain its allies from using military force by working for a negotiated settlement and the establishment of an international authority to take control of the Suez Canal. Both sides frequently exchanged their diverging viewpoints through the normal channels of interallied communication, which remained open throughout most of the crisis. The U.S. and its allies also knew that the British were economically dependent on American assistance for the pound sterling and for ensuring oil supplies to NATO Europe, should the crisis escalate into war. ${ }^{60}$

Why, then, did the British and French who knew about their dependence and the American disagreement with them, nevertheless go ahead with their military plans and deceive Washington? How is their miscalculation of the U.S. reaction to be explained?

The British and French governments reluctantly agreed to U.S. attempts for a negotiated solution, first through an international conference in London in August 1956 and later through the proposal of a Suez Canal Users' Association (SCUA) in September. But the allies were not seriously interested in the success of these efforts, since their ultimate goal was not only to secure access to the Suez Canal but also to get rid of Nasser. They endorsed the American efforts to buy time and to create a favorable climate of opinion in the U.S. and the UN.

At the same time, the governments in London and Paris perceived American behavior during the crisis as at best ambiguous, if not deceiving. John Foster Dulles earned himself a reputation of "saying one thing and doing another," as Selwyn Lloyd, the British foreign minister, put it. ${ }^{61}$ There are indeed indications that Dulles favored stronger action if Nasser rejected reasonable proposals by the London conference. In September, for example, Dulles discussed a proposal 
with the British prime minister to set up an Anglo-American working group that would consider means of weakening Nasser's regime. ${ }^{62}$

The British sense of being betrayed by the Americans increased dramatically as a result of Dulles's handling of his own SCUA proposal. Prime Minister Anthony Eden viewed it as a means to corner Nasser further and to use his expected rejection as a pretext for military action. But in an attempt to dampen the British spin on the proposal and to make it more acceptable to the Egyptians, Dulles declared that "the United States did not intend itself to try to shoot its way through" the Suez Canal. As a result, Eden concluded on October 8 that "we have been misled so often by Dulles' ideas that we cannot afford to risk another misunderstanding. . . . Time is not on our side in this matter." 63 The British felt abandoned by the American government, which in their eyes had violated the community of purpose. London then chose to deliberately deceive Washington about the military plans in October 1956 without calculating the possible consequences. First, British officials thought, in a somewhat self-deluding manner, that the U.S. did not want to hear about the military preparations. Second, the British government was convinced in some strange way that the U.S. would ultimately back it and that allied action would somehow force Washington to support what persuasion did not accomplish. Eden and his foreign minister reckoned that the choice was clear for Washington if it had to take sides between Egypt and its European allies. What they perceived as Dulles's duplicity not only created a sense of betrayal leading to the deception in the first place, it also helped to reassure them that the Americans would ultimately support their action. In short, British decision makers firmly believed in the viability of the North Atlantic partnership. They convinced themselves that the U.S. was bound by the community and would ultimately value it. They relied on reassurances such as the one uttered by Dulles ten days before the invasion of the Suez Canal: "I do not comment on your observations on Anglo-American relations except to say that those relations, from our standpoint, rest on such a firm foundation that misunderstandings of this nature, if there are such, cannot disturb them." ${ }^{\prime 64}$

But Eisenhower and Dulles, despite all ambiguous statements, never wavered in pursuing two goals: (a) to prevent the use of force and (b) to reach a negotiated settlement guaranteeing safe passage through the Suez Canal. The administration mediated between its allies and the Egyptians while at the same time trying to restrain the British and French from resorting to military action. But this does not mean that Washington had to use its overwhelming power to force its allies to give up their adventure in Egypt. While the U.S. opposition to the allied action was to be expected, the use of coercive power was not. The allies could have agreed to disagree, since no supreme American interests were at stake. ${ }^{65}$ The U.S. could have confined its opposition to condemnatory action in the UN General Assembly. In other words, U.S. decision makers made choices as to how to react to the allied military action.

The American decision to play hardball with the allies was triggered by a series of unilateral allied moves that violated norms of consultation and jeopardized the community of purpose in the eyes of American leaders. First, the 


\section{From the inside out}

British government decided at the end of August to get the North Atlantic Council involved in the crisis, against the explicit advice of the U.S. government. The allies apparently calculated that other Western Europeans would support their military preparations, while the administration thought that such a move would further complicate discussions at the London conference. ${ }^{66}$

Second, the British government told the U.S. in late September of its plans to refer the matter to the UN Security Council in order to preempt a likely Soviet move. John Foster Dulles advised against it, since he thought that such action would hinder his attempts to get the SCUA off the ground. On September 23, the British and French referred the Suez issue to the Security Council anyway.

Third, immediately before the invasion, American decision makers complained that they were left in the dark about the British and French plans and that the interallied lines of communications had gradually broken down. The State Department asked the U.S. embassies in London and Paris to find out what the two governments were up to. It received reassuring messages, since the American embassies either were deliberately misled by their sources or just second-guessed the allied governments. Intelligence information gradually came in reporting Israeli plans to invade Egypt, with possible French and British involvement. ${ }^{67}$ When the Israeli invasion started on October 29, the U.S. administration had sufficient information to suspect that France was involved in the action. But until the facts could no longer be denied, neither Eisenhower nor Dulles wanted to believe that the British government had deceived them. The sense of community led to wishful thinking by American decision makers. The U.S. then decided to bring the matter to the UN Security Council but was told by the allies that they would never support a UN move against Israel. Even then, Eisenhower did not believe what he saw. He sent an urgent message to Prime Minister Eden, expressing his confusion and demanding

that the UK and the US quickly and clearly lay out their present views and intentions before each other, and that, come what may, we find some way of concerting our ideas and plans so that we may not, in any real crisis, be powerless to act in concert because of our misunderstanding of each other. ${ }^{68}$

The extent of the Anglo-French-Israeli collusion became clear only a few hours later, when the British and French issued a joint ultimatum demanding that Israel and Egypt withdraw from the Suez Canal to allow for an Anglo-French occupation of the Canal zone. The plot was immediately apparent, since the Israeli forces had not yet reached the line to which they were supposed to retreat. Eisenhower now realized that he had been misled all along and expressed his dismay about the "unworthy and unreliable ally." Later that day, he declared that he was "inclined to think that those who began this operation should be left to work out their own oil problem - to boil in their own oil, so to speak."

The secretary of state summoned the French ambassador, telling him that "this was the blackest day which has occurred in many years in the relations between England and France and the United States. He asked how the former 
relationship of trust and confidence could possibly be restored in view of these developments." 69

Eisenhower and Dulles were not so much upset by the Anglo-French-Israeli use of force itself as by the fact that core allies had deliberately deceived them. The allies had not broken some minor consultation agreements; they had violated fundamental collective understandings that constituted the transatlantic community "trust and confidence." Once the degree of allied deception became obvious, decision makers in Washington concluded that they were themselves no longer bound by alliance norms. They decided to retaliate in kind and coerced their allies through financial pressure. Now the U.S. abandoned the community, leaving its allies no choice but to back down. As the British ambassador in Washington put it, "We have now passed the point when we are talking to friends. . . . [W]e are on a hard bargaining basis and we are dealing with an Administration of business executives." 70

While the U.S. administration was coercing its allies to withdraw from the Suez Canal, it indicated at the same time that a major effort should be made to restore the community. As soon as November 7, the president called the whole affair a "family spat" in a telephone conversation with Prime Minister Eden. He later tried to find excuses for the British behavior: "Returning to the Suez crisis, the President said he now believes that the British had not been in on the IsraeliFrench planning until the very last stages when they had no choice but to come into the operation." 71

If the British had "no choice," they could not really be blamed for deceiving the U.S. The two governments now engaged in almost ritualistic reassurances that their "special relationship" would be restored quickly. President Eisenhower and Anthony Eden's successor Harold Macmillan worked hard to reestablish the community. The Bermuda summit in March 1957 documented the restoration of the "special relationship." In the long term, the crisis resulted in a major change in U.S. policies toward nuclear cooperation with the British. In 1958, Congress amended the Atomic Energy Act to allow for the sharing of nuclear information with Britain, which London had requested throughout the decade. The violation of alliance norms during the Suez crisis reinforced rather than reduced the transatlantic ties.

As for NATO in general, the crisis led to a reform of its consultation procedures. The "Report of the Committee of Three on Non-Military Cooperation in $N A T O$ " restated the need for timely consultation among the allies on foreign policy matters in general, not just those pertaining to European security. The North Atlantic Council adopted the report in December $1956 .^{72}$

But the French-American relationship never recovered. While French leaders had already been more sanguine about the interallied conflict than the British, the crisis set in motion a trend of gradually weakening the transatlantic ties between Paris and Washington. This deinstitutionalization culminated in President de Gaulle's 1966 decision to withdraw from the military integration of NATO. The French learned different lessons from the crisis than did the British, as far as the collective identity of the transatlantic community was concerned. The case 
shows that actors' interpretations of specific events may lead to changes in how they perceive their identity, which then results in changing their practices.

In sum, the confrontation between the U.S. and its allies developed because each side felt betrayed by the other in fundamental ways. The conflict of interests alone does not explain the confrontation. Such conflicts occurred before and afterward without leading to a breakdown of the transatlantic community, but they were usually resolved through cooperation and compromise - note, for example, the almost continuous interallied disputes over nuclear strategy and deployment options, which involved the survival interests of both sides. During the Suez crisis, however, U.S. decision makers perceived the allied deception as a violation of basic rules, norms, and procedures constituting the transatlantic community. No longer bound by the norms of appropriate behavior, the U.S. used its superior power and prevailed. Both sides knew that they had violated the rules of the "alliance game" and engaged in self-serving rhetoric to cover it up. More important, the U.S. and the British worked hard to restore the transatlantic community, suggesting that they did not regard the sort of confrontations experienced during the Suez crisis as appropriate behavior among democratic allies.

I conclude, therefore, that the Suez crisis confirms liberal expectations about discourses and practices when fundamental norms governing the relationship are violated. Norm violation challenging the sense of community among the allies provides the key to understanding the interactions leading to the confrontation, the clash, and the restoration of the community.

\section{The 1962 Cuban missile crisis: Collective identity and norms}

While the Suez crisis is a case of norm violation, the Cuban missile crisis shows the collective identity of the security community in action. It represents the most serious U.S.-Soviet confrontation of the Cold War. While we know today that neither side was prepared to risk nuclear war over the Soviet missiles in Cuba, President John F. Kennedy and General Secretary Nikita Krushchev were each afraid that the other would escalate the conflict in ways that might get out of control. ${ }^{73}$ Decision makers in Washington were convinced that the supreme national interests of the United States were at stake. Why care about allies when national survival is endangered? Indeed, the conventional wisdom about the Cuban missile crisis holds that the allies were not sufficiently consulted, even though U.S. decisions directly affected their security. Even senior officials in the administration, such as Roger Hilsman, then director of intelligence in the State Department, thought that the U.S. had chosen not to consult the allies in order to preserve its freedom of action: "If you had the French Government and the British Government with all their hangups and De Gaulle's hangups we would never have done it, it's as simple as that." ${ }^{\prime 74}$

I argue that - except for the first week of the crisis - there was far more interallied consultation than most scholars assume and that key allies, particularly the British and Turkish governments, knew about details of decision making in 
Washington. Moreover, the fate of the Western Alliance was the most important foreign policy concern for U.S. decision makers, except for the direct confrontation with Moscow and Cuba. Strategic arguments about reputation and the credibility of commitments explain these concerns only to a limited extent. First, as argued above, realism is indeterminate with regard to allied consultation when the alliance leader's survival is perceived to be at stake. Second, decision makers did not worry at all about their reputation in the Organization of American States (OAS), for example, the other U.S.-led alliance, which was even more directly involved in the Cuban missile crisis. Rather, if we assume a security community of democracies, strategic concerns about reputation and credibility immediately make sense. At least, realism does not offer a better understanding of these concerns than liberal theory.

But the Cuban missile crisis also poses a puzzle for liberal propositions about the allied community of values and norms, since the U.S. violated these rules during the first week of the crisis. Whether or not to consult the allies was discussed during the very first meeting of the Executive Committee (ExComm) on October 16. Secretary of State Dean Rusk argued strongly in favor of consultation and maintained that unilateral U.S. action would put the allies at risk, particularly if the U.S. decided in favor of a quick air strike. The decision not to consult, however, did not free decision makers from concerns about the Europeans. Membership in the community of democracies formed part of the American identity, as a result of which decision makers continued to define U.S. preferences in terms of joint interests rather than unilaterally. There was unanimous consensus that U.S. inaction with regard to the Soviet missile deployment in Cuba would be disastrous for U.S. credibility vis-á-vis its allies. ${ }^{75}$ The reputation of the U.S. government was perceived to be at stake, in both domestic and alliance politics. Decision makers in the ExComm did not distinguish between the two. As a result, the decision not to consult key allies during the first week strengthened the position of the "doves" in the ExComm, who argued that an air strike and military action against the Soviet installations in Cuba without prior consultation would wreck NATO.

During the second week of the crisis, the Europeans not only were regularly informed about the U.S. deliberations but had ample opportunities to influence American thinking through a variety of bilateral and multilateral channels. Among the key allies, only the British chose to take advantage of these opportunities, while France and West Germany strongly supported the U.S. courses of action. President Kennedy had almost daily telephone conversations with Prime Minister Macmillan - which even many of his staff members did not realize.

The British were the most "dovish" of the major allies. They made sure, for example, that U.S. forces in Europe were exempted from the general alert status of U.S. troops. When Macmillan was briefed about the crisis, he assured the president that Britain would support the U.S., but he mentioned that Europeans had lived under the threat of Soviet nuclear weapons for quite some time. Since the British had internally concluded that the naval blockade of Cuba violated international law, Macmillan demanded that the U.S. made a good legal case in 
favor of the quarantine. He then wondered about possible Soviet reactions against the blockade, including attempts at trading American bases in Europe or even West Berlin for the withdrawal of the missiles from Cuba. ${ }^{76}$ Kennedy perceived Macmillan's message as the "best argument for taking no action."

The British prime minister was as concerned as President Kennedy that the crisis might get out of control, and he favored a cooperative solution. On October 24, he told David Ormsby-Gore, the British ambassador to the U.S.: "If I am right in assuming that the President's mind is moving in the direction of negotiations before the crisis worsens, I think that the most fruitful course for you to pursue at the present might be to try to elicit from him on what lines he may be contemplating a conference." ${ }^{\prime 77}$

He suggested that the U.S. should raise the blockade if the Soviets refrained from putting more missiles into Cuba. When Macmillan phoned Kennedy later, he urged the president not to rush and asked whether "a deal" could be done. When the president asked for Macmillan's advice on a possible invasion of Cuba, the prime minister strongly recommended against it. ${ }^{78}$

Whether the British proposals for de-escalation made a crucial difference in the U.S. decision-making process is unclear. It is safe to argue, however, that the close contact between Kennedy, Macmillan, and Ormsby-Gore during the second week of the crisis strengthened and reinforced the president's view. Given Kennedy's convictions about the importance of the Western Alliance, which he expressed time and again during the crisis, it was significant that a key ally whom he trusted fully endorsed his search for a "deal."

Two alliance issues strongly influenced the president's thinking during the crisis. The first was the fate of Berlin. The American commitment to Berlin was one more reason to preclude inaction against the Soviet missiles in Cuba. As the president put it during the second ExComm meeting, if the Soviets put missiles in Cuba without an American response, Moscow would build more bases and then squeeze the West in Berlin. ${ }^{79}$ Concerns about Berlin also served as another restraining factor on U.S. decisions. The city's exposure inside the Soviet bloc made it an easy target of retaliatory action against American moves in Cuba. Kennedy worried about Berlin almost constantly. Fear of Soviet action against the essentially defenseless city was one reason for his decision in favor of the blockade and against more forceful military action. ${ }^{80}$ Kennedy's personal and emotional commitment to Berlin was again apparent during the crucial ExComm meeting on October 27, when he was faced with the choice between an air strike and a "missile swap":

What we're going to be faced with is - because we wouldn't take the missiles out of Turkey, then maybe we'll have to invade or make a massive strike on Cuba which may lose Berlin.

We all know how quickly everybody's courage goes when the blood starts to flow, and that's what's going to happen in NATO . . . We start these things and they grab Berlin, and everybody's going to say, "Well that was a pretty good proposition." 81 
The Berlin issue symbolized the role of the North Atlantic Alliance in the minds of U.S. decision makers throughout the crisis - precluding both inaction and a rush to escalation. Concerns about the city and the fate of Europe in general were causally consequential not by determining specific choices but by constraining the range of options available to decision makers. President Kennedy and other ExComm members treated Berlin almost as if it were another American city, for which American soldiers were supposed to die in defense of their country. It did not seem to make a difference whether the fate of Berlin or that of New York was at stake. Berlin symbolized the allied community and the values for which the Cold War was fought. It was the city's very vulnerability to Soviet pressures that made it such a significant symbol for the U.S. commitment to the defense of Europe.

While Berlin was an important concern of U.S. decision makers during the crisis, it was peripheral to the solution to the crisis. The Jupiter medium-range ballistic missiles (MRBMs) deployed under NATO arrangements in Turkey and Italy became part and parcel of the crisis settlement. The Jupiter missiles had been deployed following a 1957 NATO decision, on U.S. request. In the meantime, the administration considered them dangerously vulnerable and militarily obsolete. Kennedy would have preferred their withdrawal long before, but the administration failed to persuade Turkey to give them up. By the time of the Cuban missile crisis, the Jupiter missiles had become a political symbol of alliance cohesion, of the U.S. commitment to NATO and to Turkey in particular, which had just returned to democratic rule.

Not surprisingly, the Jupiter MRBMs became immediately linked to the Soviet missile deployment in Cuba. Throughout the crisis, the administration was divided over a "missile swap." The split cut across divisions between departments and even led to differences of opinion within specific agencies such as the State Department and the Pentagon. The topic of the Turkish Jupiter bases also came up in various interallied discussions. A "missile swap" was discussed in the British government, but London remained opposed to an explicit "missile trade" throughout the crisis, despite its support for a "deal." At the same time, the Turkish government began to raise concerns, particularly when the Soviet ambassador in Ankara began to argue that Moscow regarded the Jupiter missiles as its "Cuba." While Dean Rusk publicly denied any connection between the Cuban missile crisis and any situation elsewhere in the world, he hinted that, in the long run, disarmament negotiations could deal with the location of weapons. ${ }^{82}$

The administration also considered speeding up plans for the Multilateral Force (MLF), a sea-based nuclear force of American, British, and French systems under a joint NATO command, which had originally been proposed by the Eisenhower administration. The U.S. then set its diplomatic machinery in motion to anticipate how the allies would react to withdrawal of the Jupiter missiles in such a context. ${ }^{83}$ The U.S. ambassador to NATO, John Finletter, responded along the lines already discussed in Washington. He argued that Turkey regarded the Jupiter missiles as a symbol of the alliance commitment to its defense and that no arrangement should be made without the approval of the Turkish government. 
Finletter strongly advised against any open deal, but then proposed a "small southern command multilateral seaborne force on a 'pilot basis"" using Polaris submarines and manned by mixed U.S., Turkish, and Italian crews. Such an arrangement could allow the U.S. to offer the withdrawal of the Jupiters to the Soviets. ${ }^{84}$ While the U.S. ambassador to Turkey cabled a gloomy assessment from Ankara, he also concurred that a strictly secret deal with the Soviets was possible, together with some military compensation for Turkey ${ }^{85}$ These cables were discussed in the ExComm meetings on October 27 and influenced the president's decisions.

Various U.S. ambassadors to NATO allies apparently talked to their host governments about a secret "missile swap" despite an explicit directive by Rusk not to talk about it. The networks provided by the transatlantic institutions made it impossible to exclude allied officials from the deliberations. British officials discussed a "missile swap"; so did NATO's permanent representatives in Paris. Most important, the Turkish foreign ministry indicated to the American and the British ambassadors that it was not completely opposed to a removal of the Jupiters, to be discussed after a suitable lapse of time and in a general NATO context. ${ }^{86}$ The president involved the British ambassador in his deliberations and also asked the British to approach their embassy in Ankara for a view on the matter. $^{87}$

When the crisis reached its climax on October 27, discussions that included the State Department, the Pentagon, U.S. diplomats in Europe, NATO representatives in Paris, and various allied governments - at least the British and the Turks - had been held, and a solution had emerged. The solution entailed a strictly secret deal between Washington and Moscow that included the removal of the Jupiter missiles from Turkey in exchange for military compensation, after the Soviets had withdrawn their missiles from Cuba.

On October 27, the ExComm devoted most of its meeting time to discussing the options of an air strike against Cuba versus a "missile swap." The sense of allied community among ExComm members served as a frame of reference in which the various courses of action were discussed. Both sides in the debate referred to the need to preserve NATO. Supporters of an air strike argued that a missile trade would lead to the denuclearization of NATO and indicate that the U.S. was prepared to tamper with the indivisibility of allied security for selfish reasons. As McGeorge Bundy put it, "In their [the Turkish] own terms it would already be clear that we were trying to sell our allies for our interests. That would be the view in all of NATO. It's irrational, and it's crazy, but it's a terribly powerful fact." ${ }^{\prime 8}$ The president was primarily concerned that the Soviet public demand might provoke a public counterresponse by the Turkish government, which would jeopardize a secret solution to the crisis. He argued that the U.S. faced a dilemma. On the one hand, the U.S. commitment to its allies was at stake. On the other hand, many alliance members around the world might regard a missile trade as a reasonable deal and would not understand if the U.S. rejected it. ${ }^{89}$

In the end, the proposal of a secret deal with the Soviets together with some military compensation for the allies carried the day with the president. It was 
agreed that the Jupiter missiles could not be removed without Turkish approval and that therefore the U.S. would have to persuade the government in Ankara. A small group of Kennedy's advisers assembled after the ExComm meeting and discussed an oral message to be transmitted to Anatoly Dobrynin, the Soviet ambassador, by Attorney General Robert Kennedy. Dean Rusk proposed that Kennedy should simply tell Dobrynin that the U.S. was determined to get the Jupiter missiles out of Turkey as soon as the crisis was over. The group also agreed to keep absolute secrecy about this in order to preserve allied unity. ${ }^{90}$

Shortly after the meeting of Kennedy's advisers, the president's brother met with Ambassador Dobrynin and told him in rather dramatic terms that the crisis was quickly escalating and that the U.S. might soon bomb the missile bases in Cuba, which could lead to war in Europe. He then told Dobrynin with surprising openness that the U.S. was prepared to remove the Jupiter missiles from Turkey but could do so only if the deal was kept secret, since alliance unity was at stake. ${ }^{91}$ Khrushchev accepted the president's proposal, thereby solving the crisis.

In sum, U.S. membership in an alliance of democratic states shaped the process by which decision makers struggled over the definition of American interests and preferences during the Cuban missile crisis. One could argue, though, that the U.S. decisions were perfectly rational given the risks and opportunities at hand and that reference to the transatlantic relationship is, therefore, unnecessary to explain American behavior. The blockade, the noninvasion pledge, and the secret "missile swap" were indeed perfectly rational decisions. But a rationalchoice account proves to be indeterminate unless alliance considerations are factored in. The opposite arguments in favor of escalating the crisis through an air strike or even an invasion were as rational as those in support of the blockade or the "missile deal." Supporters of an air strike correctly argued that the risks of escalation were minimal given the overwhelming superiority of the U.S., both locally in the region and on the global nuclear level. Only if Soviet retaliation against Europe was considered a problem could one make a rational argument against the air strike and other escalatory steps. Berlin was the American Achilles heel during the crisis, not New York City.

That U.S. decision makers did not distinguish between domestic and European concerns, that they worried as much about the fate of Berlin as about New York City, and that they regarded obsolete Jupiter missiles in Turkey as major obstacles to the solution of the crisis - these puzzles make sense if one assumes a security community of democratic nations, on behalf of which the Kennedy administration acted. Membership in the Western Alliance affected the identity of American actors in the sense that the "we" in whose name the president decided incorporated the European allies. Those who invoked potential allied concerns in the internal discourses added weight to their arguments by referring to the collectively shared value of the community. The alliance community as part of the American identity explains the lack of distinction between domestic and alliance politics as well as the sense of commitment that U.S. decision makers felt with regard to their allies. Reputational concerns and the credibility of the U.S. commitment 
to NATO were at stake during the Cuban missile crisis. But I submit that these worries can be better understood within the framework of a security community based on collectively shared values than on the basis of traditional alliance theory.

\section{The end of the cold war and the future of NATO}

Since 1985, the European security environment has changed dramatically. The Cold War is over, the U.S.-Soviet rivalry gave way to a new partnership among former opponents, Germany is united, the Warsaw Pact and even the Soviet Union have ceased to exist. Fundamental parameters in the international environment of the transatlantic relationship have been profoundly altered. The world of the 1990s is very different from the world of the 1950s and 1960s. Can we extrapolate anything from the study of European-American relations during the height of the Cold War for the future of the transatlantic ties?

Contrary to Waltzian assumptions, NATO remains alive and well so far, adjusting to the new international environment:

- In response to the end of the Cold War, NATO has started changing its force structure. Instead of heavily armored and mechanized divisions, member states are setting up intervention forces with increased mobility in accordance with the NATO decision to build an allied rapid reaction corps for "out-ofarea" purposes. ${ }^{92}$

- As to relations with the former Cold War opponents, the North Atlantic Cooperation Council was instituted in 1991, linking the sixteen allies with Eastern Europe and the successor states of the Soviet Union. Two years later, these countries joined a "partnership for peace," creating institutionalized ties between NATO's integrated military command structure and the East European and Russian militaries. Current debates center around how central Eastern European countries such as Poland, Hungary, and the Czech Republic could join the alliance without antagonizing Russia and jeopardizing its legitimate security concerns. ${ }^{93}$

- The alliance has started playing a subsidiary role in un-sponsored international peacekeeping and peace-enforcement missions, such as in the former Yugoslavia ${ }^{94}$ It is remarkable in this context that the profound conflict of interest among the Western powers with regard to the war in BosniaHerzegovina has not at all affected NATO. Rather, the U.S., Britain, France, and Germany worked hard to ensure that their disagreements over Bosnia would not adversely influence the transatlantic alliance.

I have argued here that the Western Alliance represents an institutionalization of the transatlantic security community based on common values and a collective identity of liberal democracies..$^{95}$ The Soviet domestic structure and the values promoted by communism were regarded as alien to the community, resulting in a threat perception of the Soviet Union as the potential enemy. The 
democratization of the Soviet system initiated by Mikhail Gorbachev and continued by Boris Yeltsin then started ending the Cold War in Western eyes by altering the "Otherness" of the Soviet system. The Gorbachev revolution consisted primarily of embracing Western liberal values. ${ }^{96}$ While "glasnost" introduced publicity into the Soviet political process, "perestroika" democratized it. In response, Western threat perception gradually decreased, even though at different rates and to different degrees. The Germans were the first to declare the Cold War over. They reacted not only to the democratization of the Soviet system but in particular to Gorbachev's foreign policy change toward "common security." Americans came last; Gorbachev needed to give up Eastern Europe and the Berlin Wall had to tumble down in order to convince them.

It should be noted, however, that this explanation has its limits. Liberal theory as such does not suggest that democracies should behave cooperatively toward democratizing states, as the West did toward the Soviet Union under Gorbachev. The arguments put forward in the Kantian tradition pertain to stable democracies. Since they relate to the social structure of international relations, they cannot explain the specifics as well as the differences among the Western responses to the Gorbachev revolution, i.e., agency. ${ }^{97}$ But unlike realism, a liberal argument about the transatlantic security community correctly predicts that these threat perceptions would wither away at some point when former opponents democratize and thus begin entering the community of liberal states.

The end of the Cold War, then, not only does not terminate the Western community of values, it extends that community into Eastern Europe and, potentially, into even the successor states of the Soviet Union, creating a "pacific federation" of liberal democracies from Vladivostok to Berlin, San Francisco, and Tokyo. ${ }^{98}$ But liberal theory does not necessarily expect NATO to last into the next century. It only assumes that the security partnership among liberal democracies will persist in one institutionalized form or another. ${ }^{99}$ If the democratization process in Russia gives way to authoritarian nationalism, however, liberal theorists do expect NATO to remain the dominant Western security institution and to regain its character as a defensive alliance. In this case, NATO would be expected quickly to extend its security guarantee to the new democracies in central Eastern Europe. But institutionalist arguments suggest that a transformed NATO will remain the overarching security community of the "pacific federation." It is easier to adjust an already existing organization, which encompasses an elaborate set of rules and decision-making procedures, to new conditions than it is to create new institutions of security cooperation among the liberal democracies in the Northern Hemisphere. The osce - not to mention the West European Union would have to be strengthened much further until they reach a comparable degree of institutionalization.

NATO also provides a unique institutional framework for Europeans to affect American policies. Liberal democracies successfully influence each other in the framework of international institutions by using norms and joint decision-making procedures as well as transnational politics. Playing by the rules of these institutions, they do not just constrain their own freedom of action; they also gain 
access to the decision-making processes of their partners. Reducing the institutional ties might create the illusion of independence, but it actually decreases one's impact.

\section{Conclusions: How unique is NATO?}

I have argued in this essay that traditional alliance theories based on realist thinking provide insufficient explanations of the origins, the interaction patterns, and the persistence of NATO. The North Atlantic Alliance represents an institutionalized pluralistic security community of liberal democracies. Democracies not only do not fight each other, they are likely to develop a collective identity facilitating the emergence of cooperative institutions for specific purposes. These institutions are characterized by democratic norms and decision making rules that liberal states tend to externalize when dealing with each other. The enactment of these norms and rules strengthens the sense of community and the collective identity of the actors. Domestic features of liberal democracies enable the community in the first place. But the institutionalization of the community exerts independent effects on the interactions. In the final analysis, then, democratic domestic structures, international institutions, and the collective identity of state actors do the explanatory work together.

But do the findings pertaining to the North Atlantic Alliance hold up with regard to other alliances and cooperative institutions among democracies? Comparisons can be made along two dimensions: the degree of institutionalization of the community and the extent to which collective identities have developed among its members. The only international institution that appears to score higher than NATO on both dimensions is the European Union (EU). ${ }^{100}$ While it is less integrated than NATO with regard to security and foreign policy making, the EU features unique supranational institutions such as the European Commission and the European Court of Justice. The eu member states also coordinate their economic and monetary policies to an unprecedented degree. ${ }^{101}$ As far as collective identity is concerned, there is a well-documented sense of common Europeanness among the elites of the continental member states that partially extends into mass public opinion. Interaction patterns within the eu closely resemble the transnational and transgovernmental coalitions that have been found typical for decision making in NATO. ${ }^{102}$

Compared with NATO and the EU, the U.S.-Japanese security relationship appears to represent an interesting anomaly, in the sense that it is highly institutionalized, but the collective identity component seems to be weaker. ${ }^{103}$ Japanese security was more dependent on the U.S. during the Cold War than were Western Europe and even Germany. Strongly institutionalized transnational and transgovernmental ties developed among the military and the defense establishments of the two countries. Apart from the elite level of the governing party, however, the security relationship remained deeply contested in Japanese domestic politics during the Cold War. As a result, the U.S.-Japanese security cooperation certainly qualifies as a democratic alliance establishing norms of consultation and 
compromise-oriented decision making similar to those of NATO. But given the lack of collective identity, it is less clear whether this alliance constitutes a "pluralistic security community" in Deutsch's sense. The U.S.-Japanese example, then, shows that there is some variation with regard to both institutionalization and identity components in alliances among democracies.

In contrast, identity politics appears to be particularly strong in the U.S.-Israeli security relationship, as Michael Barnett argues in this volume. Again, the variation, compared with NATO and the U.S.-Japanese alliance, seems to pertain to the identity component, while the American alliance with Israel is as highly institutionalized as the other security relationships discussed so far. As Barnett points out, recent strains in the relationship can be better explained by challenges to the collective sense of democratic community resulting from Israeli policies than by changes in the international environment in which the two states operate.

So far, I have looked only at security communities among democracies. What about alliances involving nondemocracies? If the liberal argument presented here holds true, we should find quite different interaction patterns in such relationships, since the basic ingredients for the "democratic peace" are missing. A thorough analysis is beyond the scope of this essay. But various findings appear to suggest that, indeed, interaction patterns in nondemocratic alliances are different and conform more closely to realist expectations, particularly realist bargaining theory. As to the Middle East, for example, Stephen Walt has argued that common ideology played only a limited role in the formation of alliances among Arab states. While Michael Barnett disagrees, pointing to the significance of pan-Arabism, he also concurs that this collective identity has been weaker than the sense of community among democratic allies such as the U.S. and Israel. ${ }^{104}$ A study comparing U.S. relations with Latin America and interaction patterns within the former Warsaw Pact concludes that these relations can well be analyzed within the framework of public choice and realist bargaining theories. $^{105}$

In sum, these comparisons suggest that NATO is not unique but exemplifies interaction patterns and collective identities that are quite common for security communities among democracies. At the same time, these features appear to distinguish democratic alliances from other security relationships. In this sense, alliances among democracies are indeed special, since they can build upon a strong sense of community pertaining to the domestic structures of liberal states. Nevertheless, the degree of institutionalization as well as the extent to which "pluralistic security communities" have emerged varies among democracies.

*This essay summarizes, builds upon, and expands arguments developed in Thomas Risse-Kappen, Cooperation Among Democracies: The European Influence on U.S. Foreign Policy (Princeton: Princeton University Press, 1995). Participation in the Social Science Research Council-sponsored project under the directorship of Peter Katzenstein has greatly inspired my thinking on the subject of norms, identity, and social constructivism. For 
comments on the draft of this essay, I am very grateful to the project participants, in particular Peter Katzenstein. I am also indebted to Mark Laffey, David Latham, Fred H. Lawson, Stephen Walt, Steve Weber, and several anonymous reviewers for their criticism and suggestions.

\section{Notes}

1 See, for example, Hans J. Morgenthau, Politics Among Nations: The Struggle for Power and Peace, brief ed. (1948; reprint, New York: McGraw Hill, 1993); Kenneth N. Waltz, Theory of International Politics (Reading, Mass.: Addison-Wesley, 1979); George Liska, Nations in Alliance: The Limits of Interdependence (Baltimore: Johns Hopkins University Press, 1962); Arnold Wolfers, Discord and Collaboration (Baltimore: Johns Hopkins University Press, 1962). See also Ole R. Holsti et al., Unity and Disintegration in International Alliances (New York: Wiley, 1973).

2 On this point, see Ron Jepperson, Alexander Wendt, and Peter J. Katzenstein, "Norms, Identity, and Culture in National Security," in Peter J. Katzenstein, ed., The Culture of National Security, pp. 33-75 (New York: Columbia University Press, 1996).

3 See, for example, Michael Doyle, "Liberalism and World Politics," American Political Science Review 80, no. 4 (1986): 1151-69; Robert Keohane, "International Liberalism Reconsidered," in John Dunn, ed., The Economic Limits to Modern Politics, pp. 165-94 (Cambridge: Cambridge University Press, 1990); Bruce Russett, Grasping the Democratic Peace: Principles for a Post-Cold War World (Princeton: Princeton University Press, 1993).

4 On this use of the term, see, for example, Joseph M. Grieco, "Anarchy and the Limits of Cooperation: A Realist Critique of the Newest Liberal Institutionalism," International Organization 42, no. 3 (Summer 1988): 485-507; Robert O. Keohane, International Institutions and State Power: Essays in International Relations Theory (Boulder: Westview, 1989). See also the discussion of neoliberalism in Peter J. Katzenstein, "Introduction: Alternative Perspectives on National Security," in Peter J. Katzenstein, ed., The Culture of National Security, pp. 1-32.

5 For the following, see Waltz, Theory of International Politics, ch. 6; and Glenn H. Snyder, "Alliance Theory: A Neorealist First Cut," Journal of International Affairs 44, no. 1 (Spring 1990): 103-23.

6 See Stephen M. Walt, The Origins of Alliances (Ithaca: Cornell University Press, 1987), pp. 274-76. For thorough critiques of the Waltzian notion of bipolarity, see, for example, Richard Ned Lebow, "The Long Peace, the End of the Cold War, and the Failure of Realism," International Organization 48, no. 2 (Spring 1994): 249-77; R. Harrison Wagner, "What Was Bipolarity?" International Organization 47, no. 1 (Winter 1993): 77-106.

7 See Waltz, Theory of International Politics, pp. 106, 170-73. On "relative gains" in particular, see Grieco, "Anarchy and the Limits of Cooperation." For an argument that relative gains are particularly important under bipolarity, see Duncan Snidal, "International Cooperation Among Relative Gain Maximizers," International Studies Quarterly 35, no. 4 (December 1991): 387-402.

8 Walt, The Origins of Alliances.

9 On the origins of NATO, see, for example, Richard Best, "Cooperation with LikeMinded Peoples": British Influence on American Security Policy, 1945-1949 (Westport, Conn.: Greenwood, 1986); Don Cook, Forging the Alliance: NATO, 1945-1950 (New York: Arbor House/William Morrow, 1989); Sir Nicholas Henderson, The Birth of NATO (London: Weidenfeld and Nicolson, 1982); Timothy P. Ireland, Creating the Entangling Alliance: The Origins of the North Atlantic Treaty Organization (Westport, Conn.: Greenwood, 1981).

10 On this point, see Wagner, "What Was Bipolarity?" and Robert Jervis and Jack Snyder, eds., Dominoes and Bandwagons: Strategic Beliefs and Great Power Competition in the Eurasian Rimland (New York: Oxford University Press, 1991). 
11 John Lewis Gaddis, The Long Peace (Oxford: Oxford University Press, 1987), p. 41. See also Matthew Evangelista, "Stalin's Postwar Army Reappraised," International Security 7, no. 3 (Winter 1982/83): 110-68; James L. Gormly, From Potsdam to the Cold War (Wilmington, Del.: Scholarly Resources, 1990), pp. 92-93; Melvyn P. Leffler, "National Security and U.S. Foreign Policy," in Melvyn P. Leffler and David S. Painter, eds., Origins of the Cold War, pp. 15-52, 25-27 (London: Routledge, 1994); Norbert Wiggershaus, "Nordatlantische Bedrohungsperzeptionen im 'Kalten Krieg,' 1948-1956," in Klaus A. Meier et al., eds., Das Nordatlantische BŸndnis, 1949-1956, pp. 17-54 (Munich: Oldenbourg, 1993). Perceptions of a Soviet military threat increased only after the political confrontation was already in full swing.

12 Waltz, Theory of International Politics, pp. 169, 170. Glenn Snyder applies this thought to the transatlantic alliance: "It is abundantly clear that the European allies will not do the United States' bidding when it is not in their own interest, but it is also clear that they have little positive influence over U.S. policy - when the United States does not wish to be influenced. . . . The word that most accurately describes their behavior is not domination or even bargaining, but unilateralism" (Snyder, "Alliance Theory," p. 121).

13 Details in Risse-Kappen, Cooperation Among Democracies. See also Fred Chernoff, After Bipolarity (Ann Arbor: University of Michigan Press, 1994); Helga Haftendorn, Kernwaffen und die Glaubw ̈rrdigkeit der Allianz (Baden-Baden: Nomos, 1994); Elizabeth Sherwood, Allies in Crisis: Meeting Global Challenges to Western Security (New Haven: Yale University Press, 1990).

14 For evidence, see Bruce Bueno de Mesquita, The War Trap (New Haven: Yale University Press, 1981); Stuart A. Bremer, "Dangerous Dyads: Conditions Affecting the Likelihood of Interstate War, 1816-1965," Journal of Conflict Resolution 36, no. 2 (1992): 309-41.

15 On these propositions, see, for example, Michael Handel, Weak States in the International System (London: Frank Cass, 1981); Holsti, Unity and Disintegration in International Alliances; Glenn Snyder, "The Security Dilemma in Alliance Politics," World Politics 36, no. 4 (July 1984): 461-96; Jan F. Triska, ed., Dominant Powers and Subordinate States (Durham: Duke University Press, 1986).

16 At a U.S. Senate hearing in November 1990. Quoted from Gunther Hellmann and Reinhard Wolf, "Neorealism, Neoliberal Institutionalism, and the Future of NATO," Security Studies 3, no. 1 (Autumn 1993): 3-43, 17. See also John J. Mearsheimer, "Back to the Future: Instability in Europe After the Cold War," International Security 15, no. 1 (1990): 5-56.

17 See Charles Glaser, "Why NATO Is Still Best: Future Security Arrangements for Europe," International Security 18, no. 1 (Summer 1993): 5-50.

18 As Kenneth Waltz himself put it, "With the aid of a rationality assumption one still cannot, from national interest alone, predict what the policy of a country might be" (Waltz, "Reflections on Theory of International Politics: A Response to My Critics," in Robert O. Keohane, ed., Neorealism and Its Critics, pp. 322-45 [New York: Columbia University Press, 1986], p. 331). On the indeterminate nature of realism, see also Robert O. Keohane, "Realism, Neorealism, and the Study of World Politics," ibid., pp. 1-26; Stephen Haggard, "Structuralism and Its Critics: Recent Progress in International Relations Theory," in Emanuel Adler and Beverly Crawford, eds., Progress in Postwar International Relations, pp. 403-37 (New York: Columbia University Press, 1991).

19 John G. Ruggie, "Multilateralism: The Anatomy of an Institution," International Organization 46, no. 3 (Summer 1992): 561-98, 592.

20 For efforts at systematizing a liberal theory of international relations, see Ernst-Otto Czempiel, Friedensstrategien (Paderborn: Schšningh, 1986), pp. 110-67; Doyle, "Liberalism and World Politics"; Keohane, "International Liberalism Reconsidered"; Andrew Moravcsik, Liberalism and International Relations Theory, 2d ed., Working Paper Series (Cambridge: Center for International Affairs, Harvard University, 1993); 
Russett, Grasping the Democratic Peace. My point of departure is, thus, what Jepperson, Wendt, and Katzenstein call "neoliberalism" in "Norms, Identity, and Culture in National Security," in Peter J. Katzenstein, ed., The Culture of National Security. But drawing on insights from social constructivism, I argue that a liberal theory of international relations properly understood should be located in the upper-right - "sociological" corner of figure 1 in the Jepperson, Wendt, and Katzenstein essay.

21 See Immanuel Kant, "Zum ewigen Frieden: Ein philosophischer Entwurf" (1795), in Wilhelm Weischedel, ed., Immanuel Kant: Werke in sechs Bänden (Frankfurt am Main: Insel-Verlag, 1964), 6:193-251.

22 For the state of the art, see Russett, Grasping the Democratic Peace. Two recent criticisms of the "democratic peace" finding seem to be empirically flawed. See Christopher Layne, "Kant or Cant: The Myth of the Democratic Peace," International Security 19, no. 2 (Fall 1994): 5-49; David E. Spiro, "The Insignificance of the Liberal Peace," International Security 19, no. 2 (Fall 1994): 50-86. For the rebuttals, see John M. Owen, "How Liberalism Produces Democratic Peace," International Security 19, no. 2 (Fall 1994): 87-125; Bruce M. Russett, "The Democratic Peace: And Yet It Moves," International Security 19, no. 4 (Spring 1995): 164-75.

23 See Owen, "How Liberalism Promotes Peace"; Thomas Risse-Kappen, "Democratic Peace - Warlike Democracies? A Social Constructivist Interpretation of the Liberal Argument," European Journal of International Relations 1, no. 4 (1995): 489-515.

24 See the discussion in Russett, Grasping the Democratic Peace, ch. 2.

25 See Alexander Wendt, "Collective Identity Formation and the International State," American Political Science Review 88, no. 2 (Summer 1994): 384-96.

26 Doyle, "Liberalism and World Politics," p. 1161.

27 Kant, "Zum ewigen Frieden," p. 203.

28 See John Herz, Political Realism and Political Idealism (Chicago: University of Chicago Press, 1951); Robert Jervis, "Cooperation Under the Security Dilemma," World Politics 30, no. 2 (1978): 167-214.

29 Karl W. Deutsch et al., Political Community and the North Atlantic Area (Princeton: Princeton University Press, 1957), p. 129.

30 See, for example, Kenneth A. Oye, ed., Cooperation Under Anarchy (Princeton: Princeton University Press, 1986). The "democratic peace" argument does not suggest that authoritarian states are constantly in a state of war among themselves. Rather, liberal theory posits that the causes of peace among autocracies are different from the causes for the "democratic peace" and that cooperation among authoritarian regimes is likely to remain fragile.

31 Norms are "collective expectations of proper behavior for a given identity." In the following, I mainly use the term in the sense of regulative norms that prescribe or proscribe behavior for already constituted identities. The constitutive norms of these identities are the values and rules of democratic decision making in the domestic realm. For these distinctions, see Jepperson, Wendt, and Katzenstein, "Norms, Identity, and Culture in National Security."

32 See Friedrich Kratochwil, Rules, Norms, and Decisions: On the Conditions of Practical and Legal Reasoning in International Relations and Domestic Affairs (Cambridge: Cambridge University Press, 1989), p. 63.

33 See Robert Putnam, "Diplomacy and Domestic Politics: The Logic of Two-Level Games," International Organization 42 (1988): 427-60; Peter B. Evans, Harold K. Jacobson, and Robert S. Putnam, eds., Double-Edged Diplomacy (Berkeley: University of California Press, 1993).

34 I thank Mark Laffey, Steve Weber, and an anonymous reviewer for alerting me to the following points.

35 This even shows up in quantitative studies. Instances of militarized disputes among democracies have declined over time. Moreover, most disputed cases of alleged war 
among democracies occurred during the nineteenth and early twentieth centuries. For data, see Russett, Grasping the Democratic Peace, ch. 4.

36 John Mearsheimer's discussion of social constructivism - which he mislabels "critical theory," thereby lumping together a variety of different approaches - suffers from the misunderstanding that ideational factors in world politics are somehow more subject to change than material ones. Collective identities cannot be changed like clothes. See John J. Mearsheimer, "The False Promise of International Institutions," International Security 19, no. 3 (Winter 1994/95): 5-49.

37 As Alfred Grosser put it, 1945 was "no year zero"; see Grosser, The Western Alliance: European-American Relations Since 1945 (New York: Vintage Books, 1982), pp. 3-33. See also Robert Latham, "Liberalism's Order/Liberalism's Other: A Genealogy of Threat," Alternatives 20, no. 1 (1995): 111-46, on this point.

38 See, for example, John Baylis, "Britain and the Formation of NATO" (International Politics Research Paper no. 7, Department of International Politics, University College of Wales, Aberystwyth, 1989); Best, "Cooperation with Like-Minded Peoples"; Henry B. Ryan, The Vision of Anglo-America (Cambridge: Cambridge University Press, 1987).

39 On the origins of the containment strategy, see, for example, John L. Gaddis, Strategies of Containment (Oxford: Oxford University Press, 1982); Gaddis, The Long Peace, pp. 20-47; Deborah Larson, Origins of Containment: A Psychological Explanation (Princeton: Princeton University Press, 1985); David Mayers, George Kennan and the Dilemmas of U.S. Foreign Policy (Oxford: Oxford University Press, 1988).

40 Overview in David Dimbleby and David Reynolds, An Ocean Apart: The Relationship Between Britain and America in the Twentieth Century (New York: Vintage Books, 1989), pp. 170-72.

41 Quoted from Gaddis, The Long Peace, p. 30.

42 See Gormly, From Potsdam to the Cold War, pp. 94-111.

43 Quoted from Leffler, "National Security and U.S. Foreign Policy," p. 29.

44 For conflicting interpretations of U.S. strategic interests after World War II, see Gaddis, The Long Peace; Melvyn P. Leffler, The Preponderance of Power (Stanford: Stanford University Press, 1992); Leffler, "National Security and U.S. Foreign Policy," pp. 23-26; Thomas J. McCormick, America's Half-Century: United States Foreign Policy in the Cold War (Baltimore: Johns Hopkins University Press, 1989). For an excellent overview on U.S. historiography on the origins of the Cold War, see Anders Stephanson, "The United States," in David Reynolds, ed., The Origins of the Cold War in Europe: International Perspectives (New Haven: Yale University Press, 1994), pp. 23-52.

45 See Latham, "Liberalism's Order/Liberalism's Other," on this point.

46 Stephanson, "The United States," p. 50.

47 Quotes from Truman's speeches in March 1947, contained in Gaddis, The Long Peace, p. 36.

48 See Kennan's "long telegram," in U.S. Department of State, Foreign Relations of the United States, 1946 (Washington, D.C.: U.S. Government Printing Office), 6:696-709; 'X,' "The Sources of Soviet Conduct," Foreign Affairs 25, no. 4 (July 1947).

49 See, for example, Robert Donovan, Tumultuous Years: The Presidency of Harry S. Truman (New York: Norton, 1982); Gaddis, Strategies of Containment, pp. 14-20; Gormley, From Potsdam to the .

50 On these alternatives, see Steve Weber, "Shaping the Postwar Balance of Power: Multilateralism in NATO," International Organization 46, no. 3 (Summer 1992): 633-80, 635-38. See ibid. for the following.

51 The first two notions are based on Ruggie's definition of multilateralism. See Ruggie, "Multilateralism." 
52 See, for example, Cook, Forging the Alliance; Henderson, The Birth of NATO; Ireland, Creating the Entangling Alliance; Lawrence S. Kaplan, The United States and NATO: The Formative Years (Lexington: University of Kentucky Press, 1984); Ennio Di Nolfo, ed., The Atlantic Pact: Forty Years Later (Berlin: De Gruyter, 1991); Meier et al., Das Nordatlantische Bündnis; Norbert Wiggershaus and Roland G. Foerster, eds., Die westliche Sicherheitsgemeinschaft, 1948-1950 (Boppard: Harald Boldt Verlag, 1988).

53 See Best, "Cooperation with Like-Minded Peoples."

54 On the French position, see Bruna Bagnato, "France and the Origins of the Atlantic Pact," in Di Nolfo, The Atlantic Pact, pp. 79-110; Norbert Wiggershaus, "The Other 'German Question': The Foundation of the Atlantic Pact and the Problem of Security against Germany," in ibid., pp. 111-26; Pierre Guillen, "Frankreich und die Frage der Verteidigung Westeuropas," in Wiggershaus and Foerster, Die westliche Sicherheitsgemeinschaft, pp. 103-23.

55 For details on the treaty negotiations, see Cook, Forging the Alliance; Henderson, The Birth of NATO; Ireland, Creating the Entangling Alliance; Sherwood, Allies in Crisis, pp. 5-29.

56 For details, see Risse-Kappen, Cooperation Among Democracies, ch. 3. For the following, see ibid., ch. 5.

57 See, for example, Haftendorn, Kernwaffen und die Glaubwürdigkeit der Allianz; Thomas Risse-Kappen, The Zero Option: INF, West Germany, and Arms Control (Boulder: Westview, 1988). See also Chernoff, After Bipolarity.

58 Transgovernmental relations are defined as interactions among subunits of national governments in the absence of central decisions. See Robert O. Keohane and Joseph S. Nye, Jr., "Transgovernmental Relations and International Organizations," World Politics 27 (1974): 39-62.

59 I essentially agree with Richard Neustadt's earlier analysis of the crisis. See his Alliance Politics (New York: Columbia University Press, 1970). For a similar argument, see Sherwood, Allies in Crisis, pp. 58-94. The major studies on the Suez crisis are David Carlton, Britain and the Suez Crisis (Oxford: Blackwell, 1988); Steven Z. Freiberger, Dawn over Suez (Chicago: Iven R. Dee, 1992); Keith Kyle, Suez (New York: St. Martin's, 1991); Diane B. Kunz, The Economic Diplomacy of the Suez Crisis (Chapel Hill: University of North Carolina Press, 1991); Wm. Roger Louis and Roger Owen, eds., Suez 1956 (Oxford: Clarendon Press, 1989).

60 See Diane B. Kunz, "The Importance of Having Money: The Economic Diplomacy of the Suez Crisis," in Louis and Owen, Suez 1956, pp. 215-32, 218-19; Kunz, The Economic Diplomacy of the Suez Crisis.

61 Selwyn Lloyd, Suez 1956: A Personal Account (London: Jonathan Cape, 1978), p. 38.

62 See "Memorandum of Conversation at British Foreign Office," September 21, 1956, in U.S. Department of State, Foreign Relations of the United States, 1955-1957 [hereafter FRUS 1955-1957] (Washington, D.C.: U.S. Government Printing Office, 1990), 16:548-50.

63 "Eden to Selwyn Lloyd," October 8, quoted in Wm. Roger Louis, "Dulles, Suez, and the British," in Richard Immermann, ed., John Foster Dulles and the Diplomacy of the Cold War (Princeton: Princeton University Press, 1990), pp. 133-58, 151. For the Dulles quotes, cf. ibid., pp. 149, 150; Robert Bowie, "Eisenhower, Dulles, and the Suez Crisis," in Louis and Owen, Suez 1956, pp. 189-214, 204-5.

64 "Dulles to Selwyn Lloyd," October 19, FRUS 1955-1957, 16:760.

65 U.S. anticolonialism, for example, does not explain American behavior. During the Falklands/Malvinas war in 1982, for example, the Reagan administration tacitly backed the British effort to regain the islands even though it remained officially neutral in light of its alliance obligations to both Argentina (oas) and Britain. 
66 See "Memorandum for Secretary of State," August 28, FRUS 1955-1957, 16:309; "Secretary of State to U.S. Embassy UK," August 30, ibid., pp. 339-40; "Dept. of State to certain diplomatic missions," August 31, ibid., pp. 344-45.

67 See "Dept. of State to U.S. Embassy UK," October 26, FRUS 1955-1957, 16:790; "U.S. Embassy Israel to Dept. of State," October 26, ibid., p. 785; "Dept. of State to U.S. Embassy France," October 29, ibid., pp. 815-16. For the following, see "Memorandum of Conversation at Dept. of State," October 28, ibid., pp. 803-4; "U.S. Embassy UK to Dept. of State," October 29, ibid., pp. 817-20.

68 "Eisenhower to Eden," October 30, FRUS 1955-1957, 16:848-50. See also "Memorandum of Conversation at the White House," October 29, ibid., pp. 833-39; editorial note, ibid., pp. 840-42; Bowie, "Eisenhower, Dulles, and the Suez Crisis," pp. 208-9.

69 "Memorandum of Conversation at the Dept. of State," October 30, FRUS 1955-1957, 16:867-68. For the Eisenhower quotes, see "Memorandum of Conference with the President," October 30, ibid., p. 873; "Message from Eisenhower to Eden," October 30, ibid., p. 866; "Memorandum of Conversation with the President," October 30, ibid., pp. 851-55.

70 "Lord Caccia [uk ambassador in Washington] to Foreign Office," November 28, 1956, quoted from Louis, "Dulles, Suez, and the British," pp. 155-56.

71 "Memorandum of Conversation between the President and Dulles," (my emphasis!), November 12, FRUS 1955-1957, 16:1112-14. For the preceding quote, see "Memorandum of Telephone Conversation between the President and Sir Eden," November 7, ibid., p. 1040.

72 See Sherwood, Allies in Crisis, pp. 88-94.

73 For details, see Richard N. Lebow and Janice G. Stein, We All Lost the Cold War (Princeton: Princeton University Press, 1994), pp. 19-145. See also Michael Beschloss, The Crisis Years (New York: Edward Burlingame Books, 1991), pp. 431-575; James Blight, The Shattered Crystal Ball (Savage, Md.: Rowman and Littlefield, 1990); James Blight and David Welch, On the Brink (New York: Hill and Wang, 1989); McGeorge Bundy, Danger and Survival (New York: Random House, 1988), ch. 9; Laurence Chang and Peter Kornbluh, eds., The Cuban Missile Crisis, 1962 (New York: New Press, 1992); Raymond Garthoff, Reflections on the Cuban Missile Crisis, rev. ed. (Washington, D.C.: Brookings Institution, 1989).

74 "Interview with David Nunnerly," in National Security Archive, The Cuban Missile Crisis, 1962 [hereafter NSA:CMC], microfiche collection (Washington, D.C.: ChadwyckHealey, 1990), Doc. 03251. On the alleged lack of consultation, see Richard Rosecrance, Defense of the Realm (New York: Columbia University Press, 1986), p. 13; Sherwood, Allies in Crisis, p. 122; I.F. Stone, "What Price Prestige?" in Robert A. Divine, ed., The Cuban Missile Crisis, pp. 155-65 (Chicago: Quadrangle Books, 1971).

75 As Robert McNamara put it later, "For all kinds of reasons, especially to preserve unity in the alliance, we had to indicate to the Soviets that we weren't going to accept the presence of offensive missiles in Cuba" (quoted from Blight and Welch, On the Brink, p. 188). See also "ExComm Transcripts," October 16, 1962, NSA:CMC, Doc. 00622.

76 See Harold Macmillan, At the End of the Day, 1961-1963 (London: Macmillan, 1973), pp. 184-90. For the following quote see "507th NSC Meeting," October 22, NSA:CMC, Doc. 00840.

77 "Foreign Office to Embassy Washington," October 24, in Public Records Office, London, Diplomatic Correspondence Files [hereafter PRO:FO] 371/162378.

78 See Macmillan, At the End of the Day, pp. 198-203, 202-4. See also Lebow and Stein, We All Lost the Cold War, p. 121.

79 "White House Tapes and Minutes of the Cuban Missile Crisis," International Security 10, no. 1 (Summer 1985): 164-203, 185. 


\section{From the inside out}

80 See, for example, the telephone conversation Macmillan-Kennedy, October 26, in Macmillan, At the End of the Day, pp. 209-11.

81 "October 27, 1962: Transcripts of the Meetings of the ExComm," International Security 12, no. 3 (Winter 1987/88): 30-92, 55, 58.

82 For details, see "Ambassador Hare, Ankara, to State Dept.," October 23, NSA:CMC, Doc. 01080; "Hare to State Dept.," October 24, ibid., Doc. 01260; "Rusk, Circular Cable," October 24, ibid., Doc. 01140; "Rusk to US Embassies, West Europe," October 25, ibid., Doc. 01294; "Rusk to US Embassy, Ankara," October 25, ibid., Doc. 01298.

83 "Dean Rusk to US Embassies to NATO and to Turkey," October 24, NSA:CMC, Doc. 01138.

84 "Finletter to State Dept.," October 25, NSA:CMC, Doc. 01328.

85 "Hare to State Dept." (Section 1), October 26, NSA:CMC, Doc. 01470; "Hare to State Dept." (Sections 2 and 3), October 26, NSA, Nuclear History Documents.

86 See "Embassy Ankara to Foreign Office," October 28, PRO:FO 371/162382; "Embassy Ankara to Foreign Office," October 28, ibid. 371/162381. On discussions at NATO's headquarters see "Finletter to State Dept.," October 28, NSA:CMC, Doc. 01602 .

87 According to "Embassy Washington to Foreign Office," October 27, PRO:FO $371 / 162382$.

88 “October 27, 1962: Transcripts," p. 39.

89 Bromley Smith, "Summary Record of ExComm Meeting," October 27, NSA:CMC, Doc. 01541. For the following see "October 27, 1962: Transcripts."

90 See Bundy, Danger and Survival, pp. 432-34;.

91 See Dobrynin's cable to Moscow, October 27, in Lebow and Stein, We All Lost the Cold War, pp. 524-26.

92 If the alliance was disintegrating, one would expect the members to concentrate on the defense of their national territories rather than building light and mobile forces. See Hellmann and Wolf, "Neorealism, Neoliberal Institutionalism, and the Future of NATO," p. 22.

93 For details, see "North Atlantic Cooperation Council Statement," NATO Press Service, December 20, 1991; Stephen Flanagan, "NATO and Central and Eastern Europe," Washington Quarterly 15, no. 2 (Spring 1992): 141-51; "'Partnerschaft für den Frieden' mit Osteuropa. Aber keine konkreten Zusagen für Mitgliedschaft," Süddeutsche Zeitung, January 11, 1994; "NATO Chiefs Hail New Era, But War Still Casts Clouds," International Herald Tribune [hereafter IHT], January 12, 1994; "Clinton Hints NATO Would Defend East from Attack," IHT, January 13, 1994.

94 See, for example, "Report by Ad-hoc Group of the North Atlantic Cooperation Council on Cooperation for Peacekeeping," NATO Press Service, June 11, 1993; Hellmann and Wolf, "Neorealism, Neoliberal Institutionalism, and the Future of NATO," p. 25.

95 See also Steve Weber, "Does NATO Have a Future?," in Beverly Crawford, ed., The Future of European Security (Berkeley: University of California at Berkeley, Center for German and European Studies, 1992), pp. 360-95. Emanuel Adler, "Europe's New Security Order," in ibid., pp. 287-326, shares the assessment but comes to different conclusions regarding the desirability of NATO.

96 On this point, see Daniel Deudney and G. John Ikenberry, "The International Sources of Soviet Change," International Security 16 (Winter 1991/92): 74-118; Henry Nau, "Rethinking Economics, Politics, and Security in Europe," in Richard N. Perle, ed., Reshaping Western Security, pp. 11-46 (Washington, D.C.: American Enterprise Institute Press, 1991).

97 See Thomas Risse-Kappen, "Ideas Do Not Float Freely: Transnational Coalitions, Domestic Structures, and the End of the Cold War," International Organization 48, no. 2 (Spring 1994): 185-214. 
98 On liberal and institutionalist visions of the future of European security, see Adler, "Europe's New Security Order"; Ernst-Otto Czempiel, Weltpolitik im Umbruch (Munich: Beck, 1991); James M. Goldgeier and Michael McFaul, "A Tale of Two Worlds: Core and Periphery in the Post-Cold War Era," International Organization 46, no. 3 (Spring 1992): 467-91; Charles Kupchan and Clifford Kupchan, "Concerts, Collective Security, and the Future of Europe," International Security 16, no. 1 (Summer 1991): 114-61; Dieter Senghaas, Friedensprojekt Europa (Frankfurt am Main: Suhrkamp, 1991); Stephen Van Evera, "Primed for Peace: Europe After the Cold War," International Security 15 (Winter 1990/91): 7-57.

99 I thank Andrew Moravcsik for clarifying this point to me.

100 Cooperation patterns among the Nordic states come to mind, too. Note that Scandinavian cooperation was the main example in Deutsch's original study on "pluralistic security communities." See Deutsch et al., Political Community and the North Atlantic Area.

101 See, for example, Anne-Marie Burley and Walter Mattli, "Europe Before the Court: A Political Theory of Legal Integration," International Organization 47, no. 1 (Winter 1993): 41-76; Stanley Hoffmann and Robert Keohane, eds., The New European Community (Boulder: Westview, 1991); Alberta Sbragia, ed., Euro-Politics (Washington, D.C.: Brookings Institution, 1992).

102 For details, see Richard Münch, Das Projekt Europa: Zwischen Nationalstaat, regionaler Autonomie und Weltgesellschaft (Frankfurt am Main: Suhrkamp, 1993); Anthony Smith, "National Identity and the Idea of European Unity," International Affairs 68, no. 1 (1992): 55-76; Ole Waever et al., “The Struggle for 'Europe': French and German Concepts of State, Nation, and European Union" (unpublished manuscript, 1993). On transnational and transgovernmental relations within the EU see, for example, David Cameron, "Transnational Relations and the Development of the European Economic and Monetary Union," in Thomas Risse-Kappen, ed., Bringing Transnational Relations Back In: State Actors, Domestic Structures, and International Institutions, pp. 37-78 (Cambridge: Cambridge University Press, 1995).

103 See Reinhard Drifte, Japan's Foreign Policy (London: Routledge, 1990); Peter Katzenstein and Yutuka Tsujinaka, “'Bullying,' 'Buying,' and 'Binding': U.S.-Japanese Transnational Relations and Domestic Structures," in Risse-Kappen, Bringing Transnational Relations Back In, pp. 79-111; Peter Katzenstein and Nobuo Okawara, Japan's National Security: Structures, Norms, and Policy Responses in a Changing World (Ithaca: Cornell University Press, 1993). See also Thomas U. Berger, "Norms, Identity, and National Security in Germany and Japan," in Peter J. Katzenstein, The Culture of National Security, pp. 317-356.

104 See Walt, The Origins of Alliances; Michael Barnett, "Institutions, Roles, and Disorder: The Case of the Arab States System," International Studies Quarterly 37, no. 3 (September 1993): 271-96; see also Barnett's contribution to this volume.

105 See Triska, Dominant Powers and Subordinate States. 
$\because$ Taylor \& Francis

Taylor \& Francis Group

http://taylorandfrancis.com 


\section{Part II}

\section{From the outside in}

The international sources of domestic change 
$\because$ Taylor \& Francis

Taylor \& Francis Group

http://taylorandfrancis.com 


\title{
5 The socialization of international human rights norms into domestic practices
}

\author{
Introduction (1999)
}

Thomas Risse and Kathryn Sikkink

Fifty years ago, on December 10, 1948, the United Nations General Assembly adopted the Universal Declaration of Human Rights (UDHR). At the time, the delegates clearly noted that the Declaration was not a binding treaty, but rather a statement of principles. Eleanor Roosevelt said that the Declaration "set up a common standard of achievement for all peoples and all nations," and "might well become an international Magna Carta of all mankind" (Humphrey 1984). On the fiftieth anniversary of the Declaration, it seems appropriate to evaluate the impact of these norms, now embodied in diverse international agreements and treaties. ${ }^{1}$ Have the principles articulated in the Declaration had any effect at all on the actual behavior of states towards their citizens? What are the conditions under which international human rights norms are internalized in domestic practices? In other words, what accounts for the variation in the degree to which human rights norms are implemented? And what can we learn from this case about why, how, and under what conditions international norms in general influence the actions of states? This book tries to tackle these questions.

Our project relates to broader theoretical debates in the social sciences and law about the influence of ideas and norms on the behavior of individuals and states. Scholars of international relations are increasingly interested in studying norms and ideas, but few have yet demonstrated the actual impact that international norms can have on domestic politics. Using case studies that explore the linkages between international human rights norms and changing human rights practices, we develop and present a theory of the stages and mechanisms through which international norms can lead to changes in behavior. We believe this theory will be useful in understanding the general impact of norms in international politics.

To carry out this evaluation, we chose to look at paired cases of countries with serious human rights situations from each region of the world. In addition to the well-publicized "success stories" of international human rights like Chile, South Africa, the Philippines, Poland, and the former Czechoslovakia, we also examine a series of more obscure and apparently intractable cases of human rights violations in such places as Guatemala, Kenya, Uganda, Morocco, Tunisia, and Indonesia. We reason that these countries with less propitious domestic and international situations would be hard cases for understanding the conditions 


\section{From the outside in}

under which international human rights norms could lead to changing domestic practices. Much of the research on international norms has looked at their international diffusion, or examined their impact in a single country or region. The design of this project allows us to explore the influence that a set of international human rights norms has in a wide variety of states with very different cultures and institutions. By examining the similarities and differences in the impact of human rights norms in these diverse settings, we can see the variation of norm effects across states.

The Universal Declaration of Human Rights contains thirty articles detailing diverse rights from the right to life, to the right to work, and the right to rest and leisure. Because we could not evaluate progress on all these rights, we chose a central core of rights - the right to life (which we define as the right to be free from extrajudicial execution and disappearance) and the freedom from torture and arbitrary arrest and detention. ${ }^{2}$ By choosing to focus on these rights we do not suggest that other rights in the Declaration are unimportant. But these basic "rights of the person" have been most accepted as universal rights, and not simply rights associated with a particular political ideology or system. Also, these basic rights have been widely institutionalized in international treaties that countries around the world have ratified. In this sense, it is around this core of rights that we would most expect human rights norms to have made an impact on human rights practices. If there is no progress here, we would not expect it in other less consensual areas. In addition, due to the work of Amnesty International, various United Nations human rights bodies and missions, and domestic truth commissions, there is now ample data dating back to the mid-1970s on changing levels of human rights practices for these basic rights. These data allow us to be more systematic in our evaluation of the impact of human rights norms.

As we began to complete our research, some of our cases took us by surprise. In late 1998, British officials arrested General Augusto Pinochet, former Chilean dictator, in a response to a request by Spanish judges. They asked that Pinochet be extradited to stand trial for human rights violations during his regime. In Guatemala, where security forces had killed over 100,000 people between 1966 and 1986, by 1997 forensic anthropology teams were exhuming mass graves, and truth commissions were publishing their reports on past human rights violations. In Indonesia in 1998, massive student demonstrations forced Suharto to step down from power, and a National Commission on Human Rights, set up in 1993, has developed a positive, if low-key, track record for documenting some human rights abuses and recommending changes in government policy. Despite the geographic, cultural, and political diversity of the countries represented in our cases, we saw similar patterns and processes in very different settings. On the other hand, in some countries like Tunisia and Kenya, the human rights situation, never as severe as in some of the cases discussed above, worsened or stabilized during the same period. How could we account for these changes, similarities, and differences?

This book serves two purposes, one empirical, the other theoretical. First, we want to understand the conditions under which international human rights regimes 
and the principles, norms, and rules embedded in them are internalized and implemented domestically and, thus, affect political transformation processes. We propose a five-phase "spiral model" of human rights change which explains the variation in the extent to which states have internalized these norms. We argue that the enduring implementation of human rights norms requires political systems to establish the rule of law. Stable improvements in human rights conditions usually require some measure of political transformation and can be regarded as one aspect of liberalization processes. Enduring human rights changes, therefore, go hand in hand with domestic structural changes.

We engage questions that are of interest both to academics and to activists and policy makers. Activists and policy makers have long debated the efficacy of human rights policies and pressures, but rarely had time for systematic study and analysis. Political scientists and other social scientists are increasingly interested in questions about the diffusion of international norms and principled ideas (see, for example, Finnemore 1996a, b; Finnemore and Sikkink 1998; Jepperson, Wendt, and Katzenstein 1996; Katzenstein 1996b; Klotz 1995; Kowert and Legro 1996). However, this literature is underspecified with regard to the causal mechanisms by which these ideas spread (Yee 1996) and, more important, rarely accounts for the variation in the impact of international norms (Checkel 1998). Such norms and principled ideas "do not float freely" (Risse-Kappen 1994) but affect domestic institutional change in a differential manner. The wide variety of cases examined in this volume is uniquely suited to permit a more in-depth understanding of how international norms interact with very different domestic structures.

International human rights norms provide an excellent opportunity to explore these theoretical issues for a number of reasons. First, because international human rights norms challenge state rule over society and national sovereignty, any impact on domestic change would be counter-intuitive. Second, human rights norms are well institutionalized in international regimes and organizations, and finally, they are contested and compete with other principled ideas.

This book also builds upon our earlier work on the subject. Risse-Kappen's book on transnational relations (Risse-Kappen 1995) argued that the policy impact of transnationally operating non-state actors on state policies varies according to differences in domestic institutional-structures which determine both their access to political systems and their ability to link up with domestic actors. This book goes one step further and explores the conditions under which networks of domestic and transnational actors are able to change these domestic structures themselves. Sikkink and Keck established the importance of "principled-issue" or "transnational advocacy networks" for the diffusion of international norms in the human rights and environmental issue-areas (Sikkink 1993a; Keck and Sikkink 1998). This book further elaborates the conditions under which principled ideas and international norms affect domestic institutional change and presents a causal argument about the effects of transnational advocacy networks in processes of norm diffusion.

In sum, we argue that the diffusion of international norms in the human rights area crucially depends on the establishment and the sustainability of networks 
among domestic and transnational actors who manage to link up with international regimes, to alert Western public opinion and Western governments. We argue that these advocacy networks serve three purposes, which constitute necessary conditions for sustainable domestic change in the human rights area:

1 They put norm-violating states on the international agenda in terms of moral consciousness-raising. In doing so, they also remind liberal states of their own identity as promoters of human rights.

2 They empower and legitimate the claims of domestic opposition groups against norm-violating governments, and they partially protect the physical integrity of such groups from government repression. Thus, they are crucial in mobilizing domestic opposition, social movements, and non-governmental organizations (NGOs) in target countries.

3 They challenge norm-violating governments by creating a transnational structure pressuring such regimes simultaneously "from above" and "from below" (Brysk 1993). The more these pressures can be sustained, the fewer options are available to political rulers to continue repression.

This process by which international norms are internalized and implemented domestically can be understood as a process of socialization. We distinguish between three types of causal mechanisms which are necessary for the enduring internalization of norms:

- processes of instrumental adaptation and strategic bargaining;

- processes of moral consciousness-raising, argumentation, dialogue, and persuasion;

- processes of institutionalization and habitualization.

The significance of each process varies with different stages of the socialization process. In general, we argue that instrumental adaptation usually prevails in early stages of norms socialization. Later on, argumentation, persuasion, and dialogue become more significant, while institutionalization and habitualization mark the final steps in the socialization processes. We develop a five-phase "spiral model" of norms socialization which specifies the causal mechanisms and the prevailing logic of action in each phase of the process. The model also contains hypotheses about the conditions under which we expect progress toward the implementation of human rights norms. Thus, the "spiral model" accounts for the variation in the domestic effects of international norms.

This chapter presents the research design of the book, in particular the "spiral model." The empirical chapters evaluate the theoretical propositions on the basis of paired comparisons of countries in different regions of the world. We show that the model is generalizable across cases irrespective of cultural, political, or economic differences among countries. These differences matter in terms of timing and duration of socialization processes; but they do not affect the overall validity of our explanatory model. Thus, the empirical chapters examine African 
(Hans Peter Schmitz on Kenya and Uganda; David Black on South Africa), Arab (Sieglinde Gränzer on Tunisia and Morocco), East European (Daniel Thomas on Poland and the former Czechoslovakia), Latin American (Stephen C. Ropp and Kathryn Sikkink on Chile and Guatemala), and South East Asian cases (Anja Jetschke on Indonesia and the Philippines). Together, these chapters represent a fairly comprehensive overview of the conditions of sustainable change in the human rights area. They allow for comparisons across regions which Stephen $\mathrm{C}$. Ropp and Thomas Risse discuss in the concluding chapter.

\section{Conceptualizing the impact of principled ideas and international norms on identities and interests}

This book is part of a growing literature on the impact of ideas and norms in international politics (Adler 1987; Finnemore 1993, 1996a; Goldstein and Keohane 1993b; E. Haas 1990; P. Haas 1992; P. A. Hall 1989; Jacobson 1995; Katzenstein 1996a, b; Klotz 1995; Odell 1982; Sikkink 1991; Yee 1996). This new emphasis has resulted from the empirical failure of approaches emphasizing material structures as the primary determinants of state identities, interests, and preferences. We do not mean to ignore material conditions. Rather, the causal relationship between material and ideational factors is at stake. While materialist theories emphasize economic or military conditions or interests as determining the impact of ideas in international and domestic politics, social constructivists emphasize that ideas and communicative processes define in the first place which material factors are perceived as relevant and how they influence understandings of interests, preferences, and political decisions (Adler 1991, 1997; Checkel 1998; Katzenstein 1996a, b; Kratochwil 1989; Müller 1994; Schaber and Ulbert 1994; Wendt 1992, 1995, forthcoming). In other words, material factors and conditions matter through cognitive and communicative processes, the "battleground of ideas," by which actors try to determine their identities and interests and to develop collective understandings of the situation in which they act and of the moral values and norms guiding their interactions.

We are concerned about the process through which principled ideas ("beliefs about right and wrong held by individuals") become norms ("collective expectations about proper behavior for a given identity," Jepperson, Wendt, and Katzenstein 1996: 54) which in turn influence the behavior and domestic structure of states. While ideas are about cognitive commitments, norms make behavioral claims on individuals (Katzenstein 1996b). To endorse a norm not only expresses a belief, but also creates impetus for behavior consistent with the belief. While ideas are usually individualistic, norms have an explicit intersubjective quality because they are collective expectations. The very idea of "proper" behavior presupposes a community able to pass judgments on appropriateness.

At the same time, the state is not a black box, but is composed of different institutions and individuals. Once ideas have become norms, we still need to 
understand how those norms in turn influence individual behavior of state actors:

- How and why does a member of the military who has ordered extrajudicial executions in the past decide to stop ordering executions?

- Do human rights abuses end because perpetrators are persuaded they are wrong?

- Do they end because leaders care about their international image and want other countries to think well of them? Or can we explain this behavior with more instrumental factors?

- Do perpetrators come to believe that they will be held accountable, and so they change behavior to avoid punishment?

- Do countries want to renew international military and economic aid that has been cut?

It is often not possible to do the precise research to answer these questions completely, but in this book we work to document the change (or lack thereof) in human rights practices, and then we trace the process of domestic and international normative, political, and institutional developments to try to explain the changes we observe. We also consider alternative explanations for human rights behavior to see which explanation fits the patterns we observe in each country.

In the cases studied, we find many examples of some human rights changes occurring apparently because leaders of countries care about what leaders of other countries think of them. Norms have a different quality from other rules or maxims. James Fearon argues that while rules take the form "Do X to get Y," norms take a different form: "Good people do X." Thus people sometimes follow norms because they want others to think well of them, and because they want to think well of themselves (Fearon 1997). People's ability to think well of themselves is influenced by norms held by a relevant community of actors. Scholars in international law have long recognized this intersubjective nature of norms by referring to international law as relevant within a community of "civilized nations." Today the idea of "civilized" nations has gone out of fashion, but international law and international organizations are still the primary vehicles for stating community norms and for collective legitimation. Some legal scholars now discuss a community of "liberal states" seen as a sphere of peace, democracy, and human rights, and distinguish between relations among liberal states, and those between liberal and nonliberal states (Franck 1990; Slaughter 1995). Human rights norms have a special status because they both prescribe rules for appropriate behavior, and help define identities of liberal states. Human rights norms have constitutive effects because good human rights performance is one crucial signal to others to identify a member of the community of liberal states (on definitions of norms and their constitutive effects see Finnemore and Sikkink 1998; Jepperson, Wendt, and Katzenstein 1996; Katzenstein 1996a, b; Kowert and Legro 1996; Thomson 1993). 
Our approach to the constitutive and behavioral effects of principled ideas and norms draws on social constructivism (for applications to international relations see Katzenstein 1996a; Kratochwil 1989; Wendt 1992, 1995). Actors' interests and preferences are not given outside social interaction or deduced from structural constraints in the international or domestic environment. Social constructivism does not take the interests of actors for granted, but problematizes and relates them to the identities of actors. What I want depends to a large degree on who I am. Identities then define the range of interests of actors considered as both possible and appropriate. Identities also provide a measure of inclusion and exclusion by defining a social "we" and delineating the boundaries against the "others." Norms become relevant and causally consequential during the process by which actors define and refine their collective identities and interests.

In our case, human rights norms help define a category of states - "liberal democratic states." Many (but certainly not all) of the interests these states have are quite different from those of the "others" - the authoritarian or "normviolating" states. In some cases, these liberal "clubs" are quite specific; in the case of the European Union, for example, the formal and informal rules and norms specify that only democratic states with good human rights records can join the club. In the Inter-American system, such norms are just now emerging. The Organization of American States (OAS)'s Managua Declaration of 1993, for example, is very explicit about this process of stating norms that contribute to identity formation of member states. In it the OAS members declare "the need to consolidate, as part of the cultural identity of each nation in the Hemisphere, democratic structures and systems which encourage freedom and social justice, safeguard human rights, and favor progress" (Vaky and Muñoz 1993).

But emphasizing the contribution of international norms to identity formation is not to suggest a "fair-weather" model of norm-induced domestic change whereby power, political struggles, and instrumental interests of actors are somehow absent from the story. We do not argue in terms of simple dichotomies such as "power versus norms" or "norms versus interests." Instead, we are interested in the interaction among these various factors. For example, we explore the "power of principles," that is, the use of principled ideas and international norms in domestic struggles among political actors. To the extent that human rights norms have become consensual, they can be used instrumentally in such power struggles. In the case of South Africa, the "power of principles" resulted in a sanctions regime which had powerful effects on the availability of material resources to the South African government (see Black 1999; Klotz 1995). ${ }^{3}$

Moreover, we also do not suggest that the causal arrows always point in one direction, as in "norms lead to a change in interests." There are ample examples in this book where national governments changed their human rights practices only to gain access to the material benefits of foreign aid or to be able to stay in power in the face of strong domestic opposition. In fact, the process of human rights change almost always begins with some instrumentally or strategically motivated adaptation by national governments to growing domestic and 
transnational pressures. But we also argue that this is rarely the end of the story. Even instrumental adoption of human rights norms, if it leads to domestic structural change such as redemocratization, sets into motion a process of identity transformation, so that norms initially adopted for instrumental reasons, are later maintained for reasons of belief and identity. While the old leadership is not persuaded, the new leadership has internalized human rights norms and shows a desire to take its place in a community of human rights abiding states. The Philippine president, Ferdinand Marcos, for example, adopted some human rights norms for instrumental reasons, but once democratization occurred and Corazon Aquino took office, the very identity of the Philippine state changed.

A similar process might explain the Reagan administration's prodemocracy policy. When the principled position in favor of democracy was first adopted by the Reagan administration, most interpreted it as a vehicle for an aggressive foreign policy against leftist regimes, such as the USSR, Nicaragua, and Cuba. (This would be consistent with the instrumental use of a principled idea.) But because democracy as a principled idea had achieved consensus among political elites and the general public in the United States, the Reagan administration found itself obliged to a minimal consistency in its foreign policy, and thus eventually actively encouraged democracy in authoritarian regimes which the Republicans viewed as loyal allies, such as Chile and Uruguay.

In the end, the precise direction of the causal arrows - whether norms lead to a change in (collective) identities which in turn leads to a change in (instrumental) interests or whether interests lead to a change in norms which in turn lead to a change in identities - has to be determined through careful empirical process-tracing. This book does not have a preconceived notion of the way in which the causal mechanisms work in general. But we do suggest that instrumental and material interests, processes of norm-guided identity formation, as well as argumentation, persuasion, and dialogue, on the one hand, and strategic bargaining, on the other, differ in significance during the various stages of norms socialization.

\section{A theoretical framework of norms socialization processes}

The process by which principled ideas held by individuals become norms in the sense of collective understandings about appropriate behavior which then lead to changes in identities, interests, and behavior is conceptualized in this book as a process of socialization (Finnemore 1993; Ikenberry and Kupchan 1990; Müller 1993; Schimmelfennig 1994). Socialization can be defined as the "induction of new members . . . into the ways of behavior that are preferred in a society" (Barnes, Carter, and Skidmore 1980: 35). What is crucial to this definition is that socialization presupposes a society. Internationally, it makes sense only within the bounds of an international system defined as a society of states (Bull 1977). Contrary to some conceptions of international society, however, this definition suggests that international society is a smaller group than the total number of states in the international system, and that socialization to international 
norms is the crucial process through which a state becomes a member of the international society. The goal of socialization is for actors to internalize norms, so that external pressure is no longer needed to ensure compliance. The classic social science literature on socialization recognized that much socialization occurs among peer groups and social groups. "Political socialization produces a political self . . . It is political socialization which molds and shapes the citizen's relation to the political community" (Dawson and Prewitt 1969). Because a state's political identity emerges not in isolation but in relation to and in interaction with other groups of states and international non-state actors, the concept of socialization may be useful in understanding how the international society transmits norms to its members.

We distinguish in this book three types of socialization processes which are necessary for enduring change in the human rights area:

1 processes of adaptation and strategic bargaining;

2 processes of moral consciousness-raising, "shaming," argumentation, dialogue, and persuasion;

3 processes of institutionalization and habitualization.

These processes constitute ideal types which differ according to their underlying logic or mode of social action and interaction. In reality, these processes usually take place simultaneously. Our task in this book is to identify which mode of interaction dominates in which phase of the socialization process. We suggest a rough order, which is depicted in Figure 5.1.

The first type of socialization process concerns the instrumental adaptation to pressures - both domestic and international. Governments accused of violating human rights norms frequently adjust to pressures by making some tactical concessions. They might release political prisoners or sign some international agreements, for example, in order to regain foreign aid, to overcome international

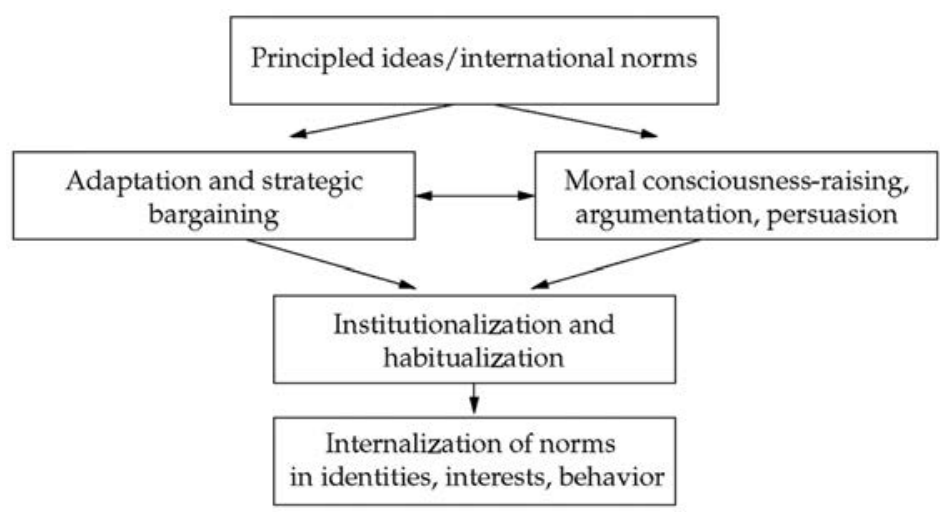

Figure 5.1 The process of norms socialization 
sanctions, or to strengthen their rule vis-à-vis domestic opposition. They might also engage in bargaining processes with the international community and/or the domestic opposition. They might even start "talking the talk" of human rights in international fora such as the United Nations (UN) Human Rights Commission. Such activities are essentially compatible with rational choice arguments about human beings as expected utility-maximizers. Actors - norm-violating governments in this case - pursue exogenously defined and primarily instrumental or material interests and change their behavior in order to reach their goals. They adjust their behavior to the international human rights discourse without necessarily believing in the validity of the norms. We argue in this book that instrumental adaptation to growing international and domestic pressures is a typical reaction of norm-violating governments in early stages of the socialization process.

The second type of socialization process which we investigate in this book, concerns argumentative discourses in the Habermasian sense (Habermas 1981, 1992, 1995b; for applications to international relations see Müller 1994; Prittwitz 1996; Risse 1997). While adaptation refers to an instrumental adjustment to international norms irrespective of discursive practices, socialization through moral discourse emphasizes processes of communication, argumentation, and persuasion. Actors accept the validity and significance of norms in their discursive practices. The notion of "moral discourse" needs to be strictly distinguished from daily communicative practices. We can differentiate between two ideal types of communicative behavior: the first focuses on the exchange of information through verbal utterances. In these instances, speakers know what they want and how they see the situation in which they act and communicate this to others. Information exchanges through communicative behavior can well be incorporated in rational choice models (see, for example, Morrow 1994; Schneider 1994). This is not what we have in mind.

The other type of communicative behavior which we identify with the notion of "discourse" in this volume, challenges the validity claims entailed in these "informations." At a most basic level, actors might try to clarify whether they understood correctly the information submitted. Do we understand you correctly that you accept the validity of international human rights norms, but claim that the alleged violations did not occur? More significant are discourses arguing over whether the situation is defined correctly. You claim that these actions are part of a fight against terrorism, but we think that they constitute human rights violations. What are they an instance of? In this case, actors might actually agree on the moral validity of the norm, but disagree whether certain behavior is covered by it.

Finally, there are moral discourses which challenge the validity claims of the norm itself. You argue that human rights are universal, but we think that our culture and way of life are alien to these individualistic norms. We argue in this book that such discourses challenging validity claims inherent in definitions of the situation as well as in principled beliefs and norms are all-pervasive in the human rights area and need to be analyzed in order to explain socialization 
processes leading to sustainable domestic change. Moral discourses in particular not only challenge and seek justifications of norms, they also entail identityrelated arguments. What I find morally appropriate depends to some degree on who I am and how I see myself. As argued above, for example, human rights define a certain category of states and, thus, relate to collective identities. The logic of discursive behavior and of processes of argumentation and persuasion rather than instrumental bargaining and the exchange of fixed interests prevails when actors develop collective understandings that form part of their identities and lead them to determine their interests. Those principled beliefs carry the day when they persuade actors in potentially winning coalitions to interpret their material and political interests and preferences in light of the idea and to accept its social obligations as appropriate. Coalitions are formed not just through the convergence of pre-existing actors' interests, but also through argumentative consensus. People become convinced and persuaded to change their instrumental interests, or to see their interests in new ways, following the principled ideas.

This is not to argue that moral discourses and discursive practices in general resemble "ideal speech" situations in the Habermasian sense, where power and hierarchies are absent and nothing but the better argument counts. In real-life situations, relationships of power and interest-based arguments are rarely completely out of the picture. Nor do communicative processes always involve the exchange of logical arguments. Actors rely on a variety of techniques to persuade, including appeals to emotion, evoking symbols, as well as the use and extension of logical arguments. Although some authors privilege the role of logic in the extension of norms (Crawford 1993), psychological research suggests that both emotion and cognition operate synergistically to produce and change attitudes (Eagly and Chaiken 1993). In the area of human rights, persuasion and socialization often involve processes such as shaming and denunciations, not aimed at producing changing minds with logic, but on changing minds by isolating or embarassing the target. Persuasion is also not devoid of conflict. It often involves not just reasoning with opponents, but also pressures, arm-twisting, and sanctions. For example, Audie Klotz's work on norms and apartheid discusses coercion, incentive, and legitimation effects that are often part of a socialization process (Klotz 1995; see also Black 1999).

Nevertheless, we claim that the logic of persuasion and of discourse is conceptually different from a logic of information exchange based on fixed preferences, definitions of the situations, and collective identities. Discursive processes are precisely the types of human interaction in which at least one of these properties of actors is being challenged.

We expect to find a mix of instrumental and argumentative rationalities governing the process by which domestic and transnational actors, states, and international institutions impact upon the human rights performance of particular regimes. We are particularly interested in investigating the characteristic patterns in the mix of the instrumental and the communicative, and the conditions under which actors change from one mode of action to the other. Here are a few examples taken from the human rights area of how argumentative rationality 
and policy deliberation, on the one hand, and instrumental adaptation, on the other, might relate to each other:

1 Repressive governments often adapt to normative pressures for purely instrumental reasons. When the pressure decreases, they return to repression, as was the case in Kenya in the early 1990s (see Schmitz 1999). Sometimes, however, they start institutionalizing human rights norms into domestic law and change their discursive practices. This in turn opens space for the domestic opposition to catch the government in its own rhetoric. At this point, instrumental and communicative rationality intertwine. It becomes very hard for the government to deny the validity of human rights norms. Political psychology talks about "self-persuasion" in this context. Over time people come to believe what they say, particularly if they say it publicly (Chaiken, Wood, and Eagly 1996: 703-705).

2 Moral consciousness-raising by the international human rights community often involves a process of "shaming." Norm-violating states are denounced as pariah states which do not belong to the community of civilized nations, as was the case with South Africa (Black 1999). Shaming then constructs categories of "us" and 'them', that is, in-groups and out-groups, thus re-affirming particular state identities. Some repressive governments might not care. Others, however, feel deeply offended, because they want to belong to the "civilized community" of states. In other words, shaming then implies a process of persuasion, since it convinces leaders that their behavior is inconsistent with an identity to which they aspire. This was the case with the Moroccan king, as Sieglinde Gränzer shows (Gränzer 1999).

3 Domestic opposition groups might rally around human rights issues for purely instrumental reasons at first, for example, to be able to communicate and to link up with international and transnational networks or to broaden the basis of domestic opposition by bringing in ideologically diverse groups. If they succeed in overthrowing the oppressive regime, however, there is less instrumental need to act upon their opposition rhetoric and to implement the human rights norms. It is, therefore, noteworthy that, in all cases of successful human rights change documented in this book, the new regimes matched their opposition words with deeds, although the fit was often less than perfect. This suggests a communicative process of identity change which leads actors to behave in ways consistent with their identity when they acquire the means to do so.

The three examples suggest that socialization processes start when actors adapt their behavior in accordance with the norm for initially instrumental reasons. Governments want to remain in power, while domestic NGOs seek the most effective means to rally the opposition. The more they "talk the talk," however, the more they entangle themselves in a moral discourse which they cannot escape in the long run. In the beginning, they might use arguments in order to further their instrumentally defined interests, that is, they engage in rhetoric (on 
rhetorical action see Schimmelfennig 1995, 1997). The more they justify their interests, however, the more others will start challenging their arguments and the validity claims inherent in them. At this point, governments need to respond by providing further arguments. They become entangled in arguments and the logic of argumentative rationality slowly but surely takes over. It follows that we expect argumentative rationality, dialogue, and processes of persuasion to prevail in later stages of the socialization process.

But argumentative processes are still not sufficient in order to socialize states into norm-abiding practices. Human rights norms can only be regarded as internalized in domestic practices, when actors comply with them irrespective of individual beliefs about their validity. In the case of Uganda (see Schmitz 1999), for example, national leader Yoweri Museveni can probably be regarded as a "true believer" in human rights. But it is less clear whether the drastic improvement in human rights conditions will survive his presidency. This points to a final type of socialization process emphasizing the gradual institutionalization of norms as theorized by sociological and historical institutionalism (P. A. Hall and Taylor 1996; Jepperson 1991; March and Olsen 1989; Powell and DiMaggio 1991; Steinmo, Thelen, and Longstreth 1992). Actors incrementally adapt to norms in response to external pressures, initially for purely instrumental reasons. National governments might then change their rhetoric, gradually accept the validity of international human rights norms, and start engaging in an argumentative process with their opponents, both domestically and abroad. The more they accept the validity of the norms and the more they engage in a dialogue about norm implementation, the more they are likely to institutionalize human rights in domestic practices. Human rights norms are then incorporated in the "standard operating procedures" of domestic institutions. This type of internalization process can be conceptualized as independent from changes in individual belief systems. Actors follow the norm, because "it is the normal thing to do." Whether they are convinced of its moral validity and appropriateness or not is largely irrelevant for habitualization processes. When we stop at a red traffic light, we usually do not question the normative implications of the rule we are just following. Once human rights norms are institutionalized in this sense, changes in government and in individual leaders matter less and less. Norms are implemented independently from the moral consciousness of actors. They are simply "taken for granted" which marks the final stage in a socialization process (see Finnemore and Sikkink 1998). Institutionalization and habitualization are necessary to "depersonalize" norm compliance and to insure their implementation irrespective of individual beliefs.

\section{Transnational advocacy networks and human rights socialization: The "spiral model"}

So far, we have developed a theoretical argument about socialization processes by identifying three ideal types of social action: instrumental adaptation, argumentative discourse, and institutionalization. To guide our empirical analysis, 
however, this conceptual framework needs to be operationalized and applied to the human rights area more specifically. In the following, we develop a five-phase "spiral model" of human rights change which incorporates simultaneous activities at four levels into one framework:

- the international-transnational interactions among transnationally operating international non-governmental organizations (INGOs), international human rights regimes and organizations, and Western states;

- the domestic society in the norm-violating state;

- the links between the societal opposition and the transnational networks;

- the national government of the norm-violating state.

The "spiral model" builds upon previous work on "principled issue or transnational advocacy networks" in the human rights area. A transnational advocacy network includes those relevant actors working internationally on an issue, who are bound together by shared values, a common discourse, and dense exchanges of information and services (Keck and Sikkink 1998; see also Risse-Kappen 1995). We follow various studies on the impact of human rights norms in Latin America emphasizing how domestic and transnational social movements and networks have united to bring pressure "from above" and "from below" to accomplish human rights change (Brysk 1993; Osiel 1986; Sikkink 1993a). Keck and Sikkink have referred to this process as the "boomerang effect" (Keck and Sikkink 1998).

A "boomerang" pattern of influence exists when domestic groups in a repressive state bypass their state and directly search out international allies to try to bring pressure on their states from outside. National opposition groups, NGOs, and social movements link up with transnational networks and INGOs who then convince international human rights organizations, donor institutions, and/or great powers to pressure norm-violating states. Networks provide access, leverage, and information (and often money) to struggling domestic groups. International contacts can "amplify" the demands of domestic groups, prise open space for new issues, and then echo these demands back into the domestic arena (see Figure 5.2).

The "boomerang model" can be integrated in a more dynamic conceptualization of the effects which these domestic-transnational-international linkages have on domestic political change. The "spiral model" which will be explored in the empirical chapters consists of several "boomerang throws" with diverging effects on the human rights situation in the target country (see Figure 5.3). It is a causal model which attempts to explain the variation in the extent to which national governments move along the path toward improvement of human rights conditions. We do not assume evolutionary progress. Rather, below we identify those stages in the model where governments might return to repressive practices. We develop hypotheses about the conditions under which we expect movement from one phase of the "spiral model" to the next. These phases are distinguished by the dominant response from the norm-violating state to the societal and 


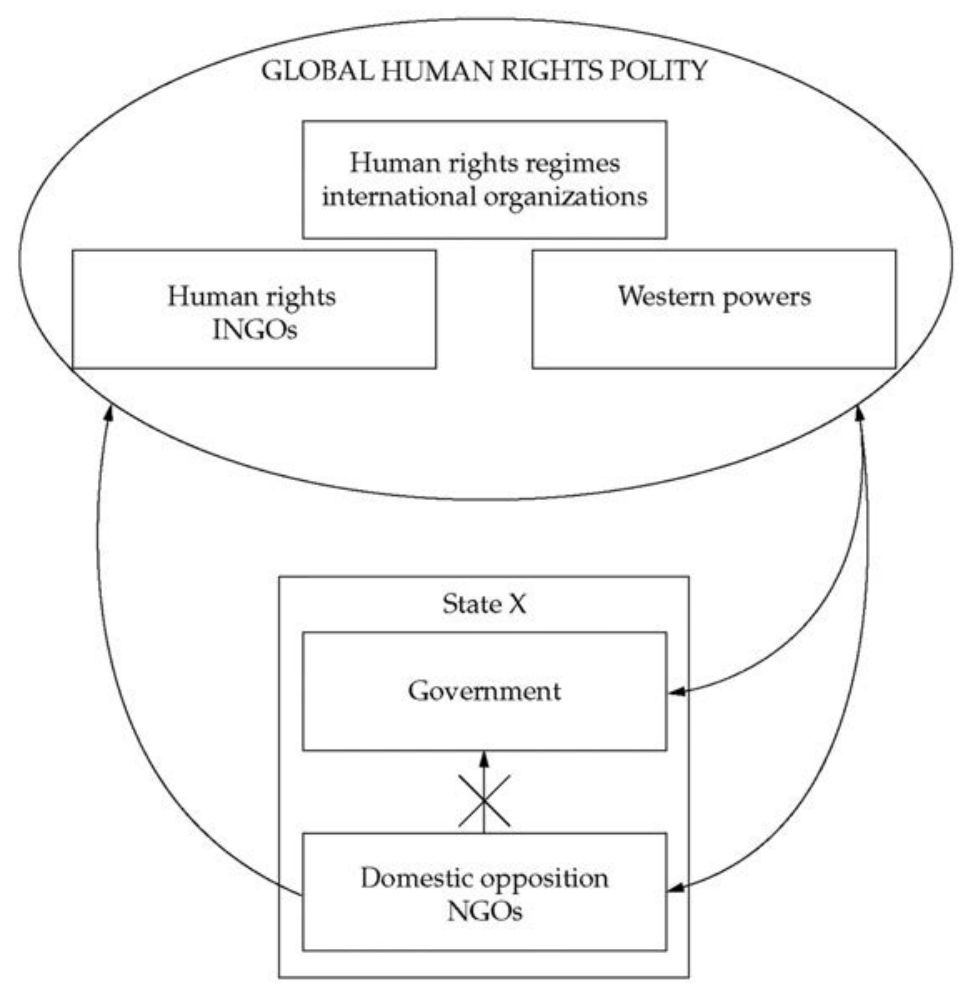

Figure 5.2 The "boomerang effect"

transnational activities. Thus, the "spiral model" serves to operationalize the theoretical framework of norm socialization developed above, to identify the dominant mode of social interaction in each phase (adaptation, arguing, institutionalization), and, ultimately, to specify the causal mechanisms by which international norms affect domestic structural change.

\section{"World time"}

Our dynamic model is based on the prior existence of international institutions which regulate human rights norms (a social structure) and of transnational advocacy networks composed of INGOs and foundations which are loosely connected to officials working for human rights IOs as well as for national governments (the norm-promoting agents). The international institutions are primarily the human rights bodies of the United Nations, and the various human rights treaties that have been drafted and ratified under UN auspices, but also include some regional institutions, such as the Inter-American Commission and Court of Human Rights. The human rights networks include international and domestic 


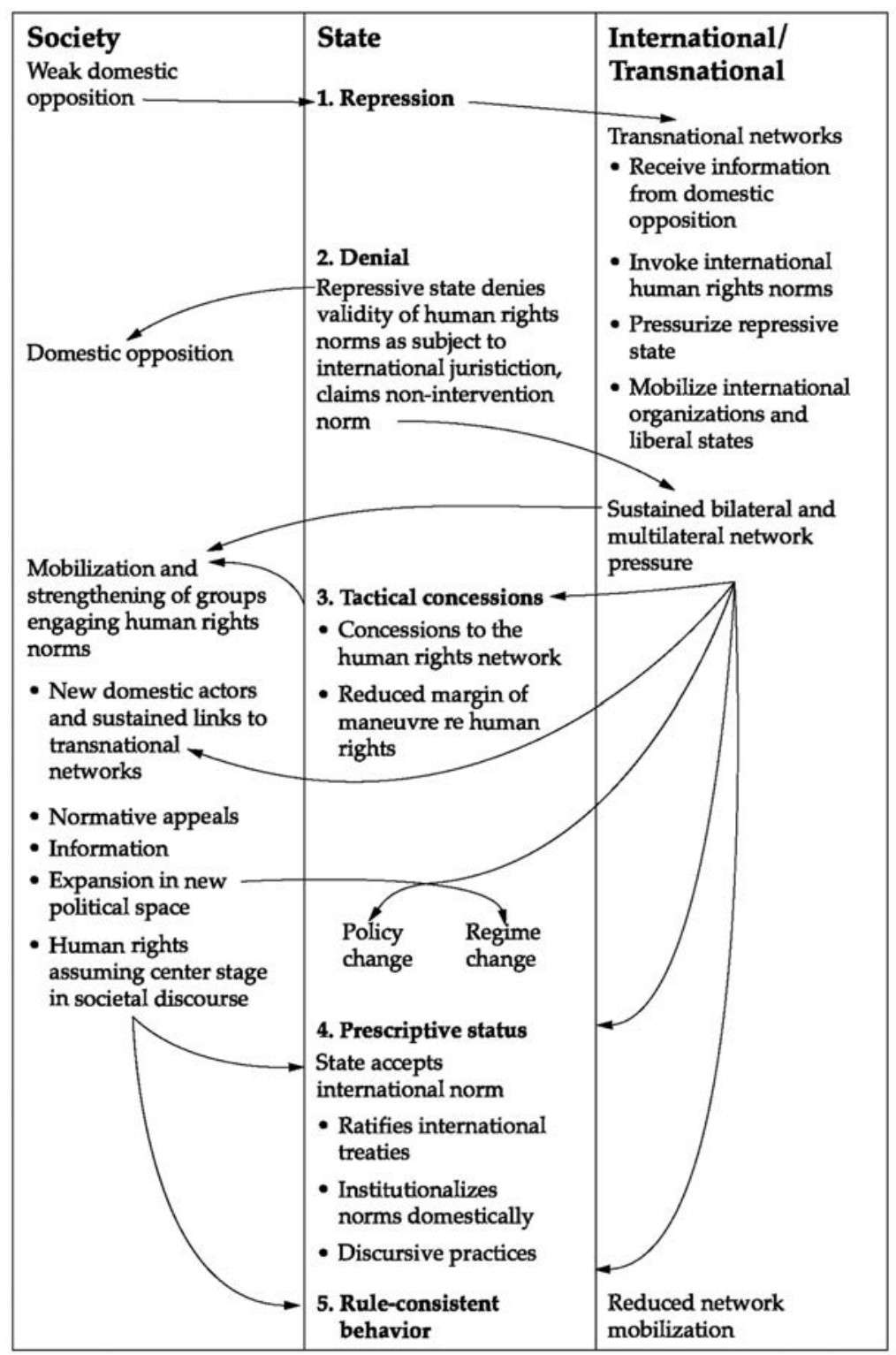

Figure 5.3 The "spiral model" of human rights change

NGOs, foundations, and some governmental and inter-governmental officials who share collective understandings and a collective identity with regard to human rights norms. Other authors have described and explained the origins and growth of these institutions and networks (Donnelly 1991; Forsythe 1991); we explore what role they play in our case studies. 
The existence and strength of human rights institutions, norms, and networks, however, increased significantly over time, and thus the cases take place at different moments in "world time." Prior to 1973, international human rights treaties had not yet entered into force and the strength of international human rights norms and institutions was much weaker. No country had yet adopted an explicit bilateral human rights policy, and fewer human rights NGOs existed. The cases of Chile and South Africa are important in this period since both cases begin prior to the existence of strong international networks and institutions, and these cases actually contribute to the growth of the network, to the emergence of human rights foreign policies, and to more activist orientations by international organizations, as Ropp and Sikkink discuss (Ropp and Sikkink 1999).

Between 1973 and 1985, transnational human rights NGOs and advocacy networks expanded and states and networks built the international social structure of human rights norms and institutions. In 1976, the international human rights covenants came into effect, and new institutions, such as the United Nations Human Rights Committee, emerge. Between 1973 and 1990, most Western countries developed some form of explicit bilateral and multilateral human rights policies. After 1985, we can say that the world began a process of a genuine international "norms cascade," as the influence of international human rights norms spread rapidly (on norms cascades, see Sunstein 1997). Country cases that begin before the norms cascade will take longer to move through the phases than cases of repression that begin after the norms cascade has taken place. A completed norms cascade leads to a point where norms are internalized and gain a "taken for granted quality" (Finnemore and Sikkink 1998; see also Risse and Ropp 1999). If the international human rights norms cascade is sustained, states are less likely to engage in a lengthy "denial" stage, since human rights norms become increasingly accepted.

\section{Phase 1: Repression and activation of network}

The starting point for our research is a repressive situation in the state under investigation - the "target" - where domestic societal opposition is too weak and/or too oppressed to present a significant challenge to the government. The levels of repression vary greatly among the countries in the volume, from extreme repression bordering on genocide (as in the case of Guatemala) to much lower levels of repression as in the case of Tunisia.

This phase of repression might last for a long time, since many oppressive states never make it on to the agenda of the transnational advocacy network. Moreover, the degree of repression unfortunately determines to some degree whether transnational networks can even acquire information about human rights conditions in the country. Very oppressive governments sometimes do not become the subject of international campaigns by the advocacy networks, because information gathering requires at least some minimal links between the domestic opposition and the transnational networks if the latter is to gain access to the norm-violating state. Only if and when the transnational advocacy network succeeds in gathering sufficient information on the repression in the "target state," 
can it put the norm-violating state on the international agenda moving the situation to phase 2 (hypothesis 1).

\section{Phase 2: Denial}

This phase of the "spiral model" puts the norm-violating state on the international agenda of the human rights network and serves to raise the level of international public attention toward the "target state." The initial activation of the transnational network often results from a particularly awesome violation of human rights such as a massacre and leads to the mobilization of the international human rights community. This stage is characterized first by the production and dissemination of information about human rights practices in the target state. Such information is often compiled with the cooperation of human rights organizations in the target state. The transnational network then starts lobbying international human rights organizations as well as Western states - from public opinion to policy makers and national governments. This "lobbying" usually involves some discursive activities in terms of moral persuasion. Western governments and publics, for example, are reminded of their own identity as promoters of human rights. Human rights organizations frequently remind Western states of their own standards in this area and demand that they live up to them. Network activists often point to inconsistencies in Western state behavior, stressing that they had condemned human rights violations in one state, but not another, where violations are just as egregious. This also typically involves some "shaming." So moral persuasion takes place during the first phase, but it involves networks persuading Western states to join network attempts to change human rights practices in target states. These lobbying activities might lead to some initial pressure on the target state to improve its human rights conditions.

The initial reaction of the norm-violating state in the cases considered here is almost always one of denial. "Denial" means that the norm-violating government refuses to accept the validity of international human rights norms themselves and that it opposes the suggestion that its national practices in this area are subject to international jurisdiction. Thus, denial goes further than simply objecting to particular accusations. The norm-violating government charges that the criticism constitutes an illegitimate intervention in the internal affairs of the country. The government may even succeed in mobilizing some nationalist sentiment against foreign intervention and criticism. Thus the initial "boomerang throw" often appears to be counterproductive because it allows the state to solidify domestic support. The presence of a significant armed insurgent movement in the target country can dramatically extend this stage, by heightening domestic perceptions of threat and fear. Any insurgent movement success appears to validate the government's claim that the order or the very integrity of the nation is at stake, and thus isolates domestic human rights organization and international pressures by identifying these groups as conscious or unconscious accomplices of terrorism.

We count the denial stage as part of the socialization process because the fact that the state feels compelled to deny charges demonstrates that a process of 
international socialization is already under way. If socialization were not yet under way, the state would feel no need to deny the accusations that are made. Governments which publicly deny the validity of international human rights norms as interference in internal affairs, are at least implicitly aware that they face a problem in terms of their international reputation. It is interesting to note in this context that denial of the norm almost never takes the form of open rejection of human rights, but is mostly expressed in terms of reference to an allegedly more valid international norm, in this case national sovereignty. Nevertheless, the denial stage can also last for quite a long time. Some repressive governments care little about international pressures. Moreover, they might kill off or buy off the domestic opposition.

Because of changes in "world time" it is possible that denial and backlash is a normative phase particular to a period in which new international norms have emerged, but when they are still strongly contested internationally. Governments, through their denial, engage in this contestation. If this is the case, we would expect the denial stage to disappear in cases of more fully institutionalized norms. The timing of the disappearance of the denial phase may differ from one region to another. For example, no state in Western Europe has denied the prescriptive status of human rights norms since the military junta in Greece in the late 1960s. In Latin America, it is possible that the historical limits to the denial phase are being reached in the mid-1990s, but we would expect this contestation to continue much longer in Asia and Africa.

In sum, however, norm-violating governments still have many strategies at their disposal to fight off international and transnational pressure. The domestic opposition is still too weak to be able to mount a major challenge to the regime. Therefore, the transition to the third phase constitutes the biggest challenge for the transnational human rights network. This transition primarily depends on the strength and mobilization of the transnational network in conjunction with the vulnerability of the norm-violating government to international pressures (hypothesis 2; see Keck and Sikkink 1998; Klotz 1995; Sikkink 1993a, b).

Almost all human rights campaigns involve particular kinds of material pressures, for example, when aid becomes conditional on human rights performance, and these pressures are indisputably important for understanding the early stages of influence. But target vulnerability may also come from prior normative commitments. Vulnerability may simply represent a desire to maintain good standing in valued international groupings (Klotz 1995). To the degree that a nation values its membership in an emerging community of liberal states, it will be more vulnerable to pressures than a state that does not value such membership. We would expect that countries receiving large military and economic aid flows will be more vulnerable to human rights pressures than those not receiving such flows.

\section{Phase 3: Tactical concessions}

If international pressures continue and escalate, the norm-violating state seeks cosmetic changes to pacify international criticism. Although the norm-violating government might then temporarily improve the situation - for example, by 


\section{6}

releasing prisoners - we do not expect a stable amelioration of human rights conditions. This more sustained period of international concern, however, may allow the initial "rally around the flag" effect of phase 2 to wear off. The minor cosmetic changes, such as the release of prisoners, or greater permissiveness about domestic protest activities, may allow the repressed domestic opposition to gain courage and space to mount its own campaign of criticism against the government. At this point the repressive government is usually acting almost solely from an instrumental or strategic position, trying to use concessions to regain military or economic assistance, or to lessen international isolation.

The most important effect of this second phase of transnational mobilization is, therefore, not so much to change the behavior of the government as to facilitate social mobilization in the target country. In other words, if the transnational network succeeds in forcing the norm-violating state to make tactical concessions, the focus of activities is likely to shift from the transnational to the domestic level. The increased international attention serves to create and/or strengthen local networks of human rights activists whose demands are empowered and legitimated by the transnational/international network, and whose physical integrity may be protected by international linkages and attention. In this sense the transnational network serves to help creating space for the domestic groups and to amplify their demands in the international arena.

This is the most precarious phase of the spiral model, since it might move the process forward toward enduring change in human rights conditions, but can also result in a backlash (see Gränzer 1999 on Tunisia). If a government responds with unrelenting repression of activists, it can temporarily break the upward spiral process. At the beginning of phase 3 , the domestic human rights movement is often relatively small and dependent on a handful of key leaders. Arresting or killing these leaders decapitates the movement and the resulting fear paralyzes it. This, for example, is what happened in the case of the repression of the demonstrations in Tiananmen Square in China, and the initial response of the Guatemalan government to human rights pressures in the late 1970s (see Ropp and Sikkink 1999). While such actions can temporarily nip an incipient domestic opposition in the bud, this rarely suspends the spiral indefinitely, but mostly delays it. The additional repression is costly to the government in terms of its domestic legitimacy, and may validate international criticism by revealing more clearly the coercive power of the state.

If the cycle is not delayed, the domestic opposition is likely to gain strength. The fully mobilized domestic NGO networks linked to the global human rights polity can then be activated at any time. Toward the end of the tactical concession phase, norm-violating governments are no longer in control of the domestic situation. Whenever they commit another serious violation of human rights, the domestic-transnational network is activated and now pressures the government "from above" and "from below" (Brysk 1993). "From above," donor countries are now likely to coordinate foreign aid, making it contingent on human rights improvements. "From below," repression gradually ceases to serve its purpose of suppressing opposition. People start losing their fears.

In this phase of the socialization process, we expect the two ideal types of instrumental and of argumentative rationality to matter, with the latter gaining 
in significance. First, on the level of domestic society, human rights claims are likely to serve as the main principled idea around which an opposition coalition can be formed (see Jetschke 1999 on the Philippines, and Schmitz 1999 on Uganda). We expect argumentation and deliberation to become important in the coalition-building processes of the domestic opposition. Some domestic groups, however, recognizing that human rights claims have more international support and legitimacy, may take up the human rights banner because it is an easier way to criticize the government rather than because they profoundly believe in human rights principles. Thus, we assume a mix of instrumental and argumentative rationality in this crucial phase of domestic network formation.

Second and equally important, norm-violating governments no longer deny the validity of the international human rights norms when they start making tactical concessions. In the beginning, these concessions can mostly be explained on the grounds of instrumental interests. At this stage of the process, "shaming" of norm-violating governments becomes a particularly effective communicative tool of the transnational advocacy network. As argued above, human rights "persuasion" creates ingroups and outgroups (human rights norm supporters, or liberal democratic states versus human rights norm violators). States are subject to a normative process of shaming, and relegation to an outgroup, which they often resent, and sometimes feel is sufficiently disturbing for either their international image or their domestic legitimacy that they are willing to make human rights concessions (see Gränzer 1999 on Morocco). That shaming is usually reinforced by material sanctions of some sort strengthens the move to make minor changes.

When they make these minor concessions, states almost uniformly underestimate the impact of these changes, and overestimate their own support among their population. They think the changes are less costly than they are, and they anticipate that they have greater control over international and domestic processes. Leaders of authoritarian states (like many political scientists) tend to believe that "talk is cheap" and do not understand the degree to which they can become "entrapped" in their own rhetoric. As a result, states are often taken by surprise by the impact their initial changes create - in terms of both international processes and domestic mobilization. By the time they realize their mistakes, they have already unleashed forces of opposition beyond the expectations of the regime, and the situation is often out of their control.

"World time" may provide part of the explanation for this entrapment. Since human rights networks and policies were growing and changing rapidly at the time when many governments entered the tactical concessions phase, they can not be expected to know the extent of pressures and policies they would face. Governments reasoning from the past (when human rights regimes and networks were relatively weak) would understandably underestimate the impact of tactical changes in a new world context.

A similar process is likely to happen on the level of rhetoric and communicative action. Governments no longer deny the validity of the norm and start "talking the human rights talk." Initially, they usually reject any concrete allegations of violations and denounce their critics as "foreign agents" or simply as ignorant. By doing so, they nevertheless start engaging in a public controversy with their critics who usually respond by justifying their accusations. This process of arguing over human 
rights violations takes place both in public and in international organizations such as the UN Human Rights Commission (for evidence see Schmitz 1999 on Kenya and Uganda, Jetschke 1999 on Indonesia and the Philippines, and Ropp and Sikkink 1999 on Chile and Guatemala). In the beginning of such a process, the arguments on both sides resemble the logic of rhetorical action (Schimmelfennig 1995, 1997) whereby justifications are used to further one's interests without being prepared to really challenge the validity claims inherent in these interests. Slowly but surely, governments become entrapped in their own rhetoric and the logic of arguing takes over. The more norm-violating governments argue with their critics, the more likely they are to make argumentative concessions and to specify their justifications and the less likely they are to leave the arguing mode by openly denouncing their critics. At this stage then, reputational concerns keep governments in a dialogical mode of arguing. Instrumental reasons and argumentative rationality reinforce each other. At the same time, critics of human rights violations such as INGOs increasingly take the justifications of governments for their behavior more seriously and start engaging in a true dialogue with them concerning how to improve the human rights situation. In other words, a process which began for instrumental reasons, with arguments being used merely rhetorically, increasingly becomes a true dialogue over specific human rights allegations in the "target state." We expect this to be increasingly the case in the later stages of the "tactical concessions" phase.

This process of "self-entrapment" into argumentative behavior also implies that norm-violating governments take the transnational advocacy networks and the domestic opposition more seriously and start treating them as valid interlocutors which in turn only serves to further strengthen and empower them. Faced with a fully mobilized domestic opposition linked up with transnational networks for whom human rights have achieved consensual status, norm-violating governments no longer have many choices. Some rulers start a process of "controlled liberalization" (O'Donnell and Schmitter 1986: 7ff; Przeworski 1986; Wurfel 1990; see Gränzer 1999 on Morocco) and begin implementing human rights norms domestically. Other leaders seriously miscalculate the situation, increase the level of repression which - at this stage - only serves to strengthen the domestic opposition and to annoy their last remaining international supporters (see Schmitz 1999 and Jetschke 1999 on Uganda and the Philippines). As a consequence, they are likely to be thrown out of power (see also Thomas 1999 on Poland and the former Czechoslovakia and Black 1999 on South Africa). Resulting either from a regime change or from "controlled liberalization," this stage in the socialization process marks the transition to "prescriptive status" (hypothesis 3).

\section{Phase 4: "Prescriptive status"}

"Prescriptive status" means that the actors involved regularly refer to the human rights norm to describe and comment on their own behavior and that of others (Rittberger 1993: 10-11); the validity claims of the norm are no longer controversial, even if the actual behavior continues violating the rules. We argue that the process by which principled ideas gain "prescriptive status" should be decisive for their sustained impact on political and social change. In this stage of the process, 
argumentative behavior matters most. But how can we differentiate between prescriptive status achieved through discursive processes of argumentation and persuasion, on the one hand, and purely instrumental or rhetorical support for a principled idea, on the other? National governments may, for example, refer to human rights norms instrumentally when dealing with the UN Human Rights Commission in order to achieve Western goodwill or economic benefits. It is ultimately impossible, of course, to establish without doubt that actors believe in what they say. We are not that interested in the "true beliefs" of actors, as long as they are consistent in their verbal utterances and their words and deeds ultimately match. For the purpose of this book, we use the following indicators for "prescriptive status"; governments are considered as accepting the validity of human rights norms if and when:

1 they ratify the respective international human rights conventions including the optional protocols;

2 the norms are institutionalized in the constitution and/or domestic law;

3 there is some institutionalized mechanism for citizens to complain about human rights violations;

4 the discursive practices of the government acknowledge the validity of the human rights norms irrespective of the (domestic or international) audience, no longer denounce criticism as "interference in internal affairs," and engage in a dialogue with their critics.

As to these discursive practices, we adopt the following criteria:

- Prescriptive status in the sense of recognizing the validity claims of a normative idea implies argumentative consistency, independent of the audience. Actors who change their arguments with regard to the idea depending on with whom they are dealing, become suspect.

- $\quad$ Prescriptive status can be particularly well investigated in those circumstances in which material and power-related interests ought to shift, but actors nevertheless continue adhering to the validity of the norm. Do governments who have engaged in controlled liberalization, stick to their words even though the domestic and transnational pressures for change have decreased (cf. Gränzer 1999 on Morocco)? Alternatively, what happens after a regime change? Does the opposition who gained new power stick to the human rights discourse over a sustained period of time even after it has fully consolidated its rule (cf. Black 1999 on South Africa, Schmitz 1999 on Uganda, Jetschke 1999 on the Philippines, and Thomas 1999 on Eastern Europe)?

- Prescriptive status of a norm can also be well examined in situations in which the actual behavior is still partly inconsistent with it. How do national governments treat accusations by the transnational networks and others of continued violations of human rights? If they engage in a dialogue with their critics, try to legitimize their behavior by referring to the norm, apologize, or promise and deliver compensation, the normative validity of the idea can be inferred.

- Last but not least, of course, words need to be matched by deeds. Prescriptive status of international human rights norms implies that governments make 
a sustained effort to improve the human rights conditions. In other words, we expect the "prescriptive status" phase to be followed over time by the ultimate phase of our socialization model, "rule-consistent behavior" (see, however, the case of Guatemala, described in Ropp and Sikkink 1999).

What mode of social action and interaction dominates the phase of prescriptive status? As argued above, we expect the communicative behavior between the national governments and their domestic and international critics to closely resemble notions of dialogue, of argumentation and justification. At the same time, the institutionalization of the norms into domestic law and ensuing domestic practices begins in this phase of the process. New institutions to protect human rights are created, public officials including police forces are trained, and procedures for individual complaints are instituted.

We operationalize prescriptive status as a country-level variable. If prescriptive status were the result of primarily domestic factors, we would expect human rights norms to achieve prescriptive status in different countries at very different times. And yet, in most of the countries investigated in this volume, human rights norms received prescriptive status around the same period - in the decade from 1985 to 1995. Our case countries are so different as regards all other aspects of domestic structures that the convergence around the dating of prescriptive status is puzzling unless there is an international process of socialization underway. Yet, why does international norm learning appear in the period 1985 to 1995 ? There is no obvious reason for this - the basic norms in the UDHR and the main international institution, the UN Human Rights Commission, have been around since 1948; the main treaties have been in force since 1976. One possible explanation is that norm socialization requires time; it is for the most part a communicative process, and takes time to engage in the kind of dialogue and contestation inherent to communication. Another is that norm socialization required all the pieces of the relevant social structure to be in place for the process to be effective. The relevant social structures include not only the norms, but also a range of international institutions to oversee compliance with the norms, and the network to monitor norm compliance and norm breaking. Not until the mid-1980s were all the parts of this structure fully formed and dense with the increasing number of human rights treaties, institutions, NGOs, increased foundation funding for human rights work - and human rights had become a part of foreign policy of key countries. We will further explore this aspect which points to some sort of "world time" and to developments on the global level in the concluding chapter of this volume (see Risse and Ropp 1999).

\section{Phase 5: Rule-consistent behavior}

"Prescriptive status" is a necessary step toward, but not identical with, rule-consistent behavior. Governments might accept the validity of human rights norms, but still continue to torture prisoners or detain people without trial and so on. Sometimes, national governments are not fully in control of their police and military forces, who commit the human rights violations. In any case, it is crucial for this phase of the spiral 
model that the domestic-transnational-international networks keep up the pressure in order to achieve sustainable improvements of human rights conditions. The particular difficulty in this phase is that gross violations of fundamental human rights might actually decrease in the target state and that, therefore, international attention might decline, too. While many INGOs have acknowledged the problem in the meantime, international institutions and Western states are sometimes satisfied when rulers start accepting the validity of human rights claims in the sense of prescriptive status. This is particularly problematic when there has been a regime change bringing the opposing coalition into power, including human rights activists. Nevertheless, we argue that sustainable change in human rights conditions will only be achieved at this stage of the process when national governments are continuously pushed to live up to their claims and when the pressure "from below" and "from above" continues (hypothesis 4). Only then can the final stage in the socialization process be reached, whereby international human rights norms are fully institutionalized domestically and norm compliance becomes a habitual practice of actors and is enforced by the rule of law. At this point, we can safely assume that the human rights norms are internalized.

During this phase of the process, we may see a "two-level game" dynamic evolve, in which domestic leaders who believe in the human rights norms take power, but may lack strength vis-à-vis their domestic opponents (especially in the military) to implement those norms. These leaders may then use international human rights pressures to gain influence against their domestic opponents. As Putnam has suggested, international human rights pressures may allow foreign leaders to shift the balance of power in their domestic game in favor of a policy they preferred for exogenous reasons (Evans, Jacobson, and Putnam 1993; Putnam 1988). This appears to be a dynamic in the case of the Aquino government in the Philippines, and in the case of the de Leon Carpio administration in Guatemala in the period 1993 to 1996 (cf. Jetschke 1999; Ropp and Sikkink 1999).

This is a short description of the "spiral model" of human rights change establishing the causal mechanisms and the process by which internationally established norms affect domestic structural change through the activities of principled-issue networks linking domestic NGOs, transnationally operating INGOs, international institutions, and national governments. Table 5.1 summarizes the spiral model with regard to (a) the dominant actors whose efforts are crucial to move the socialization process from one phase to the next, and (b) the dominant mode of social interaction across the various levels.

We posit, first, that the transnational human rights networks - in conjunction with international regimes and organizations as well as Western powers - are crucial in the early phases in terms of:

- $\quad$ putting the repressive regimes on the international agenda;

- $\quad$ starting a process of "shaming" and moral consciousness-raising;

- $\quad$ empowering and strengthening the initially weak domestic opposition.

During later stages of the model, activities of the internal networks and of the domestic opposition become increasingly significant, the crucial transition taking 
Table 5.1 The spiral model, dominant actors, and dominant interactions modes

\begin{tabular}{|c|c|c|c|c|c|}
\hline Phase & 1. Repression & 2. Denial & $\begin{array}{l}\text { 3. Tactical } \\
\text { concessions }\end{array}$ & $\begin{array}{l}\text { 4. Prescriptive } \\
\text { status }\end{array}$ & $\begin{array}{l}\text { 5. Rule-consistent } \\
\text { behavior }\end{array}$ \\
\hline $\begin{array}{l}\text { Dominant } \\
\text { actors moving } \\
\text { process to } \\
\text { next phase }\end{array}$ & $\begin{array}{l}\text { Transnational } \\
\text { human rights } \\
\text { networks }\end{array}$ & $\begin{array}{l}\text { Transnational } \\
\text { human rights } \\
\text { networks }\end{array}$ & $\begin{array}{l}\text { Transnational } \\
\text { networks } \\
\text { and domestic } \\
\text { opposition }\end{array}$ & $\begin{array}{l}\text { National } \\
\text { governments and } \\
\text { domestic society }\end{array}$ & $\begin{array}{l}\text { National } \\
\text { governments and } \\
\text { domestic society }\end{array}$ \\
\hline $\begin{array}{l}\text { Dominant } \\
\text { mode of } \\
\text { interaction }\end{array}$ & $\begin{array}{l}\text { Instrumental } \\
\text { rationality }\end{array}$ & $\begin{array}{l}\text { Instrumental } \\
\text { rationality }\end{array}$ & $\begin{array}{l}\text { Instrumental } \\
\text { rationality } \rightarrow \\
\text { rhetorical } \\
\text { action } \rightarrow \\
\text { argumentative } \\
\text { rationality }\end{array}$ & $\begin{array}{l}\text { Argumentative } \\
\text { rationality and } \\
\text { institutionalization }\end{array}$ & $\begin{array}{l}\text { Institutionalization } \\
\text { and habitualization }\end{array}$ \\
\hline
\end{tabular}

place during the "tactical concessions" phase. Only if and when the domestic opposition fully mobilizes and supplements the pressure "from above" by pressure "from below" can the transition toward prescriptive status and sustained improvement of human rights conditions be achieved.

Second, we claim that the dominant modes of social interaction also change during different phases of the model. In the initial phases, most of the actions can be easily explained by instrumental reasons. Norm-violating governments, for example, want to remain in power, (re-)gain foreign aid etc., and, therefore, deny the validity of norms and/or make tactical concessions. Toward later stages of the socialization process, argumentative rationality increasingly takes over. Governments under transnational and domestic pressure for change are increasingly forced to argue with the opposition and to enter into a true dialogue (cf., for example, Black 1999 on South Africa). Once human rights norms have gained prescriptive status in the "target state," institutionalization and habitualization processes become the dominant mode of social action.

In conclusion, we need to address one more point: our spiral model does not assume evolutionary progress toward norm implementation, but claims to explain variation and lack of progress. What are the conditions under which the spiral model can be interrupted resulting in a stabilization of the status quo of norm violation? First, as discussed above, regimes might return to oppression after some tactical concessions in phase 3 when international pressures have decreased. Moreover, rulers of the target state might not care about transnational and international opposition to their behavior and simply increase repression in order to effectively prevent the emergence of local NGO networks. The less dependent national governments are on the outside world - in terms of both material and ideational resources - the less they should be concerned. In other words, oppressive rulers have some leeway during the initial stages of the spiral model when both the domestic opposition and the domestic-transnational linkages are rather weak. Once tactical concessions have led to a fully mobilized domestic opposition with transnational links, however, there is not much which oppressive rulers can do to fight off the pressure and to continue the violation of human rights. The second critical moment comes in phase 4 when 
human rights have gained prescriptive status on the national level, but actual behavior still lags behind. In this instance, the strength of the domestic opposition and the local NGO network is no longer a primary problem, but the difficulty of keeping up the international pressure is. This is especially acute where a country avoids human rights violations of high-profile opposition leaders, but continues endemic and low-level human rights abuses, such as routine use of torture for common criminals. The co-existence of relatively high levels of political participation and competition with human rights abuses can erode international attention. Cases such as Mexico, Brazil, and Turkey come to mind.

\section{Alternative explanations}

There are two major alternative explanations to our model of norm internalization induced by principled-issue networks operating on the domestic and transnational levels. The first alternative account is compatible with (neo-)realist or (neo-)Marxist approaches according to which principled ideas matter if they are backed by superior economic and/or military power, or if they conform to materially defined actors' interests relating to their international environment. Stephen Krasner has argued, for example, that human rights are promoted and implemented resulting from the interests, pressures and capabilities of great powers (Krasner 1993). This approach would need to explain, however, why great powers change their positions on which norms they choose to back. For example, why did the United States move from a position, before 1973, in which human rights were seen as an inappropriate part of foreign policy to a position in which human rights formed an important pillar of US policy by the 1990s?

With regard to Third World countries, one could also assume that human rights conditions improve resulting from pressures by the World Bank and/or donor countries employing "good governance" criteria. State actors in Third World countries might enact liberalizing measures in order to get financial and economic development aid from the West or from multilateral institutions such as the World Bank and the International Monetary Fund (IMF). These approaches would need to explain why these "good governance" criteria were added relatively recently to conditionality requirements of multilateral institutions, often over the resistance of more technical staff who felt they were unrelated to the core tasks of the institutions. Moreover, exogenous shock waves in international politics such as the end of the Cold War leading to changes in the international distribution of power might also improve human rights conditions through some sort of snowball effect (Huntington 1991; Kitschelt 1992).

This account is already included in our spiral model to the extent that some individuals in international financial institutions and in the governments of Western great powers form part of the transnational human rights advocacy network. But this book investigates and problematizes the preferences of these actors rather than simply assuming them. If Western donors start coordinating foreign aid or the World Bank attaches "good governance" criteria to their structural adjustment programs, these changes in policies might well result from network and INGO activities. Insofar as the spiral model does not assume the absence of coercive power in the process of inducing domestic change in the human rights area, it accommodates 
this explanation. Only if it can be shown empirically that pressures generated by great powers and/or international financial institutions are the most significant factors in the domestic-transnational-international link to induce sustainable human rights improvements, or if any changes in state human rights practices end as soon as external material pressures end, would this constitute a challenge to our model.

The second alternative proposition to our model also denies significant independent causal value to principled ideas, but explains it with the "primacy of domestic politics" (Kehr 1970) in the sense of changes in the economic structure of the target state. This alternative account condenses insights from modernization theories (Przeworski and Limongi 1997; for a thorough critique see Schmitz 1997). These arguments can be divided into the economic perspective claiming a direct correlation between economic growth and democratization, on the one hand, and the social system approach emphasizing inter alia urbanization, literacy and the role of mass media, on the other (Brachet-Márquez 1992: 96). Emerging new social strata (middle classes) are expected to become agents of change (M. Robinson 1995: 73). The creation of economic interests not linked with state activities necessitates the implementation of rational and impartial political institutions which secure expanding market exchanges through the rule of law. "Therefore, this hypothesis asserts that countries with the fastest growing middle class will experience the greatest political liberalization" (Wilson 1994: 266).

There is no question that those who become active and mobilize in domestic human rights networks and in NGOs overwhelmingly belong to urbanized middle classes. The issue is not the social and class origins of NGO activists, but whether changes in socio-economic conditions lead to political mobilization processes. If this were indeed the case, we would not have to bother about complicated processes of linking domestic actors with transnational INGOs and international institutions to explain sustainable human rights improvements. But approaches stemming from modernization theory must confront the dilemma that only two decades ago the political development literature made exactly the opposite argument - that the processes and necessities of economic development for more advanced developing states required an authoritarian form of government (Collier 1979; O'Donnell 1973). The bureaucratic authoritarian model was developed to try to explain the puzzle of why the most developed states in Latin America with the largest middle classes - Brazil, Argentina, Chile, and Uruguay - in the 1960s and 1970s experienced the most repressive forms of authoritarian rule in their history. The idea of some automatic correlation between market economy and democracy, or between a particular stage of economic development and a particular regime type needs to confront this kind of confounding evidence. The empirical chapters will each assess the alternative accounts.

\section{Conclusions}

This book investigates the conditions under which international human rights ideas and norms contribute to domestic political change. Norms influence political change through a socialization process that combines instrumental interests, material pressures, argumentation, persuasion, institutionalization, and habitualization. We attempt to explore the particular mix of material pressures with communicative processes. 
But even if material leverage is available, the target country must be sensitive to the pressures, and it is often the communicative dimension that heightens the sensitivity to pressures. As the case of economic sanctions against Haiti in 1993 and 1994 and Guatemala in the 1970s made clear, some governments can resist pressures successfully for long periods. Countries most sensitive to pressure are not those that are economically weakest, but those that care about their international image. Linking human rights practices to money, trade, or prestige is not a sufficient condition for effectiveness. Haiti's military rulers chose to hang on to power in the face of universal moral censure and economic collapse. Only the threat of military invasion led to a last-minute agreement to step down from power.

It is this dimension that is most difficult to capture in research. Scholars have long recognized that even repressive regimes depend on a combination of coercion and consent to stay in power, and that consensus is the basis from which the state derives its legitimation. But in addition to securing domestic consent and legitimacy, states also seek international legitimacy. This book suggests that some states are keenly aware of the approval of other states. Through processes of persuasion and socialization, states communicate the emergent norms of international society, create ingroups and outgroups as normative communities, and may convince norm-violating states that the benefits of membership in the in-group outweigh the costs. The cases where network campaigns have been most successful are those countries that have internalized the discourse of liberalism to a greater degree.

Our book has wider implications for the literature on democratization, which has tended to neglect the international dimension of democratization, despite the "wave-like" quality of global trends in democratization (Huntington 1991) suggesting that some international factors are at work. We do not argue that international factors are the only factors responsible for democratization, but rather that international norms and networks may provide key support for democratization processes at crucial stages, and that they have been a necessary, though far from sufficient, condition for the most recent wave of democratization. We will explore this theme further in the concluding chapter.

\section{Notes}

We thank the participants of the transatlantic workshops and the 1997 ISA panel for their helpful and insightful comments. We are particularly grateful for critical remarks by Michael Barnett, Sieglinde Gränzer, Anja Jetschke, Audie Klotz, Stephen Ropp, Philippe Schmitter, and Hans Peter Schmitz.

1 The main general international treaties that embody the rights in the Universal Declaration of Human Rights are the International Covenant on Civil and Political Rights and the International Covenant on Economic, Social, and Cultural Rights. Both entered into force in 1976. There are also specific international treaties elaborating certain rights with the UDHR such as the Convention Against Torture and Other Cruel, Inhuman or Degrading Treatment or Punishment, which entered into force in 1987.

2 There are two exceptions in this book. Thomas 1999 on Eastern Europe concentrates on freedom of expression and freedom to assemble rights, while Black 1999 on South Africa focuses on racial equality.

3 Audie Klotz refers to "normative power" in this context. 


\section{References}

Adler, Emanuel. 1987. The Power of Ideology: The Quest for Technological Autonomy in Argentina and Brazil. Berkeley CA: University of California Press.

Adler, Emanuel. 1991. Cognitive Evolution: A Dynamic Approach for the Study of International Relations and their Progress. In Progress in Postwar International Relations, edited by E. Adler. New York: Columbia University Press, 43-87.

Adler, Emanuel. 1997. Seizing the Middle Ground: Constructivism in World Politics. European Journal of International Relations 3 (3): 319-363.

Barnes, James, Marshall Carter, and Max Skidmore. 1980. The World of Politics. New York: St. Martin's Press.

Black, David. 1999. The Long and Winding Road: International Norms and Domestic Political Change in South Africa. In The Power of Human Rights, edited by T. Risse, S. Ropp, and K. Sikkink. Cambridge, UK: Cambridge University Press, 78-108.

Brachet-Márquez, Viviane. 1992. Explaining Socio-political Change in Latin America: The Case of Mexico. Latin American Research Review 27 (3): 91-122.

Brysk, Alison. 1993. From Above and Below: Social Movements, the International System, and Human Rights in Argentina. Comparative Political Studies 26 (3): 259-285.

Bull, Hedley. 1977. The Anarchical Society. A Study of Order in World Politics. New York: Columbia University Press.

Chaiken, Shelly, Wendy Wood, and Alice H. Eagly. 1996. Principles of Persuasion. In Social Psychology: Handbook of Basic Principles, edited by E. T. Higgins and A. Kruglanski. New York: Guilford Press, 702-742.

Checkel, Jeffrey T. 1998. The Constructivist Turn in International Relations Theory. World Politics 50 (2): 324-348.

Collier, David. ed. 1979. The New Authoritarianism in Latin America. Princeton: Princeton University Press.

Crawford, Neta C. 1993. Decolonization as an International Norm: The Evolution of Practices, Arguments, and Beliefs. In Emerging Norms of Justified Intervention, edited by L. Reed and C. Kaysen. Cambridge MA: American Academy of Arts and Sciences.

Dawson, Richard E., and Kenneth Prewitt. 1969. Political Socialization. Boston: Little, Brown and Co.

Donnelly, Jack. 1991. Progress in Human Rights. In Progress in Postwar International Relations, edited by E. Adler. New York: Columbia University Press, 312-358.

Eagly, Alice, and Shelly Chaiken. 1993. The Psychology of Attitudes. Fort Worth TX: Harcourt Brace Jovanovich.

Evans, Peter B., Harold K. Jacobson, and Robert D. Putnam. eds. 1993. Double-Edged Diplomacy: International Bargaining and Domestic Politics. Berkeley CA: University of California Press.

Fearon, James D. 1997. What Is Identity (As We Now Use the Word)? draft manuscript, Stanford University.

Finnemore, Martha. 1993. International Organization as Teachers of Norms: The United Nations Educational, Scientific, and Cultural Organization and Science Policy. International Organization 47 (4): 565-597.

Finnemore, Martha. 1996a. National Interests in International Society. Ithaca: Cornell University Press.

Finnemore, Martha, and Kathryn Sikkink. 1998. International Norm Dynamics and Political Change. International Organization 52(4): 887-917. 
Forsythe, David P. 1991. The Internationalization of Human Rights. Lexington, Mass: Lexington Books.

Franck, Thomas M. 1990. The Power of Legitimacy Among Nations. New York/Oxford. Goldstein, Judith, and Robert O. Keohane. eds. 1993b. Ideas and Foreign Policy: Beliefs, Institutions and Political Change. Ithaca, N.Y.: Cornel University Press.

Gränzer, Sieglinde. 1999. Changing Discourse: Transnational Advocacy Networks in Tunisia and Morocco. In The Power of Human Rights, edited by T. Risse, S. Ropp, and K. Sikkink. Cambridge, UK: Cambridge University Press, 109-133.

Habermas, Jürgen. 1981. Theorie des kommunikativen Handelns. 2 vols. Frankfurt/M.: Suhrkamp.

Habermas, Jürgen. 1992. Faktizität und Geltung. Beiträge zur Diskurstheorie des Rechts und des demokratischen Rechtsstaats. Frankfurt/M.: Suhrkamp.

Habermas, Jürgen. 1995b. Vorstudien und Ergänzungen zur Theorie des kommunikativen Handelns. Frankfurt/M.: Suhrkamp.

Hall, Peter A., and Rosemary C. R. Taylor. 1996. Political Science and the Three New Institutionalisms. Political Studies XLIV, 952-973.

Humphrey, John P. 1984. Human Rights and the United Nations: A Great Adventure. Dobbs Ferry, NY: Transnational Publishers.

Huntington, Samuel P. 1991. The Third Wave. Democratization in the Late Twentieth Century. Norman: University of Oklahoma Press.

Ikenberry, John G., and Charles A. Kupchan. 1990. Socialization and Hegemonic Power. International Organization 44 (3): 283-315.

Jepperson, Ronald L. 1991. Institutions, Institutional Effects and Institutionalism. In The New Institutionalism in Organizational Theory, edited by P. J. DiMaggio and W. P. Powell. Chicago: Chicago University Press, 143-163.

Jepperson, Ronald, Alexander Wendt, and Peter J. Katzenstein. 1996. Norms, Identity, and Culture in National Security. In The Culture of National Security: Norms and Identity in World Politics, edited by P. J. Katzenstein. New York: Columbia University Press, 33-75.

Jetschke, Anja. 1999. Linking the Unlinkable? International Norms and Nationalism in Indonesia and the Philippines. In The Power of Human Rights, edited by T. Risse, S. Ropp, and K. Sikkink. Cambridge, UK: Cambridge University Press, 134-171.

Katzenstein, Peter J. ed. 1996a. The Culture of National Security. Norms and Identity in World Politics. New York: Columbia University Press.

Katzenstein, Peter J. 1996b. Cultural Norms and National Security. Police and Military in Postwar Japan. Ithaca NY: Cornell University Press.

Kausikan, Bilahari. 1994. Human Rights: Asia's Different Standard. Media Asia 21 (1): 45-51.

Keck, Margret, and Kathryn Sikkink. 1998. Activists Beyond Borders. Transnational Advocacy Networks in International Politics. Ithaca NY: Cornell University Press.

Kehr, Eckart. 1970. Der Primat der Innenpolitik. Berlin: de Gruyter.

Kitschelt, Herbert. 1992. Political Regime Change: Structure and Process-Driven Explanations? American Political Science Review 86 (4): 1028-1034.

Klotz, Audie. 1995. Norms in International Relations. The Struggle against Apartheid. Ithaca, NY: Cornell University Press.

Kowert, Paul, and Jeffrey Legro. 1996. Norms, Identity, and Their Limits: A Theoretical Reprise. In The Culture of National Security: Norms and Identity in World Politics, edited by P. J. Katzenstein. New York: Colombia University Press, 451-497.

Kratochwil, Friedrich. 1989. Rules, Norms, and Decisions. Cambridge: Cambridge University Press. 
March, James G., and Johan P. Olsen. 1989. Rediscovering Institutions. New York: The Free Press.

Morrow, James D. 1994. Modeling the Forms of International Cooperation: Distribution versus Information. International Organization 48 (3): 387-423.

Müller, Harald. 1993. The Internalization of Principles, Norms, and Rules by Governments: The Case of Security Regimes. In Regime Theory and International Relations, edited by V. Rittberger. Oxford: Clarendon Press, 361-388.

Müller, Harald. 1994. Internationale Beziehungen als kommunikatives Handeln. Zur Kritik der utilitaristischen Handlungstheorien. Zeitschrift für Internationale Beziehungen 1 (1): $15-44$.

Odell, John. 1982. U.S. International Monetary Policy: Markets, Power, and Ideas as Sources of Change. Princeton NJ: Princeton University Press.

O’Donnell, Guillermo. 1973. Modernization and Bureaucratic Authoritarianism: Studies in South American Politics. Berkeley, California: Institute of International Studies, University of California.

O’Donnell, Guillermo, and Philippe C. Schmitter. 1986. Transitions from Authoritarian Rule. Tentative Conclusions about Uncertain Democracies. Baltimore: Johns Hopkins University Press.

Osiel, Mark. 1986. The Making of Human Rights Policy in Argentina: The Impact of Ideas and Interests on a Legal Conflict. Journal of Latin American Studies 18: 135-178.

Powell, Walter W., and Paul J. DiMaggio. eds. 1991. The New Institutionalism in Organizational Analysis. Chicago - London: University of Chicago Press.

Prittwitz, Volker von. ed. 1996. Verhandeln und Argumentieren. Dialog, Interessen und Macht in der Umweltpolitik. Opladen: Westdeutscher Verlag.

Przeworski, Adam. 1986. Some Problems in the Study of the Transition to Democracy. In Transition from Authoritarian Rule. Prospects for Democracy, edited by G. O'Donnell, P. C. Schmitter and L. Whitehead. Baltimore: Johns Hopkins University Press, 47-63.

Przeworski, Adam, and Fernando Limongi. 1997. Modernization: Theories and Facts. World Politics 49 (2): 155-183.

Risse-Kappen, Thomas. 1994. Ideas Do Not Float Freely: Transnational Coalitions, Domestic Structures, and the End of the Cold War. International Organization 48 (2): 185-214.

Risse-Kappen, Thomas. ed. 1995. Bringing Transnational Relations Back In: Non-State Actors, Domestic Structures, and International Institutions. Cambridge: Cambridge University Press.

Risse, Thomas. 1997. Let's Talk! Insights from the German Debate on Communicative Behavior and International Relations. Paper presented at Annual Convention of the American Political Science Association, Aug. 27-31, at Washington DC.

Risse, Thomas, and Stephen Ropp. 1999. International Human Rights Norms and Domestic Change: Conclusions. In The Power of Human Rights, edited by T. Risse, S. Ropp, and K. Sikkink. Cambridge, UK: Cambridge University Press, 234-278.

Rittberger, Volker. 1993. Research on International Regimes in Germany: The Adaptive Internalization of an American Social Science Concept. In Regime Theory and International Relations, edited by V. Rittberger. Oxford: Clarendon Press, 3-22.

Robinson, Mark. 1995. Strengthening Civil Society in Africa: The Role of Foreign Political Aid. IDS-Bulletin 26 (2): 70-80.

Ropp, Stephen, and Kathryn Sikkink. 1999. International Norms and Domestic Politics in Chile and Guatemala. In The Power of Human Rights, edited by T. Risse, S. Ropp, and K. Sikkink. Cambridge, UK: Cambridge University Press, 172-204. 
Schaber, Thomas, and Cornelia Ulbert. 1994. Reflexivität in den Internationalen Beziehungen. Literaturbericht zum Beitrag kognitiver, reflexiver und interpretativer Ansätze zur dritten Theoriedebatte. Zeitschrift für Internationale Beziehungen 1 (1): 139-169.

Schimmelfennig, Frank. 1994. Internationale Sozialisation neuer Staaten. Heuristische Überlegungen zu einem Forschungsdesiderat. Zeitschrift für Internationale Beziehungen 1 (2): 335-355.

Schimmelfennig, Frank. 1995. Debatten zwischen Staaten: Eine Argumentationstheorie internationaler Systemkonflikte. Opladen: Leske \& Budrich.

Schimmelfennig, Frank. 1997. Rhetorisches Handeln in der internationalen Politik. Zeitschrift für internationale Beziehungen 4 (2): 219-254.

Schmitz, Hans-Peter. 1997. Why Structural and Agency-based Approaches Fail to Explain Democratisation - Cultural and Institutional Aspects of Political Change in Kenya and Uganda. Paper presented at 25th ECPR Joint Sessions of Workshops, 27th February 1997, at Bern.

Schmitz, Hans-Peter. 1999. Transnational Activism and Political Change in Kenya and Uganda. In The Power of Human Rights, edited by T. Risse, S. Ropp, and K. Sikkink. Cambridge, UK: Cambridge University Press, 39-77.

Schneider, Gerald. 1994. Rational Choice und kommunikatives Handeln. Eine Replik auf Harald Müller. Zeitschrift für Internationale Beziehungen 1 (2): 357-366.

Sikkink, Kathryn. 1991. Ideas and Institutions: Developmentalism in Brazil and Argentina. Ithaca NY: Cornell University Press.

Sikkink, Kathryn. 1993a. Human Rights, Principled Issue Networks, and Sovereignty in Latin America. International Organization 47 (3): 411-441.

Sikkink, Kathryn. 1993b. The Power of Principled Ideas: Human Rights Policies in the United States and Western Europe. In Ideas and Foreign Policy, edited by J. Goldstein and R.O. Keohane. Ithaca: Cornell University Press, 139-170.

Slaughter, Ann-Marie. 1995. International Law in a World of Liberal States. The European Journal of International Law 6: 139-170.

Steinmo, Sven, Kathleen Thelen, and Frank Longstreth. eds. 1992. Structuring Politics. Historical Institutionalism in Comparative Analysis. Cambridge - New York: Cambridge University Press.

Thomas, Daniel. 1999. The Helsinki Accords and Political Change in Eastern Europe. In The Power of Human Rights, edited by T. Risse, S. Ropp, and K. Sikkink. Cambridge, UK: Cambridge University Press, 205-233.

Thomson, Janice. 1993. Norms in International Relations: A Conceptual Analysis. International Journal of Group Tensions 23 (2): 67-83.

Vaky, Viron P., and Heraldo Munoz. 1993. The Future of the Organization of American States. New York: Twentieth Century Fund Press.

Wendt, Alexander. 1992. Anarchy is what states make of it: The social construction of power politics. International Organization 88 (2): 384-396.

Wendt, Alexander. 1995. Constructing International Politics. International Security 20 (1): $71-81$.

Wilson, Ernest J. III. 1994. Creating a Research Agenda for the Study of Political Change in Africa. In Economic Change and Political Liberalization in Sub-Saharan Africa, edited by J. A. Widner. Baltimore: Johns Hopkins University Press, 253-271.

Wurfel, David. 1990. Transition to Political Democracy in the Philippines: 1978-88. In Democratic Transition and Consolidation in Southern Europe, Latin America, and Southeast Asia, edited by D. Ethier. London: McMillan, 110-135.

Yee, Albert S. 1996. The Causal Effects of Ideas on Policies. International Organization 50 (1): 69-108. 


\title{
6 Conceptualizing the domestic impact of Europe (2003)
}

\author{
Tanja A. Börzel and Thomas Risse
}

\section{Introduction}

For decades, European studies have been mostly concerned with explaining European integration and Europeanization processes themselves. Debates between neofunctionalism, (liberal) intergovernmentalism, and the 'multi-level governance' perspective centred around the question of how to account for the emerging European polity. This research, therefore, adopted a 'bottom-up' perspective, in which the dynamics and the outcome of the European institution-building process are the main dependent variable (see e.g. Puchala 1972; Wallace and Wallace 1996; Moravcsik 1998; Héritier 1999). More recently, however, an emerging literature focusses on the impact of European integration and Europeanization on domestic political and social processes of the member states and beyond. This move toward studying 'top-down' processes is desperately needed in order to fully capture how Europe and the European Union (EU) matter. It fits nicely with recent developments in international studies in general, which increasingly study the domestic effects of international institutions and norms. As far as the European Union is concerned, we will get a more comprehensive picture if we study the feedback processes among and between the various levels of European, national, and subnational governance.

While we are aware of these various feedback loops, this paper self-consciously restricts itself to the 'top-down' perspective. How do European integration and Europeanization more generally affect domestic policies, politics, and polities of the member states and beyond? To answer this question, we use the emerging literature on the topic to develop some preliminary hypotheses on the conditions under which we would expect domestic change in response to Europeanization. We seek to simplify various propositions made in the literature and to point out where further research is needed. Our arguments can be summarized as follows.

Whether we study policies, politics, or polities, there are two conditions for expecting domestic changes in response to Europeanization. First, Europeanization must be 'inconvenient', that is, there must be some degree of 'misfit' or incompatibility between European-level processes, policies, and institutions, on the one hand, and domestic-level processes, policies, and institutions, on the other. This degree of fit or misfit leads to adaptational pressures, which constitute a necessary 
but not sufficient condition for expecting domestic change. The second condition is that various facilitating factors - be it actors, be it institutions - respond to the adaptational pressures, thus inducing the change.

One can conceptualize the adaptational processes in response to Europeanization in two ways, which in turn lead to different emphases concerning these facilitating factors. Here, we refer to two variants of the 'new institutionalism' in political science, rational choice institutionalism, on the one hand, and sociological (or constructivist) institutionalism, on the other (see March and Olsen 1989, 1998; Hall and Taylor 1996; Risse 2002). From a rationalist perspective following the 'logic of consequentialism', the misfit between European and domestic processes, policies, and institutions provides societal and/or political actors with new opportunities and constraints to pursue their interests. Whether such changes in the political opportunity structure lead to a domestic redistribution of power, depends on the capacity of actors to exploit these opportunities and avoid the constraints. Two mediating factors with opposite effects influence these capacities:

1 Multiple veto points in a country's institutional structure can effectively empower actors with diverse interests to resist adaptational pressures emanating from Europeanization.

2 Formal institutions might exist providing actors with material and ideational resources to exploit new opportunities, leading to an increased likelihood of change.

The logic of rationalist institutionalism suggests that Europeanization leads to domestic change through a differential empowerment of actors resulting from a redistribution of resources at the domestic level.

In contrast, a sociological or constructivist perspective emphasizes a 'logic of appropriateness' (March and Olsen 1998) and processes of persuasion. European policies, norms, and the collective understandings attached to them exert adaptational pressures on domestic-level processes, because they do not resonate well with domestic norms and collective understandings. Two mediating factors influence the degree to which such misfit results in the internalization of new norms and the development of new identities:

1 'Change agents' or norm entrepreneurs mobilize in the domestic context and persuade others to redefine their interests and identities.

2 A political culture and other informal institutions exist which are conducive to consensus-building and cost-sharing.

Sociological institutionalism suggests that Europeanization leads to domestic change through a socialization and collective learning process, resulting in norm internalization and the development of new identities.

The two logics of change are not mutually exclusive. They often occur simultaneously or characterize different phases in a process, of adaptational change. 
Our paper concludes with some suggestions as to how to link the two mechanisms and to specify conditions under which each logic dominates.

The paper proceeds in the following steps. First, we specify what we mean by 'domestic impact' of Europeanization. Second, we develop the concept of 'misfit' and distinguish between differential empowerment and socialization as the two theoretical logics of domestic adaptation to Europe. Third, we discuss the degree and direction of domestic changes to be expected by the two logics and causal mechanisms, focusing on the question of whether we are likely to see convergence or divergence. We conclude with propositions on how differential empowerment and socialization relate to each other.

\section{Europeanization and the 'goodness of fit'}

\section{Europeanization and the dimensions of domestic change}

Scholars who adopt a 'top-down' perspective have used the concept of Europeanization in different ways, which gave rise to considerable confusion in the literature (for critical discussions see Radaelli 2000; Eising forthcoming). For pragmatic reasons, and since we are interested in understanding both the processes by which European integration affects domestic change and the outcome of this change, we follow the proposal by Risse, Cowles, and Caporaso. They conceptualize Europeanization as the 'emergence and the development at the European level of distinct structures of governance, that is, of political, legal, and social institutions associated with political problem solving that formalizes interactions among the actors, and of policy networks specializing in the creation of authoritative European rules' (Risse et al. 2001: 3). Europeanization is understood as a process of institution-building at the European level in order to explore how this Europeanization process impacts upon the member states. We use the distinction between policies, politics, and polity to identify three dimensions along which the domestic impact of Europeanization can be analysed and processes of domestic change can be traced (see Figure 6.1).

Whether we focus on policies, politics, or polity, the general proposition that Europeanization affects the member states is no longer controversial. We can also see an emerging consensus that Europeanization has a differential impact on domestic policies, politics, or polities (see Kohler-Koch 1998a; Kohler-Koch and Eising 1999; Cowles et al. 2001; Héritier et al. 2001). Only few authors expect increasing convergence in domestic policies and institutions in response to Europeanization (e.g. Knill and Lehnkuhl 1999; Schneider 2001). The issue is no longer whether Europe matters but how it matters, to what degree, in what direction, at what pace, and at what point of time. In other words, the more recent literature on the domestic impact of Europe has focused on identifying the causal mechanisms through which Europeanization can affect the member states. Most studies draw on several mechanisms to explain the domestic change they observe (see e.g. Héritier et al. 1996; Hooghe 1996; Haverland 1999; Knill and Lehnkuhl 1999; Börzel 2002; Héritier et al. 2001). We argue below that 


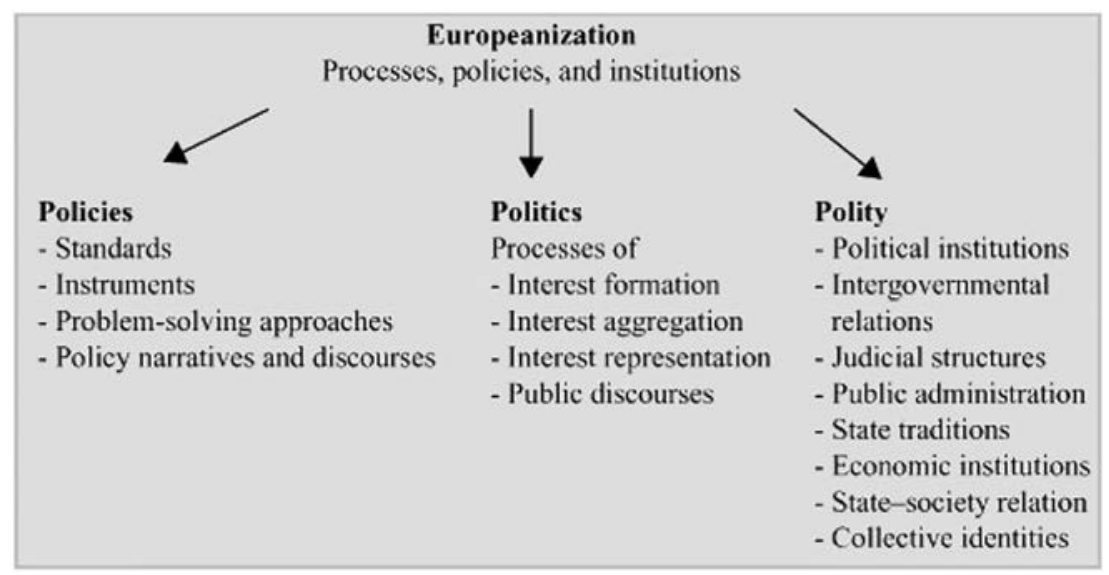

Figure 6.1 The domestic effect of Europeanization

the different causal mechanisms can be collapsed into two logics of domestic change. In the following, and drawing on Cowles et al. (2001) and Börzel (1999), we develop a conceptual framework that allows us to integrate the various mechanisms.

\section{Misfit as a necessary, but not sufficient condition of domestic change}

While focusing on different causal mechanisms, most studies share the proposition that Europeanization is only likely to result in domestic change if it is 'inconvenient'. There must be some 'misfit' (Duina 1999) or 'mismatch' (Héritier et al. 1996) between European and domestic policies, processes, and institutions. The 'goodness of fit' (Risse et al. 2001) between the European and the domestic level determines the degree of pressure for adaptation generated by Europeanization on the member states: The lower the compatibility between European and domestic processes, policies, and institutions, the higher the adaptational pressure.

This proposition is rather trivial, since there is no need for domestic changes, if Europeanization fits perfectly well with domestic ways of doing things. If European environmental regulations, for example, match with domestic policies, member states do not need to change their legal provisions. In general, if European norms, rules, and the collective understandings attached to them are largely compatible with those at the domestic level, they do not give rise to problems of compliance or effective implementation more broadly speaking. Nor do they provide new opportunities and constraints to domestic actors that would lead to a redistribution of resources at the domestic level, empowering some actors while weakening others. European policy frames which resonate with domestic policy 


\section{4}

ideas and discourses are unlikely to trigger collective learning processes which could change actors' interests and identities. The European system of judicial review only empowers national courts and citizens in member states whose legal systems are alien to judicial review (Conant 2001). The Single Market, finally, only provides exit options for firms which used to operate within closed and protected markets. Those firms which already enjoyed open competition across borders had little to gain from the Single Market provisions. In brief, misfit and resulting adaptational pressures constitute the starting point for any causal mechanism discussed in the literature.

Ultimately, adaptational pressures are generated by the fact that the emerging European polity encompasses structures of authoritative decision making which might clash with national structures of policy making, and that the EU member states have no exit option given that EU law constitutes the law of the land. This is a major difference to other international institutions which are simply based on voluntary intergovernmental arrangements. We distinguish two types of misfits by which Europeanization exerts adaptational pressure on the member states.

First, European policies might lead to a policy misfit between European rules and regulations, on the one hand, and domestic policies, on the other. Policy misfits essentially equal compliance problems. European policies can challenge national policy goals, regulatory standards, the instruments or techniques used to achieve policy goals, and/or the underlying problem-solving approach (Héritier et al. 1996; Börzel 2000). Such policy misfit can also exert adaptational pressure on underlying institutions (Caporaso and Jupille 2001; Sbragia 2001; Schneider 2001). As policy misfits produce adaptational costs at the domestic level, member states strive to 'upload' their policies to the European level in order to reduce their compliance problems. Regulatory contest results from these efforts, particularly among the powerful member states. Yet, since it is unlikely that the same group of member states succeeds most of the time in uploading its preferences unto the European level, this contest gives rise to a regulatory 'patchwork' of EU rules and regulations following a very diverse pattern of policies, problem-solving approaches, and administrative styles (Héritier 1996). This regulatory patchwork, however, produces significant degrees of misfit for all those member states who did not succeed in uploading their preferences to the European level and, thus, are required to change their policies and even institutional structures in response to Europeanization. As a result, all member states - including the 'big three', Great Britain, France, and Germany face significant, albeit different degrees of adaptational pressures when they have to download European policies (Börzel 2002; Cowles et al. 2001).

This is an important finding which challenges several dominant approaches in the study of European integration. Liberal intergovernmentalism, for example, implies that bargains are struck among the powerful member states at the level of lowest common denominator (Moravcsik 1993, 1998). It follows that Britain, France, and Germany are unlikely to face significant adaptational pressures 
from Europeanization. This proposition is thoroughly refuted by the available evidence on Europeanization effects (e.g. Duina 1999; Knill and Lenschow 2000; Cowles et al. 2001; Héritier et al. 2001). From a different theoretical angle, sociological institutionalism would expect that the more institutional structures at the European and domestic levels look alike (structural isomorphism), the less adaptational pressures member states should face (DiMaggio and Powell 1991; Olsen 1995). German domestic structures, for example, show many similarities with the emerging European polity (multilevel system; decentralization; federalism, etc.; see Bulmer 1997; Katzenstein 1997). Yet, Germany has experienced as many misfits with Europeanization processes as other member states (Cowles and Risse 2001).

This latter argument points to a second type of misfit and adaptational pressure which we need to distinguish from policy misfit. Europeanization can cause institutional misfit, challenging domestic rules and procedures and the collective understandings attached to them. European rules and procedures, for example, which give national governments privileged decision powers vis-à-vis other domestic actors, challenge the territorial institutions of highly decentralized member states which grant their regions autonomous decision powers (Börzel 2002). The accessibility of the European Commission for societal interests challenges the statist business-government relations in France and the corporatist system of interest mediation in Germany (Conant 2001; Cowles 2001). Europeanization might even threaten deeply collective understandings of national identity as it touches upon constitutive norms such as state sovereignty (Checkel 2001; Risse 2001). Institutional misfit is less direct than policy misfit. Although it can result in substantial adaptational pressure, its effect is more likely to be long term and incremental.

Policy or institutional misfit, however, is only the necessary condition for domestic change. Whether misfits produce a substantial effect at the domestic level depends on the presence of various factors facilitating adaptation and serving as catalysts for domestic change. Only if and when these intervening factors are present can we expect a transformation of policies, politics, or polities in the member states.

\section{Facilitating factors as sufficient conditions for domestic change}

The domestic effect of Europeanization can be conceptualized as a process of change at the domestic level in which the member states adapt their processes, policies, and institutions to new practices, norms, rules, and procedures that emanate from the emerging European system of governance (Olsen 1996, 1997). Rationalist and sociological institutionalisms identify different mechanisms of institutional change, which can be equally applied to the change of policies and politics. ${ }^{1}$ The two logics of change stress different factors facilitating domestic adaptation in response to Europeanization. 


\section{Domestic change as a process of redistribution of resources}

Rationalist institutionalism embodies a 'logic of consequentialism' (March and Olsen 1998), which treats actors as rational, goal-oriented, and purposeful. Actors engage in strategic interactions using their resources to maximize their utilities on the basis of given, fixed, and ordered preferences. They follow an instrumental rationality by weighing the costs and benefits of different strategy options taking into account the (anticipated) behaviour of other actors. From this perspective, Europeanization is largely conceived as an emerging political opportunity structure which offers some actors additional resources to exert influence, while severely constraining the ability of others to pursue their goals. Liberal intergovernmentalists have suggested that European opportunities and constraints strengthen the action capacities of national executives enhancing their autonomy vis-à-vis other domestic actors (Moravcsik 1994). Neofunctionalists come to the opposite conclusion that Europeanization provides societal and subnational actors with new resources, since the European Union enables them to circumvent or bypass the national executives (Marks 1993; Sandholtz 1996). Proponents of multilevel governance approaches in turn argue that Europeanization does not empower one particular group of actors over the others but increases their mutual interdependence, giving rise to more cooperative forms of governance (Grande 1996; Kohler-Koch 1996; Rhodes 1997). The three resource dependency approaches all predict convergence, but around very different outcomes.

Neither can account for the differential impact of Europeanization observed at the domestic level. The evidence suggests that Europeanization does not systematically favour one particular group of domestic actors over others. For instance, while French firms gained more autonomy vis-à-vis their national government by circumventing it (Schmidt 1996), Spanish firms did not (Aguilar Fernandez 1992). The Italian regions have been far less able to ascertain their domestic power than their Austrian or British counterparts (Rhodes 1996; Desideri and Santantonio 1997; Morass 1997). While the Spanish territorial structure is undergoing profound change in response to adaptational pressure, German federalism has been reinforced by Europeanization. While the equal pay and equal treatment directives empowered womens' groups in Great Britain, they had virtually no effect in France (Caporaso and Jupille 2001).

We argue that Europeanization only leads to a redistribution of resources and differential empowerment at the domestic level if (1) there is significant misfit providing domestic actors with additional opportunities and constraints (necessary condition), and (2) domestic actors have the capacities to exploit such new opportunities and avoid constraints, respectively (sufficient condition). Two mediating factors influence these action capacities (cf. Risse et al. 2001: 9-10).

1 Multiple veto points in a country's institutional structure can empower actors with diverse interests to avoid constraints emanating from Europeanization pressures and, thus, effectively inhibit domestic adaptation (Tsebelis 1995; 
Haverland 2000; Héritier et al. 2001). The more power is dispersed across the political system, and the more actors have a say in political decision making, the more difficult it is to foster the domestic consensus or 'winning coalition' necessary to introduce changes in response to Europeanization pressures. A large number of institutional or factual veto players impinges on the capacity of domestic actors to achieve policy changes and limits their empowerment. The European liberalization of the transport sector, for example, empowered societal and political actors in highly regulated member states, which had been unsuccessfully pushing for privatization and deregulation. But while the German reform coalition was able to exploit European policies to overcome domestic opposition to liberalization, Italian trade unions and sectoral associations successfully blocked any reform attempt (Héritier et al. 2001; Héritier 2001; Kerwer and Teutsch 2001). The variation can be explained if we take into account the large number of veto players in the Italian system.

2 Existing formal institutions can provide actors with material and ideational resources necessary to exploit European opportunities and to promote domestic adaptation. The European political opportunity structure may offer domestic actors additional resources. But many are unable to exploit them when they lack the necessary action capacity. Direct relations with European decision-makers provide regions with the opportunity to circumvent their central government in European policy making. But many regions do not have sufficient resources (manpower, money, expertise) to be permanently present at the European level and to exploit the new opportunities. While Bavaria or Catalonia are strong enough to maintain regular relations with EU institutions, Estremadura or Bremen simply lack the action capacity to do this. Many regions then rely on their central governments to channel their interests into the European policy process (Jeffery 2000). In the United Kingdom, public agencies and related complementary institutions, the Equal Opportunities Commission in particular, provided womens' organizations with the means to use EU equal pay and equal treatment directives in furthering gender equality. In the absence of such an institution, French women were not able to overcome domestic resistance to implement the EU equal pay and equal treatment policies (Tesoka 1999; Caporaso and Jupille 2001).

In sum, and following a rationalist institutional logic, we can conceptualize the adaptational pressures or the degrees of misfit emanating from Europeanization as providing new opportunities for some actors and severely constraining other actors' freedom of manoeuvre. Whether actors can exploit these opportunities or circumvent the constraints depends on intervening factors such as the number of veto points in the political system, on the one hand, and the (in-) existence of supporting formal institutions, on the other. These two factors determine whether the new opportunities and constraints resulting from Europeanization in case of misfit translate into an effective redistribution of resources among actors and, thus, whether Europeanization does indeed lead to a differential empowerment of actors. 


\section{Domestic change as a process of socialization and learning}

Sociological institutionalism draws on the 'logic of appropriateness' (March and Olsen 1989, 1998) according to which actors are guided by collective understandings of what constitutes proper, that is, socially accepted behaviour in a given rule structure. These collective understandings and intersubjective meanings influence the ways in which actors define their goals and what they perceive as 'rational' action. Rather than maximizing their subjective desires, actors strive to fulfil social expectations. From this perspective, Europeanization is understood as the emergence of new rules, norms, practices, and structures of meaning to which member states are exposed and which they have to incorporate into their domestic practices and structures.

Sociological institutionalism offers two potential explanations for domestic change in response to Europeanization, one more structuralist, the other more agency-centred. The first account focuses on institutional isomorphism, suggesting that institutions which frequently interact, are exposed to each other, or are located in a similar environment develop similarities over time in formal organizational structures, principles of resource allocation, practices, meaning structures, and reform patterns (DiMaggio and Powell 1991; Meyer and Rowen 1991; Scott and Meyer 1994). Institutional isomorphism explains a process of homogenization of organizational structures over time. It ultimately rests on a form of structural determinism assuming that actors strive to match institutions to environmental changes. Rather than adapting to functional imperatives, organizations respond to changes in their normative and cognitive environment giving rise to institutional isomorphism. The conditions for isomorphism can vary. It appears to be most likely in environments with stable, formalized, and clear-cut organizational structures (Scott and Meyer 1994: 118). Provided that institutions are exposed to such an environment, they are expected to respond with similar changes in their institutional structure. This argument is faced with serious problems in explaining variation in institutional adaptation to a similar environment. It cannot account for the differential impact of Europe, since the causal mechanism identified should lead to structural convergence.

There is a second, more agency-centred version of sociological institutionalism which theorizes differences in the degree to which domestic norms and institutions change in response to international institutional arrangements. This version focuses on socialization processes by which actors learn to internalize new norms and rules in order to become members of (international) society in good standing' (Finnemore and Sikkink 1998; Checkel 1999a). Actors are socialized into new norms and rules of appropriateness through processes of arguing, persuasion, and social learning and to redefine their interests and identities accordingly. This perspective generates expectations about the differential impact of Europeanization, since 'misfit' constitutes the starting condition of a socialization process. While citizenship norms of the Council of Europe resonated well with traditional citizenship practices in France (ius solis), they directly contradicted the historical understandings of citizenship in Germany (ius sanguinis), thus creating a serious misfit (Checkel 2001). The idea of 
cooperative governance emulated by the European Commission fitted German cooperative federalism but challenged statist policy-making practices in Italy and Greece (Kohler-Koch 1998b). The more European norms, ideas, structures of meaning, or practices resonate (fit) with those at the domestic level, the more likely it is that they will be incorporated into existing domestic institutions (Olsen 1996: 272), and the less likely it is that the European norms will lead to domestic change. High cognitive or normative misfit as lack of resonance is equally unlikely to cause substantial domestic change since domestic actors and institutions will resist adaptation (see below). We argue in turn that high misfit may lead to processes of socialization and learning resulting in the internalization of new norms and the development of new identities, provided that (one of) two mediating factors are present:

1 'Change agents' or norm entrepreneurs mobilize at the domestic level. Norm entrepreneurs do not only pressure policy-makers to initiate change by increasing the costs of certain strategic options. Rather, they use moral arguments and strategic constructions in order to persuade actors to redefine their interests and identities, engaging them in processes of social learning. Persuasion and arguing are the mechanisms by which these norm entrepreneurs try to induce change (Risse 2000). There are two types of norm- and idea-promoting agents. Epistemic communities are networks of actors with an authoritative claim to knowledge and a normative agenda (Haas 1992b). They legitimate new norms and ideas by providing scientific knowledge about cause-and-effect relationships. Epistemic communities are more influential in inducing change, the higher the uncertainty about cause-and-effect relationships in the particular issue-area among policy-makers, the higher the consensus among the scientists involved, and the more scientific advice is institutionalized in the policy-making process (Haas 1992a; Adler and Haas 1992). In the case of the European single currency, the euro, a coalition of central bankers and national technocrats successfully advocated a monetarist approach which produced dramatic changes in domestic monetary policy, even in countries such as Italy and Greece which had to undergo painful adaptation (Radaelli 1998; Dyson and Featherstone 1999). Advocacy or principled issue networks are bound together by shared beliefs and values rather than by consensual knowledge (Keck and Sikkink 1998). They appeal to collectively shared norms and identities in order to persuade other actors to reconsider their goals and preferences. Processes of complex or 'doubleloop' learning (Agyris and Schön 1980), in which actors change their interests and identities as opposed to merely adjusting their means and strategies, occur rather rarely. They usually take place after critical policy failure or in perceived crises and situations of great uncertainty (Checkel 1999a). While persuasion and social learning are mostly identified with processes of policy change, they transform domestic institutions, too. As Checkel argues, Germany underwent (p.68) a profound and constitutive change of its citizenship norms resulting from a learning process instigated by an advocacy network (Checkel 2001). 
2 A political culture and other informal institutions conducive to consensusbuilding and cost-sharing also facilitate domestic change in response to Europeanization. Informal institutions entail collective understandings of appropriate behaviour that strongly influence the ways in which domestic actors respond to Europeanization pressures. First, a consensus-oriented or cooperative decision-making culture helps to overcome multiple veto points by rendering their use inappropriate for actors. Cooperative federalism prevented the German Länder from vetoing the European Treaty revisions which deprived them of core decision powers (Börzel 2002). The German litigational culture encouraged citizens to appeal to national courts for the deficient application of Community Law, while such a culture was absent in France where litigation is much lower (Conant 2001). Second, a consensus-oriented political culture allows for a sharing of adaptational costs which facilitates the accommodation of pressure for adaptation (Katzenstein 1984). Rather than shifting adaptational costs upon a social or political minority, the 'winners' of domestic change compensate the 'losers'. The German government shared its decision powers in European policy making with the Länder to make up for their Europe-induced power losses (Börzel 2002). Likewise, the consensual corporatist decision-making culture in the Netherlands and Germany facilitated the liberalization of the transport sector by offering compensation to the employees as the potential losers of the domestic changes (Héritier 2001; Héritier et al. 2001). A confrontational and pluralist culture, however, may inhibit domestic change, as the example of the Spanish regions in response to Europeanization pressures documents. The competitive institutional culture initially prevented the regions from cooperating with the Spanish central state in order to reap the benefits of Europeanization and to share its costs, respectively.

Norm entrepreneurs and consensus-oriented cultures affect whether European ideas, norms, and the collective understandings which do not resonate with those at the domestic level, are internalized by domestic actors giving rise to domestic change. This sociological logic of domestic change emphasizes arguing, learning, and socialization as the mechanisms by which new norms and identities emanating from Europeanization processes are internalized by domestic actors and lead to new definitions of interests and of collective identities. The logic also incorporates mimetic processes whereby institutions emulate others to reduce uncertainty and complexity (DiMaggio and Powell 1991; Radaelli 2000). Emulation is a significant mechanism by which member states learn from their neighbours and other Europeans how to respond effectively to adaptational pressures from Europeanization.

The two logics of domestic change as summarized in Figure 6.2 are not mutually exclusive. They often work simultaneously or dominate different phases of the adaptational process. We come back to this point in the concluding part of the paper. 


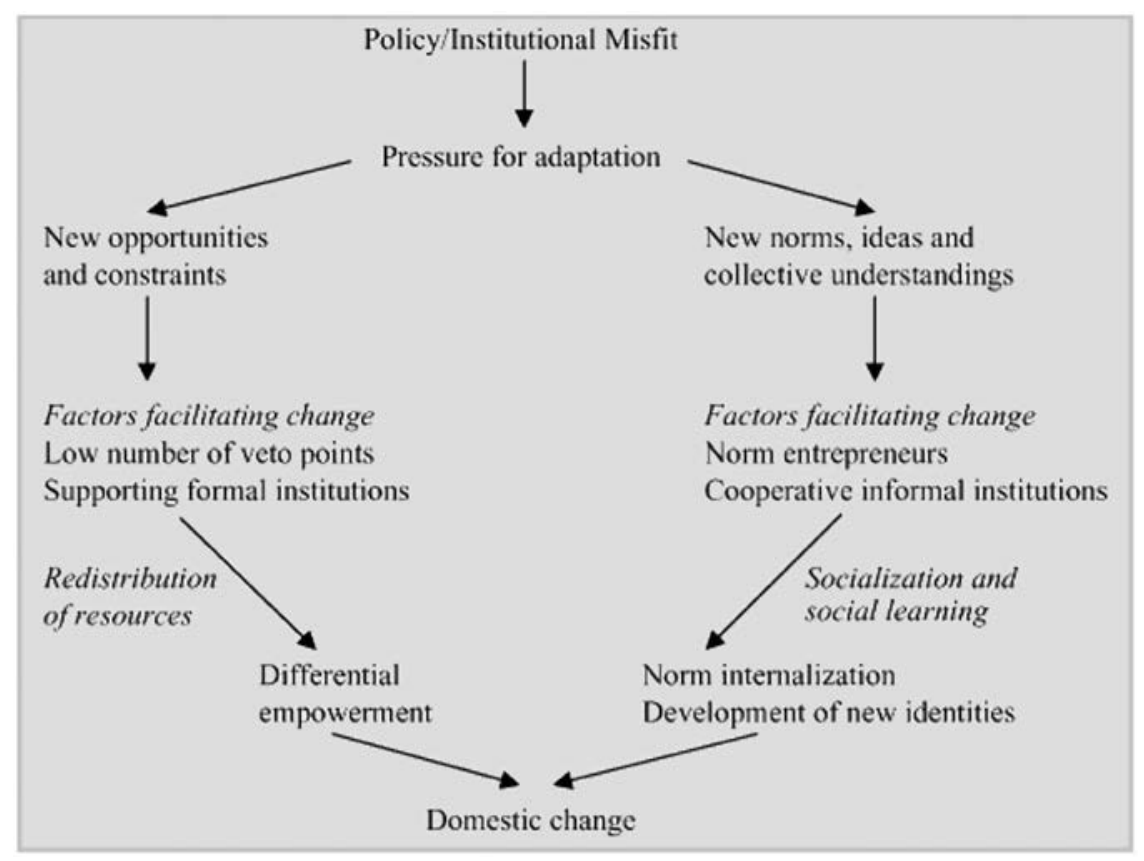

Figure 6.2 Two logics of domestic change

\section{The outcome of domestic change in response to Europeanization}

The two logics generate different propositions about the degree and direction of domestic change. Both take misfit as the necessary condition of domestic change and converge around the expectation that the lower the misfit, the smaller the pressure for adaptation and thus the lower the degree of expected domestic change. But the two logics depart on the effect of high adaptational pressure.

\section{Absorption, accommodation, or transformation?}

Domestic change in response to Europeanization pressures can be weak or strong. We distinguish here three degrees of domestic change:

1 Absorption: Member states incorporate European policies or ideas into their programs and domestic structures, respectively, but without substantially modifying existing processes, policies, and institutions. The degree of domestic change is low

2 Accommodation: Member states accommodate Europeanization pressures by adapting existing processes, policies, and institutions without changing their 
essential features and the underlying collective understandings attached to them. One way of doing this is by 'patching up' new policies and institutions onto existing ones without changing the latter (Héritier 2001). The degree of domestic change is modest

3 Transformation: Member states replace existing policies, processes, and institutions by new, substantially different ones, or alter existing ones to the extent that their essential features and/or the underlying collective understandings are fundamentally changed. The degree of domestic change is high.

The rationalist institutionalist perspective suggests that the more Europeanization provides new opportunities and constraints (high adaptational pressure), the more likely a redistribution of resources is, which may alter the domestic balance of power and which may empower domestic actors to effectively mobilize for policy change by overriding domestic veto points. Medium adaptational pressure is also likely to result in domestic transformation if there are supporting formal institutions. In the presence of multiple veto points, however, medium adaptational pressure will be at best accommodated, if not absorbed, even if this means non-compliance in case of policy misfit. Finally, the mere absorption of low pressure of adaptation may be prevented by formal institutions which support domestic actors in exploiting modest new opportunities.

Sociological institutionalism, by contrast, argues that high adaptational pressure is likely to meet strong institutional inertia preventing any domestic change. New norms, rules, and practices do not simply replace or harmonize existing ones. Profound and abrupt changes should only be expected under conditions of crisis or external coercion (Olsen 1996). Actors are more open to learning and persuasion, if new norms and ideas, albeit 'inconvenient', are compatible with collectively shared understandings and meaning structures. Therefore, medium pressure for adaptation is most likely to result in domestic transformation, at least in the long run. Processes of adaptation evolve along institutional paths.

In sum, the two logics predict opposite outcomes under conditions of high adaptational pressure. Moreover, sociological institutionalism would expect domestic change beyond absorption only as the result of a long-term process of incremental adaptation (cf. Table 6.1). Unfortunately, the available empirical evidence does not allow us yet to evaluate these propositions. Further systematic research is necessary to link the various causal mechanisms and intervening factors to the degree of domestic change to be expected in order to evaluate the assumptions.

\section{Convergence or divergence?}

Most of the literature on the domestic impact of Europeanization tends to analyse the outcome of domestic change in terms of the likelihood of convergence of policies and institutions among the member states. But measuring convergence and divergence is extremely tricky. Answers vary according to the level at which 
Table 6.1 The different degrees of domestic change

\begin{tabular}{llll}
\hline & $\begin{array}{l}\text { High adaptational } \\
\text { pressure }\end{array}$ & $\begin{array}{l}\text { Medium adaptational } \\
\text { pressure }\end{array}$ & $\begin{array}{l}\text { Lowadaptational } \\
\text { pressure }\end{array}$ \\
\hline Facilitating factors & RI: & RI: & RI: \\
& Transformation & Transformation & Accommodation \\
& SI: & SI: & SI: \\
& Inertia (unless & Gradual & Accommodation \\
external shock) & transformation & RI: \\
No facilitating & RI: & RI: & Inertia \\
factors & Accommodation & Accommodation/ & absorption \\
& SI: & SI: & SI: \\
& Inertia & Accommodation/ & Absorption \\
& & absorption & \\
\hline
\end{tabular}

one looks for convergence (Knill and Lenschow 2001) and the issue supposedly subject to convergence. What looks like convergence at the macro-level may still show a significant degree of divergence at the micro-level. Economic and Monetary Union gave rise to policy convergence among the twelve members with regard to inflation and budgetary restraints, as well as to institutional convergence concerning the independence of central banks. But it did not lead to similar institutional arrangements in the economic and fiscal policy area. And the means by which the member states reduced their budget deficits varied enormously - from austerity programs to new 'euro' taxes (in the case of Italy, see Sbragia 2001). While all member states responded to the liberalization of telecommunication by creating independent regulatory agencies, they adopted different institutional setups, reflecting variation in administrative structures (Böllhoff 2002; Schneider 2001).

Thus, authors need to specify very clearly at what level of policies and/or institutional arrangements they would expect converging processes or rather continued divergence among the member states. In any case, policy convergence seems to be more likely than institutional convergence as policy changes are more easily achieved (see the chapters in Cowles et al. 2001). Moreover, EU rules and regulations require convergence in policy outcomes (such as low inflation or budgetary restraint in the case of EMU), while they leave substantial discretionary power to the member states with regard to the means to ensure compliance. Thus, we need to specify what we mean by 'policy convergence': convergence in outcome (which equals compliance with EU law and, thus, is not particularly interesting to observe) or convergence in policy processes and instruments. This is often confused in the literature, as a result of which we know surprisingly little about the degree of policy convergence not related to policy outcomes.

As to the degree of institutional convergence, resource dependency and sociological institutionalist approaches generally lean towards convergence. Resource 
dependency predicts a redistribution of resources strengthening one group of actors over the others or reinforcing their mutual dependence. Arguments about institutional isomorphism (see above) suggest that institutions which frequently interact, are exposed to each other, or are located in a similar environment, become more similar over time (DiMaggio and Powell 1991; Meyer and Rowen 1991). However, we have sufficient empirical evidence that the outcome of the domestic effects of Europeanization is much more diverse than either resource dependency or sociological institutionalist approaches would expect.

The most comprehensive empirical studies on the domestic institutional effects of Europeanization so far showed that most empirical instances of domestic institutional change fall in the 'mixed' category whereby some countries converged toward similar policy or system-wide structures, while others retained their specific institutional arrangements, state-society relations, or cultural understandings (Kohler-Koch 1998b; Cowles et al. 2001; Héritier et al. 2001). There is not a single empirical case in which convergence meant the complete homogenization of domestic structures across member states. There is no evidence that domestic institutional change meant the comprehensive rejection of national administrative styles, legal cultures, societal relationships, and/or collective identities. As to the latter, France did not shed its national identity when adopting a European one. The meanings of 'Europe' differed in the German and French political discourses, even though the elites in both countries have incorporated Europeanness into their collective nation-state identities (Risse 2001). The traditional tensions between the Spanish regions and central government did not disappear as a result of a more cooperative arrangement in territorial matters (Börzel 2002). There is no general convergence toward cooperative federalism in Europe, just a movement toward such structures among federal states such as Germany and Spain.

These findings refute those schools of thought that expect strong structural convergence. According to the economic convergence school (Strange 1996; Woolcock 1996), we would expect increasing similarities in institutional arrangements in areas exposed to global market forces, that is, mostly areas of negative integration (Scharpf 1996). While the case of telecommunications confirms the argument, the case of the monetary and economic union does not (except with regard to independent central banks). Once again, one should not confuse convergence in policy outcomes (such as low inflation, budgetary constraints, etc.) with convergence in policy instruments, let alone institutional arrangements. In contrast, others have argued that EU policies of positive integration prescribe concrete institutional models for domestic compliance which should then result in institutional convergence (Knill and Lehnkuhl 1999; Radaelli 2000). The studies cited above refute this proposition, too.

Our analytical framework can easily explain why we do not find convergence across the board. First, as argued above, the 'goodness of fit' between Europeanization, on the one hand, and the domestic policies, politics, and institutional arrangements, on the other, varies enormously among the member states. Only those EU countries which exhibit similar domestic arrangements also face similar 
adaptational pressures as the necessary condition for domestic change. Second, and quite irrespective of the pressures for adaptation, each member state has a different set of institutions and actors facilitating or inhibiting change in response to these pressures. Multiple veto points, supporting formal institutions, norm entrepreneurs, and cooperative formal institutions mediate between the adaptational pressures and the outcome of domestic change. The facilitating factors identified by our two logics of domestic change can explain the absence of full convergence and should lead us to expect only partial, or some "clustered convergence', where some member states converge toward similar policies or institutions, but others do not. Member states facing similar pressures for adaptation are likely to converge around similar outcomes, because similar actors are empowered and are likely to learn from each other in searching for ways to respond to adaptational pressure. The regions of federal and regionalized member states by now rely on cooperation with their central government to inject their interests into the European policy process, a finding which does not hold for less decentralized member states (Börzel 1999).

\section{Conclusions: Toward integrating the two logics of domestic change}

We have argued in this chapter in favour of a rather parsimonious approach to the study of the domestic impact of Europeanization. Whether we study policies, politics, or polities, a misfit between European-level and domestic processes, policies, or institutions constitutes the necessary condition for expecting any change. But adaptational pressures alone are insufficient. There must be mediating factors enabling or prohibiting domestic change and accounting for the empirically observable differential impact of Europe. We have introduced two pathways leading to domestic changes which are theoretically grounded in rationalist and sociological institutionalisms, respectively. On the one hand, rationalist institutionalism follows a logic of resource redistribution emphasizing the absence of multiple veto points and the presence of supporting institutions as the main factors facilitating change. On the other hand, sociological institutionalism emphasizes a socialization and learning account, focusing on norm entrepreneurs as 'change agents' and the presence of a cooperative political culture as the main mediating factors. We claim that Europeanization might lead to convergence in policy outcomes, but only to partial and 'clustered convergence' with regard to policy processes and instruments, politics, and polities.

We need to be aware, however, that 'goodness of fit', adaptational pressures, and domestic responses to Europeanization are not static phenomena. Europeanization processes are constantly in motion and so are the domestic adaptations to them. There are also continuous feedback processes leading from the domestic levels to the European one. The analytical framework proposed here is not meant to suggest a static picture of Europeanization and domestic change. Rather, it is meant as a tool to enable systematic empirical research on the domestic impact of Europeanization, which would be impossible if we did not keep some variables constant. 
Moreover, the two pathways identified in this chapter are by no means mutually exclusive. Of course, we need to distinguish analytically between the two logics of action and interaction emphasized by rationalist institutionalism and sociological institutionalism, respectively. In practice, however, the two logics often occur simultaneously or characterize different phases in processes of adaptational change. Future research has to figure out how the two pathways and causal mechanisms relate to each other. In conclusion, we build upon March and Olsen's (1998: 952-3) interpretations of how the logic of consequentialism and the logic of appropriateness may be linked. First, a clear logic should dominate an unclear one. In the case of Europeanization, this would mean that the 'socialization/learning' pathway is the more likely to be followed, the more the actors are uncertain about their preferences and strategy options. In contrast, the 'resource redistribution' pathway is likely to prevail if actors' preferences are well-defined and the available strategy options known.

Second, the two pathways might relate to each other in a sequential way. For example, norm entrepreneurs might be empowered by supportive institutions, but then start a socialization process of persuasion in order to overcome multiple veto points in the domestic system. In contrast, if domestic change in response to Europeanization involves high redistributional costs, a socialization process might be necessary to overcome stalemate and to develop new rules of fairness on the basis of which actors can then bargain over the distribution of costs.

Finally, the logic of consequentialism exogenizes preferences and identities, while the logic of appropriateness endogenizes them. As a result, the more Europeanization exerts adaptational pressures on constitutive and deeply embedded institutions (such as citizenship rules) and collective identities, the more the socialization/learning pathway is necessary to induce constitutive change. The example of the French elites and their collective identity is instructive in this regard. When the French socialists with President Mitterrand assumed power during the early 1980s, their economic and monetary policies quickly turned out to be incompatible with what was required under the European monetary system (a quite substantial misfit). In response, Mitterrand changed course and adjusted French economic policies accordingly. This change of policies turned out to be incompatible with the Socialist preferences and collective identities of the French left. As a result, the French Socialists adjusted their preferences to Europe and increasingly (re-)defined French state identity as part and parcel of a collective European identity (Risse 2001). In this case, we can explain the original policy change as an instrumental adaptation to reduce economic and political costs. However, it then led to a more profound change of preferences and even collective identities.

It is too early to say which of these propositions hold under which circumstances. Future research needs to specify under which conditions instrumental adaptation to Europeanization pressures suffices for domestic change, and when more profound change of preferences and identities is necessary for member states to adjust to Europe. Yet current empirical work has clearly demonstrated 
that Europe matters, leading to sometimes quite significant transformations of domestic policies, politics, and polities in the member states.

\section{Note}

An earlier version of this paper was presented at the 2000 Annual Convention of the American Political Science Association, Washington DC, and published as a European Integration Online Paper (http://eiop.or.at/eiop/texte/2000-015a.htm). We thank Klaus Goetz, Christine Ingebritsen, Claudio Radaelli, and two anonymous reviewers for their critical comments and suggestions.

1 The following draws on Olsen (1996), Börzel (2002), and Checkel (1999b).

\section{References}

Adler, Emanuel and Peter Haas (1992). 'Conclusion: Epistemic Communities, World Order, and the Creation of a Reflective Research Program'. International Organization 46(1): 367-90.

Aguilar Fernandez, Susana (1992). 'Environmental Monitoring and Environmental Information in Spain', in Peter Knöpfel, Helmut Weidner, and R. Zieschank (eds), Environmental Monitoring and Reporting in Selected Countries (Basel, Frankfurt a/M: Helbing and Lichtenhahn).

Agyris, Chris and Donald A., Schön (1980). Organizational Learning (Reading, Mass.: Addison-Wesley).

Böllhoff, Dominik (2002). The New Regulatory Regime - The Institutional Design of Telecommunications Regulation at the National Level', in A. Héritier (eds), Common Goods: Reinventing European and International Governance (Lanham: Rowman and Littlefield Publishers), 235-61.

Börzel, Tanja, A. (1999). 'Towards Convergence in Europe? Institutional Adaptation to Europeanization in Germany and Spain', Journal of Common Market Studies 37(4): 573-96.

(2000). 'Why There Is No Southern Problem. On Environmental Leaders and Laggards in the European Union', Journal of European Public Policy 7(1).

(2002). States and Regions in the European Union. Institutional Adaptation in Germany and Spain (Cambridge: Cambridge University Press).

Bulmer, Simon (1997). 'Shaping the Rules? The Constitutive Politics of the European Union and German Power', in Peter J. Katzenstein (ed.), Tamed Power. Germany in Europe (Ithaca, NY: Cornell University Press), 49-79.

Caporaso, James, A. and Joseph Jupille (2001). 'The Europeanization of Gender Equality Policy and Domestic Structural Change', in Maria Green Cowles, James A. Caporaso and Thomas Risse (eds), Transforming Europe. Europeanization and Domestic Change (Ithaca, NY: Cornell University Press), 21-43.

Checkel, Jeffrey T. (1999a). 'International Institutions and Socialization'. Working Paper, 5. Oslo: ARENA, University of Oslo, February.

(1999b). 'Social Construction and Integration'. Journal of European Public Policy 6(4).

(2001). 'The Europeanization of Citizenship'? in Maria Green Cowles, James A. Caporaso, and Thomas Risse (eds), Transforming Europe. Europeanization and Domestic Change (Ithaca, NY: Cornell University Press), 180-97. 
Conant, Lisa Joy (2001). 'Europeanization and the Courts: Variable Patterns of Adaptation among National Judiciaries', in Maria Green Cowles, James A. Caporaso, and Thomas Risse (eds), Transforming Europe. Europeanization and Domestic Change (Ithaca, NY: Cornell University Press), 97-115.

Cowles, Maria Green (2001). 'The Transatlantic Business Dialogue and Domestic BusinessGovernment Relations', in Maria Green Cowles, James A. Caporaso and Thomas Risse (eds), Transforming Europe. Europeanization and Domestic Change (Ithaca, NY: Cornell University Press), 159-79.

James Caporaso, and Thomas Risse eds. (2001). Transforming Europe: Europeanization and Domestic Change (Ithaca, NY: Cornell University Press).

and Thomas Risse (2001). 'Transforming Europe: Conclusions', in Maria Green

Cowles, James A. Caporaso and Thomas Risse (eds), Transforming Europe. Europeanization and Domestic Change (Ithaca, NY: Cornell University Press), 217-38.

Desideri, Carlo and Vincenzo Santantonio (1997). 'Building a Third Level in Europe: Prospects and Difficulties in Italy', in Charlie Jeffery (ed.), The Regional Dimension of the European Union. Towards a Third Level in Europe? (London: Frank Cass), 96-116.

DiMaggio, Paul J. and Walter W. Powell (1991). 'The Iron Cage Revisited: Institutional Isomorphism and Collective Rationality in Organizational Fields', in Walter W. Powell and Paul J. DiMaggio (eds), The New Institutionalism in Organizational Analysis (Chicago, London: University of Chicago Press), 63-82.

Duina, Francesco G. (1999). Harmonizing Europe. Nation-States within the Common Market (New York: State University of New York Press).

Dyson, Kenneth and Keith Featherstone (1999). The Road to Maastricht (Oxford: Oxford University Press).

Eising, Rainer. forthcoming. 'Integration und Europäisierung', in Markus Jachtenfuchs and Beate Kohler-Koch (eds), Europäische Integration, new edition.

Finnemore, Martha and Kathryn Sikkink (1998). 'International Norm Dynamics and Political Change', International Organization 52(4): 887-917.

Grande, Edgar (1996). 'The State and Interest Groups in a Framework of Multi-level Decision-making: The Case of the European Union', Journal of European Public Policy 3(3): 318-38.

Haas, Peter M. (1992a). 'Introduction: Epistemic Communities and International Policy Coordination', International Organization 46(1): 1-36.

ed. (1992b). 'Knowledge, Power and International Policy Coordination', International Organization, Special Issue. 1 ed. 46.

Hall, Peter A. and Rosemary C. R. Taylor (1996). 'Political Science and the Three New Institutionalisms', Political Studies 44: 952-73.

Haverland, Markus (1999). National Autonomy, European Integration, and the Politics of Packaging Waste (Amsterdam: Thela Thesis).

(2000). 'National Adaptation to European Integration: The Importance of Institutional Veto Points', Journal of Public Policy 20(1): 83-103.

Héritier, Adrienne (1996). 'The Accommodation of Diversity in European Policy-Making', Journal of European Public Policy 3(2): 149-76.

(1999). Policy-Making and Diversity in Europe. Escape from Deadlock (Cambridge: Cambridge University Press).

(2001). 'Differential Europe: National Administrative Responses to Community Policy', in Maria Green Cowles, James A. Caporaso and Thomas Risse (eds), Transforming Europe. Europeanization and Domestic Change (Ithaca, NY: Cornell University Press), 44-59. 
Héritier, Adrienne et al. (2001). Differential Europe - New Opportunities and Restrictions for Policy Making in Member States (Lanham, MD: Rowman and Littlefield).

Héritier, Adrienne, Christoph Knill, and Susanne Mingers (1996). Ringing the Changes in Europe. Regulatory Competition and the Transformation of the State. Britain, France, Germany (Berlin, New York: Walter de Gruyter).

Hooghe, Liesbet (ed.) (1996). Cohesion Policy and European Integration: Building MultiLevel Governance (Oxford: Oxford University Press).

Jeffery, Charlie (2000). 'Sub-National Mobilization and European Integration', Journal of Common Market Studies 38(1): 1-23.

Katzenstein, Peter J. (1984). Corporatism and Change. Austria, Switzerland, and the Politics of Industry (Ithaca and London: Cornell University Press).

Katzenstein, Peter J. (1997). 'United Germany in an Integrating Europe', in Peter J. Katzenstein (ed.), Tamed Power. Germany in Europe (Ithaca, NY: Cornell University Press), 1-48.

Keck, Margret and Kathryn Sikkink (1998). Activists Beyond Borders. Transnational Advocacy Networks in International Politics (Ithaca, NY: Cornell University Press).

Kerwer, Dieter and Michael Teutsch (2001). 'Elusive Europeanisation. Liberalising Road Haulage in the European Union', Journal of European Public Policy.

Knill, Christoph and Dirk Lehnkuhl (1999). How Europe Matters. Different Mechanisms of Europeanization. European Integration on-line Papers 3(7).

- and Andrea Lenschow (eds) (2000). Implementing EU Environmental Policy: New Approaches to an Old Problem (Manchester: Manchester University Press). (2001). 'Seek and Ye Shall Find'. Linking Different Perspectives on Institutional Change. Comparative Political Studies 34: 187-215.

Kohler-Koch, Beate (1996). 'The Strength of Weakness. The Transformation of Governance in the EU', in Sverker Gustavsson and Leif Lewin (eds), The Future of the Nation State. Essays on Cultural Pluralism and Political Integration (Stockholm: Nerenius and Santerus), 169-210.

(1998a). 'Europäisierung der Regionen: Institutioneller Wandel als sozialer Prozeß', in Beate Kohler-Koch et al. (eds), Interaktive Politik in Europa. Regionen im Netzwerk der Integration (Opladen: Leske and Budrich), 13-31.

(ed.) (1998b). Interaktive Politik in Europa. Regionen im Netzwerk der Integration. (Opladen: Leske and Budrich).

and Rainer Eising (eds) (1999). The Transformation of Governance in the European Union (London: Routledge).

March, James G. and Johan P. Olsen (1989). Rediscovering Institutions (New York: The Free Press).

(1998). 'The Institutional Dynamics of International Political Orders', International Organization 52(4): 943-69.

Marks, Gary (1993). 'Structural Policy and Multilevel Governance in the European Community', in Alan Cafruny and Glenda Rosenthal (eds), The State of the European Community II: Maastricht Debates and Beyond (Boulder: Lynne Riener), 391-410.

Meyer, John W. and Brian Rowen (1991). 'Institutionalized Organizations: Formal Structures as Myth and Ceremony', in Paul J. DiMaggio and Walter W. Powell (eds), The New Institutionalism in Organizational Analysis (Chicago: University of Chicago Press), 41-62.

Morass, Michael (1997). 'Austria: The Case of a Federal Newcomer in European Union Politics', in Charlie Jeffery (ed.), The Regional Dimension of the European Union. Towards a Third Level? (London: Frank Cass), 76-95. 
Moravcsik, Andrew (1993). 'Preferences and Power in the European Community. A Liberal Intergovernmentalist Approach', Journal of Common Market Studies 31(4): 473-524. (1994). Why the European Community Strengthens the State: Domestic Politics and International Cooperation. Working Paper, 52 (Cambridge, Mass.: Harvard University).

(1998). The Choice for Europe: Social Purpose and State Power from Rome to Maastricht (Ithaca, NY: Cornell University Press).

Olsen, Johan P. (1995). Europeanization and Nation-State Dynamics. Working Paper, 9. Oslo: ARENA, March 1995.

(1996). 'Europeanization and Nation-State Dynamics', in Sverker Gustavsson and Leif Lewin (eds), The Future of the Nation-State (London: Routledge), 245-85.

(1997). 'European Challenges to the Nation State', in B. Steunenberg and F. van Vught, Political Institutions and Public Policy Hague et al. (Dordrecht: Kluwer Academic Publishers), 157-88.

Puchala, Donald J. (1972). 'Of Blind Men, Elephants and International Integration', Journal of Common Market Studies 10(3): 267-84.

Radaelli, Claudio (1998). 'Networks of Expertise and Policy Change in Italy', South European Society and Politics 3(2): 1-22.

- (2000). Whither Europeanization? Concept Stretching and Substantive Change. European Integration on-line Papers 4 (8):.

Rhodes, R.A.W. (1996). Governing without Governance: Order and Change in British Politics. Inaugural lecture, Newcastle upon Tyne: University of Newcastle, 18 April 1996.

- (1997). Understanding Governance. Policy Networks, Governance, Reflexivity and Accountability (Buckingham and Philadelphia: Open University Press).

Risse, Thomas (2000). “"Let’s Argue!” Communicative Action in International Relations'. International Organization 54(1): 1-39.

(2001). 'A European Identity? Europeanization and the Evolution of Nation-State Identities', in Maria Green Cowles, James A. Caporaso, and Thomas Risse (eds), Transforming Europe. Europeanization and Domestic Change (Ithaca, NY: Cornell University Press), 198-216.

(2002). Constructivism and the Study of International Institutions: Toward Conversations across Paradigms', in Ira Katznelson and Helen V. Milner (eds), Political Science as Discipline? Reconsidering Power, Choice, and the State at Century's End (New York: W. W. Norton).

Risse, Thomas, James Caporaso, and Maria Green Cowles (2001). Europeanization and Domestic Change. Introduction, in Maria Green Cowles, James Caporaso and Thomas Risse (eds), Transforming Europe: Europeanization and Domestic Change (Ithaca, NY: Cornell University Press), 1-20.

Sandholtz, Wayne (1996). 'Membership Matters: Limits of the Functional Approach to European Institutions', Journal of Common Market Studies 34(3): 403-29.

Sbragia, Alberta (2001). 'Italy Pays for Europe: Political Leadership, Political Choice, and Institutional Adaptation', in Maria Green Cowles, James A. Caporaso and Thomas Risse (eds), Transforming Europe. Europeanization and Domestic Change (Ithaca, NY: Cornell University Press), 79-98.

Scharpf, Fritz W. (1996). 'Negative and Positive Integration in the Political Economy of European Welfare States', in Gary Marks et al. (eds), Governance in the European Union (London, Thousand Oaks, New Delhi: Sage), 15-39.

Schmidt, Vivien (1996). From State to Market? The Transformation of French Business and Government (Cambridge: Cambridge University Press). 
Schneider, Volker (2001). 'Institutional Reform in Telecommunications: The European Union in Transnational Policy Diffusion', in Maria Green Cowles, James A. Caporaso and Thomas Risse (eds), Transforming Europe. Europeanization and Domestic Change (Ithaca, NY: Cornell University Press), 60-78.

Scott, W. Richard and John W. Meyer (1994). Institutional Environments and Organizations - Structural Complexity and Individualism (London: Sage Publications).

Strange, Susan (1996). The Retreat of the State. The Diffusion of Power in the World Economy (Cambridge: Cambridge University Press).

Tesoka, Sabrina (1999). 'Judicial Politics in the European Union: Its Impact on National Opportunity Structures for Gender Equality'. MPIfG Discussion Paper, 99/2, Köln: Max-Planck-Institut für Gesellschaftsforschung.

Tsebelis, George (1995). 'Decision Making in Political Systems. Veto Players in Presidentialism, Parliamentarism, Multicameralism and Multipartism', British Journal of Political Science 25(3): 289-325.

Wallace, Helen and William Wallace (eds) (1996). Policy-Making in the European Union (Oxford: Oxford University Press).

Woolcock, Stephen (1996). 'Competition among Forms of Corporate Governance in the European Community: the Case of Britain', in Suzanne Berger and Ronald Dore (eds), National Diversity and Global Capitalism (Ithaca, NY: Cornell University Press), 179-96. 


\title{
7 European institutions and identity change
}

\author{
What have we learned? (2004)
}

\author{
Thomas Risse
}

This book has both theoretical and empirical purposes. Theoretically, we strive to understand how new (international) institutions affect people's social identities. How do political institutions shape people's beliefs about who they are and to which communities they belong? What are the causal pathways by which institutions affect social identities and by which identities and institutions coevolve? Empirically, we focus on the European experience, in particular the ways in which more than forty years of European integration have affected people's sense of belonging. Is there an emerging European identity, and if so, does it replace, coexist with, or otherwise interact with individuals' multiple identities? And what is the substantive content of this European identity? Is there a difference between elite-level identification processes with Europe and the Europeanness of "ordinary" people?

To answer these questions, we have embarked on a multidisciplinary and multimethodological approach. The authors in this book are political scientists, sociologists, social psychologists, linguists, and anthropologists using such diverse research tools as quantitative survey data, laboratory experiments, indepth interviews, discourse analysis, and historical interpretation. Our hope is that a multidimensional approach gives us additional analytical leverage in tackling such an elusive concept as "European identity."

In the following, I try to summarize some of our findings, to highlight agreements as well as differences among the authors, and to suggest avenues for future research. I concentrate on a discussion of the empirical findings of the book. While the introduction by Herrmann and Brewer focuses primarily on theoretical questions involved in studying collective identities, I emphasize what the book tells us about the empirical subject of European identity. Therefore, this chapter focuses on the insights, from a multidisciplinary approach, into European identity as the "dependent variable." How do European and other identities of individuals and social groups go together? What do we know about the substance and content of European identity? How can we explain the large gap between elite identification with Europe and the feelings of ordinary citizens, who seem to be more alienated from Europe?

While the chapters in this book provide excellent descriptions of what we seem to know about the extent to which people identify with Europe, they are 
less concerned with explaining the evolution of European identity. Nevertheless, this book yields some insights into the reasons why we can see changes over time in identification with Europe. I will also highlight methodological problems in studying the subject matter of European identity that seem to be apparent in this volume. I conclude with the implications of our findings for the policy debates about the future of the European Union. Why bother with studying identities? Do we need European identity to build a European polity?

\section{European and other identities: How do they go together?}

It is no longer controversial among scholars and - increasingly - policy makers that individuals hold multiple social identities. People can feel a sense of belonging to Europe, their nation-state, their gender, and so on. It is wrong to conceptualize European identity in zero-sum terms, as if an increase in European identity necessarily would decrease one's loyalty to national or other communities. Europe and the nation are both "imagined communities" (Anderson 1991), and people can feel as part of both communities without having to choose some primary identification. Analyses from survey data suggest, and social psychological experiments confirm, that many people who strongly identify with their nation-state also feel a sense of belonging to Europe (Duchesne and Frognier 1995; Martinotti and Steffanizzi 1995; see Citrin and Sides 2004; Castano 2004).

However, there are social contexts in which European and national identities might conflict. Two of Siapera's narratives concern situations in which journalists feel that they have to take sides in a confrontation between "Europe" and the nation-state. According to one account, Europe has to be built against the nationstate, and a European public opinion is supposed to overcome old-fashioned nationalism. The other account takes the opposite perspective and assumes that national identities cannot be superseded by the construction of a European identity (Siapera 2004). Laffan's account (2004) of "double hatting" in the Committee of Permanent Representatives (COREPER) at the Council also suggests a sometimes conflictual relationship between European and national identities among officials working in Brussels. This conflict results from the somewhat contradictory role identities of these officials. On the one hand, they are supposed to work toward a common European goal and negotiate consensual outcomes with their fellow Europeans (see also Lewis 1998a, 1998b, 2000). On the other hand, they are still national representatives and, therefore, supposed to defend their respective national interests.

Interestingly enough, zero-sum relationships and potential conflicts between European and national identities are represented in this book only in cases focusing on professionals working in Brussels. Journalists reporting from Brussels to their national media markets and COREPER officials have in common that Europe and their respective nation-states are highly salient and "real" entities for them. Both are very "entitative," to use the term from social psychology (Castano 2004). Journalists and national permanent representatives have 
to constantly negotiate between their commitment to Europe and their commitment to their nation-state. No wonder that these two groups perceive Europe and the nation as often in conflict with each other. It seems to be the social context of their professional environment that leads them to sometimes conceptualize the two identities in conflictual terms.

However, the other chapters of this book show little evidence of a zero-sum relationship between European and other identities. This finding is trivial for scholars studying collective identities, but it nevertheless has important implications for the political debates about Europe and the nation-state. Take the contemporary debate about the future of the European Union and about a European constitution. Many people still hold that Europe lacks a demos, one indicator being the lack of strong identification with Europe in mass public opinion (e.g., Kielmansegg 1996). Yet, as Citrin and Sides demonstrate, "country first, but Europe, too" is the dominant outlook in most EU countries, and people do not perceive this as contradictory (Citrin and Sides 2004, for similar findings see Marks and Hooghe 2003). Moreover and more important, the real cleavage in mass opinion is between those who only identify with their nation, on the one hand, and those perceiving themselves as attached to both their nation and Europe, on the other hand. Citrin and Sides show that the individual willingness to support further European integration increases quite dramatically from the former to the latter group. Marks and Hooghe add that exclusive identification with the nation-state is more powerful in explaining opposition to European integration than calculations about economic costs and benefits (Marks and Hooghe 2003). They also show that the effect of exclusive identification with one nation-state varies widely across countries. "Nationalist" Portuguese are far less inclined to oppose European integration than, say, "nationalist" British.

Generally speaking, therefore, willingness to grant the EU authority requires some identification with Europe, but not an identification that actually prioritizes Europe over the nation. In other words, the European polity does not require a demos that replaces a national with a European identity, but one in which national and European identities coexist and complement each other. This is a significant empirical finding that speaks directly to the current debate on the future of the union.

Our findings show much more than the rather simple insight that European and national identities can go together. The chapters suggest quite a bit about how multiple identities go together and how they relate to each other. The introduction of this book suggests three ways in which we can think of multiple identities. First, identities can be nested, conceived of as concentric circles or Russian Matruska dolls, one inside the next. My identity as a Rhinelander is nested in my German identity, which is again nested in my Europeanness. Second, identities can be cross-cutting. In this configuration, some, but not all, members of one identity group are also members of another identity group. I can feel a strong gender identity and a sense of belonging to Europe, but not all members of my gender group also identify with Europe. Third, identities can be separate. For example, I could be the only professor in a sports club, 
as a result of which my identification with my professional colleagues would be kept separate from my loyalty to the soccer club associates. There would be no overlap in group memberships.

There is a good deal of evidence presented in this book that we can think of the relationship between European and other identities as nested and/or crosscutting, while there are only a few instances of separate European and other identities. As to nestedness, we find the "Russian Matruska doll" model of European and other identities on the level both of elites and of mass public opinion. This model suggests some hierarchy in people's sense of belonging and loyalties. European and other identities pertaining to territorially defined entities can be nested into each other so that "Europe" forms the outer boundary, while one's region or nation-state constitutes the core. The survey data mentioned above that mass publics in most countries hold national and regional identities as their primary sense of belonging, while Europe runs a distinct second, are consistent with such a concept of how multiple identities relate (cf. Bruter 2004; Citrin and Sides 2004). Laffan's (2004) and Wodak's (2004) reports about Commission officials also suggest a nestedness of European identity, but here "Europe" forms the core, while national identification recedes into the background. Social context and psychological reality (Castano 2004) would explain the difference between the social identities of Commission officials and those of citizens in most EU member states. For the latter, Europe and the EU are distant realities at best and probably less reified than imagined national communities. Meinhof's in-depth interviews with people in border regions suggest that Europe is indeed far away from people's daily lives (Meinhof 2004). They would refer to Europe only when directly asked about it by the interviewer. Hence the ordering whereby national identities form the core and European identity the outer boundary of the Russian doll. For Commission officials, the social context works the other way round and pushes toward strong identification with Europe. Finally, the "Russian doll" idea is consistent with the data reported by Mummendey and Waldzus (2004), according to which national identities form a subgroup within a superordinate group, Europe in this case.

But we also see examples of cross-cutting identities. The chapters by Laffan (2004) and Wodak (2004) seem to suggest that members of the European Parliament (MEPs) hold such overlapping identities, feeling a sense of belonging to Europe and to their party groups. The same holds true for the journalists in Brussels (see Siapera 2004). Their professional identities cut across their identification with Europe. Siapera shows that distinct role identities of journalists as investigators, chroniclers, or therapeutic analysts go together with distinct perspectives on the construction of Europe (antinational, national, postnational).

Unfortunately, most mass opinion survey instruments, as well as the social psychological experiments, reported in this volume do not evaluate identification with Europe as cross-cutting with other social identities. The implicit model of multiple identities behind these instruments is the "Russian doll" concept. Yet, we could conceive of even the relationship between European and national identities as cross-cutting. Some, but not all, people who strongly identify with 
their nation-state also identify with Europe, as the Eurobarometer data suggest (Citrin and Sides 2004). Moreover, the two groups - "nation only" and "nation and Europe" - hold rather different political attitudes across a wide range of issues. In particular, people identifying with their nation and with Europe are less nationalist, less xenophobic, and hold more cosmopolitan values in general (but see the findings by Mummendey and Waldzus 2004 on in-group projection, discussed below). Their ideological convictions place them more to the left than their nationalist counterparts. Ideology in general represents another identity marker that cuts across European identity.

There is a fourth way of conceptualizing the relationship between European and other identities that people might hold. We could call it a "marble cake" model of multiple identities. According to this model, the various components of an individual's identity cannot be neatly separated on different levels, as the concepts of nestedness and of cross-cutting identities both imply. What if identity components influence each other, mesh and blend into each other? What if my self-understanding as German inherently contains aspects of Europeanness? Can we really separate out a Catalan from a European identity? As another example, take the major European party families. From the 1950s on, Christian Democratic parties in Continental Europe have been at the forefront of European integration. Europeanness has always been a constitutive component of post-World War II Christian Democratic ideology originating from the interwar period. The same holds true for modern Social Democrats in Europe. It is interesting to note that the turn toward accepting capitalism and the social market economy experienced by the German Social Democrats in the late 1950s, the French Socialists in the early 1980s, and British Labor in the 1990s went hand in hand with a stronger identification with European integration in each of these cases. Today, Europeanness forms a constitutive part of modern Social Democratic ideology (for details see Marcussen et al. 1999; Risse 2001).

The chapters in this volume do not systematically explore such a "marble cake" concept of European and other identities. Yet, most of the evidence is actually consistent with it, starting with the "nation first, Europe second" identification found in the Eurobarometer data (Citrin and Sides 2004). Theoretically speaking, Breakwell's Identity Process Theory (2004) probably comes closest to such an understanding how European and other identity components might go together. The identity change of European Social Democracy described above, for example, could be analyzed in terms of the assimilation/accommodation dynamics to which Breakwell refers in her chapter. Moreover, as Breakwell points out, being European is not the same as being a citizen of an EU member state. EU membership leads to an identity change that impacts on the previous national identity. Since EU membership identity then interacts with rather different national identity constructions, the overall effect is not homogenous, leading to a generalized EU identity. Rather, Europe and the EU become enmeshed with given national identities, leading to rather diverging identity outcomes.

A most important corollary of such a conceptualization concerns the content and substance of what it means to identify with Europe. Breakwell talks about 
the "emptiness" of Europe as a category, which implies that different groups might fill it with very different contents. Indeed, a longitudinal study of political discourses about Europe among the major parties in France, Germany, and Great Britain revealed that the meaning of Europe varied considerably (Marcussen et al. 1999; Risse et al. 1999). For the German political elites, "Europe" and the European integration meant overcoming one's own nationalist and militarist past (Engelmann-Martin 2002). The French elites, in contrast, constructed Europe as the externalization of distinct French values of Republicanism, enlightenment, and the mission civilisatrice. While French and German political elites managed to embed Europe in their understandings of national identity, the British elites constructed Europe in contrast to their understandings of the nation, particularly the English nation (Knopf 2002).

Finally, the in-group projection model presented by Mummendey and Waldzus (2004) points to the dangers of a European identity that is fully integrated into one's own national sense of belonging. This implies not only that "Europe" means different things to different people. If people simply transfer their own national values onto the European stage, and if they fill their understanding of Europe with meanings derived from their national models of political and social life, this might in the end decrease rather than increase tolerance among the European peoples.

Whether nested, cross-cutting, or enmeshed, the various ways in which we can think about multiple identities and their relationships with one another suggest important desiderata for future research. It has become conventional wisdom among scholars that individuals hold multiple social identities. One can feel a sense of belonging to Europe as well as to one's region and/or political party. It is far less clear what this actually means. Future research should, therefore, specify the different ways in which the multiplicity of identities can be conceptualized, derive competing propositions from these models, and test them empirically.

So far, I have used the terms "European identity" and "Europe" as if their content and substantive meanings were clear and well defined. Breakwell's (2004) notion of the emptiness of Europe as a social identity marker already challenges this view. She notes that "Europe" and "the EU" connote different things for different people (see also Bruter 2004). But what do our findings suggest about the substantive content of European identity in terms of both "Who is us?" (composition of group identity) and "What is us?" (content of group identity; see the introduction).

\section{"Who is us?" and "what is us?": The composition and the content of European identity}

\section{Europe's emptiness as an identity category}

The chapters in this book do not present a uniform picture of what it means in substantive terms to be European. Breakwell (2004) points to the possibility that the EU and Europe are poorly defined as superordinate categories and that, therefore, they may have various and rarely unchallenged social meanings. If European identity 
means quite different things to different people in terms of its ideological, territorial, political, cultural, or even religious connotations, it does not mean much if we find in survey data that people identify with "Europe." At least, we should not draw any major conclusions for the European polity. Moreover, the symbolic and mythological identity markers of Europe are rather weakly developed. Most people might by now recognize the European (EU) flag or European symbols on their passports, driver's licenses, or automobile license plates (see also Bruter 2004). There is also evidence that the single currency, the euro, has already left a substantial mark in people's mind as a symbol of European integration. The introduction of euro bills and coins in people's pockets has already begun to affect citizens' identification with the EU and Europe in general (see evidence in Risse 2003a). But how many people can identify the "Ode to Joy" as the European anthem?

Or take the events following the September 11, 2001, attacks on the United States. While policy makers all over Europe routinely referred to the need to build a strong European foreign and security policy in the fight against international terrorism, symbols of national foreign policies prevailed in the media representations. We watched British Prime Minister Tony Blair and German Chancellor Gerhard Schröder as well as their foreign ministers travelling around the globe, talking to Arab leaders, and making solemn statements at "ground zero" in New York. We rarely saw Mr. "European Foreign Policy" Solana at similar functions. We did not learn that every single statement by a European leader had been coordinated with fellow Europeans through the framework of the European Common Foreign and Security Policy. Things have further deteriorated with the intra-European conflict concerning the Iraq war. The common framework of European foreign policy was sidestepped, and foreign policy became, once again, a purely national affair.

Breakwell's claim about the emptiness of Europe and the EU as identity categories is corroborated by Meinhof's findings from her in-depth interviews (Breakwell 2004; Meinhof 2004). There was no spontaneous mentioning of Europe or the EU by people in the border towns of Meinhof's study, even though the significance of EU enlargement is quite obvious for them. When confronted with photographs containing European symbols, interviewees would still not refer to Europe. Only when asked direct questions concerning their attachment to Europe would people start talking about it. However, the statements were contradictory and inconsistent; respondents gave very different accounts of what Europe means for them (see Meinhof 2004). These results differ substantially from the findings based on survey data, which points to some methodological problems in measuring European identity. At least, we can probably infer that Europe was not a salient reality in the particular social context of Meinhof's interviews.

\section{European or EU identity?}

Setting aside the problem that Europe might be an empty signifier for many people, we need to distinguish European and EU identity (cf. Breakwell 2004). This is particularly important if we want to find out what effects, if 
any, Europeanization and European integration have had on identity. People might feel a sense of belonging to Europe in general, while feeling no attachment to the EU at all - and vice versa. Yet, as Laffan (2004) suggests, the EU as an active identity builder has successfully achieved identity hegemony in terms of increasingly defining what it means to belong to "Europe." First, EU membership has significant constitutive effects on European state identities. States in Europe are increasingly defined as EU members, nonmembers, or would-be members. Their status in Europe and to some degree worldwide depends on these categories. There is no way that European states can ignore the EU, even such devoted nonmembers as Switzerland.

Second, the EU has achieved identity hegemony in the sense that "Europe" increasingly denotes the political and social space occupied by the EU. In the context of Eastern enlargement, Central Eastern European states want to "return to Europe," as if they were currently outside the continent. When Italy prepared itself for entering the euro-zone, the main slogan was "entrare l'Europa" (entering Europe!), as if Italy - one of the six founding members of the European Community - had ever left it (Sbragia 2001). In these contexts, "Europe" is used synonymously with "the EU." To the extent that people identify Europe with the EU, this would be a remarkable achievement of forty years of European integration. If Europe and the EU are used interchangeably, it means that the latter has successfully occupied the social space of what it means to be European. One could then not be a "real" European without being an EU member. This point appears to contradict the notion of Europe as an empty identity category. At least, it would mean that the EU increasingly fills the meaning space of Europe with a specific content.

But what substantive content do people refer to when they identify with Europe and/or the EU? What attributes, symbols, and values describe the prototypical member of the European in-group (see the introduction by Brewer and Herrmann)? At this point, Bruter's (2004) distinction between civic and cultural components of European identity is quite helpful.

\section{Civic and/or cultural components of European identity}

Bruter's chapter points out that it makes a difference whether Europe is defined in civic or cultural terms. "Culture" in this understanding encompasses history, ethnicity, civilization, heritage, and other social similarities. "Civic" identity is much more circumscribed and refers to the identification of citizens with a particular political structure such as the EU or the political institutions of the nation-state (see also Eisenstadt and Giesen 1995). Bruter (2004) finds that people systematically distinguish between these two dimensions. His evidence is corroborated by a Europe-wide focus group study commissioned by the EU Commission's Governance Unit that also included nine accession candidates. This study shows that people by and large identify "Europe" as a historical, political, and cultural space rather than a territorial entity (OPTEM 2001). In contrast, when Europe is introduced in mostly territorial terms, attachment rates 
drop dramatically, as a recent Special Eurobarometer study shows (EOS Gallup Europe 2001). In this case, comparatively more people feel attached to the "world" than to Europe. In other words, it is Bruter's cultural identity that seems to form the substance of citizens' identification with Europe as a whole.

Bruter (2004) also points out that the distinction allows us to differentiate between identification with the EU as a distinct civic and political entity, on the one hand, and a larger Europe as a culturally and historically defined social space, on the other. The distinction appears to resonate with quite a few chapters in this volume. As Laffan (2004) points out, European institutions - both the EU and the Council of Europe - deliberately try to construct a postnational civic identity in the Habermasian sense (Habermas 1994, 1996; Dewandre and Lenoble 1994), emphasizing democracy, human rights, a market economy, the welfare state, and cultural diversity. These values have become constitutive for the EU, since one cannot become a member without subscribing to them (from the Copenhagen criteria onward). As the enlargement debates show, the self-description of the EU and the dominant discourses surrounding it have moved quite a long way toward building a polity and going beyond simple market integration (see also Laffan, O'Donnell, and Smith 2000). Wodak's (2004) data appear to corroborate the point, even though her findings suggest that European elite groups orient toward both civic and cultural components of European identity.

But does this civic understanding of European identity resonate with European citizens? If Bruter's (2004) findings were generalizable, the answer would be yes. But Eurobarometer data, unfortunately, do not allow for distinguishing between cultural and civic understandings of European identity. Citrin and Sides (2004) present some evidence in their chapter that is at least consistent with Bruter's findings from his pilot studies with student groups. Education, income, and ideology all have a positive impact on levels of attachment to Europe. Moreover, attachment to Europe is strongly correlated with support for the EU and willingness to cede authority and sovereignty to EU institutions in various policy domains. Finally, the more people identify with Europe, the less xenophobic and the more positive toward Eastern enlargement they are. Hostility toward immigrants, in contrast, correlates strongly with exclusively national identifications. These findings support Laffan's (2004) rather optimistic statement that the EU has occupied the social identity space of "Europe" and that the substance of "Europe" contains more and more understandings consistent with a civic identity.

She also points out that the social construction of EU identity as put forward by EU institutions points to moral values such as democracy, human rights, and the like, as well as a commitment to the rule of law. A recent study of European discourses in the public sphere corroborates her argument. The debate about Jörg Haider and his populist party's entry into the Austrian government in 2000, as well as the EU reaction to it, was framed in terms of the values that hold the EU together. "Europe" was constructed as both a moral and a legal community, and the EU "sanctions" against Austria were discussed in terms of whether they were consistent with European identity (for evidence see Van de Steeg et al. 2003; Risse 2003b). 
Whether these data are generalizable remains to be seen. On the one hand, there is the evidence, reported above, that Europeans distinguish between cultural and civic aspects of their Europeanness, with the former attached to "Europe" as a whole and the latter to the EU in particular. On the other hand, if the EU increasingly defines "Europe" in civic political terms, this would gradually become the dominant view of what it means to be European. This latter claim, if corroborated by further research, would lead to a quite dramatic conclusion regarding the impact of forty years of European integration on identity constructions in Europe, the guiding question of this volume. Not only would the EU increasingly define what it means to be "European," it would also fill "Europeanness" with distinct postnational civic and liberal values, as far as its substance is concerned. European integration would have led to a quite dramatic reconstruction of European identity.

These optimistic conclusions have to be taken with a grain of salt, though. Mummendey and Waldzus, on the one hand, and Meinhof, on the other, see quite different dynamics at work, which are not easily reconcilable with the liberal interpretation of what Europe means to its citizens (Mummendey and Waldzus 2004; Meinhof 2004).

\section{Europe's multiple others and the in-group projection model}

Social identities not only describe the content and the substance of what it means to be a member of a group. They also describe the boundaries of the group, that is, who is "in" and who is "out" (see Herrmann and Brewer 2004). As a result, we can infer quite a bit about the substance of European identity if we know more about the European Others. The first problem we encounter in this context concerns Europe's “fuzzy boundaries." As Castano points out in his contribution (2004), clear boundaries are an important ingredient of entitativity as a precondition of identification. But where does Europe end? A quick look at those international organizations that carry "Europe" in their name shows that there is no uniform answer to the question. Europe is characterized by overlapping and unclear boundaries. The EU itself currently ends at the former East-West border of the cold war, but will expand considerably toward the east and southeast starting in 2004. At the EU Helsinki summit in December 1999, Turkey was given an accession perspective, too. The European Economic and Monetary Union (EMU) with the single currency, encompasses twelve of the fifteen EU member states. The European Single Market, which includes the European Economic Area, encompasses some non-EU members such as Norway. "Schengenland," with its absence of internal border controls, has even more complicated borders, since it includes Norway, but not the EU member Great Britain. Consider the following: if you travel by car from Germany via France and Spain to Portugal, you never have to show your passport and you retain one single currency, the euro. However, if you travel by car and by boat from Germany via Denmark to Norway, you leave the euro-zone at the German-Danish border, and the EU at the Danish-Norwegian border, but you never have to show your passport because of Schengenland. These are unclear boundaries par excellence. 
Other European political organizations have even broader definitions of "Europe." The Council of Europe, for example, includes the Ukraine and Russia. The same is true of the security area for the Organization for Security and Cooperation in Europe (OSCE), which has the United States and Canada among its members. The OSCE "Europe" ranges from San Francisco and Vancouver all the way to Vladivostok.

In sum, "Europe" as a space of political organization and institutionalization has no clear boundaries. What about the social meanings and understandings of "Europe"? There is surprisingly little in the various chapters on the constructions of European Others. Meinhof's chapter (2004) strongly suggests that Othering still takes place along the old cold war border, including the former border between East and West Germany. Her interviewees showed strong and hostile feelings toward their fellow citizens in the immediate eastern neighborhood. This was particularly significant among young people who had little personal experience with the Eastern "foreigners," thus corroborating findings from research about stereotyping, according to which lack of contact increases negative stereotypes. In these interviews then, "Europe" is still identified with "Western" Europe, while the East continues to represent the European Other.

Yet, one should not forget that strong Othering is context dependent. Just as there is no fixed assessment of what Europe constitutes positively, there are no fixed European Others. In the context of Meinhof's (2004) interviews, which specifically examined border communities, it is not too surprising that the "East" is represented as a threatening European Other. In a different social context, such as EU Committees on Employment and Social affairs (see Wodak 2004), the United States and Japan are repeatedly referred to as the European out-group. Here, the discourse centers around the European social model, which is represented as distinct from both the American and Japanese systems of welfare states. In yet another political context, the German discourse on European integration, we found that Germany's own past of militarism and nationalism constituted the European Other against which the European integration project was to be built (Risse 2001; Risse and Engelmann-Martin 2002; Engelmann-Martin 2002). In a similar way, the recent European-wide controversy about the ascent to power of a right-wing party in Austria constructed the out-group as some sort of enemy within, since nobody denied that Austria was a legitimate member of the EU (Van de Steeg et al. 2003). The issue was whether European values of democracy and human rights were consistent with the rise to power of a xenophobic party that did not distance itself sufficiently from the European Nazi past. In sum, Europe has many Others that are referred to and represented in a contextdependent way. This does not mean at all that anything goes, but it warns us not to reify the concept of European identity and to fix its meaning once and for all (see also Siapera's chapter, this volume, demonstrating that the meaning of Europe varies considerably depending on the discursive context).

Finally, Mummendey and Waldzus's (2004) in-group projection model contradicts those who assume that the more citizens identify with Europe, the more they will be tolerant and sympathetic to fellow Europeans. The in-group projection 
model suggests that this is highly conditional on the complexity with which Europe is presented. Citizens who project their own values on Europe and then identify with their "national" Europe tend to be less tolerant with fellow Europeans. If, for example, German understandings of "Europe" and the EU largely conform to visions of German social and political order, this might lower rather than increase German tolerance of Italians. The German discourse on the euro and the convergence criteria was a case in point. Since the euro was presented to a skeptical German public as the Deutsche Mark writ large, the Italian lira as the symbol of a weak currency was not supposed to join the euro-zone almost by definition. Of course, Germans were in for a surprise when Italy qualified for the EMU (see Sbragia 2001).

At first glance, the evidence presented by Mummendey and Waldzus (2004) and by Meinhof (2004) contradicts the liberal cosmopolitan picture painted by Laffan's (2004), Bruter's (2004), and Citrin and Sides's (2004) chapters, according to which identification with Europe increases tolerance for foreigners and decreases xenophobia. But Mummendey and Waldzus (2004) point out that the degree of in-group projection depends on the complexity with which the superordinate identity (Europe in this case) is presented. A Europe that is simply Germany or France writ large might invite in-group projection, while a civic representation of Europe in the Habermasian sense would work against it. One possible way to solve the apparent contradiction would be to point out that the more Europe is identified in civic rather than cultural-ethnic terms (see Citrin and Sides 2004; Bruter 2004) and the more cultural diversity is emphasized (cf. Laffan's references to identity pointers in EU documents, Laffan 2004), the less in-group projection might play a role. We could also assume that the high correlation between income, education, and liberalism, on the one hand, and identification with Europe, on the other, might mitigate against in-group projection (Citrin and Sides 2004). In this case, however, it remains unclear whether it is European identity as such that works against in-group projection, or the liberal and cosmopolitan values that higher educated people are more likely to hold. People holding liberal values might also be less xenophobic and, therefore, feel more European. These possibilities of how the various attitudes relate to each other and coevolve suggest that it is far from clear which causal mechanisms are at work here and what accounts for what.

The somewhat contradictory findings lead to another issue, namely that European integration has been an elite-driven project so far and that, therefore, the identity changes toward a liberal civic identity are largely confined to the elite level.

\section{Elites, masses, and the psychological existence of the European Union}

In general, the chapters confirm that the EU is an elite-driven project - similar to other nation-building projects. No wonder that identification with and support for Europe and its institutions is highest among political and social elites. 
Eurobarometer data demonstrate an enormous gap between elite support (in fact, elite consensus) for the EU, on the one hand, and widespread skepticism among the larger public, on the other. According to 1998 data, European elites supported EU membership almost unanimously ( 94 percent mean across the EU fifteen), while only a bit more than 50 percent of the mass public endorsed membership of their own country. Countries with the largest gaps between mass public and elite support for EU membership include Germany, Austria, Sweden, Belgium, Spain, Finland, and the United Kingdom (Spence 1998). Of course, these data do not measure identification with Europe, but support for the EU. But since attachment to Europe and support for integration covary, we can safely assume that identification with Europe among the elites is also higher than among the citizens, who rank Europe and the EU a distant second (or third after regional identification; cf. Citrin and Sides 2004).

Yet, European and national identities are not zero-sum propositions, and citizens can negotiate strong national identities and some secondary identification with Europe. Moreover, Citrin and Sides point to a quite dramatic change during the 1990s. From 1991 to 2000, the number of those who felt attachment to their nation-state only declined by almost 20 percent across the EU fifteen, while the percentage of those who perceived some sense of belonging to their nation-state and to Europe increased by about the same number. The greatest increase in dual identification took place in Portugal and, interestingly enough, Germany, while Greece is the only outlier with no change at all. These developments are quite interesting, since support for EU membership and perceived benefits from EU membership - the latter being the main indicator for "utilitarian" evaluations of the EU - declined during the 1990s (Citrin and Sides 2004). At the same time, the correlations between identification with and attachment to Europe, on the one hand, and support levels for the EU as well as perceived benefits from EU membership, on the other hand, grew stronger.

How can we explain these developments, both the difference between elite and mass identification with Europe and the change during the 1990s? I suggest that the social psychological concept of entitativity is key (see Castano 2004). "Entitativity" refers to the reification of a community resulting from increasingly shared cultural values, a perceived common fate, increased salience, and boundedness, which then lead to collective identification. Castano points out, though, that the increased salience of a community in people's lives does not necessarily increase support for the community; it could also result in growing rejection. Different levels of entitativity could well explain the enormous difference between elite and mass identification with Europe and the EU. The EU is certainly very real for Europe's political, economic, and social elites. Whoever is doing business in Europe has to constantly be aware of and refer to EU rules and regulations. Policy makers and government officials on all levels of governance spend a considerable amount of their daily time dealing with the EU (Wessels 2000; Rometsch and Wessels 1996). In other words, the EU has a real psychological existence for the European political, social, and economic elites, as a result of which their sense of belonging is also rather high. 
For the citizens, the EU is still a more distant community than the nation-state, despite the fact that EU rules and regulations cover almost every political issue area by now. There are at least three reasons for this relating to the concept of entitativity. First, while EU law is the law of the land, has direct effects, and overrides national law, EU authorities do not implement European rules and regulations, but national and subnational authorities do. Thus, when citizens are confronted with, say, environmental regulations in their daily lives, they do not even know that these are EU rules more often than not. The salience of the EU is rather low, even if the EU affects the citizens' lives on a daily basis. Second, "Europe" has fuzzy boundaries. While there are plenty of indicators telling me that I have left Germany, it is unclear when I have left Europe. Having to show my passport is certainly not a valid indicator, as I argued above regarding the funny boundaries of Schengenland. The same holds for the euro-zone of the single currency, which now encompasses twelve of the fifteen EU member states.

Last but not least, the elite discourses in most EU member states about the EU are ambivalent at best when it comes to "shared values" and "common fate." On the one hand, there is the conscious identity construction of a liberal and civic community emanating from the EU and its various institutions (for the latest effort see Commission of the European Communities 2001; see also Laffan 2004). On the other hand, national policy makers routinely reify the nation-state in their dealings with Brussels. Whenever they can charge the EU with the responsibility for some tough decision at home, they adopt a populist rhetoric of conscious blame shifting ("Brussels made me do it") and construct EU institutions as remote bureaucracies that cannot be trusted (in contrast to national governments, of course). At the same time, whenever the EU succeeds in solving a commonly perceived problem, national policy makers take the credit in front of national media. Few citizens know, for example, that the liberalization of telecommunication markets, slashing people's telephone bills across Europe during the last ten years, was actually due to EU initiatives. The ambivalent position taken by the media certainly does not help to increase the psychological existence of the European Union. As Siapera (2004) points out, journalists in Brussels who routinely report about the EU hold multiple affiliations and see their professional role in ways that add to the ambivalent and fuzzy picture of the EU emanating from the mass media.

In sum, it is probably safe to argue that the EU as a community still lacks the psychological existence that is a condition for collective identification among its citizens. At the same time, things seem be changing, the more Europe hits home. The change in sense of attachment to Europe reported by Citrin and Sides (2004) could well result from an increasing reality of the EU in people's daily lives. The single market and Schengenland, for all their fuzziness, have increased the entitativity of the EU. The introduction of the euro bills and coins has already left its mark on citizens' awareness of the EU. Eurobarometer data show that the euro has quickly become the second most salient identity marker for the European Union (details in Risse 2003a). The advent of the euro is a huge social science experiment. If Castano (2004) and others are right, we should observe an increase 
in identification with Europe in the years to come - with both the single currency and EU enlargement.

\section{The EU and identity change}

So far, I have mostly dealt with the chapters' findings concerning individuals' attachment to Europe in relation to their other collective identities. In social science jargon, I have discussed what we seem to know about the "dependent variable" of this volume. Yet, the purpose of this book is not only to describe the degree to which citizens - elites and masses alike - identify with the EU and with Europe in general, but to explain identity change resulting from more than forty years of European integration. Do the European institutions affect collective identities? Do they lead to a greater sense of belonging to Europe? And if so, what are the mechanisms of identity change?

Unfortunately, our knowledge about the effects of the EU on collective identity allows for only tentative conclusions. There are two stories about identities and institutions, as mentioned in the introduction to this volume. The first - rationalist story exogenizes identities and interests in the institution-building process. As a result, one would expect institutions to have little impact on identities. In EU studies, the most prominent approach in this regard is liberal intergovernmentalism (e.g., Moravcsik 1998). Economic interdependence leads to changes in actors' preferences in favour of international cooperation. The preferences are aggregated by national governments, which then negotiate binding agreements and institutions to insure credible commitments. This story leaves little space for institutional feedback effects on actors' preferences, let alone identities. We can treat it as the "null hypothesis" for this book.

The second - constructivist - story endogenizes identities/interests and institutions. Accordingly and over time, institutions become part and parcel of the social and power structure that forms the social environment in which people act. Institutions tend to have constitutive effects on corporate actors such as national governments and interests groups, but also on individuals. Since people act in an environment structured by the institutions, the latter affect their interests, preferences, and collective identities. We should then expect identities and institutions to coevolve, with the causal arrows between the two pointing in both directions. The EU should be no exception. It might well have been created to serve specific interests based on given identities. But this would be the beginning, not the end, of the story. Over time, we would expect a complex cotransformation of the EU together with people's identities and interests.

What do our authors tell us about these two stories? Once again, we need to distinguish between the level of political, economic, and social elites in Europe and that of ordinary citizens, because of the difference in psychological existence that the EU has for the two groups. As to the elites, various chapters in this volume demonstrate that the EU as an institution has had a clear impact on actors' collective identities. On the deepest, constitutive level, Laffan (2004) argues, the EU increasingly defines state identity in Europe. There are no "neutral" states 
in Europe anymore vis-à-vis the EU. You are either in, almost in, or you are out. EU membership is a constitutive feature of statehood in Europe defining the social and institutional space in which nation-states act in Europe. As Sandholtz put it years ago, "membership matters" (Sandholtz 1996; see also Laffan, O'Donnell, and Smith 2000). In short, the EU increasingly is Europe.

This is a dramatic finding. If the EU defines what it means to be European, the European integration process has left its marks on the deepest levels of state- and nationhood in Europe. It has done so within only forty years and entirely peacefully. This disconfirms the notion that community building and nation building are inherently linked to war making (Tilly 1975, 1985). Forty years later, we can confirm the success of what the founders of the European Community set out to do - to create a European peace order that redefines European statehood after centuries of wars and nationalism. Moreover, our findings substantiate empirically the Habermasian vision of a postnationalist European identity and statehood (Habermas 1994, 1996). The chapters in this volume, particularly those by Laffan (2004), Bruter (2004), and Citrin and Sides (2004), demonstrate that Europeanness as "EU-ness" centers around a civic identity of liberal values such as human rights, democracy, a market economy, and the welfare state.

Apart from these constitutive effects, European institutions also have a concrete impact on those working in and dealing with them. Laffan (2004), Wodak (2004), and Siapera (2004) demonstrate in their chapters how different types of institutions and different types of social (or discursive) contexts create different (role) identities relating to these institutions (see also Checkel, 1999a). The European Commission as the "guardian of the treaties" portrays an image and selfunderstanding of strong identification with Europe and European integration as its dominant role identity. In contrast, the Council of Ministers and COREPER favor "double hatting" as the dominant role identity. Officials at COREPER need to be "janus-faced" (Lewis 1998b) in the sense of identifying with and representing their nation-state, but at the same time working toward a common European perspective for problem solving. Last but not least, the European Parliament (EP), as well as the working environment of journalists in Brussels, creates cross-cutting triple identities. EP members have to negotiate between their national identity, their Europeanness, and their party affiliation (see also Wodak 2004), while journalists' professional identity interacts in various and context-dependent ways with their Europeanness and their national role identities (Siapera 2004).

These chapters show that the different settings of EU institutions shape the role identities of actors involved in them in distinct ways. In contrast, the impact of the EU on identity changes among the European citizens is expected to be much more diffuse. We cannot assume that people differentiate clearly between, say, the European Commission and the European Parliament, and that these institutions affect their daily lives in distinguishable ways, leading to differences in ways of identification, as is the case on the level of elites. But does this imply that we have to accept the null hypothesis that the EU has had no impact on the social identities of citizens? 
Breakwell and Meinhof come closest to such a view (Breakwell 2004; Meinhof 2004). Breakwell emphasizes the emptiness of Europe as a category, as a result of which it should play little or no role in shaping personal identities. But she also points out that the EU and its institutions should have a differential impact on nation-state identities. Meinhof found references to Europe and the EU only if the interviewer explicitly pointed people in this direction.

Bruter's (2004) chapter presents a methodology by which we could measure and specify the identity-shaping impact of EU institutions better than the current survey instruments allow. His distinction between a civic and a cultural European identity allows us to differentiate between identification with Europe in general, on the one hand, and with the EU as a political institution, on the other. The evidence reported by Citrin and Sides (2004) is at least consistent with his interpretation. If Bruter's findings were generalizable across larger populations, we could conclude that the EU indeed has had its distinct identity-shaping and constitutive effects on both elites and ordinary citizens. Yet, we need a lot more empirical research to make conclusive statements. ${ }^{1}$

Two factors appear to mitigate between EU institutions, on the one hand, and the identification with the EU among citizens, on the other. First and once again, the psychological existence of the EU should play a role (Castano 2004). The more the social context in which people act is remote from or disaffected by the EU, the less people should identify with it in that context. The fuzziness and unboundedness with which the EU is often presented in the national media discourses is likely to matter here, too. While the experiments reported in Castano's chapter portrayed "Europe" in overall positive terms as common fate, the media representation of the EU is much more ambivalent, if not outright negative in many instances. No wonder, then, that people with moderate levels of support for the EU have difficulty perceiving it as an entitative community. In sum, the variation in entitativity explains to a large extent the different levels of identification with the EU by the elites, on the one hand, and ordinary citizens, on the other.

Second, "Europe" and European integration resonate in different ways with historically and culturally embedded understandings of the nation-state and of national sovereignty (Breakwell 2004; see also Risse 2001). In the German and French political and intellectual discourses, including the media, Europe has become part and parcel of what it means to be German or French these days. This is very different from the British discourse, in which a stark contrast has been constructed and is being reified between what it means to be "English," on the one hand, and "European," on the other. Here, Europe is still the - albeit friendly - Other, that is, the Continent (see Knopf 2002). One would assume that the EU's impact on collective identities varies significantly according to the degree to which Europe is embedded in the collective historical memory of citizens.

But what are the causal mechanisms by which the EU impacts on collective identities? The introduction by Herrmann and Brewer (2004) mentions three such mechanisms. Functional models assume that institutions almost automatically change 
people's perception of community and sense of belonging. Socialization concepts focus on actors' differential experiences with the institution and its consequences. Finally, persuasion models focus on institutions as identity-shaping agents. Deliberate efforts may be made to create collective identification through myths, symbols, or framing.

What do our findings suggest about these mechanisms? There is little evidence for a functional logic at play. Haas's idea that those elites who profit most from the union would gradually transfer their loyalty to supranational institutions seems to be disconfirmed (Haas 1958). Neofunctionalism's basic argument has been that European integration would lead to identity changes among those transnational interest groups benefiting from European integration. There is little evidence for such a mechanism. Farmers, for example, who arguably benefit most from the EU through the Common Agricultural Policy (CAP), are not particularly known for their enthusiasm for European integration. In more general terms, the data presented by Citrin and Sides (2004, particularly in table 8.3) show rather modest correlations between attachment to and identification with Europe, on the one hand, and individual perceptions of benefiting from the EU, even though this correlation grew stronger during the 1990s. The direction of the causal arrows also remains unclear from these data. One could, for example, turn the functional logic on its head and argue that strong identification with the EU leads to a sense of profiting from EU membership, rather than the other way round.

Socialization appears to be a better candidate for explaining the findings in various chapters. This is particularly true for those who are directly involved in the daily business of EU policy making, either in Brussels or in national capitals (see Laffan 2004; Siapera 2004; Wodak 2004; see also Egeberg 1999; Lewis 2000; Wessels 2000; Checkel, 1999a). Laffan's chapter in particular demonstrates that individuals working in EU institutions tend to adjust to the various "logics of appropriate behavior" (March and Olsen 1998) in these institutions. These officials have direct experience with the institutions and need to internalize their rules of appropriateness at least to some degree in order to be able to carry out their tasks. As a result, we expect them to develop a stronger sense of group identity with the EU than those who have less direct experience with its institutions.

Different degrees of socialization in terms of direct experience with the EU would also explain the huge gap between elite identification with Europe and that of the mass public. But the findings reported by Bruter (2004) and by Citrin and Sides (2004) are at least consistent with an interpretation that sees socialization dynamics at work. The ability of citizens to identify with the EU in terms of a civic and political identity and the reported increase in (secondary) identification with Europe and the EU during the 1990s could be explained on the basis of the socialization hypothesis. During the 1990s, the EU has become more visible in people's lives - from the single market to the single currency, Schengenland, Eastern enlargement, and, most recently, debates about institutional reform and the Constitutional Convention. At the same time, the EU has started portraying 
an image of itself as a political actor on the world scene going beyond pure market integration. The civic identity that Bruter (2004) finds in his data conforms precisely to the social construction that $\mathrm{EU}$ institutions try to convey to the citizens.

This leads to the third mechanism connecting institutions and social identities, persuasion. Persuasion does not constitute an alternative account to socialization, but complements it by emphasizing the active role of institutions as agents of identity construction. A complex picture emerges. On the one hand, the attempt by European leaders to deliberately construct the EU around civic and postnational values has made some inroads in people's perception of and identification with the EU. The growing visibility of the EU in people's lives is connected to a specific content and substance of European identity as civic and postnational, emphasizing liberal values of democracy, human rights, and the social market economy with a strong welfare state component. On the other hand, as mentioned above, the EU is often presented in the national discourses, including the media, in a rather fuzzy and contradictory manner. In other words, the homogeneity that Castano calls for as a prerequisite for psychological existence and identity building is clearly lacking (see also Breakwell 2004).

In sum, most chapters in this volume represent snapshots rather than long-term analyses of trends concerning European identity. As a result, we can only speculate about the mechanisms linking European institutions and identity change. The available evidence suggests, however, that further inquiry should probably pursue the investigation along the socialization and persuasion paths.

\section{Points of contention and methodological implications}

The authors in this volume share a social constructivist understanding of social identities, irrespective of disciplinary backgrounds. Even primordial and essentialist constructions of national or ethnic identities are just this - social constructions (for a recent discussion see Fearon and Laitin 2000). There is also general agreement that social identities imply distinctions between in-groups and outgroups, entail cognitive, evaluative, motivational, and affective components, and are evoked in a context-dependent manner in situations in which they become socially salient. It follows that individuals hold multiple identities, as a result of which we can reject zero-sum understandings of national or regional versus European identities (see above).

Yet, there are also points of theoretical contention represented in this volume resulting from the different disciplinary, metatheoretical, and methodological backgrounds of our authors. Two controversial issues need to be discussed here. First, how stable or fluid are social identities? On the one hand, data from mass opinion surveys (Bruter 2004; Citrin and Sides 2004) and from psychological experiments (Castano 2004; Mummendey and Waldzus 2004) imply a fundamental stability of identification processes. Otherwise, these data could not be used for descriptive and/or causal inferences about European identity. On the other hand, Meinhof (2004) and Siapera (2004), who use discourse 
analysis, emphasize the fluidity of social identities, including European identity. In Siapera's case, for example, journalists' identification with Europe seems to vary from one discursive context to the next. Meinhof's data reveal that citizens referred to Europe only when interviewers specifically pointed to it. She argues that people do not relate spontaneously to Europe and that they do so only when triggered by stimuli.

Does this imply that the identification processes found in mass survey data are statistical artifacts, at least on the level of ordinary citizens? Does it imply that the findings reported in this volume are methodology driven in the sense that whether we find European identity or not depends on the method chosen? I do not think so. One way to reconcile the different findings from survey data as compared to discourse analysis is to point to the context dependency of social identities. If social identities, including European identities, are invoked in a context-dependent way wherever they become salient (and if only triggered by certain stimuli), they might appear rather fluid, but only at first glance. In fact, multiplicity, stability, and context dependency of social identities can easily go together. Thus, what appears on the surface as fluid and forever malleable might actually be pretty stable inside, and "identity change" might be simply a question of changing the social contexts in which different layers of an individual's multiple identities become salient. When my gender identity is invoked, my Europeanness might well recede into the background, and vice versa. Siapera's data, for example, are consistent with an interpretation that journalists identify with Europe to varying degrees, depending on the social and political context in which this identification becomes salient or not. This is confirmed by Wodak's findings (2004); she also uses discourse analysis, but shows rather stable identity patterns between the groups investigated. Last but not least, Meinhof's data (2004), with almost nonexisting references to a common European fate, might be explicable on the grounds that she studied border communities in which the overwhelming salience of the self/Other distinction outweighs all other identification processes.

A second issue of contention in this volume concerns the "depth" of identification with Europe found in the various chapters. To what degree does identification with Europe imply loyalty to the EU defined as willingness to pay a price for one's identity? What happens when European policies and requirements conflict with national policies and traditions? There is little in the chapters of this volume enabling us to measure with some degree of certainty the potential costs attached to one's proclaimed identity. On the one hand, the findings of Laffan's and Wodak's chapters, for example, are consistent with a concept of role identities according to which actors know the rules of appropriateness attached to their professional institution. These findings do not necessarily imply a deep sense of loyalty to the institution. On the other hand, the survey data reported in this volume try to figure out the degree to which people negotiate between their national/regional and their European identities. This implies that people have a sense of loyalty to their respective communities, at least to some extent (see Citrin and Sides 2004, on attachment to Europe). 
Whether survey data succeed in tapping into people's loyalty toward the EU is an altogether different matter. We know little with regard to whether people who say they identify with Europe are also prepared to pay a price for their sense of belonging. This points to an important area of future research. ${ }^{2}$

\section{Instead of conclusions: Why bother? European identity and the European polity}

This volume concentrates, first, on describing the degree to which European elites and citizens identify with and feel attached to Europe and the EU in its various dimensions and how this sense of European identity compares to other identifications that people might hold. Second, we try to explain the evolution of European identity over more than forty years of European integration and institutional buildup, and how it has led to an increased salience and psychological existence of the EU in the lives of elites and ordinary citizens.

But why bother? Political scientists are less inclined to study social identities per se unless it can be shown that they matter somehow with regard to political outcomes. Does it make a difference to have demonstrated in this volume that elites and ordinary citizens alike increasingly identify with Europe in conjunction with their sense of loyalty to national or subnational communities, and that the EU increasingly defines and constitutes what it means to be European?

In general, political scientists and practitioners alike see a clear link between identity and a functioning political order. Accordingly, a democratic polity requires the diffuse support of the citizens in order to be legitimate. Identification with a political order is seen as a source of diffuse support and, thus, of legitimacy. The higher the sense of loyalty toward a political community among the citizens, the more they are prepared to accept inconvenient decisions and policies of their governments, that is, to pay a price for their identity. Europe as a polity should be no exception. Yet, conventional wisdom holds that the evolving European political order lacks a demos, mainly because there is neither European identity nor a European public sphere (Kielmansegg 1996; Scharpf 1999, 167). While this volume does not address the latter issue (but see Eder, Hellmann, and Trenz 1998; Eder and Kantner 2000; Kantner 2002; Van de Steeg et al. 2003), the chapters strongly challenge the notion that there is no significant European identity on which to build a European polity.

To put it bluntly, this volume and other contributions to the state of the art of European identity show an emerging European demos. Yet, the European polity does not require a demos that replaces national with European identities, but one in which national and European identities coexist. Europeanization, European integration, and European identities coevolve over time, at both the elite and the mass levels. The causal arrows between European integration and institution building, on the one hand, and the evolution of European identities, on the other, seem to run both ways. The increasing psychological existence ("entitativity") of the EU in people's daily lives seems to affect their identification with Europe as a political community. At the same time, support for European integration 
and attachment to Europe appear to be closely related, motivating European elites to continue on the path of institution building. A study on elite support for and opposition to the single currency revealed that the variation in national attitudes toward the euro can be explained by differences in European identity among these elites (Risse et al. 1999; Risse 2003a; see also Banchoff 1999).

While the European polity seems to coexist and coevolve with a growing sense of European identity, overly optimistic statements should also be avoided on the basis of our findings. We still know little about the precise causal relationships and mechanisms between European integration, on the one hand, and European identity, on the other. This volume - and the ever-increasing literature on European identity in general - is much better at describing the degree to which people feel attached to Europe and the EU than at explaining the development of a European identity and linking it to the evolution of European institutions. The causal pathways identified here - institutionalization, socialization, and persuasion - are far from specified. We can only hint at some of the reasons for the enormous variation in the sense of belonging to Europe revealed in our data. Finally, our findings suggest that European and national identities can go together and giving up one's loyalty to the nation is not required for a European demos. But we know little about those social and political contexts in which European and national identities might actually clash.

Despite these limitations, our volume demonstrates how much progress has been made in recent years in research on European identity and its relationship to other social identities that people hold. We show from a multidisciplinary perspective that the sense of attachment to the EU among Europeans is continuously increasing, leading to an emerging European demos as the democratic underpinning of the European polity. The available evidence shows that there is an increasing sense of community among European citizens, elites and ordinary people alike. The EU represents a genuine community of fate for the political, economic, and social elites in Europe, and it essentially defines modern statehood in Europe for them. Among the citizens, identification with and attachment to Europe has also grown in recent years, while exclusive loyalties to the nation-state are in decline. The EU is understood as a civic community, as distinct from cultural understandings of Europe in general. Given this state of affairs, the future of an enlarged European Union appears less gloomy than many observers seem to think.

\section{Notes}

I thank Tanja Börzel, Marilynn Brewer, Richard Herrmann, and an anonymous reviewer for critical comments on the draft, and the participants in the joint project of the Robert Schuman Centre of Advanced Studies and the Mershon Center for clarifying my views on the subject. Many insights developed in this chapter also stem from discussions at the 1999-2001 European Forum, "Between Europe and the Nation-State," of the European University Institute. Finally, I thank the students of the postgraduate program on European studies in Berlin for their critical comments.

1 Bruter is currently directing a Europe-wide research program in this area that is funded by the Commission's Fifth Framework Programme on Socio-Economic Research. 
2 A final point of contention concerns the apparent contradiction between the in-group projection model presented by Mummendey and Waldzus (2004) and the Eurobarometer data, according to which identification with Europe correlates with tolerance for foreigners and immigrants and decreases xenophobia (Citrin and Sides 2004). See above for a discussion.

\section{References}

Anderson, Benedict. 1991. Imagined Communities. Reflections on the Origin and Spread of Nationalism. London: Verso.

Banchoff, Thomas. 1999. German Identity and European Integration. European Journal of International Relations 5 (3): 259-289.

Breakwell, Glynis M. 2004. Identity Change in the Context of Growing Influence of European Union Institutons. In Transnational Identities: Becoming European in the $E U$, edited by Richard K. Herrmann, Thomas Risse, and Marilynn Brewer. Lanham, MD: Rowman \& Littlefield, 25-9.

Bruter, Michel. 2004. Civic and Cultural Components of a European Identity: A Pilot Model of Citizens Level of European Identity. In Transnational Identities: Becoming European in the EU, edited by Richard K. Herrmann, Thomas Risse, and Marilynn Brewer. Lanham, MD: Rowman \& Littlefield, 186-213.

Castano, Emanuele. 2004. European Identity: A Socio-Psychological Perspective. In Transnational Identities: Becoming European in the EU, edited by Richard K. Herrmann, Thomas Risse, and Marilynn Brewer. Lanham, MD: Rowman \& Littlefield, 40-58.

Checkel, Jeffrey T. 1999a. International Institutions and Socialization. Working Paper, 5. Oslo: ARENA, University of Oslo, February.

. 1999b. Social Construction and Integration. Journal of European Public Policy 6 (4).

Citrin, Jack, and John Sides. 2004. More than Nationals: How Identity Choice Matters in the New Europe. In Transnational Identities: Becoming European in the EU, edited by Richard K. Herrmann, Thomas Risse, and Marilynn Brewer. Lanham, MD: Rowman \& Littlefield, 161-185.

Commission of the European Communities. 2001. European Governance: A White Paper. Brussels: July 25.

Dewandre, N., and J. Lenoble, eds. 1994. Projekt Europa. Postnationale Identität: Grundlage für eine europäische Demokratie. Berlin.

Duchesne, Sophie, and Andre-Paul Frognier. 1995. Is There a European Identity? In Public Opinion and Internationalized Governance, edited by Oskar Niedermayer and Richard Sinnott. Oxford: Oxford University Press.

Eder, Klaus. 1998. Von der Herausbildung europäischer Elitenöffentlichkeit zur Europäisierung nationaler Öffentlichkeit. Bedingungen und Wirkungen einer Expansion von Öffentlichkeit in Europa. Antrag an die Deutsche Forschungsgemeinschaft, Münchner Projektgruppe für Sozialforschung e.V. Humboldt Universität zu Berlin, München, Berlin.

Eder, Klaus, Kai-Uwe Hellmann, and Hans-Jörg Trenz. 1998. Regieren in Europa jenseits öffentlicher Legitimation? Eine Untersuchung zur Rolle von politischer Öffentlichkeit in Europa. In Regieren in entgrenzten Räumen. PVS-Sonderheft, edited by Beate KohlerKoch. Opladen: Westdeutscher Verlag.

Egeberg, Morton. 1999. 'Transcending Intergovernmentalism.' Identity and Role Perceptions of National Officials in European Decision-Making. Journal of European Public Policy 6 (3): 456-474. 
Eisenstadt, Shmuel N., and Bernhard Giesen. 1995. The Construction of Collective Identity. European Journal of Sociology 36: 72-102.

Fearon, James D., and David D. Laitin. 2000. Violence and the Social Construction of Ethnic Identity. International Organization 54 (4): 845-877.

Gallup Europe. 2001. Flash Eurobarometre 92 “Gouvernance”. Report, Brussels: Janvier Fevrier 2001.

Haas, Ernst B. 1958. The Uniting of Europe: Political, Social, and Economic Forces 1950-57. Stanford, CA: Stanford University Press.

Habermas, Jürgen. 1994. Staatsbürgerschaft und nationale Identität. In Projekt Europa. Postnationale Identität: Grundlage für eine europäische Demokratie, edited by N. Dewandre and J. Lenoble. Berlin.

1996. Der europäische Nationalstaat - Zu Vergangenheit und Zukunft von Souveränität und Staatsbürgerschaft. In Die Einbeziehung des Anderen, edited by Jürgen Habermas. Frankfurt/Main: Suhrkamp.

Herrmann, Richard K., and Marylinn Brewer. 2004. Identities and Institutions: Becoming European in the EU. In Transnational Identities: Becoming European in the EU, edited by Richard K. Herrmann, Thomas Risse, and Marilynn Brewer. Lanham, MD: Rowman \& Littlefield, 1-22.

Kielmansegg, Peter Graf. 1996. Integration und Demokratie. In Europäische Integration, edited by Markus Jachtenfuchs and Beate Kohler-Koch. Opladen: Leske \& Budrich, 47-71.

Laffan, Brigid. 2004. The European Union and Its Institutions as 'Identity Builders'. In Transnational Identities: Becoming European in the EU, edited by Richard K. Herrmann, Thomas Risse, and Marilynn Brewer. Lanham, MD: Rowman \& Littlefield, 75-96.

Laffan, Brigid, Rory O’Donnell, and Michael Smith. 2000. Europe's Experimental Union. Rethinking Integration. London: Routledge.

Lewis, Jeffrey. 1998a. Constructing Interests: The Committee of Permanent Representatives and Decision-Making in the European Union. PhD. dissertation, Department of Political Science, University of Wisconsin-Madison, Madison WI.

- 1998b. Wearing a Janus-Face: The Permanent Representatives of the European Union. Paper presented at Eleventh International Conference of Europeanists, at Baltimore MD.

- 2000. The Method of Community in EU Decision-Making and Administrative Rivalry in the Council's Infrastructure. Journal of European Public Policy 7 (2): 261-289.

March, James G., and Johan P. Olsen. 1998. The Institutional Dynamics of International Political Orders. International Organization 52 (4): 943-969.

Marcussen, Martin, Thomas Risse, Daniela Engelmann-Martin, Hans-Joachim Knopf, and Klaus Roscher. 1999. Constructing Europe. The Evolution of French, British, and German Nation-State Identities. Journal of European Public Policy 6 (4): 614-633.

Martinotti, Guido, and Sonia Steffanizzi. 1995. Europeans and the Nation-State. In Public Opinion and Internationalized Governance, edited by Oskar Niedermayer and Richard Sinnott. Oxford: Oxford University Press, 163-189.

Meinhof, Ulrike. 2004. Europe Viewed From Below: Agents, Victims, and the Threat of the Other. In Transnational Identities: Becoming European in the EU, edited by Richard K. Herrmann, Thomas Risse, and Marilynn Brewer. Lanham, MD: Rowman \& Littlefield, 214-244.

Moravcsik, Andrew. 1998. The Choice for Europe: Social Purpose and State Power From Rome to Maastricht. Ithaca NY: Cornell University Press.

Mummendey, Amelie, and Sven Waldzus. 2004. National Difference and European Plurality: Discrimination and Tolerance Between European Countries. In Transnational 
Identities: Becoming European in the EU, edited by Richard K. Herrmann, Thomas Risse, and Marilynn Brewer. Lanham, MD: Rowman \& Littlefield, 59-72.

OPTEM. 2001. Perceptions de l'Union Europeenne. Attitudes et attentes a son egard. Etude qualitative aupres du public des 15 Etats membres et de 9 pays candidats a l'adhesion. Versailles: Commission Europeenne, Mars 2001.

Risse, Thomas. 2001. A European Identity? Europeanization and the Evolution of NationState Identities. In Transforming Europe. Europeanization and Domestic Change, edited by Maria Green Cowles, James A. Caporaso and Thomas Risse. Ithaca, NY: Cornell University Press, 198-216.

Risse, Thomas, and Daniela Engelmann-Martin. forthcoming. Identity Politics and European Integration: The Case of Germany. In The Idea of Europe, edited by Anthony Pagden. Cambridge: Cambridge University Press.

Risse, Thomas, Daniela Engelmann-Martin, Hans Joachim Knopf, and Klaus Roscher. 1999. To Euro or Not to Euro. The EMU and Identity Politics in the European Union. European Journal of International Relations 5 (2): 147-187.

Rometsch, Dietrich, and Wolfgang Wessels, eds. 1996. The European Union and the Member States: Towards Institutional Fusion? Manchester and New York: Manchester University Press.

Sandholtz, Wayne. 1996. Membership Matters: Limits of the Functional Approach to European Institutions. Journal of Common Market Studies 34 (3): 403-429.

Sbragia, Alberta. 2001. Italy Pays for Europe: Political Leadership, Political Choice, and Institutional Adaptation. In Transforming Europe. Europeanization and Domestic Change, edited by Maria Green Cowles, James A. Caporaso and Thomas Risse. Ithaca, NY: Cornell University Press, 79-98.

Scharpf, Fritz W. 1999. Regieren in Europa. Frankfurt/M.: Campus.

Siapera, Eugenia. 2004. EU Correspondents in Brussels: Between Europe and the Nation-State. In Transnational Identities: Becoming European in the EU, edited by Richard K. Herrmann, Thomas Risse, and Marilynn Brewer. Lanham, MD: Rowman \& Littlefield, 129-157.

Spence, Jacqueline M. 1998. The European Union. "A View from the Top" - Top Decision Makers and the European Union. Report, Wavre: EOS Gallup Europe.

Tilly, Charles. 1975. The Formation of the Nation State. Princeton, NJ: Princeton University Press.

1985. War Making and State Making as Organized Crime. In Bringing the State Back In, edited by Peter B. Evans, Dietrich Rueschemeyer and Theda Skocpol. Cambridge: Cambridge University Press.

Wessels, Wolfgang. 2000. Die Öffnung des Staates. Modelle und Wirklichkeit grenzüberschreitender Verwaltungspraxis 1960-1995. Opladen: Leske \& Budrich.

Wodak, Ruth. 2004. National and Transnational Identities: European and Other Identities Constructed in Interview with EU Officials. In Transnational Identities: Becoming European in the EU, edited by Richard K. Herrmann, Thomas Risse, and Marilynn Brewer. Lanham, MD: Rowman \& Littlefield, 97-128. 


\title{
8 External actors, state-building, and service provision in areas of limited statehood
}

\author{
Introduction (2014)
}

\author{
Stephen D. Krasner and Thomas Risse
}

This special issue begins with the empirical observation that the ideal-typical conception of a consolidated state is misleading rather than illuminating. A consolidated state enjoys the privileges of international legal sovereignty, including recognition, the right to enter into treaties, and to join international organizations. It is a full "Westphalian/Vattelian" sovereign: Domestic authority structures are autonomously determined. It exercises effective domestic sovereignty, what we term here statehood, that is, the monopoly over the legitimate use of force and the ability to successfully make, implement, and enforce rules and regulations across all policy arenas within its territory (Krasner 1999; Risse 2011).

This ideal typical construct is far removed from the situation that exists in most of the world's polities. Most relevant for this special issue, there are wide variations in statehood. These variations are here to stay and it makes little sense to orient external efforts at capacity-building and service provision toward an ideal of consolidated statehood that only exists in some parts of the world.

In areas of limited statehood, some of the functions that have traditionally been associated with the state have been assumed by external actors. For example, in 2000, the German automobile giant Daimler introduced a largescale HIV/AIDS prevention and treatment program for its workers, their families, and local communities in South Africa (see Hönke and Thauer 2014). In 2003, the government of the Solomon Islands delegated security provision and law enforcement to the Regional Assistance Mission to Solomon Islands (RAMSI) led by Australia and New Zealand (see Matanock 2014). In the early 2000s, the Global Alliance for Vaccines and Immunization - a transnational public-private partnership funded by the Bill and Melinda Gates Foundation succeeded in immunizing about $50 \%$ of Sierra Leone's children, while the civil war in the country was still in full swing (see Schäferhoff 2014 on the Global Fund and the fight against Malaria, Tuberculosis, and HIV/AIDS in Somalia).

These are just three examples for external actors - state and nonstate - engaging in "state-building" or providing public services in countries where the state does not have the administrative capacity (either material or institutional) to exercise effective control over activities within its own borders. We call these "areas of 
limited statehood." External state and nonstate actors have provided tens of billions of dollars for service provision in such states. In 2003-2004, official aid commitments for basic social services defined as "basic education," "basic health," "population and reproductive health," "basic drinking water supply and basic sanitation," and "multisector aid for basic social services" amounted to $\$ 7.1$ billion. ${ }^{1}$ In 2008-2009, aid disbursements for public health totaled $\$ 17.3$ billion. $^{2}$ In 2010, the Bill and Melinda Gates Foundation had more than $\$ 37$ billion in assets and spent about $\$ 1.5$ billion on global health and 0.5 billion on global development, figures comparable with several smaller Organisation for Economic Co-operation and Development (OECD) countries.

This special issue focuses on the extent to which external actors enhance the capacity (statehood) of authority structures in weak states (what we term "statebuilding"), or directly contribute to the provision of collective goods and services, such as public health, clean environment, and infrastructure, that state authorities are unable to make available themselves. Despite a large literature on statebuilding, postconflict peace-building, and development assistance, ${ }^{3}$ we know surprisingly little about the effectiveness of external efforts at state-building, or public service provision in areas of limited statehood. As we argue in this special issue, the provision of collective goods and services is possible even under extremely adverse conditions of fragile or failed statehood.

We argue that three factors determine success: legitimacy, task complexity, and institutionalization, including the provision of adequate resources. We also suggest a causal argument showing how these three factors are connected and how they influence each other:

1 Legitimacy: There are many different legitimacy dynamics. For this special issue, the most important involve empirical legitimacy derived from the engagement of domestic actors (whether national elites or local audiences) and from the outputs provided by the external actor and the extent to which these capacity-building or service-provision efforts are seen as being normatively appropriate by the target populations. Fritz Scharpf refers to these two dynamics as input and output legitimacy (Scharpf 1999). The activities pursued by external actors might or might not be regarded as legitimate by actors in target states. Politically relevant audiences in the target state must accept the legitimacy of efforts by external organizations. This is a necessary condition for effectiveness: no legitimacy, no success. With legitimacy, simple tasks, which require a limited number of interventions by a single actor, can be accomplished even with modestly institutionalized and funded governance structures.

2 Task Properties: Tasks can be distinguished along two dimensions: the number of interventions that must be undertaken to successfully enhance state capacity or deliver a service, and the number of organizations or entities that must be coordinated. The most simple task is one requiring a single intervention by one organization. Smallpox immunization would be an example. The simpler the task, the more likely it is to be provided. More 
complex tasks, all tasks associated with state-building, and some associated with service provision, are more difficult to provide, especially in failed states, where indigenous state capacity hardly exists, as opposed to polities with areas of limited statehood.

3 Institutional Design: The institutional arrangement linking external and national/local actors matters for the effectiveness of either enhancing state capacity or providing collective goods and services. Institutional design features include the degrees of legalization, formal institutionalization, and level of resources. Appropriate resourcing and higher legalization increase the prospects for effective state-building and service provision. Institutional structures can be provided by the external actors or by the host state.

The special issue is divided in two parts. The articles by Lake and Fariss (2014), Matanock (2014), and Börzel and van Hüllen (2014) demonstrate the challenges facing external actors engaged in state-building, the attempt to enhance state capacity or statehood. State-building is always a complex task. Only under stringent conditions is it possible to effectively build state institutions from the outside. These conditions include long-lasting resource commitments, the creation of highly institutionalized and legalized organizational structures, and compatible, if not identical, conceptions of legitimacy between the international community, national elites, and local communities. The article by Lake and Fariss demonstrates that efforts to enhance governance capacity or provide services through coercion or imposition are particularly challenging because they lack input legitimacy, which can only be provided by the voluntary engagement of politically consequential actors in the target state. The articles in this special issue demonstrate that contractual arrangements resulting in either delegated authority (Matanock 2014) or negotiated modes of external influence (Börzel and van Hüllen 2014) are likely to be more effective than hierarchical or coercive interference.

The articles by Lee et al. (2014), Beisheim et al. (2014), Schäferhoff (2014), and Hönke and Thauer (2014), examine service delivery rather than statebuilding. Lee et al., using cross-national data, demonstrate that once fully consolidated states (most of the OECD world) are taken out of the analysis, the relationship between degrees of statehood, on the one hand, and service delivery, on the other hand, is surprisingly weak. Service delivery has been admirable in some areas of limited statehood in which the state has very little capacity. There are other polities with much higher state capacity where service delivery has been wanting. The level of state capacity in areas of limited statehood does not explain the degree of service provision. The other articles in the second section of this special issue show that the ability of external organization to provide services depends on the legitimacy enjoyed by these organizations, the complexity of the tasks they are engaged in, and their institutional design (Beisheim et al. 2014; Hönke and Thauer 2014; Schäferhoff 2014).

In the following, we first explain our understanding of limited statehood followed by a discussion of the dependent variables of this special issue: statebuilding and the provision of collective goods and services. Finally, we discuss 
the explanatory variables and scope conditions for effective state-building and for service provision highlighted in this special issue.

\section{Limited statehood}

Our understanding of "limited statehood" must be distinguished from the way in which notions of "fragile," "failing," or "failed" statehood are used in the literature (see Risse 2011 for the following). Most typologies in the literature and data sets on fragile states, "states at risk," etc. reveal a normative orientation toward the Western model (e.g., Fukuyama 2004; Rotberg 2003, 2004). The benchmark is usually the democratic and capitalist state governed by the rule of law (Leibfried and Zürn 2005). This bias toward consolidated statehood is problematic for two reasons. First, it obscures the fact that most states are neither consolidated nor failed. They are characterized by areas of limited statehood. Second, it confuses key research questions, including the one investigated here: There is no linear relationship between service provision and the level of statehood or state capacity in areas of limited statehood. If we define statehood in terms of the public goods and services consolidated states are supposed to provide, we can no longer distinguish between state capacity and the provision of services.

In this special issue, we distinguish between statehood or state capacity, on the one hand, and the provision of public goods and services, on the other hand. We follow Max Weber's conceptualization of statehood as an institutionalized structure with the ability to rule authoritatively (Herrschaftsverband) and to legitimately control the means of violence (Weber 1921/1980; on statehood in general, see Benz 2001; Schuppert 2009). While no state governs hierarchically all the time, consolidated states possess the ability to authoritatively make, implement, and enforce central decisions for a collectivity. In other words, consolidated states command "domestic sovereignty," that is, "the formal organization of political authority within the state and the ability of public authorities to exercise effective control within the borders of their own polity" (Krasner 1999, 4). This understanding allows us to distinguish between statehood as an institutional structure of authority and the services it provides. The latter is an empirical, not a definitional question. The fact that a state has a monopoly over the legitimate use of force does not necessarily mean that it will provide security for all of its citizens.

We can now define more precisely what "limited statehood" means. Limited statehood concerns those areas of a country in which central authorities (governments) lack the ability to implement and enforce rules and decisions and/or in which the legitimate monopoly over the means of violence is lacking. The ability to enforce rules or to control the means of violence can be differentiated along two dimensions: (1) territorial, that is, parts of a country's territorial space, and (2) sectoral, that is, with regard to specific policy areas. It follows that the opposite of "limited statehood" is not "unlimited" but "consolidated" statehood, that is, those areas of a country in which the state enjoys the monopoly over the 
means of violence and/or the ability to make and enforce central decisions. Statehood is not a dichotomous variable; there are degrees of limited statehood.

The following map shows the variation in statehood for most countries (Figure 8.1). The degree of statehood is derived from three indicators (see Lee, WalterDrop, and Wiesel 2014 for details): "failure of state authority" and "portion of country affected by fighting"4 (measuring the state monopoly over the means of violence), as well as "fiscal extraction capacity" measuring state capacity. ${ }^{5}$

A small percentage of states in the contemporary international system can be characterized as having consolidated statehood, that is, fully effective domestic sovereignty (dark gray on the map). On the other end of the spectrum are fragile, failing, or failed states (black). Failed or failing states are those that have more or less lost the state monopoly on the use of force and/or do not possess effective capacities to enforce decisions (e.g., Somalia, Democratic Republic of Congo, Afghanistan). The vast majority of states in the contemporary international system have "areas of limited statehood" (white); that is, in parts of the territory or in some policy areas the central government lacks the capacity to implement decisions and/or its monopoly over the means of violence is challenged. Territorial examples include the Amazon region in Brazil, Northeast Kenya, and parts of Southern Italy. Policy examples include legislation for issues such as the environment, schooling, and social security in many developing countries that is never implemented, or the inability to collect taxes in some more developed countries such as Greece.

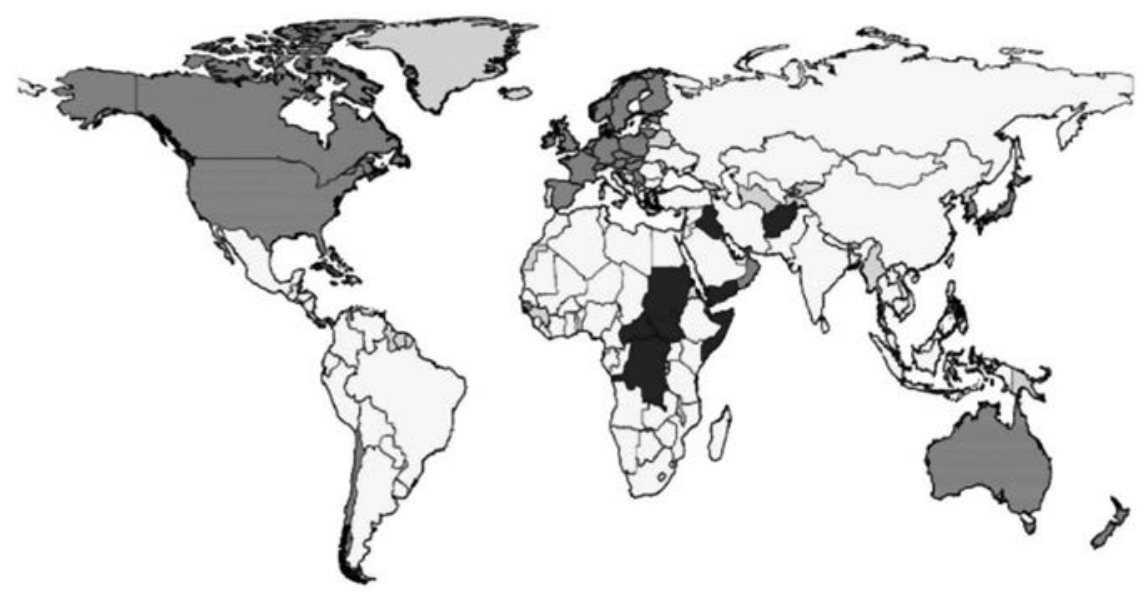

Figure 8.1 World map: Degrees of statehood

Dark gray: consolidated states; white: countries with areas of limited statehood; black: failed states; light gray: missing values.

Sources and Indicators: See Lee, Walter-Drop, and Wiesel (2014). 
Almost all states, including failed and failing states, as well as states with areas of limited statehood, have international legal sovereignty. Many also have "Westphalian/Vattelian" sovereignty; that is, their domestic authority structures, feeble though they may be, are autochthonously determined and not interfered with by external actors. What is lacking in all countries except those with consolidated statehood is full domestic sovereignty (see Krasner 1999 on these distinctions).

In areas of limited statehood, collective goods and services may be provided by a variety of actors. Some of these actors will be domestic; others will not. This special issue concentrates on the external actors. International or transnational actors that could provide collective goods include official national development agencies, international financial institutions, transnational nongovernmental organizations (NGOs), religious organizations, and multinational corporations. Our focus in this special issue is on these actors and their role in both service provision and the enhancement of state capacity.

\section{The dependent variables: State capacity and the provision of collective goods and services}

\section{Enhancement of state capacity}

This special issue investigates two distinct but related issues: efforts by external actors to enhance state capacity, on the one hand, and efforts to provide collective goods and services, on the other hand. As to the former, many external actors - mostly state actors such as foreign governments, development agencies, and international organizations - actively engage in state-building; that is, they try to tackle limited statehood directly through various measures aimed at capacity- and institution-building. The articles by Lake and Fariss, Matanock, and Börzel and van Hüllen suggest that the former is difficult, although possible in some circumstances.

Lake and Fariss (2014) examine international trusteeships, that is, efforts by the international community to directly exercise authoritative rule. They point to a set of core challenges associated with trusteeships: External actors will inevitably upset the domestic balance of power; there may not be political support for large amounts of funding over an extended period of time; a mandate provided by the United Nations will not necessarily conform with legitimacy conceptions of local elites and populations; the success of the trustee in delivering services may weaken the output legitimacy of any successor government. Lake and Fariss find few examples in which trusteeships improve the governance capacity of failed states or in areas of limited statehood. Moreover, their statistical analysis shows no relationship between international trusteeships, on the one hand, and the effective provision of public services, on the other hand, our second dependent variable in this special issue.

Matanock's (2014) article assesses delegation agreements. These are voluntary arrangements in which the national government agrees to delegate state functions 
to external actors. In cases of deep delegation, external actors are given direct authority; expatriates hold official positions and are not subject to national law. The RAMSI is one example. Ceding authority is costly for national elites and they will only agree to deep delegation if they have no other option. Usually delegation is shallower: Some state activities are contracted out, but the scope of activities and the legal authorities of external actor are constrained. The International Commission against Impunity in Guatemala (CICIG), for instance, can investigate major crimes, but prosecutions must be brought to a Guatemalan official. Matanock suggests that delegation agreements can be successful in carrying out specific tasks. Her statistical analysis of United Nations Chapter VI Peacekeeping Missions that are based on the consent of the host country and, thus, represent delegation agreements, demonstrates the ability of these missions to significantly reduce the levels of violence. Her statistical findings, based on Chapter VI interventions alone, are more positive than those of Lake and Fariss, whose database includes Chapter VII, which do not require country consent, as well as Chapter VI interventions (compare Lake and Farris 2014, and Matanock 2014). Unlike trusteeships, delegations agreements, although complex, have a good chance of securing input legitimacy because they are the result of contracting.

Börzel and van Hüllen (2014) examine arrangements involving European Union (EU) assistance for anticorruption programs in the Southern Caucasus. All of these programs were complex in that they involved multiple interventions across different agencies in the target countries and coordination among different offices of the EU. Successful strengthening of state institutions, however, depended critically on the resonance of the EU's anticorruption policy with social norms prevalent in the countries. Only in Georgia did mass mobilization against corruption provide an incentive for political elites to effectively implement institutional changes in line with the EU's demands. In Armenia, where national elites did not come under pressure "from below," national elites had no incentive to effectively fight corruption.

This part of the special issue yields two conclusions: First, success in fullfledged state-building by external actors through imposition and authoritative rule is extremely difficult, as the examples of Afghanistan and Iraq demonstrate. Input legitimacy is only possible in such cases if domestic actors support a trusteeship even if they played no direct role in its creation. This is possible where the external actors have expelled an alien overlord, for instance, the Indonesians from East Timor, but not where they have displaced a regime that had significant domestic support, for example, the Taliban in Afghanistan. In the latter case, only minorities will give the external actors input legitimacy. Success for trusteeships is also rare because the tasks associated with such efforts are extremely complex, involving many different and interrelated domestic and external actors.

Second, state-building efforts that proceed from contracting (by delegation, see Matanock 2014, or by interstate agreements, see Börzel and van Hüllen 2014) are more likely to be successful. At a minimum, contracting makes input legitimacy much more likely because the political elites governing the country 
must positively agree to terms. Projects that are focused on specific aspects of state-capacity rather than full-fledged trusteeships are less complex: Although the task may involve many interventions, it can be accomplished through the actions of a limited number of agents. Funding requirements for such interventions are more modest and, because of explicit contracting with the state, will be institutionalized and legalized.

\section{Provision of collective goods and services}

The second part of the special issue concentrates on efforts by external actors to directly contribute to the provision of collective goods and services, such as access to clean water, sanitation, and nutritious food (Beisheim et al. 2014), public security (Hönke and Thauer 2014), and public health (Schäferhoff as well as Hönke and Thauer 2014).

Our basic finding is that some services are provided even in areas where statehood is woefully lacking. The following scatter plot depicts the (non-) provision of collective goods across countries (Lee, Walter-Drop, and Wiesel 2014, for details; Figure 8.2).

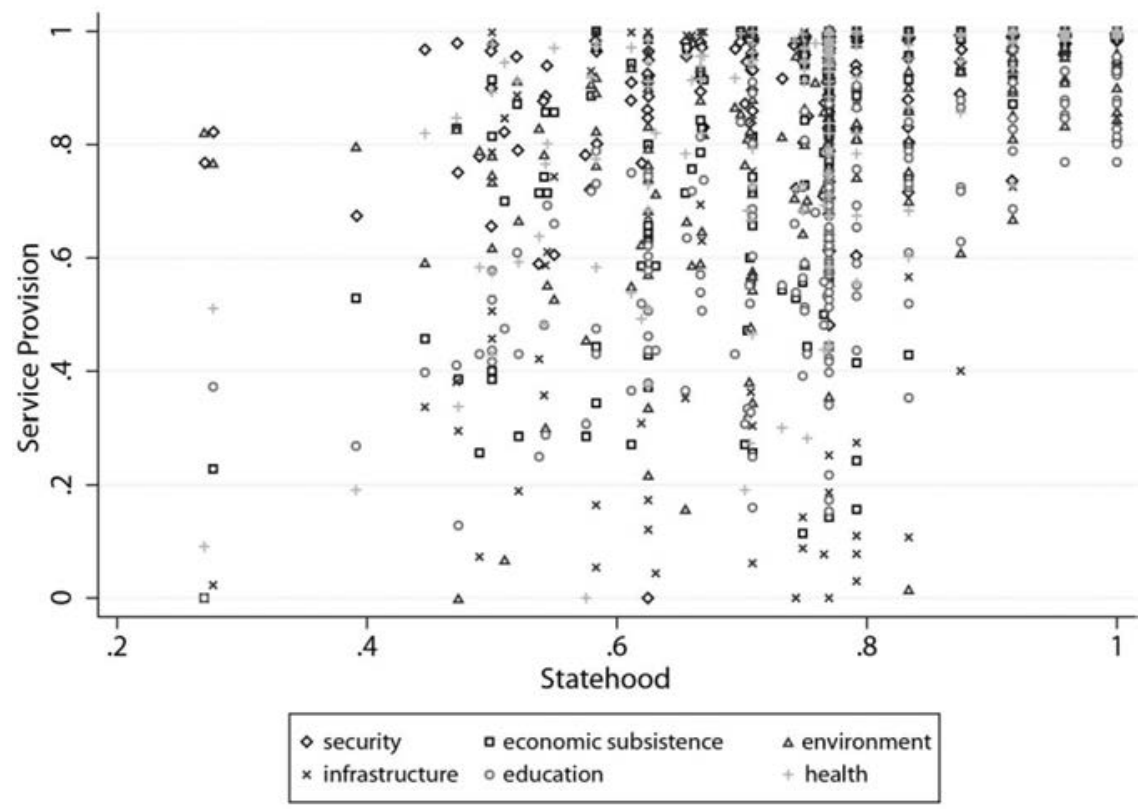

Figure 8.2 Service provision and degrees of statehood 2010

Note: The $x$-axis measures statehood in the same way as the global map in Figure 8.1. The $y$-axis measures various composite indicators for service provision based on a variety of data sources: World Bank, UN Statistics Development Indicators, United Nations Office on Drugs and Crime, WHO, CIA, SIPRI, UNESCO, UCDP etc. See Lee et al. 2014 for details. Each dot represents a particular type of service provision by country. For example, the + dot at $0.3 / 0.1$ represents (extremely poor) health provision in a failed state. 
Three findings stand out: First, not surprisingly, consolidated states, those with a statehood score of 0.9 or above, provide collective goods in most areas. Second, collective goods provision in failed or failing states, those at or below a score of 0.4 on the statehood index is limited, but not completely impossible. Failed states score particularly poorly for infrastructure, economic subsistence, and health. Third and most important, in countries with areas of limited statehood, those with statehood scores between 0.4 and 0.9 , the variation in the degree to which collective goods are provided is very high. ${ }^{6}$ The variation does not disappear in areas of limited statehood if we control for two macro variables often used indevelopment studies and comparative politics: regime type (democracy vs. autocracy), and economic development (gross domestic product per capita; see Lee, Walter-Drop, and Wiesel 2014 for details).

Our focus is on international or transnational rather than domestic actors and their ability to provide public goods and services effectively. External state and nonstate actors can act alone or provide collective goods and services in failed states through public-private partnership (PPP; see Schäferhoff, Campe, and Kaan 2009; also Beisheim et al. 2014; Schäferhoff 2014). State actors include foreign governments and their (development) agencies as well as international organizations. Nonstate actors include international NGOs including churches and charities, as well as profit-seeking multinational corporations (on the latter, see Börzel and Thauer 2013; Hönke and Thauer 2014; Prakash and Potoski 2006).

Four articles in this special issue deal with the provision of collective goods and services in areas of limited statehood as well as failed and failing states. Lee et al. provide a general overview and large-n analysis demonstrating that service provision and degrees of statehood rarely correlate - except for consolidated statehood (see above). Lee et al. also show that simple services can be provided even in failed states.

Beisheim et al. (2014) compare 10 projects by two service-providing PPPs pertaining to the UN Millennium Goals in areas of limited statehood in South Asia and East Africa. They argue that services associated with complex tasks, such as setting up sustainable water and sanitation services or providing fortified school meals, can be accomplished only when the transnational PPP has institutionalized the terms of obligation and monitoring and when it enjoys or builds legitimacy at the local level. In addition, the PPP's institutional design must be able to provide resources for capacity building and to maintain a certain flexibility for tailoring projects to local needs.

Schäferhoff (2014) looks at a particular PPP, namely, the Global Fund to Fight AIDS, Tuberculosis, and Malaria and its effectiveness in Somalia. State capacity varies across Somalia's different territories. Schäferhoff demonstrates that simple tasks, such as the distribution of antimalaria bednets or tuberculosis (TB) treatment, can be accomplished even in central Somalia, where the state has been virtually absent for the past 20 years. In contrast, a complex task such as AIDS treatment could only be accomplished in Somaliland, a quasi-state with a more or less functioning infrastructure. 
Hönke and Thauer (2014) concentrate on unlikely service providers, multinational corporations, and their efforts to combat HIV/AIDS and to contribute to public security in South Africa and the Democratic Republic of Congo, which are both complex tasks. They concur with the other contributions to this special issue that legitimacy is a necessary condition for success. In their cases, legitimacy arises from the compatibility between international norms and normative beliefs held by state actors (see also Börzel and van Hüllen 2014). In addition, Hönke and Thauer demonstrate that institutional design matters, too, explaining the variation in effectiveness of service provision once legitimacy is given.

\section{Explanations: Legitimacy, task properties, and institutional design}

This special issue cannot pretend to offer a complete and empirically tested theory of the factors that influence the success of external efforts to improve state capacity and service delivery in areas of limited statehood. However, the contributions to this special issue suggest that three factors largely explain the empirical variation in outcomes with regard to both enhancing the institutional capacity of states (part 1 of the special issue) and the provision of public goods and services (part 2 of the special issue):

The ability of external actors to enhance state capacity or to provide services in areas of limited statehood depends on:

- the legitimacy of external actors in the eyes of local communities and "stake-holders";

- the complexity of the task or service being provided; and

- the institutional design of the governance structures delivering the goods or services.

It goes without saying that these three sets of factors represent continuous, not dichotomous variables. We begin by describing each of these factors and then discuss possible interactions among them.

\section{Legitimacy}

There is a huge literature on the legitimacy of transnational governance (see, e.g., Benz and Papadopoulos 2006; Clark 2005; Dingwerth 2007; Hurd 1999; March and Olsen 1998; Risse 2006; Schmelzle 2011; Zürn 2000). However, this literature often does not distinguish adequately between empirical legitimacy (the degree to which those being ruled or governed accept the social and political order as fair and appropriate leading to voluntary compliance), on the one hand, and normative legitimacy, on the other hand (the degree to which legitimacy can be justified according to external or universal moral and normative standards). We concentrate on empirical legitimacy and argue that it constitutes a necessary condition for the effectiveness of state-building or service delivery. Empirical 
legitimacy can be conferred for both moral and pragmatic reasons: the degree to which external organizations and the norms promoted by them are viewed as conforming with local or national normative standards, and the effectiveness of these organizations with regard to their provision of desired goods and services.

There are several different sources of legitimacy. For this project, three are of particular importance: input legitimacy, output legitimacy, and the conformity of international norms with moral beliefs held by local or national communities. To begin with, the degree to which the institutional design enables those being governed to have a say in the rule- or decision-making process - its participatory quality will affect the legitimacy accorded to external actors engaged in capacity building or service provision. Fritz W. Scharpf calls this "input legitimacy" (Scharpf 1999). The development community discusses this as "ownership" or "stakeholder" principles. The relative importance of different actors in the target state, national and local, will depend on the activity involved and domestic political structures. Even in states with no accountability, service provision to a target population will be impossible unless local actors regard the activities of external "governors" (Avant, Finnemore, and Sell 2010) as legitimate. For activities that target national-level governance structures, legitimation by local actors will be less important than validation from national political elites. The articles by Lake and Fariss (2014), Matanock (2014), Börzel and van Hüllen (2014), as well as by Beisheim et al. (2014) highlight the different national and local actors that might be consequential for legitimating external organizations engaged in governance support and service provision.

Input legitimacy results from a strategic and political process. The actors involved at the national and local levels will depend on elite calculations and political structures. In the Solomon Islands, the success of RAMSI enhanced support among the population, putting pressure on national elites to keep to their original bargain (Matanock 2014). In Georgia, Saakashvili embraced EU programs because anticorruption was a key element of his appeal to the electorate (Börzel and van Hüllen 2014).

External actors are more likely to enjoy input legitimacy and, hence, to be effective if they are operating through institutional arrangements that were created through contracting rather than imposition. Contracts are voluntary. They will only be signed if all parties perceive themselves to be better off. The benefits of contracting, however, may be highly asymmetrical. The extent of input legitimacy derived from contracting will depend on the complementarity between the normative frames of national and external actors, and the extent to which national actors, especially in the case of capacity building at the national level, regard the contract as providing significant benefits. In the Solomon Islands, as Matanock (2014) argues, political leaders accepted deep delegation to external actors by endorsing the creation of RAMSI. Absent RAMSI, which took control of financing, the judicial system, and the police, the state would have collapsed and local leaders would have been adrift or dead.

The delegation of authority to external actors is rare; negotiated institutional agreements that do not involve ceding authority to external actors are more 
common. External actors operate under agreement with state authorities, although the discretion they enjoy and the ability of the state to monitor them will vary. The Börzel and van Hüllen (2014) discussion of EU efforts to reduce corruption in the Southern Caucasus is a case of enhancing state capacity where the external actors transfer resources and knowledge but do not have legal authority. The leverage of the EU was limited. Success depended on the extent to which the preferences of external and internal actors were complementary.

In contrast, institutional arrangements created through imposition are less likely to be successful (Lake and Farris 2014). They are inevitably hierarchical insofar as external actors exercise authoritative rule directly. As a result, there may be no support from national elites, or only from elites that opposed the government that is being displaced. Hence, with imposition there can be little presumption of input legitimacy. Trusteeships have to rely mostly on output legitimacy, the second source of legitimacy.

Output legitimacy derives from the level of performance of actors and is, thus, directly related to effectiveness (Scharpf 1999). To avoid circular reasoning with regard to our dependent variable, we consider output legitimacy with regard to two processes:

1 Local domestic actors and communities might consider international actors as legitimate in anticipation of their performance or because they trust their knowledge and moral authority.

2 Over time, a virtuous cycle might evolve in which the initial performance of external actors meets the expectations of local communities which then increases the formers' legitimacy and, hence, their effectiveness (see articles by Beisheim et al. 2014; Matanock 2014; Schäferhoff 2014).

International legitimation matters, but only to a limited degree. This points to the third source of legitimacy, the congruence or compatibility of international norms with domestically held norms or moral beliefs (Börzel and van Hüllen 2014; Hönke and Thauer 2014). National and/or local actors and communities are the critical players with regard to the acceptance of the activities of external actors as legitimate and appropriate. Even when, for instance, a de facto trusteeship is legitimated by a UN Security Council resolution, this does not guarantee acceptance by key local actors (Lake and Farris 2014). The validation of service provision by multinational corporations through transnational NGOs or international organizations may be consequential for legitimacy, but only if such validation alters the understandings of actors in the target state. If national norms do not conform with international norms, then local actors can de-legitimate efforts by external actors to provide even the simplest services. The South African government under Thabo Mbeki, for example, successfully de-legitimized programs by multinational corporations to fight HIV/AIDS as incompatible with domestically held beliefs about the sources of the pandemic and appropriate remedies (Hönke and Thauer 2014). In sum, it is domestic legitimacy that ultimately counts. 


\section{Task complexity}

Task complexity is another important determinant of whether an external provider can be successful. Although obvious, the literature on state-building and on international development rarely mentions this factor. Task complexity depends on the number of specific interventions required for success and on the number of actors or entities that must be coordinated to administer these interventions. The simplest tasks are those requiring one intervention by one entity. Some health services, for instance, involve simple tasks such as one-shot immunizations. Such services have been provided across the world, even in countries that have only minimal state capacity. They have saved millions of lives. Other health services are more complex because they require more than one intervention but can still be carried out by a single entity. TB offers one example: Patients must take their medication over an extended period of time but treatment can be provided by a single provider. Schäferhoff (2014) shows that TB treatments can be carried out even in areas with no statehood, such as central Somalia, but this required local legitimacy, adequate funding, and appropriate institutionalization.

In general, the articles in this special issue show that relatively simple services such as TB treatment, or the distribution of antimalaria bednets (Schäferhoff 2014), can be effectively provided by external actors even under conditions of failed statehood. In contrast, the more complex the task, the more it requires at least some minimum institutional capacity of the host state or - as a functional equivalent highly institutionalized contractual arrangements among the external actors.

The most complex tasks are those requiring many interventions involving a number of different entities. Efforts to enhance governance capacity across a number of different sectors offer the clearest examples. In Afghanistan and Iraq, multiple agencies from different countries, international and regional organizations were involved in many different areas, including training bureaucrats, building capacity in the judicial system, combating narcotics trafficking, funding a national army and police forces, and supporting minority and women's rights. External interventions aimed at whole-sale state-building almost never succeed, as they require an extraordinary amount of resources and staying power from the external interveners (Lake and Farris 2014). Interventions targeted at one specific activity that can be conducted by one single external entity may succeed in building state capacity, but probably only in that one arena. Examples include EU efforts to fight corruption in Georgia (Börzel and van Hüllen 2014), UN Chapter VI Peacekeeping Missions, or the prosecution of major crimes in Guatemala (Matanock 2014). RAMSI is one of the rare examples of a successful effort at wholesale state-building based on a full delegation agreement (Matanock 2014).

\section{Institutional design}

The design of the institutional arrangements linking external to domestic actors (whether state or nonstate), including the material resources available to them, constitutes the third set of factors influencing the effective provision of collective goods and services or the enhancement of state capacity in areas of limited statehood. 
Entities are more likely to be successful if they are:

- adequately funded; and

- more rather than less institutionalized and legalized.

First, efforts by external actors to enhance state capacity in areas of limited statehood or directly contribute to the provision of goods and services require sufficient financial resources. This sounds trivial, but - as the article by Lake and Farris (2014) demonstrates - most efforts at external state-building through imposition and trusteeships have not been provided with adequate resources over a long period of time (see also Beisheim et al. 2014).

Second, institutional structures may be more or less legalized and institutionalized. The literature on institutionalization and legalization (see, e.g., Abbott et al. 2000; Goldstein et al. 2000; Koremenos, Lipson, and Snidal 2001; Liese and Beisheim 2011) suggests that governance structures are more likely to be effective:

- if the decision-making rules are precisely defined and if the terms of obligation are well specified;

- if there are sufficient monitoring capacities (preferably by independent authorities); and

- if the institutional design allows for flexible adaptation to local conditions on the ground.

Highly institutionalized structures can be provided by the external actors themselves, by the host state, or by contractual arrangements between the external actors and the host state. The articles in part 2 of the special issue demonstrate that various forms of institutional design explain whether or not external efforts at providing collective goods and services in areas of limited statehood are successful when task complexity is high (see Beisheim et al. 2014; Hönke and Thauer 2014). This includes the ability of the governance structures to adapt flexibly to changing local conditions (Beisheim et al. 2014). "One size fits all" institutional arrangements are unlikely to be effective.

Highly institutionalized arrangements between external and domestic actors or - in some cases - provided solely by the external actors, can compensate for extremely limited state capacity and, thus, substitute for weak state capacity. At the same time, if there is at least some state capacity in areas of limited statehood, this can also help to foster successful service provision (see Schäferhoff 2014 on the quasi-state Somaliland).

\section{Causal inferences}

Figure 8.3 below captures the conclusions that we draw from the contributions to this special issue. Legitimacy is essential for success. If tasks are simple, success can be achieved with limited institutionalization. If tasks are complex, success requires higher levels of institutionalization. Each of the possible 


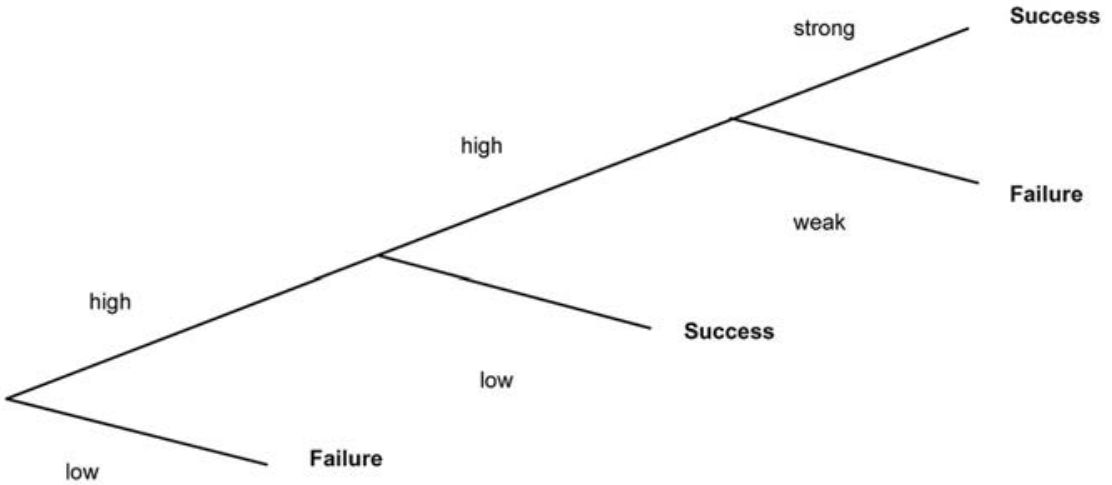

Legitimacy

Task Complexity

Institutional Design

Figure 8.3 Legitimacy, task complexity, and institutional design

outcomes described in Figure 8.3 can be illustrated by cases from the articles in this special issue.

The first decision point in Figure 8.3 concerns legitimacy, that is, the acceptance by domestic actors - national and/or local, state and/or nonstate. It is essential for the success of any effort by external actors to enhance state capacity or provide services. If a project is the result of contracting, then input legitimacy derives from participation (Matanock 2014). If the efforts of external actors are successful over time, if state capacity increases, or if services are delivered, output legitimacy is likely to increase, too. Initially, output legitimacy may be entirely utilitarian, conveyed because recipients get some specific material benefit. Over time, a virtuous circle may result in legitimacy being accorded for moral as well as materially self-interested reasons. If legitimacy is low, then regardless of task complexity or degree of institutionalization of the external actors, statebuilding and service delivery projects will fail. Legitimacy conveyed by national or local actors and communities is a necessary, albeit not sufficient, condition for successful interventions by external actors.

Lack of legitimacy is a core reason why Western efforts at state-building in Iraq and Afghanistan have failed (Lake and Farris 2014). In contrast, the Australianled effort in Timor-Leste, which has been regarded as legitimate by most local actors, has been more successful. The same holds true for RAMSI in the Solomon Islands and for CICIG in Guatemala (Matanock 2014). In Papua New Guinea and initially in Guatemala, however, more ambitious state-building efforts based on deep delegation failed, because they could not secure minimal levels of local support. Variation in legitimacy and the congruence between international anticorruption norms and locally held beliefs also explain the success of EU efforts to combat corruption in Georgia as compared to its failures in Armenia and Azerbaijan (Börzel and van Hüllen 2014). Only when efforts by automobile 


\section{From the outside in}

and mining companies to combat HIV/AIDS in South Africa were legitimated by the government did they become successful (Hönke and Thauer 2014). Input legitimacy through local participation was necessary for the effectiveness of transnational PPP to provide access to clean water, sanitation, and nutritious food (Beisheim et al. 2014). HIV/AIDS treatment in Puntland and Southeast Somalia had no chance of success because engaging with the disease at all was regarded as illegitimate by key political actors and the population (Schäferhoff 2014).

If a project does enjoy legitimacy, then success is easy if the task is simple rather than complex (the second decision point in Figure 8.3). Simple service delivery, especially in the area of health, has transformed the lives of individuals around the world. Immunization has eliminated smallpox, and reduced the incidence of other communicable diseases. Child survival rates have increased because of the use of oral rehydration therapy and the encouragement of breast-feeding. The greatest success in service provision by external actors in failed states and areas of limited statehood has been in activities that are accepted as legitimate by the target population and that require only a limited number of interventions and modest coordination among actors. As Schäferhoff (2014) demonstrates in his contribution, distributing antimalaria bednets and even fighting TB - a somewhat more complex task - could be effectively accomplished even in war-torn Central Somalia, a quintessential failed state for the past 20 years.

With legitimacy, complex state-building and service delivery can be successful but only if the efforts of external actors are highly institutionalized including being well funded (see the third decision point in Figure 8.3). As Matanock (2014) points out, the Solomon Islands in 2003 was a failed state. RAMSI, which took over key state functions, has been well funded, receiving about one billion Australian dollars over its first six years of operation. The country is better off than it was before RAMSI was established, although it is not clear whether RAMSI's success will be preserved once the mission is ended. In Guatemala, more ambitious efforts to establish an independent prosecutorial office failed because they could not secure support from local elites. But CICIG, a special investigative office established through an agreement with the UN Secretary General, has contributed to the prosecution of a number of powerful individuals, something that the judicial system had previously failed to do. Both RAMSI and CICIG are highly institutionalized and well funded. The same holds true for the EU's anticorruption efforts in the Southern Caucasus (Börzel and van Hüllen 2014). The observed variation in outcomes in the Caucasus is explained by different degrees of legitimacy.

With regard to complex service delivery, Beisheim et al. (2014) also confirm the importance of the third decision point in Figure 8.3. Well-resourced PPPs with a high degree of institutionalization managed to effectively deliver services with regard to the UN Millennium Development Goals, while less institutionalized and less well-funded PPPs failed. At the local level, Beisheim et al. also find that the institutional design of a PPP project has to be sound in terms of obligation and monitoring, but also flexible and adaptive to adjust to local conditions and problems that are pertinent to areas of limited statehood. 
With regard to complex tasks in public health, HIV/AIDS treatment was, as Schäferhoff (2014) points out, successfully introduced into Somaliland where there is some state capacity that could be joined with that of external actors. One critical step was the willingness of the Somaliland government to legitimate efforts to address the threat posed by HIV/AIDs. Well-funded international programs made it possible to introduce treatment for infected individuals. Variation in the degree of institutionalization also explains successful attempts by multinational corporations to combat HIV/AIDS in South Africa (Hönke and Thauer 2014).

\section{Conclusions}

There is a huge gap between what states are supposed to do and what governments can actually accomplish. On the one hand, there are internationally generated templates and scripts calling for the provision of a wide range of services. ${ }^{7}$ There is a near-universal acceptance that consolidated statehood - understood as internationally recognized, autonomous, territorial units capable of governing effectively within their own borders - is an ideal type toward which all polities ought to be oriented. On the other hand, most states in the contemporary international system are not characterized by consolidated statehood. In many polities there are areas of limited statehood in which central authorities are unable to effectively enforce decisions. Yet areas of limited statehood are not ungoverned spaces where nothing gets accomplished and Hobbesian anarchy reigns. Rather, over the course of the last decades, a variety of other actors - state and nonstate have stepped or stumbled into these spaces. External actors are part and parcel of these efforts to govern areas of limited statehood building state capacity and providing collective goods and services. The results of these international initiatives are uneven. They depend on, first, the legitimacy accorded to these external actors by national elites and local communities; second, the task characteristics of the collective goods and services being provided; and third, the institutional design of the governance arrangements aiming to enhance state capacity or to provide services.

Legitimacy is a necessary, but not sufficient, condition for the effectiveness of external efforts at state-building or service provision. The absence of legitimacy inevitably leads to failure. But legitimacy does not guarantee success, especially for complex tasks. Complex activities, including enhancing state capacity and delivering services that require multiple interventions and coordination across different agencies, require highly institutionalized arrangements among the external "governors" as well as between the external actors, the host states, and national elites and local communities in order to be effective. They also require adequate resources and long-term commitments.

In sum, this special issue challenges the often implicit assumption in much of the literature in development studies, including the recent scholarship on failed states. This literature is oriented toward consolidated statehood including full domestic sovereignty as the ideal way to provide collective goods and services. Efforts are assumed to be focused on moving badly governed states along some 


\section{From the outside in}

continuum that ends with Denmark or Norway. This model, often implicit, fails to capture the multifarious ways in which external actors have contributed to enhancing governance capacity and service delivery in failed states and areas of limited statehood.

The policy conclusions from the special issue are obvious:

1 Wholesale efforts at state-building from the outside which include military interventions and hierarchical imposition are likely to fail, because they cannot secure local legitimacy and/or sufficient resources (Lake and Farris 2014).

2 In contrast, state-building through contracts between host state and external actors is more legitimate in the eyes of target communities (Matanock 2014; Börzel; van Hüllen 2014). Such efforts are more likely to be effective if they are geared toward more circumscribed tasks such as promoting some specific parts of the rule of law system rather than wholesale state-building.

3 With regard to service provision, external actors can successfully accomplish simple tasks such as child immunization even in failed states or in war zones (Schäferhoff 2014). Complex service provision such as HIV/AIDS prevention, or access to water and sanitation require not only local legitimacy but also highly institutionalized arrangements among the external actors and/or between the latter and their local hosts (see Matanock 2014; Beisheim et al. 2014; Hönke and Thauer 2014; Schäferhoff 2014).

In sum, international organizations and the foreign aid community should critically evaluate their organizational templates for state-building and service provision, and should cease orienting themselves toward consolidated statehood ("Denmark") as the ultimate goal of development efforts. Rather, they should consider those governance arrangements that are likely to be legitimate, effective, and sustainable in areas of limited statehood. This special issue provides initial answers as to the scope conditions for effective governance under these circumstances.

\section{Acknowledgements}

We thank the participants to the Berlin workshop on May 25-26, 2011, and to the San Diego workshop on March 30-31, 2012, as well as audiences at Stanford University, the University of Chicago, the International Studies Association Annual Convention, San Francisco 2013, and the American Political Science Association, Chicago 2013, for their input. We are also grateful to Michael Barnett, Marianne Beisheim, Tanja Börzel, James Fearon, Jana Hönke, Andrea Liese, John Owen, Christian Thauer, Vera van Hüllen, Joseph Wright, the editors of Governance, and three anonymous reviewers for their very detailed comments on the draft. This special issue reports findings from a joint project of the Collaborative Research Center 700 "Governance in Areas of Limited Statehood," 
based at the Freie Universität Berlin, Germany, and the Center for Development, Democracy, and the Rule of Law (CDDRL) at Stanford University. Funding for this project has been made possible by the German Research Foundation (DFG) and the CDDRL.

\section{Notes}

1 OECD, Development Assistance Committee, http://www.oecd.org/document/9/0,3746, en_2649_34447_36923273_1_1_1_1,00.html; OECD, Analysis of Basic Social Services 1995-2004 (Paris: 2006), p. $\overline{3}$ at http://www.oecd.org/dataoecd/21/1/40162681.pdf

2 http://www.oecd.org/dataoecd/26/39/49907438.pdf

3 On state-building and postconflict peace-building, see, for example, Caplan (2005), Chestermann (2005), Cousens and Kumar (2001), Fearon and Laitin (2004), Fukuyama (2004), Marten Zisk (2004), Paris (2004), Stedman, Rothchild, and Cousens (2002). On foreign aid and democracy promotion, see, for example, Knack (2004), Lumsdaine (1993), Schraeder, Hook, and Taylor (1998), Arts and Dickson (2004), Magen, Risse, and McFaul (2009), and Youngs (2001).

4 Source: Political Instability Task Force (PITF), Center for Global Policy, George Mason University, Washington DC.

5 Source: Institutional Profiles Database.

6 Note that our measurement of statehood is orthogonal to regime type and that the indicators for governance performance used in Figure 2 do not include human rights or the rule of law.

7 For this argument about universally accepted standards of what states are supposed to deliver, see Meyer (1987) and Meyer et al. (1997).

8 Those who are providing the services, on this term see Avant, Finnemore, and Sell (2010).

\section{References}

Abbott, Kenneth W., Robert O. Keohane, Andrew Moravcsik, Anne-Marie Slaughter, and Duncan Snidal. 2000. "The Concept of Legalization." International Organization 54 (3): 401-419.

Arts, Karin, and Anna K. Dickson, ed. 2004. EU Development Cooperation: From Model to Symbol? Manchester, UK: Manchester University Press.

Avant, Deborah, Martha Finnemore, and Susan K. Sell. 2010. "Who Governs the Globe?" In Who Governs the Globe?, ed. Deborah Avant, Martha Finnemore and Susan K. Sell. Cambridge, UK: Cambridge University Press.

Beisheim, Marianne, Andrea Liese, Hannah Janetschek, and Johanna Sarre. 2014. "Transnational Partnerships: Conditions for Successful Service Provision in Areas of Limited Statehood." Governance 27 (4): 655-673.

Benz, Arthur. 2001. Der Moderne Staat. Grundlagen Der Politologischen Analyse. Oldenbourg: München-Wien.

Benz, Arthur, and Iannis Papadopoulos, ed. 2006. Governance and Democracy. Comparing National, European, and International Experiences. London: Routledge.

Börzel, Tanja A., and Christian Thauer, ed. 2013. Business and Governance in South Africa. Houndmills, Basingstoke: Palgrave Macmillan.

Börzel, Tanja A., and Vera van Hüllen. 2014. "State-Building and the European Union's Fight against Corruption in the Southern Caucasus: Why Legitimacy Matters." Governance 27 (4): 613-634. 


\section{From the outside in}

Caplan, Richard. 2005. International Governance of War-Torn Societies. Oxford: Oxford University Press.

Chestermann, Simon. 2005. You, the People: The United Nations, Transitional Administrations, and State-Building. Oxford: Oxford University Press.

Clark, Ian. 2005. Legitimacy in International Society. Oxford: Oxford University Press.

Cousens, Elizabeth M., and Chetan Kumar, ed. 2001. Peacebuilding As Politics: Cultivating Peace in Fragile Societies. Boulder, CO: Lynne Rienner.

Dingwerth, Klaus. 2007. The New Transnationalism: Transnational Governance and Democratic Legitimacy. Houndmills, Basingstoke: Palgrave Macmillan.

Fearon, James D., and David D. Laitin. 2004. "Neotrusteeship and the Problem of Weak States." International Security 28 (4): 5-43.

Fukuyama, Francis. 2004. State Building: Governance and World Order in the TwentyFirst Century. Ithaca, NY: Cornell University Press.

Goldstein, Judith L., Miles Kahler, Robert O. Keohane, and Anne-Marie Slaughter, ed. 2000. Legalization and World Politics. Special Issue of International Organization. Cambridge, MA: MIT Press.

Hönke, Jana, and Christian Thauer. 2014. "Multinational Corporations and Service Provision in Sub-Saharan Africa: Legitimacy and Institutionalization Matter." Governance 27 (4): 697-716.

Hurd, Ian. 1999. "Legitimacy and Authority in International Politics." International Organization 53 (2): 379-408.

Knack, Stephen. 2004. "Does Foreign Aid Promote Democracy?" International Studies Quarterly 48 (1): 251-266.

Koremenos, Barbara, Charles Lipson, and Duncan Snidal, ed. 2001. Rational Design: Explaining the Form of International Institutions. Special Issue of International Organization. Cambridge, UK: Cambridge University Press.

Krasner, Stephen D. 1999. Sovereignty. Organized Hypocrisy. Princeton, NJ: Princeton University Press.

Lake, David, and Christopher J. Farris. 2014. "Why International Trusteeship Fails: The Politics of External Authority in Areas of Limited Statehood." Governance 27 (4): 569-587.

Lee, Melissa M., Gregor Walter-Drop, and John Wiesel. 2014. "Taking the State (Back) Out? Statehood and the Delivery of Collective Goods." Governance 27 (4): 635-654.

Leibfried, Stephan, and Michael Zürn, ed. 2005. Transformations of the State? Cambridge, UK: Cambridge University Press.

Liese, Andrea, and Marianne Beisheim. 2011. "Transnational Public-Private Partnerships and the Provision of Collective Goods in Developing Countries." In Governance without a State? Policies and Politics in Areas of Limited Statehood, ed. Thomas Risse. New York: Columbia University Press.

Lumsdaine, David. 1993. Moral Vision in International Politics: The Foreign Aid Regime, 1949-1989. Princeton, NJ: Princeton University Press.

Magen, Amichai, Thomas Risse, and Michael McFaul, ed. 2009. Promoting Democracy and the Rule of Law. American and European Strategies. Houndmills, Basingstoke: Palgrave-Macmillan.

March, James G., and Johan P. Olsen. 1998. "The Institutional Dynamics of International Political Orders." International Organization 52 (4): 943-969.

Marten Zisk, Kimberley. 2004. Enforcing the Peace: Learning from the Imperial Past. New York: Columbia University Press. 
Matanock, Aila M. 2014. "Governance Delegation Agreements: Shared Sovereignty as a Substitute for Limited Statehood.” Governance 27 (4): 589-612.

Meyer, John M. 1987. "The World Polity and the Authority of the Nation State." In Institutional Structure: Constituting State, Society and the Individual, ed. George M. Thomas, John W. Meyer, Francisco O. Ramirez, and John Boli. London: Sage.

Meyer, John W., John Boli, George M. Thomas, and Francisco O. Ramirez. 1997. "World Society and the Nation-State." American Journal of Sociology 103 (1): 144-181.

Paris, Roland. 2004. At War's End: Building Peace after Civil Conflict. Cambridge, UK: Cambridge University Press.

Prakash, Aseem, and Matthew Potoski. 2006. The Voluntary Environmentalists: Green Clubs, ISO 14001, and Voluntary Environmental Regulations. Cambridge, UK: Cambridge University Press.

Risse, Thomas. 2006. "Transnational Governance and Legitimacy." In Governance and Democracy. Comparing National, European and International Experiences, ed. Arthur Benz and Ioannis Papadopoulos. London: Routledge.

- 2011. "Governance in Areas of Limited Statehood: Introduction and Overview." In Governance without a State? Policies and Politics in Areas of Limited Statehood, ed. Thomas Risse. New York: Columbia University Press.

Rotberg, Robert I., ed. 2003. State Failure and State Weakness in A Time of Terror. Washington, DC: Brookings Institution Press.

- ed. 2004. When States Fail. Causes and Consequences. Princeton, NJ: Princeton University Press.

Schäferhoff, Marco. 2014. "External Actors and the Provision of Public Health Services in Somalia." Governance 27 (4): 675-695.

Schäferhoff, Marco, Sabine Campe, and Christopher Kaan. 2009. "Transnational PublicPrivate Partnerships in International Relations. Making Sense of Concepts, Research Frameworks, and Results." International Studies Review 11 (3): 451-474.

Scharpf, Fritz W. 1999. Governing in Europe. Effective and Democratic? Oxford: Oxford University Press.

Schmelzle, Cord. 2011. "Evaluating Governance: Effectiveness and Legitimacy in Areas of Limited Statehood." SFB Working Paper Series 26, Berlin: Freie Universität Berlin.

Schraeder, Peter J., Steven W. Hook, and Bruce Taylor. 1998. "Clarifying the Foreign Aid Puzzle: A Comparison of American, Japanese, French, and Swedish Aid Flows." World Politics 50 (2): 294-323.

Schuppert, Gunnar Folke. 2009. Staat Als Prozess. Eine staatstheoretische Skizze in sieben Aufzügen. Frankfurt/Main: Campus.

Stedman, Stephen J., Donald Rothchild, and Elizabeth M. Cousens, eds. 2002. Ending Civil Wars: The Implementation of Peace Agreements. Boulder, CO: Lynne Rienner.

Weber, Max. 1921/1980. Wirtschaft und Gesellschaft. Tübingen: J. C. B. Mohr.

Youngs, Richard. 2001. The European Union and the Promotion of Deomcracy: Europe's Mediterranean and Asian Policies. Oxford: Oxford University Press.

Zürn, Michael. 2000. "Democratic Governance Beyond the Nation-State: The EU and Other International Institutions.” European Journal of International Relations 6 (2): $183-221$. 
$\because$ Taylor \& Francis

Taylor \& Francis Group

http://taylorandfrancis.com 


\section{Part III}

\section{In between spaces}

Transnational relations and the diffusion of ideas and institutions 
$\because$ Taylor \& Francis

Taylor \& Francis Group

http://taylorandfrancis.com 


\section{Ideas do not float freely \\ Transnational coalitions, domestic structures, and the end of the Cold War (1994)}

\section{Thomas Risse-Kappen}

Efforts to explain the "end of the cold war," that is, the systemic transformation of world politics that started with the turnaround in Soviet foreign policy in the late 1980s, have to find answers to at least two sets of questions. First, why did Soviet foreign policy change as it did rather than in other conceivable ways, thereby setting in motion a process leading to the cold war's end? How can it be explained that a great power dramatically shifted its course toward accommodationist policies, withdrew from its (informal) empire, and then even collapsed in a comparatively peaceful way? Why did the Soviet Union in retreat never try to forcefully stem the tide?

Second, how can it be explained that Western powers, that is, the alleged winners of the cold war, never attempted to exploit the situation, thereby accelerating their opponent's collapse? What accounts for the specific Western response to the changes in the Soviet Union? Why did both the United States and its Western European allies contribute to end the cold war in a comparatively smooth way?

I argue in this article that structural or functional explanations for the end of the cold war - whether realist or liberal - are underdetermining and cannot account for both the specific content of the change in Soviet foreign policy and the particular Western response to it. These theories need to be complemented by approaches that emphasize the interaction of international and domestic influences on state behavior and take the role of ideas - knowledge, values, and strategic concepts - seriously. Ideas intervene between material power-related factors on the one hand and state interests and preferences on the other. ${ }^{1}$

In response to the first set of questions, I argue that some of the ideas that informed the reconceptualization of Soviet security interests and centered around notions of "common security" and "reasonable sufficiency" originated in the Western liberal internationalist community comprising arms control supporters in the United States as well as peace researchers and left-of-center political parties in Western Europe. ${ }^{2}$ This community formed transnational networks with "new thinkers" in the foreign policy institutes and elsewhere in the former Soviet Union. Mikhail Gorbachev, as a domestic reformer and uncommitted thinker in foreign policy, was open to these ideas because they satisfied his needs for coherent and consistent policy concepts. As a result, the new ideas became causally consequential for the turnaround in Soviet foreign policy. 
In response to the second set, I claim that these very ideas also had an impact on the Western reactions to the new Soviet policies, albeit to different degrees. I illustrate this point with regard to the cautious American and the enthusiastic (West) German responses to the revolution in Soviet foreign policy.

Ideas, however, do not float freely. Decision makers are always exposed to several and often contradictory policy concepts. Research on transnational relations and, most recently, on "epistemic communities" of knowledge-based transnational networks has failed so far to specify the conditions under which specific ideas are selected and influence policies while others fall by the wayside. ${ }^{3}$ The transnational promoters of foreign policy change must align with domestic coalitions supporting their cause in the "target state" to make an impact. I argue that access to the political system as well as the ability to build winning coalitions are determined by the domestic structure of the target state, that is, the nature of its political institutions, state-society relations, and the values and norms embedded in its political culture.

In the former Soviet Union with its state-controlled structure, the transnational actors needed to gain access to the very top of the decision-making hierarchy to have an impact. Their specific ideas and concepts also had to be compatible with the beliefs and goals of the top decision makers.

Access to the U.S. political system, with its society-dominated structure, is comparatively easy, while the requirements for building winning coalitions are profound. Moreover, concepts such as common security were rather alien to a political culture emphasizing pluralist individualism at home and sharp zero-sum conflicts with ideological opponents abroad. As a result, the liberal arms controllers and their societal supporters together with their European allies succeeded in moving the Reagan and Bush administrations toward cautious support for Gorbachev's policies, but not much further.

As to the German "democratic corporatist" structure, access to political institutions is more difficult than in the U.S. case, but strong policy networks such as the party system ensure profound influence once access is achieved. Common security resonated well with a political culture emphasizing consensus-building and compromise among competing interests at home and abroad. The concept was embedded in the German foreign policy consensus even before Gorbachev embraced it. This explains the enthusiastic German response to the new Soviet foreign policy years before the Berlin Wall came down.

In sum, I argue that the transnational networks of liberal internationalists promoting common security, vigorous arms control efforts, and a restructuring of defense postures were active in all three countries but succeeded to very different degrees. The difference in impact can largely be explained by the variation in domestic structures of the three countries.

\section{Deficiencies of prevailing theories}

There is no need to engage in rather complex arguments about domesticinternational linkages and the transnational diffusion of ideas if it can be shown that more parsimonious theories are sufficient in accounting for the dramatic 
turnaround in Soviet foreign policy and the accommodating Western response. But the prevailing structural approaches in international relations theory are mostly indeterminate and thus cannot adequately answer the two sets of questions raised above. They are not wrong, but they need to be supplemented by more complex approaches to explain the dramatic changes in world politics. ${ }^{4}$

Sophisticated realism goes a long way toward showing how the interaction between international systemic and domestic economic factors created a set of conditions that permitted the accommodationist foreign policies pursued by the Gorbachev coalition. Kenneth Oye, for example, argues that the long-term decline of the Soviet economy and the decreasing growth rates of the Eastern European states led to a growing burden on the Soviet Union during the early 1980s that required a fundamental policy change. ${ }^{5}$ At the same time, nuclear deterrence as a systemic condition in East-West relations precluded the resort to adventurous foreign policies which might otherwise have been the response of a declining great power. ${ }^{6}$ One might add that the nuclear deterrence system could also explain the cautious U.S. response to the change in Soviet foreign policy. Bullying Gorbachev into speeding up the retrenchment from Third World conflicts and from Eastern Europe was too risky, given that even a Soviet Union in retreat possessed enough nuclear missiles to annihilate the United States.

One can agree with this analysis and still remain puzzled by the Gorbachev revolution and by at least part of the Western response. The Soviet economic crisis and the nuclear deterrence system would have permitted a variety of state responses of which the new Soviet foreign policy was only one. Why did the reformers in the Politburo embark upon perestroika and glasnost instead of technocratic economic reforms that would have kept the repressive state apparatus intact? The Chinese leadership pursued just such a path under roughly similar domestic conditions. With regard to foreign policy, Gorbachev could have continued or rather returned to the détente and arms control of the 1970s, which would have allowed him a similar international breathing space to promote internal reforms. Instead, he radically changed the Soviet foreign policy outlook, embracing common security and reasonable sufficiency for military means. Moreover, he matched words with deeds by embarking on unilateral initiatives in the nuclear and conventional arms fields that seemed to come right out of the textbooks for "strategies of reassurance." $\mathrm{He}$ accepted the zero option for intermediate-range nuclear forces (INF) together with intrusive on-site inspections, unilateral troop withdrawals, and asymmetrical cuts in Soviet conventional forces. These moves took place even before the Soviet leadership decided to let Eastern Europe go. In sum, Gorbachev went far beyond what one can reasonably expect from a "prudent" realist perspective. Even sophisticated realism does not tell us which of the possible choices was to be expected by the Soviet Union.

Realist bargaining theory, however, might be used to make an additional point. Some argue that Ronald Reagan's coercive strategy toward the Soviet Union and his massive arms buildup during the early 1980s finally drove Moscow's leadership over the edge. ${ }^{8}$ Cornered by the West and faced with an economic crisis at home, Gorbachev had virtually no choice but to cut losses in military 


\section{In between spaces}

and foreign policy, since striking back at the United States was precluded by the nuclear deterrence system. In short, the combination of structural international and domestic conditions with Western "peace through strength" led to the turnaround in Soviet foreign policy.

There is some evidence that the Western reaction to Brezhnev's foreign policy was perceived by the "new thinkers" as a further incentive to change Soviet foreign policy. But to argue that peace through strength together with the structural conditions left no choice to the Soviet Union seems to miss the mark. First, the initial Soviet response to the Western buildup was arms racing as usual. Under Andropov and Chernenko, who faced similarly gloomy economic conditions as Gorbachev, Moscow not only left the negotiating table in 1983 but also accelerated the production and deployment of new nuclear weapons. ${ }^{9}$ Second, some "new thinkers" argue that Reagan's buildup made it harder rather than easier for them to push for changes in the Soviet security outlook. ${ }^{10}$ The transformation of Moscow's foreign policy was contested all along; conservatives in the military and other institutions drew the opposite conclusion from the Reagan buildup than the Gorbachev coalition. That the latter prevailed must be explained by the dynamics of Soviet domestic politics rather than assumed away theoretically.

As to the Western response to the Gorbachev revolution, the American caution may be roughly accounted for by a sophisticated realist argument. It is the German "Gorbimania" that should pose a puzzle to realists. ${ }^{11}$ As a divided frontline state on the East-West border, Germany had a lot to gain or lose by the success or failure of Gorbachev's reforms. On the one hand, the rapidly decreasing Soviet threat could have induced the enthusiasm with which Bonn supported the new Soviet foreign policy. On the other hand, the risks involved in a premature and overly accommodative reaction to Gorbachev could just as well have led to a cautious policy similar to that of the United States. Realism does not predict which of the two lines of reasoning the West Germans would follow.

In sum, sophisticated realism can explain how structural conditions and Western policies created a window of opportunity and thus a demand for new ideas in foreign policy. The theory fails, however, to show why particular ideas were selected over others that were equally possible but that would have led to different foreign policies. ${ }^{12}$ Thus, the end of the cold war serves to confirm the indeterminate nature of the realist approach. ${ }^{13}$

But a major competitor of realism in international relations theory, liberal theory, does not score much better in explaining the momentous changes in world politics. ${ }^{14}$ Liberal accounts take the role of ideas in foreign policy seriously and emphasize that perceptions, knowledge, and values shape the response of state actors to changing material conditions in the domestic and international environments. Several liberal "second image reversed" arguments have been made to explain the end of the cold war. Daniel Deudney and G. John Ikenberry suggested, for example, that the Soviet Union was faced with an international environment in which liberal ideas about democracy, human rights, and market economy not only dominated but also proved successful in serving human needs. ${ }^{15}$ 
As a result, Moscow found itself more and more isolated and, finally, was unable to cut off the country from these long-term liberal trends. In short, Soviet-type communism lost the competition over the organization of political, social, and economic life. ${ }^{16}$

There are three problems with this analysis. First, even large-scale failure does not necessarily result in the adoption of the competitor's approach to the problem. Again, the Chinese attempt to embark on economic reforms while maintaining the repressive political system is a case in point.

Second, the analysis cannot explain the timing of the Soviet foreign policy change. Why did the Soviet leadership acknowledge the victory of liberalism in the mid-1980s and not, say, ten or twenty years earlier?

Third, the argument that the Soviet leadership essentially adopted Western ideas about domestic and foreign policies ignores that Moscow was confronted with more than one Western "liberal" concept. In the foreign policy area, for example, one approach that dominated U.S. foreign policy during Reagan's first term (peace through strength) was alien to a liberal conceptualization of world politics. It was rooted in a Hobbesian understanding of international relations and in realist bargaining theory. A second approach - deterrence plus détente was adopted by the North Atlantic Treaty Organization's Harmel report in 1967 and dominated the foreign policies of most Western European countries during the 1970s and early 1980s. It combined liberal and realist ideas and claimed that limited "cooperation under anarchy" was possible across the East-West divide. ${ }^{17}$ Finally, there was a genuine liberal institutionalist or - by European standards - Social Democratic vision of common security. It held that a "security partnership" (in the words of Helmut Schmidt) through multilateral institutions could transform the East-West conflict and the nuclear deterrence system and that far-reaching peace and cooperative arrangements were possible among opponents. ${ }^{18}$

How is it to be explained that the new Soviet leadership under Gorbachev subscribed to this third concept while discarding the other two? A liberal account emphasizing the international sources of the Soviet change cannot answer that question.

One might argue, though, that Gorbachev could safely embark upon liberal internationalist foreign policies because he knew that the Western democracies would not exploit the Soviet pullback. Democracies not only rarely fight each other, it is claimed, but also tend to exert moderation in their foreign policies toward nondemocracies. ${ }^{19}$ Once the Soviet Union embraced détente and arms control, it could count on an equally accommodative Western response. This argument not only asserts that the Soviet leadership believed in liberal theory but also offers an explanation for the Western reaction to the change in Soviet foreign policy.

Unfortunately, the claim is based on a misreading of the "democratic peace" argument. ${ }^{20}$ While it is conceptually and empirically well-established that democracies rarely fight each other, there is not much evidence that liberal democracies pursue moderate foreign policies toward nondemocracies or even political systems 
in transition to democracy. ${ }^{21}$ Immanuel Kant never argued that democracies are peaceful in general..$^{22}$ Rather, they are engaged in as many militarized disputes and wars with autocracies or partially authoritarian states (such as the former Soviet Union under Gorbachev) as the latter are among themselves. This is not to suggest that the West could have waged war against a Soviet Union in retreat. But liberal theory is indeterminate with regard to a democratic state's reaction to a retreating authoritarian state; Reagan's earlier peace through strength, Bush's caution, and Genscher's enthusiasm are all compatible with the approach.

To understand the revolution in Soviet foreign policy and the various Western responses to it which together brought the cold war to an end, one cannot ignore domestic politics and leadership beliefs. Thus, Matthew Evangelista and Sarah Mendelson emphasize that Gorbachev had to first consolidate his domestic power base in the Politburo and the Central Committee before the turnaround in foreign policy was possible. Richard Lebow argues that leaders committed to broad economic and political reforms tend to be motivationally biased toward accommodative foreign policies under certain conditions. Janice Stein maintains that Gorbachev was predisposed toward "new thinking" in foreign policy and embarked on "learning by doing." ${ }^{23}$

Domestic politics accounts and learning theories offer significant insights into why particular ideas carry the day in specific policy choices while others fail. However, they do not tell us much about the origins of those ideas. Three possibilities come to mind as regards the case under discussion here. First, Gorbachev himself might have developed the new foreign policy beliefs during earlier periods of time and then put them into practice once he had assumed power. There is not much evidence, though, that Gorbachev held firm foreign policy convictions prior to his entering office, particularly in comparison to the clarity of his domestic reform ideas. His few foreign policy speeches during the early 1980 s do not reveal much more than a general open-mindedness toward EastWest cooperation. Even the first major attempt to outline the new foreign policy concept, Gorbachev's report to the Twenty-seventh Communist Party Congress in early 1986, represents a strange mix of "old" and "new thinking." Shevardnadze also suggested that Gorbachev knew all along that he was opposed to Brezhnev's foreign policies but did not have a consistent framework and a coherent concept of international politics before he entered office. ${ }^{25}$ It is clear, though, that he learned extremely quickly.

Second, the ideas and foreign policy concepts might have originated in domestic intellectual communities ${ }^{26}$ that then gained access to the leadership. Jeff Checkel has convincingly shown that "institutchiks" at the Institute of the World Economy and International Relations (IMEMO) were able to convince Gorbachev through advisers such as Aleksandr Yakovlev and Yevgeniy Primakov that world politics had to be analyzed in nonclass categories such as "interdependence" and that his enemy image of American capitalism had to be changed. ${ }^{27}$ Of course, these analysts might have read the book by Robert Keohane and Joseph Nye, ${ }^{28}$ but there is not much evidence that transnational contacts were important to them (with the possible exception of Yakovlev's time as the Soviet ambassador to 
Canada). Mendelson has equally demonstrated that the decision to withdraw from Afghanistan was influenced by a domestic epistemic community. ${ }^{29}$

Analyzing world politics in non-Marxist-Leninist categories (a change in worldviews according to Judith Goldstein and Robert Keohane's categories) was certainly a precondition for the foreign policy revolution. ${ }^{30}$ But it is unlikely that worldviews determine a transformation of specific policies. Rather, these basic assumptions about the world open up an intellectual space for changes in principled or causal beliefs which - in the words of Goldstein and Keohane - "provide road maps that increase actors' clarity about goals or ends-means relationships" and thus affect policies. ${ }^{31}$ Strategic prescriptions such as common security and reasonable sufficiency or nonoffensive defense combine principled and causal beliefs - values and knowledge - and are then operationalized into specific policies. ${ }^{32}$

But since strategic prescriptions centering around common security were new to the Soviet security debate, their intellectual origins must be found outside the country and its foreign policy institutes. ${ }^{33}$ Indeed, Checkel argues that the epistemic community at IMEMO was less influential regarding the new approach to military security than, for example, natural scientists at the Academy of Sciences technical divisions (such as Yevgeny Velikhov and Roald Sagdeev) and institutchiks at the United States of America and Canada Institute (ISKAN) who regularly participated in exchanges and meetings with Western security analysts and scholars. ${ }^{34}$ Complementing his analysis, I argue below that transnational networks between those in the West who supported common security and nonoffensive defense on the one hand and natural scientists and institutchiks at ISKAN on the other were crucial in promoting the new Soviet approach to security. The foreign policy ideas of these transnational exchanges translated a somewhat diffuse "new thinking" about foreign policy into a coherent security policy. Moreover, when Gorbachev not only embraced these concepts but also matched his words with deeds, he could count on the support of the very groups in the West that had provided the ideas in the first place. It is no coincidence that Gorbachev's new foreign policy met the most immediate and most positive response in Germany where common security had gradually become ingrained in the foreign policy consensus of the society. It is also not surprising that a positive response to Gorbachev's overtures took longest in the United States, where liberal internationalist and Social Democratic ideas about foreign policy were not part of mainstream thinking. Thus, the emphasis on transnational networks not only sheds additional light on the origins of the "new thinking" in Soviet foreign policy but, in conjunction with the dynamics of domestic politics, also helps to explain the variation in Western responses to the Gorbachev revolution.

\section{Transnational relations and the end of the Cold War}

In the following section I first identify the actors who developed the new strategic prescriptions about security and the transnational networks through which these concepts were promoted. I then look at the differential impact of these ideas on 
the security policies of the three countries discussed here: the Gorbachev revolution in foreign policy and the American and German responses to it.

\section{Transnational actors and their ideas: The liberal internationalist community}

Four intellectual communities can be identified that together form a "liberal internationalist community" sharing political values and policy concepts. First, the liberal arms control community in the United States has to be mentioned. Its origins date back to the late 1950s when it was among the first to promote the idea of arms control to stabilize the deterrence system..$^{35}$ This community comprises an alliance of (1) natural scientists organized in such groups as the Union of Concerned Scientists (UCS) and the Federation of American Scientists (FAS); (2) policy analysts at various think tanks such as the Brookings Institution; (3) scholars at academic institutions; (4) public interest groups such as the Natural Resources Defense Council (NRDC); and (5) policymakers in the U.S. Congress, mostly liberal Democrats.

The contribution of this group to the broader liberal internationalist agenda during the late 1970s and early 1980s consisted primarily of specific proposals in the nuclear arms control area. The main focus during that time was to oppose the Reagan administration's efforts to do away with nuclear arms control. In particular, the community concentrated on promoting a comprehensive nuclear test ban and on preserving the 1972 Anti-Ballistic Missile (ABM) Treaty threatened by Reagan's Strategic Defense Initiative (SDI). ${ }^{36}$

The second subgroup of the liberal internationalist community consisted of mostly Western European peace researchers based at various institutes such as the Stockholm International Peace Research Institute, the Peace Research Institute in Oslo, the Institute for Peace Research and Security Policy in Hamburg, the Peace Research Institute in Frankfurt, and various universities.

The third group includes European policymakers in Social Democratic and Labour parties and their transnational organization, the Socialist International. Security specialists in the German Social Democratic Party (SPD) as well as the British and Dutch Labour parties were particularly important for the liberal internationalist debate during the period under consideration. ${ }^{37}$

The two European components of the liberal internationalist community shared the concerns of their U.S. counterparts about the future of arms control. But their main contribution to the transnational liberal agenda consisted of developing the concepts of common security and nonoffensive defense (or, to use the German misnomer, strukturelle Angriffsunfähigkeit, that is, "structural inability for offensive operations").

Common security transformed the original arms control idea of stabilizing strategic deterrence through cooperative measures into a concept transcending the notion of national security. The notion claimed that the security dilemma in international relations could be overcome through stable cooperative arrangements and peace orders. Common security emphasized that security in the nuclear 
age could no longer be achieved through unilateral measures and that there is no security for anybody in the East-West relationship unless everybody feels secure. As Egon Bahr, the leading German SPD promoter of the idea, put it:

[Security partnership] starts with the insight that war can no longer be won and that destruction cannot be restricted to one side. . . The consequence of this insight is that there is no reliable security against an opponent, but only with an opponent. There is only common security and everybody is partner in it; not despite potential enmity, but because of this enmity. ${ }^{38}$

Common security was widely discussed among peace researchers as well as mainstream and center-left parties in the Benelux countries, Great Britain, Scandinavia, and West Germany during the late 1970s and early 1980s. In West Germany, for example, then Chancellor Helmut Schmidt introduced the idea of a security partnership between East and West in 1978 but conceptualized it mainly as complementing nuclear deterrence. In 1979 the SPD adopted the concept and eventually transformed it into the notion of common security to gradually overcome deterrence..$^{39}$ By the time Gorbachev came into power, common security was one of the mainstream foreign policy concepts in Europe.

The European peace research community also developed proposals to restructure the Western conventional force posture in such a way that offensive operations would become virtually impossible - nonoffensive defense - and, thus, to overcome the security dilemma by reconciling peaceful intentions with purely defensive capabilities. ${ }^{40}$ By the mid-1980s, various European Social Democratic and Labour parties had adopted nonoffensive defense in their policy platforms.

The fourth component of the transnational community provided the link with the former Soviet Union. It consists of natural scientists and policy analysts in various institutes, primarily at the Academy of Science (for example, the Kurchatov Institute of Atomic Energy headed by Velikhov, the Space Research Institute headed by Sagdeev, and the foreign policy institutes IMEMO and ISKAN). The Soviet "new thinkers" were mainly on the receiving end of ideas promoted by their European and American counterparts.

These four groups not only shared values and policy concepts but also exchanged frequently their views. Since the connections between the U.S. and the European arms control communities are well-documented, I concentrate on the East-West exchanges.

First, specific nuclear arms control proposals were the subject of increasingly institutionalized contacts between the U.S. arms control community, particularly natural scientists working for the UCS, the FAS, and the NRDC, and Soviet experts such as Velikhov and Sagdeev. Evangelista has documented these exchanges and shown in detail how these interactions influenced Soviet arms control decisions. His analysis provides further empirical evidence for the argument developed in this article. ${ }^{41}$

Second, the concept of common security was introduced to Soviet institutchiks and foreign policy experts through the Palme commission (the Independent 
Commission for Disarmament and Security, named after former Swedish Prime Minister and Social Democrat Olof Palme). ${ }^{42}$ It was founded in September 1980 and brought together mostly elder statesmen and-women from around the world to study East-West security issues. Academician Georgii Arbatov, the head of ISKAN, served as the Soviet member, while retired General Mikhail Milstein of the same institute was one of the principal advisers. ${ }^{43}$ Common security was introduced into the commission's deliberations by the German Social Democrat Bahr, who had also been one of the architects of German Ostpolitik. In 1982 the Palme commission issued a report (Common Security) that defined the principles of a cooperative East-West security regime and spelled them out with regard to arms control, confidence-building measures, and economic cooperation.

Third, there were regular exchanges between various West European Social Democratic and Labour parties - particularly the German SPD - and Communist parties in Eastern Europe and the Soviet Union. These relations had been established during the détente period of the 1970s and were continued throughout the 1980s. The SPD, for example, conducted regular meetings on security policy issues with the East German, Polish, Soviet, and other Communist parties. Agreements were worked out on principles of common security, on nuclear and chemical weapon free zones in Central Europe, and on nonoffensive defense. ${ }^{44}$ The Social Democrats tried to build on the consensus achieved in the Palme commission and to gain the support of its recommendations by the Eastern Europeans and Soviets. Given the reality of East-West relations in the pre-Gorbachev era, Western participants in these contacts had to walk a thin line. On the one hand, the contacts legitimized official Eastern European and Soviet policy proposals by promoting nuclear weapon free zones and the like. On the other hand, they served to make the concept of common security acceptable in the East as well as notions that later became known as military glasnost (on-site inspections, for example).

Fourth, the concept of nonoffensive defense reached the Soviet institutchiks primarily through transnational exchanges with Western European peace researchers and military experts. Some of these contacts were initiated through well-known frameworks such as the Pugwash conferences. ${ }^{45}$ In 1984, for example, Pugwash established a working group on conventional forces that became a major EastWest forum on these issues; it included most of the European peace researchers, such as Anders Boserup, Horst Afheldt, and Albrecht von Müller, specializing in "alternative defense" models. Andrei Kokoshin, deputy director of ISKAN and one of the most prominent "new thinkers" in Soviet foreign policy, participated regularly. He became a leading proponent of a defensive restructuring of the Soviet armed forces. Moreover, the annual Pugwash conferences regularly dealt with issues of defensive restructuring, particularly the 1988 meeting in the Soviet Union. Western experts of the nonoffensive defense community were frequently consulted by the institutchiks and even Soviet military academies. ${ }^{46}$ This is all the more significant since nonoffensive defense was alien to traditional Soviet military thinking. In fact, the initial reaction of even civilian experts in the Soviet Union to the alternative defense debate in Western Europe had been 
quite hostile and turned more sympathetic in their publications only after Gorbachev had come into power. ${ }^{47}$ Thus, glasnost opened up space to discuss new ideas in public.

In sum, liberal internationalist ideas about common security and nonoffensive defense reached "new thinkers" in several Soviet institutes through a variety of transnational exchanges with like-minded groups in the West. But what are the indications that these transnational exchanges were politically consequential, that is, had an impact on the Gorbachev revolution in Soviet foreign policy? ${ }^{48}$

\section{Transnational exchanges and the turnaround in Soviet security policy}

In February 1986 Gorbachev made the following remarks about his vision of security:

Security cannot be built endlessly on fear of retaliation, in other words, on the doctrines of "containment" or "deterrence." . . In the context of the relations between the USSR and the USA, security can only be mutual, and if we take international relations as a whole it can only be universal. The highest wisdom is not in caring exclusively for oneself, especially to the detriment of the other side. It is vital that all should feel equally secure. . . . In the military sphere we intend to act in such a way as to give nobody grounds for fear, even imagined ones, about their security. ${ }^{49}$

These remarks excerpted from Gorbachev's report to the Twenty-seventh Party Congress closely resemble the Palme commission's report on common security as well as the above-quoted statements by Bahr. ${ }^{50}$ They represent the first instance in which the Soviet leader identified himself with a new concept of security alien to traditional Soviet thinking. But was there also a causal link beyond a mere correlation? There are various indications that ideas about common security developed by European peace researchers and Social Democrats indeed influenced Gorbachev's thinking.

First, the Soviet leader himself acknowledged that his views about international security and disarmament were "close or identical" to those of European Social Democrats such as Willy Brandt, Bahr, and the Palme commission. ${ }^{51}$ In a meeting with Brandt, he argued that the "new thinking" combined traditions going back to Lenin with insights from "our socialist friends" and "proposals reflected in such documents as reports by the commissions of Palme, Brandt, and Brundtland." ${ }^{52}$ Gorbachev made a deliberate effort to develop closer contacts with the Socialist International and its chairman, Brandt. At the same time, European Social Democrats were, of course, eager to promote their security policy ideas directly to the Soviet leader.

One could argue, of course, that these references to Western thinking by Gorbachev were self-serving and meant to legitimize his own views. Even if true, the similarities between his arguments and those of European analysts and 
policymakers are still striking; and the Soviet leader knew about these affinities. Moreover, as mentioned above, Gorbachev did not hold firm convictions on foreign policy before he entered office. Finally, he matched words with deeds; his policy proposals and actions on nuclear and conventional weapons in Europe directly followed from the newly developed strategic prescriptions on enhancing international security.

Second, the transnational links mentioned above between European institutes and policymakers on the one hand and institutchiks at ISKAN and other Soviet institutes on the other became increasingly important for the reconceptualization of the Soviet approach to security. ISKAN's head, Arbatov - a member of the Palme commission - while certainly not among the most radical "new thinkers," belonged to the inner circle of Gorbachev's foreign policy advisers during the early years of perestroika. Arbatov was extremely impressed by Bahr - "one of the outstanding political minds of our time" - and considered him a friend. ${ }^{53}$ Arbatov's son Alexei headed the new Department of Disarmament and International Security at IMEMO and was far more radical than was his father. The Palme report and its international clout became a major tool for liberal institutchiks to influence both Foreign Minister Shevardnadze and Gorbachev. According to the senior Arbatov, the Palme commission was significant in changing the political thinking in the Soviet Union and introduced the concept of common security to officials. The publication of the Palme report in Moscow also confronted the Soviets with Western estimates of the conventional (im)balance in Europe. ${ }^{54}$

It is thus quite plausible to assume that European ideas about common security reached Gorbachev both directly, through European Social Democrats, and indirectly, through ISKAN and other institutchiks, as well as through his closest advisers such as Yakovlev or Shevardnadze.

Proposals to restructure the Soviet conventional posture toward nonoffensive defense seem to have influenced the leadership in a similar way. The above-cited report to the Twenty-seventh Party Congress already mentioned the defensive orientation of the Soviet military doctrine and the concept of reasonable sufficiency without being specific. One year later, Gorbachev referred to doctrines of defense "connected with such new or comparatively new notions as the reasonable sufficiency of armaments, non-aggressive defense, elimination of disbalance and asymmetries in various types of armed forces, separation of the offensive forces of the two blocs, and so on and so forth." 55

An intensive debate about the implications for the conventional force posture followed among civilian and military analysts in the Soviet Union. The military in particular claimed that "defensive defense" referred to the overall goals of Soviet military doctrine rather than its implementation. The institutchiks argued that reasonable sufficiency should lead to a restructuring of Soviet military forces in such a way as to preclude the ability to conduct (counter-)offensive operations. ${ }^{56}$ ISKAN analysts such as Vitalii Zhurkin, Sergei Karaganov, and Andrei Kortunov as well as its deputy head Kokoshin became leading advocates of the concept. The latter embraced Western ideas of nonoffensive defense and translated 
them into the Soviet context. He published various articles on the subject, together with Major General Valentin Larionov of the General Staff Academy. ${ }^{57}$ As mentioned above, Kokoshin was involved in transnational exchanges at Pugwash and had frequent contacts with European peace researchers such as Boserup and Lutz Unterseher, who were also in touch with the junior Arbatov, Karganov, and the bureaucracy of the Soviet foreign ministry. ${ }^{58}$

In December 1988 Gorbachev showed that he sided with the institutchiks and the "new thinkers" in Shevardnadze's Foreign Ministry when he announced large-scale unilateral troop reductions. Shortly afterward, the Soviet Union accepted the core of Western proposals at the Conventional Forces in Europe negotiations to establish conventional parity in Central Europe. Two years later, the Soviet Defense Ministry published a draft statement on military doctrine that explicitly defined sufficiency as the inability "for conducting large-scale offensive operations." "No "New thinking" had reached the defense bureaucracy.

These are just two examples suggesting that important parts of the reorientation of Soviet security policy were indeed influenced by strategic prescriptions transmitted to the leadership through transnational interactions. ${ }^{60}$ Once the foreign policy experts and their transnational contacts had aligned with the domestic reform coalition in the Soviet Union, the transnational exchanges influenced the very content of the new Soviet security policy and, thus, the scope of the change. The new leadership needed independent expertise outside the military, which opened a window of opportunity for civilians. ${ }^{61}$ As a result, the institutchiks influenced the attitudes of policymakers such as Gorbachev and Shevardnadze. The new ideas about common security and reasonable sufficiency transformed a general uneasiness with the state of Soviet international affairs into a coherent foreign policy concept. The institutchiks and their transnational networks persuaded the Gorbachev coalition of necessary and bold steps to change Soviet foreign policy toward the West. At the same time, their ideas also rationalized and legitimized the need for a turnaround in foreign policy. It is impossible to separate both aspects of how ideas influence policy decisions.

The contribution of the institutchiks and their transnational contacts to the change in Soviet foreign policy was not trivial. By helping Gorbachev match words and deeds, they were crucial in targeting his message to a receptive Western audience, particularly in Europe. Transforming Western attitudes toward the Soviet Union, however, was itself critical not only to end the cold war but also to create the benign international environment that Gorbachev needed to pursue perestroika and glasnost domestically.

\section{Liberal internationalists and the Western responses to Gorbachev: The U.S. and German cases}

As mentioned above, the same transnational coalitions that provided the Gorbachev coalition with new ideas about common security, nonoffensive defense, and military glasnost also targeted the West. In fact, most peace researchers and liberal arms controllers in Western Europe and the United States were 
primarily concerned about Western policies and did not expect the Soviet Union to be receptive to their proposals. Nevertheless their impact varied from country to country. I illustrate this in the following sections by the examples of the United States and West Germany.

The United States: preservation of arms control and cautious response to Gorbachev. In the U.S. case, the liberal arms control community pursued three main objectives during the 1980s: (1) to bring the Reagan administration back on the arms control track and to preserve the nuclear arms control agreements of the 1970s such as the ABM treaty; (2) to convince the administration of the necessity to launch rigorous arms control efforts in the areas of test ban negotiations and nuclear reductions; and (3) to ensure a positive American response to the Gorbachev revolution in foreign policy.

Liberal arms controllers succeeded on the first goal, failed on the second, and achieved mixed results on the third. It is not clear in the successful cases, though, that the members of the arms control community were the most important actors to achieve the outcome. ${ }^{62}$

First, when the Reagan administration brought hard-liners into power, the U.S. arms control community was removed from policy influence. It was the American peace movement and what became known as the "freeze campaign" that revived the arms control process together with pressure from the European allies. ${ }^{63}$ Empowered by social movement pressure, the intellectual expert community reentered the policymaking process, particularly in Congress. The main impact was to shift the bureaucratic balance of power from conservative hard-liners such as Caspar Weinberger and Richard Perle to moderate conservatives such as George Shultz and Paul Nitze. The policy impact of this shift first became visible in early 1984 when Reagan gave several moderate foreign policy speeches that later led to the Shultz-Gromyko agreement to resume arms control talks in January 1985, that is, even before Gorbachev came into office.

Second, the single most important success of the liberal arms control community in the United States was probably to preserve the ABM treaty despite Reagan's SDI. ${ }^{64}$ In this case, a powerful coalition emerged including liberal internationalists, Congress (particularly Senator Nunn who became chairman of the Senate Armed Services Committee in 1986), and the European allies.

But third, the arms control community was less successful in the absence of such a domestic winning coalition. In 1986-87, for example, a transnational coalition between the U.S. NRDC and the Soviet Academy of Science tried to influence U.S. testing policy. In a trial of "private diplomacy," they established seismic verification stations close to the two principal nuclear testing sites in the United States and the Soviet Union. The stations demonstrated publicly that a comprehensive test ban was verifiable and thus discredited a major U.S. objection to a test stop. ${ }^{65}$ The transnational alliance quickly gained access to Congress. In the autumn of 1986, the House of Representatives passed an amendment to the defense budget bill calling for a one-year moratorium on nuclear tests, but a countercoalition including the Reagan administration, Republicans in Congress, and leading Democrats such as Senator Nunn defeated the House resolution. 
Fourth, the efforts of the liberal internationalist community did not have a long-term impact on attitudes toward the Soviet Union and the cold war in general. The liberal arms controllers failed to build a stable policy consensus around their strategic prescriptions. Common security, for example, remained a minority position in the United States. As a result, the Reagan administration reacted rather cautiously to the changes in Moscow, even though Reagan developed a friendly personal relationship with Gorbachev. As late as early 1989, half a year before the Berlin Wall came down, the new Bush administration advocated "status quo plus" as its response to the Gorbachev revolution. ${ }^{66}$

Germany: "security partnership" and "Gorbimania." The reluctant U.S. response to the revolution in Soviet foreign policy contrasts with the West German answer. ${ }^{67}$ As mentioned above, ideas about common security and nonoffensive defense originated in the European peace research community as well as in Social Democratic and Labour parties during the late 1970s. The German SPD was crucial in promoting these ideas domestically and in Europe. By the mid-1980s, before Gorbachev assumed power, a stable German public and elite consensus on common security emerged ranging from the center-left to the center-right and comprising both the SPD and the two governing parties, the Christian Democrats and the Free Democrats. However, ideas about a defensive restructuring of the German armed forces were still contested. The attitude of the Bonn government under Chancellor Kohl toward nonoffensive defense changed to some extent only after the Soviet Union had embraced the concept.

The liberal internationalist community of peace researchers and Social Democrats did not somehow manipulate the German public into believing these ideas, as some have suggested. ${ }^{68}$ Similar to the dynamic interaction between the freeze campaign and the arms control community in the United States, the German peace movement opened a window of opportunity for common security to gain widespread acceptance. The peace movement emerged in reaction to the confrontational U.S.-Soviet relationship of the early 1980 s and to the planned deployment of new medium-range missiles (INF) on German soil; their majority advocated unilateral disarmament and, thus, more radical ideas than common security. But in response to social movement pressure, German societal organizations such as churches and trade unions quickly supported the ideas promoted by peace researchers and the SPD. By about 1982-83, there was strong support for common security, as can be documented in public opinion polls. ${ }^{69}$

Shortly afterward, Christian Democrat leaders such as Chancellor Kohl and Richard von Weizsäcker, the Federal President, increasingly used common security language in their speeches. They refrained from the Social Democratic slogan "security partnership" calling it instead "community of responsibility" (Verantwortungsgemeinschaft). Thus, the conservative Christian Democrats showed support for the ideas in order to preserve their constituency. Common security became the center of a new German security policy consensus in the mid-1980s; this occurred after the peace movements had vanished but before Gorbachev initiated his foreign policy change. 
German enthusiasm for Gorbachev and the revolution in Soviet foreign policy is easy to explain, given these domestic developments. Gorbachev's overtures tapped into the German domestic consensus on security policy and, consequently, fell almost immediately on fertile ground in Bonn. Gorbachev's acceptance of the INF zero option in 1986 became the defining moment for the Germans to embrace his policies. One has to bear in mind in this context the divisiveness of the German INF debate in the early 1980s as well as the fact that the German SPD and then Chancellor Schmidt had promoted the zero option which later became Reagan's INF negotiating position back in $1979 .{ }^{70}$ Thus, popular support for the Soviet leader skyrocketed, and the center-right Kohl government, in particular Free Democrat Foreign Minister Genscher, became the first in the West to appreciate the changes in Soviet foreign policies. From about mid-1986 on, while most of its allies were still skeptical, the German government promoted a positive Western response to the new Soviet foreign policy ("Genscherism"). Germany became the first and only Western state to commit substantial amounts of financial assistance to the Soviet economic reform process. In sum, the cold war was over for the Germans before it was over in reality, that is, about two years before the Berlin Wall came down.

\section{The limits of transnationalism: Domestic structures as intervening variables}

I have tried to document above that a liberal internationalist and transnational community of scholars, policy analysts, and center-left political parties promoted new strategic prescriptions such as common security, nonoffensive defense, and far-reaching arms control agreements during the late 1970s and early 1980s. "New thinkers" in the Soviet Union picked up these ideas and influenced the views of the Soviet leadership. The particular content of Gorbachev's foreign policy revolution cannot be understood without the input of this transnational community. The transnational community also influenced Western policies in response to Gorbachev, albeit to different degrees. It was less successful in the United States but very effective in West Germany by contributing to create a new foreign policy consensus around common security. In sum, I suggest that the end of the cold war - both in the East and the West - cannot be adequately understood without taking the role of these transnationally transmitted ideas into account.

But the argument has limits. There is considerable variation in the impact of these ideas. Only the Soviet Union under Gorbachev reconceptualized its security policy toward both common security and nonoffensive defense. The German polity achieved a domestic consensus on the former but remained reluctant on the latter, while the American public and elite opinion failed to agree on either of the two concepts. Moreover, the interval between the initial promotion of these ideas in the target countries and their acceptance by the political leaderships varies considerably. If we take the Palme commission report as the first instance in which Soviet institutchiks became exposed to common security, it 
took less than four years for the ideas to have a policy impact. It took about ten years in Germany to accomplish the same result - from the mid-1970s, when peace researchers and Social Democrats started promoting the strategic prescriptions, to the mid-1980s. In Washington, common security never became as relevant politically as in Moscow and Bonn.

How is this considerable variation in policy impact to be explained? To influence policies, transnational actors need, first, channels into the political system of the target state and, second, domestic partners with the ability to form winning coalitions. Ideas promoted by transnational alliances or epistemic communities do not matter much unless those two conditions are met. In other words, we have to look at intervening variables between transnational alliances and policy change. I suggest that it is differences in domestic structures among the three countries that account for a large extent of the variation in policy impact of the transnationally circulated ideas.

Originally developed in the field of comparative foreign economic policy, domestic structure approaches have generated empirical research across issueareas to explain variation in state responses to international pressures, constraints, and opportunities. ${ }^{71}$ The concept refers to the structure of the political system, society, and the policy networks linking the two. Domestic structures encompass the organizational apparatus of political and societal institutions, their routines, the decision-making rules and procedures as incorporated in law and custom, as well as the values and norms prescribing appropriate behavior embedded in the political culture.

This last point marks a departure from earlier conceptualizations of domestic structures, which emphasized organizational characteristics of state and society but neglected the political culture and thus insights from the "new institutionalism," particularly the focus on communicative action, duties, social obligations, and norms. ${ }^{72}$ Political culture, then, refers to those worldviews and principled ideas - values and norms - that are stable over long periods of time and are taken for granted by the vast majority of the population. Thus, the political culture as part of the domestic structure contains only those ideas that do not change often and about which there is societal consensus. ${ }^{73}$

Until about 1988-89, the former Soviet Union represented an extremely statecontrolled domestic structure with a highly centralized decision-making apparatus. ${ }^{74}$ Such structures lead to top-down policy-making processes, leaving less room for policy innovations unless they are promoted by the top leadership. It follows that leadership beliefs are expected to matter more than attitudes of the wider population. ${ }^{75}$

Centralized and state-dominated domestic structures provide transnational coalitions with comparatively few access points into the political system. They have to reach the top echelon of the decision-making structure directly rather than building winning coalitions in civil society. Prior to Gorbachev's gaining power, the transnational exchanges between Western liberal internationalists and Soviet institutchiks had almost no impact on Soviet foreign policy. Since the top leadership in the former Soviet Union controlled to which voices it wanted to 
listen, a reform-oriented leadership had to gain power first. It needed to be openminded, and its worldviews needed to be predisposed toward the strategic prescriptions promoted by the transnational actors. The negligible policy impact of the transnational coalition during the Brezhnev period as compared with the Gorbachev era can thus be explained.

Beyond a general proclivity toward foreign policy change, there also seems to be a more specific reason why Gorbachev was attracted to common security. ${ }^{76}$ His domestic reform ideas closely resembled policy concepts promoted by democratic socialism and the Socialist International, which emphasized political democracy and a market economy with a heavy dose of state interventionism. Common security, however, formed the core of the foreign policy beliefs of the European Social Democratic and Labour parties. Gorbachev - who made a strong and, needless to say, successful effort to gain the support of the European Social Democrats - might have been attracted to their foreign policy ideas because they were promoted by groups that also held similar beliefs with regard to domestic politics.

In sum, the combination of a centralized decision-making structure with a reform-oriented leadership explains why the strategic prescriptions promoted by the transnational coalition had such a strong impact on Gorbachev's foreign policy revolution in a comparatively short period of time. Once a channel into the top decision-making circle was open, the transnational coalition profoundly influenced policies. Given the absence of a strong civil society backing the ideas, the impact depended almost entirely on the leadership's willingness to listen.

In contrast to the Soviet Union, the United States represents, of course, a comparatively society-dominated domestic structure with a strong organization of interest groups in which societal demands can be mobilized rather easily. At the same time, it lacks effective intermediate organizations such as a strong party system; and its political system is comparatively fragmented and decentralized without a powerful center (Congress versus Executive, Pentagon versus State Department, etc. $).{ }^{77}$ Moreover and throughout the cold war, the American national security culture incorporated rather strong and consensual enemy images of the Soviet Union and defined national security mainly in military terms. ${ }^{78}$

Society-dominated structures are expected to mediate the impact of transnational coalitions in almost the opposite way as state-controlled structures. Transnational actors should have few problems in finding access into the decentralized political system. While this initial hurdle is comparatively low, the task of building a winning coalition is expected to be more complex than in state-dominated systems. Since society-dominated structures are characterized by frequently shifting coalitions, transnational alliances may successfully influence policies in the short run, but their long-term impact is probably rather limited.

Indeed, the liberal arms control community had virtually no problems finding channels into the political system but failed to form stable winning coalitions with a lasting policy impact. The group was successful only to the extent that its demands were compatible with either a public opinion consensus - as in the case of Reagan's return to the arms control table - or the views of powerful 
players in Congress - as in the case of the preservation of the ABM treaty. The more far-reaching goals of the community, however, required a change in basic attitudes toward the Soviet Union and a mellowing of the U.S. cold war consensus as a precondition of forming a domestic winning coalition. This was possible only after the cold war was over.

Germany represents a third type of domestic structure, the democratic corporatist model. ${ }^{79}$ It is characterized by comparatively centralized societal organizations, strong and effective political parties, and a federal government that normally depends on a coalition between at least two parties. As a result and supported by cultural norms emphasizing social partnership between ideological and class opponents, the system is geared toward compromise-oriented consensus-building in its policy networks.

Democratic corporatist structures tend to provide societal and transnational forces with fewer access points to political institutions than do society-dominated systems. Their policy impact should also be more incremental because of the slow and compromise-oriented nature of the decision-making processes. But any impact made is expected to last longer because corporatist structures are geared toward institutionalizing consensus on policies.

As argued above, ideas about common security were gradually picked up, first, by the SPD as one of the two leading mass integration parties and, second, by societal organizations; they thereby reached the constituency of the conservative Christian Democrats. In the end, the polarized debate about détente during the 1970s and about nuclear weapons during the early 1980s evolved into a new consensus centered around common security, which explains the German enthusiasm for the Gorbachev revolution. The structure of German political institutions and policy networks explains why it took much longer for the new ideas to influence policies than in the Soviet case. The German political culture was geared toward class and ideological compromise, and past experiences with Ostpolitik explain why common security or security partnership became a consensual belief as the foreign policy equivalent of the domestic social partnership.

In sum, a domestic structure approach that incorporates political culture can account for the differential foreign policy impact of ideas promoted by transnational communities. The channels by which these ideas enter the policymaking process and become incorporated into national foreign policies seem to be determined by the nature of the political institutions. At the same time, the strategic prescriptions need to be compatible with the worldviews embedded in the political culture or held by those powerful enough to build winning coalitions. In the case of the former Soviet Union and its centralized decisionmaking structure, the transnational coalition's policy ideas required both incorporation into Gorbachev's basic beliefs and his determination to implement reforms in order to have an impact. In the German case, a political culture geared toward compromise and consensus represented a functional equivalent in that it enabled elite and public opinion to accept the strategic prescription of common security. 


\section{Conclusions}

This article has made three points. First, the prevailing realist and liberal theories of international relations account for underlying structural changes opening a window of opportunity for the end of the cold war. But if we want to understand its immediate causes, we need to explain the specific content of Gorbachev's foreign policy revolution as well as the Western responses to it. Structural explanations are insufficient for this task. Rather, an account is required which integrates international and domestic politics.

Second, the content of the Soviet foreign policy change and the Western reactions which together brought the cold war to an end were informed by specific principled and causal beliefs - values and strategic prescriptions. Some of these ideas originated independently of each other in various domestic intellectual communities. Others, particularly those informing the reconceptualization of Soviet security interests, emanated from a transnational liberal internationalist community comprising the U.S. arms control community, Western European scholars and center-left policymakers, as well as Soviet institutchiks. These ideas were causally consequential for the end of the cold war.

Third, however, the ideas had a differential impact in the former Soviet Union, the United States, and Germany. The difference can be explained by a revised domestic structure approach that incorporates political culture. The differences between the Soviet, U.S., and German domestic structures explain to a large degree the variation in policy impact of the transnational networks and their strategic prescriptions.

I conclude, therefore, that structural theories of international relations need to be complemented by approaches that integrate domestic politics, transnational relations, and the role of ideas if we want to understand the recent sea change in world politics. The approach presented here does not pretend to offer a general theory of international relations. It is more limited and focuses instead on comparative foreign policy - a neglected and undertheorized field. As a result, the main competitors are neither realism nor liberalism, but behavioral decisionmaking analysis as well as rational choice and state-as-unitary actor assumptions. Bureaucratic politics and cognitive psychological accounts offer complementary rather than alternative explanations.

The approach presented here promises insights with regard to two questions in the study of comparative foreign policy. First, the argument developed in this article could prove helpful in analyzing the policy impact of transnational actors and coalitions. Reviving this subject is long overdue to move beyond the earlier sterile debate between society-dominated versus state-centered approaches to world politics. The focus on domestic structures as intervening variables between transnational coalitions and the foreign policy of states appears to offer a way of theorizing systematically about the interactions between states and transnational relations. ${ }^{80}$

Second, this article attempts to contribute to the study of how ideas matter in foreign policy. Many scholars recently have drawn attention to the institutional conditions under which new values and policy strategies become politically relevant. ${ }^{81}$ 
A modified domestic structure approach incorporating long-held worldviews embedded in the political culture appears to account for the variation in impact of transnationally diffused principled and causal beliefs across different countries.

But the argument developed in this article differs in one important aspect from the approach adopted by Goldstein and Keohane, who argue that "the materialistically egocentric maximizer of modern economic theory" allows us to "formulate the null hypothesis" against which the role and impact of ideas can be measured. ${ }^{82}$ The problem is that both the reconceptualization of Soviet security interests and the German enthusiasm for Gorbachev are perfectly consistent with such a null hypothesis - after the event. I have tried to argue above that the issue is not whether the end of the cold war can be explained on the basis of power relationships. Rather, a power-based analysis using the model of egoistic utility maximizers is underdetermining in the sense that it leaves various options as to how actors may define their interests in response to underlying structural conditions. The role and impact of ideas must then be conceptualized as intervening variables between structural conditions and the definition of actors' interests and preferences. Studying ideas does not offer alternative accounts to structural explanations, but the latter are notoriously insufficient if we want to understand the way actors define and interpret their interests.

\section{Notes}

This and the other articles in this Symposium were prepared for International Organization and for Richard N. Lebow and Thomas Risse-Kappen, eds., International Relations Theory and the End of the Cold War (New York: Columbia University Press, 1995). The article draws on insights from two collaborative projects: the abovereferenced project; and Thomas Risse-Kappen, ed., Bringing Transnational Relations Back In: Non-state Actors, Domestic Structures, and International Institutions (Cambridge, UK: Cambridge University Press, 1995). I thank the contributors to both projects for helping to clarify my thoughts on the subject. I am also very grateful to Richard Ned Lebow, John Odell, Steve Ropp, Jack Snyder, and several anonymous reviewers for helpful comments on the draft of this article. Moreover, since I cannot claim to be an expert on the former Soviet Union, I owe a lot to the work of Matthew Evangelista and that of Robert Herman. Finally, I thank Janice Stein, who originated this article's title. I would also like to acknowledge the support of Cornell University's Peace Studies Program, Yale University's International Security Program, and the International Studies Program at the University of Wyoming.

1 This article is part of a growing body of literature on the role of ideas in foreign policy. With regard to the former Soviet Union, see in particular George Breslauer and Philip Tetlock, eds., Learning in U.S. and Soviet Foreign Policy (Boulder, Colo.: Westview, 1991); Jeff Checkel, "Ideas, Institutions, and the Gorbachev Foreign Policy Revolution," World Politics 45 (January 1993), pp. 271-300; Matthew Evangelista, "Sources of Moderation in Soviet Security Policy," in Philip Tetlock and Robert Jervis, eds., Behavior, Society and Nuclear War, vol. 2 (New York: Oxford University Press, 1991); Matthew Evangelista, Taming the Bear: Transnational Relations and the Demise of the Soviet Threat, forthcoming; Robert Herman, "Soviet New Thinking: Ideas, Interests, and the Redefinition of Security," Ph.D. diss., Cornell University, Ithaca, N.Y., in preparation; Sarah E. Mendelson, "Internal Battles and External Wars: Politics, 
Learning, and the Soviet Withdrawal from Afghanistan," World Politics 45 (April 1993), pp. 327-60; Rey Koslowski and Friedrich V. Kratochwil, "Understanding Change in International Politics: The Soviet Empire's Demise and the International System," and Janice G. Stein, "Political Learning by Doing: Gorbachev as Uncommitted Thinker and Motivated Learner," both in this issue of International Organization; and Richard N. Lebow, "Why Do Leaders Seek Accommodation with Adversaries," in Richard N. Lebow and Thomas Risse-Kappen, eds., International Relations Theory and the End of the Cold War, 1995. On ideas and foreign policy in general, see Emanuel Adler, The Power of Ideology: The Quest of Technological Autonomy in Argentina and Brazil (Berkeley: University of California Press, 1987); Judith Goldstein, "Ideas, Institutions, and American Trade Policy," International Organization 42 (Winter 1988), pp. 179-217; Judith Goldstein and Robert Keohane, eds., Ideas and Foreign Policy (Ithaca, N.Y.: Cornell University Press, 1993); Ernst Haas, When Knowledge Is Power (Berkeley: University of California Press, 1990); Peter Haas, ed., Knowledge, Power, and International Policy Coordination, special issue, International Organization 46 (Winter 1992); John Odell, U.S. International Monetary Policy: Markets, Power, and Ideas as Sources of Change (Princeton, N.J.: Princeton University Press, 1982); and Kathryn Sikkink, Ideas and Institutions: Developmentalism in Brazil and Argentina (Ithaca, N.Y.: Cornell University Press, 1991).

2 I use the term "common security" (in Russian, vseobshaia bezopasnost') throughout the article, even though Soviet/Russian and American authors frequently speak of "mutual security" (vzaimnaia bezopasnost') or "equal security" (bezopasnost' dlia vsekh). I do this for two reasons. First, each term refers to the same concept. Second, common security is the generic term for the concept as it was originally used in the German security debate (gemeinsame Sicherheit) and later in the Palme commission's report. See Independent Commission on Disarmament and Security Issues, Common Security: A Blueprint for Survival (New York: Simon and Schuster, 1982). On the various Russian terms, see Georgii Arbatov, Zatianuvsheesia vysdorovlenie (1953-1988 gg.), Svidetel'stvo sovremennika (Moscow: Mezhdunarodnye otnosheniia, 1991), pp. 240-41 (This appeared in English as: The System: An Insider's Life in Soviet Politics [New York: Random House, 1992].). I thank Matt Evangelista for clarifying the Russian terms for me and for alerting me to Arbatov's book.

3 On epistemic communities, see P. Haas, Knowledge, Power, and International Policy Coordination; and E. Haas, When Knowledge Is Power. On transnational relations, see Robert Keohane and Joseph Nye, eds., Transnational Relations and World Politics (Cambridge, Mass.: Harvard University Press, 1971).

4 The following discussion is based on Isabelle Grunberg and Thomas Risse-Kappen, "A Time of Reckoning? Theories of International Relations and the End of the Cold War," in Pierre Allan and Kjell Goldmann, eds., The End of the Cold War: Evaluating Theories of International Relations (Dordrecht, Netherlands: Martinus Nijhoff Publishing, 1992), pp. 104-46.

5 Kenneth Oye, "Explaining the End of the Cold War: Morphological and Behavioral Adaptations to the Nuclear Peace," in Lebow and Risse-Kappen, International Relations Theory and the End of the Cold War. For a critical discussion of this argument see Matthew Evangelista, "Internal and External Constraints on Grand Strategy: The Soviet Case," in Richard Rosecrance and Arthur Stein, eds., Beyond Realism: Domestic Factors and Grand Strategy (Ithaca, N.Y.: Cornell University Press, forthcoming).

6 Robert Gilpin, War and Change in World Politics (Cambridge: Cambridge University Press, 1981).

7 For excellent surveys of strategies of reassurance see Alexander George, "Strategies for Facilitating Cooperation," in Alexander George, Philip Farley, and Alexander Dallin, eds., U.S.-Soviet Security Cooperation (New York: Oxford University Press, 
1988), pp. 692-711; Richard N. Lebow and Janice G. Stein, "Beyond Deterrence," Journal of Social Issues 43 (Winter 1987), pp. 5-72; Janice Stein, "Reassurance in International Conflict Management," Political Science Quarterly 106 (Fall 1991), pp. 431-51.

8 See, for example, John Lewis Gaddis, "Hanging Tough Paid Off," Bulletin of Atomic Scientists 45 (January 1989), pp. 11-14; Valéry Giscard d'Estaing, Henry Kissinger, and Yasuhiro Nakasone, "East-West Relations," Foreign Affairs 68 (Summer 1989), pp. 1-21, and especially pp. 8-9. See also Robert Einhorn, Negotiating from Strength: Leverage in U.S.-Soviet Arms Control (New York: Praeger, 1985).

9 For empirical evidence see Fred Chernoff, "Ending the Cold War: The Soviet Retreat and the U.S. Military Buildup," International Affairs 67 (January 1991), pp. 111-26; Ted Hopf, "Peripheral Visions: Brezhnev and Gorbachev Meet the 'Reagan Doctrine,"” in Breslauer and Tetlock, Learning in U.S. and Soviet Foreign Policy; Mendelson, "Internal Battles and External Wars"; and Thomas Risse-Kappen, "Did 'Peace Through Strength' End the Cold War," International Security 16 (Summer 1991), pp. 162-88. For a general discussion of Western leverage on the Soviet Union, see Jack Snyder, "International Leverage on Soviet Domestic Change," World Politics 42 (October 1989), pp. 1-30.

10 For evidence see Mendelson, "Internal Battles and External Wars," p. 334.

11 I am referring to West German enthusiasm for Gorbachev in 1987 and 1988, that is, two years before the Soviet leadership consented to German reunification.

12 For a similar point see Checkel, "Ideas, Institutions, and the Gorbachev Foreign Policy Revolution," pp. 274 and 279-80.

13 Waltz seems to acknowledge this point when he writes that "any theory of international politics requires also a theory of domestic politics." See p. 331 of Kenneth Waltz, "Reflections on Theory of International Politics: A Response to My Critics," in Robert Keohane, ed., Neorealism and Its Critics (New York: Columbia University Press, 1986), pp. 322-45. On the indeterminate nature of realism see also Robert Keohane, "Realism, Neorealism, and the Study of World Politics," in ibid., pp. 1-26; Stephen Haggard, "Structuralism and Its Critics: Recent Progress in International Relations Theory," in Emanuel Adler and Beverly Crawford, eds., Progress in Postwar International Relations (New York: Columbia University Press, 1991); and Richard Ned Lebow, "The Long Peace, the End of the Cold War, and the Failure of Realism," in this issue of International Organization.

14 For examples of efforts at systematizing liberal thinking in international relations, see Ernst-Otto Czempiel, Friedensstrategien (Strategies for peace) (Paderborn, Germany: Schöningh, 1986); Robert Keohane, "International Liberalism Reconsidered," in John Dunn, ed., The Economic Limits to Modern Politics (Cambridge: Cambridge University Press, 1990), pp. 165-94; Andrew Moravcsik, "Liberalism and International Relations Theory," working paper no. 92-6, Center for International Affairs, Harvard University, Cambridge, Mass., 1992; and Bruce Russett, Grasping the Democratic Peace (Princeton, N.J.: Princeton University Press, 1993).

15 Daniel Deudney and G. John Ikenberry, "The International Sources of Soviet Change," International Security 16 (Winter 1991-92), pp. 74-118; and Daniel Deudney and G. John Ikenberry, "Soviet Reform and the End of the Cold War: Explaining Large-scale Historical Change," Review of International Studies 17 (Summer 1991), pp. 225-50. For a critique of the argument, see Mendelson, "Internal Wars and External Battles," pp. 330-31.

16 For an extreme version of this argument see Francis Fukuyama, The End of History and the Last Man (New York: Free Press, 1991).

17 Grieco calls this perspective "neoliberal institutionalism," while Jack Snyder uses the term "defensive realism." See Joseph M. Grieco, "Anarchy and the Limits of Cooperation: A Realist Critique of the Newest Liberal Institutionalism," International 
Organization 42 (Summer 1988), pp. 485-507; and Jack Snyder, "Myths, Modernization, and the Post-Gorbachev World," in Lebow and Risse-Kappen, International Relations Theory and the End of the Cold War. See also Kenneth W. Oye, ed., Cooperation Under Anarchy (Princeton, N.J.: Princeton University Press, 1986). This approach also influenced much of the original arms control literature. See, for example, Thomas Schelling and Morton Halperin, Strategy and Arms Control, 2d ed. (New York: Pergamon and Brassey, 1985); and Hedley Bull, The Control of the Arms Race (London: Weidenfeld and Nicolson, 1961).

18 The bible of that approach is Independent Commission on Disarmament and Security Issues Common Security. See also Egon Bahr, Was wird aus den Deutschen? (What will happen to the Germans?) (Reinbek, Germany: Rowohlt, 1982); and Dieter S. Lutz, ed., Gemeinsame Sicherheit (Common security), 2 vols. (Baden-Baden, Germany: Nomos, 1986).

19 For this argument see Snyder, "Myths, Modernization, and the Post-Gorbachev World."

20 See Michael Doyle, "Liberalism and the End of the Cold War," in Lebow and RisseKappen, International Relations Theory and the End of the Cold War; Michael Doyle, "Liberalism and World Politics," American Political Science Review 80 (December 1986), pp. 1151-69; and Russett, Grasping the Democratic Peace.

21 For the most recent data on the democratic peace see Russett, Grasping the Democratic Peace. See also the special issues of the Journal of Conflict Resolution 35 (June 1991) and of International Interactions 18 (February 1993); and Zeev Maoz and Bruce Russett, "Alliances, Contiguity, Wealth, and Political Stability: Is the Lack of Conflict Among Democracies a Statistical Artefact?” International Interactions 17 (1992), pp. $245-67$.

22 Compare Immanuel Kant, “Zum Ewigen Frieden: Ein philosophischer Entwurf” [1795] (Perpetual peace: A philosophical sketch), in Wilhelm Weischedel, ed., Immanuel Kant: Werke in sechs Bänden (Immanuel Kant: Works in six volumes), vol. 6 (Frankfurt: Insel-Verlag, 1964), pp. 193-251.

23 See Evangelista, "Sources of Moderation in Soviet Security Policy"; Mendelson, "Internal Battles and External Wars"; Lebow, "Why Do Leaders Seek Accommodation With Adversaries?"; and Stein, "Political Learning by Doing." See also Robert Legvold, "Soviet Learning in the 1980s," in Breslauer and Tetlock, Learning in U.S. and Soviet Foreign Policy; and Jack Snyder, "The Gorbachev Revolution: A Waning of Soviet Expansionism," International Security 12 (Winter 1987-88), pp. 93-131.

24 See M.S. Gorbachev, "Speech in the British Parliament," 18 December 1984, in M.S. Gorbachev, Speeches and Writings (Oxford: Pergamon Press, 1986), pp. 123-30; and M.S. Gorbachev, "Report to the Twenty-seventh Congress of the Communist Party of the Soviet Union," 25 February 1986, in ibid., pp. 1-109. (In particular, see pp. 5-21 of the latter for an example of "old thinking," which emphasized the world class struggle, and pp. 70-85 for a mix of "old" and "new thinking.")

25 Shevardnadze is quoted in Checkel, "Ideas, Institutions, and the Gorbachev Foreign Policy Revolution," p. 294 (particularly footnote 78).

26 I hesitate to use the term "epistemic communities," since Peter Haas's definition emphasizes policy-relevant knowledge and shared causal beliefs as their primary source of authority. While the intellectual community in the former Soviet Union shared certain knowledge claims about international politics, their internal consensus derived mostly from shared principled beliefs or values. To put it differently, their "knowledge claims" made sense only if one shared their values. Moreover, their "expertise and competence in a particular domain" was only "recognized" (another part of Haas's definition) when Gorbachev came into power and increasingly relied on their ideas. Finally, their competence remained contested in the Soviet domestic debate. On the definition of epistemic communities, see Peter Haas, "Introduction: Epistemic Communities and International Policy Coordination," in P. Haas, Knowledge, 
Power, and International Policy Coordination, pp. 1-35 and especially p. 3. For a discussion, see Margaret Keck and Kathryn Sikkink, "International Issue Networks in the Environment and Human Rights," paper prepared for the seventeenth International Congress of the Latin American Studies Association, 24-27 September 1992, Los Angeles.

27 Checkel, "Ideas, Institutions, and the Gorbachev Foreign Policy Revolution."

28 Robert Keohane and Joseph Nye, Power and Interdependence (Boston: Little, Brown, 1977).

29 Mendelson, "Internal Battles and External Wars."

30 See Judith Goldstein and Robert Keohane, "Ideas and Foreign Policy: An Analytical Framework," in Goldstein and Keohane, Ideas and Foreign Policy, pp. 3-30.

31 The quotation is from ibid., p. 3.

32 On the term "strategic prescription," see Checkel, "Ideas, Institutions, and the Gorbachev Foreign Policy Revolution," p. 281. Strategic prescriptions contain both values (such as peace and security) and assumptions about causal relationships between ends and means. Thus, they do not fall neatly in one of the two categories of principled or causal beliefs identified by Goldstein and Keohane.

33 For the evolution of Soviet security thinking see Stephen Kull, Burying Lenin: The Revolution in Soviet Ideology and Foreign Policy (Boulder, Colo.: Westview, 1992); and Allen Lynch, Gorbachev's International Outlook: Intellectual Origins and Political Consequences, Institute for East-West Security Studies Occasional Paper no. 9 (Boulder, Colo.: Westview, 1989).

34 Checkel, "Ideas, Institutions, and the Gorbachev Foreign Policy Revolution," pp. 291-94.

35 For overviews see Emanuel Adler, "The Emergence of Cooperation: National Epistemic Communities and the International Evolution of the Idea of Nuclear Arms Control," in P. Haas, Knowledge, Power, and International Policy Coordination, pp. 101-45; Gert Krell, "The Problems and Achievements of Arms Control," Arms Control (December 1981), pp. 247-86.

36 On the domestic arms control debate during the Reagan administration see Dan Caldwell, The Dynamics of Domestic Politics and Arms Control: The SALT II Treaty Debate (Columbia: University of South Carolina Press, 1991); Michael Krepon, Arms Control in the Reagan Administration (Washington, D.C.: University Press of America, 1989); Bernd W. Kubbig, Amerikanische Rüstungskontrollpolitik: Die innergesellschaftlichen Auseinandersetzungen in der ersten Amtszeit Ronald Reagans (U.S. arms control policy: The domestic debates during Reagan's first term) (Frankfurt M.: Campus, 1988); David Meyer, A Winter of Discontent: The Freeze and American Politics (New York: Praeger, 1990); and Philip G. Schrag, Listening for the Bomb: A Study in Nuclear Arms Control Verification (Boulder, Colo.: Westview, 1989).

37 On the German debate see Jeffrey Boutwell, The German Nuclear Dilemma (Ithaca, N.Y.: Cornell University Press, 1990); and Thomas Risse-Kappen, Die Krise der Sicherheitspolitik: Neuorientierungen und Entscheidungsprozesse im politischen System der Bundesrepublik Deutschland 1977-1984 (The crisis of security policy: New orientations and decision-making processes in the political system of the Federal Republic of Germany, 1977-1984) (Mainz, Germany: Grünewald-Kaiser, 1988).

38 See p. 108 of Egon Bahr, "Sozialdemokratische Sicherheitspolitik" (Social Democratic security policy), Die Neue Gesellschaft no. 2 (1983), pp. 105-10 (my translation and emphasis). See also Bahr, Was wird aus den Deutschen? Egon Bahr, "Gemeinsame Sicherheit: Gedanken zur Entschärfung der nuklearen Konfrontation in Europa" (Common security: Thoughts on the de-escalation of the nuclear confrontation in Europe), Europa-Archiv 37 (1982), pp. 421-30; and Lutz, Gemeinsame Sicherheit.

39 For details see Risse-Kappen, Die Krise der Sicherheitspolitik, pp. 110-18 and $152-71$. 
40 See, for example, Horst Afheldt, Defensive Verteidigung (Defensive defense) (Reinbek, Germany: Rowohlt, 1983); Anders Boserup and Andrew Mack, Krieg ohne Waffen (War without weapons) (Reinbek, Germany: Rowohlt, 1974); Anders Boserup, Foundations of Defensive Defense (New York: Macmillan, 1990); Bjorn Mụller, Nonoffensive Defense: A Bibliography (Copenhagen: Center for Peace and Conflict Research, 1987); Bjorn Muller, Common Security and Non-offensive Defense: A Neorealist Perspective (Boulder, Colo.: Lynne Rienner Publishing, 1992); Studiengruppe Alternative Sicherheitspolitik (Study Group on Alternative Security Policy) Strukturwandel der Verteidigung (Structural change of defense) (Opladen, Germany: Westdeutscher Verlag, 1984); Albrecht A.C. von Müller, "Integrated Forward Defense," manuscript, Starnberg, Germany, 1985. On the security dilemma see Robert Jervis, "Cooperation Under the Security Dilemma," World Politics 30 (January 1978), pp. 186-214.

41 Evangelista, Taming the Bear; and Matthew Evangelista, "Transnational Relations, Domestic Structures, and Security Policy in the U.S.S.R. and Russia," in Risse-Kappen, Bringing Transnational Relations Back In.

42 See Independent Commission on Disarmament and Security Issues, Common Security.

43 Arbatov, The System, pp. 311-12. Milstein frequently published in Western journals. See, for example, Mikhail Milstein, "Problems of the Inadmissability of Nuclear Conflict," International Studies Quarterly 20 (March 1976), pp. 87-103.

44 The most far-reaching agreement was the SPD-Polish Communist Party declaration entitled "Criteria and Measures for Establishing Confidence-Building Security Structures in Europe," Warsaw, signed 2 February 1988. For details see Stephan Kux, "Western Peace Research and Soviet Military Thought," manuscript, Columbia University, New York, 20 April 1989.

45 On the history of Pugwash, see Joseph Rotblat, Scientists in the Quest for Peace: A History of the Pugwash Conference (Cambridge, Mass.: MIT Press, 1972).

46 For details, see Kux, "Western Peace Research and Soviet Military Thought"; and Matthew Evangelista, "Transnational Alliances and Soviet Demilitarization," paper prepared for the Council on Economic Priorities, October 1990, manuscript pp. 33-41. See also Anders Boserup, "A Way to Undermine Hostility," Bulletin of the Atomic Scientists 44 (September 1988), pp. 16-19. On the various Pugwash meetings, see Joseph Rotblat and Laszlo Valki, eds., Coexistence, Cooperation, and Common Security: Annals of Pugwash 1986 (New York: St. Martin's Press, 1988); and Joseph Rotblat and V.I. Goldanskii, eds., Global Problems and Common Security: Annals of Pugwash 1988 (Berlin: Springer-Verlag, 1989).

47 For the initial Soviet reactions, see Stephan Tiedtke, Abschreckung und ihre Alternativen: Die sowjetische Sicht einer westlichen Debatte (Deterrence and its alternatives: The Soviet view of a Western debate) (Heidelberg, Germany: Forschungsstätte der Evangelischen Studiengemeinschaft, 1986).

48 Tracing the policy impact of transnational coalitions requires extensive data on decision-making processes in order to allow for causal inferences. Compared with these requirements, the evidence presented below still is not satisfactory. For further and more detailed studies see Evangelista, Taming the Bear; Evangelista, "Transnational Relations, Domestic Structures, and Security Policy in the U.S.S.R. and Russia"; and Herman, Soviet New Thinking.

49 Gorbachev, "Report to the Twenty-Seventh Congress of the Communist Party of the Soviet Union," pp. 71 and 74. For a more coherent and less ambiguous argument about common security see Mikhail Gorbachev, Perestroika: New Thinking for Our Country and the World (New York: Harper and Row, 1987), pp. 140-44. For comprehensive analyses of the new Soviet thinking about security, see Kull, Burying Lenin; Raymond Garthoff, Deterrence and the Revolution in Soviet Military Doctrine (Washington, D.C.: Brookings Institution, 1990); and Klaus Segbers, Der 
sowjetische Systemwandel (The Soviet system change) (Frankfurt M.: Suhrkamp, 1989), pp. 299-330.

50 See, for example, Independent Commission on Disarmament and Security Issues, Common Security, pp. 6-11.

51 Compare Gorbachev, Perestroika, pp. 206-7; see also p. 196 regarding the Brandt commission on North-South issues.

52 Pravda, 6 April 1988, as quoted in Kux, "Western Peace Research and Soviet Military Thought," p. 13. See also Evangelista, "Transnational Alliances and Soviet Demilitarization," pp. 29-31. As Georgii Arbatov put it: "We do not claim to have invented all the ideas of the new thinking. Some of them originated outside the Soviet Union with people such as Albert Einstein, Bertrand Russell, and Olof Palme. We are developing them, along with our own ideas, into a full program for international conduct." See Stephen F. Cohen and Katrina Vanden Heuvel, eds., Voices of Glasnost (New York: W.W. Norton, 1989), p. 315.

53 Arbatov, The System, p. 171.

54 See Arbatov, The System, pp. 311-12; Checkel, "Ideas, Institutions, and the Gorbachev Foreign Policy Revolution," pp. 291-94; Mendelson, "Internal Battles and External Wars," p. 340; Lynch, Gorbachev's International Outlook, pp. 56-58; and Pat Litherland, "Gorbachev and Arms Control: Civilian Experts and Soviet Policy," Peace Research Report no. 12, University of Bradford, November 1986. As regards Alexei Arbatov, see his book Lethal Frontiers: A Soviet View of Nuclear Strategy, Weapons, and Negotiations (New York: Praeger, 1988), which first appeared in Russian in 1984 and shows a superb knowledge of the American strategic debate.

55 Gorbachev, Perestroika, pp. 142-43. See also his "Report to the Twenty-seventh Congress of the Communist Party of the Soviet Union," p. 74.

56 For details of these arguments, see Garthoff, Deterrence and the Revolution in Soviet Military Doctrine, pp. 149-85; Stephen M. Meyer, "The Sources and Prospects of Gorbachev's New Political Thinking on Security," International Security 13 (Fall 1988), pp. 124-63; R. Hyland Phillips and Jeffrey I. Sands, "Reasonable Sufficiency and Soviet Conventional Defense," International Security 13 (Fall 1988), pp. 164-78; and Willard C. Frank and Philip S. Gillette, eds., Soviet Military Doctrine from Lenin to Gorbachev, 1915-1991 (Westport, Conn.: Greenwood, 1992).

57 See, for example, Andrei Kokoshin and Valentin Larionov, "Confrontation of Conventional Forces in the Context of Ensuring Strategic Stability," in Hans Günter Brauch and Robert Kennedy, eds., Alternative Conventional Defense Postures in the European Theater, vol. 2 (New York: Crane Russak, 1992), pp. 71-82. The Russian original of this article first appeared in 1988. See also Andrei Kokoshin, "Restructure Forces, Enhance Security," Bulletin of the Atomic Scientists 44 (September 1988), pp. 35-38; Andrei Kokoshin and Valentin Larionov, Prevention of War: Doctrines, Concepts, Prospects (Moscow: Progress, 1991); and Valentin Larionov, "Soviet Military Doctrine: Past and Present," in Frank and Gillette, Soviet Military Doctrine from Lenin to Gorbachev, pp. 301-19.

58 For details of these exchanges, see Evangelista, "Transnational Alliances and Soviet Demilitarization," pp. 31-37.

59 Frank and Gillette, Soviet Military Doctrine from Lenin to Gorbachev, p. 397.

60 Other examples include arms control proposals on test ban negotiations and the ABM treaty (as indicated by Evangelista, "Transnational Relations, Domestic Structures, and Security Policy in the U.S.S.R. and Russia") and ideas about the "common European home" and the Conference for Security and Cooperation in Europe. See Gorbachev, Perestroika, pp. 194-98. I thank one of the anonymous reviewers for alerting me to this.

61 See Litherland, "Gorbachev and Arms Control: Civilian Experts and Soviet Policy"; Lynch, Gorbachev's International Outlook; and Kimberley Martin Zisk, "Soviet 
Academic Theories on International Conflict and Negotiation: A Research Note," Journal of Conflict Resolution 34 (December 1990), pp. 678-93.

62 What follows is rather sketchy. However, there are enough empirical analyses available to support the argument. For example, see the literature quoted above in footnote 36. See also Bernd W. Kubbig, Die militärische Eroberung des Weltraums (The military conquering of space), vol. 1 (Frankfurt M.: Campus, 1990). The best narratives of arms control under the Reagan and Bush administrations are Strobe Talbott, Deadly Gambits (New York: Knopf, 1984); Strobe Talbott, The Master of the Game (New York: Knopf, 1988); and Strobe Talbott and Michael Beschloss, At the Highest Levels (Boston: Little, Brown, 1993). See also George Shultz's memoirs, Turmoil and Triumph (New York: Charles Scribner's Sons, 1993).

63 The best analysis of the freeze campaign is Meyer, A Winter of Discontent.

64 See Kubbig, Militärische Eroberung des Weltraums; and Raymond Garthoff, Policy Versus the Law: The Reinterpretation of the ABM Treaty (Washington, D.C.: Brookings Institution, 1987).

65 For details on this case see Michéle Flournoy, "The NRDC/SAS Test Ban Verification Project: A Controversial Excursion in Private Diplomacy," manuscript, Washington, D.C., 1989; and Schrag, Listening for the Bomb. For a discussion of the Soviet involvement in these activities see Evangelista, "Transnational Relations, Domestic Structures, and Security Policy in the U.S.S.R. and Russia."

66 The cautious and reactive U.S. approach to the revolutionary changes in the Soviet Union and Eastern Europe is well-documented in Beschloss and Talbott, At the Highest Levels.

67 This discussion builds on my earlier work, in particular Die Krise der Sicherheitspolitik. See also Boutwell, The German Nuclear Dilemma; and Barry Blechman and Cathleen Fisher, The Silent Partner: West Germany and Arms Control (Cambridge, Mass.: Ballinger, 1988). On the evolution of European public opinion on security policy see Richard Eichenberg, Public Opinion and National Security in Western Europe (Ithaca, N.Y.: Cornell University Press, 1989).

68 See, for example, Jeffrey Herf, "War, Peace, and the Intellectuals: The Long March to the West German Peace Movement," International Security 10 (Spring 1986), pp. 172-200.

69 Details about this support can be found in Risse-Kappen, Die Krise der Sicherheitspolitik, pp. 43-89.

70 See Thomas Risse-Kappen, The Zero Option: INF, West Germany, and Arms Control (Boulder, Colo.: Westview, 1988); and Talbott, Deadly Gambits.

71 See, for example, Peter Katzenstein, ed., Between Power and Plenty (Madison: University of Wisconsin Press, 1978); Peter Katzenstein, Small States in World Markets (Ithaca, N.Y.: Cornell University Press, 1984); Peter Gourevitch, Politics in Hard Times (Ithaca, N.Y.: Cornell University Press, 1986); G. John Ikenberry, Reasons of State: Oil Politics and the Capacities of the American Government (Ithaca, N.Y.: Cornell University Press, 1988); and G. John Ikenberry, David Lake, and Michael Mastanduno, eds., The State and American Foreign Economic Policy (Ithaca, N.Y.: Cornell University Press, 1988). For examples of attempts to apply the approach to other issue-areas, see Michael Barnett, "High Politics is Low Politics: The Domestic and Systemic Sources of Israeli Security Policy, 1967-1977," World Politics 42 (July 1990), pp. 529-62; Matthew Evangelista, Innovation and the Arms Race (Ithaca, N.Y.: Cornell University Press, 1988); Matthew Evangelista, "Domestic Structures and International Change," in Michael Doyle and G. John Ikenberry, eds., New Thinking in International Relations Theory, forthcoming; and Thomas Risse-Kappen, "Public Opinion, Domestic Structure, and Foreign Policy in Liberal Democracies," World Politics 43 (July 1991), pp. 479-512. For the following see also my "Introduction," in Risse-Kappen, Bringing Transnational Relations Back In. 
72 See, for example, James G. March and Johan P. Olsen, Rediscovering Institutions: The Organizational Basis of Politics (New York: Free Press, 1989); G. John Ikenberry, "Conclusion: An Institutional Approach to American Foreign Economic Policy," in G. John Ikenberry et al., State and American Foreign Economic Policy, pp. 219-43; and Friedrich Kratochwil, Rules, Norms, and Decisions (Cambridge: Cambridge University Press, 1989). For various applications, see Peter Katzenstein and Nobuo Okawara, "Japan's National Security: Structures, Norms, and Politics," International Security 17 (Spring 1993), pp. 84-118; Peter Katzenstein and Nobuo Okawara, Japan's National Security: Structures, Norms, and Policy Responses in a Changing World (Ithaca, N.Y.: Cornell University Press, 1993); and Thomas Berger, "From Sword to Chrysanthemum: Japan's Culture of Anti-militarism," International Security 17 (Spring 1993), pp. 119-50.

73 It is thus important to distinguish between consensual ideas that are stable over time and those that are altered frequently and are promoted by specific groups. The strategic prescriptions discussed in this article are examples of the latter type of ideas. I thank John Odell and an anonymous reviewer for alerting me to this point.

74 See Evangelista, Innovation and the Arms Race; and Evangelista, "Transnational Relations, Domestic Structures, and Security Policy in the U.S.S.R. and Russia."

75 A domestic structure approach explains why cognitive and learning theories are so widely used to explain the Gorbachev revolution. See Breslauer and Tetlock, Learning in U.S. and Soviet Foreign Policy; and Stein, "Political Learning by Doing." For a similar point see Sue Peterson, "Strategy and State Structure: The Domestic Politics of Crisis Bargaining," Ph.D. diss., Columbia University, New York, 1993.

76 I owe the following argument to Steve Ropp.

77 Of course, U.S. autonomy is greater in national security affairs than in other issueareas. But compared with the former Soviet state, the difference is still striking.

78 On the "cold war consensus" in the United States and its limits see Bruce Russett, Controlling the Sword (Cambridge, Mass.: Harvard University Press, 1990), chap. 3; and Eugene Wittkopf, Faces of Internationalism: Public Opinion and American Foreign Policy (Durham, N.C.: Duke University Press, 1990).

79 See Peter Katzenstein, Corporatism and Change (Ithaca, N.Y.: Cornell University Press, 1984); and Peter Katzenstein, Policy and Politics in West Germany (Philadelphia: Temple University Press, 1989).

80 For a further evaluation of this approach see the chapters in Risse-Kappen, Bringing Transnational Relations Back In. See also Kathryn Sikkink, "Human Rights, Principled Issue-Networks, and Sovereignty in Latin America," International Organization 47 (Summer 1993), pp. 411-41.

81 See, for example, Checkel, "Ideas, Institutions, and the Gorbachev Foreign Policy Revolution"; Goldstein, "Ideas, Institutions, and American Trade Policy"; Goldstein and Keohane, Ideas and Foreign Policy; Odell, U.S. International Monetary Policy; and Sikkink, Ideas and Institutions.

82 Goldstein and Keohane, "Ideas and Foreign Policy: An Analytical Framework," p. 26. 


\title{
10 "Let's argue!": Communicative action in world politics (2000)
}

\author{
Thomas Risse
}

\section{Introduction}

The controversy between social constructivism and rational choice has become one of the most significant recent debates in the field of international relations and has largely crossed disciplinary boundaries between international relations and comparative politics. ${ }^{1}$ In the U.S.-dominated intellectual community, this debate largely focuses on the differences between the "logic of consequentialism" theorized by rational choice approaches and the "logic of appropriateness" conceptualized by mostly sociological institutionalism. Using insights from recent controversies within the German-speaking international relations community, I claim that processes of argumentation, deliberation, and persuasion constitute a distinct mode of social interaction to be differentiated from both strategic bargaining - the realm of rational choice - and rule-guided behavior - the realm of sociological institutionalism. Apart from utility-maximizing action, on the one hand, and rule-guided behavior, on the other, human actors engage in truth seeking with the aim of reaching a mutual understanding based on a reasoned consensus (verständigungsorientiertes Handeln), challenging the validity claims involved in any communication. I claim that Jürgen Habermas's critical theory of communicative action is helpful in conceptualizing the logic of arguing and can actually be brought to bear to tackle empirical questions in world politics.

A focus on arguing helps to clarify two issues in the rationalist-constructivist debate. First, it furthers our understanding of how actors develop a common knowledge concerning both a definition of the situation and an agreement about the underlying "rules of the game" that enable them to engage in strategic bargaining in the first place. Thus, arguing constitutes a necessary (though not sufficient) step in a negotiating process. Arguing is also relevant for problem solving in the sense of seeking an optimal solution for a commonly perceived problem and for agreeing on a common normative framework. Seeking a reasoned consensus helps actors to overcome many collective action problems. I illustrate this point empirically using the negotiated settlement ending the Cold War in Europe. Second, argumentative rationality appears to be crucially linked to the constitutive rather than the regulative role of norms and identities by providing actors with a mode of interaction that enables them to mutually challenge and 
explore the validity claims of those norms and identities. When actors engage in a truth-seeking discourse, they must be prepared to change their own views of the world, their interests, and sometimes even their identities. Some of these debates actually take place in the public sphere, which has to be distinguished from the realm of diplomatic negotiations. My empirical example for such a process concerns public discourses in the human rights area, particularly those between transnational human rights advocacy networks and national governments accused of norm violation.

I proceed as follows. First, using the debate between rational choice and social constructivism as a starting point, I distinguish between three logics of social interaction. Second, I further distinguish between bargaining, rhetorical action, and truth-seeking arguing and then clarify the latter with reference to Habermas's theory of communicative action and the debate in the German-speaking international relations community. Third, I discuss critical issues concerning the relevance of argumentative rationality for international relations, particularly the alleged absence of a "common lifeworld" in world politics as well as the relationship between power and arguing. Fourth, I introduce two settings in international affairs in which arguing might occur - diplomatic negotiations and public discourses - and specify how argumentative rationality matters in these settings. Finally, I illustrate my argument through two empirical cases - the negotiations leading to an end of the Cold War in Europe and to German unification within NATO, on the one hand, and international public discourses concerning the domestic implementation of international human rights norms in various countries, on the other.

\section{Argumentative rationality, social constructivism, and rational choice}

\section{Three logics of social action}

There is considerable confusion in the field of international relations about what precisely is at stake in recent controversies between rational choice and social constructivism. Is the debate about the role of ideas or cultural factors as opposed to material interests in political life? Does it concern constitutive norms and identities as opposed to instrumental interests of actors? Does it center on deep ontological, methodological, or even epistemological differences?

Regarding epistemology, constructivists of various orientations disagree among themselves as to the possibility of making truth claims and generalizations in social sciences. But the methodological, epistemological, and ontological differences between, say, sophisticated rational choice and moderate social constructivism are usually vastly overstated. Rather, it might be helpful to distinguish between the two metatheoretical approaches as emphasizing different logics or modes of social action and interaction that are characterized by different rationalities as far as the goals of action are concerned (Handlungsrationalität; see Figure 10.1). ${ }^{2}$ Each mode of action can be thought of as an ideal type that rarely 


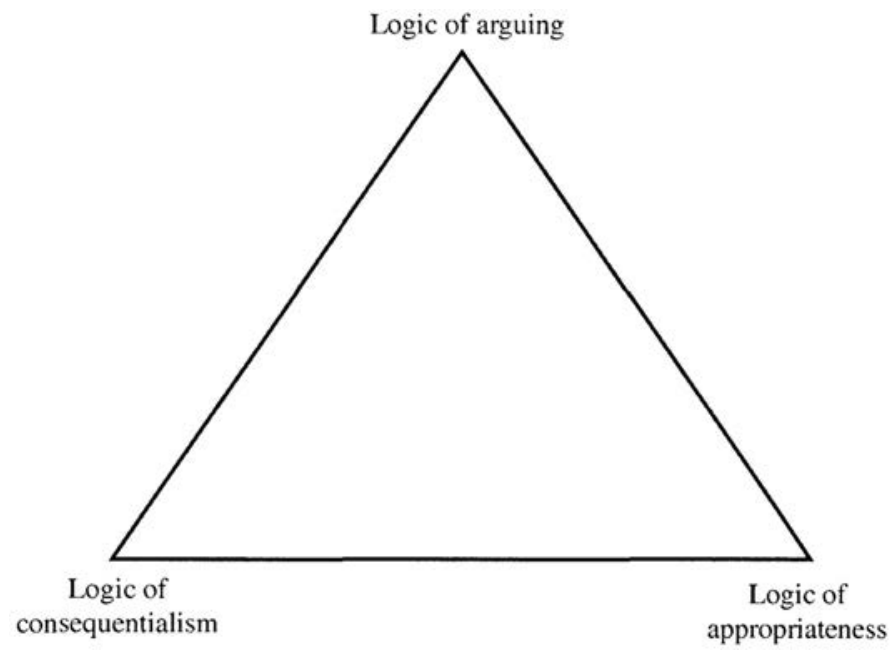

Figure 10.1 Three logics of social action

occurs in pure form in real life. If the "games real actors play"3 usually combine several modes of social interaction, we should not exaggerate the differences among metatheoretical orientations, such as rational choice capturing the logic of consequentialism, on the one hand, and social constructivism encompassing both rule-guided and deliberative behavior, on the other. If behavior in the real social world can almost always be located in some of the intermediate spaces between the corners of the triangle in Figure 10.1, one single metatheoretical orientation probably will not capture it. Rather, the controversies mainly focus on how far one can push one logic of action to account for observable practices and which logic dominates a given situation.

I start with the distinction introduced by James March and Johan Olsen between a "logic of consequentialism" and a "logic of appropriateness." consequentialism" is the realm of rational choice approaches that treat the interests and preferences of actors as mostly fixed during the process of interaction. Rational choice focuses on strategic interactions in which agents participate on the basis of their given identities and interests and try to realize their preferences through strategic behavior. This is the realm of instrumental rationality whereby the goal of action is to maximize or optimize one's own interests and preferences. To the extent that this is only possible through cooperative behavior, egoistic utility maximizers are expected to collaborate or coordinate their behavior with others. This is where rational choice approaches are at their best, since they analyze those modes of action and interaction where instrumental rationality prevails: "Rational choice is instrumental: it is guided by the outcome of action. Actions are valued and chosen not for themselves, but as more or less efficient 
means to a further end." ${ }^{5}$ In international relations, neoliberal institutionalism or rationalist regime analysis have convincingly shown that "cooperation under anarchy" is possible and that self-interested actors can achieve stable and enduring cooperation and overcome collective action dilemmas. ${ }^{6}$ Many ideational accounts are compatible with an instrumentally rational logic of action. Under conditions of uncertainty or incomplete information, for example, instrumentally rational actors can use ideas as road maps or signposts indicating how they could best realize their interests under given circumstances. ${ }^{7}$ Moreover, principled and causal beliefs can enter the utility functions of actors, affect cost-benefit calculations, and influence the strategic interactions themselves.

Most social constructivists in international relations and comparative politics emphasize a different rationality, the "logic of appropriateness": "Human actors are imagined to follow rules that associate particular identities to particular situations, approaching individual opportunities for action by assessing similarities between current identities and choice dilemmas and more general concepts of self and situations." 8 Rule-guided behavior differs from instrumentally rational behavior in that actors try to "do the right thing" rather than maximizing or optimizing their given preferences. Normative rationality implies constitutive effects of social norms and institutions, since these rules not only regulate behavior, that is, they have causal effects, but also define social identities ("good people do $X$ "). This is where the "value added" of constructivism comes in. Following Nicholas Onuf, Fritz Kratochwil, and Alexander Wendt, constructivism points to the constitutive role of ideational factors. ${ }^{9}$ Socially shared ideas - be it norms ("collective expectations about proper behavior for a given identity"10) or social knowledge about cause-and-effect relationships - not only regulate behavior but also constitute the identity of actors. The norm of sovereignty, for example, regulates the interactions of states in international affairs and also defines what a state is. Human rights norms not only protect citizens from state intervention but also (and increasingly) define a "civilized state" in the modern world. Although it is difficult to develop valid empirical indicators for distinguishing the regulative from the constitutive effects of socially shared ideas, ${ }^{11}$ social constructivism's contribution to the study of ideas in international relations consists of emphasizing that collective norms and understandings constitute the social identities of actors and also define the basic "rules of the game" in which actors find themselves in their interactions. This does not mean, however, that constitutive norms cannot be violated or never change. The content of the norm of sovereignty has changed dramatically over time, becoming more circumscribed, particularly when it comes to human rights. But sovereignty still constitutes a state - as opposed to any other corporate actor (a multinational corporation, for example) - insofar as we cannot define what a state is without reference to the notion of sovereignty.

The constitutive effects of social norms also point to a further difference between social constructivism and rational choice. Proponents of the former emphasize against the latter the social aspect of ideational factors. They disagree with a methodologically individualist view of human action according to which 


\section{In between spaces}

"the elementary unit of social life is the individual human action." 12 The fundamental insight of the structure-agency debate is not just that structures and agents are mutually codetermined in a causal way. The crucial point is that social constructivists insist on the mutual constitutiveness of (social) structures and agents. Constructivists claim against individualism that human agents do not exist independently from their social environment and its collectively shared systems of meanings ("culture" in a broad sense). At the same time, social constructivists maintain that human agency creates, reproduces, and changes culture by way of daily practices. In sum, social constructivism occupies a - sometimes uneasy - ontological middle ground between individualism and structuralism by claiming that there are properties of structures and of agents that cannot be reduced to or collapsed into each other. ${ }^{13}$ This means for the study of ideas that one can continue to study "beliefs" in terms of what is inside people's minds and simultaneously insist that these beliefs are representations and enactments of social and intersubjective culture. ${ }^{14}$

So far, most of the controversy between rational choice and social constructivism, at least in American international relations, has focused on the relationship between the "logic of consequentialism" and the "logic of appropriateness." Thus, the debate is concentrated on the lower axis of the triangle in Figure 10.1. ${ }^{15}$ Rationalist institutionalism, for example, explains a great deal about the emergence of norms and institutions, about the norm of reciprocity as the result of and the condition for cooperative strategic interaction, and about the behavior of "boundedly rational" actors whose information-processing capacities are constrained by social norms. ${ }^{16}$ The extent to which an imagery emphasizing the constraining effects of norms can account for and accommodate their constitutive effects is the subject of the debate between rationalist and sociological institutionalism.

But this debate has overlooked the proposition that the "logic of appropriateness" as introduced by March and Olsen actually encompasses two different modes of social action and interaction. In many social situations, actors regularly comply with norms that they have thoroughly internalized and that, therefore, are "taken for granted." Whereas strategic behavior is explicitly goal-oriented, the "taken for grantedness" of norm-regulated behavior implies that enacting the norm need not be a conscious process, even though norms that are no longer believed will probably disappear or soon change. This is how the most powerful social institutions influence behavior, and theorizing about the process is the realm of sociological institutionalism, which points to various socialization processes to explain how actors internalize a given social norm. ${ }^{17}$

However, March and Olsen also talk about rule-guided behavior as a conscious process whereby actors have to figure out the situation in which they act, apply the appropriate norm, or choose among conflicting rules. ${ }^{18}$ The more the norms are contested, the less the logic of the situation can be captured by the statement "good people do $X$ " than by "what does 'good' mean in this situation?" or even "what is the right thing to do?" But how do actors adjudicate which norm applies? They argue. I suggest, therefore, that social constructivism encompasses 
not only the logic of appropriateness but also what we could call a "logic of truth seeking or arguing" (moving toward the upper corner of the triangle in Figure 10.1). When actors deliberate about the truth, they try to figure out in a collective communicative process (1) whether their assumptions about the world and about cause-and-effect relationships in the world are correct (the realm of theoretical discourses); or (2) whether norms of appropriate behavior can be justified, and which norms apply under given circumstances (the realm of practical discourses).

Arguing implies that actors try to challenge the validity claims inherent in any causal or normative statement and to seek a communicative consensus about their understanding of a situation as well as justifications for the principles and norms guiding their action. Argumentative rationality also implies that the participants in a discourse are open to being persuaded by the better argument and that relationships of power and social hierarchies recede in the background. ${ }^{19}$ Argumentative and deliberative behavior is as goal oriented as strategic interaction, but the goal is not to attain one's fixed preferences, but to seek a reasoned consensus. Actors' interests, preferences, and the perceptions of the situation are no longer fixed, but subject to discursive challenges. Where argumentative rationality prevails, actors do not seek to maximize or to satisfy their given interests and preferences, but to challenge and to justify the validity claims inherent in them - and they are prepared to change their views of the world or even their interests in light of the better argument.

Communicative action and the logic of argumentation and persuasion have not yet been systematically explored in the American international relations debates. ${ }^{20}$ But they have been the focus of a distinct German version of the controversy between rationalists and social constructivists that has taken place in the Zeitschrift für Internationale Beziehungen (ZIB, Journal of International Relations) since 1994. ${ }^{21}$ This debate focuses on the relationship between the "logic of consequentialism" and the "logic of arguing" (the left-hand axis of the triangle in Figure 10.1). I use the ZIB debate to conceptualize the logic of argumentative rationality and to make it empirically applicable to international relations. Turning to this debate, I begin with some conceptual clarifications of the logic of arguing using Jürgen Habermas's theory of communicative action. ${ }^{22}$

\section{Jürgen Habermas and the logic of arguing}

To begin with, it is quite trivial that communicative behavior is all-pervasive in international relations as in any other social setting. We talk a lot, but we do not necessarily argue, reason, or deliberate. Strategic interactions of the most conflictual kind - as in compellence and deterrence models - are all about communication. We can distinguish among different forms of communicative behavior corresponding to a movement along the left-hand axis of the triangle in Figure 10.1. First, communication can take the form of bargaining on the basis of fixed preferences, which corresponds to the logic of consequentialism or instrumental rationality. Following Jon Elster, bargaining is characterized by a 
logic of the market (similar to instrumental rationality as defined earlier) whereby actors try to accomplish their goals by exchanging demands backed by credible promises, threats, or exit opportunities. ${ }^{23}$ The goal is to maximize, optimize, or satisfy given preferences as much as possible. Bargaining involves communication that is primarily directed at exchanging information about preferences, making promises, or threatening. Communication as information exchange is clearly part of any bargaining process and can be easily accommodated by rational choice. Quite some progress has been made in incorporating communication as information exchange about preferences and perceived definitions of the situation in bargaining models. These models are commonly identified as "cheap talk" as opposed to the exchange of "costly" signals. ${ }^{24}$ Cheap talk models refer to a subset of games under uncertainty and incomplete information. They concentrate on verbal utterances to exchange information about each other's preferences and model the conditions under which the exchange of truthful information leads to cooperation. However, these preferences and the underlying identities of actors are still considered to be fixed. Cheap talk models also do not violate the "common knowledge" assumption of conventional game theory, since the interaction partners both know that they act under incomplete information and they also know that the others know that they act under uncertainty, and so forth.

Moving further up on the left-hand axis of the triangle in Figure 10.1, actors might use arguments in a strategic mode in order to justify their identities and preferences. Following Frank Schimmelfennig, I call this type of communication "rhetorical action." ${ }^{25}$ The point is that actors use arguments to persuade or convince others that they should change their views of the world, their normative beliefs, their preferences, and even their identities. There are many social circumstances, including bargaining situations, in which actors need to give reasons why they prefer certain courses of action or why their interests are justified. But actors engaging in rhetoric are not prepared to change their own beliefs or to be persuaded themselves by the "better argument." If everybody in a communicative situation engages in rhetoric - the speaker, the target, and the audience - they can argue strategically until they are all blue in the face and still not change anyone's mind. Thus, rhetoric presupposes, in order to be successful, that at least one person in the audience is prepared to be convinced by the better argument. Its condition for success is, therefore, based on the logic of argumentative rationality oriented toward common understanding. Rhetorical action is then located somewhere in between the logic of consequentialism and the logic of arguing on the left-hand axis of the triangle in Figure 10.1. Even rhetorical exchanges often involve further movement toward the logic of arguing, since speakers need to respond to each other's arguments. They cannot simply repeat their utterances, if they want to convince a skeptical audience, but need to come up with ever more sophisticated justifications. As I will illustrate later in this article, argumentative processes might well begin as purely rhetorical exchanges but often evolve toward true reasoning.

But what is "true reasoning?" Habermas introduces behavior oriented toward reaching a common understanding (verständigungsorientiertes Handeln) as follows: "I speak of communicative actions when the action orientations of the 
participating actors are not coordinated via egocentric calculations of success, but through acts of understanding. Participants are not primarily oriented toward their own success in communicative action; they pursue their individual goals under the condition that they can co-ordinate their action plans on the basis of shared definitions of the situation." ${ }^{26}$ The goal of such communicative action is to seek a reasoned consensus (Verständigung as opposed to Verstehen). In arguing mode, actors try to convince each other to change their causal or principled beliefs in order to reach a reasoned consensus about validity claims. And, in contrast to rhetorical behavior, they are themselves prepared to be persuaded. Successful arguing means that the "better argument" carries the day, while one's (material) bargaining power becomes less relevant. As Harald Müller put it,

once collective actors - states - reach the limits of purely strategic behavior, they know intuitively and by experience that the repertoire for action of all actors - their own and that of their opponents - contains the alternative of action oriented toward common understanding (Verständigungshandeln). This is the decisive difference to the utilitarian paradigm which does not entail this alternative. . . . [Actors] also have indicators at their disposal intuitively and by experience - by which to judge if and when the partner is willing and able to switch from one mode of action to the other. Communicative discourse allows for the test of these criteria. ${ }^{27}$

Building on speech act theory as proposed by J. L. Austin and J. R. Searle, Habermas distinguishes three types of validity claims that can each be challenged in a discourse. ${ }^{28}$ The first concerns the truth of assertions made, that is, the conformity with perceived facts in the world (for example, is my interpretation of Habermas substantially correct?). Theoretical discourses challenge the validity claims of primarily causal assertions and beliefs. The second validity claim focuses on the moral rightness of the norms underlying arguments (is writing an article on Habermas morally justifiable while innocent children die?). Practical discourses justify and criticize the validity claims of principled beliefs and norms. The third validity claim concerns the truthfulness and authenticity of the speaker (do I mean what I say about arguing, or am I just trying to position myself in an academic discourse?). The authenticity of a speaker can be challenged in a discourse only to some extent (for example, by probing the consistency between my words and deeds) but ultimately relies on trust.

Habermas posits that our communicative practices work and are effective only because we assume that we can revert to argumentation in order to challenge validity claims made in our daily utterances. Communicative processes oriented toward achieving mutual understanding counterfactually presuppose an "ideal speech situation" whereby nothing but the better arguments count and where actors try to persuade each other and are themselves open to being convinced:

In this sense, communicative action points to an argumentation in which participants justify their validity claims in front of an ideally extended 
audience. Participants in argumentation proceed from the idealized assumption of a community of communication (Kommunikationsgemeinschaft) which is debordered from social space and historical time. They must . . . presuppose the possibility of an ideal community "within" their real social situation. $^{29}$

Interests and identities are no longer fixed, but subject to interrogation and challenges and, thus, to change. The goal of the discursive interaction is to achieve argumentative consensus with the other, not to push through one's own view of the world or moral values. Since the validity claims of identities and interests are at stake in theoretical and practical discourses, an argumentative consensus has constitutive effects on actors. This point helps to clarify the mutual constitutiveness of agents and social structure that social constructivism emphasizes. Agents are not simply the puppets of social structure, since they can actively challenge the validity claims inherent in any communicative action. At the same time, they are social agents that produce and reproduce the intersubjective structures of meanings through their communicative practices. ${ }^{30}$

Argumentative rationality in the Habermasian sense is based on several preconditions. First, argumentative consensus seeking requires the ability to empathize, that is, to see things through the eyes of one's interaction partner. Second, actors need to share a "common lifeworld" (gemeinsame Lebenswelt), a supply of collective interpretations of the world and of themselves, as provided by language, a common history, or culture. A common lifeworld consists of a shared culture, a common system of norms and rules perceived as legitimate, and the social identity of actors being capable of communicating and acting. ${ }^{31}$ It provides arguing actors with a repertoire of collective understandings to which they can refer when making truth claims. At the same time, communicative action and its daily practices reproduce the common lifeworld. Finally, actors need to recognize each other as equals and have equal access to the discourse, which must also be open to other participants and be public in nature. In this sense then, relationships of power, force, and coercion are assumed absent when argumentative consensus is sought. This implies respect for two principles: all interested parties may participate in the argumentative discourse, and all participants have equal rights concerning making an argument or challenging a validity claim. ${ }^{32} \mathrm{I}$ discuss these conditions further in the following sections.

\section{Communicative action and rational choice}

How far can one push rational choice-based theories to accommodate argumentative behavior? Otto Keck points out in this context that the assumption of "common knowledge" about the structure of the game as prevalent in orthodox game theory presupposes what should be problematic, that is, a common definition of the situation. In orthodox game theory, any uncertainty or ignorance about the structure of the game (including the set of feasible actions of each player and the players' preferences) is common knowledge. The players know what other 
players are uncertain about or ignorant of and the others know that they know it, and so on. ${ }^{33}$ Keck proposes a family of communication games that are no longer based on the "common knowledge" assumption, but start with incompatible definitions of the situation and then model the decision of a player whether to communicate to the other in such a way that points out the differences in their definitions of the situation. He conceptualizes communication as a choice between different verbal utterances, such as asking a question, giving a hint, or concealing something. As a result, recipients of such information might choose new ways of acting, learn about unforeseen consequences of their actions, or even change their utility functions ${ }^{34}$ Keck argues that a modification of the assumptions of orthodox game theory, though not violating fundamentals of rational choice, can help to incorporate meaningful communication into the game and address two problems of rational choice identified by social constructivists: (1) how can common knowledge be achieved? (2) how can preferences change during the interaction itself? ? $^{35}$

But communication in these games still involves exchanging information, whether it concerns the world outside of the players or the players' utility functions. Players have the choice of lying or telling the truth, of revealing or concealing their preferences. They choose according to these preferences and strategies. They want to reach their goals and strategize. They might well change their view of the world or even their utility functions resulting from the information received ${ }^{36}$ At best, the players in these communication games engage in rhetorical action as defined earlier. This is not controversial, but it has little to do with challenging validity claims in a theoretical or practical discourse ${ }^{37} \mathrm{Com}-$ munication in truth-seeking discourses oriented toward reaching a reasoned consensus is not motivated by the players' desire to realize their individual preferences - be they egoistic or altruistic. Communication is motivated by the desire to find out the "truth" with regard to facts in the world or to figure out "the right thing to do" in a commonly defined situation.

One could ask, however, why actors are motivated in the first place to seek the truth in negotiating situations. Rational actors interested in realizing their values and desires must be interested in correcting false information and cognitions about the outside world, the consequences of their action, and the preferences of their interaction partners. As a result, they should be willing to discuss the validity claims of their cognitions and should be open to being persuaded and changing their minds. It is entirely possible that a slave convinces his or her master that the latter is economically and socially better off if the former is freed and employed by the master as a paid worker. Bernhard Zangl and Michael Zürn claim that, therefore, argumentative processes are entirely consistent with a rational choice program broadly defined. ${ }^{38}$ In this case then, searching for the truth is motivated by the desire to change the situation in such a way as to solve or at least mitigate social dilemmas.

At this point, sophisticated rational choice and moderate social constructivism can readily admit that each theorizes different modes of social interaction that are both necessary to explain significant phenomena in the world but cannot be 
collapsed into each other. For example, let us assume a dilemma situation that originates because of differing and conflicting preferences (if preferences are in harmony, we neither need to argue nor to bargain in order to achieve cooperation; sheer information should do) and that requires collaboration rather than pure coordination to solve or mitigate it. ${ }^{39}$ Instrumentally rational actors should be interested in such a situation to "get the facts right" and to acquire "common knowledge." Thus, truth seeking refers here to a reasoned consensus on the "facts in the world" reached through a theoretical discourse. Although a change in underlying interests might result from such a consensus, such a discourse does not require that actors question their preferences.

But "common knowledge" also refers to the "rules of the game," that is, the underlying principles guiding the interaction. If the master is convinced to free the slave, we have witnessed a process of persuasion in a practical or moral discourse leading to a change of interests and identities. In this case, the participants in the discourse need to be prepared to have their interests questioned and challenged. Thus, a reasoned consensus about underlying principles of interaction - the "rules of the game" - can no longer be reached if the participants follow a logic of consequentialism, since their interests are at stake and subject to justification. Thus, it might be in the enlightened self-interest of rational actors to enter such a conversation. But it is quite different to suggest that such argumentative exchanges can be modeled by rationalist approaches. Even instrumentally rational actors need to adopt a mode of social interaction whereby their exogenous goals only form background conditions, while the predominant mode of social action consists of mutually justifying validity claims oriented toward achieving collective understandings. In the absence of "common knowledge," argumentative rationality is necessary for developing trust in the authenticity of the speech acts (does the speaker mean what he or she says?); for advancing an argumentative consensus on the definition of the situation (can we agree on the underlying problem or aspects of it?); and for acquiring a collective understanding of the underlying normative framework (what principles should guide our efforts at finding a cooperative solution?). ${ }^{40}$

Of course, there are some functional equivalents to trust in various interaction settings. If an agreement has a hegemonic enforcer, trust among the participants might not be necessary. Absent coercion, though, trust building has been established by the negotiation literature as a precondition for reaching cooperative solutions to dilemma situations ${ }^{41}$ Findings from experimental research support the point. As Elinor Ostrom points out, face-to-face communication increases the likelihood of cooperation drastically: "Exchanging mutual commitment, increasing trust, creating and reinforcing norms, and developing a group identity appear to be the most important processes that make communication efficacious. ${ }^{~}{ }^{42}$ Results from social psychological research on persuasion also suggest that the trustworthiness of the communicator as unbiased increases the persuasiveness of an argument during communication. ${ }^{43}$

As to the necessity of reaching a consensus on the definition of the situation and on the underlying normative framework, I do not suggest here that actors 
always have to agree on everything before they can cooperate. Some pragmatic cooperative arrangements can be achieved by "agreeing to disagree" and not to reach a consensus on ultimate truth claims. Wage bargaining does not require that labor and business agree on the prospects for the domestic economy or on the best economic strategy for reducing unemployment. But labor and business need to accept each other as valid interlocutors and negotiating partners, they need to have a common understanding on what it is that they are bargaining about, and they need to reach a consensus on underlying principles (such as whether wages should be attached to rates of inflation, company profits, or productivity growth). Of course, they might try to impose their respective viewpoints on the other by means of coercion (such as lock-outs and strikes). But absent effective coercive means at their disposal or a hegemonic enforcer, it is hard to see how negotiators could acquire the "common knowledge" necessary for any (distributive) bargaining situation without entering into an argumentative process with the goal of achieving a reasoned consensus. On the basis of these collective understandings that define and clarify the game they are playing, actors can then engage in strategic bargaining to reach a distributive compromise.

\section{Arguing and international relations}

One could agree with everything so far and still object that this metatheoretical debate about the foundations of social action is utterly irrelevant in furthering our understanding of world politics. There are essentially two major arguments against the claim that arguing plays a substantial role in international relations:

1 International relations are anarchic, and, thus, there is no "common lifeworld" supplying collective interpretations of the world to the actors involved. Actors in world politics do not share a common language, history, or culture.

2 Relationships of power are never absent in international relations. It is, therefore, preposterous to assume that truth-seeking discourse is possible in international politics.

In other words, two crucial preconditions for argumentative rationality as identified by Habermas are missing in world politics. I address each of these objections in the following section in order to then specify when we might expect arguing in international affairs.

\section{Preconditions of arguing in world politics}

\section{International relations - a common lifeworld?}

The existence of a "common lifeworld" represents a crucial background condition for argumentative behavior supplying common experiences with the world and its history as well as a common system of values and norms to which actors 
can refer in their communications. However, Habermas's theory is rather silent on the question of how much of a common lifeworld people need to share in order to communicate in a reasonable manner. ${ }^{44}$ Moreover, the lifeworld itself is open to argumentative challenges and counterchallenges; that is, the collective supply of interpretations can itself be questioned during a discourse.

First, in a most fundamental sense, anarchy in international affairs could itself be considered a limited common lifeworld if this is the shared cultural background against which actors communicate in world politics. Note, however, that "anarchy" in this context does not refer to the pre-social Hobbesian "state of nature," but already constitutes an, albeit "thin," collective (social) interpretation of the world. But this point only helps to some degree, since a shared interpretation of the world as a "dog eat dog" world is not particularly conducive to a reasonable dialogue. Meaningful communication requires that actors see at least some room for cooperation with their interaction partners and, thus, wish to overcome a world of sheer hostility. ${ }^{45}$ If so, they can actually construct their common lifeworld as a prerequisite for building mutual trust in the authenticity of each other's communications. As Harald Müller pointed out, prenegotiations usually encompass a phase whereby actors construct such a common lifeworld in a symbolic sense, mainly through narratives. Almost ritualistic references to common experiences such as suffering during wars frequently serve such purposes ${ }^{46}$ The exchange of memories of World War II, for example, has been a regular feature of almost all East-West negotiations during the Cold War. One might dismiss such practices as sheer rhetoric in light of the tough bargaining problems at hand. However, they appear to be a precondition for establishing the trustworthiness of negotiating partners.

Second, focusing on international relations allows us to differentiate among social situations such as "anarchy" where actors have to construct their common lifeworld almost from scratch and to develop stable patterns of expectations and interactions, on the one hand, and dense interaction patterns within highly regulated international institutions, on the other. For example, pluralistic security communities based on a collective identity and shared values and norms might constitute a common lifeworld. ${ }^{47}$ The European Union or the transatlantic community come to mind. We can also infer from the literature on the "democratic peace" 48 that democracies not only rarely fight each other but also develop a collective identity based on shared liberal values and norms constituting a common lifeworld. Moreover, some issue-areas in world politics, such as trade, human rights, or the environment, are heavily regulated by international regimes and organizations. A high degree of international institutionalization might then provide a common lifeworld. International institutions create a normative framework structuring interaction in a given issue-area. They often serve as arenas in which international policy deliberation can take place. Whether they can play this role or not depends largely on their organizational structure. Nonhierarchical and networklike international institutions characterized by a high density of mostly informal interactions should provide the structural conditions in international relations to allow for discursive and argumentative processes. ${ }^{49}$ 
Third, one might object here that a common lifeworld resembles "common knowledge" in game theory. ${ }^{50}$ How can I claim that argumentative reasoning is necessary to establish the common knowledge that game theory takes as given if a common lifeworld in terms of a shared history, common experiences, and a common culture is itself a prerequisite for deliberative discourses? To answer this question, it might be helpful to distinguish among three social situations. The first situation resembles the "anarchy" in world politics mentioned earlier, with little common lifeworld and even less common knowledge. In such a situation, actors can construct the common lifeworld through narratives by referring to shared experiences, common historical memories, and the like. This then might enable them to engage in a communicative process in order to reach a consensus on a joint definition of the situation and, thus, to develop the common knowledge necessary for a bargaining process. Second, if actors find themselves in a densely institutionalized environment, the common lifeworld might not be a problem, but common knowledge still is, if and when actors are uncertain about their own interests and/or lack knowledge about important features of the situation. As mentioned earlier, even instrumentally rational actors should be interested in arguing in such cases. Third, in densely institutionalized environments, actors might share a common lifeworld and they might know what they want. Only then would the common lifeworld equal the common knowledge in game theory. Argumentative discourse might still be necessary to reach a cooperative solution, but not to establish common knowledge (see later discussion).

In sum, the degree to which a common lifeworld exists in international relations varies considerably according to world regions and issue-areas. Even "anarchy" constitutes an, albeit "thin," common lifeworld from which actors can move on to refer to common experiences, develop shared understandings of history, and, thus, to develop a collective culture.

\section{Arguing and power}

The second objection raised against emphasizing argumentative rationality is more difficult to tackle. Habermas's point that relationships of power are supposed to be absent in ideal speech situations where only the "better argument" counts has met with considerable criticism and has been labeled both "idealistic" and "utopian." Power as a relationship of influencing an actor's behavior against the actor's will might affect arguing in at least two ways: First, power relations might define who has legitimate access to a discourse. The UN Security Council is a perfect example of how some states are more equal than others in terms of having permanent access to the deliberations. Second, they might affect what counts as a "good argument." It makes a difference in the UN Security Council whether the United States or Cameroon pushes a certain argument. At least, the latter probably has to make a much greater argumentative effort than the former to gain support for its views. More important, power asymmetries in the Security Council might affect who says what and when and how arguments are framed in the first place. 
Michel Foucault raised objections against the possibility of an "ideal speech situation" that go deeper and do not just concern the possibility that power relationships external to the discourse might influence actors engaged in arguing. ${ }^{51}$ According to Foucault, power as a social structure resides in the discourse itself. The rules of the discourse prescribe which arguments can be legitimately used by the participants. As Elster points out, it is virtually impossible in public debates to make self-serving arguments or to justify one's claims on self-interested grounds. ${ }^{52}$ Even rhetorical arguments that try to justify egoistic interests must normally refer to some universalistic values or commonly accepted norms. National governments that want to participate in the global human rights discourse might still object to specific accusations of norm violations. But it is virtually impossible for them to deny the validity of global human rights norms themselves without risking being labeled as "pariah" states. While Habermas's "ideal speech situation" implies that any argument can be used in a theoretical or practical discourse, Foucault's objection posits that the social context of such discourses establishes clear boundaries of what can be legitimately argued.

Some of these objections indicate a misunderstanding of Habermas's theory of communicative action, whereas others reflect deep theoretical disagreements. First, the ideal speech situation is not meant as a statement about the empirical world or - even worse - some utopian ideal; instead it constitutes primarily a counterfactual presupposition. To quote Habermas,

I do not assert that a valid consensus can only be achieved under conditions of the ideal speech situation. Communicative daily practice is embedded in a sea of cultural taking for grantedness, i.e., of consensual certainties; . . . As soon as one component of this naively known and pre-reflexive background is transformed into the semantic content of a verbal utterance, the certainties enter the conditions of criticizable knowledge: They may become subject to dissent. Only when this dissent is persistent enough to provoke a discursive treatment of the disputed issue, does this become an instance of which I assert that a reasoned consensus cannot be achieved unless the participants in the discourse assume that they persuade each other only on the basis of better arguments. If one side uses privileged access to arms, wealth, or prestige in order to wring agreement from the other by way of sanctions or rewards, none of the participants will doubt that the conditions for argumentation are no longer satisfied. ${ }^{53}$

An alleged reasoned consensus might often be an illusion, and the analyst's task is then to criticize it. Interestingly enough, we can only "know" such a false agreement if measured against a reasoned consensus resulting from truthseeking argumentation. The earlier-mentioned social psychological literature on persuasion seems to suggest that people are indeed capable of distinguishing between strategic reasoning and arguing. Biased or self-interested communicators are far less persuasive than those who are perceived to be neutral or motivated by moral values. ${ }^{54}$ The criticism of rational argumentation as just another 
form of domination and discipline presupposes argumentative rationality in the sense that the objection itself can only be made within a reasoned discourse. ${ }^{55}$

Moreover, one should not forget that the various modes of social action strategic behavior, norm-guided behavior, and argumentative/discursive behavior represent ideal types that rarely occur in pure form in reality (see Figure 10.1). We often act both strategically and discursively - that is, we use arguments to convince somebody else that our demands are justified - and by doing so we follow norms enabling our interaction in the first place (language rules, for example). As a result, the empirical question to be asked is not whether actors behave strategically or in an argumentative mode, but which mode captures more of the action in a given situation.

These counterarguments to various objections raised against the possibility of an "ideal speech situation" in international affairs only help to some extent. The Habermasian condition of "equal access" to the discourse, for example, is simply not met in world politics. But does this mean that those actors who are privileged to participate in the discourse of international organizations or in interstate negotiations never engage in truth-seeking behavior and in arguing over norms? We can probably relax the condition of "equal access" as long as the condition of nonhierarchy among participants in a discourse can be met. Concerning the UN Security Council, for example, it might not worry us too much that there are permanent and nonpermanent members, as long as this does not determine what counts as a "good argument."

This latter point concerns precisely the objection that the structure and social context of an argumentative process delineate the boundaries of which types of arguments can be legitimately made or are viewed as "reasonable arguments." But does this objection imply that truth seeking and argumentative rationality are impossible within those structural boundaries of a discourse? Furthermore, does it imply that human beings are forever caught within the boundaries of their discourses and cannot challenge the very legitimacy of these boundaries under any circumstances? I do not think so. Rather, I suggest treating Foucault's points as valid objections against an "anything goes" view of truth-seeking discourses. We can treat these arguments as attempts to provoke a discussion between the logic of arguing and the logic of appropriateness along the right axis of the triangle in Figure 10.1.

The real issue then is not whether power relations are absent in a discourse, but to what extent they can explain the argumentative outcome. We need some indicators for knowing an arguing situation in international politics when we see one. The following criteria offer some clues:

- By carefully examining the communicative utterances of speakers it should be possible to establish whether the conditions are present for argumentative rationality in terms of nonhierarchy. Communicative situations where actors point to their rank or status to make an "argument" do not qualify as a discourse.

- Discursive rationality requires argumentative consistency. Actors changing their arguments depending on the audience with which they are dealing probably engage in rhetorical behavior. 
- Assuming that the materially more powerful actors do not necessarily have the better arguments, an arguing situation should disproportionately empower the weaker actors who have less material resources at their disposal. This might refer empirically to small states, such as Cameroon in the earlier example of the UN Security Council, or to the impact of nonstate actors such as international nongovernmental organizations (INGOs) in international negotiations. If INGOs convince the more powerful actors to change their minds, we have probably witnessed arguing.

- Argumentative rationality can be investigated particularly well in situations where instrumental interests of actors (material or ideational) are stacked against the arguments being made. If actors change their mind in a communicative process, even though their instrumental interests would suggest otherwise, we have probably observed a process of persuasion.

- Whether actors engage in dialogue and argumentation or not should be particularly obvious in situations in which they are accused of violating certain norms of appropriate behavior to which they have previously agreed. Do they dismiss such accusations as irrelevant or engage in some self-serving rhetoric? Or do they start justifying their behavior, give reasons for their action, or even apologize?

In sum, we do not need to posit an "ideal speech situation" in world politics and can even relax some of the strict preconditions for argumentative rationality but still maintain that truth-seeking behavior leading to a reasoned consensus is possible in international affairs. We have probably witnessed processes of argumentative persuasion when powerful governments change their minds and subsequently their behavior, even though their instrumental interests would suggest otherwise, or when materially less powerful actors such as small states or nonstate actors carry the day. Moreover, the more the rules of international institutions prescribe nonhierarchical relations among actors, the more these rules should enable arguing and policy deliberation.

\section{So what? Does arguing matter?}

So far, I have suggested that it is neither outrageous nor heroic to assume that the logic of arguing sometimes prevails in international relations. Based on the preceding discussion, the following conditions should be conducive to truthseeking behavior in world politics:

- The existence of a common lifeworld provided by a high degree of international institutionalization in the respective issue-area.

- Absent international institutions, conscious efforts by actors to construct such a common lifeworld through narratives that enable them to communicate in a meaningful way.

- Uncertainty of interests and/or lack of knowledge about the situation among the actors. 
- International institutions based on nonhierarchical relations enabling dense interactions in informal, network-like settings.

But does arguing really matter? What can we infer from the preceding discussion about the consequences of truth-seeking and argumentative processes on the outcomes of international negotiations and other processes? Does establishing a reasoned consensus about the situation on the ground and/or the norms guiding the interaction make for a "better" outcome? In the following, I distinguish between two settings in world politics where arguing might be expected under certain circumstances: diplomatic negotiations and public debates among various actors.

\section{Arguing and international negotiations}

Concerning international negotiations, it is useful to distinguish among stages in a negotiating process. The first phase in which arguing matters concerns the process of "getting to the table." ${ }^{56}$ This involves agenda setting as well as developing the "common knowledge" about the situation and the underlying principles for negotiations that then enable a negotiating process. As to agenda setting, actors need to be convinced that there is a problem to solve in a cooperative process before they can start negotiating. We know from the literature on epistemic communities and advocacy coalitions that transnational actors often serve as agenda setters in multilateral negotiations by pointing the international community to new problems or reframing issues in a new way. A most recent prominent example concerns the international campaign leading to an international treaty banning antipersonnel landmines. ${ }^{57}$ INGOs and other transnational actors normally do not command important material resources. Consequently, they have to rely on the "power of the better argument." We can posit, therefore, that arguing matters in terms of putting new questions or new problems on the agenda of international negotiations.

The prenegotiating phase also involves establishing "common knowledge." As discussed earlier, arguing establishes trust among actors regarding mutual belief in the truthfulness of one's respective speech acts and in the authenticity of the speakers. Moreover, if actors are uncertain about their interests or lack the knowledge to tackle a particular situation, they are likely to engage in truthseeking behavior to develop "common knowledge" in a mixed motive situation in terms of both a collective definition of the situation and of the underlying principles and norms guiding the interaction (the "rules of the game"). ${ }^{58}$

Once common knowledge is established, actors can engage in the actual negotiations, including distributive bargaining following the logic of consequentialism. But cooperative success in negotiations is by no means assured. The next step in multilateral negotiating processes where arguing and communication geared toward a reasoned consensus might be necessary concerns the "production" or "problem-solving" part of such negotiations, that is, the search for an optimal rather than a "lowest common denominator" solution to a collective 
action problem. ${ }^{59}$ This is where the widely known "negotiator's dilemma" becomes relevant: "The successful joint search for better overall solutions requires creativity, effective communication, and mutual trust, whereas success in the distributive battle depends on strategic, and even opportunistic, communication and withholding of available information - and a good deal of distrust against potential misinformation." ${ }^{60}$ Specialists on negotiations suggest disentangling the problem-solving part of negotiations as much as possible from the distributive bargaining part, particularly since a joint agreement about principles, norms, and rules is a necessary condition for a successful distributive bargain. Some specialists recommend solving the "negotiator's dilemma" sequentially (solving the commonly perceived problem first, then engaging in distributive bargains), and others suggest having different negotiators deal with the two aspects separately. ${ }^{61}$ The assumption underlying these tactics is that arguing allows negotiators to tackle the problem-solving dimension of multilateral negotiations and to achieve agreements on principles of fairness and justice, which then allow for distributive bargains.

I next discuss an empirical example of international negotiations - the Two plus Four talks ending the Cold War in Europe and enabling German unification within NATO - which concerned both problem-solving and distributive questions. I claim that an arguing process was indeed necessary to resolve the "production part" of these negotiations, which then allowed for distributive bargaining with a satisfactory result for the participants. This case study involves a mix of argumentative and instrumental rationality and is, therefore, located on the left axis of the triangle in Figure 10.1.

\section{Arguing in the international public sphere}

Communicative processes in world politics are not confined to secret diplomatic negotiations. In fact, Habermas's original points concerning communicative action involved arguing not so much behind closed doors, but in the public sphere of modern democracies. ${ }^{62}$ The existence of a public sphere ensures that actors have to regularly and routinely explain and justify their behavior. Although such public spheres are taken for granted in democratic polities, they vary dramatically in international relations. Compare the secrecy of some international negotiations with the publicity of UN-sponsored world summit meetings or with the semipublic proceedings before the UN Human Rights Commission and its subcommittees. I assume in this context that the speakers in a public discourse are likely to use arguments in a rhetorical sense, that is, trying to convince others and to persuade an audience rather than being prepared to be persuaded themselves. These audiences do not necessarily consist of the larger public, but can also be other state actors in an international setting. Although rhetorical action in the sense specified earlier dominates much of these meetings, the actors at least presuppose audiences who are prepared to listen and be persuaded.

As to the preconditions for argumentative rationality, debates in the international public sphere differ from diplomatic negotiations in bi- or multilateral 
settings in various respects. First, they are more open in terms of access, since public spheres are usually not confined to state actors. ${ }^{63}$ Nonstate actors such as nongovernmental organizations (NGOs) or advocacy networks participate regularly in international public discourses.

Second, debates in the international public sphere are more likely to invoke identity-related issues. Many international public discourses actually touch on normative issues that are directly linked to the social identities of actors. The debate about humanitarian intervention, for example, concerns understandings of two conflicting and constitutive norms of international society: sovereignty as a state property and human rights as a property of individuals. ${ }^{64}$ Thus, this discourse cannot be separated from identity-related issues, since it concerns the social identity of states and of their citizens. The same holds true for human rights questions in general (see later discussion). International human rights norms are increasingly understood as a constitutive property of what it means to be a modern and civilized state.

Third, public discourses have a "civilizing" effect on actors. As claimed earlier, justifying selfish interests on the basis of egoistical reasons is nearly impossible in the public sphere. ${ }^{65}$ Rather, even actors such as profit-seeking multinational corporations must justify their actions on the basis of some common goods or shared values. Such behavior, however, allows other actors to scrutinize and criticize these arguments with regard to a common normative framework with which everybody in the audience agrees.

Fourth and related to the third point, the more an issue is subject to public scrutiny, the more likely it becomes that materially less privileged actors have access to the discourse and that their arguments carry the day and convince an audience. Moreover, actors who can legitimately claim authoritative knowledge or moral authority (or both) should be more able to convince a skeptical public audience than actors who are suspected of promoting "private" interests. The moral power and authority of many NGOs seems to be directly related to this feature of public discourses. ${ }^{66}$

In sum, communicative behavior in various international public arenas is likely to involve all three logics of social action specified earlier. The logic of consequentialism is present to the extent that actors use rhetoric to convince others to change their interests, identities, or views of the world. The logic of appropriateness prescribes what is considered a legitimate truth claim in a given public discourse and, thus, circumscribes the boundaries of this discourse. Finally, the logic of argumentative rationality and truth-seeking behavior is likely to take over if actors are uncertain about their own identities, interests, and views of the world and/or if rhetorical arguments are subject to scrutiny and counterchallenges leading to a process of "argumentative self-entrapment."

To illustrate these points, I discuss the case of public arguing in the human rights area, particularly debates between advocacy groups, such as (I)NGOs, and national governments accused of norm violation. This case involves a particular mix of rhetorical, rule-guided, and argumentative behavior leading to argumentative self-entrapment. 


\section{The power of the better argument - two empirical examples}

\section{“Friendly persuasion:” Arguing and the end of the Cold War ${ }^{67}$}

A quite extraordinary argumentative process took place during the international negotiations ending the Cold War in Europe and settling the international issues concerning German unification. In the end, the Soviet Union under President Mikhail Gorbachev agreed to German unification within NATO in exchange for limits on Germany's and NATO's military posture in the former East Germany, on the one hand, and the transformation of NATO from an anti-Soviet alliance to a cooperative security institution, on the other. At the same time, these negotiations laid the groundwork for the post-Cold War security architecture in Europe, creating a surprisingly stable security partnership between the former Soviet Union/Russia and Western Europe (less so between the United States and Russia). Under circumstances of enormous turmoil and uncertainty on both sides, the outcome of these negotiations went well beyond a simple compromise and represented an almost optimal solution to the security problems of all concerned, including particularly Germany's neighbors. In other words, the Two plus Four talks ${ }^{68}$ solved the "production" or problem-solving part of international negotiations to a startling degree that one would not have expected on the basis of the initial negotiating positions of the governments concerned. Although several compromise solutions were possible, I claim that this particular outcome largely resulted from a successful effort on both sides at arguing out the differences in a true dialogue of mutual persuasion. During these talks, which took place from late 1989 to September 1990, Western policymakers, particularly the United States and Germany, engaged the Soviet leadership in a continuous dialogue to convince Gorbachev to agree to German unification within NATO.

One has to ask, of course, whether Moscow had a genuine choice. The Soviet Union had already lost its East European empire when the negotiations began in early 1990. Its economy was in a deep crisis and increasingly dependent on Western aid and credits. There is no question that the overall balance of power had considerably shifted in favor of the West. The use of force against German unification within NATO was not a serious option, since this would have ruined relations with the West and probably Gorbachev's domestic reform program, too. We know in hindsight, of course, that things worsened for the Soviet Union Gorbachev lost his job and the Soviet Union disintegrated. But decision makers in Washington, Bonn, and Moscow did not anticipate this. Given the speed with which the Cold War order fell apart in 1989-90, they were extremely worried about instabilities in Central Europe and faced enormous uncertainties. ${ }^{69}$ It is all the more significant how a cooperative solution was worked out during the Two plus Four talks.

Although Moscow could no longer influence events or bargaining outcomes in its desired direction, it still could make life quite miserable for the West and for Germany in particular. First, Moscow could have forced the German people to choose between unification and NATO membership, thereby triggering a major 
domestic dispute in the country during an election year. Second, the Soviet Union could have provoked an international crisis and confrontation with Bonn and Washington by fully insisting on its legal rights over Germany as an allied power. The price to be paid by both sides would have been to start another Cold War just as the first one was about to end peacefully. Third, in the absence of a cooperative agreement with the West, the Soviet Union could have decided to leave its 300,000 troops in East Germany. The West could have not done much short of using force to prevent such a course of action. Each of these three options was discussed in Moscow at the time, and each was taken quite seriously by Western policymakers. ${ }^{70}$ In other words, both sides perceived the situation as rather open; Soviet agreement to German unification within NATO was not to be taken for granted. The Soviet Union still had some bargaining leverage.

Although several negotiating outcomes were possible in this particular situation, it was arguing rather than bargaining that ultimately laid the groundwork for a cooperative post-Cold War security order in Europe. The arguing process in this case was not so much about establishing "common knowledge." Although it did not take place in an environment strongly regulated by international institutions, both sides had been interacting since the mid-1980s when Gorbachev and his foreign minister Shevardnadze came into power; they had created a common lifeworld establishing mutual trust. In this case arguing was about problem solving to establish which norms should guide the post-Cold War security architecture in Europe. It entailed a practical discourse on the "right thing to do" in this peculiar situation.

The negotiations between the Western powers and the Soviet Union included televised public discourses in the East and the West as well as secret negotiations and fulfilled to a large extent the preconditions for argumentative rationality. Particularly the U.S. and German governments tried to reassure their Soviet counterparts that they were not trying to exploit the current weakness of the Soviet Union. President Bush told Chancellor Kohl, "we will not exacerbate the problem by having the President of the United States posturing on the Berlin Wall." ${ }^{\prime 11}$ Both leaders reassured Gorbachev and Shevardnadze time and again that they had no interest in further destabilizing an already tense domestic situation in the Soviet Union. Western leaders treated their Soviet counterpart as an equal and serious negotiating partner, even though the power relationship between them was increasingly asymmetrical. That reassurances were also in the Western interest in order to gain bargaining concessions from the Soviet Union is beside the point. Avoiding aggravating language in a tense negotiation serves a communicative purpose. It acknowledges empathy for the bargaining partner's concerns and communicates that the partner's demands are legitimate even if disagreed with.

Of course, traditional distributive bargaining played a significant role in the negotiations settling the Cold War in Europe. But there have been crucial moments mostly in a bilateral context - where actors did not pursue instrumentally defined goals, but communicated in order to learn more about each other and to genuinely convince each other. At least two of the three main actors did not hold fixed 
preferences during the negotiations settling the Cold War. First and most important, the Soviet leadership changed its preferences not only over policies but also over outcomes in the course of the talks. The Soviet leaders remained opposed to German unification prior to 1989 , even though they sometimes engaged in speculative talk about what might happen in the future. When events in Germany unfolded, Gorbachev and Shevardnadze gradually changed their minds. They come across as lacking fixed preferences and as being open to persuasion and communication - another precondition for argumentative rationality. U.S. and German officials frequently concluded from their conversations that "the Soviet government did not seem to know where it was going," that Gorbachev and Shevardnadze "seem to be genuinely wrestling with these problems, but [had] yet to fashion a coherent or confident response." 72 Gorbachev appeared as an "uncommitted thinker and motivated learner," as Janice Gross Stein put it. ${ }^{73}$ U.S. and German leaders embarked on a process of friendly persuasion and engaged in almost continuous conversations with Shevardnadze and Gorbachev.

As to the German government, its preferences over outcomes seemed to be fixed from late 1989 on, when Kohl determined to push for unification. But Bonn's preferences over policies to attain this goal were influenced by events and by talks with various world leaders. The strategy toward unification changed several times as events unfolded, including its form, its speed, and the settlement of its international consequences. The only actors whose preferences over outcomes and policies remained rather fixed during the entire process were U.S. leaders. Once the Bush administration had decided to push for rapid German unification within NATO, it held this course rather steadily. U.S. leaders understood that Soviet security concerns had to be accommodated somehow and that some restrictions had to be placed on NATO forces in former East Germany. But there is not much evidence that U.S. negotiators were open to persuasive processes during their talks with German or Soviet leaders. President Bush and Secretary of State Baker were convinced that their preferred outcome was the right solution to the problem, and they engaged in a genuine attempt at persuading their Soviet counterparts whom they trusted as valid interlocutors.

Several conclusions emerge from this variation in the extent to which actors held fixed preferences during the talks. The United States largely followed a "logic of consequentialism" and engaged in rhetorical action; its negotiators mainly used arguments and justifications rather than threats to persuade the Soviet leadership. As suggested earlier, rhetorical action as a tool to reach one's goals can only be effective if the other listens and remains open to persuasion. The Soviet leadership listened indeed, thus following the "logic of arguing." Both sides then engaged in a discourse about the validity claims inherent in each other's preferences and about the norms that should guide their approach to the issues. Two examples illustrate my point.

The first example concerns a discourse challenging claims over alleged "national interests." This discourse framed the question in mainly realist terms. In early February 1990, James Baker tried to persuade Gorbachev that a neutral 
Germany would pose a greater threat to Soviet security than one firmly integrated in NATO. Thus, Baker challenged a Soviet policy that dated back to the 1950s whereby unification would only be acceptable if Germany became neutral and left NATO. Gorbachev had already acknowledged that there was nothing terrifying about German unification. Baker then asked the Soviet leader whether he preferred an independent Germany outside NATO and without U.S. troops on its territory, or a united Germany in NATO with the assurance "that there would be no extension of NATO's current jurisdiction eastward." Gorbachev remained noncommittal at first and maintained that any extension of the zone of NATO was unacceptable. Baker agreed. Gorbachev now seemed to think openly. He argued that he could see advantages of having U.S. troops in Germany. He then continued that we "don't really want to see a replay of Versailles, where the Germans were able to arm themselves.... The best way to constrain that process is to ensure that Germany is contained within European structures." He promised that the Soviet side would think about it, but that he could not give a clear answer right away. While Baker held a firm line in this conversation, Gorbachev appeared to be genuinely struggling with the question of how to interpret Soviet security interests. In contrast to other Soviet officials with whom U.S. negotiators met at the time, he appeared to be "truly flexible on the German question," as Philip Zelikow and Condoleezza Rice put it. ${ }^{74}$

One could argue, of course, that a unified Germany that remained firmly anchored in NATO was in the "enlightened" self-interest of the Soviet Union. Of course, it was - except that the vast majority of the Soviet leadership did not think so until 1990. When the negotiations started, Gorbachev and Shevardnadze were firmly convinced that a neutral Germany was best for Soviet interests. They changed their minds during the process of negotiations.

The second example concerns a moral discourse about norms. This discourse was even more important, since it led to Gorbachev's principal agreement that united Germany could remain in NATO if it chose to do so. During the U.S.Soviet summit at the end of May 1990, Bush and Gorbachev chaired a meeting of both delegations. The conversation started in a rather polemical manner, with both sides accusing each other of fearing German attempts to threaten peace in Europe once again. ${ }^{75}$ Gorbachev then accepted the realist argument that the U.S. presence in Europe was stabilizing but requested that NATO needed to change. In a decisive move, Bush reframed the issue from a realist discourse into a liberal one. He linked German membership in NATO to the question of self-determination and the principles of the Conference on Security and Cooperation in Europe (CSCE) according to which Germany should have the right to decide for itself which alliance it would join. Gorbachev agreed to this argument right away. ${ }^{76}$ The two leaders then settled on a formula whereby the United States would advocate Germany's membership in NATO but Germany's decision would be respected if it chose otherwise.

If Zelikow and Rice are correct, Gorbachev agreed to NATO membership of united Germany on the spot. His delegation was completely stunned, and some members started infighting in front of U.S. officials. There was "a palpable 


\section{In between spaces}

feeling . . . among Gorbachev's advisers of almost physically distancing themselves from their leader's words." 77 The authors conclude that Gorbachev changed his mind right at the table. If so, the incident probably constituted one of the most extraordinary cases of arguing in international negotiations. The two leaders were engaged in a discourse about norms. Bush apparently persuaded Gorbachev by reframing the NATO issue from realist terms linked to Soviet security and stability in Europe to a liberal argument emphasizing democracy and selfdetermination. He also linked it to the CSCE principles in which Gorbachev believed. Persuasion worked when the U.S. president justified united Germany's membership in NATO on the basis of principled beliefs that fit the core of Gorbachev's convictions. Thus, the normative claims implied in the idea of "selfdetermination" appear to have finally persuaded the Soviet leadership that it should accept rapid German unification within NATO. In a sense then, the principle of self-determination served as the main and most effective legitimizer of Western demands, up to the final international settlement of the German question. Note that self-determination had originally motivated the demands for German unity articulated by the peaceful protesters in East Germany, from "we are the people!" to "we are one people!" And only after both sides had agreed on the appropriate normative principles that should shape the situation could they solve the distributive issues involved, such as German credits for the Soviet economy and payments for the resettlement of Red Army soldiers to the Soviet Union.

I am not suggesting that the Two plus Four talks and the bilateral meetings in conjunction with them represented "ideal speech situations" in the strict sense of the concept. But I claim that we cannot explain the cooperative outcome of these negotiations without acknowledging that argumentative rather than instrumental rationality prevailed during crucial phases. Although there were good reasons why the Soviet Union should accept a unified Germany within NATO and these reasons were indeed argued about at the negotiating table - Moscow still had choices. Both sides not only tried to genuinely understand each other's concerns but also engaged in a discourse challenging the respective normative claims of each other's preferences. As a result, the Soviet leadership changed its preferences right at the negotiating table when Bush persuaded Gorbachev to reconsider the normative framework within which to deal with the German issue. Arguing was used here in a problem-solving mode to produce a consensus on the underlying norm for the post-Cold War environment. The Soviet leadership apparently found Western liberal standards of self-determination more convincing than realist arguments about security and stability in Europe.

\section{Socializing human rights norms into domestic practices}

My second empirical example deals with the process by which actors are socialized into international norms and start implementing these norms into their domestic practices. ${ }^{78}$ Given the stakes in the human rights area, the interference of external actors in the domestic affairs of state, this case represents a "most 
unlikely" example of arguing processes. Two features are of interest here: (1) human rights issues are identity related and constitutive in the sense of defining membership in the community of civilized nations; and (2) the norm-promoting agents, mostly INGOs, do not command many material resources; they can rely only on the power of the better argument. ${ }^{79}$

The socialization of international human rights norms into domestic practices involves all three logics of social action, with each of them dominating in particular phases of the process. Argumentative processes are particularly crucial (1) when mobilizing international public opinion, Western governments, and international organizations about the human rights situation in a norm violating state; (2) when the oppressive state starts "talking the talk" and begins justifying its actions at international human rights organizations and the like; and (3) in some rare cases, when the transnational and domestic advocacy coalition actually manages to convince rather than force repressive leaders to change course and remedy the human rights situation for good.

I concentrate on the latter two cases, because we would expect strategic bargaining or coercion through economic sanctions, rather than argumentative processes, to be decisive here. The communications between governments accused of norm violations and transnational advocacy networks as well as domestic opposition groups initially do not fulfill any of the conditions for argumentative rationality specified earlier. The speakers do not recognize each other as equals, and they certainly do not empathize with each other. We can nevertheless observe a gradual process whereby the communications move, by means of rhetorical behavior, from purely instrumental rationality toward a dialogue.

The communications between norm-violating governments and transnational as well as domestic advocacy networks resemble a public discourse that is carried out in front of international as well as domestic audiences in the target state. The international audiences include Western states, Western publics, and international organizations, and the domestic audiences mainly consist of the society of the target state. In general, instrumental interests and strategic rationality dominate the early phases of the controversy, whereas argumentative behavior becomes more relevant later. Norm-violating governments initially deny the validity of international human rights norms and are not interested in engaging in a serious dialogue with their critics. At this stage of the process, the two sides do not accept each other as valid and truthful interlocutors. The advocacy coalition treats the norm-violating state as an international pariah, an outsider to the community of civilized nations. At the same time and in response, norm-violating governments not only deny the validity of the international norms but also ridicule their accusers as ignorant "foreigners," "communists," or "terrorists." Kenya's arap Moi, Indonesia's Suharto, and the communist regimes in Eastern Europe as well as the white minority in South Africa used very similar rhetoric in this regard. Their main target audience was domestic society in an attempt to fight off the challenges to their legitimacy. Many Third World governments engage in an anti-colonial and anti-imperialist as well as nationalist discourse at this stage. 
Under increasing international pressures, norm-violating governments feel that they must make some concessions in order to increase their international legitimacy or simply to regain foreign aid. This transition to tactical concessions is accompanied by an important change in rhetoric. Norm-violating governments no longer deny the validity of the international norm, but they continue to ridicule their critics and to reject specific allegations of norm violations. Toward later stages of this phase and in conjunction with continuing transnational and increasingly domestic pressures, we observe a striking development toward arguing. The more norm-violating governments accept the validity of international norms, the more they start arguing with their critics over specific accusations. If the transnational and domestic pressure increases, norm-violating governments start engaging in a public dialogue with their critics, and the logic of arguing incrementally takes over. I discuss two cases in more detail, Indonesia and Morocco. ${ }^{80}$

When Indonesian police forces committed a massacre in East Timor in November 1991 that was witnessed by the UN Special Rapporteur on Torture, the international outcry forced the government to move from denial of human rights norms to tactical concessions. This change was accompanied by a dramatic change in rhetoric. At the 1992 session of the UN Human Rights Commission, the Indonesian delegate claimed that Indonesia strictly prohibited the practice of torture. He also stated that the invitation of the Special Rapporteur had been motivated by the desire "to learn and benefit from such a visit in order to minimize, if not eradicate, the practice of torture in Indonesia." ${ }^{" 81}$ This statement not only acknowledged the validity of the international norm but also was the first time the Indonesian government accepted allegations of torture.

From then on, the Indonesian government cooperated fully with the Human Rights Commission during the 1993-97 sessions and acknowledged specific human rights violations. In 1996, for example, Indonesia presented the Human Rights Commission with a list of detailed measures undertaken to deal with human rights violations, including immediate investigations of some abuses in East Timor. At first, government officials differentiated between valid critiques by UN (that is, interstate) bodies and inaccurate or baseless allegations by INGOs. The attitude toward the latter changed over time, particularly when two prominent East Timorese NGO leaders gained the Nobel Peace Prize in 1996. In turn, NGO officials also modified their argumentative behavior and acknowledged "the legitimate concerns of countries in preserving their national unity and territorial integrity. Many developing countries, Indonesia being a prime example, experienced a traumatic nation-building process with numerous attempts from within and without to undermine the unity of the state. ${ }^{\prime 82}$ Such a statement by the most prominent East Timorese opposition leader would have been unthinkable only five years earlier. The discourse between the Indonesian government and its critics shifted dramatically over time. It began with a contestation of the underlying norm (self-determination and human rights versus noninterference in internal affairs) and a complete denial of the authenticity and credibility of the respective speakers. Later, however, the underlying norms became consensual - human rights in particular - and the speakers accepted each other as valid interlocutors. 
As a result, the discourse began focusing on questions of norm compliance and implementation on the ground.

This change in public discourse had significant repercussions for the domestic situation, since it empowered the opposition against Suharto. When the economic crisis hit Indonesia in the fall of 1997, the domestic opposition was fully mobilized, and Suharto ultimately had to resign. His successor, Habibie, immediately opened a dialogue with the domestic opposition and began implementing important human rights norms, even though Indonesia still has a long way to go.

The Moroccan case represents an unusual example of a process of public persuasion involving the late King Hassan II, the ruler, and his domestic as well as transnational critics. ${ }^{83}$ The case is counterintuitive, since Morocco is both an Islamist state and a monarchy where the king's position constitutes a societal taboo. As in the other case, King Hassan II claimed the principle of noninterference against international human rights norms until about 1990. The more the transnational and domestic network pressures increased during the late 1980s and early 1990s, the more the king's rhetoric changed. When he instituted the Moroccan Human Rights Commission in 1990, for example, he claimed that human rights were a constitutive part of the Islamic tradition. He also argued at the UN General Assembly two years later that the principles embodied in the Universal Declaration of Human Rights reflected values prevailing in Morocco for the last fourteen centuries. He now reconstructed Moroccan identity as belonging to the (Western) community of civilized nations: "Our history, thanks to the creative spirit, which illustrates a large contribution to the sciences, the arts, to civilization, and to the law, shows that our country has always seen itself as living in a civilized society next to the developed states and nations." ${ }^{\prime 4} \mathrm{Com}-$ pared to two years earlier, the nationalist discourse had completely changed. Morocco now desired to be part of the civilized international community, which included respecting human rights.

At the same time, the king no longer denied that human rights violations occurred in Morocco and recognized that continuous human rights violations betrayed the image of Morocco as a civilized nation that he wanted to portray to the outside world. As a result, the mission of the newly founded Human Rights Commission was to "purify the face of Morocco." ${ }^{" 85}$ His words and deeds set in motion a process that enabled domestic human rights networks to become more and more outspoken. They began interacting regularly with the state-sponsored Human Rights Commission, which later became the Ministry of Human Rights. Today, Morocco is the most liberal of the Maghreb states; human rights policies have been implemented in domestic law, and violations have decreased substantially. The Moroccan king thus began a process of controlled liberalization from above. This outcome is all the more remarkable, since his rule was never challenged domestically and he continued to enjoy great popularity.

What these and other cases have in common is that the communicative behavior between a norm-violating government and its transnational and domestic critics changes dramatically over time. At first, neither side accepts the other as a valid interlocutor. When the process moves toward tactical concessions, an increasing 
consensus emerges about the validity of international human rights norms. Normviolating governments accept the norms rhetorically in order to decrease the international and domestic pressures against them. They keep denouncing their critics and do not accept the authenticity of their arguments. At this stage, rhetorical action prevails. Argumentative concessions are part of a larger picture of tactical moves to fight off the transnational and domestic opposition. So far, the process remains fully within the logic of consequentialism.

However, when norm-violating governments find it necessary to make rhetorical concessions and cease denying the validity of human rights norms, a discursive opening is created for their critics to challenge them further: If you say that you accept human rights, then why do you systematically violate them? The usual response is that such violations either did not occur or are marginal developments. The discourse then shifts toward the issue of whether norm violations constitute isolated incidents or are systematic in character. At this point during the tactical concession phase, the arguments of both sides become more and more detailed and also more legalistic. It is no longer a discourse on the validity of the norm, but on the interpretation of the law of the land. At the same time, the two sides gradually accept each other as valid interlocutors. They no longer denounce each other as ignorant foreigners or pariah states. Arguments that would not have been acceptable in earlier stages of the debate are now treated as valid points. There are many examples whereby norm-violating Third World governments convincingly argue that they were not fully in control of their own armed forces or their police. In earlier stages of the argumentative process, human rights advocates would have dismissed such a point out of hand as self-serving. Finally, the argumentative consistency of actors irrespective of the audience increases dramatically. Toward the beginning of the tactical concession phase, norm-violating governments might "talk the talk" at the UN and toward the Western donor community but adopt an entirely different language when making statements targeted at a domestic audience. Later, the arguments become substantially more consistent.

In sum then, the evidence shows a process of argumentative "self-entrapment" that starts as rhetorical action and strategic adaptation to external pressures but ends with argumentative behavior resembling the criteria defined earlier. How can one explain this process of argumentative "self-entrapment" theoretically? It is not an "ideal speech situation," since governments do not enter the process of arguing voluntarily but are forced into a dialogue by the pressures of fully mobilized domestic and transnational networks. They might also face economic or political sanctions by the international community. At the same time, the dialogue no longer resembles rhetorical exchanges, either, through which both sides use arguments to justify their given interests and behavior but are unprepared to reconsider and change their preferences. Even these "forced dialogues" have all the characteristics of a true argumentative exchange. Both sides accept each other as valid interlocutors, try to establish some common definition of the human rights situation, and agree on the norms guiding the situation. In other words, they behave as if they were engaged in a true moral discourse. 
Argumentative rationality has taken over. And it matters: Governments that started moving down the road of arguing eventually matched words with deeds in terms of an improved human rights record. Those that did not continued to commit serious human rights abuses while making some tactical concessions here and there. ${ }^{86}$

\section{Conclusions}

In this article I introduced a mode of social action and interaction that has so far been largely overlooked in the U.S.-dominated international relations debate between rational choice and social constructivism, which has mainly focused on the differences between instrumental rationality, on the one hand, and normguided behavior, on the other. Drawing on insights from a theoretical debate within the German-speaking international relations community, I suggested that actors have a third mode of social action at their disposal: arguing and deliberating about the validity claims inherent in any communicative statement about identities, interests, and the state of the world. Arguing and truth-seeking behavior presuppose that actors no longer hold fixed interests during their communicative interaction but are open to persuasion, challenges, and counterchallenges geared toward reaching a reasoned consensus.

I then posited that the preconditions for argumentative rationality, particularly a "common lifeworld" and the mutual recognition of speakers as equals in a nonhierarchical relationship, are more common in international relations than is usually assumed. International institutions, for example, provide an informationrich environment and a normative framework structuring interactions. Public spheres enabling challenges and counterchallenges to validity claims also exist in many issue-areas and regions of the world. In the absence of these social structures, actors can construct common lifeworlds through narratives during prenegotiations in order to establish mutual trust in their authenticity as speakers. Arguing processes are more likely to occur both in negotiating settings and in the public sphere,

- the more actors are uncertain about their interests and even identities;

- the less actors know about the situation in which they find themselves and about the underlying "rules of the game" ("common knowledge"); and

- the more apparently irreconcilable differences prevent them from reaching an optimal rather than a merely satisfactory solution for a widely perceived problem ("problem solving").

I distinguished between arguing and policy deliberation in international negotiations and in the international public sphere. In either context, however, arguing is likely to increase the influence of the materially less powerful, be it small states or nonstate actors such as INGOs.

Finally, I illustrated my claims with two plausibility probes for the relevance of arguing in international relations. The first concerned the East-West talks 
leading to a negotiated settlement of the Cold War in Europe and German unification within NATO. The problem-solving part of these negotiations required a reasoned consensus about the underlying principles and norms guiding interactions in the post-Cold War order. Only when both sides went into an arguing mode and reached an understanding about the norm - self-determination in this case - were they able to settle the distributive issues, too. The second case focused on the implementation of international human rights norms into domestic practices of Third World states. Sustained changes in human rights practices occur when governments become convinced through arguing processes that human rights constitute part of their collective identity as a modern member of the international community. Moreover, the human rights case served as an example of how arguing empowers actors who lack material resources and so must rely on the "power of the better argument," transnational advocacy networks in this case.

I do not claim that truth seeking is all-pervasive in world politics. First, even if actors are engaged in truth-seeking behavior in a given situation, they might still fail to reach an argumentative consensus. Second, we rarely observe pure argumentative rationality prevailing in world politics; instead we see various combinations of the three rationalities identified earlier. But focusing on argumentative processes allows us to become more specific in the conversation between rational choice and social constructivism by "unpacking" the latter. As to rational choice, the logic of arguing challenges the assumption that actors hold fixed interests and identities during the process of interaction. As to the logic of appropriateness, argumentative rationality brings agency back in and allows us to overcome the structuralist bias in some social constructivist statements. ${ }^{87}$ Social constructivism often emphasizes learning and socialization processes in order to link social structure to agents. The two empirical cases discussed in this article illustrate how arguing provides a mechanism for both learning and norms socialization in social settings.

\section{Notes}

Earlier versions of this article were presented to the annual meeting of the American Political Science Association, Washington, D.C., August 1997; the 3rd Pan-European Conference on International Relations. Vienna, September 1998; and the Max Planck Institute for the Study of Societies, Cologne, Germany, 1998. I thank Michael Barnett, Tanja Börzel, Mlada Bukovansky, Jeffrey Checkel, Thomas Diez, Martha Finnemore, Stefano Guzzini, Anja Jetschke, Otto Keck, Mathias Maier, Marc Lynch, Rodger A. Payne, Fritz Scharpf, Hans Peter Schmitz, Kathryn Sikkink, Jens Steffek, Katia Tieleman, Alexander Wendt, Bernhard Zangl, Michael Zürn, two anonymous reviewers, and the editors of $I O$ for their extremely helpful and constructive comments on the draft. Moreover, I thank the Ph.D. researchers at the European University Institute for their lively arguing over "arguing" during my spring 1999 seminar. Finally, while Harald Müller never commented on this particular article, his work strongly influenced my own thoughts on the subject. Research on this article was partly funded by a research grant from the European University Institute and by the Deutsche Forschungsgemeinschaft (German Research Foundation). 
1 For recent contributions and reviews of the debates in international relations, see, for example, Adler 1997; Checkel 1998; Finnemore 1996b; Finnemore and Sikkink 1998; Hopf 1998; Katzenstein 1996; Klotz 1995; Price and Reus-Smit 1998; Schaber and Ulbert 1994; Wendt 1992 and 1999; as well as several contributions in Katzenstein, Keohane, and Krasner 1998b. On related debates in comparative politics, see, for example, Hall and Taylor 1996; Powell and DiMaggio 1991; and Steinmo, Thelen, and Longstreth 1992.

2 In other words, I am not concerned with irrational behavior, which, by definition, is not goal-oriented. But I want to emphasize that the term rationality cannot be and should not be confined to rational choice and its specific understandings.

3 Scharpf 1997.

4 March and Olsen 1989 and 1998. I owe the suggestion of the triangle to the editors of IO.

5 Elster 1989, 22.

6 See, for example, Hasenclever, Mayer, and Rittberger 1997; Keohane 1984 and 1989a; Martin and Simmons 1998; Oye 1986; and Zürn 1992. For general accounts, see Ostrom 1998; Ostrom, Gardner, and Walker 1994; and Scharpf 1997.

7 Goldstein and Keohane 1993.

8 March and Olsen 1998, 951. On the following, see also Finnemore and Sikkink 1998.

9 See Onuf 1989; Kratochwil 1989; and Wendt 1999. For an excellent review of their work, see Zehfuss 1998.

10 Jepperson, Wendt, and Katzenstein 1996, 54.

11 A general rule could be that we find constitutive norms and the like whenever we cannot even describe the very properties of actors, including corporate actors, without reference to some underlying social rules. The same applies to interaction processes. We only "know" a chess game by its rules.

12 Elster 1989, 13. See Adler 1997, 324-25; and Wendt 1999, chap. 4, for the following.

13 For excellent statements on these positions, see Wendt 1999, chap. 4, and Adler 1997. On the agency-structure debate in general, see Wendt 1987; Carlsnaes 1992; and Dessler 1989.

14 There is a further corollary of this statement. Rational choice, beginning with methodological individualism, has a hard time theorizing the social realm and nonindividualistic logics of social action, whereas constructivism can easily accommodate the logic of consequentialism in the sense that there are social circumstances in which acting instrumentally is appropriate and legitimate.

15 See the various reviews of this debate in Adler 1997; Checkel 1998; Katzenstein, Keohane, and Krasner 1998a, 674-82; Kahler 1998; and Ruggie 1998.

16 See, for example, Axelrod 1997; Axelrod and Keohane 1986; and Keohane 1984 and 1989b. On bounded rationality, see Simon 1982.

17 See, for example, Finnemore 1996b; Finnemore and Sikkink 1998; and Powell and DiMaggio 1991. For an excellent review of the various institutionalisms, see Hall and Taylor 1996.

18 See March and Olsen 1989 and 1998.

19 Jürgen Habermas calls this "communicative action." Habermas 1981, vol. 1, 141-51. Since communications are all-pervasive in social action and interaction - including strategic behavior (see later), I prefer the term "argumentative" rationality, since the goal of such communicative behavior is to reach argumentative consensus on validity claims of norms or assertions about the world.

20 See, however, Kratochwil 1989; and Onuf 1989. Although Kratochwil's and Onuf's work on norms has been widely received in the American international relations community, their emphasis on communicative behavior derived from speech act theory has been largely ignored. See also Alker 1996; Linklater 1996; and most recently Lynch 1999; and Payne 1999. 
21 See Müller 1994 and 1995; Schneider 1994; Keck 1995 and 1997; Risse-Kappen 1995; Schmalz-Bruns 1995; Jaeger 1996; Müller 1996; Prittwitz 1996b; and Zangl and Zürn 1996.

22 I am not interested in the endless debates about whether or not Habermas's social philosophy is purely normative or can be applied to tackle empirical questions (see the various contributions in Elster 1998b and the excellent discussion in Chambers 1996, 155-72). My aim is to illustrate that we can shed light on many important issues in international relations when we incorporate argumentative rationality and deliberative processes in our theoretical "tool kit."

23 Elster 1986. For excellent reviews, see Saretzki 1995 and 1996.

24 See Morrow 1994; Schneider 1994; Cooper et al. 1992; and Farrell and Rabin 1996.

25 Schimmelfennig 1995 and 1997.

26 Habermas 1981, vol. 1, 385 (my translation). For the following, see Prittwitz 1996a; Saretzki 1996; Lose 1998; and Eriksen and Weigard 1997.

27 Müller 1994, 28 (my translation).

28 Habermas 1981, vol. 1, 397-452.

29 Habermas 1992, 391.

30 On this point, see Lose 1998, 5.

31 Habermas 1981, vol. 2, 209.

32 Lose 1998, 9.

33 For this and the following, see Keck 1995 and 1997. See also Keck 1987; Sebenius 1992, 349-50; Plümper 1995; and Wendt 1999, chap. 4.

34 Keck 1987, 1993, and 1997, 141-42.

35 On this point, see also Ferreira, Gilboa, and Maschler 1995.

36 Some of this can be captured by Bayesian updating in standard game theory.

37 Müller 1995. See also Risse-Kappen 1995.

38 Zangl and Zürn 1996. See also Gehring 1999, chap. 5. I owe the following point to Otto Keck.

39 Stein 1983.

40 Müller 1994, 29-30.

41 See, for example, Zartman and Berman 1982; Stein 1989; Ostrom 1998; and Ostrom, Gardner, and Walker 1994, 328.

42 Ostrom 1998, 7.

43 Chaiken, Wood, and Eagly 1996, 710, 716. Of course, this does not imply that people never lie in face-to-face interactions. But lying presupposes trust in order to be effective. If the actors in a communication fundamentally distrust each other, they cannot even successfully lie.

44 In his original argument, Jürgen Habermas sharply distinguished the "common lifeworld" from the "system world," which is functionally differentiated through complex divisions of labor and where instrumental rationality prevails. Modern political systems - we could add international relations - were originally conceptualized as part of the latter.

45 A focus on arguing shares this assumption with neoliberal institutionalism.

46 See Müller 1994, 33-35. As one anonymous reviewer pointed out, a communicative discourse could actually begin with very little shared understanding and work from there.

47 See Adler and Barnett 1998; and Deutsch 1957.

48 See Russett 1993; and Owen 1997.

49 On networks as a structure of nonhierarchical and communicative interaction, see Börzel 1998.

50 I owe this point to the editors of IO.

51 See, for example, Foucault 1978 and 1991; Habermas 1985; and Love 1989. Thomas Diez helped me to clarify the following points. 
52 Elster 1998a.

53 Habermas 1995, 553.

54 See, for example, Chaiken, Wood, and Eagly 1996. See also Johnston 1998.

55 On this point, see Chambers 1996, 137-38.

56 Stein 1989.

57 Price 1998. See also Haas 1992; and Keck and Sikkink 1998.

58 "Common knowledge" entails information about the structure of the game ("definition of the situation") and its underlying rules. It does not entail agreement about a cooperative norm solving the collective action problem.

59 Neofunctionalism talks about "upgrading the common interest" (Haas 1958). The point is not to reach some solution to a collective action problem, but a solution that the participants perceive as innovative and optimal.

60 Scharpf 1997, 124. See also Lax and Sebenius 1986.

61 See Zintl 1992; and Mayntz 1997.

62 See Habermas 1990 and 1992; and Chambers 1996. I owe the following argument to Marc Lynch. Lynch 1999. See also Payne 1999.

63 This does not mean that there are no restrictions to public access. Getting attention in the international public arena is still hard; but everything else being equal, access for nonstate actors is still easier in the public sphere than in (secret) diplomatic negotiations.

64 Finnemore 1996a.

65 On this point, see Elster 1986 and 1998b.

66 See, for example, Keck and Sikkink 1998.

67 This part builds on Risse 1997. "Friendly persuasion" is a chapter title in Zelikow and Rice 1995, 251.

68 "Two" stands for the two Germanies, and "four" stands for the Allied Powers: France, Great Britain, the Soviet Union, and the United States.

69 This is the overall impression one gets from the memoir literature on the events in 1989-90. See, for example, Gorbachev 1995; Shevardnadze 1991; Teltschik 1991; Genscher 1995; and Baker 1995.

70 See Zelikow and Rice 1995; Elbe and Kiessler 1996; and Beschloss and Talbott 1993.

71 Quoted from Zelikow and Rice 1995, 112. See also Elbe and Kiessler 1996.

72 Zelikow and Rice 1995, 130, 232. See also ibid., 108-109, 131.

73 Stein 1995.

74 Zelikow and Rice 1995, 184. The other quotes are from ibid., 183-84. See also Gorbachev's account in Gorbachev 1995, 715-16.

75 Gorbachev 1995, 722-23. For the U.S. version, see Zelikow and Rice 1995, 276-79.

76 Testifying to the extreme sensitivity of this conversation, Gorbachev's account puts a different spin on it. According to his version, it was Bush who agreed that Germany was free to leave NATO if it wanted to. A comparison of the U.S. version and Gorbachev's account appears to indicate that the Soviet leader quoted selectively from the Soviet records. Compare Gorbachev 1995, 722-23, with Zelikow and Rice 1995, 276-78.

77 Zelikow and Rice 1995, 278.

78 This part summarizes Risse 1999 and is based on research reported in Risse, Ropp, and Sikkink 1999.

79 See Keck and Sikkink 1998; Sikkink 1993; and Smith, Chatfield, and Pagnucco 1997.

80 For the following, see Jetschke 1997 and 1999.

81 United Nations ECOSOC, Commission on Human Rights, 48th Session, Summary Record of the 25th meeting (E/CN.4/1992/SR.25, par. 53-54), quoted from Jetschke 1997. See ibid. and Jetschke 1999 for the following.

82 Nobel Peace Prize winner José Ramos Horta at the 1997 session of the Human Rights Commission, quoted from Jetschke 1997, 12. 
83 For the following, see Gränzer 1998 and 1999.

84 Speech to the nation, 8 May 1990, quoted from Gränzer 1998, 6 (my translation).

85 Speech of 8 May 1990.

86 In contrast to Morocco, Tunisia provides an interesting example of a country whose leadership initially engaged in human rights rhetoric accompanied by tactical concessions but then did not move further along the path, partly because of a lack of transnational and domestic mobilization. For details, see Gränzer 1999.

87 On this bias, see Checkel 1998.

\section{References}

Adler, Emanuel. 1997. Seizing the Middle Ground: Constructivism in World Politics. European Journal of International Relations 3 (3):319-63.

Adler, Emanuel, and Michael Barnett, eds. 1998. Security Communities. Cambridge: Cambridge University Press.

Alker, Hayward A. 1996. Rescuing "Reason" from the "Rationalists": Reading Vico, Marx, and Weber as Reflective Institutionalists. In Alker, Rediscoveries and Reformulations: Humanistic Methodologies for International Studies, 207-37. Cambridge: Cambridge University Press.

Axelrod, Robert A. 1997. The Complexity of Cooperation: Agent-Based Models of Competition and Collaboration. Princeton N.J.: Princeton University Press.

Axelrod, Robert A., and Robert O. Keohane. 1986. Achieving Cooperation Under Anarchy: Strategies and Institutions. In Cooperation Under Anarchy, edited by Kenneth A. Oye, 226-54. Princeton N.J.: Princeton University Press.

Baker, James A. III. 1995. The Politics of Diplomacy: Revolution, War, and Peace, 1989-1992. New York: G. P. Putnam's Sons.

Beschloss, Michael R., and Strobe Talbott. 1993. At the Highest Levels: The Inside Story of the End of the Cold War. Boston: Little, Brown and Co.

Börzel, Tanja A. 1998. Organizing Babylon - On the Different Conceptions of Policy Networks. Public Administration 76 (2):253-73.

Carlsnaes, Walter. 1992. The Agency-Structure Problem in Foreign Policy Analysis. International Studies Quarterly 36 (3):245-70.

Chaiken, Shelly, Wendy Wood, and Alice H. Eagly. 1996. Principles of Persuasion. In Social Psychology: Handbook of Basic Principles, edited by E. T. Higgins and A. W. Kruglanski, 702-42. New York: Guilford Press.

Chambers, Simone. 1996. Reasonable Democracy: Jürgen Habermas and the Politics of Discourse. Ithaca, N.Y.: Cornell University Press.

Checkel, Jeffrey T. 1998. The Constructivist Turn in International Relations Theory. World Politics 50 (2): 324-48.

Cooper, Russell, Douglas V. DeJong, Robert Forsythe, and Thomas W. Ross. 1992. Communication in Coordination Games. Quarterly Journal of Economics 107 (2):739-71.

Dessler, David. 1989. What's at Stake in the Agent-Structure Debate? International Organization 43 (3): 441-73.

Deutsch, Karl W., Sidney A. Burrell, Robert A. Kann, Maurice Lee, Jr., Martin Lichterman, Raymond E. Lindgren, Francis L. Loewenheim, and Richard W. Van Wagenen. 1957. Political Community and the North Atlantic Area: International Organization in the Light of Historical Experience. Princeton, N.J.: Princeton University Press.

Elbe, Frank, and Richard Kiessler. 1996. A Round Table with Sharp Corners: The Diplomatic Path to German Unity. Baden-Baden: Nomos. 
Elster, Jon. 1986. The Market and the Forum: Three Varieties of Political Theory. In Foundations of Social Choice Theory, edited by Jon Elster and Aanund Hylland, 103-32. Cambridge: Cambridge University Press.

. 1989. Nuts and Bolts for the Social Sciences. Cambridge: Cambridge University Press.

1998a. Introduction. In Deliberative Democracy, edited by Jon Elster, 1-18. Cambridge: Cambridge University Press.

Elster, Jon, ed. 1998b. Deliberative Democracy. Cambridge: Cambridge University Press. Eriksen, Erik Oddvar, and Jarle Weigard. 1997. Conceptualizing Politics: Strategic or Communicative Action? Scandinavian Political Studies 20 (3):219-41.

Farrell, Joseph, and Matthew Rabin. 1996. Cheap Talk. Journal of Economic Perspectives 10 (3):103-18.

Ferreira, J.-L., I. Gilboa, and M. Maschler. 1995. Credible Equilibria in Games with Utilities Changing During the Play. Games and Economic Behavior 10 (2):284-317.

Finnemore, Martha. 1996a. Constructing Norms of Humanitarian Intervention. In The Culture of National Security: Norms and Identity in World Politics, edited by Peter J. Katzenstein, 153-85. New York: Columbia University Press.

. 1996b. Norms, Culture, and World Politics: Insights From Sociology's Institutionalism. International Organization 50 (2):325-47.

Finnemore, Martha, and Kathryn Sikkink. 1998. International Norm Dynamics and Political Change. International Organization 52 (4):887-917.

Foucault, Michel. 1978. Dispositive der Macht. Berlin: Merve Verlag.

- 1991. Politics and the Study of Discourse. In The Foucault Effect: Studies in Governmentality, edited by Graham Burchell, Colin Gordon, and Peter Miller, 53-72. London: Harvester Wheatsheaf.

Gehring, Thomas. 1999. Die Theorie spezifischer Institutionen und die Europäische Union. Ein Beitrag zur Verbindung von Rationalismus und Konstruktivismus. Habilitationsschrift, Fachbereich Politische Wissenschaft, Freie Universität Berlin.

Genscher, Hans-Dietrich. 1995. Erinnerungen. Berlin: Siedler.

Goldstein, Judith, and Robert O. Keohane, eds. 1993. Ideas and Foreign Policy: Beliefs, Institutions, and Political Change. Ithaca, N.Y.: Cornell University Press.

Gorbachev, Mikhail. 1995. Erinnerungen. Berlin: Siedler.

Gränzer, Sieglinde. 1998. Staatliche Menschenrechtsdiskurse in Marokko. Unpublished manuscript, European University Institute, Florence, Italy.

1999. Changing Discourse: Transnational Advocacy Networks in Tunisia and Morocco. In The Power of Human Rights: International Norms and Domestic Change, edited by Thomas Risse, Stephen C. Ropp, and Kathryn Sikkink, 109-33. Cambridge: Cambridge University Press.

Haas, Ernst B. 1958. The Uniting of Europe: Political, Social, and Economic Forces 1950-57. Stanford, Calif: Stanford University Press.

Haas, Peter M., ed. 1992. Knowledge, Power, and International Policy Coordination. International Organization 46 (1). Special issue.

Habermas, Jürgen. 1981. Theorie des kommunikativen Handelns. 2 vols. Frankfurt am Main: Suhrkamp.

— 1985. Der philosophische Diskurs der Moderne. Frankfurt am Main: Suhrkamp. 1990. Strukturwandel der Öffentlichkeit. Frankfurt am Main: Suhrkamp.

1992. Faktizität und Geltung. Beiträge zur Diskurstheorie des Rechts und des demokratischen Rechtsstaats. Frankfurt am Main: Suhrkamp. 
. 1995. Replik auf Einwände. In Habermas, Vorstudien und Ergänzungen zur Theorie des kommunikativen Handelns, 475-570. Frankfurt am Main: Suhrkamp.

Hall, Peter A., and Rosemary C. R. Taylor. 1996. Political Science and the Three New Institutionalisms. Political Studies 44 (5): 936-57.

Hasenclever, Andreas, Peter Mayer, and Volker Rittberger. 1997. Theories of International Regimes. Cambridge: Cambridge University Press.

Hopf, Ted. 1998. The Promise of Constructivism in International Relations Theory. International Security 23 (1): 171-200.

Jaeger, Hans-Martin. 1996. Konstruktionsfehler des Konstruktivismus in den Internationalen Beziehungen. Zeitschrift für Internationale Beziehungen 3 (2):313-40.

Jepperson, Ronald, Alexander Wendt, and Peter J. Katzenstein. 1996. Norms, Identity, and Culture in National Security. In The Culture of National Security: Norms and Identity in World Politics, edited by Peter J. Katzenstein, 33-75. New York: Columbia University Press.

Jetschke, Anja. 1997. Government Rhetoric: Indonesia and the Philippines. Unpublished manuscript, European University Institute, Florence, Italy.

1999. Linking the Unlinkable? International Norms and Nationalism in Indonesia and the Philippines. In The Power of Human Rights: International Norms and Domestic Change, edited by Thomas Risse, Stephen C. Ropp, and Kathryn Sikkink, 134-71. Cambridge: Cambridge University Press.

Johnston, Alastair Ian. 1998. Socialization in International Institutions: The ASEAN Regional Forum and IR Theory. Paper presented at the workshop "The Emerging International Relations of the Asia-Pacific Region," University of Pennsylvania, Philadelphia, May.

Kahler, Miles. 1998. Rationality in International Relations. International Organization 52 (4):919-41.

Katzenstein, Peter J., ed. 1996. The Culture of National Security: Norms and Identity in World Politics. New York: Columbia University Press.

Katzenstein, Peter J., Robert O. Keohane, and Stephen D. Krasner. 1998a. International Organization and the Study of World Politics. International Organization 52 (4):645-85.

Katzenstein, Peter J., Robert O. Keohane, and Stephen D. Krasner, eds. 1998b. International Organization at Fifty: Exploration and Contestation in the Study of World Politics. International Organization 52 (4). Special issue.

Keck, Margaret E., and Kathryn Sikkink. 1998. Activists Beyond Borders: Advocacy Networks in International Politics. Ithaca, N.Y.: Cornell University Press.

Keck, Otto. 1987. The Information Dilemma: Private Information as a Cause of Transaction Failure in Markets, Regulation, Hierarchy, and Politics. Journal of Conflict Resolution 31 (1):139-63.

- 1993. Information, Macht und gesellschaftliche Rationalität. Das Dilemma rationalen kommunikativen Handelns, dargestellt am Beispiel eines internationalen Vergleichs der Kernenergiepolitik. Baden-Baden: Nomos.

- 1995. Rationales kommunikatives Handeln in den internationalen Beziehungen. Ist eine Verbindung von Rational-Choice-Theorie und Habermas' Theorie des kommunikativen Handelns möglich? Zeitschrift für Internationale Beziehungen 2 (1):5-48.

. 1997. Zur sozialen Konstruktion des Rational-Choice-Ansatzes. Einige Klarstellungen zur Rationalismus-Konstruktivismus-Debatte. Zeitschrift für Internationale Beziehungen 4 (1):139-51. 
Keohane, Robert O. 1984. After Hegemony: Cooperation and Discord in the World Political Economy. Princeton, N.J.: Princeton University Press.

Press.

Press. 1989b. International Institutions: Two Approaches. In Keohane, International Institutions and State Power, 158-79. Boulder, Colo.: Westview Press.

Klotz, Audie. 1995. Norms in International Relations: The Struggle Against Apartheid. Ithaca, N.Y.: Cornell University Press.

Kratochwil, Friedrich V. 1989. Rules, Norms, and Decisions: On the Conditions of Practical and Legal Reasoning in International Relations and Domestic Affairs. Cambridge: Cambridge University Press.

Lax, David A., and James K. Sebenius. 1986. The Manager as Negotiator: Bargaining for Cooperation and Competitive Gain. New York: Free Press.

Linklater, Andrew. 1996. The Achievements of Critical Theory. In International Theory: Positivism and Beyond, edited by Steve Smith, Ken Booth, and Marysia Zalewski, 279-98. Cambridge: Cambridge University Press.

Lose, Lars G. 1998. Communicative Action and the Social Construction of Diplomatic Societies: Communication and Behavior in the Real World. Paper presented at Femmôller Workshop, Femmôller Æbeltoft, Denmark, 24-28 June.

Love, Nancy S. 1989. Foucault and Habermas on Discourse and Democracy. Polity 22 (2):269-83.

Lynch, Marc. 1999. State Interests and Public Spheres: The International Politics of Jordanian Identity. New York: Columbia University Press.

March, James G., and Johan P. Olsen. 1989. Rediscovering Institutions: The Organizational Basis of Politics. New York: Free Press.

- 1998. The Institutional Dynamics of International Political Orders. International Organization 52 (4):943-69.

Martin, Lisa L., and Beth A. Simmons. 1998. Theories and Empirical Studies of International Institutions. International Organization 52 (4):729-57.

Mayntz, Renate. 1997. Soziale Dynamik und politische Steuerung. Theoretische und methodologische Überlegungen. Frankfurt am Main: Campus.

Morrow, James D. 1994. Modeling the Forms of International Cooperation: Distribution Versus Information. International Organization 48 (3):387-423.

Müller, Harald. 1994. Internationale Beziehungen als kommunikatives Handeln. Zur Kritik der utilitaristischen Handlungstheorien. Zeitschrift für Internationale Beziehungen 1 (1):15-44.

. 1995. Spielen hilft nicht immer. Die Grenzen des Rational-Choice-Ansatzes und der Platz der Theorie kommunikativen Handelns in der Analyse internationaler Beziehungen. Zeitschrift für Internationale Beziehungen 2 (2):371-91.

Müller, Michael. 1996. Vom Dissensrisiko zur Ordnung der internationalen Staatenwelt. Zum Projekt einer normativ gehaltvollen Theorie der internationalen Beziehungen. Zeitschrift für Internationale Beziehungen 3 (2):367-79.

Onuf, Nicholas Greenwood. 1989. World of Our Making: Rules and Rule in Social Theory and International Relations. Columbia: University of South Carolina Press.

Ostrom, Elinor. 1998. A Behavioral Approach to the Rational Choice Theory of Collective Action. American Political Science Review 92 (1):1-22.

Ostrom, Elinor, Roy Gardner, and James Walker. 1994. Rules, Games, and Common-Pool Resources. Ann Arbor: University of Michigan Press. 
Owen, John M. 1997. Liberal Peace, Liberal War: American Politics and International Security. Ithaca, N.Y.: Cornell University Press.

Oye, Kenneth, ed. 1986. Cooperation Under Anarchy. Princeton, N.J.: Princeton University Press.

Payne, Rodger A. 1999. Persuasion, Frames, and the Construction of International Norms: Evidence from the Climate Change Debate. Paper presented at the 20th Annual Meeting of the International Studies Association, Washington, D.C.

Plümper, Thomas. 1995. Quasi-rationale Akteure und die Funktion internationaler Institutionen. Zeitschrift für Internationale Beziehungen 2 (1):49-77.

Powell, Walter W., and Paul J. DiMaggio, eds. 1991. The New Institutionalism in Organizational Analysis. Chicago and London: University of Chicago Press.

Price, Richard. 1998. Reversing the Gun Sights: Transnational Civil Society Targets Land Mines. International Organization 52 (3):613-44.

Price, Richard, and Christian Reus-Smit. 1998. Dangerous Liaisons? Critical International Theory and Constructivism. European Journal of International Relations 4 (3):259-94.

Prittwitz, Volker von, ed. 1996a. Verhandeln und Argumentieren. Dialog, Interessen und Macht in der Umweltpolitik. Opladen: Westdeutscher Verlag.

—. 1996b. Verständigung über die Verständigung. Anmerkungen und Ergänzungen zur Debatte über Rationalität und Kommunikation in den Internationalen Beziehungen. Zeitschrift für Internationale Beziehungen 3 (1):133-47.

Risse-Kappen, Thomas. 1995. Reden ist nicht billig. Zur Debatte um Kommunikation und Rationalität. Zeitschrift für Internationale Beziehungen 2 (1):171-84.

Risse, Thomas. 1997. The Cold War's Endgame and German Unification (A Review Essay). International Security 21 (4):159-85.

- 1999. International Norms and Domestic Change: Arguing and Strategic Adaptation in the Human Rights Area. Politics and Society 27 (4):526-56.

Risse, Thomas, Stephen C. Ropp, and Kathryn Sikkink, eds. 1999. The Power of Human Rights: International Norms and Domestic Change. Cambridge: Cambridge University Press.

Ruggie, John Gerard. 1998. What Makes the World Hang Together? Neo-Utilitarianism and the Social Constructivist Challenge. International Organization 52 (4):855-85.

Russett, Bruce. 1993. Grasping the Democratic Peace: Principles for a Post-Cold War World. Princeton, N.J.: Princeton University Press.

Saretzki, Thomas. 1995. "Arguing" oder "Bargaining": Selbstbindung der Politik durch öffentliche Diskurse. In Macht der Öffentlichkeit - Öffentlichkeit der Macht, edited by Gerhard Göhler, 277-307. Baden-Baden: Nomos.

. 1996. Wie unterscheiden sich Argumentieren und Verhandeln? In Verhandeln und Argumentieren. Dialog, Interessen und Macht in der Umweltpolitik, edited by Volker von Prittwitz, 19-39. Opladen: Leske und Budrich.

Schaber, Thomas, and Cornelia Ulbert. 1994. Reflexivität in den Internationalen Beziehungen. Literaturbericht zum Beitrag kognitiver, reflexiver und interpretativer Ansätze zur dritten Theoriedebatte. Zeitschrift für Internationale Beziehungen 1 (1):139-69.

Scharpf, Fritz W. 1997. Games Real Actors Play: Actor-Centered Institutionalism in Policy Research. Boulder, Colo.: Westview Press.

Schimmelfennig, Frank. 1995. Debatten zwischen Staaten: Eine Argumentationstheorie internationaler Systemkonflikte. Opladen: Leske und Budrich.

- 1997. Rhetorisches Handeln in der internationalen Politik. Zeitschrift für Internationale Beziehungen 4 (2):219-54. 
Schmalz-Bruns, Rainer. 1995. Die Theorie kommunikativen Handelns - eine Flaschenpost? Anmerkungen zur jüngsten Theoriedebatte in den Internationalen Beziehungen. Zeitschrift für Internationale Beziehungen 2 (2):347-70.

Schneider, Gerald. 1994. Rational Choice und kommunikatives Handeln. Eine Replik auf Harald Müller. Zeitschrift für Internationale Beziehungen 1 (2):357-66.

Sebenius, James K. 1992. Challenging Conventional Explanations of International Cooperation: Negotiation Analysis and the Case of Epistemic Communities. International Organization 46 (1):323-65.

Shevardnadze, Eduard. 1991. Die Zukunft gehört der Freiheit. Reinbek: Rowohlt.

Sikkink, Kathryn. 1993. Human Rights, Principled Issue-Networks, and Sovereignty in Latin America. International Organization 47 (3):411-41.

Simon, Herbert A. 1982. Models of Bounded Rationality. 2 vols. Cambridge, Mass.: MIT Press. Smith, Jackie, Charles Chatfield, and Ron Pagnucco, eds. 1997. Transnational Social Movements and Global Politics: Solidarity Beyond the State. Syracuse, N.Y.: Syracuse University Press.

Stein, Arthur A. 1983. Coordination and Collaboration: Regimes in an Anarchic World. In International Regimes, edited by Stephen D. Krasner, 115-40. Ithaca, N.Y.: Cornell University Press.

Stein, Janice Gross. 1995. Political Learning by Doing: Gorbachev as Uncommitted Thinker and Motivated Learner. In International Relations Theory and the End of the Cold War, edited by Richard Ned Lebow and Thomas Risse-Kappen, 223-58. New York: Columbia University Press.

Stein, Janice Gross, ed. 1989. Getting to the Table: The Processes of International Prenegotiation. Baltimore, Md.: Johns Hopkins University Press.

Steinmo, Sven, Kathleen Thelen, and Frank Longstreth, eds. 1992. Structuring Politics: Historical Institutionalism in Comparative Analysis. Cambridge: Cambridge University Press.

Teltschik, Horst. 1991. 329 Tage: Innenansichten der Einigung. Berlin: Siedler.

Wendt, Alexander. 1987. The Agent-Structure Problem in International Relations Theory. International Organization 41 (3):335-70.

- 1992. Anarchy Is What States Make of It: The Social Construction of Power Politics. International Organization 88 (2):391-425.

- 1999. Social Theory of International Politics. Cambridge: Cambridge University Press.

Zangl, Bernhard, and Michael Zürn. 1996. Argumentatives Handeln bei internationalen Verhandlungen. Moderate Anmerkungen zur post-realistischen Debatte. Zeitschrift für Internationale Beziehungen 3 (2):341-66.

Zartman, I. William, and Maureen R. Berman. 1982. The Practical Negotiator. New Haven. Conn.: Yale University Press.

Zehfuss, Maja. 1998. Sprachlosigkeit schränkt ein. Zur Bedeutung von Sprache in konstruktivistischen Theorien. Zeitschrift für Internationale Beziehungen 5 (1):109-37.

Zelikow, Philip, and Condoleezza Rice. 1995. Germany Unified and Europe Transformed: A Study in Statecraft. Cambridge, Mass.: Harvard University Press.

Zintl, Reinhard. 1992. Kooperation und Aufteilung des Kooperationsgewinns bei horizontaler Politikverflechtung. In Horizontale Politikverflechtung. Zur Theorie von Verhandlungssystemen, edited by Arthur Benz, Fritz W. Scharpf, and Reinhard Zintl, 97-146. Frankfurt am Main: Campus.

Zürn, Michael. 1992. Interessen und Institutionen in der internationalen Politik: Grundlegung und Anwendung des situationsstrukturellen Ansatzes. Opladen: Leske und Budrich. 


\title{
11 From Europeanization to diffusion
}

\author{
Introduction (2012)
}

\author{
Tanja A. Börzel and Thomas Risse
}

This special issue explores to what extent policies and institutions of the European Union spread across different contexts. Are the EU's attempts to transfer its policies and institutions to accession countries sustainable? To what extent does the EU promote its institutions beyond its borders and beyond Europe? To what degree do other regions of the world emulate or copy the EU's institutional features, what are the mechanisms of this diffusion - and what are its limits?

In EU studies, these questions have been the subject of Europeanization research, which has explored the EU's impact on the domestic policies, institutions, and political processes of the member states as well as on the accession candidates, particularly with regard to its Eastern enlargement (overviews in Börzel and Risse 2007; Featherstone and Radaelli 2003; Graziano and Vink 2006; Sedelmeier 2011). Students of Europeanization have identified both necessary conditions ('misfit' giving rise to adaptational pressure) and causal mechanisms (legal imposition, positive and negative incentives, and socialisation by persuasion and learning) through which 'Europe hits home'.

These approaches have been increasingly criticised by their top-down perspective, which tends to prejudge the EU as the main source of domestic change 'screen[ing] out other domestic causes' (Bulmer and Burch 2005: 864; also see Radaelli and Pasquier 2006). Moreover, they rely heavily on the 'shadow of hierarchy', which not only allows the EU to legally impose its policies and institutions on its member states but also provides important incentives for them to comply. The further we move away from the EU and its immediate neighbours, the more this criticism seems to hold and the less it makes sense to call the spread of EU policies and institutions 'Europeanization'. The EU Treaties influenced the ASEAN Charter in 2008 (see Jetschke and Murray 2012), and the Andean Court of Justice was modelled on the European Court of Justice (ECJ; see Alter 2012; also Alter and Helfer 2010). But neither Asia nor Latin America are becoming European in the process. Nor is the EU the only source of regional and domestic institutional change. Even in current candidate countries, for which $\mathrm{EU}$ accession requires direct institutional changes, the $\mathrm{EU}$ is not the only game in town in driving domestic reforms (Noutcheva and Düzgit 2012). Moreover, with geographical proximity to the EU and Europe in general decreasing, the EU's ability to make non-members comply with its standards and its institutional 
prescriptions becomes weaker. Last but not least, the more distant countries and regions are from Europe, the less significant efforts by the EU become to directly influence institutional change. Instead, Latin American, Asian, and African countries may actively adopt or mimic European institutional solutions and adapt them to their specific needs.

Moving away from Europe allows us, first, to systematically vary several factors that have been identified as crucial by Europeanization research, such as the 'shadow of hierarchy' (in the case of member states, see e.g. Börzel 2010) or the 'shadow of conditionality' (in the case of accession candidates, see e.g. Schimmelfennig and Sedelmeier 2005). Second, it provides us with the opportunity to systematically explore more indirect mechanisms by which the EU may influence institutional change that may be better captured by diffusion approaches.

This special issue embeds Europeanization studies into the larger research on transnational diffusion processes (see e.g. Gilardi 2012; Holzinger et al. 2007; Meyer et al. 1997; Simmons et al. 2008). We argue that the mechanisms and scope conditions of Europeanization are largely compatible with various factors identified in the study of transnational diffusion, while the latter is better suited to capture the more indirect ways in which the EU may affect domestic or regional institutional change.

The articles in this special issue explore transnational diffusion processes with regard to Europeanization after accession (Sedelmeier 2012; Spendzharova and Vachudova 2012), accession candidates (Turkey and Western Balkans: Noutcheva and Düzgit 2012), the European neighbourhood in the Southern Caucasus (Börzel and Pamuk 2012) as well as the Middle East (Magen 2012; van Hüllen 2012) and in other regions of the world (Alter 2012 on the emulation of the European Court of Justice; Jetschke and Murray 2012 on East Asia; and Lenz 2012 on the diffusion of EU institutional models in Latin America and Africa).

This introduction provides the conceptual framework that guides the articles in their venture to study the spread of European policies and institutions. First, we specify institutional change as the 'dependent variable' of this special issue. Second, we discuss how Europeanization research and diffusion studies relate to each other and can be fruitfully combined to identify processes and mechanisms by which ideas and institutions of the EU spread. Third, we introduce scope conditions which are likely to affect domestic (or regional) change in response to the promotion or emulation of EU ideas and institutions. Finally, we give a brief overview of the special issue.

\section{The 'dependent variable': Institutional change}

The articles in this special issue share institutional change as their dependent variable. The authors explore the degree to which these changes can be traced back to the EU and its policies and institutions, be it directly through coercion, conditionality, socialisation, and persuasion, or indirectly through normative emulation, lesson-drawing, and competition. Some of the papers concentrate on 
institutional change only, while others include behavioural change following institutional transformations (e.g. Börzel and Pamuk 2012; Noutcheva and Düzgit 2012; Spendzharova and Vachudova 2012). In some cases, the causal pathway moves from behavioural or policy change toward institutional change (e.g. Sedelmeier 2012 investigating post-accession compliance of new member states and Magen 2012 exploring Israel's emulation of EU standards and institutions).

By focusing on institutional change as our dependent variable, we follow the lead of Europeanization research which has convincingly argued that policy change in response to the EU is not particularly puzzling for member states and accession candidates which have to comply with EU rules and regulations anyway (see Börzel and Risse 2007; Cowles et al. 2001; Goetz and Hix 2000; Schimmelfennig and Sedelmeier 2005). This 'compliance pull' is at work even in many neighbouring countries that are required to adopt parts of the acquis communautaire if they want to do business and trade with the EU and its members (Börzel and Langbein 2012). The more interesting question is under which conditions the adoption of EU policies results in domestic institutional change and to what extent EU institutions directly induce such changes. The more we move away from the EU and its neighbours, the more unlikely institutional change adapting or responding to EU policies and institutions becomes. In this sense, institutional change is harder to demonstrate empirically than policy change.

The articles in this special issue use a rather broad and encompassing understanding of institutions. We understand institutions as social structures and systems of rules, both formal and informal (following e.g. Hall and Taylor 1996; March and Olsen 1989; Powell and DiMaggio 1991). Organisations are formal institutions with written rules and procedures prescribing behaviour. Organisations also encompass informal understandings such as bureaucratic routines and cultures. But there are also entirely informal systems of rules and norms, the latter defined as expectations of appropriate behaviour based on a given collective identity (see Jepperson et al. 1996).

The first part of this special issue dealing with new member states, accession candidates, or countries in the EU neighbourhood concentrates on domestic institutional change as the dependent variable. Sedelmeier (2012) looks at the degree of lock-in in the new Central East European member states in the case of institutions promoting gender equality at the workplace, while Spendzharova and Vachudova (2012) examine the consolidation or lack thereof of democratic reforms in post-accession Bulgaria and Romania. The institutionalisation of the rule of law is the dependent variable in the article on the accession candidates Turkey and the Western Balkans by Noutcheva and Düzgit (2012). With regard to the EU neighbourhood, Börzel and Pamuk (2012) examine - again - the establishment of the rule of law and the fight against corruption in the Southern Caucasus while van Hüllen (2012) investigates the (limited) effects of EU democracy promotion on domestic institutional reforms in the Maghreb and Magen (2012) explores broader institutional change in Israel in response to the EU.

The articles in the second part of the special issue, looking at Latin America, Africa, and Asia, focus on the extent to which regional institutions adapt to, 
emulate, or resist EU institutions. Alter (2012) examines to what extent the institutional design of the European Court of Justice has been emulated in various parts of the world. Lenz (2012) analyses the diffusion of EU institutions to Latin America (Mercosur) and to the Southern African Development Community (SADC), while Jetschke and Murray (2012) look at the degree to which the Association of Southeast Asian Nations (ASEAN) has emulated EU institutions.

Demonstrating that the EU has induced institutional change directly or indirectly tells us little about compliance with these institutions, however. In fact, diffusion research leads us to expect that the more formal institutions and organisational features are simply copied from different local or regional contexts leading to institutional isomorphism, the more likely becomes decoupling between formal rules, informal understandings, and behavioural practices (DiMaggio and Powell 1991). Merely downloading institutional designs from one context into another is likely to lead to less behavioural compliance with the rules and regulations than active adaptation and alteration of institutional features to a given domestic or regional context. Some, but not all, articles in this volume investigate whether indeed behavioural practices follow institutional change (see particularly Börzel and Pamuk; Jetschke and Murray 2012; Sedelmeier 2012; Spendzharova and Vachudova 2012).

Having clarified our dependent variable, we now move toward our theoretical framework, namely the integration of Europeanization studies into the larger diffusion research.

\section{From Europeanization to diffusion: Mechanisms}

The special issue starts from the assumption that Europeanization and diffusion research can be fruitfully combined in order to overcome problems of 'top-down' approaches that tend to over-emphasise the role of the EU and legal compliance for (institutional) change. More specifically, we argue that Europeanization research can be regarded as a special instance of policy and institutional diffusion. Diffusion is conceived as a process through which ideas, normative standards, or - in our case - policies and institutions spread across time and space (see Gilardi 2012; Simmons et al. 2006; Strang and Meyer 1993). Like Europeanization mechanisms, the various diffusion mechanisms discussed below relate to the major logics of social action that rest on distinct assumptions about actors and their relations with social structures and institutions (see Börzel and Risse 2009a, for the following). It should be noted, however, that these logics of action are ideal types that rarely occur exclusively in real life:

1 Instrumental rationality or logic of consequences: actors are conceived as (mostly self-interested) utility maximisers who select their course of action according to cost-benefit calculations.

2 Normative rationality or logic of appropriateness: actors are thought of as rule followers who 'do the right thing' because they want to be part of a particular community and have been socialised into following rules. 


\section{In between spaces}

3 Communicative rationality or logic of arguing: actors deliberate and try to persuade each other about the validity claims inherent in any causal or normative statement. Arguing involves reason-giving and challenging these reasons as well as the legitimacy of norms (Habermas 1981; Risse 2000).

In addition, we distinguish between two types of diffusion mechanisms. First, ideas, policies, and institutions might diffuse through direct influence mechanisms. An agent of diffusion actively promotes certain policies or institutional models in her interactions with a receiving actor or group of actors. Second, diffusion also occurs through indirect mechanisms, namely emulation. Here, the action starts at the receiving end. Actors need to solve a problem or to overcome a crisis and look around for 'best practices' and institutional solutions that serve their needs (logic of consequences). They might also simply 'download' an institutional model, because this is the way things are done in a given community to which one wants to belong (logic of appropriateness). ${ }^{1}$

Europeanization studies typically emphasise - at least implicitly - the first type of diffusion, the direct influence model. Most scholars define Europeanization as the 'domestic impact of Europe and the EU' in the sense that EU members and non-members adapt and change domestic institutions in response to EU rules and regulations (Börzel and Risse 2007; Featherstone and Radaelli 2003). A 'misfit' or incompatibility between European demands for change, on the one hand, and domestic policies, institutions, and political processes, on the other, constitutes a necessary condition for domestic change. Institutions mediate or filter the domestic impact of Europe, which emanates from pressure of adaptation caused by such misfit. In this special issue, the articles on new member states, accession candidates, and the European neighbourhood countries (ENC) specifically draw on Europeanization research. Its mechanisms of institutional change are compatible with the direct influence model of diffusion and can be mapped unto four mechanisms which have also been identified by diffusion research (see Table 11.1).

The first mechanism, which is often overlooked in the literature defining diffusion as voluntary adaptation to external influences (Holzinger et al. 2007),

Table 11.1 Diffusion mechanisms following direct influence model

\begin{tabular}{ll}
\hline $\begin{array}{l}\text { Social mechanism and underlying } \\
\text { theory of social action }\end{array}$ & Promoter of ideas (sender) \\
\hline $\begin{array}{l}\text { Coercion (force or legal imposition) } \\
\text { Manipulating utility calculations }\end{array}$ & $\begin{array}{l}\text { Coercive authority (Herrschaft), legal force } \\
\text { (instrumental rationality) }\end{array}$ \\
Socialisation (normative rationality) & $\begin{array}{l}\text { Promote ideas through providing an } \\
\text { authoritative model (normative pressure) }\end{array}$ \\
Persuasion (communicative rationality) & $\begin{array}{l}\text { Promote ideas as legitimate or true through } \\
\text { reason-giving }\end{array}$ \\
\hline
\end{tabular}

Source: Börzel and Risse (2009a). 
concerns physical or legal coercion. Strictly speaking, coercion is only relevant with regard to internal diffusion following the obligation by member states to comply with EU law. In its external relations, the EU hardly uses coercion, even though some aspects of accession conditionality are hard to distinguish from law enforcement. Note, however, that in the case of member states or accession candidates, legal coercion has to be distinguished from the use of force in the sense that member states or accession candidates have voluntarily agreed to be subject to coercion by virtue of them being EU members or candidates to membership. In sum, we expect legal coercion as a diffusion mechanism only to be at play with regard to member states and, to a lesser extent, accession candidates.

The second mechanism concerns diffusion through manipulating utility calculations by providing negative and positive incentives. The promoters of institutional models can induce other actors to adopt their ideas by trying to change their utility functions. They offer rewards, e.g. in the form of financial and technical assistance, or impose costs through sanctions or empowering domestic actors who push for the adoption of the institutional solution.

The EU routinely uses positive and negative incentives to induce institutional change in accession candidates and in its neighbourhood, thereby pursuing its own instrumental interests, such as security, stability, prosperity, and environmental protection. In its attempt to induce other actors to accept and adopt its institutions, the EU and the member states rely on external incentives (conditionality), on the one hand, and technical and financial assistance (capacitybuilding), on the other (Börzel et al. 2008; Kelley 2004; Schimmelfennig and Sedelmeier 2005; Vachudova 2005). Conditionality tries to manipulate the costbenefit calculations of target actors through creating positive and negative incentives. Capacity-building, by contrast, provides target actors with additional resources enabling then to make (strategic) choices to begin with. Yet the EU often uses financial and technical assistance as an (additional) incentive to reward domestic change (reinforcement by reward and support; see Schimmelfennig et al. 2003). Research has identified the differential empowerment of domestic actors who are then enabled to promote institutional change by providing political elites with incentives (electoral support, shaming campaigns) as an effective mechanism of Europeanization (Börzel and Risse 2007). This mechanism is also compatible with an incentive model of directly influencing change. In general, then, we expect this mechanism to be relevant particularly with regard to accession candidates and the European neighbourhood as well as other countries which seek market access to the EU (Börzel and Pamuk 2012; Noutcheva and Düzgit 2012; Sedelmeier 2012; Spendzharova and Vachudova 2012; van Hüllen 2012). The further we move away from Europe and the more the EU itself is interested in market access to other regions, the less we expect this influence mechanism to matter.

The third mechanism works through normative rationality or the logic of appropriateness and involves socialisation (March and Olsen 1989, 1998). Rather than maximising their egoistic self-interest, actors seek to meet social expectations 
in a given situation. Processes of socialisation often result in complex learning by which actors redefine their interests and identities (Checkel 2005b; Johnston 2007). They can also work through habitualisation. By talking the talk, actors may change their social practices and dispositions, finally ending up walking the walk.

From this perspective, the EU can be understood as a gigantic socialisation agency which actively tries to promote rules, norms, practices, and structures of meaning to which member states are exposed and which they have to incorporate into their domestic structures (see also Checkel 2005a). The EU is a 'teacher of norms' (Finnemore 1993) with regard to member states, accession candidates, and countries in its neighbourhood. Socialisation also relies on domestic actors, but the ways in which domestic actors facilitate reforms are different. Norm entrepreneurs such as epistemic communities or advocacy networks socialise domestic actors into new norms and rules of appropriateness through persuasion and social learning, and they redefine their interests and identities accordingly (Börzel and Risse 2007). The more active norm entrepreneurs are and the more they succeed in making EU policies resonate with domestic norms and beliefs, the more successful they will be in bringing about domestic change. Thus, socialisation mechanisms should be particularly relevant in conjunction with incentive-based modes of influence, and with regard to countries and regions aspiring to become part of the liberal community of democratic states (Börzel and Pamuk 2012; Noutcheva and Düzgit 2012; van Hüllen 2012).

Fourth, and closely related to socialisation, persuasion is based on communicative rationality or the logic of arguing. As mentioned above, it refers to situations in which actors try to persuade each other about the validity claims inherent in any causal or normative statement. The EU uses persuasion continuously in dealing with accession candidates, neighbouring countries, and in its external relations with third countries in general. As Judith Kelley has shown, for example, accession conditionality is always accompanied by efforts to persuade candidate countries of the normative validity and appropriateness of the EU's institutional models (Kelley 2004). Moreover, political dialogue as a way to promote norms and institutions constitutes a regular part of the EU's toolbox in promoting human rights, democracy, and the rule of law in third countries including accession candidates (Börzel and Risse 2009b). Finally, the further we move away from Europe, the fewer incentives the EU has to offer to promote its policies and institutions and the more it has to rely on mechanisms of persuasion and of communication to make its case. Mechanisms of persuasion are, therefore, expected to matter particularly when the EU deals with other regions of the world (Jetschke and Murray 2012; Lenz 2012).

None of these four mechanisms assumes that the agents at the receiving end of diffusion are simply passive recipients of EU policies and institutions. Rather, the adoption of and adaptation to EU norms, rules, and institutional models into domestic or regional structures mostly involve active processes of interpretation, incorporation of new norms and rules into existing institutions, and also resistance to particular rules and regulations. Social learning as a process of acquiring and 
incorporating new norms and new understandings into one's belief systems, for example, involves active engagement, not passive 'downloading' of some new rules and institutional 'software'. As research has shown time and again, the result of these adaptation, learning, and transformation processes is differential Europeanization rather than convergence (Cowles et al. 2001; Héritier et al. 2001; Schimmelfennig and Sedelmeier 2005; Sedelmeier 2011).

These active processes of adaptation, change, interpretation, and resistance are observed in the current accession states (Noutcheva and Düzgit 2012) as well as the neighbourhood countries (Börzel and Pamuk 2012; van Hüllen 2012), where ruling elites (ab)use EU demand for domestic institutional change to advance their own political agenda and ensure their political survival. They become even more relevant when we move toward the more indirect ways in which EU institutions might affect both domestic change and modes of regional cooperation beyond the nation-state. Diffusion processes do not require active promoters of ideas or institutional solutions. Emulation of institutional models such as the EU in different regional contexts could well be completely independent from any effort by the EU to promote certain norms or regulations. Emulation only requires agents looking for institutional designs outside their own realm to solve certain problems or to mimic the behaviour of their peers.

In this context, we can distinguish three mechanisms of emulation (see Table 11.2). First, competition involves unilateral adjustments of behaviour toward 'best practices'. Actors compete with each other over meeting certain performance criteria, e.g. creating employment or fostering economic growth, to which they unilaterally adjust their behaviour accordingly (Busch et al. 2005; Elkins et al. 2006; Vogel 1995). Competition entails not only the diffusion of ideas as normative standards for political or economic behaviour but also the diffusion of causal beliefs, e.g. by learning from best practice, on how to best reach these standards (Börzel 2007). Actors, in turn, borrow ideas in order to improve their performance (functional emulation) in comparison to others.

The EU has sought to encourage competition among countries seeking closer relations with the EU. While the EU's external relations have been largely structured around regional dimensions (Börzel et al. 2008), accession and neighbourhood countries also negotiate bilateral agreements with the EU based on their performance with regard to adopting European policies and institutions (Bauer et al. 2007). Next to this 'regatta principle', the EU has used the Open Method of Coordination developed internally in sensitive areas of EU

Table 11.2 Emulation: Indirect mechanisms of diffusion

\begin{tabular}{ll}
\hline Underlying theory of social action & Mechanism \\
\hline Instrumental rationality & Competition (functional emulation) \\
& Lesson drawing (functional emulation) \\
Normative rationality & Mimicry (normative emulation) \\
\hline
\end{tabular}


policy-making (education, employment, health) in its attempt to foster cooperation among countries within one region setting benchmarks and organising regular peer reviews (Tulmets 2003).

Second, lesson-drawing resembles competition insofar as actors look to others for policies and rules that effectively solved similar problems elsewhere and are transferable into their domestic context (Dolowitz and Marsh 2000; Meyer and Rowan 1977). Institutions may become 'contagious' (Myers 2000: 175) under conditions of uncertainty, policy failure, and dissatisfaction with the status quo. Lesson-drawing usually starts with actors who are faced with a particular political or economic problem which requires institutional change to solve it. They then look around for institutional solutions which are suitable to solve their problems. When lesson-drawing is at play, one should expect the selective rather than wholesale adoption of institutional solutions, since they need to be tailored to the problems at hand.

Both lesson-drawing and competition are based on instrumental rationality, since they follow a functional logic. Actors cannot achieve their goals - e.g. economic performance in a globalised world - and look for or compete about 'best practices' to increase their performance. We assume that lesson-drawing constitutes a prime mechanism by which actors in regions outside Europe look at EU institutions to promote cooperation and integration in their respective regions. We also expect them to strategically adapt EU solutions to their particular needs (Alter 2012; Jetschke and Murray 2012; Lenz 2012).

Third, actors may also emulate others for normative reasons, e.g. to increase their legitimacy (Polillo and Guillén 2005). Or they might simply imitate others because the appropriateness is taken for granted (mimicry; see Haveman 1993; Meyer and Rowan 1977). Normative emulation/mimicry are thus based on the logic of appropriateness. For example, states might want to be members of an international community 'in good standing' and thus fight corruption, improve their human rights standards, or institute the rule of law. As a result, they look around for institutional solutions which they then emulate. In this case, the driving force is not instrumental rationality, but the desire to be a legitimate member of a community. Mimicry is based on the same social logic of appropriateness, but involves a less active process. It almost resembles the automatic 'downloading' of an institutional 'software' irrespective of functional need, simply because this is what everybody does in a given community. Thus, we expect normative emulation or mimicry to be at work particularly in situations and in regions where the EU is considered particularly legitimate (Alter 2012; Jetschke and Murray 2012; Lenz 2012).

In sum, diffusion research provides us with a series of mechanisms by which EU policies and institutions might spread worldwide (or not). These mechanisms, particularly those based on the active promotion of institutional ideas by an agent, are compatible with Europeanization approaches. Whether or not these mechanisms ultimately lead to diffusion and to domestic institutional change depends on scope conditions, to which we now turn. 


\section{Scope conditions for institutional change}

The articles in this special issue not only specify the processes and mechanisms by which European policies and institutions diffuse into different countries and regions of the world. They also spell out scope conditions under which we expect diffusion processes to occur leading to institutional change (or not). We distinguish here among four such potential scope conditions.

\section{Domestic incentives}

Europeanization research has confirmed time and again that domestic institutional change responding to EU rules and regulations is unlikely to take place unless domestic actors in politics or society take them up and demand reforms themselves. The differential empowerment of domestic actors has been identified as a powerful scope condition to account for variation in the degree of Europeanization (see above). Research on the Europeanization of accession candidates has shown that EU conditionality empowers liberal reform coalitions in target countries who then use the EU demands to pressure for domestic reform (Schimmelfennig and Sedelmeier 2004, 2005).

Next to the logic of instrumental rationality, according to which actors use EU demands to further their own interests and benefits, domestic norm entrepreneurs can be equally empowered by EU norms to call for institutional change as the 'right thing to do', i.e. following a logic of appropriateness (Börzel and Risse 2007). Moreover, the EU does not only empower liberal reform coalitions who provide ruling elites with domestic incentives to introduce domestic institutional change (Noutcheva and Düzgit 2012; Spendzharova and Vachudova 2012). If EU demands align with the political preferences or survival strategy of (semi-)authoritarian and corrupt elites, the latter can use EU policies and institutions to push their own political agenda and consolidate their power (Börzel and Pamuk 2012; Noutcheva and Düzgit 2012; van Hüllen 2012).

Domestic incentives are likely to matter even in cases in which we do not find any direct EU influence. Emulation processes also depend upon domestic actors in some states or regions to demand domestic change and who then look for policies and institutions to meet their goals. We expect, for example, that the diffusion of EU institutional models of regional integration in other parts of the world is to be explained by the domestic incentives for actors in powerful states in those regions (Jetschke and Murray 2012; Lenz 2012).

\section{Degrees of (limited) statehood}

States vary considerably in the degree to which they are able to adopt, implement, and enforce decisions. While failed, failing, and fragile states are rather rare in the international system, 'areas of limited statehood' are ubiquitous (Risse 2011). Many countries lack the capacity to implement and enforce the law in large parts of their territory or with regard to some policy areas. Yet state 
capacity is a decisive precondition for governments to adopt and adapt to EU demands for domestic institutional change. Moreover, non-state actors (civil society and business) equally require the capacity to push the reform agenda at the domestic level by exerting pressure on state actors, talking them into domestic change and/or providing them with additional resources. Finally, the EU might be less inclined to push for domestic change in states whose institutions are already fragile. Thus, the institutional and administrative capacity of states and degrees of statehood in general play a crucial role in mitigating the transformative power of the EU (Börzel 2011).

However, it is less clear how limited statehood affects the various diffusion mechanisms. On the one hand, we assume that the more limited statehood characterises parts of the territory or some policy areas, the less likely it is that the diffusion of EU institutions leads to sustainable institutional change and a transformation of domestic practices (Börzel and Pamuk 2012; Noutcheva and Düzgit 2012; van Hüllen 2012). On the other hand, limited statehood and lack of state capacity might induce domestic and regional actors to adopt EU institutional solutions to increase their legitimacy (Jetschke and Murray 2012; van Hüllen 2012) or as a substitute, irrespective of their functionality. In this case, we would expect normative emulation or mimicry (Alter 2012; Lenz 2012).

\section{Democracy vs. autocracy}

The democratic quality of a regime influences the willingness of state actors to promote domestic change in response to EU influence (Schimmelfennig 2005). The costs of adaptation to EU demands for domestic change are lower for incumbent governments of democratic states with market economies than for authoritarian regimes, which have a firm grip on economy and society as a result of which compliance with EU requirements threatens their hold on power. At the same time, the latter are less likely to face pressure from below since domestic actors lack the political autonomy to mobilise in favour of compliance with EU demands for reform. Thus, we expect that the more authoritarian a regime is, the less likely the EU is to influence domestic institutional change. This scope condition applies particularly to EU demands for domestic reforms with regard to human rights, the rule of law, democracy, or market economy. In the case of authoritarian regimes, these EU demands directly threaten the survival of the regimes, as a result of which they are unlikely to lead to institutional reforms, unless other conditions are met (e.g. mobilisation of domestic opposition with regard to human rights, see Risse et al. 1999). Likewise, the more democratic the members of a regional organisation, the more likely it should emulate EU institutions, not only because of greater resonance. Autocratic regimes are also more reluctant than democracies to voluntarily forgo aspects of their 'Westphalian' sovereignty (Jetschke and Murray 2012 on Southeast Asia).

Note, however, that regime type is not a dichotomous variable, but there are degrees of democracy and autocracy. Several articles in this special issue explore to what degree EU efforts at the promotion of democracy, human rights, the rule 
of law, and good governance lead to institutional change in target countries with different degrees of democratisation (Börzel and Pamuk 2012; Noutcheva and Düzgit 2012; Spendzharova and Vachudova 2012; van Hüllen 2012).

\section{Power (a)symmetries}

Last but not least, the distribution of material and ideational resources between the $\mathrm{EU}$, on the one hand, and target countries or regions, on the other, is likely to matter in explaining the variation in domestic change. The degree of interdependence crucially shapes the pressure for adaptation the EU is able to exert and the power of the target country to resist such pressures. Except for Russia, the economic and political power of the EU renders its external relations with neighbouring countries rather asymmetrical. In principle, accession candidates, but also ENC have much to gain by closer relations with the EU which then increases the EU's ability to exert pressure. However, some states possess resources (gas, oil) of interest to the EU, are of strategic importance, and/or have the potential to create substantial negative externalities for the EU (illegal immigration, crossborder crime). Strategic or economic goals can seriously undermine the consistency of the EU in pushing for domestic change in its neighbourhood (Börzel and Pamuk 2012; van Hüllen 2012). Israel is another interesting example of a country balancing its economic dependence on the EU through its security relationship with the United States (Magen 2012).

Power (a)symmetries not only matter with regard to the EU's neighbourhood. The further we move away from Europe, the more complex the picture becomes. On the one hand, the power relationship between the EU and the BRICS (Brazil, Russia, India, China, and South Africa) as well as other emerging economies is rather symmetrical as a result of which the EU and its partners treat each other as equals (Jetschke and Murray 2012). In these cases, mutual interest in granting each other market access leads to a rather balanced relationship which also circumscribes the EU's abilities to successfully demand institutional reforms. On the other hand, there are also many countries in the world which are crucially dependent on getting access to the most important market of the developed world. As a result, the EU is able to exert considerable pressure for institutional reform (Lenz 2012). Finally, power relationships are not only relevant with regard to material resources. One should also keep in mind ideational resources and discursive power (overview in Barnett and Duvall 2005). The EU's discourse on human rights and democracy, for example, is increasingly challenged by the People's Republic of China, on the one hand, and by left-leaning governments in Latin America, on the other. As a result, an ideational balance of power is emerging. A similar example pertains to the so-called 'Asian way' of regional integration which has served as a powerful counterdiscourse rejecting the EU's supranationalism as inappropriate for Southeast Asia (Jetschke and Murray 2012). In sum, however, we would expect that - everything else being equal - the EU is the more able to exert direct influence and adaptational pressure for institutional change, the greater the material power asymmetries in its favour.

Table 11.3 summarises the theoretical framework of this special issue. 
Table 11.3 Theoretical framework

\begin{tabular}{|c|c|}
\hline Dependent variable & $\begin{array}{l}\text { Domestic or regional institutional change which can be } \\
\text { traced to the EU's direct or indirect influence }\end{array}$ \\
\hline Mechanisms of diffusion & $\begin{array}{l}\text { Direct influence: } \\
\text { - Coercion } \\
\text { - Manipulating utility calculations through incentives and } \\
\text { capacity-building } \\
\text { - Socialisation } \\
\text { - Persuasion } \\
\text { Indirect influence: } \\
\text { - Competition/functional emulation } \\
\text { - Lesson-drawing/functional emulation } \\
\text { - Mimicry/normative emulation }\end{array}$ \\
\hline Scope conditions & $\begin{array}{l}\text { - Domestic incentives } \\
\text { - Degrees of (limited) statehood } \\
\text { - Democracy vs. autocracy } \\
\text { - Power (a)symmetries }\end{array}$ \\
\hline
\end{tabular}

\section{Overview of the special issue}

The articles in this special issue are divided in three groups. The first group deals with the Europeanization of new member states and accession candidates and thus focuses on the direct influence mechanisms specified above. The second group of articles also investigates primarily direct influence mechanisms, but with regard to the ENC which do not have an accession perspective. The dependent variable of these six articles is domestic institutional change, particularly with regard to democracy, human rights, and the rule of law. In contrast, the third group of articles in this special issue focus on regional institutional change as their dependent variable, namely the degree to which regional cooperation and integration efforts follow EU models. These articles also examine emulation and thus the more indirect mechanisms of diffusion specified above. All articles in this special issue focus on the same scope conditions for institutional change.

\section{Europeanization of new member states and accession candidates}

With the ever-growing transfer of competences to the European Union, students of European politics have become increasingly interested in how European integration has transformed the domestic institutions, policies, and political processes in the member states. Eastern enlargement then created a unique opportunity for the next generation of Europeanization research to test the various approaches that had emerged to account for the conditions and causal mechanisms through which the EU triggers domestic change. The power 
asymmetries of the accession process, by which candidate countries have to Europeanise as a condition and not as a consequence of membership, significantly mitigate the domestic impact of the EU. So do the varying degrees of statehood and democracy in the Central and Eastern European countries, the Western Balkans, and Turkey. It seems that 'accession Europeanization' has triggered only limited institutional change, which varies, however, across time, countries, and policy areas. The articles by Sedelmeier (2012), Spendzharova and Vachudova (2012), and Noutcheva and Düzgit (2012) explore to what extent our Europeanization model of direct influence mechanisms can account for these findings.

\section{Promoting institutional change in the European neighbourhood}

With the borders of the EU moving eastwards, students of Europeanization have been awarded yet another real-world experiment. As in case of accession candidates, the EU seeks to transform the domestic institutions of its eastern and southern neighbours in order to foster peace, stability, and prosperity. Yet the European Neighbourhood Countries do not have a membership perspective, at least not in the foreseeable future, so that the big carrot is missing. Moreover, the Southern and Eastern neighbours of the EU suffer from both weak statehood and weak democracy, if not outright autocratic systems. Since the EU can neither coerce its neighbouring countries into domestic institutional change nor provide sufficient incentives to pay off the adaptation costs, the misfit between EU and domestic institutions does not translate into strong adaptational pressures. Nevertheless, our authors do find domestic institutional change, at least to some degree. The articles by Börzel and Pamuk (2012), Magen (2012), and van Hüllen (2012) explore how we need to expand our theoretical toolbox in order to theorise voluntary domestic change in response to the diffusion of EU policies and institutions.

\section{Diffusing EU institutions beyond Europe}

As argued above, mostly indirect mechanisms of diffusion (emulation) are at play when the EU's institutional models travel beyond the European neighbourhood. In Asia, Africa, and Latin America, the EU's transformative power is even more limited than in its neighbourhood. Moreover, and with regard to models for regional cooperation and integration, the EU is not the only game in town. Both, free trade areas according to WTO rules (including its dispute settlement mechanisms) and the comprehensive North American Free Trade Area (NAFTA) of Canada, the US, and Mexico constitute alternatives to the EU's multi-level governance system that encompasses a whole variety of policy areas as well as supranational institutions interfering deeply with the 'Westphalian' sovereignty of states. Yet we do observe the emulation of EU institutions in most unlikely regions of the world, such as Africa and Asia. But the adoption of EU models is rather selective in other parts of the world and the behavioural practices are 


\section{In between spaces}

also different, as Alter (2012), Lenz (2012), and Jetschke and Murray (2012) demonstrate in this special issue.

The concluding piece by Börzel and Risse (2012) summarises the major findings of the special issue and discusses several avenues for further research combining Europeanization and diffusion approaches.

\section{Acknowledgements}

This special issue resulted from the project 'The Transformative Power of Europe' at the Research College (Kolleg-Forschergruppe, KFG) at the Freie Universität Berlin, funded by the German Research Foundation (Deutsche Forschungsgemeinschaft) whose generous support is gratefully acknowledged. The various drafts of the papers were presented at the KFG's first international conference, 10-11 December 2009, and at a workshop on 22-23 October 2010 at the KFG. We thank all participants and discussants for their input and critical comments. In particular, we are grateful to Tina Freyburg, Liesbet Hooghe, Anja Jetschke, Diana Panke and an anonymous reviewer for their comments on this introduction.

\section{Note}

1 Our distinction between direct and indirect influence differs from concepts such as leverage versus linkage (Levitsky and Way 2005) or external governance (Lavenex and Schimmelfennig 2010) since these still take the EU as the sender of policies and institutions employing soft or hard mechanisms.

\section{References}

Alter, Karen J. (2012). 'The Global Spread of European Style International Courts', West European Politics, 35:1, 135-54.

Alter, Karen J., and Laurence R. Helfer (2010). 'Nature or Nurture? Judicial Lawmaking in the European Court of Justice and the Andean Tribunal of Justice', International Organization, 64:4, 563-92.

Barnett, Michael, and Raymond Duvall (2005). 'Power in International Politics', International Organization, 59:1, 39-75.

Bauer, Michael, Christoph Knill, and Diana Pitschel (2007). "Differential Europeanization in Eastern Europe: The Impact of Diverse EU Regulatory Governance Patterns', Journal of European Public Policy, 29:4, 405-24.

Börzel, Tanja A. (2007). 'European Governance - Verhandlungen und Wettbewerb im Schatten von Hierarchie', Politische Vierteljahresschrift, Sonderheft 'Die Europäische Union. Governance and Policy-Making', 41, 61-91.

Börzel, Tanja A. (2010). 'European Governance - Negotiation and Competition in the Shadow of Hierarchy', Journal of Common Market Studies, 48:2, 191-219.

Börzel, Tanja A. (2011). 'When Europe Hits Limited Statehood. Europeanisation and Domestic Change in the Western Balkans', KFG Working Papers. Research College 'The Transformative Power of Europe'. Berlin: Freie Universität Berlin.

Börzel, Tanja A., and Julia Langbein, eds. (2012). 'Convergence without Accession? Explaining Policy Change in the EU's Eastern Neighbourhood', Europe-Asia Studies, Special Issue, forthcoming. 
Börzel, Tanja A., and Yasemin Pamuk (2012). 'Pathologies of Europeanization. Fighting Corruption in the Southern Caucasus', West European Politics, 35:1, 79-97.

Börzel, Tanja A., and Thomas Risse (2007). 'Europeanization: The Domestic Impact of EU Politics', in Knud Eric Jorgensen, Mark A. Pollack and Ben Rosamond (eds.), Handbook of European Union Politics. London: Sage, 483-504.

Börzel, Tanja A., and Thomas Risse (2009a). 'The Transformative Power of Europe: The European Union and the Diffusion of Ideas', KFG Working Papers. Research College 'The Transformative Power of Europe'. Berlin: Freie Universität Berlin.

Börzel, Tanja A., and Thomas Risse (2009b). 'Venus Approaching Mars? The European Union's Approaches to Democracy Promotion in Comparative Perspective', in Amichai Magen, Thomas Risse and Michael McFaul (eds.), Promoting Democracy and the Rule of Law. American and European Strategies. Houndmills, Basingstoke: Palgrave Macmillan, 34-60.

Börzel, Tanja A., and Thomas Risse (2012). 'When Europeanization Meets Diffusion. Exploring New Territory', West European Politics, 35:1, 192-207.

Börzel, Tanja A., Yasemin Pamuk, and Andreas Stahn (2008). 'One Size Fits All? How the European Union Promotes Good Governance in Its Near Abroad', SFB 700 Working Paper 18. Berlin: Freie Universität Berlin.

Bulmer, Simon, and Martin Burch (2005). 'The Europeanization of the UK Government: From Quiet Revolution to Explicit Step-change?', Public Administration, 83:4, 861-90.

Busch, Per-Olof, Helge Jörgens, and Kerstin Tews (2005). 'The Global Diffusion of Regulatory Instruments: The Making of a New International Environmental Regime', Annals of the American Academy of Political and Social Science, 598, 146-67.

Checkel, Jeffrey T., ed. (2005a). International Institutions and Socialization in Europe. Special Issue of International Organization. Cambridge: Cambridge University Press.

Checkel, Jeffrey T. (2005b). 'International Institutions and Socialization in Europe: Introduction and Framework. International Organization', International Organization, 59:4, 801-26.

Cowles, Maria Green, James A. Caporaso, and Thomas Risse, eds. (2001). Transforming Europe. Europeanization and Domestic Change. Ithaca, NY: Cornell University Press.

DiMaggio, Paul J., and Walter W. Powell (1991). 'The Iron Cage Revisited: Institutional Isomorphism and Collective Rationality in Organizational Fields', in Walter W. Powell and Paul J. DiMaggio (eds.), The New Institutionalism in Organizational Analysis. Chicago: University of Chicago Press, 63-82.

Dolowitz, David P., and David Marsh (2000). 'Learning from Abroad: The Role of Policy Transfer in Contemporary Policy-Making', Governance, 13:1, 5-24.

Elkins, Zachary, Andrew T. Guzman, and Beth A. Simmons (2006). 'Competing for Capital: The Diffusion of Bilateral Investment Treaties 1960-2000', International Organization, 60:4, 811-46.

Featherstone, Keith, and Claudio Radaelli, eds. (2003). The Politics of Europeanization. Oxford: Oxford University Press.

Finnemore, Martha (1993). 'International Organization as Teachers of Norms: The United Nations Educational, Scientific, and Cultural Organization and Science Policy', International Organization, 47:4, 565-97.

Gilardi, Fabrizio (2012). 'Transnational Diffusion: Norms, Ideas, and Policies', in Walter Carlsnaes, Thomas Risse and Beth Simmons (eds.), Handbook of International Relations, 2nd ed. London: Sage.

Goetz, Klaus H., and Simon Hix, eds. (2000). Europeanised Politics? European Integration and National Political Systems. London: Frank Cass. 
Graziano, Paolo, and Maarten P. Vink, eds. (2006). Europeanization: A Handbook for a New Research Agenda. Houndmills and London: Palgrave/Macmillan.

Habermas, Jürgen (1981). Theorie des kommunikativen Handelns. 2 vols. Frankfurt a.M.: Suhrkamp.

Hall, Peter A., and Rosemary C.R. Taylor (1996). 'Political Science and the Three New Institutionalisms', Political Studies, 44, 952-73.

Haveman, Heather A. (1993). 'Follow the Leader: Mimetic Isomorphism and Entry into New Markets', Administrative Science Quarterly, 38:4, 593-627.

Héritier, Adrienne, Dieter Kerwer, Christoph Knill, Dirk Lehmkuhl, and Michael Teutsch (2001). Differential Europe - New Opportunities and Restrictions for Policy Making in Member States. Lanham, MD: Rowman \& Littlefield.

Holzinger, Katharina, Helge Jörgens, and Christoph Knill (2007). 'Transfer, Diffusion und Konvergenz: Konzepte und Kausalmechanismen', in Politische Vierteljahresschrift, Sonderheft 38. Wiesbaden: VS Verlag für Sozialwissenschaften, 11-38.

Jepperson, Ronald L., Alexander Wendt, and Peter J. Katzenstein (1996). 'Norms, Identity, and Culture in National Security', in Peter J. Katzenstein (ed.), The Culture of National Security: Norms and Identity in World Politics. New York: Columbia University Press, $33-75$.

Jetschke, Anja, and Philomena Murray (2012). 'Diffusing Regional Integration: The EU and Southeast Asia', West European Politics, 35:1, 174-91.

Johnston, Alastair Ian (2007). Social States. China in International Institutions, 1980-2000. Princeton, NJ: Princeton University Press.

Kelley, Judith G. (2004). Ethnic Politics in Europe. The Power of Norms and Incentives. Princeton, NJ: Princeton University Press.

Lavenex, Sandra, and Frank Schimmelfennig, eds. (2010). EU External Governance. Projecting EU Rules Beyond Membership. London: Routledge.

Lenz, Tobias (2012). 'Spurred Emulation: The EU and Regional Integration in Mercosur and SADC', West European Politics, 35:1, 155-73.

Levitsky, Steven, and Lucan Way (2005). 'International Linkage and Democratization', Journal of Democracy, 16:3, 20-34.

Magen, Amichai (2012). 'Israel and the Many Pathways of Diffusion', West European Politics, 35:1, 98-116.

March, James G., and Johan P. Olsen (1989). Rediscovering Institutions. The Organizational Basics of Politics. New York and London: The Free Press.

March, James, and Johan P. Olsen (1998). 'The Institutional Dynamics of International Political Orders', International Organization, 52:4, 943-69.

Meyer, John W., and Brian Rowan (1977). 'Institutionalized Organizations: Formal Structures as Myth and Ceremony', American Journal of Sociology, 83:2, 340-63.

Meyer, John W., John Boli, George M. Thomas, and Francisco O. Ramirez (1997). 'World Society and the Nation-State', American Journal of Sociology, 103:1, 144-81.

Myers, Daniel J. (2000). 'The Diffusion of Collective Violence: Infectiousness, Susceptibility, and Mass Media Networks', American Journal of Sociology, 106:1, 173-208.

Noutcheva, Gergana, and Senem Aydin Düzgit (2012). 'Lost in Europeanization? The Western Balkans and Turkey', West European Politics, 35:1, 59-78.

Polillo, Simone, and Mauro F. Guillén (2005). 'Globalization Pressures and the State: The Worldwide Spread of Central Bank Independence', American Journal of Sociology, 110:6, 1764-802.

Powell, Walter W., and Paul J. DiMaggio, eds. (1991). The New Institutionalism in Organizational Analysis. Chicago and London: University of Chicago Press. 
Radaelli, Claudio M., and Romain Pasquier (2006). 'Conceptual Issues', in Paolo Graziano and Maarten P. Vink (eds.), Handbook of Europeanization: New Research Agendas. Houndmills, Basingstoke: Palgrave Macmillan, 35-45.

Risse, Thomas (2000). 'Let's Argue!' Communicative Action in International Relations', International Organization, 54:1, 1-39.

Risse, Thomas, ed. (2011). Governance without a State? Policies and Politics in Areas of Limited Statehood. New York: Columbia University Press.

Risse, Thomas, Stephen C. Ropp, and Kathryn Sikkink, eds. (1999). The Power of Human Rights: International Norms and Domestic Change. Cambridge: Cambridge University Press.

Schimmelfennig, Frank (2005). 'Strategic Calculation and International Socialization: Membership Incentives, Party Constellations, and Sustained Compliance in Central and Eastern Europe', International Organization, 59:4, 827-60.

Schimmelfennig, Frank, and Ulrich Sedelmeier (2004). 'Governance by Conditionality: EU Rule Transfer to the Candidate Countries of Central and Eastern Europe', Journal of European Public Policy, 11:4, 661-79.

Schimmelfennig, Frank, and Ulrich Sedelmeier, eds. (2005). The Europeanization of Central and Eastern Europe. Ithaca, NY: Cornell University Press.

Schimmelfennig, Frank, Stefan Engert, and Heiko Knobel (2003). 'Costs, Commitment and Compliance. The Impact of EU Democratic Conditionality on Latvia, Slovakia and Turkey', Journal of Common Market Studies, 41:3, 495-518.

Sedelmeier, Ulrich (2011). 'Europeanisation in New Member and Candidate States', Living Reviews of European Government, 6:1, 1-52.

Sedelmeier, Ulrich (2012). 'Is Europeanization Through Conditionality Sustainable? Lock-in of Institutional Change after EU Accession', West European Politics, 35:1, $20-38$.

Simmons, Beth, Frank Dobbin, and Geoffrey Garrett, eds. (2008). The Global Diffusion of Markets and Democracy. Cambridge: Cambridge University Press.

Spendzharova, Aneta, and Milada Anna Vachudova (2012). 'Catching Up? Consolidating Liberal Democracy in Bulgaria and Romania', West European Politics, 35:1, 39-58.

Strang, David, and John W. Meyer (1993). 'Institutional Conditions for Diffusion', Theory and Society, 22:4, 487-511.

Tulmets, Elsa (2003). 'Les programmes d'aide de l'Union Européenne à l'Est: Analyser l'impact des réformes', Revue d'études comparatives Est-Ouest, 34:3, 5-36.

Vachudova, Milada Anna (2005). Europe Undivided: Democracy, Leverage and Integration after Communism. Oxford: Oxford University Press.

van Hüllen, Vera (2012). 'Europeanization through Cooperation? EU Democracy Promotion in Morocco and Tunisia', West European Politics, 35:1, 117-34.

Vogel, David (1995). Trading Up: Consumer and Environmental Regulation in a Global Economy. Cambridge: Harvard University Press. 
$\because$ Taylor \& Francis

Taylor \& Francis Group

http://taylorandfrancis.com 


\section{Index}

absorption 161

accommodation 161-2

activation of network 133-4

Adenauer, Konrad 42

Adler, Emanuel 4

Afghanistan 34, 37, 39, 41, 203

Afheldt, Horst 230

Africa 135

"alternative defense" models 230

Amnesty International 6, 118

Anderson, Jeffrey 4

Andropov, Yuri 224

Antholis, William 71

Anti-Ballistic Missile (ABM) Treaty 228, 234

antipersonnel landmine treaty 267

Arbatov, Georgii 230

arbitrary arrest and detention 118

arguing: common lifeworld 261-3; end of the Cold War and 270-4; international negotiations and 267-8; in international public sphere 268-9; international relations 261-8; power and 263-6; preconditions in world politics 261 ; reasons for 266-7

argumentative consensus 127, 258

argumentative discourses 126

argumentative rationality $136-7$, 250-5, 258

argumentative "self-entrapment" 278

Asia 135

assertions 257

Atomic Energy Act 95

attentive public 27
Austin, J. L. 257

Australia 197

Austria 180, 184

authenticity 257

authoritarian regimes 65

authoritarian systems 63-4

Bachteler, Tobias 71

Bahr, Egon 229, 231

Baker, James 272-3

"balance of power" 80

"balance of threat" $80,82,87$

bargaining 255-6

bargaining processes 85

Barnett, Michael 4, 105

Beisheim, Marianne 199, 205

Belgium 184

Berlin 98-9

Berlin Wall 103, 222, 235

Bill and Melinda Gates Foundation 197-8

bipolarity 79

Blair, Tony 178

"boomerang effect" model 7, 130-1

Börzel, Tanja 8, 13, 199, 202

Boserup, Anders 230

bottom-up approach 25-6, 27, 46

Brandt, Willy 2, 42, 231

Breakwell, Glynis M. 176-7, 178, 188

Breakwell's Identity Process Theory 175

Bretton Woods institutions 88

Brewer, Marilynn 9, 172, 188

Brezhnev, Leonid I. 36, 224, 226

Bringing Transnational Relations Back In (Risse-Kappen) 6 
British Foreign Office 90

Brookings Institution 228

Bruter, Michael 180, 183

Bulgaria 88

Bundy, McGeorge 100

Bush administration 40, 222, 235, 272

Bush, George H. W. 40, 226, 271, 273-4

capitalist market economies 68

Caporaso, Jim 8

Carlsnaes, Walter 9

Carter administration 39

Central Intelligence Agency (CIA) 88

'change agents' 151, 159

"cheap talk" models 10-11, 256

Checkel, Jeff 226, 227

Chernenko, Konstantin 224

Chile 117, 124, 133

China 56, 91, 136

Christian Democratic Union (CDU) 31, 33, 43-4, 235, 239

Churchill, Winston 88

Citrin, Jack 174, 180, 183, 188, 191

coalition-building processes $28-9$

"codetermination" 85

coercion 295

"cohabitation" 42

Cold War 4, 5, 78, 81-2, 89, 102-4

Collaborative Research Center 700

(Sonderforschungsbereich) 12

collective identity: democratic domestic structures and 67-9; effects of European Union on 186-90; "free world" 86; norms constituting 62

Committee of Permanent Representatives (COREPER) 173, 187

Committee on the Present Danger 39

Common Foreign and Security Policy (CFSP) 78

"common knowledge" 258-60, 263

common lifeworld 258

common security $221,228-9$

communicative action 9, 10-11, 257, 258-61

communicative behavior 126

communicative practices $257-8$

A Community of Europeans? (Risse) 9

community of values $68,85,97,103$

comprehensive test ban 234
Conference on Security and Cooperation in Europe (CSCE) 70, 273-4

consensus building 48

consolidated states 197

consultation norms 85

containment strategy 87

convergence $162-5$

Cooperation Among Democracies (RisseKappen) 4

"cooperation under anarchy" perspective 84

"cooperative internationalists" 31

cooperative solution 98

Cornell University 3, 5

corporatist model 32-3

Correlates of War project 57

cost-benefit calculations 60

Council of Europe 180

Court of Human Rights 131

Cowles, Maria Green 8

cross-cutting identities 174

Cuba 124

Cuban missile crisis 82, 96-102

The Culture of National Security

(Katzenstein) 4

Czechoslovakia 117

Czempiel, Ernst-Otto 2, 4, 5, 55

Daimler AG 197

debates 268-9

"defensive positionalists" 79

de Gaulle, Charles 30, 41, 95, 96

delegation agreements 202-3

democratic corporatism 29

democratic decision-making 60-2

democratic international institutions 85

democratic norms $62-4,66,83-4$

democratic peace: creation of $86-7$; empirical findings 56-8; externalization of democratic norms $62-4$; finding of 57-8; institutional constraints and the complexity of democratic decision-making 60-2; literature on 5; participatory constraints and rational cost-benefit calculations 59-60; prevailing explanations 58-64; social constructivist interpretation of 5, 55-72; social constructivist interpretation of the normative argument 64-70; suggestions 
for a research agenda on 70-2; warlike democracies 56-7

Democratic Republic of Congo 206

D'Estaing, Giscard 41

Deudney, Daniel 224

Deutsch, Karl W. 4, 67, 78, 84

diffusion 293-8

diffusion mechanisms: emulation 297-8; socialization processes 295-6; types of 293-8; utility calculations 295; voluntary adaptation $294-5$

divergence $162-5$

Dixon, William 58

Dobrynin, Anatoly 101

domestic change: degrees of 161-2, 163; dimensions of 152-3; EU influence to promote $300-1$; facilitating factors as sufficient conditions for 155 ; integrating logics of 165-7; logics of 161; as necessary but not sufficient condition 153-5; outcome in response to Europeanization 161-5; as process of redistribution of resources 156-60; as process of socialization and learning 158-60

domestic incentives 299-300

domestic network formation 136-7

domestic orders 67,86

"domestic sovereignty" 200

domestic structure approach 3, 6, 28-9, 46

domestic structures: collective identity and

67; France 30-4; Germany 30-4, 239;

as intervening variables 236-9; Japan

30-4; United States 30-4, 238-9

"double hatting" 173

Doyle, Michael 55, 65, 68, 84

"dual containment" 90

Dulles, John Foster 92-5

Easton, David 2

East Timor 203, 276

economic convergence school 164

Eden, Anthony 93-5

egoistic utility maximizers model 241

Eisenhower, Dwight D. 93-5

Elster, Jon 255, 264

"empire of the evil" 89

empirical legitimacy 206-7

emulation 297
Engelmann-Martin, Daniela 9

entitativity 181, 184-6, 192

Equal Opportunities Commission 157

Euro crisis 10, 14

European Commission 187

European Economic and Monetary Union (EMU) 181

European Economic Area 181

European identity: civic and/or cultural components of 179-81; collective identities of $9,173-7$; composition and content of 177-83; European polity and 192-3; European Union identity and 178-9; Europe's emptiness as identity category $177-8$; in-group projection model 177, 181-3; multiple others and the in-group projection model 181-3; points of contention and methodological implications 190-2; "Russian doll" concept 174-5

Europeanization: adaptational processes 151-2; diffusion mechanisms 293-8; dimensions of domestic change 152-3; domestic change as process of redistribution of resources 156-60; domestic effect of 153; 'goodness of fit' and 152-5, 164-5; institutional change 291-3; institutional misfit 155; misfit 153-5; of new member states and accession candidates 302-3; outcome of domestic change in response to 161-5; policy misfit 154-5; scope conditions for institutional change 299-301

European Parliament 175, 187

European polity 178, 192-3

European Union (EU): assistance for anticorruption programs in the Southern Caucasus 203; causal mechanisms that impact on collective identities 188-9; civic and/or cultural components of 179-81; diffusing institutions beyond Europe 303-4; diffusion mechanisms 293-8; elites, masses, and psychological existence of 183-6; equal pay and equal treatment directives 157; European identity and 178-9; Europe's emptiness as identity category 177-8; feedback loops 150 ; Helsinki summit 181; identity change 
186-90; influence to promote domestic change 300-1; institutional change 291-3; institutionalized norms 67 ; laws 154; membership identity 176 , 184 ; power asymmetries 301 ; rules and regulations 154, 163; scope conditions for institutional change 299-301

European University Institute (EUI) 8-9

Evangelista, Matthew 226

Executive Committee (ExComm) 97-9

face-to-face communication 260

Farris, Christopher J. 199, 202

Fashoda crisis 58

Fearon, James 122

Federation of American Scientists (FAS) 228, 229

Finland 184

Finletter, John 99-100

formal institutions 151, 157, 165

Forrestal, James 87

Foucault, Michel 264, 265

France: domestic structure 30-4; economic policies 166; "first use" of nuclear weapons 27; incorporation of Europeanness into collective nation-state identity 164; meaning of Europe 177; "nuclear monarchy" 32; nuclear policies of 27-8; perception of American power 84; policy networks 32-3; political institutions 30-1; public impact on foreign policy toward 47; public impact on foreign policy toward Soviet Union 41-2; public opinion reactions to Soviet foreign policy 34-8; role of public opinion in foreign policy-making process 34 ; structure of society $31-2$; Suez crisis 92 ; wartime alliance 87

Free Democratic Party 235

"freeze campaign" 234

Freie Universität Berlin 9, 11

French Communist Party (PCF) 41

French Parliament 30

French Socialist Party (PSF) 31

Gaddis, John Lewis 80

Gaullist Party (RPR) 31

Genscher, Hans-Dietrich 226, 236
"Genscherism" 39, 236

German Parliament 30-1

German-Polish treaty 2

German Research Foundation (Deutsche

Forschungsgemeinschaft) 6

German Social Democrats (SPD) 31

Germany: corporatist model 32-3;

"democratic corporatist" structure

222; domestic structure 30-4, 239;

EU membership 184; as European

other 182; "first use" of nuclear

weapons 27; German unification

270-4, 280; Gorbimania 224, 235-6;

incorporation of Europeanness into

collective nation-state identity 164 ;

liberal internationalists and the Western

responses to Gorbachev 235-6; meaning

of Europe 177, 183; nuclear policies of

27-8; policy networks 32-3; political

institutions 30-1; public impact on

foreign policy toward 47; public impact on foreign policy toward Soviet

Union 42-4; public opinion reactions to Soviet foreign policy $34-8$; role of public opinion in foreign policy-making process 34 ; security partnership 235-6; structure of society $31-2$

Global Alliance for Vaccines and Immunization 197

Global Fund to Fight AIDS, Tuberculosis, and Malaria 205

Goldstein, Judith 227, 241

'goodness of fit' 152-5

Gorbachev, Mikhail: foreign policy advisors of 6 ; foreign policy change 103, 221, 222-6, 231-6, 240, 241, 270-4; Gorbachev revolution 34, 223; Japanese policy toward Soviet Union and 45; liberal internationalists and the Western responses to 233-6; "perestroika" 2; U.S. policy toward Soviet Union and 36, 39-40

Gorbimania 224, 235-6

Gourevitch, Peter 29

"governance" paradigm 12

Great Britain 84, 87, 92, 177

Greece 135

Guatemala 117, 118

Gulf crisis 69 
Habermas, Jürgen 1, 250, 257

habitualization 125

Haider, Jörg 180

Handbook of International Relations

(Carlsnaes, Risse, \& Simmons) 9

Harriman, Averell 87

Hassan II, King of Morocco 277

Herrmann, Richard 9, 172, 188

Hilsman, Roger 96

historical institutionalism 3

HIV/AIDS prevention and treatment program 197, 206

Hönke, Jana 199, 206

human rights: norms 121-4; socializing human rights norms into domestic practices 274-9; "spiral model" of human rights change $6-8,120,131-44$; "success stories" 117; violations 117

human rights networks 131-3

Hungary 88

ideal speech situation 264-5, 274

identity change 186-90

identity formation $68,121-4$

identity politics 105

Ikenberry, G. John 4, 224

immigrants 180

Indonesia 117, 275-7

informal institutions 160

in-group projection model 177, 181-3

input legitimacy 207

Institute for Peace Research and Security Policy 228

Institute of Atomic Energy 229

Institute of USA and Canada of the Russian Academy of Sciences (ISKRAN) 6, 229, 230, 232

Institute of World Economy and International Relations (IMEMO) 6, 226, 230, 232

institutional change: as dependent variable 291-3; scope conditions for 299-301

institutional constraints $60-2,83$

institutionalist approach 29

institutionalization 125, 129, 199, 210

institutional misfit 155

instrumental adaptation 125-6, 128

instrumental rationality 136-7, 253

Inter-American Commission 131 intermediate-range nuclear forces (INF) 223, 235

Intermediate-Range Nuclear Forces Treaty 3,4

International Commission against Impunity in Guatemala (CICIG) 203

International Crisis Behaviour project 57

International Monetary Fund 88

international non-governmental organizations (INGOs) 131, 138, 141, 143, 144, 267

International Organization 3, 11

international public sphere 268-9

international trusteeships 202

Iraq 69, 203

"iron curtain" speech 89

Israel 92, 94

issue publics 27

Italy 179

Japan: corporatist model 32-3; domestic structure 30-4; "first use" of nuclear weapons 27 ; nuclear policies of 27-8; policy networks 32-3; political institutions 30-1; public impact on foreign policy toward 47; public impact on foreign policy toward Soviet Union 44-5; public opinion reactions to Soviet foreign policy 34-8; role of public opinion in foreign policy-making process 34 ; structure of society $31-2$

Jetschke, Anja 7

journalists 173-4

Journal of Common Market Studies 8

Jupiter missiles 99-101

Kant, Immanuel 55, 59-60, 61, 67, 78, 83, 84, 226

Kantner, Cathleen 10

Karaganov, Sergei 232

Katzenstein, Peter 3, 4, 29

Keck, Margret 7

Keck, Otto 258-9

Kennan, George F. 87, 89

Kennedy administration 101

Kennedy, John F. 96-101

Kennedy, Robert 101

Kenya 117, 118, 275

Keohane, Robert 4, 226, 227, 241 


\section{Index}

Khrushchev, Nikita 96-101

Knopf, Hans-Joachim 9

Kohl, Helmut 43-4, 235, 236, 271-2

Kokoshin, Andrei 230, 232

Korean War 56, 91

Kortunov, Andrei 232

Krasner, Stephen 143

Kratochwil, Friedrich 4

Krell, Gert 2

Labor Party 176, 228

Laffan, Brigid 175, 180, 183, 186, 191

Lake, David 199, 202

Larionov, Valentin 233

Latin America 135

Layne, Christopher 57-8

Lebow, Richard Ned 3, 5, 226

Lee, Melissa M. 199, 205

legal coercion 295

legalization 210

legitimacy 198, 213, 298

lesson-drawing 298

Liberal Democratic Party (LDP) 30, 33, 45

liberal intergovernmentalism 186

liberal internationalist community 228-31

liberal theories of international relations $82-3$

limited statehood: causal inferences 210-13; characteristics of 200-2; degrees of 299; external state and nonstate actors and 197-8; institutionalization 199, 209-10; legitimacy 198, 206-8; provision of collective goods and services 204-6; state capacity $202-4$; task complexity 198-9, 209

Lippmann, Walter 87

Lloyd, Selwyn 92

logic of appropriateness $151,158-60$, $250,252-5$

logic of consequentialism 151, 156, 166, $250,252-5$

"long telegram" 89

Macmillan, Harold 95, 97-8

Magna Carta 117

Managua Declaration 123

Maoz, Zeev 58

March, James 252, 254

Marcos, Ferdinand 124
Marcussen, Martin 9

Marshall, George 87

mass public opinion 27, 72

Matanock, Aila M. 202, 212

Meinhof, Ulrike Hanna 175, 178, 182, 188, 191

Mendelson, Sarah 226

"militant internationalists" 31

'Militarized Interstate Dispute' 58

Milstein, Mikhail 230

Mitterrand, François 32, 41-2, 166

moral discourses 126-7

Morocco 117, 277

Müller, Harald 2, 5, 10, 257

multinational corporations 206

multiple others 181-3

multiple veto points $151,156-7,165$

Mummendey, Amélie 175, 176, 177, 182-3

Museveni, Yoweri 129

Mutual Security Treaty 31

Nakasone, Yasuhiro 44-5

Nasser, Gamal Abdel 92

National Commission on Human

Rights 118

National Museum of Wildlife Art 7

Natural Resources Defense Council

(NRDC) 228, 229, 234

neoliberal institutionalism 78, 82-3

neoliberalism 86

nested identities 174-5

New Zealand 197

Nicaragua 124

Nitze, Paul 234

non-governmental organizations (NGOs)

132, 133, 136, 141, 144, 202, 205, 269

nonstate actors 198, 205, 206

normative emulation/mimicry 298

normative legitimacy 206-7

norm entrepreneurs $151,159,165$

norms 14, 62-4, 66, 83-4, 85, 119, 121-4, 253-4, 257, 274-9

North American Free Trade Area

(NAFTA) 303

North Atlantic Treaty Organization

(NATO): end of the Cold War and the future of 102-4; German unification 270-4, 280; Harmel report 225; liberal 
interpretation of the transatlantic security community $87-92$; nuclear policies 3,43 ; realism and cooperation patterns in 80-1; realism and the endurance after Cold War 81-2; realism and the origins of 79-80; as security community of liberal democracies 4,67 ; "Soviet threat" 78; uniqueness of 104-6 North Korea 69

Norway 181

nuclear arms control 39-40, 91, 228

Nunn, Samuel Jr. 234

Nye, Joseph 226

Obama, Barack 4

Ohio State University 9

Olsen, Johan 252, 254

Onuf, Nicolas 4

Open Method of Coordination 297

Organization for Economic Co-operation and Development (OECD) 198

Organization for Security and Cooperation in Europe (OSCE) 78, 182

Organization of American States (OAS) 123

Ormsby-Gore, David 97-8

Ostpolitik 2, 26, 30, 37, 42-3, 239

Ostrom, Elinor 260

output legitimacy 207

Owen, John 57, 71

Oxford Handbook of Comparative Regionalism (Börzel \& Risse) 13

Oye, Kenneth 223

'pacific federations' $55-6,58,67,78$, 84, 103

Page, Benjamin 39

Palme commission 229-30, 231

Palme, Olof 230

Pax Christi 2

peace activism 2

peace movements 2

peace research 2

Peace Research Institute Frankfurt (PRIF) 2, 5, 228

Peace Studies Program, Cornell University 3

Peloponnesian war 71

"perestroika" 2
Perle, Richard 234

'Perpetual Peace' (Kant) 55, 61

The Persistent Power of Human Rights

(Risse, Ropp, \& Sikkink) 7

Philippines 117

Pinochet, Augusto 118

pluralistic security communities: among autocratic leaders 84 ; definition of 67 ; democratic allies in 82-7; European Union 56; formation of 58, 78; transatlantic relationship 56

Poland 10, 88, 117

policy misfit $154-5$

policy networks 28-9, 32-4

political culture 151,160

"political opportunity structures" 28

power 263-6

power asymmetries 85,301

Power of Human Rights (Risse, Ropp, \& Sikkink) 7, 10

practical discourses 257

"prescriptive status" 138-40

Primakov, Yevgeniy 226

principled-issue networks 119-20, 143

provision of collective goods and services 204-6

psychological attribution theory 66

publicity 69,72

public opinion: impact in four liberal democracies 30-45; impact on foreign policy toward Soviet Union 39-45; indirect effects of 46; reactions to Soviet foreign policy $34-8$; theoretical concepts and methodological problems 25-9

public-private partnership (PPP) 205, 212-13

Puchala, Donald 8

Putnam, Robert 86

rational choice approaches $250,252-5$, 258-61

rational choice institutionalism 151

rationalist institutional logic 151, 157, 162

Reagan administration 124, 222, 228, 234-5

Reagan, Ronald 3, 27, 39, 43, 89, 223, 226

Regional Assistance Mission to Solomon

Islands (RAMSI) 197, 203, 207, 212 
"Report of the Committee of Three on Non-Military Cooperation in NATO" 95 republican liberalism 78-9

Research College (Kolleg-Forschergruppe) 12

resource dependency approach 163-4 rhetorical action 11, 256

Rice, Condoleezza 273

Robert Schuman Centre for Advanced Studies 8

Romania 88

Roosevelt administration 88

Roosevelt, Eleanor 117

Roosevelt, Franklin D. 87

Ropp, Stephen 7

Roscher, Klaus 9

Ruggie, John 4

Ruhr crisis 58

rule-consistent behavior 140-3

rule-guided behavior 253-4

rule of law 61,83

Rummel, Rudolph 57

Rusk, Dean 97, 99, 101

Russett, Bruce 4-5, 55, 58, 63, 71

"Russian doll" concept 174-5

Sagdeev, Roald 229

Sandholtz, Wayne 187

Schäferhoff, Marco 199, 205, 212-13

Scharpf, Fritz W. 207

"Schengenland" 181, 185, 189

Schimmelfennig, Frank 9, 256

Schmidt, Helmut 3, 43, 225, 229, 236

Schmitz, Hans Peter 7

Schröder, Gerhard 178

Searle, J. R. 257

"second image reversed" 6,8

security dilemma 84

security partnership 235-6

"self-entrapment" 138

shaming 125, 128

Shapiro, Robert 39

Shevardnadze, Eduard 226, 232, 233, 271-2

Shultz, George 234

Shultz-Gromyko agreement 234

Siapera, Eugenia 173, 175, 185

Sides, John 174, 180, 183, 188, 191

Sikkink, Kathryn 7
Simmons, Beth 9

social constructivism 3, 6, 64-5, 123

Social Democratic Party (SPD) 33, 43,

176, 225, 228-9, 235

socialization processes: alternative explanations 143-4; argumentative discourses 126; concepts 189; diffusion mechanisms 295-6; European Union identity and 189-90; institutionalization processes 125,129 ; instrumental adaptation 125-6, 128; socializing human rights norms into domestic practices 274-9; "spiral model" of human rights change 6-8, 120, 131-44; types of 124-9

societal control 29

societal fragmentation 46

society-dominated policy network 32

sociological institutionalism 151, 158-60, $162,250,252-5$

Solana, Javier 178

Somalia 205

South Africa 117, 133, 197, 206, 275

Soviet Academy of Science 234

Soviet-British "percentages agreement" 88

Soviet foreign policy: French policy toward 41-2; German policy toward 42-4; Japanese policy toward 44-5; public impact on foreign policy toward 39-45; public opinion reactions to $34-8$; U.S. policy toward 39-41

Soviet Union: change in foreign policy 103, 221, 222-6, 231-6, 240, 241, 270-4; Cold War policies 79-80; Cuban missile crisis 96-102; domestic structures as intervening variables 236-9; origins of NATO and 87-91; perception of power 84; Reagan administration foreign policy against 124, 234-5; transnational exchanges and turnaround in Soviet security policy 231-2

Space Research Institute 229

Spain 184

speech act theory 257

"spiral model" of human rights change: alternative explanations 143-4; denial 134-5; development of 7-8, 120 ; dominant actors 142 ; dominant 
interactions modes 142; human rights networks 131-3; phases of 133-43; "prescriptive status" 138-40; purpose of 131; repression and activation of network 133-4; rule-consistent behavior 140-3; tactical concessions 135-8

Spiro, David 57-8

Stalin, Joseph 88, 89

state-building 197-8

state capacity $202-4$

state-dominated policy network 29

Stephanson, Anders 89

Stockholm International Peace Research Institute 228

Suez Canal Users' Association (SCUA) 92-5

Suez crisis $78,92-6$

Suharto 118, 275-7

Sweden 184

tactical concessions $135-8$

task complexity 198-9

test ban negotiations 91

Thauer, Christian 199

"three-level" game 90

Tiananmen Square demonstrations 136

Transforming Europe (Cowles, Caporaso, \& Risse) 8

transnational advocacy networks 7 ,

119-20, 129-30

transnationalism 236-9

transnational relations $7,70,72,119$, 227-36

Truman administration 87-9

Tunisia 117,118

Turkey 99-101

"two-level games" 86, 141

Uganda 117, 129

Union of Concerned Scientists (UCS) 228, 229

United Kingdom 157, 184

United Nations: General Assembly

117; human rights bodies and missions 118, 131; Human Rights

Commission 138, 139, 140, 268, 276, 277; Human Rights Committee

132; international trusteeships 202;

Millennium Development Goals 205,
212; Special Rapporteur on Torture 276; Universal Declaration of Human Rights 117-18, 140, 277

United States: Cold War policies 79-80;

Cuban missile crisis 96-102; domestic structure 30-4, 238-9; European influence during Cold War 81; European influence on foreign policy 71 ; "first use" of nuclear weapons 27 ; foreign policy 124; German unification 270-4; nuclear policies of 27-8; policy networks 32-3; political institutions 30-1; public impact on foreign policy toward 47; public impact on foreign policy toward Soviet Union 39-41; public opinion reactions to Soviet foreign policy 34-8; Reagan administration foreign policy against Soviet Union 124, 234-5; role of public opinion in foreign policy-making process 34 ; society-dominated policy network 32; structure of society $31-2$; wartime alliance 87

Universal Declaration of Human Rights (UDHR) 117-18, 140, 277

University of Bonn 2

University of Frankfurt 1

University of Konstanz 6, 8

University of Uppsala 9

University of Wyoming 3, 7, 15

Uruguay 124

US civil war 57

U.S. Congress 30, 40, 228

U.S. House of Representatives 40, 234

van de Steeg, Marianne 10

van Hüllen, Vera 199, 202

"varieties of capitalism" perspective 3

Velikhov, Evgeny 229

Venezuela crisis 58

Vergleichende Kriegsursachenforschung project 57

Vietnam War 56

von Müller, Albrecht 230

von Weizsäcker, Richard 235

Waldzus, Sven 176, 177, 182-3

Wallace, Henry 87

Walt, Stephen M. 80 


\section{Index}

Waltz, Kenneth 57

Waltzian structural realism 4, 59, 79

warlike democracies 56-7

Weber, Max 200

Weimar Republic 58

Weinberger, Caspar 234

Wendt, Alexander 4

West European Politics (Börzel \& Risse) 13

West European Union (WEU) 78

"Westphalian/Vattelian" sovereignty 202

Wittkopf, Eugene 31

Wodak, Ruth 175, 180, 191

World Bank 88, 143

World Politics 3

"world time" 135, 137
World Trade Center terrorist attacks 14,178

World Trade Organization (WTO) 303

World War I 87

World War II 33, 56, 79, 84

Yakovlev, Aleksandr 226

Yale University 3, 4, 6

Yeltsin, Boris 103

Zangl, Bernhard 259

Zeitschrift für Internationale Beziehungen 10

Zelikow, Philip 273

Zhurkin, Vitalii 232

ZIB debate 10-11, 255

Zürn, Michael 259 